UNIVERSIDAD POLITÉCNICA DE VALENCIA

Departamento de Comunicación Audiovisual, Documentación e Historia del Arte

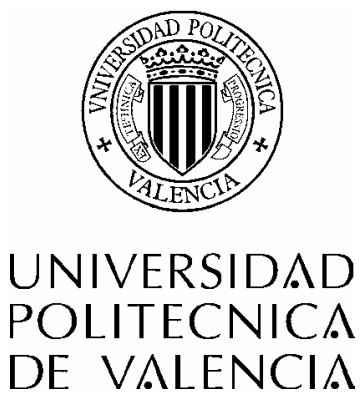

\title{
FUENTES DOCUMENTALES PARA \\ EL ESTUDIO DE LA MÚSICA EN \\ el Cine español de los AÑos 40
}

TESIS DOCTORAL

Presentada por:

David Roldán Garrote

Dirigida por:

Dra. Eulalia Adelantado Mateu

Valencia, junio de 2003 
El presente trabajo aborda el tema de la música en el cine español de los años 40 a través de fuentes documentales. Tras un almacenamiento y clasificación en formato digital, se ha desarrollado una herramienta para su gestión y clasificación de los mismos.

Estas fuentes nos han permitido generar un discurso en el que se han tenido en cuenta diversos aspectos que directamente afectan a la composición de música para cine: contexto histórico, político, económico y social.

Una vez realizdo los análisis pertinentes, se ha abordado directamente el tema bajo distintas ópticas, obteniendo un retrato de la profesión de músico de cine y su repercusión tanto en la industria como en la sociedad.

El present treball tracta de la música en el cinema espanyol dels anys 40 a través de les fonts documentals. A més d'un emmagatzematge i classificació en format digital, s'hi ha desenvolupat una eina per a la seua gestió i classificació.

Aquestes fonts ens ha permet generar un discurs dins del qual s'hi ha tingut en compte diversos aspectes que directament afecta a la composició de música cinematográfica: context històric, polític, econòmic $\mathrm{i}$ social.

Després d'un anàlisi adequat, es procedeix a una profundització del tema des de diferents òptiques, aconseguint una descripció de la professió de música de cinema i la seua repercussió tan a la industria com a la societat

The present dissertation approaches the music's topic in the Spanish cinema of the years 40 through documental sources. After a storage and classification in digital format, a tool has been developed for its administration and classification of the same ones.

These sources have allowed us to generate a speech in which it has been kept in mind diverse aspects that directly affect to music's composition for cinema: historical, political, economic and social context.

Once carried out the pertinent analyses, it has been approached the optic different low topic directly, obtaining a portrait of cinema musician's profession and their repercussion as much in the industry as in the society. 
A mis padres:

soy lo que soy gracias a ellos. 
La tesis doctoral que presentamos recoge los esfuerzos y esperanzas, no solo de quienes suscriben estas palabras sino, de todos aquellos que colaboraron con nosotros e hicieron posible su conclusión. Queremos dar las gracias desde estas líneas a todos quienes han aportado información o su trabajo. Desde aquí y con nuestro más sincero agradecimiento...

... a Eulalia Adelantado, sin ella esta Tesis no se hubiese terminado.

... a familiares y herederos de los protagonistas de nuestra "historia".

Francisca Martos (Juan Quintero Muñoz), Manuel Halffter (Ernesto Halffter), Josefina Rebollo (Modesto Rebollo Pata), José Luis García-Leoz (Jesús García-Leoz), Antonio Durán Barbá (Juan Durán Alemany), Manuel López-Quiroga Clavero (Manuel López-Quiroga Miguel), Ma Reyes Elicegui Cans (Manuel Parada de la Puente), Ma Josefa Cebrián Collado (Miguel Ansis Arbó), Pilar Ruiz Gómez (José Casas Augé), Juliana San José de la Fuente (Ramon Ferrés Mussolas), Ma Jesús Guridi Ispizuea (Jesús Guridi), Ernestina Martínez Quintela (Federico Martínez Tudó), Luis Fernando Moraleda Barhona (Fernando Moraleda Bellver), Ernestina Muñoz Cruz (José Muñoz Molleda), Francisco Ruiz de Azagra Sanz (José Ruiz de Azagra), Luisa Casarrubios Lechuga (Gabriel Salvador Ruiz de Luna Arroyo), Antonio de León Arias de Saavedra (Rafael de León), Ma Carmen González Feijoo (Emilio Lehmberg), Pilar Arrieta Moreno Torroba (Federico Moreno Torroba), Blanca Celia Solimano maiztegui (Isidro Buenaventura Maiztegui Pereiro).

... a todos los profesionales de la industria con quienes mantuvimos contacto:

José Luis Borau (director, guionista y productor de cine), Juan Mariné (director de fotografía y restaurador), José Nieto (compositor), Julio Arce (musicólogo), Ricardo Bayon (orquestador y arreglista), José Antonio Nieves Conde (director), Imperio Argentina (actriz y cantante), Amparo Rivelles (actriz), José Luis Berlanga (director), Cristóbal Halffter (compositor), Juan Ángel Sáiz (Saimel Ediciones), Concha Figueras (restauradora).

... a nuestros compañeros investigadores y documentalistas que nos han ayudado o apoyado:

Aurea Ortiz (Filmoteca de Valencia), Josep Lluis i Falcó (Universidad de Barcelona), Alfrendo Morán (investigador), Carlos Colón Perales (Universidad de Sevilla), Julio Pérez Perucha (investigador), José Martí Parreño (investigador), Eva Sales Ortiz (Universidad Politécnica de Valencia), Carmen Mellado Rubio (documentalista de Les Corts Valencianes), Begoña Santamaría (Jefa de Secretaría General - SGAE), Ana Vega Toscano (locutora y musicóloga), Juan Miguel Company (Universitat de Valencia), Roberto 
Portillo (Fundación Autor), Carlos Javier Pellejero (Servicios Culturales, Diputación de Navarra), Josep Palau (Filmoteca de Valencia), Vicente Ponce (Universidad Politécnica de Valencia).

... a nuestros amigos informáticos, que han hecho posible la base de datos Multimedia MCE40:

David Pardo Gimilio, Miguel Vicente Martínez.

... a nuestros amigos y colaboradores que nos apoyaron en todo momento:

César Sastre de la Cruz, Alejandro Sánchez Márquez, Ricardo Hernández Fernández, Joaquín Sánchez.

... a Oscar Albentosa García, por todo.

... a nuestra familia, por todo y más.

... y a las instituciones (junto con quienes trabajan en ellas) que hemos consultado:

Filmoteca Nacional, Filmoteca de Barcelona, Filmoteca de Valencia, Hemeroteca Municipal Conde Duque de Madrid, Biblioteca Nacional, Archivo de Compositores Vascos [ERESBIL], Centro de Documentación Musical de Madrid, Diputación Foral de Navarra , Fundación Juan March, Fundación Autor, IICMU, SGAE. 
Presentación a la investigación ......................................................... 13

Delimitación del corpus ............................................................... 14

Objetivos de la investigación ................................................................15

Hipótesis de trabajo y metodología .................................................16

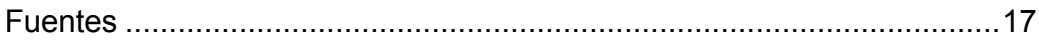

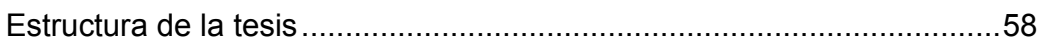

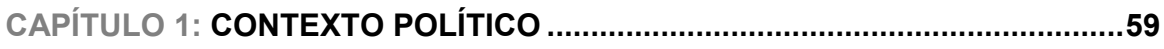

El asentamiento de los estamentos franquistas .................................61

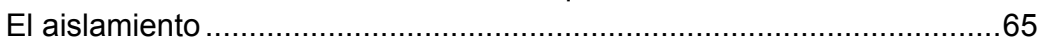

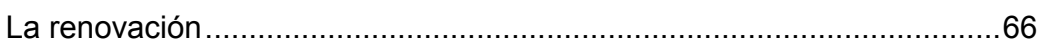

CAPÍTULO 2: CONTEXTO JURÍDICO ...........................................................69

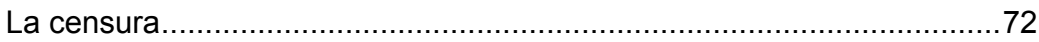

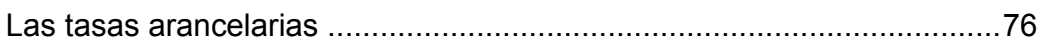

La importación de películas .......................................................... 78

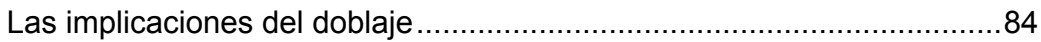

Créditos y Premios Cinematográficos ............................................... 88

La regulación de la programación ...................................................89

Otras reglamentaciones ............................................................ 91

El Noticiario Cinematográfico Español ................................................93

El Círculo de Escritores Cinematográficos ...........................................95

El Instituto Cinematográfico Español.................................................98

CAPÍTULO 3: CONTEXTO CINEMATOGRÁFICO...........................................103

Etapas en la producción cinematográfica..........................................106

Los géneros en el cine español de los años cuarenta..........................107

La incidencia de las clasificaciones en los géneros .............................121

Producir para importar.............................................................126

La importación de películas y su repercusión

en la producción cinematográfica ...................................................132

CAPÍTULO 4: EL CINE Y LA MÚSICA.........................................................147

El cine y la música de cine .......................................................150

La música de cine en España ..........................................................157

CAPÍTULO 5: LOS COMPOSITORES EN EL CINE ESPAÑOL ..........................167

Tipologías musicales en las películas .............................................169

Relación de compositores y actividad musical desempeñada................175

Componer música para el cine en España........................................185

Los compositores y los prácticos .......................................189

Tiempo limitado para componer ........................................191

Recursos técnicos limitados .......................................... 194

Dos tipologías musicales........................................................... 199 
Objetivos 243

Características y funcionalidad de MCE40 ....................................... 244

Modelos de acceso a la información .................................................. 246

Acceso a la información del Administrador ......................................... 246

Fichas Catalográficas e Informes .................................................. 247

Acceso a la información del Usuario...................................................... 283

Fichas Catalográficas e Informes .................................................... 285

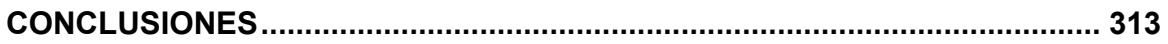

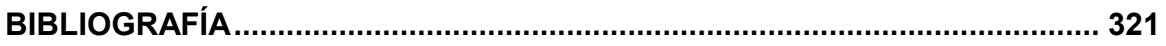

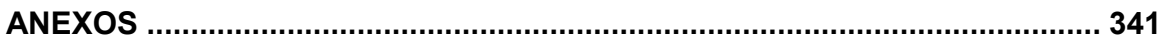

ANEXOS I: Entrevistas ................................................................. 343

ANEXOS II: Gobiernos franquistas ................................................... 403

ANEXOS III: Legislación ......................................................................... 409

ANEXOS IV: I Certamen Cinematográfico Hispanoamericano ......................... 533

ANEXOS V: Premios del Círculo de Escritores Cinematográficos ................... 545

ANEXOS VI: Bases de Datos en Internet .................................................. 551

ANEXOS VII: «Método de Análisis de la Música Ciinematográfica» Josep Lluis I Falcó.............................................................. 575

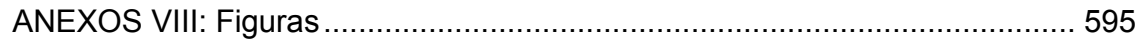

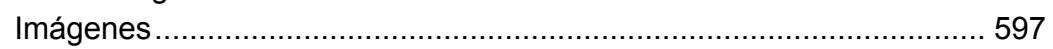

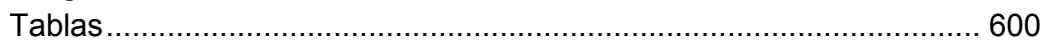

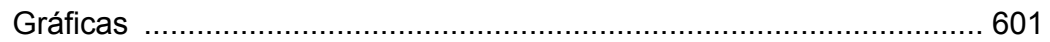

Ilustraciones ......................................................................... 601

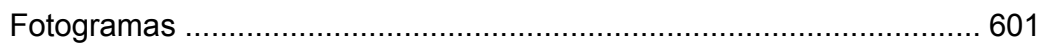


INTRODUCCIÓN 


\section{Presentación a la investigación}

La elección de la música de cine español de los años cuarenta como objeto de este trabajo de investigación responde a varios impulsos. El primero y más importante es el personal, desde que tenemos uso de razón nuestra vocación musical ha pasado primero por el aprendizaje del violín y, tiempo más tarde, la pertenencia a diversos grupos instrumentales y vocales. En segundo lugar, por la fascinación que para nosotros tiene el cine como espectador y como investigador.

La música de la década de los cuarenta resulta para nosotros fascinante. A medida que nos íbamos adentrando en el estudio de la música de cine de la época, descubríamos cuanta riqueza expresiva, tonal estaba contenida en esa música. Algunos de los compositores como Parada, Quintero o como Leoz eran comparables en calidad musical y técnica con los mejores músicos de cine de la industria norteamericana.

Pero quizá el abandono más tremendo se ciñe sobre la actividad artística y creativa desarrollada por los compositores, que dio lo mejor de ellos mismos en unas circunstancias adversas para el desarrollo de su trabajo. Nadie pone en tela de juicio la labor y calidad de nombres tan emblemáticos de la música cinematográfica de Hollywood como Max Steiner, Miklos Rozsa o Erich Wolfgang Korngold, pero nadie recuerda ni se tienen en tan alta estima el trabajo de los compositores españoles como Juan Quintero o Jesús García Leoz, coetáneos a los anteriores, con una producción tan prolija e interesante, que no debería ser despreciada.

Cómo era posible que la historiografía, no les hubiera dado la importancia que su trabajo merecía?

La respuesta no es otra que la falta de interés de las instituciones encargadas de preservar y difundir la labor de estos músicos, quizá en la base se encuentra una característica que, aunque nos pese, sigue arraigada en nuestra cultura y que está relacionada, pensamos, con un mal entendido complejo de inferioridad. Siempre lo mejor y más bueno, es lo que viene de fuera, del extranjero como dirían en la década de los cuarenta. Esta actitud ha favorecido en gran medida el actual deterioro del patrimonio músico-fílmico español y por supuesto el olvido del mismo.

Contra este olvido se levantan algunas voces que intentan con mucho esfuerzo la edición de álbumes dedicados a la recuperación digital de la música de cine español. Quizá, la constancia por hacer realidad un sueño largamente acariciado ha hecho que José Nieto, haya lanzado al mercado tres álbumes, fruto de un proyecto de investigación musical. Este proyecto iniciado con el registro de partituras cinematográficas del maestro Quintero, uno de los maestros más prolíficos de la época, y continuado con García Leoz y Manuel Parada de la Puente se presenta como la punta de un iceberg que debería ser, necesariamente, continuado.

En este sentido, la presente tesis doctoral nace con el afán de continuar la labor de recuperación y porque no decirlo de reivindicación de la labor de unos hombres que musicaron una parte importante de nuestra historia cinematográfica. 


\section{Delimitación del corpus}

En una primera aproximación pensamos delimitar nuestro estudio a la música de cine realizada en la década de los años cuarenta, comprendiendo ésta desde 1940 a 1950. A medida que fue avanzando nuestra investigación, especialmente en los aspectos políticos y jurídicos relacionados con el desarrollo de la industria cinematográfica de la época, nos vimos obligados a ampliar nuestra investigación al año 1939 por razones obvias relacionadas con el fin de la guerra civil que supuso un doloroso punto de inflexión en la historia de nuestro país. Por otra parte, cuando nos vimos obligados a estudiar el contexto legislativo promovido por el primer gobierno franquista referente a la industria cinematográfica de la época, nos encontramos con un entramado político y jurídico construido ya anteriormente. De hecho, la primera orden ministerial que afecta a la cinematografía española es de fecha 2 de noviembre de 1938. Firmada por Serrano Súñer, esta orden regulaba para el Bando Nacional las atribuciones de la Junta Superior de Censura Cinematográfica, desgraciadamente esta legislación acabó por aplicarse a todo el estado español como consecuencia de la victoria franquista. Recién terminada la guerra, el 24 de noviembre de 1939 se crea por orden ministerial el Departamento de cinematografía, dependiente de la Dirección general de propaganda, cuyas competencias incluirán la tramitación de los permisos de rodaje.

Otra razón que tenemos que considerar es que la industria cinematográfica no dejo de funcionar durante la contienda, realizándose fundamentalmente cortometrajes propagandísticos tanto en el bando nacional como en el republicano. Por lo que respecta a la ficción y según datos obtenidos de la Filmoteca Nacional ${ }^{1}$ en el año 1939 se produjeron un total de 12 películas: cinco comedias (Amores de juventud, La linda Beatriz, La tonta del bote, Los cuatro Robinsones, Los hijos de la noche) , 5 dramas (El genio alegre, El rey que rabió, La canción de Aixa, Manolenka, Santa Rogelia), un musical (Mariquilla Terremoto) y un film histórico (Sierra de Teruel). Así pues, para entender el desarrollo de la industria cinematográfica española de la década de los cuarenta era necesario retrotraernos a 1938 y 1939.

El corpus total de películas con las que hemos trabajado en esta tesis asciende a 478, incluyendo las realizadas entre 1939 y 1950 . Constituyen el primer objeto de estudio porque las películas son el ámbito natural en el que se desarrolla la actividad creadora de los compositores, objeto de nuestra investigación.

El número total de compositores que desempeñaron algún tipo de actividad musical en el cine de la época, asciende a 288. Además hemos considerado necesario incorporar al corpus, los 60 autores de las letras de las canciones que forman parte de la banda sonora de las películas de referencia, fundamentalmente, por la estrecha relación que mantuvieron con los compositores.

Pero como de reconstruir la memoria de un periodo histórico se trata y más concretamente de la memoria de los compositores, hemos trabajado también con un total

\footnotetext{
${ }^{1}$ Los datos incluyen año de producción, fecha de estreno, guión y otros datos técnicos. MINISTERIOR DE EDUCACIÓN Y CIENCIA, Cinematografía. http://www.cultura.mecd.es/cine/jsp/plantillaAncho.jsp?id=13 [enero de 2003].
} 
de 564 documentos. En general se trata de documentos únicos, de carácter privado que han ido apareciendo a lo largo de nuestra investigación, algunos de ellos inéditos.

Algunos de estos documentos están íntimamente ligados a las biografías de los compositores, otros como las 14 partituras manuscritas de Juan Quintero Muñoz que nos proporcionó su viuda nos permiten reconstruir la personalidad musical del maestro ceutí.

\section{Objetivos de la investigación}

A la hora de abordar nuestra investigación se buscó reunir una parte de documentos de la época que pudieran darnos una visión lo más amplia y completa del objeto de estudio propuesto. El resultado fue la búsqueda incansable durante cuatro años por filmotecas, archivos y bibliotecas públicas. Esto nos hizo constatar una idea que de antemano teníamos preconcebida: la poca bibliografía existente al respecto. En una conversación mantenida con Juan Ángel Sáiz y José Nieto, compositor de música para el cine e investigador preocupado por la recuperación del patrimonio fílmico español nos alertaron sobre las pistas a seguir. En primer lugar, nos dirigimos al SGAE de Valencia y luego de Madrid, donde, aunque parezca mentira, poca información nos proporcionaron sobre nuestro objeto de estudio, la música de cine en España. En segundo lugar, hicimos un rastreo de los familiares y herederos de los compositores con el fin de que tuvieran a bien recibirnos y poder explicarles en persona los objetivos de nuestra investigación. La reacción fue de lo más positiva en todos los casos. Así que nos pusimos manos a la obra y concertamos una serie de entrevistas y conversaciones telefónicas con: Francisca Martos (Juan Quintero Muñoz), Manuel Halffter (Ernesto Halffter), Josefina Rebollo (Modesto Rebollo Pata), José Luis García-Leoz (Jesús García-Leoz), Antonio Durán Barbá (Juan Durán Alemany), Manuel López-Quiroga Clavero (Manuel López-Quiroga Miguel), Ma Reyes Elicegui Cans (Manuel Parada de la Puente), Ma Josefa Cebrián Collado (Miguel Ansis Arbó), Pilar Ruiz Gómez (José Casas Augé), Juliana San José de la Fuente (Ramon Ferrés Mussolas), Ma Jesús Guridi Ispizuea (Jesús Guridi), Ernestina Martínez Quintela (Federico Martínez Tudó), Luis Fernando Moraleda Barhona (Fernando Moraleda Bellver), Ernestina Muñoz Cruz (José Muñoz Molleda), Francisco Ruiz de Azagra Sanz (José Ruiz de Azagra), Luisa Casarrubios Lechuga (Gabriel Salvador Ruiz de Luna Arroyo), Antonio de León Arias de Saavedra (Rafael de León), Pilar Arrieta Moreno Torroba (Federico Moreno Torroba), Blanca Celia Solimano maiztegui (Isidro Buenaventura Maiztegui Pereiro).

A estos encuentros habría que sumar los mantenidos con distintas personalidades vinculadas a la industria cinematográfica y del mundo académico que han desarrollado una importante labor en el terreno que nos ocupa. De este modo contactamos con: José Luis Borau (director, guionista y productor de cine), Juan Mariné (director de fotografía y restaurador), José Nieto (compositor), Julio Arce (musicólogo), Ricardo Bayon (orquestador y arreglista), José Antonio Nieves Conde (director), Imperio Argentina (actriz y cantante), Amparo Rivelles (actriz), José Luis Berlanga (director), Cristóbal Halffter (compositor), Concha Figueras (restauradora), Josep Lluis i Falcó (Universidad de Barcelona), Alfrendo Morán (investigador), , Julio Pérez Perucha (investigador), Ana Vega Toscano (locutora y musicóloga), Juan Miguel Company (Universitat de Valencia), Roberto Portillo (Fundación 
Autor), Carlos Javier Pellejero (Servicios Culturales, Diputación de Navarra), Vicente Ponce (Universidad Politécnica de Valencia).

\section{Hipótesis de trabajo y metodología}

El resultado de varios viajes por la geografía española con el fin de ir completando nuestra investigación, fue muy esperanzador. De pronto nos vimos con una cantidad ingente de documentos, mayor del que esperábamos. Fotografías, partituras, programas de manos, guiones musicales manuscritos, invitaciones personales, etc....

Después de esta alegría inicial, se nos planteaba un problema: qué hacer con toda esa documentación, como conservarla, como ordenarla y dónde guardarla. Así pues, nos planteamos como objetivo primero la digitalización de todos los documentos que estaban en nuestro poder. Una vez digitalizados los mismos, y dado que la naturaleza de éstos era heterogénea (textos, fotografías, partituras, registros sonoros,...) emprendimos la tarea de implementar una base de datos de características multimedia que permitiera acceder a los documentos y poder visualizar y/o escuchar los mismos. De este modo tendríamos la posibilidad de generar una base de datos que nos permitiría proceder al análisis de la actividad musical desarrollada para el cine de la época.

Después de realizar un análisis del software disponible en el mercado, decidimos utilizar el Microsoft Access 2000, las razones se explican con mayor nivel de detalle en el capítulo 6 de esta tesis. Para el desarrollo de la base de datos multimedia se tuvieron en cuenta tres aspectos importantes.

La peculiaridad de las fuentes y documentos que la misma debía gestionar, para lo que fue necesaria la elaboración personalizada de cada una de las fichas catalográficas correspondientes a cada una de las tipologías de documentos: películas, compositores, partituras, discografía, revistas, prensa, fotografías, fotogramas, carteles, legislación. El paso siguiente fue introducir los datos, 1.320 referencias.

Era importante también crear una base de datos con la suficiente flexibilidad para albergar un crecimiento de documentos y ser susceptible de emigrar a otros entornos multimedia como la web.

En paralelo fuimos trabajando distintas ideas relativas al diseño gráfico de la misma. Después de desechar varias opciones, nos centramos en la propuesta más sencilla desde el punto de vista gráfico, ya que no queríamos que el excesivo diseño restara protagonismo a los documentos en sí.

Una vez creada la aplicación multimedia y habiendo introducido en la misma los documentos, se procedió a realizar un análisis en torno a la música de cine de la época y por extensión al cine de la misma.

Cotejados los primeros datos de producción, nos interesaba saber qué factores determinaron que en la década de los 40 se realizaran más de 400 largometrajes de ficción, lo que sin duda era una cifra elevada teniendo en cuenta que el país acababa de salir de la guerra civil y se encontraba al borde de la ruina. ¿Qué papel tuvieron en este 
sentido los permisos de importación y doblaje de películas extranjeras? ¿Cómo afectó la clasificación en los contenidos de las películas, en especial en la evolución de los 'géneros? ¿En qué medida todo el engranaje jurídico emanado de las circunstancias históricas y sociopolíticas del momento, repercutió de un modo directo en el producción cinematográfica y de forma indirecta en la tipología musical compuesta para el cine?

Si tenemos en cuenta el elevado nivel de producción de la industria y la consiguiente demanda de música de cine, podemos afirmar que en los años cuarenta se crea la especialización profesional en este ámbito. ¿Cuáles eran las condiciones técnicas y materiales en las que se desarrollaba la labor de los compositores? ¿Hubo reconocimiento público de su trabajo? ¿La profesionalización repercutió en la elaboración de técnicas y lenguajes afines al medio? ¿Puede hablarse de una homogeneidad musical en el cine de la década de los cuarenta? O por el contrario, ¿la música dentro del relato cinematográfico se individualiza necesariamente, creando cada compositor un estilo personal propio? ¿Podemos distinguir diversidad de estilos musicales?

Nos interesaba saber si el trabajo realizado por los compositores era consecuencia de un proceso previo de reflexión teórica en torno a la música de cine o por el contrario los compositores llegaron a generar una técnica musical sustentada en la observación y la experimentación, sin un planteamiento teórico a priori ¿La labor desarrollada por compositores en el ámbito del cine Hollywoodiense constituyó un punto de referencia para los músicos españoles?

\section{Fuentes}

Dado que nuestro objeto de estudio es la música en el cine español de los años cuarenta, las películas de la época constituyen una fuente de primer orden porque son el ámbito natural en el que se desarrolla la actividad creadora de los compositores, objeto de nuestra investigación. Las películas que estaban disponibles en la Filmoteca Valenciana se han visionado en la moviola que la institución tiene destinada para investigadores, el resto se han visionado en formato vídeo VHS y en DVD.

Una de las primeras fuentes consultadas fueron las revistas especializadas en cine. No se trata de fuentes que vayan a revelarnos las estrategias, los métodos y demás aspectos circundantes al objeto de nuestro estudio, sino, más bien, éstas proporcionan una perspectiva general de la visión que sobre la música de cine se tenía en aquel momento. Como veremos más adelante, el acercamiento a estas publicaciones resultó de lo más sorprendente, puesto que hallamos en sus páginas artículos muy sugerentes en cuyas líneas se plantean debates y teorías que, en un principio, no esperamos encontrar. Igualmente, la presencia de compositores aportando su opinión sobre diversos aspectos de la vida profesional y la industria se reveló como una magnífica fuente para obtener de primera mano las opiniones de los compositores. La importancia de este hallazgo tiene mayor importancia de la que a primera vista pueda parecer. Si tenemos en cuenta que, aún hoy, la atención que la prensa y las revistas especializadas conceden a los músicos de cine es más bien reducida e inexistente, era lógico pensar que en los años 40 ocurriría lo mismo pero la realidad nos demostró lo contrario. 
Las revistas y la prensa de la época nos revelan la repercusión que los compositores y la música de cine tienen en la época. Así pues, hemos considerado necesario el acercamiento a estas publicaciones puesto que en sus páginas hallamos artículos y entrevistas realizadas a los compositores en los que éstos van aportando su opinión sobre diversos aspectos relacionados con la profesión y la industria cinematográfica.

La elección de cuales iban a ser las revistas a estudiar no resultó especialmente difícil. En los años 40 existe una gran variedad de magazines dedicados al séptimo arte, pero pocos presentaban unas características apropiadas, tales como ser de tirada nacional, tener entidad propia, centrar su actividad editorial en la música de cine y tener una repercusión importante. Escasamente tres publicaciones responden a estas cualidades: Primer Plano, RadioCinema y Cámara. Otras como Espectáculo centrada en el mundo de la farándula, aportan datos de interés de menor.

Después de cotejar y examinar, número por número entre 1939 a 1950 de cada una de las revistas mencionadas ${ }^{2}$, obtuvimos más de un centenar de referencias, a las que tenemos que sumar aquéllas que nos fueron proporcionando los herederos de los compositores consultados. Así pues, hemos podido comprobar la importancia y papel que cada una de estas publicaciones desempeñó en el panorama cinematográfico de la época. Así pues, como se pude apreciar en la siguiente gráfica, de Primer Plano obtuvimos un $53 \%$ de referencias frente al $34 \%$ y el $13 \%$ de RadioCinema y Cámara respectivamente. De este modo, queda clara la importancia y repercusión de cada una de las revistas por lo que se refiere a la repercusión que la música de cine tuvo en la época.

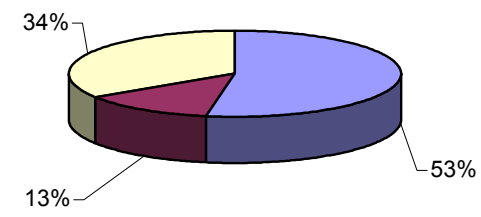

$\square$ Primer Plano $\square$ CÁMARA $\square$ RadioCinema

Gráfica 1: Incidencia de artículos musicales en revistas

La repercusión en todas las revistas mencionadas no fue la misma, como hemos tenido ocasión de comprobar. RadioCinema aporta entrevistas y reportajes especialmente interesantes, Cámara nos resulta interesante aunque sus artículos sobre música de cine en su mayoría son traducciones del inglés o francés y Primer Plano nos ofrece un buen

\footnotetext{
${ }^{2}$ De las copias examinadas de Primer Plano, la depositada en la Filmoteca Española se encuentra en un estado lamentable, por tratarse de la más consultada, mientras que la contenida en la biblioteca de la SGAE, de acceso muy restringido estaba en prefecto estado.
} 
número de referencias directas, 39, y un nutrido grupo de artículos relativos a aspectos técnicos del sonido, entrega de premios y debates diversos.

La salida al mercado de Primer Plano se produjo el día 20 de octubre de 1940 y se mantendrá en los quioscos hasta mediados de los años 60. Su influencia, durante los primeros diez años de existencia, resultó crucial dentro del mundo intelectual y cinematográfico. De hecho nos parece suficientemente significativa la definición que da José Enrique Monterde cuando comenta que:

“...el lugar ocupado por Primer Plano en el marco del aparato cinematográfico estatal del primer franquismo. No cabe ninguna vacilación en considerar este magazine como una muestra inequívoca del oficialismo cinematográfico, inserto en la llamada prensa del 'Movimiento', y como tal controlada desde las altas instancias del Régimen; de hecho se trataba del portador cinematográfico del franquismo instalado en el poder, en una forma equivalente - salvando las distancias, por supuesto - a lo que representaba Cinema en el ámbito del estado mussoliniano. ${ }^{3 "}$

Compartimos las consideraciones anteriores pero aún así consideramos que para nuestro objeto de estudio, la música de cine español de los 40 , tiene un indiscutible valor a pesar de la manipulación a la que se refiere Monterde. Encontraremos desde artículos y debates en torno al cine musical autóctono, buscando sus raíces en el folklore o la zarzuela y el Género Chico, pasando por amplios reportajes explicando los sistemas de sonido de las salas, incluyendo entre sus páginas entrevistas a los compositores.

Por su parte, RadioCinema nace con el conflicto de la guerra civil en La Coruña. Dos años más tarde, en 1938 se desplaza a Madrid la redacción del magazine y allí se mantendrá hasta el momento de su cierre en 1963. Al igual que ocurriera con Primer Plano, RadioCinema tendrá su momento de esplendor en la década de los cuarenta y supondrá, en cierta medida, una alternativa a la revistas institucionales. Manteniendo un cierto rigor pero sin pretender abordar temas de gran altura, la revista rápidamente se hará un lugar en el mercado editorial. Sus contenidos serán de lo más variado y poco a poco se acercará a la "prensa rosa", característica principal que la diferenciará de Primer Plano.

Cámara, se presenta como una mezcla de revista del corazón, moda y cine. Hace acto de aparición en 1941, un año después de Primer Plano, y en un primer momento su aparición será mensual para pasar a quincenal rápidamente. Su desaparición tendrá lugar en 1952, a los once años de haber nacido. Su formato llama la atención por su reducido tamaño con respecto a los magazines de la época. Parece más un libro que una revista. Sus contenidos son más prosaicos y de menor interés. En su maquetación abundan las imágenes y el texto se queda en un segundo lugar, por lo que los contenidos aportados por esta publicación son de segundo orden.

Cine Experimental se presenta como una rareza dentro del mundo editorial pero al mismo tiempo nos da una valiosa información sobre la otra cara del cine de la época.

\footnotetext{
${ }^{3}$ Monterde, J. E. (2001) "Hacia un cine franquista: La línea editorial de Primer Plano entre 1940 y 1945», en La herida de las sombras. El cine español en los años 40, Madrid, Academia de las Artes y las Ciencias Cinematográficas de España, AEHC.
} 


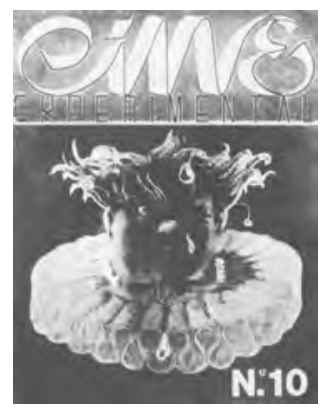

Imagen 1: Portada de Cine Experimental

Frente a la frivolidad de algunas de las revistas anteriormente comentadas, Cine Experimental aborda temas de gran calado relacionados con la industria cinematográfica.

En un principio la dirección de la misma correrá a cargo de Victoriano López aunque a partir del número 7 se hará cargo de la misma Serrano de Osma, dando un aire menos austero a la revista, que cerrará a los dos años de su nacimiento, en 1946.

A partir de 1949 la revista Primer Plano abre una serie de artículos ${ }^{4}$ destinados a explicar la historia y funcionamiento de algunos sistemas de registro de sonido contemporáneos, tanto extranjeros como nacionales lo que pone de manifiesto el interés que la técnica llegó a despertar en aquellos días. No debemos olvidar, que precisamente, el sonido estereofónico nace para el cine con el estreno de Fantasía (1941) de Walt Disney, convirtiéndose en toda una revolución, similar al acaecido años más tarde con la llegada del Dolby Stereo en los setenta o el THX en los noventa. Como toda innovación en los sistemas de sonido, su influencia en la música de cine es inevitable en cuanto implica mejoras en los registros musicales y su repercusión en la percepción por parte del público de la música en las películas.

La música nos pone en situación ${ }^{5}$, publicado el 27 de julio de 1941, es un artículo escrito por Herbert Stothart, director musical de la Metro Goldwyn Mayer y conocido por sus partituras para películas como El mago de Oz (1938) o Ser o no ser (1942). A lo largo de estas líneas, el maestro hace un poco de historia y pone de manifiesto que todavía la composición para cine no ha creado por el momento un lenguaje y un código definitivos. Por último, acaba explicando someramente los pasos seguidos por él para la conclusión de una banda sonora.

El artículo La música en el cine ${ }^{6}$ reflexiona sobre un tema singular y llamativo. La creación de "películas concierto" con los mejores nombres de la escena mundial dentro de

\footnotetext{
${ }^{4}$ Saínz de LA Hoya, R. «Sistema de sonido "Fantasía” de RCA», en Primer Plano, año X, núm. 452, 12 de junio de 1949.

${ }^{5}$ Stothart, H. «La música nos pone en situación» en Primer Plano, año II, núm. 41, 27 de julio de 1941.

${ }^{6}$ «La música en el cine», en Primer Plano, año XI, núm. 520.
} 
la música clásica: directores de prestigio, intérpretes, etcétera. En el artículo, Antonio de las Heras nos dice:

"Desde que el cine se hizo sonoro -afirma-, la aportación de melodías, ritmos y fondos musicales ha sido casi obligado para los directores ansiosos de dar una mayor profundidad artística a sus producciones. Con este criterio se han hecho, a no dudar, muchos aficionados a la música, que luego ampliaron sus conocimientos en el mundo apropiado, y necesariamente fueron a buscar los conciertos sinfónicos o los solistas virtuosos ${ }^{7}$ ".

Como sospechábamos, cuando preguntamos sobre dichas producciones, ninguno de nuestros entrevistados había oído hablar de ellas, por lo que tan solo se queda en una idea "interesante" que seguramente nacería a raíz del estreno de Fantasía (1941).

Abel Gance, famoso director francés que se hizo mundialmente famoso por su visión personal de la figura del dictador francés, Napoleón, realiza un magnífico retrato del compositor Arthur Honegger, con quien trabajó en numerosas ocasiones, incluida su "Napoleón". A través de estas líneas se puede percibir la simpatía y respeto del director por su músico y la presencia de este artículo denota, cuanto menos, algún interés, por parte de la directiva de la revista mostrando aspectos vinculados a la música de cine. El artículo, en esta ocasión, no se trata de una traducción ${ }^{8}$ sino de un texto encargado con ocasión de la visita a nuestro país del director francés.

La música de la última"Carmen no es de Bizet ${ }^{9}$ es otro ejemplo de texto traducido para Cámara, a partir de material cedido por un periódico norteamericano. Mario Castelnuovo-Tedesco, compositor de amplio renombre que sería maestro de grandes compositores del cine norteamericano como John Williams o Jerry Goldsmith, es presentado como el autor de la partitura de una versión moderna de Carmen, en la que el compositor rechaza adaptar la música de Bizet a favor de una propia de aires andaluces e hispanos.

Para la misma revista se traduce otro interesante artículo en que se efectúa un repaso a los distintos procedimientos realizados en el Hollywood de la Edad de Oro en la creación de la música. Para la ocasión se toma la figura de Alfred Newman, que aparece en las fotografías que ilustran el texto. Dichas fotografías aparecen también en el artículo aparecido en RadioCinema titulado La preparación de la música para películas ${ }^{10}$, cuyo contenido es parecido al anterior, aunque en nuestra opinión, parece más un resumen del ya citado.

Como hemos comentado anteriormente, la presencia de la música clásica en el cine se convierte en tema recurrente y de debate, junto a la "polémica" suscitada tras el estreno de la película Vuelan mis canciones (1940) de Willy Forst, que supuso todo un éxito de taquilla y un fenómeno social. Este gran éxito trajo consigo el interés de "intelectuales"

\footnotetext{
${ }^{7}$ Heras, Antonio de las. «La música y los músicos en el cine». Primer Plano, año II, número 59. 30 de noviembre de 1941.

${ }^{8}$ En la entrevista que mantuvimos con Juan Mariné, nos confesó que nunca había oído hablar de estas películas, aunque sí recordaba conciertos de música de cine efectuados en Barcelona. [ver anexo de entrevistas].

9 «La música de la última "Carmen”, no es de Bizet», en Cámara, año VIII, núm. 139, 15 de octubre de 1948.

${ }^{10}$ «La preparación de la música para películas», en RadioCinema, año V, núm. 97, 29 de febrero de 1944.
} 
que vieron en este nuevo "género" musical un medio de educar musicalmente a las grandes masas.

Resulta altamente sorprendente el elevado número de escritos que sobre este tema se llegan a publicar en la época, lo que ponen de manifiesto las revistas de la época es la necesidad de reivindicar un género musical de raíces propias, tanto en los aspectos puramente musicales como en los argumentales, recurriendo como es menester a la propia "cosecha" de compositores nacionales como Albéniz. Otros incluso atacan los ritmos modernos empleados en algunas películas.

\begin{abstract}
"Poco a poco van desapareciendo - se alegra Manuel Pastor - las estridencias y desacordes del saxofón y del 'jazz' como símbolos de lo excéntrico y ultramoderno, sin emotividad y sin delicadas expresiones, para dejar paso al gran género musical de los más renombrados maestros de la composición. ${ }^{11 "}$
\end{abstract}

Es importante reseñar en este momento, el sentimiento encontrado que hacia el folklore y la canción española (identificada con el andalucismo) se respira es estas páginas. En un primer momento se rechaza el folklore, identificando éste con lo que se dará en llamar "españolada", reprobado por las altas esferas del Régimen pero adorado por el público como recuerda José Luis Borau:

"Cuando sí gustó el cine español fue antes de la Guerra Civil. Aquellas películas de CIFESA de Florian Rey con Imperio Argentina y Miguel Ligero fueron grandísimos éxitos. Nobleza baturra (1935), La verbena de la Paloma (1935), etc.. ${ }^{12 ،}$

Pocos eran, en los medios oficiales, quienes se atrevían a levantar lanzas a favor de este tipo de cine. Como ya observamos, Imperio Argentina ${ }^{13}$ no tiene reparos en defender esta postura. Igual hará, a comienzos de la década de los cincuenta, Pier Vanni Bobbio $^{14}$ en una visita realizada a nuestro país en el que muestra su agrado por la canción española. Por el contrario, son numerosos los defensores de la utilización comedida de dicho folklore en pos de un mayor empleo de la zarzuela y el Género Chico como fuentes de referencia para la creación y desarrollo de nuestro musical cinematográfico.

Francisco Casares defiende en la revista RadioCinema, que en:

“...el extranjero se realizan constantemente películas inspiradas en las grandes óperas de fama universal. Nosotros tenemos un tesoro propio ni imitado ni imitable fuera de nuestros ámbitos: la Zarzuela. $Y$ en términos generales, el género chico. El éxito, tan excepcional como merecido, aunque se le hayan negado refrendados que parecían inexcusables, de 'La

\footnotetext{
${ }^{11}$ PASTOR, M. «El cine y la música». RadioCinema, año II, número 34. 15 de agosto de 1939.

${ }^{12}$ Entrevista con José Luis Borau. Madrid, 25 de julio de 2003.

${ }^{13}$ FERnÁndeZ BARREIRA, F. «Yo se lo que costó levantar el cine español, hoy próspero». Primer Plano, año $V$, número 180. 26 de marzo de 1944.

14 «Es una lastima que en España no se hagan más películas musicales». Primer Plano, año XII, número 594. 2 de marzo de 1954.
} 
Revoltosa', convertida en producción cinematográfica, confirma esa aseveración. ${ }^{15,}$

Y Núñez Polo un año antes expone en Cámara que:

“...indudablemente, podrían llevarse al cine las notas de nuestros Barbieri, Chueca, Chapi de ayer; o las de Serrano, Alonso, Moreno Torroba, Sorozábal, de hoy. Sería interesante el emprender tal empresa con seriedad y decisión. Claro que harian falta guiones, adaptaciones inteligentes, $y$ esto nos trae a la memoria que no hace mucho el Sindicato Nacional del Espectáculo convocó un concurso, precisamente de guiones de Zarzuelas y ... fue declarado desierto. ${ }^{16 "}$

Según estas últimas palabras, la falta de guiones buenos es considerada la razón fundamental del fracaso del cine musical español. Es entonces, tras la sombra de la ya cintada cinta de W. Fost, que las vidas de los compositores se convierten en fuente de inspiración y de reclamo para el público. Consecuencia de las misma es la película Sarasate (1941), dirigida por Ricardo Bruch.

Luis Gómez Mesa, afirma en 1941, en plena fiebre musical, que:

"...en la biografía de un músico famoso siempre hay motivos suficientes para idear y realizar una película interesante. Lo fundamental es que el autor que cumpla ese cometido sepa hallar en la personalidad elegida sus facetas más inspiradas $y$ atrayentes $y$, concluido este trabajo preparatorio - descubridor $y$ documentado -, adaptarlo a las peculiaridades del cine. ${ }^{17,}$

y concluye afirmando que

“...el día que en el panorama de nuestro cine aparezca una película biográfica de un gran músico español, compuesta con 'ritmo, melodía y armonía', como ordenaba Schubert a sus discípulos para la interpretación de sus obras y obedeció Willy Forst en Vuelan mis canciones en la imagen y en el fondo; ese acontecimiento señalará la hora triunfal de nuestra producción filmica... ${ }^{18 "}$

Por otro lado, en un extenso artículo publicado en Primer Plano bajo el título ¿Se puede, por un efecto espectacular hacer de una vida una ficción $?^{19}$, se arremete contra el "falseamiento" de una biografía a favor de un argumento idóneo e interesante para el público, desposeyendo de este modo, al cine, de una de sus principales armas, la dramatización.

\footnotetext{
${ }^{15}$ CASARES, F. «Nuestro género lírico y el cine nacional». RadioCinema, año XII, número 171. septiembre de 1950.

${ }^{16}$ NúÑEZ POLO. «Los films musicales». Cámara, año IX, número 159. 15 de septiembre de 1949.

${ }^{17}$ Gómez MeSA, L. «Futuro de la película musical española». RadioCinema, año IV, número 70.30 de octubre de 1941.

${ }^{18}$ Ibídem.

${ }^{19}$ CASTÁn PALOMAR, F. «¿Se puede, por un efecto espectacular hacer de una vida una ficción», en Primer Plano, año IV, núm. 124, 28 de febrero de 1943.
} 
La cantidad de artículos publicados al respecto no dejan de fluir, especialmente durante los primeros años cuarenta, siendo RadioCinema la publicación que más interés parece mostrar sobre esta polémica, convirtiéndose en la principal fuente de ellos.

Por último, la incorporación de comentarios de compositores de gran prestigio internacional, como Bernard Herrmann, en artículos sobre la música para la imagen se pueden leer en artículos como, La música en las películas ${ }^{20}$, donde se traducen unas declaraciones realizadas por el maestro neoyorquino, acerca de la interacción entre música y cine. Se puede decir que a excepción de García Leoz o Ruiz de Azagra, en España parece no existir preocupación alguna por teorizar sobre la música de cine.

La música de los años cuarenta, y principalmente las comedias de la primera mitad de la década, está imbuida de las tendencias musicales del momento. Autores como Durán Alemany se hicieron muy conocidos gracias a canciones populares, muy alejadas de la copla y la canción española. No solo hicieron fortuna y alcanzaron popularidad sino que además, crearon todo un estilo de musicar para un determinado género, como fue la comedia de comienzos de la década. Estas tendencias musicales introducidas por autores como Durán Alemany, Augusto Algueró, Ruiz de Azagra, etc., se convirtieron en foco de atención para publicaciones como Cámara y Primer Plano.

Si bien en Cine con melodías de "swin" ${ }^{21 "}$ se recrea el autor en hablar del cine americano propagandístico de la II Guerra Mundial con las chicas pin-up al ritmo de esta música, en la doble página que contiene Cine en $\mathrm{Jazz}^{22}$ se hace un repaso a la historia del jazz en el cine norteamericano.

Cabe destacar la publicación de la letra de uno de los grades éxitos del momento, $P U-P U-P I-D U$, que lanzó a la fama tanto la película para la que fue compuesta, El difunto es un vivo (1941), como a su compositor. La pieza es un claro exponente de las canciones de moda que harían acto de presencia en gran parte de la producción de comedias. Incluso autores como Juan Quintero Muñoz, identificado por el gran público por sus trabajos sinfónicos para las grandes producciones históricas de finales de los cuarenta y principios de los cincuenta fue todo un experto en este tipo de piezas, por las que tenía especial interés.

\footnotetext{
${ }^{20}$ Antequera, J. A. «La música en las películas». Primer Plano, año VIII, número 341. 27 de abril de 1947.

21 "Cine con melodías de "Swin”, en Cámara (1946)

${ }^{22}$ Margueríe, A. «Cien en "jazz”», en Cámara, año VI, núm. 85, 15 de julio de 1946.
} 


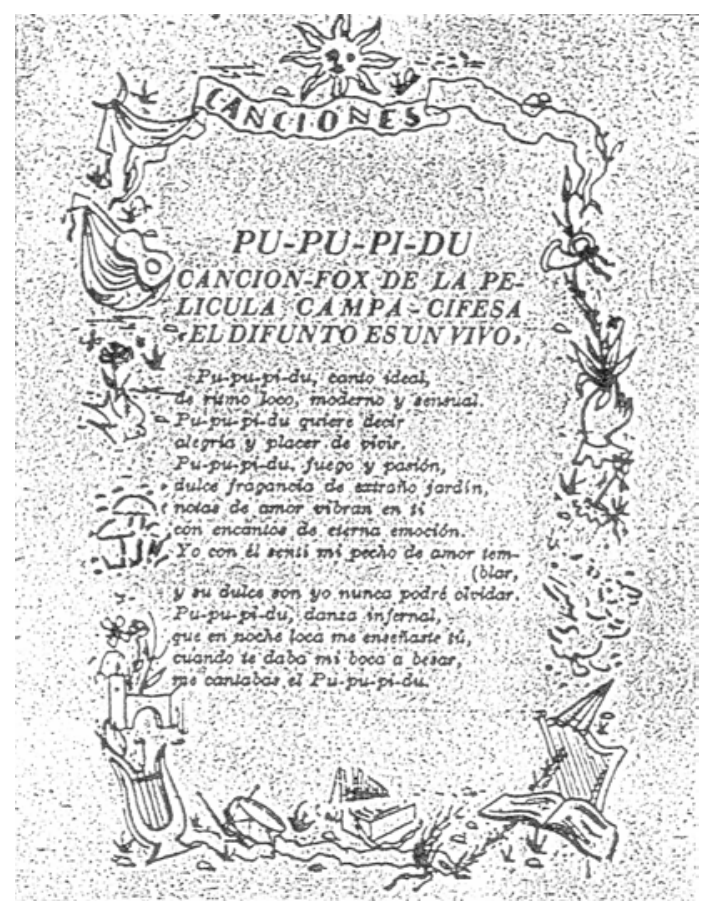

Imagen 2: Letra de la canción "Pu-pu-pi-du”. Primer Plano, 1 de enero de 1942

Aunque distanciadas en el tiempo, el número de entrevistas localizadas en las revistas de la época no es nada desdeñable. Especialmente significativa será una sección de Primer Plano titulada "2 minutos en la calle con..." donde el periodista Castán Colomar efectúa numerosas "microentrevistas" a técnicos y artistas. Entre los maestros entrevistados destacan el maestro Alonso, Conrado del Campo, García-Leoz, Montorio y Moraleda. Los temas a tratar en ellas resultan de lo más dispar, y estando supeditadas al personaje en cuestión. Si a Moraleda se le pregunta por su afición a los toros y el pasodoble; Montorio muestra su interés por componer canciones y su adversión hacia la música de fondo (mostrando una falta total de conocimiento sobre teoría musical en el cine al quejarse de su poca repercusión en el público); Conrado del Campo expone su interés por la música de cine y su pasión por la música castellana pero se queda sin aportar nada nuevo, a pesar de tratarse del compositor más influyente del momento. Su puesto en el Conservatorio Superior de Madrid le convirtió, por capricho del destino, en maestro y mentor de casi la totalidad de los compositores que decidieron dedicarse al cine; el Maestro Alonso por su parte aporta un poco de luz sobre el sistema de composición utilizado por él para la sincronización de la música con las imágenes aunque reconoce su preferencia por la zarzuela frente al cine.

El caso de García Leoz es sumamente interesante. Durante toda la década va a gozar de gran prestigio. Esta circunstancia va a favorecer la aparición de un nutrido número de artículos y entrevistas. A lo largo de estos interesantes reportajes, el maestro expondrá 
con claridad sus opiniones sobre la creación de nuevo género y estilo de música para el cine, los problemas que acuciaban a la industria cinematográfica como la falta de medios, las posibilidades coestructuradoras de la música con la imagen en movimiento, y un largo etcétera.

Durán Alemany, Rafael Martínez y Ruiz de Azagra defenderán la profesión de músico de cine y la necesidad de que su trabajo se valore y reconozca por su valor artístico e importancia en el conjunto del engranaje industrial.

Debido al género de películas en la que participaron durante la primera mitad de la década, comedias alocadas, donde la presencia de música "moderna" era muy habitual, estos autores se ven normalmente asediados sobre preguntas alrededor del papel desempeñado por estas canciones en las películas, tanto a nivel narrativo como comercial.

Es muy curioso observar en estas crónicas como se llega a abordar el tema de las grabaciones en disco de los grandes éxitos del cine, incluso la inclusión de letras de canciones como la del Pu-pu-pi-dú, compuesta por Durán Alemany.

Manuel Parada por su parte, se mantiene normalmente alejado de la prensa, aunque no es difícil encontrar fotografías de él en reportajes sobre estrenos cinematográficos. Tampoco es extraño que se le pregunte sobre algún estreno o partitura para dar su opinión, pero en conjunto no se encuentran prácticamente entrevistas ni monográficos del maestro.

En cuanto a Juan Quintero Muñoz, a pesar de gozar del apoyo y respeto de la industria, no parece interesar a la prensa especializada de la época. Salvo alguna que otra entrevista de poca relevancia, su nombre solo resuena en la sección de cotilleos. Encontramos referencias con fotografías en cafés junto a su esposa, Francisca Martos, y a su inseparable amigo Juan de Orduña, para el que compuso la música de la mayor parte de sus películas.

Tanto en Primer Plano como en RadioCinema se encontraron multitud de pequeños artículos donde se pedía la opinión de varios músicos con respecto a un tema de actualidad musical o cinematográfico que podía ir desde las películas musicales, pasando por los problemas que acuciaban a la música de cine, hasta su opinión respecto a un estreno determinado. La imagen siguiente muestra una doble página de la revista RadioCinema; bajo el título La música en el cine para 1947, aparece un artículo que recoge la opinión de los compositores Jesús Guridi, Ruiz de Azagra, López-Quiroga, García-Leoz, Quintero y Parada sobre el futuro de la música de cine. 


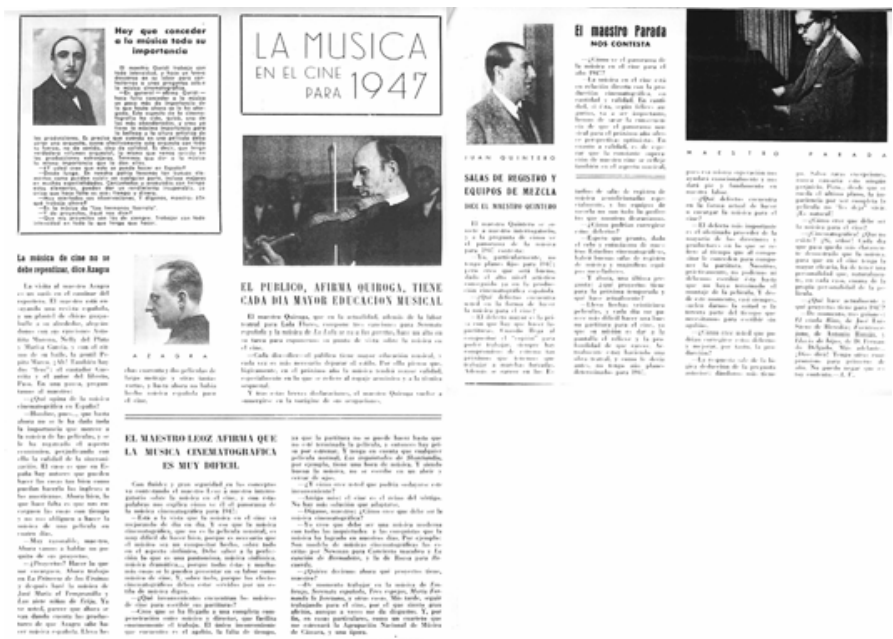

Imagen 3: RadioCinema, año VIII, núm 130, 1 diciembre 1946

Otras revistas contemporáneas especializadas que incorporan artículos de música de cine han sido incluidas en la base de datos MCE40. Rosebud Banda Sonora o Música de cine $^{23}$, ambas ya veteranas en el ámbito nacional, y otras de carácter más generalista como Fotogramas o Archivos de la Filmoteca.

Música de Cine, publicada en Valencia, tiene una vida de apenas cinco años. Dirigida a los aficionados a las bandas sonoras, en sus filas encontramos a colaboradores como Joseph Lluis i Falcó, Alejandro Pachón o Federico Torres entre otros. En sus páginas no hemos encontrado mucho material vinculado al objeto de nuestra investigación salvo un artículo de Joseph Lluis i Falcó sobre la obra de Manuel Parada y otra reseña acerca de la partitura de José Nieto compuesta para la restauración de La Aldea Maldita.

Rosebud Banda Sonora, sale por primera vez en junio de 1996 manteniéndose hasta la fecha (a excepción de un año en que dejó de editarse). Revista pensada para el aficionado a la música de cine, trata en pocas ocasiones el periodo del que nos ocupamos en este estudio, a pesar de lo cual, se trata de una revista de referencia obligada para el coleccionista y aficionado a las bandas sonoras así como investigadores, por el nutrido número de entrevistas a compositores nacionales y europeos principalmente que incorpora en sus páginas. Asimismo tiene entre sus páginas una sección dedicada a la crítica de libros de música de cine que nos parece muy interesante.

Los Archivos de la Filmoteca es una publicación mensual dedicada al cine en general con un nutrido grupo de colaboradores de prestigio en los ámbitos de la crítica

\footnotetext{
${ }^{23}$ Música de Cine mantiene su actividad en dos temporadas. La primera durante últimos años 80 y en su segunda etapa, a los principios de los 90 .
} 
cinematográfica como son José Luis Téllez, Juan Miguel Company, Julio Pérez Perucha, etc.

Resulta evidente la necesidad de seguir buscando información en revistas, tanto de la época como actuales. Pero para ello será necesaria una ardua labor que se puede prolongar indefinidamente, necesitando para ello el apoyo de las instituciones para continuar la labor, como ya apuntamos al comienzo de este apartado.

Dentro de las fuentes consultadas se encuentran los anuarios de cinematografía de 1940, 1941 y 1950. Estas publicaciones contienen una valiosa información acerca de múltiples aspectos técnicos, artísticos e industriales del mundo del cine. Desde listado de películas estrenadas, tanto extranjeras como nacionales, hasta estudios porcentuales de la repercusión de distintos parámetros en la evolución de nuestra industria.

La prensa diaria resulta un magnífico escenario para la comprensión y análisis de una época histórica determinada. El rastreo de los diarios más importantes como "Dígame" o el "ABC" en busca de material alrededor de compositores de cine o acerca de la propia música hubiese significado una tarea titánica para una sola persona por lo que el seguimiento de la prensa fue relativo y motivada, normalmente, por el conocimiento de la existencia de tal o cual artículo. Esto no quiere decir que no se plantee más adelante, cuando se tengan los medios, tiempo y dinero suficiente, realizar dicha labor necesaria e imprescindible.

En la aplicación multimedia que hemos creado y cumplimentado, se presenta casi una cincuentena de artículos, críticas, entrevistas, y referencias variadas a la obra o persona de los distintos compositores del periodo a tratar. Salvo algunas referencias aportadas directamente por nosotros mismos, el material contenido en esta sección ha sido proporcionado por los distintos herederos con quienes hemos mantenido contacto. Especialmente se agradece las aportaciones de don Manuel Halffter, don Antonio Durán Barbá, doña Josefa Rodríguez, don José Luis García-Leoz, don José Luis López-Quiroga Claveño, doña $\mathrm{M}^{a}$ Jesús Guridi, doña $\mathrm{M}^{a}$ Josefa Cebrian, doña $\mathrm{M}^{a}$ Reyes Elicegui y doña Francisca Martos entre otros muchos por su ayuda y entrega incondicional.

Como se puede apreciar en la siguiente tabla, se nota un mayor interés por acercarse a los compositores y su obra por arte de unos pocos diarios en contraposición con el resto. De todos ellos, ABC y de La Prensa muestran un mayor interés por esta disciplina. 


\begin{tabular}{|l|l|}
\hline Nombre de la publicación & \multicolumn{1}{l|}{ Total } \\
\hline ABC & 7 \\
ARRIBA & 1 \\
BARCELONA TEATRE & 1 \\
DIARIO DE NAVARRA & 1 \\
DÍGAME & 2 \\
EL ALCAZAR & 1 \\
ESPECTÁCULO & 1 \\
INFORMACIONES & 2 \\
LA PRENSA & 7 \\
MADRID & 1 \\
MEDITERRANEO & 1 \\
MENAJE & 1 \\
YA & 1 \\
\hline Total general & 27 \\
\hline
\end{tabular}

Tabla 1: Nombre de publicaciones diarias con artículos con referencia a compositores.

La información procedente de los periódicos suele estar vinculada al estreno de alguna película en la que los compositores participaron y siempre que en la misma se haga alusión a la labor de éstos. Para hacer un repaso al contenido de dichas referencias, hemos decidido dividirlas por autores, puesto que, como acabamos de decir, éstos han sido proporcionados, en su mayor parte, por sus herederos y lógicamente tienen relación directa con ellos.

Como ya se comenta en las revistas especializadas, la presencia del maestro Halffter en los medios impresos tuvo mucha repercusión y, en especial cuando se embarcó en la aventura de Bambú (1945). De esta cinta tenemos cinco reseñas de críticas y promocionales de la realización del filme donde se nombra al compositor, más una apreciable entrevista que bajo el título de La personalidad musical de Ernesto Halffter éste da su opinión sobre la música de cine y habla de su labor en dicho medio.

Para completar la información se incluye un par de artículos dedicados a El amor brujo (1949), película inspirada en la obra de Manuel de Falla cuya adaptación y fondos musicales realizó su discípulo Halffter. En ellas podemos encontrar no solo la opinión del propio maestro sino la de autores tan importantes como Regino Sáinz de la Maza, Jesús García-Leoz y Federico Moreno Torroba. 


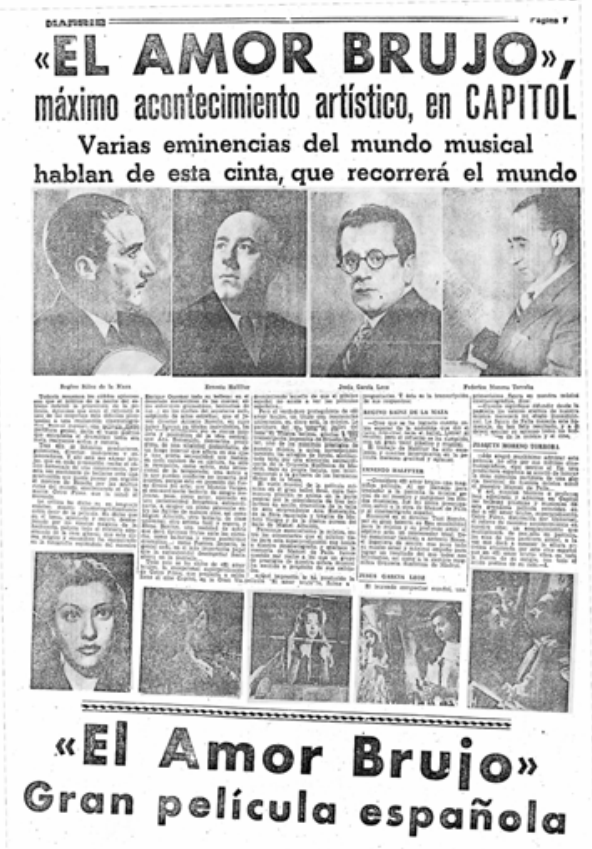

Imagen 4: «El Amor Brujo» Gran película española

Jesús García-Leoz en la actualidad ha sido olvidado, relegado al mayor de los ostracismos, pero en vida gozó de un gran prestigio, tanto para el público como para los compañeros de la profesión. Su labor compositiva no se ciñó solamente al cine. A pesar de haber compuesto una cantidad ingente de largometrajes y películas de cortometraje, su obra para cámara y orquesta sinfónica es inmensa. A través de las reseñas presentadas aquí se puede reconocer el reconocimiento que tuvo. La mayor parte de ellos pertenecen a la noticia de su muerte, venida por sorpresa. Todos los periódicos importantes dieron la noticia y se celebraron conciertos en memoria del maestro. Paradójicamente, en las revistas especializadas consultadas no se hizo mención alguna a su fallecimiento, algo que contrasta con la atención recibida por la prensa diaria.

"Jesús García Leoz muere cuando arribaba a la meseta de su madurez, al logro perfecto de su estilo, cuando se encontraba literalmente rebosante de música, tan rebosante que podía en pocos días borbotar toda una partitura tan rica y sorprendente de poesía, flexibilidad y gracia como la de su «Primavera del portalı. Aún no nos hemos repuesto de la dolorosa sorpresa de la noticia - de su muerte -. [...] Era ante todo, un perfecto artesano, que gozaba con la buena mano de obra. Pero además y por don del cielo un gran artista, un enamorado de la mejor música antigua y contemporánea y un devoto de la 
más alta poesía española que él recreaba en sus obras líricas con penetrante fervor y sensibilidad en carne viva. ${ }^{24 "}$

También se incluye una referencia sobre una noticia acerca de un concierto dirigido por el prestigioso, popular y archiconocido Ataúlfo Argenta donde se interpreta una obra de Leoz:

"Ataúlfo Argenta puso todo su fervor encariñado, su capacidad de gran artista, su gesto más noble también - aquella sobria ofrenda, una y otra vez repetida, que, con un gesto, centraba el homenaje colectivo en la partitura - al servicio póstumo del amigo y colega. Todos cuantos trabajamos con Jesús Leoz, incluso aquellos que no habian logrado su intimidad, le tuvieron que oír, en la temporada última, sus encendidos, ilusionados juicios sobre esta "sonatina" que la Nacional anunciaba desde el principio de la serie para hoy. [...] En su memoria se duplicaron los aplausos. Sin bravos. Sin, incluso, esa vibración que solo el frenesí depara. Con serena, honda redondez; con admiración sincera. Con dolor unánime. ${ }^{25, "}$

También se incluye una doble página aparecida recientemente en el Diario de Navarra a raíz de la entrega a las autoridades del archivo completo de obras del autor con el fin de constituir una fundación para recuperar la memoria de uno de los compositores más importantes de la primera mitad del siglo XX de nuestro país.

Francisca Martos, viuda de Juan Quintero Muñoz, nos entregó desde recortes de páginas de sociedad hasta críticas y entrevistas aparecidas en la prensa de la época. El material es muy variado y muestra la versatilidad del autor y su amor por el teatro, que a pesar de no ser especialmente recordado en la actualidad, cosechó grandes éxitos entre las bambalinas y las tramoyas. Esto se puede apreciar con claridad en la siguiente crítica aparecida el día 10 de mayo de 1948 en Valencia tras el estreno en el teatro Apolo de la comedia musical Ayer estrené vergüenza.

"El maestro Quintero, tan diestro en la composición musical de este género lírico, ha compuesto una partitura en extremo agradable. Música pegadiza, de ritmos modernos, inspirada dentro de su línea. Si en algunos números se eleva en composición de algunos dúos o romanzas de mayor ambición, pronto vuelve al camino de lo ligero, en donde se desenvuelve con facilidad, porque así lo requiere la tónica general de esta clase de operetas. El éxito de Quintero fue completo y muchos de los números de su partitura tuvieron que ser repetidos ante la insistencia del público. ${ }^{26,}$

Parte de este material corresponde a los años cincuenta y sesenta, pero se han incluido por la información biográfica que implica. Resulta llamativo comprobar cómo Quintero, a pesar de llevar una vida tranquila y alejada del mundanal ruido del cine junto a

\footnotetext{
${ }^{24}$ DiEGo, G. «Doble luto. ABC», Madrid, día 27 de marzo de 1953.

25 «Argenta y la Orquesta Nacional interpretan obras de Mendelssohn, Strauss, Wolf y Leoz en el Palacio de la música». ABC, sábado, 14 de marzo de 1953 [Edición de la mañana, pp 33].

${ }^{26}$ «Se estrenó la comedia musical "Ayer estrené vergüenza” ». 10 de mayo de 1948. (publicación desconocida)
} 
su mujer, aparece en noticias de sociedad junto a personalidades como los Perojo y Amparo Ribelles; o concediendo una exclusiva sobre sus "vacaciones" en Benidorm.

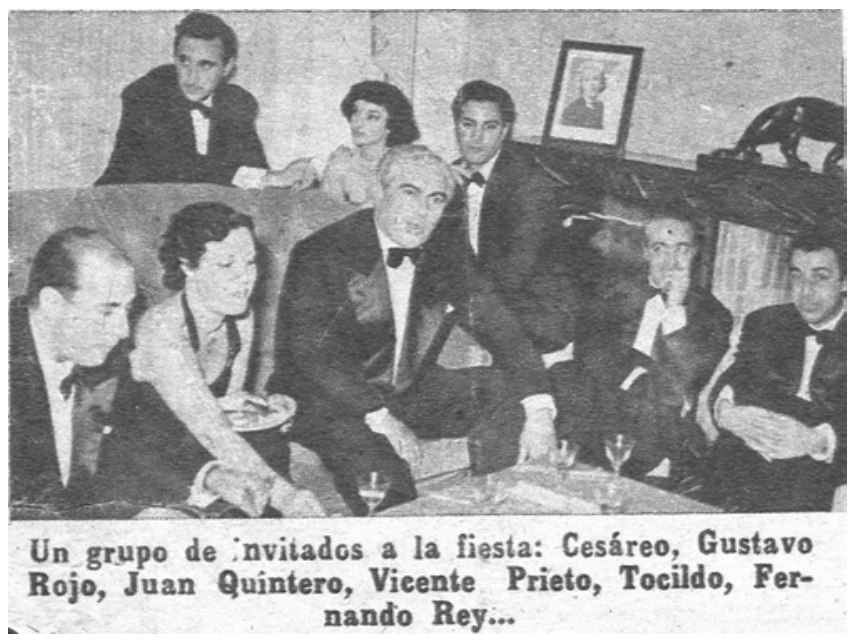

Imagen 5: Imagen extraída de la noticia: Fiesta en casa de los Perojo.

En cuanto a las críticas, cabe destacar que la prensa solía alabar la labor del maestro, por lo menos nombrando su acreditación. Esto también se puede constatar en la Historia del Cine de Méndez-Leite. Cada vez que se hace mención a un largometraje musicado por Quintero, el autor se deshace en elogios al trabajo de él, fiel reflejo de la predisposición de la prensa respecto al compositor ceutí.

La salida al mercado discográfico del primer volumen dedicado a clásicos españoles dirigidos por José Nieto, trajo consigo un puñado de noticias al respecto, alguna a página completa, dedicadas al compositor y su obra a partir del contenido del $C D$ publicado por la Fundación Autor y la SGAE. Periódicos tan distantes y diferentes como Mediterráneo, publicado en Castellón, hasta el $\mathrm{ABC}$, de tirada nacional, se hicieron eco de la novedad y aprovecharon la ocasión para reivindicar la obra del maestro.

Manuel Parada de la Puente se consolidó en el mundo del teatro y del cine como uno de los autores más prolijos y apreciados. Su escritura de cuidada factura le valió numerosos galardones y el apoyo del Régimen que se puede constatar en su nombramiento como director musical del Teatro Nacional. La sintonía del NO-DO y la música de Raza, película emblemática que pretendió sentar las bases del nuevo cine nacional son obras suyas. Precisamente, con fecha del 31 de diciembre de 1941 sale en El Alcázar la noticia de la grabación de la música de esta singular película de José Luis Sáenz de Heredia.

"La música de "Raza", concebida y compuesta bajo un punto de vista de unidad temática, ofrece en toda la acción en que se precisa un apoyo emocional auditivo de acuerdo con el momento estético. 
El tema básico de carácter heroico, subraya todos los momentos con las narraciones de actos en que el heroísmo de nuestra raza se puso de manifiesto.

Ya figura en la cabecera de la cinta, sobresaliendo por encima de la gran masa orquestal que juega el motivo del preludio con sonoridades brillantes, $y$ al final se convierte en marcha triunfal vigorosa y amplia que, por fin, cede el paso al "hosanna" en un momento emocionadísimo de la película, canta un nutridísimo coro de niños.

La interpretación de la partitura ha sido hecha por una sección de ochenta magníficos profesores de la orquesta Nacional Sinfónica y Filarmónica de Madrid, bajo la dirección del autor, el ilustre maestro Manuel Parada, director musical del teatro Español. La parte coral está a cargo de los coros de concierto y del coro infantil del Seminario de Madrid. ${ }^{27,}$

Como ya hemos comentado, de Durán Alemany tenemos en este momento una amplia documentación de críticas, reseñas a conciertos, etcétera extraído de diversas fuentes periodísticas. De este ingente material se ha seleccionado una muestra de críticas y noticias vinculadas al compositor. En ellas se puede apreciar la popularidad del maestro y su repercusión en los ambientes de jazz y música "moderna", así como en el mundo discográfico, consecuencia directa del éxito de canciones escritas para películas. Al respecto, el maestro opinaba que:

“...también es indispensable que el número -canción- se beneficie de un buen lanzamiento. Radio, discos, película, este es el itinerario de cualquiera de estas canciones americanas que hoy hacen furor. La popularidad de un número se logra martilleando con él los oídos de la gente. Durán Alemany sabe bastante de esto, pues cuenta en su haber éxitos ruidosos. "Arrullo de amor», que cantaron hasta enronquecer Rafael Medida y Mercedes Vecino. $Y$ «El cochero tirolés», desprendido de un cortometraje. $Y$ el fox lento titulado «Sin ti», y el otro «Quimera»... ${ }^{28 " ~}$

En estos mismos escritos encontramos una de las reivindicaciones que, aún hoy, siguen demandando los músicos del sector. La mejor remuneración de sus servicios, el control de la difusión de su obra y los derechos de autor, discurso éste que sigue sonando en la actualidad.

"Piensa que cobramos sesenta céntimos por la retransmisión de un disco nuestro en la Radio, aunque ese disco, como ocurre en la sección de discos solicitados, no hayan pedido un centenar de personas. En cuanto al cine, los autores percibimos un ínfimo tanto por ciento sobre el aforo del local. Cuatro mil pesetas es la mayor cantidad que por una película he cobrado por este concepto. Todavía, si al encargarnos la música el productor nos remunerara

\footnotetext{
${ }^{27}$ «La partitura de "Raza”, compuesta por el maestro Manuel Parada es interpretada por las Orquestas Nacional Sinfónica y Filarmónica, coaligadas». El Alcazar, 31 de diciembre de 1941.

${ }^{28}$ «La canción procura poco dinero», dice Durán Alemany
} 
decentemente... Pero apenas si se nos paga el trabajo material, el papel y la tinta.

Durán Alemany conoce a fondo estas materias, y ha luchado por la dignificación y veracidad de los derechos de autor. Pertenece a la comisión nombrada por la Sociedad de Autores para acabar con esa vituperable práctica de "la rueda" $29 "$

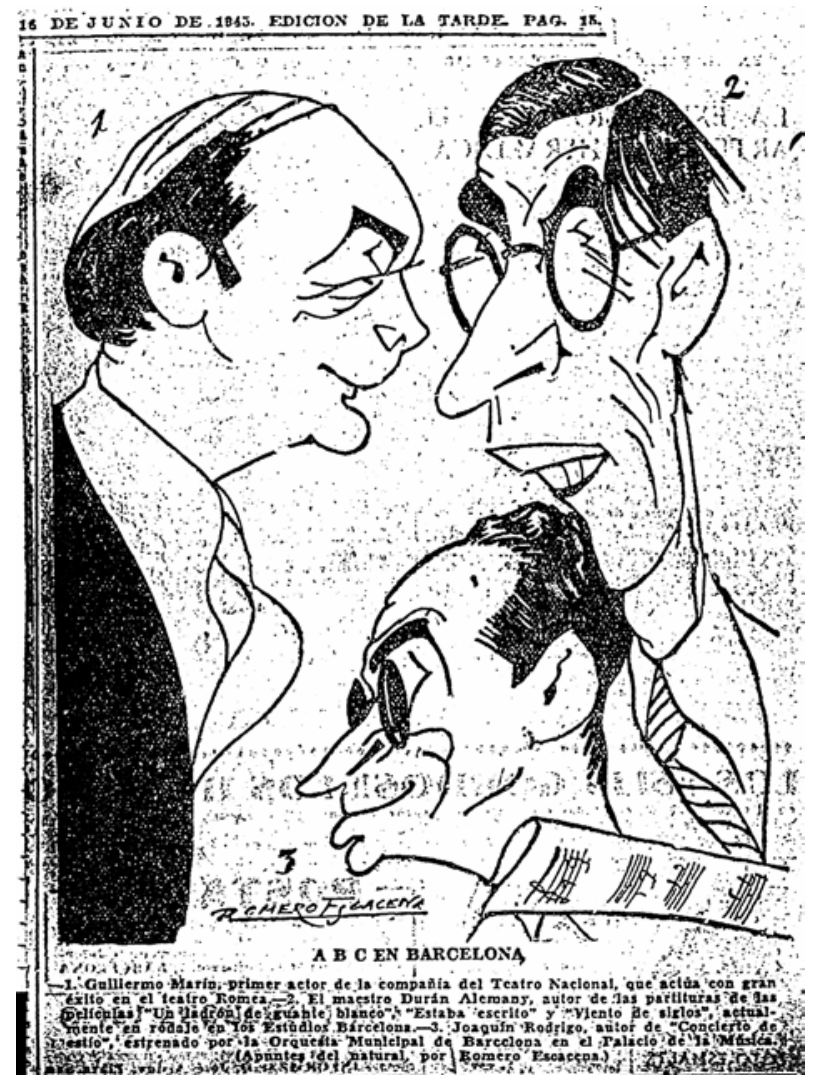

Imagen 6: Caricatura de Durán Alemany publicada en ABC

A través de la prensa de la época hemos podido también obtener información relativa a tres campañas publicitarias que emplearon la música de cine como factor esencial de la estrategia comercial de difusión. Las películas fueron: Bambú (1945), Garbancito de la Mancha (1945) y Pársifal (1952). Hemos elegido estos tres títulos por la gran repercusión que tuvieron en los medios.

\footnotetext{
${ }^{29}$ Ibídem.
} 
En el caso Bambú (1945) es fácilmente reconocible el interés puesto por Primer Plano en apoyar un producto de dimensiones épicas y nacionalistas, en cuya producción se encontraban profesionales apoyados por el Régimen. La película, firmada por José Luis Sáenz de Heredia, contaba entre sus filas en la interpretación, como máxima estrella, a Imperio Argentina y, como compositor, a Ernesto Halffter. Esta colaboración fue muy sonada pues era el regreso al mundo del cine, tras veinte años de silencio cinematográfico, del maestro Halffter, figura española de renombre mundial.

Estas tres personalidades fueron cruciales para la campaña publicitaria emprendida. En los artículos que aparecen en la siguiente tabla, encontramos entrevistas a cada uno de ellos realizadas durante distintas fases de la producción, posproducción, estreno y exhibición. Evidentemente, para nosotros el principal interés radica en la utilización del maestro Halffter como reclamo comercial, especialmente dirigido para atraer a las pantallas a aquellos intelectuales o melómanos reacios a asistir a la proyección de una "españolada" interpretada por Imperio Argentina.

El maestro concedió numerosas entrevistas para ayudar en la campaña de propaganda. Esta circunstancia ha sido muy beneficiosa para nosotros pues estos texto son un magnífico legado, porque en estas entrevistas el maestro no se dedicaba simplemente a hablar del filme, también desarrolla un interesante discurso sobre la música de cine, muy cercano, por otro lado, al mostrado por Turina, y que nos sirve para poder hacernos una composición de lugar sobre la idea que tenía el maestro de la música de cine.

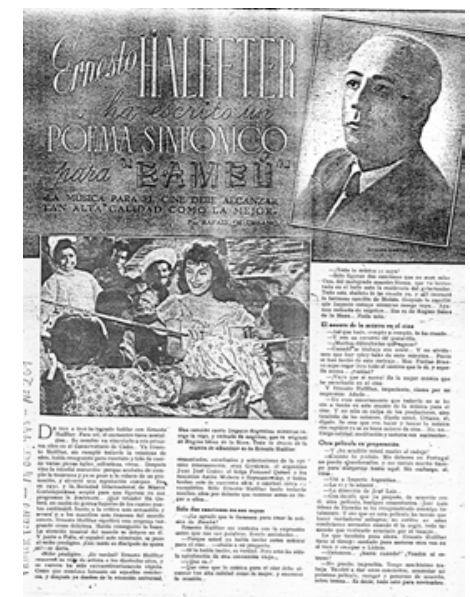

Imagen 7: « Ernesto Halffter ha escrito un poema sinfónico para "Bambú”», en Primer Plano, año VI, núm. $261,{ }^{30}$

Garbancito de la Mancha (1945) es tratado con más profundidad cuando hablamos de los géneros cinematográficos, donde se encontraran reproducciones de las páginas dedicadas por Primer Plano a la misma. Aquí debemos destacar el fuerte dispositivo

\footnotetext{
${ }^{30}$ Urbano, R. « Ernesto Halffter ha escrito un poema sinfónico para "Bambú”», en Primer Plano, año VI, núm. 261, 14 de octubre de 1945.
} 
desplegado por la productora así como de las instituciones públicas que apoyaron incondicionalmente el proyecto, sustentando la campaña en dos puntos destacables de la película. Por un lado, el esfuerzo realizado por la industria para conseguir un producto como Garbancito $^{31}$ y, por otro, la figura del maestro Guerrero, muy popular por entonces, que aportaba a la producción respetabilidad, prestigio y, desde una visión meramente comercial, popularidad.

El caso de Pársifal (1952), aunque se encuentra fuera del periodo de estudio, hemos decidido incluirlo por tratarse de un filme altamente peculiar. A través de los artículos publicados acerca de esta película, se percibe un maniqueísmo exacerbado lleno de exultante optimismo respecto a una obra eminentemente religiosa ${ }^{32}$ en donde tiene especial importancia las referencias musicales. Como se puede apreciar, el título de algunos textos no nos deja margen para la interpretación: La música de Wagner en el cine con "Pársifal", y como subtítulo,"162 profesores han sido necesarios para el registro de la música que ha de servir de fondo a las imágenes de la película". En este artículo podemos encontrar cinco fotografías sobre la sesión de grabación así como comentarios sobre la grandiosidad de la obra.

Los tres artículos seleccionados están distanciados en el tiempo muy poco, coincidiendo con la postproducción y estreno del filme. En la siguiente tabla hemos enumerado los artículos publicados en Primer Plano y RadioCinema correspondientes a estas producciones que causaron una gran expectación.

\begin{tabular}{|l|}
\hline Titulo \\
\hline Primer Plano \\
\hline José Luis Saez de Heredia está ultimando la preparación de "Bambú" \\
\hline Halffter ha escrito un poema sinfónico para "Bambú" \\
\hline "Bambú", la próxima película de imperio argentina" \\
\hline Son alegre de "Bambú" \\
\hline "Garbancito de la Mancha", \\
\hline $\begin{array}{l}\text { La salvación del cine español está en la música española, afirma el maestro } \\
\text { Guerrero. }\end{array}$ \\
\hline Horas antes del estreno con el director y los autores de "Garbancito de la \\
Mancha" \\
\hline "Pársifal" \\
\hline La música de Wagner en el cine con 'Pársifa' \\
\hline $\begin{array}{l}\text { Los realizadores y el protagonista de Parsifal hablan para Primer Plano antes del } \\
\text { estreno. }\end{array}$ \\
\hline RadioCinema \\
\hline Lo que será "Bambú" \\
\hline
\end{tabular}

Tabla 2: Referencias a promociones de películas

\footnotetext{
${ }^{31}$ Primer largometraje de dibujos animados en color realizado en Europa.

${ }^{32}$ A comienzo de la década de los cincuenta el fervor religioso en el cine se encuentra en su máximo esplendor.
} 
La necesidad de conseguir hasta los detalles más nimios respecto a un compositor resultan necesarios para reconstruir su vida, analizar su obra y repercusión así como su personalidad. Para ello se ha realizado una labor de recopilación de todo documento vinculado a los compositores.

En este aspecto, ha sido nuevamente de gran utilidad la colaboración de los herederos y personajes con quienes nos hemos entrevistado a fin de llevar a buen puerto la presente tesis. Su presteza y confianza en nosotros ha resultado crucial. La hija del Maestro Rebollo llegó a confiarnos fotografías personales y programas de mano de la época; la viuda de Juan Quintero Muñoz nos entregó un total de 14 partituras manuscritas de su esposo; etc.

Este tipo de fuentes recoge desde catálogos de la obra de tal o cual autor, hasta programas de mano y entrevistas personales. En general se trata de documentos únicos o de carácter privado aportados por los herederos o por nosotros mismos, en el caso de las entrevistas realizadas y la correspondencia.
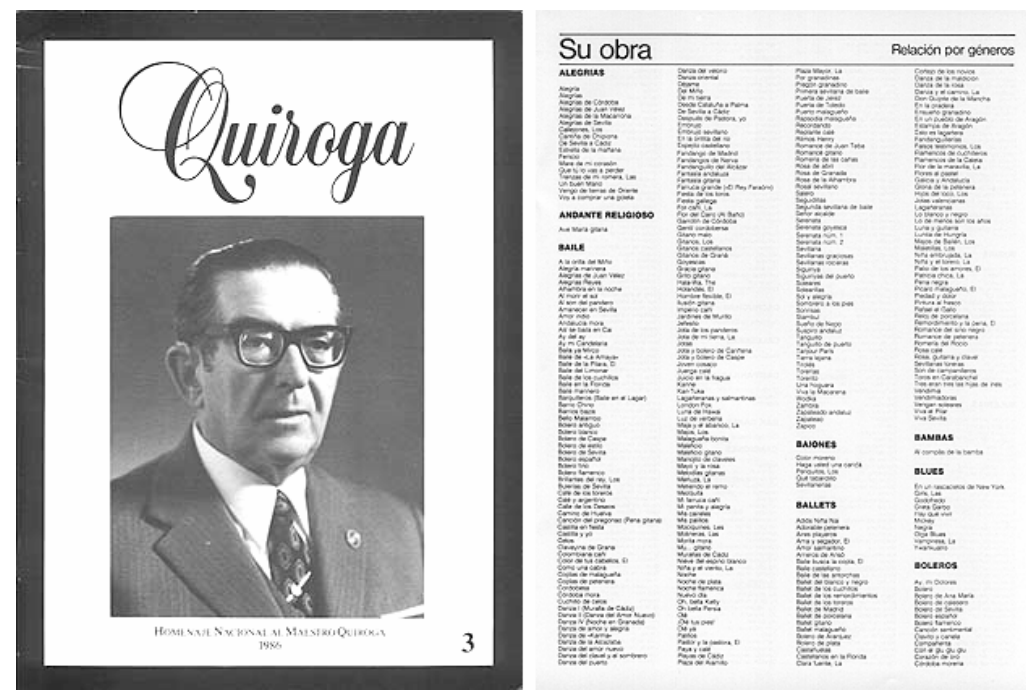

Imagen 8: Portada y hoja interior del cuadernillo en homenaje al maestro Quiroga.

Como ya se ha comentado, durante los últimos años, la familia y herederos de Jesús García-Leoz ha realizado tremendos esfuerzos por revivir la memoria del maestro. Entre las medidas a tomar, estuvo la ordenación y catalogación de la obra completa del músico, así como su entrega al Gobierno Foral de Navarra para la constitución futura de una fundación o casa museo.

"Jesús García Leoz es un músico navarro de este siglo, conspicuo y laureado mientras vivió. Hoy García Leoz permanece en la memoria de los olvidados, de los que, por ejemplo, no han merecido un estudio monográfico, ni una calle 
dedicada en Pamplona. Tampoco en su ciudad natal, Olite. Estas navidades podremos oír algunas de sus obras más destacadas, van a salir al mercado algunas grabaciones de títulos suyos y la familia entregará al Gobierno Foral el archivo de la obra original, recogida y clasificada en treinta y cinco cajas por Julián Ayesa, olitense y organista de la Catedral de Pamplona. ${ }^{33 "}$

La clasificación y catalogación de la obra que consta de varios centenares de partituras, todas ellas identificadas en un total de catorce páginas, donde se especifica su localización, título, año, clasificación, intérprete y género (forma musical). Como es evidente, en este listado se incluyen las obras compuestas para la gran pantalla, desde la música para un noticiario cinematográfico de 1933 o Noche de Ronda de 1934 hasta ¡Bienvenido Mr. Marshall! de 1952, Surcos de 1951 o El hombre y la lluvia de 1953.

Según nos confesó el mismo Nieto en una reunión mantenida en la Escuela de Cine de Madrid en 1999 y que refrendó en la carpetilla del disco, la partitura del NO-DO estaba desaparecida y fue necesario recuperarla a través de la técnica del dictado musical (como hiciese Christopher Palmer con la reconstrucción de tantas partituras clásicas del cine norteamericano de los años 30,40 y 50 ).

"Curiosamente, la partitura de esta sintonía - se refiere al NO-DO -, que es su obra más popular, ha desaparecido por lo que la música que aparece en este disco es una reconstrucción realizada a partir del registro sonoro del famoso noticiario español. ${ }^{34}$ "

Durante el periodo de obtención de información nos encontramos con tres tipos de documentos íntimamente ligados a las biografías de los compositores. Las biografías escritas por los mismos músicos o por los herederos de éstos, las biografías publicadas en programas de mano o libros y por último, los curriculum vitae escritos por los compositores para ser presentados en busca de algún trabajo. En MCE40 se encuentran digitalizadas las biografías enviadas por los herederos de los maestros Parada, Moraleda y Rebollo. En los tres casos redactadas y generadas por los propios familiares y de gran valor para nosotros por aportar datos en ocasiones poco conocidos.

Un ejemplo de esto lo tenemos en el material proporcionado por la viuda del maestro Quintero Muñoz. Entre el material que nos fue entregado se encontraban dos notas autobiográficas mecanografiadas por el propio compositor junto a dos curriculum vitae, uno de los cuales está datado en la década de los cincuenta y otro en los sesenta.

\footnotetext{
${ }^{33}$ García Leoz, el gran músico de Olite, rescatado. Diario de Navarra, 17 de diciembre de 1995.

34 José Nieto. Introducción. Carpetilla CD. José Nieto dirige la música de Manuel Parada. Clásicos del Cine Español, Vol. 3. Fundación Autor. Pag. 4.
} 


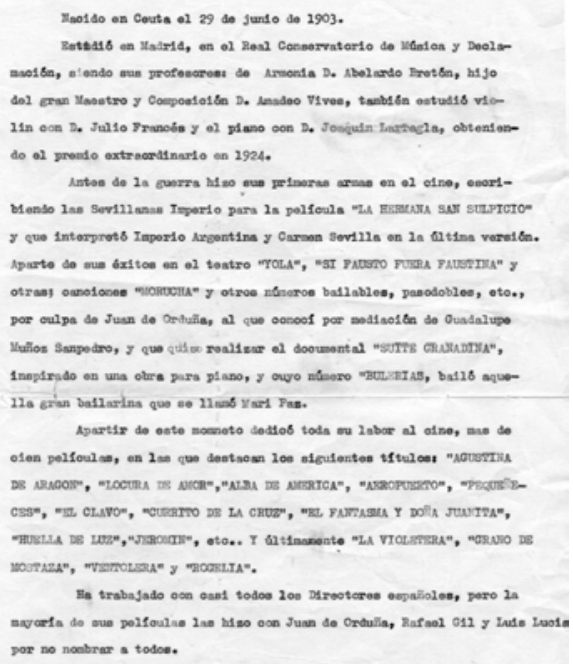

Imagen 9: Hoja del curriculum vitae de Juan Quintero Muñoz

Se decidió incluir también la correspondencia mantenida, tanto por carta ordinaria como por e-mail, con herederos y demás personalidades relacionadas con el ámbito de la música de cine. Sólo se han incluido aquellas que consideramos que aportan algún dato de interés sobre el tema objeto de nuestro estudio. De este modo, se presentan cartas de los herederos de Moreno Torroba, Moraleda, Parada, Durán Alemany y López-Quiroga.

\begin{tabular}{|ll|}
\hline fuente & Descripción \\
\hline Carta & Carta de contacto de los familiares del maestro Moraleda. \\
\hline Carta & $\begin{array}{l}\text { Carta de contestación del hijo del maestro Torroba donde me } \\
\text { corrige un dato sobre su padre. }\end{array}$ \\
\hline Carta & $\begin{array}{l}\text { Se menciona la cesión de la obra de su marido a la Biblioteca } \\
\text { Nacional }\end{array}$ \\
\hline Carta & Breve biografía del maestro Casas Augé \\
\hline e-mail & $\begin{array}{l}\text { Contiene algunos datos relacionados con material } \\
\text { proporcionado por el hijo del maestro Durán Alemany. }\end{array}$ \\
\hline e-mail & $\begin{array}{l}\text { e-amil enviado por el hijo de López-Quiroga en contestación a } \\
\text { unas dudas sobre la autoría de algunas películas de su } \\
\text { padres. }\end{array}$ \\
\hline
\end{tabular}

Tabla 3: Referencia a correspondencia. 
Las entrevistas han sido uno de nuestros principales objetivos, puesto que estos documentos automáticamente pasan a ser fuentes primarias de excepcional valor. En el momento de concluir estas líneas se han transcrito seis entrevistas de las nueve realizadas y tenemos en proyecto la realización de tres más que consideramos de alto interés. Por otro lado, también se ha incluido una entrevista a Juan Quintero Muñoz, llevada a cabo en la Internacional Radio Televisión de Barcelona y transcrita a máquina, como si se tratase del guión seguido en la misma.

Los personajes entrevistados han sido:

- Cristóbal Halffter (compositor)

- $\quad$ Ricardo Bayon (arreglista y orquestador) - no trascrita

- $\quad$ Manuel Halffter (hijo de Ernesto Halffter)

- Paquita Martos (viuda de Juan Quintero Muñoz) - solo se trascribe la primera de las cuatro entrevistas realizadas.

- José Luis Borau (director de cine)

- Juan Antonio Nieves Conde (director de cine)

- Juan Mariné (director de fotografía)

- José Nieto (compositor) - no trascrita

- Julio Arce (investigador y musicólogo) - no trascrita

Personalidades pendientes de entrevistar:

- Imperio Argentina (cantante y actriz) ${ }^{35}$

- $\quad$ Amparo Ribelles (actriz)

- José Luis Berlanga (director de cine)

Cada una de las entrevistas mantenidas fue única y personal. Todas ellas proporcionan una visión particular por parte de cada uno de los entrevistados, dando cada uno su versión de un mismo hecho histórico, refiriéndonos multitud de anécdotas. Precisamente, esta es la razón por la que consideramos que son documentos de excepcional valor.

La entrevista con Cristóbal Halffter resultó ser la más corta y directa de cuantas realizamos. El compositor es un hombre muy ocupado y en aquellos momentos se encontraba preparando el estreno de su mayestática ópera «El Quijote» en el Teatro Real de Madrid. A pesar de su brevedad en las respuestas, tuvo un trato magnífico y aportó su visión de los compositores de música "de concierto".

Por el contrario, su primo, Manuel Halffter, nos concedió una entrevista larga y entretenida, donde se habló de la carrera en el cine de su padre desde los inicios hasta sus

\footnotetext{
${ }^{35}$ Por desgracia, su recientísima muerte hará imposible dicha entrevista en el futuro.
} 
últimas películas. Se habla de la relación profesional con Sáenz de Heredia y Rafael Gil así como sus inicios e interés por el cine y la música.

Don Manuel nos puso en contacto con Ricardo Bayon, copista y arreglista que trabajó para casi todos los compositores del cine español, como por ejemplo Parada. La conversación que tuvimos fue de lo más encantadora, pero el hombre, por desgracia, ya entrado en años no mantenía un discurso lo suficientemente hilado como para poder transcribir de un modo fiable la misma. En esta ocasión se habló de la labor del arreglista en nuestro país y de su relación con distintos compositores, incluidos norteamericanos e italianos con los que trabajó en coproducciones.

Con Francisca Martos la situación fue diferente. La entrevista no aporta grandes novedades a lo ya conocido sobre el maestro Quintero aunque sí se relata el modus operandis del compositor en las grabaciones, donde ella misma ayudaba al compositor a controlar la sincronización, algo en lo que el músico ceutí era un verdadero experto. Se comentan los inicios en el cine de la mano de su amigo inseparable y mentor, Juan de Orduña. Ambos comenzaron simultáneamente en el oficio.

De las entrevistas transcritas e incluidas en la Base de Datos Multimedia, la correspondiente a José Antonio Nieves Conde resulta de lo más entretenida y completa. El venerable director demuestra su elocuencia hablando de todo tipo de temas relacionados con el cine. Por desgracia, la larga charla no se ha transcrito completa por el momento, siendo presentados aquí tan solo aquellos momentos en que se habló de la sonorización de películas, y su relación con los distintos compositores con quienes colaboró: Jesús Guridi, García Leoz, etc,. Esperamos en un futuro no muy lejano dar a conocer la entrevista completa de casi cuatro otras que mantuvimos. Los otros temas tratados fueron sobre la industria, el cine mudo, las superproducciones extranjeras en España (como Doctor Zhivago de la que contó un par de anécdotas muy divertidas).

En una línea muy similar se encuentran las conversaciones mantenidas con José Luis Borau y Juan Mariné. En el primer caso la entrevista se realizó en dos bloques por problema técnicos ajenos a la voluntad de ambos. En ella se tratan dos temas principalmente. Por un lado, nos habló de la Escuela de Cine y sus orígenes, y por otro, del ambiente cinematográfico que se vivía en los años cuarenta en España. En un último bloque, hablamos de su relación con los músicos de cine en sus películas y su relación con la música.

Juan Mariné, todo un maestro y conocedor de nuestro cine, mantuvo un discurso sencillo y directo en el que abordamos una gran multitud de temas que irían desde su relación con el compositor Jesús García Leoz, del que era gran amigo, hasta anécdotas sobre producciones en las que colaboró o aspectos técnicos diversos relacionados con la música de cine.

Las entrevistas con José Nieto y Julio Arce estuvieron más centradas en qué tipos de fuentes eran necesarias para el estudio de la música de cine en la época que nos ocupa. 


\begin{tabular}{|ll|}
\hline Tipo de fuente & Descripción \\
\hline Entrevista & $\begin{array}{l}\text { Trascripción de una breve entrevista en la radio } \\
\text { al maestro quintero fechada hacia el año 1954. }\end{array}$ \\
\hline Entrevista & $\begin{array}{l}\text { Entrevista a Critóbal Halffter donde se habla de } \\
\text { su primera banda sonora, así como de la labor de } \\
\text { la composición para cine }\end{array}$ \\
\hline Entrevista & $\begin{array}{l}\text { Charla con J. A. Nieves Conde donde se habla } \\
\text { de García Leoz, Guridi, Parada, Azagra, así } \\
\end{array}$ \\
& $\begin{array}{l}\text { como de la realización de diversos filmes del } \\
\text { director y vivencias personales. }\end{array}$ \\
\hline Entrevista & $\begin{array}{l}\text { Charla con Paquita Martos (viuda del maestro } \\
\text { Quintero) donde se habla de la labor de su } \\
\text { marido en el cine. }\end{array}$ \\
\hline Entrevista & $\begin{array}{l}\text { Entrevista con Manuel Halffter, hijo de Ernesto } \\
\text { Halffter, donde se dan a conocer diversos datos } \\
\text { del maestro dentro de la música de cine. }\end{array}$ \\
\hline Entrevista & $\begin{array}{l}\text { Entrevista con José Luis Borau, director de cine. } \\
\text { En ella se habla de la Escuela de cine y de la } \\
\text { aceptación del cine español en la década de los } \\
\text { cuarenta por los propios españoles. }\end{array}$ \\
\hline Entrevista & $\begin{array}{l}\text { Entrevista a Juan Marine, director de fotografía. } \\
\text { En ella se tratan todo tipo de temas entre los que } \\
\text { destacan la referencias a Jesús García Leoz, } \\
\text { Azagra, Durán Alemany, el doblaje, la industria, } \\
\text { Joselito, etc. }\end{array}$ \\
\hline
\end{tabular}

Tabla 4: Ejemplo de referencias a las entrevistas.

En cuanto a las entrevistas concertadas, esperamos que en un plazo no muy lejano se puedan producir y así podamos seguir completando nuestra base de datos en torno a la música de cine.

Los programas de mano, tanto de conciertos como de estrenos cinematográficos, se presentan aquí como documentos gráficos del momento. Tal vez, desde el punto de vista de la información aportada sobre un compositor en cuestión, los programas de conciertos o de ceremonias en recuerdo de algún evento son los más interesantes por los textos incluidos.

En el programa impreso para la despedida de López-Quiroga, podemos leer:

"Quiroga ha cultivado con notable aceptación la zarzuela y el sainete: «Los amos del barrio», "El presagio rojo», "La marquesa», "El cortijo de las matas», "La reina fea», "Pepita Romero» y otras, hasta un total de treinta y seis títulos, conocieron el halago del éxito y cimentaron su prestigio de compositor preparado para mayores empresas musicales. También el séptimo 
arte, el cine sonoro, modalidad artística de cronometrada y complicada adaptación musical, inscribe en su catálogo de los últimos años, medio centenar de títulos del más fértil e inspirado compositor actual. ${ }^{36, "}$
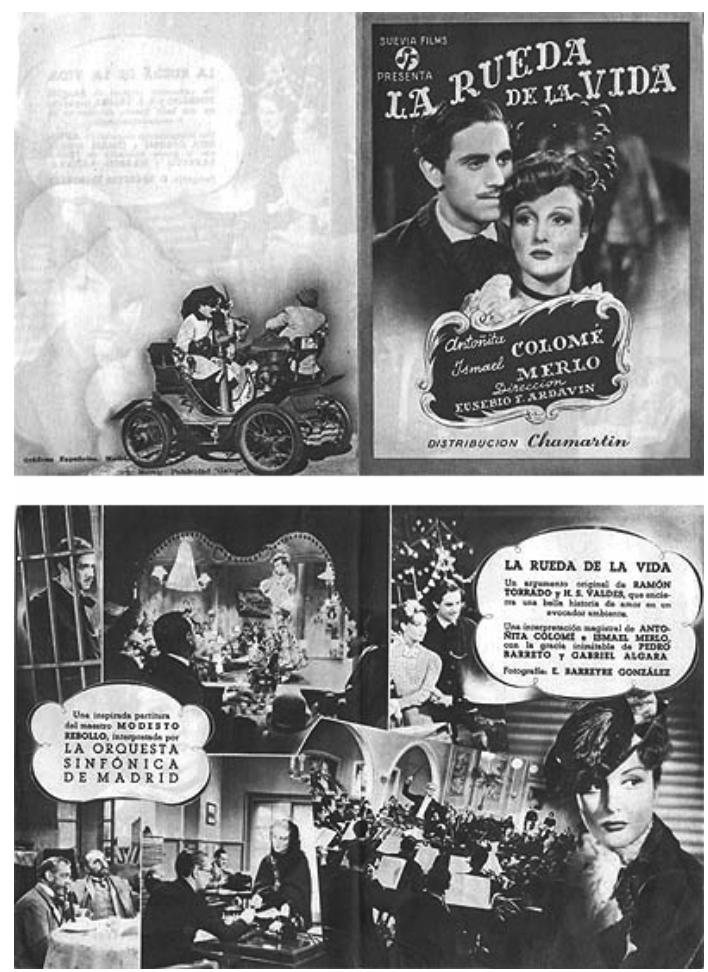

Imagen 10: Programa de mano de "La rueda de la vida"

El resto de documentos incluidos son de diversa índole y procedencia. Desde menús de ceremonias de estrenos hasta un interesante guión musical de Juan Quintero.

Como se habrá deducido, los documentos de mayor interés son aquellos relacionados con la producción fílmica, por lo que el guión firmado por Quintero, con anotaciones personales supone una fuente de primera mano para aquellos interesados en estudiar la obra del maestro. El formato de papel y el modo en que está escrito muestra lo esquemáticamente que trabajaba el maestro, así como la división por bloques bien estructurados que aplicaba a la construcción de las piezas.

En la imagen que se muestra a continuación, se puede leer la rima perteneciente a una de las canciones de la película escrita de puño y letra a lápiz en el reverso de la última hoja por el propio compositor.

${ }^{36}$ Programa dedicado al maestro Quiroga. Madrid 1972. 


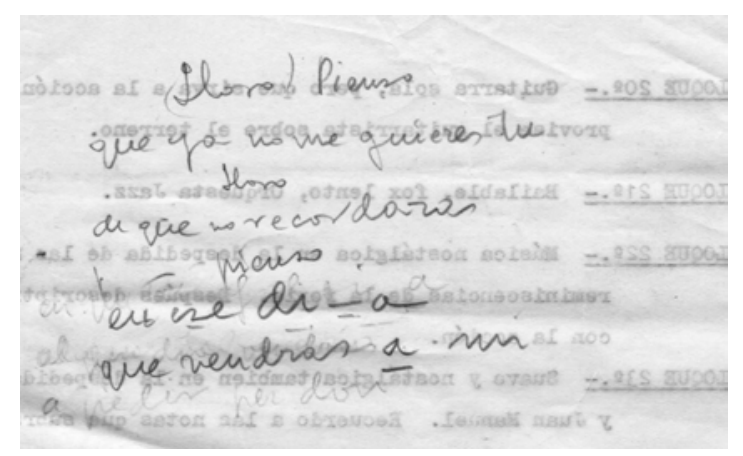

Imagen $11^{37}$ : Texto escrito a mano por Juan Quintero en el reverso de una de las hojas del guión musical de "La violetera"

También incluimos una crónica escrita por Turina sobre un concierto en homenaje a John Milanés donde se interpreta la "sonatina" de García Leoz. En ella podemos leer una edificante pero partidista, crítica de la obra del músico de Olite:

"La "sonatina" de mi sobrino Leoz es una preciosidad no solamente como materia musical, sino también como construcción perfecta, acabadísima, con una mezcla sugestiva de escritura moderna, dentro de un ambiente dieciochesco. ${ }^{38, "}$

Como hemos tenido ocasión de ver en nuestra investigación, los aspectos y medidas de naturaleza jurídica resultan de vital importancia en el desarrollo de la actividad cinematográfica de la época. Por esta razón resulta inevitable consultar dicha legislación para obtener la información necesaria para comprender la evolución de nuestro cine.

En un principio para la obtención de datos relativos a la maraña jurídica dictada en aquellos años, nos servimos de diversas fuentes. Por un lado, se tomaron reseñas de los anuarios de cine en los que se presentaban las transcripciones de algunas leyes, y las referencias a los BOE que López García publicó en el año 1945 en su libro La industria cinematográfica española ${ }^{39}$. Una vez estudiado el contenido de las mismas, se decidió cotejar todo el material a través de los servicios de documentación de las Cortes Valencianas que tienen acceso a los Boletines Oficiales del Estado anteriores a 1960.

En este caso, recurrir a las fuentes originales sirvió para confirmar los datos ya obtenidos y así pudimos obtener algunas leyes más que en las publicaciones consultadas no se habían incluido ni se nombraban.

Por otro lado, se tuvo que hacer uso de los volúmenes del Aranzadi con el fin de localizar algunas normativas que no aparecían inicialmente o que no llegaron a aparecer

\footnotetext{
${ }^{37}$ (Lloro) pienso / que ya no me quieres tu / lloro / de que no recordarás / pienso / en ese día / que vendrás a mi.

${ }^{38}$ TURINA. J. La capa del Milanés. Programa de mano.

${ }^{39}$ LÓPEZ GARCíA, V. (1945) La industria cinematográfica española, Madrid, ANII.
} 
por ningún lado, como ocurre con la supuesta ley del doblaje obligatorio de 1941 que no hemos llegado a localizar por ninguno de los medios consultados.

A la hora de incluir este material en MCE40 se presentaron dos opciones. O bien se digitalizaban como se había hecho con el resto de la documentación rescatada o bien se tecleaba de nuevo para convertirlo en formato de texto. La primera opción parecía la más directa y lógica siguiendo el esquema de parámetros utilizados durante todo el proceso de construcción de la aplicación, pero debido al gran volumen de tamaño que requería esta opción sumada a la dificultad de lectura del material conseguido del Boletín Oficial del Estado hicieron vencer la balanza hacia la segunda opción.

De esta forma, tanto en la base de datos multimedia realizada como en la presente tesis, se puede tener acceso a los contenidos transcritos de las fuentes originarias en un total de 35 disposiciones.

En nuestra Aplicación multimedia se recogen un buen número de referencias bibliográficas dentro del amplio espectro del mundo del cine y de la música de cine. En sus registros encontraremos todo tipo de publicaciones, desde monografías sobre directores y músicos de cine hasta estudios clásicos sobre cine, pero sin olvidar que nuestro objetivo principal no es el cine en sí sino la música de cine. Esta es la razón por la que hemos tenido especial interés en incluir todas aquellas referencias que hemos considerado importantes vinculadas al mundo de la música de cine y, por extensión, al de las bandas sonoras.

Dentro de este bloque nos encontraremos desde los magníficos textos escritos por José Nieto ${ }^{40}$, Russell Lack ${ }^{41}$, o Michael Chion ${ }^{42}$, pasando por el gran clásico de Adorno y Eisler $^{43}$, hasta libros insustanciales como Cine y música: el arte al servicio del arte ${ }^{44}$ de Carlos A. Cuellar. Como se pude comprobar, todos ellos hacen especial referencia a teorías de la música de cine pero también nos hemos encontrado con libros que abordan el tema desde perspectivas diferentes.

Las monografías de compositores no se encuentran fácilmente en el mercado por obvias razones comerciales. Son libros de difícil comercialización y normalmente se trata de publicaciones aparecidas a raíz de algún evento cultural, festival, etcétera. El festival de cine de Alcalá de Henares publicó en 1986 una extenso libro-entrevista a Carmelo Bernaola $^{45}$. Por su parte, el Festival de Valladolid, en su dinámica de generar publicaciones de profundo calado, editó un libro monográfico con entrevistas y un cd sobre la figura de José Nieto ${ }^{46}$, y Joan Padrol $^{47}$ ha sacado a la luz una larga lista de entrevistas en un

\footnotetext{
${ }^{40}$ NiETO, J. (1996) Música para la imagen, influencia secreta, Madrid, SGAE.

${ }^{41}$ LACK, R. (1999) La música en el cine, Madrid, Cátedra - signo e imagen.

${ }^{42}$ CHIÓN, M. (1985) La música en el cine, Barcelona, Piados.

${ }^{43}$ AdORno, T. W.; EISLER, H. (1981) El cine y la música, Madrid, Fundamentos.

${ }^{44}$ Cuéllar Alejandro, C. A. (1998) Cine y música: el arte al servicio del arte, Valencia, Sevicio de Publicaciones de la UPV.

${ }^{45}$ Padrol, J.; Bodegas, R.; Calvo, F. (Coord.) Evolución de la banda sonora en España: Carmelo Bernaola, Madrid, Festival de Cine de Alcalá de Henares.

${ }^{46}$ Álvarez, R.; ARCE, J. C. (1996) La armonía que rompe el silencio. Conversaciones con Pepe Nieto, Valladolid, La Semana Internacional de Valladolid.

${ }^{47}$ PAdRoL, J. (1998) Pentagramas de película. Entrevistas a grandes compositores de bandas sonoras, Madrid, Nuer.
} 
volumen editado tanto en catalán como en castellano. A pesar de ello, no hemos encontrado buenas monografías de compositores de los años cuarenta, sí se han incluido algunas muy interesantes de grandes maestros de la composición como las dedicadas a Miklos Rozsa ${ }^{48}$, Nino Rota ${ }^{49}$, Ennio Morricone ${ }^{50}$ o Mario Nascimbene ${ }^{51}$.

Como es lógico, no vamos a ir enumerando cada uno de los libros incluidos, tan solo llamar la atención sobre algunos que consideramos importantes. En MCE40 se encontrará un listado que el investigador podrá usar como referencia cuando se disponga a realizar estudios o investigaciones sobre la música en el cine. La mayor parte de los textos incluidos están escritos en castellano aunque se han incluido algunos de obligada referencia como el conocido Film music a neglected art ${ }^{52}$ de Roy M. Prendergast o el clásico pero difícil de conseguir, Film music ${ }^{53}$ de Jack London.

Con respecto al mundo del cine, y en general al cine de los años cuarenta en España, se hace una recopilación de textos e historias del cine escritas en aquellos tiempos. En especial queremos resaltar la Historia del Cine ${ }^{54}$ de Cabero y el preclaro La industria cinematográfica española ${ }^{55}$ de Victoriano López.

En el apartado de documentos gráficos se incluyen fotografías, fotogramas, foto fija y cartelística de la cinematografía de la época y centrada en los personajes protagonistas de nuestra historia, los músicos. La importancia de reunir este material puede parecer banal y poco adecuado para el estudio de una disciplina como la música de cine, de naturaleza abstracta y que se desarrolla en el tiempo, mientras que los elementos aquí recogidos resultan ser todo lo contrario. Pero lo cierto es que estos documentos pueden ser una fuente atractiva como complemento, para formar o redondear el conjunto de la época y la incidencia de la música en ella.

La elaboración de carteles fue muy fecunda en este periodo, con la consolidación de artistas de la talla de Antonio Raga o Peris Aragó, sin nombrar al ya establecido y respetado José Renau, maestro entre los maestros y extensible a excelentes profesionales como Chapí, Olcina, Vila, Alberto Peris y Donat.

A través de las pinceladas y sintetismos propios de la cartelística de la época, a mitad de camino entre la pintura dieciochesca y la sencillez propia del medio publicitario, estos artistas supieron imprimir en ellos una estética y visión del mundo particular y representativa de la vida en la primera España franquista.

\footnotetext{
${ }^{48}$ Rózsa, M. (1982) Double Life, New York, Wynwood press.

${ }^{49}$ LATORRE, J. M. (1989) Nino Rota. La imagen de la música, Barcelona, Montensinos.

${ }^{50}$ MiCELI, S. (1997) Morricone: la música, el cine, Valencia, Fundación Municipal de Cine, Mostra de Valencia Colección Mitemas.

${ }^{51}$ NASCIMBENE, M. (1992) Nascimbene, mario: malgre moi, autobiografía de un músico de cine, Valencia, Fundación Municipal de Cine, Mostra de Valencia - Colección Mitemas.

52 Prendergast, R. M. (1992) Film Music, a Neglected Art: a Critical Study of Music in Films, London, W. W. Norton \& Co.

${ }^{53}$ LONDON, K. (1970) Film music, London, Faber and Faber.

${ }^{54}$ CABero, J. A. (1949) Historia de la cinematografía española. Madrid, Gráficas Cinema.

${ }^{55}$ LÓPEZ GARCiA, V. (1945) La industria cinematográfica española, Madrid, Asociación Nacional de Ingenieros Industriales.
} 
No solo son de gran valor para el estudioso de las artes gráficas o de la publicidad. En ellos podemos oler los aromas añejos de un periodo histórico distorsionado y falseado, donde podremos ver con sorpresa como la figura del compositor podía llegar a resultar un "reclamo" para el espectador. Carteles creados para películas como Locura de amor (1948), Agustina de Aragón (1950) o Último día (1952) incluyen el nombre de Quintero en el apartado musical junto al fotográfico que siempre era incluido. No es que se tratase de la tónica general, pero la presencia de estos nombres en el cartel supone un paso adelante en la percepción que de los compositores se hacía llegar al público.

En el siguiente apartado se han incluido reproducciones de los carteles de las siguientes películas:

\begin{tabular}{|ll|}
\hline Título & Año \\
\hline ¡A mí la legión! & 1941 \\
\hline ¡A mi no me mire usted! & 1941 \\
\hline ¡Legión de héroes! & 1941 \\
\hline Agustina de Aragón & 1950 \\
\hline Angustia & 1947 \\
\hline Balarrasa & 1950 \\
\hline Boda accidentada & 1942 \\
\hline De mujer a mujer & 1950 \\
\hline Deliciosamente tontos & 1943 \\
\hline Don Quijote de la Mancha & 1947 \\
\hline El beso de Judas & 1951 \\
\hline El clavo & 1944 \\
\hline El crimen de Pepe Conde & 1946 \\
\hline El difunto es un vivo & 1941 \\
\hline El fantasma y doña Jacinta & 1944 \\
\hline Ella, él y sus millones & 1944 \\
\hline Eloísa está debajo de un almendro & 1943 \\
\hline Garbancio de la Mancha & 1945 \\
\hline Goyescas & 1942 \\
\hline La gitanilla & 1940 \\
\hline La vida empieza a medianoche & 1944 \\
\hline Locura de amor & 1948 \\
\hline Mariquilla Terremoto & 1939 \\
\hline Raza & 1941 \\
\hline Truanes de honor & 1950 \\
\hline Tuvo la culpa Adán & 1944 \\
\hline
\end{tabular}

Tabla 5: Referencia a carteles 
Las fotografías aportadas en este espacio son de fuentes muy diversas. Desde fotografías personales entregadas por los familiares y herederos hasta algunas extraídas de libros monográficos sobre los autores.

La mayor parte del material contenido por el momento, se reduce a unos pocos compositores, habiendo en ellas algunas de gran valor por su contenido e inexistencia de negativos y reproducciones de la misma que convierte dicho material en perecedero y factible de desaparecer para siempre con el paso del tiempo.

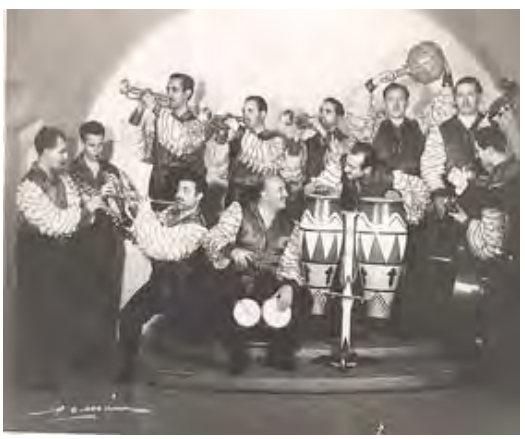

Imagen 12: Casas Augé y su orquesta

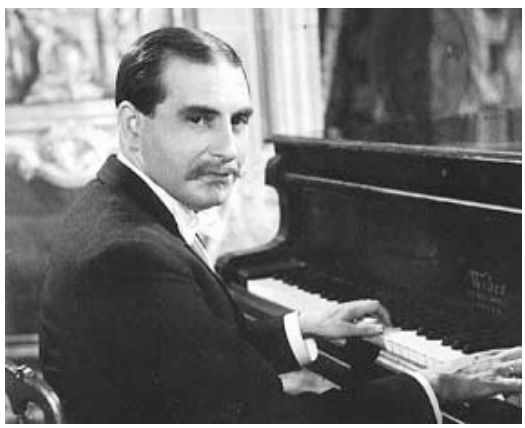

Imagen 14: Juan Quintero tocando el piano durante el rodaje de Pequeñeces

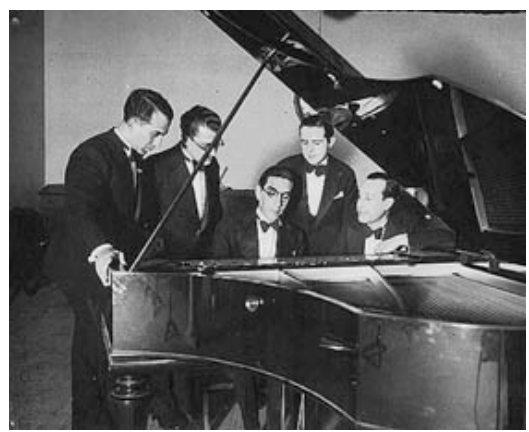

Imagen 13: Durán Alemany al piano junto al grupo "Orfeo"

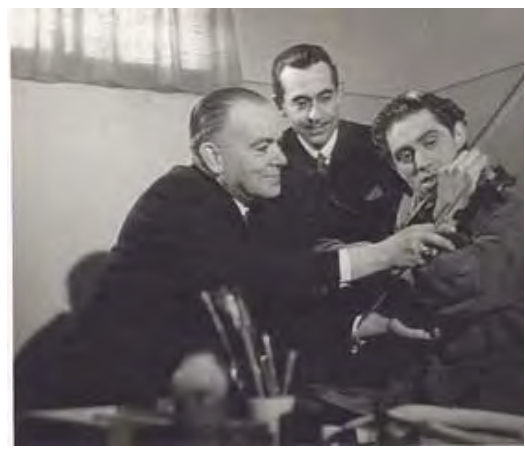

Imagen 15: EI maestro Rebollo aleccionando a Ismael Merlo (entre ellos Ardavín)

En la siguiente tabla aparece el listado pormenorizado del material fotográfico incluido en la aplicación MCE40. En ella se encuentra material de los siguientes músicos: Asíns Arbó, Casas Augé, Conrado del Campo, Jesús Guridi, García Leoz, López-Quiroga, Ruiz de Luna, Moraleda, Jesús Quintero y Modesto Rebollo. 
Descripción

Ataúlfo Argenta

Ataúlfo Argenta dirigiendo en Londres.

Miguel Asíns Arbó

Miguel Asíns Arbó, junto a la entrada de un cine donde se exhibe el film "La Vaquilla".

Miguel Asíns Arbó, caricatura.

Homenaje a Miguel Asíns Arbó con motivo del premio nacional de música. De izq. A der.: el compositor, Ataúlfo Argenta, Nestor Martínez (Valencia 1950).

Miguel Asíns Arbó en los estudios de rtve durante la grabación de la b.s. de "España en Guerra" (1983-86).

Casas Augé dirigiendo.

Casas Augé junto a la orquesta

Casas Augé junto a sus compañeros

Conrado del Campo

Conrado del Campo

Jesús Guridi con su nieta

Jesús Guridi

Jesús Guridi junto con pablo Bilbao Aristegui.

Jesús Guridi con su hija María Jesús.

Jesús Guridi (París, 1904)

Jesús Guridi

Jesús Guridi de niño tocando la guitarra, Vitoria, 29/12/1895

Jesús Guridi, caricatura

Jesús Guridi, en un sello de correos (1983)

Jesús Guridi al piano

Jesús Guridi, caricatura

Jesús Guridi, caricatura

Sello de correos en honor del maestro Guridi

De pie: Pagola, Olaizola, Urteaga, Beobide, Echeveste, Izurraeteguiz;

Sentados: Otaño, Gabiola, Donostia, Guridi y Almandoz (1922).

Jesús Guridi con los componentes de la orquesta que estrenó la obra "mirentxu". Bilbao (1910).

Jesús Guridi

Jesús Guridi

Imperio Argentina (fotografía promocional).

Jesús García Leoz.

Jesús García Leoz

El maestro Leoz junto al crítico Fernández-Cid.

García Leoz junto a $M^{a}$ Ángeles Morales y Ataúlfo Argenta.

López-Quiroga 


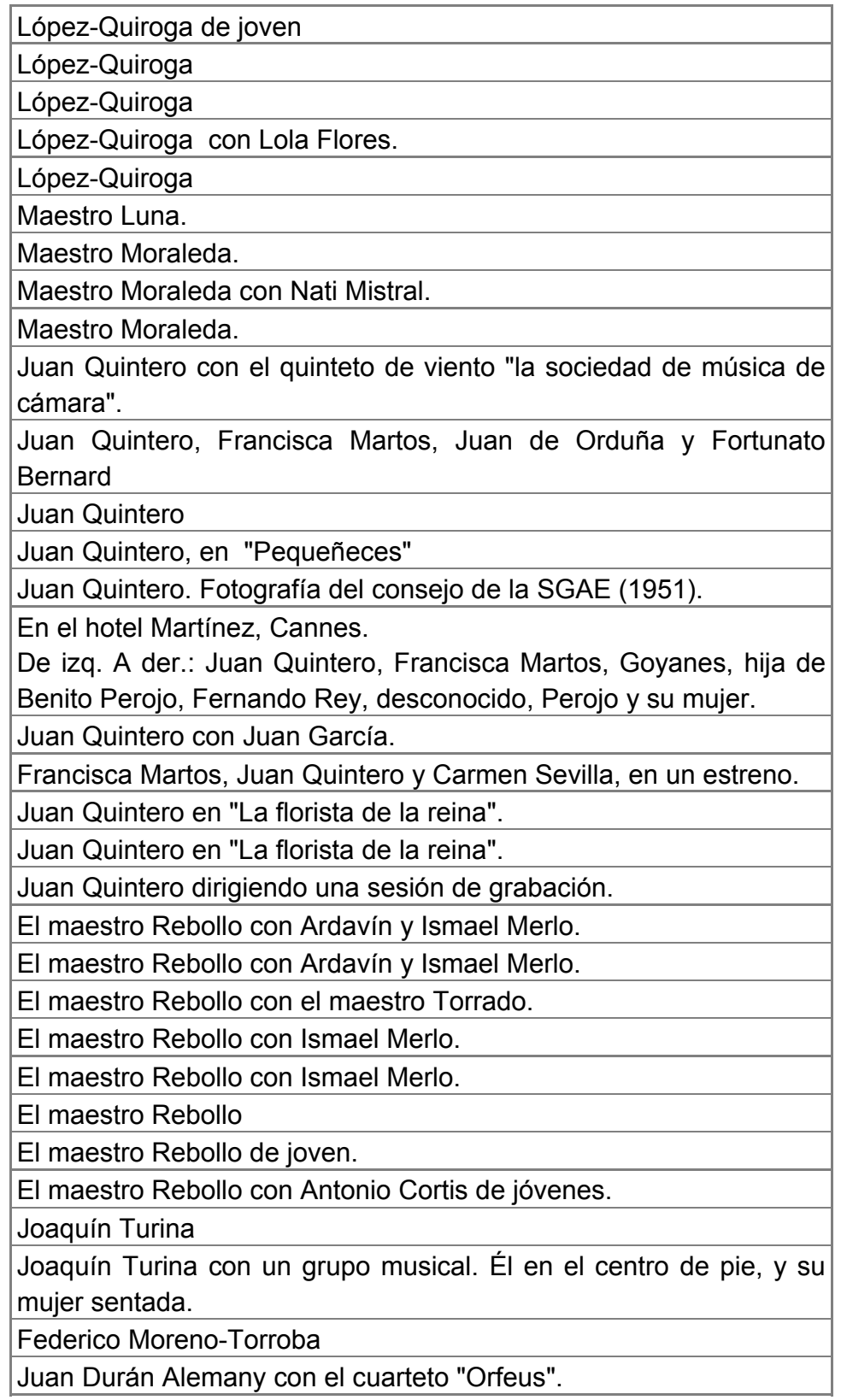

Tabla 6: Referencias al material fotográfico

La Foto Fija y los Fotogramas se han incluido en la base de datos a modo de ilustración de las fuentes primigenias de nuestro estudio, el cine de los años cuarenta, estos documentos proporcionan información relativa a las producciones, bien sea a través fotogramas o de foto fija realizadas durante el rodaje. 
Por el momento se encuentran digitalizadas e incluidas en MCE40 las siguientes referencias:

\begin{tabular}{|c|c|}
\hline Película & Año \\
\hline ¡A mi la legión! & 1942 \\
\hline ¡Campeones! & 1943 \\
\hline ¡Campeones! & 1943 \\
\hline Agustina de Aragón & 1950 \\
\hline Boda accidentada & 1942 \\
\hline Boda accidentada & 1942 \\
\hline Currito de la cruz & 1948 \\
\hline De mujer a mujer & 1950 \\
\hline Deber de esposa & 1944 \\
\hline Deliciosamente tontos & 1942 \\
\hline El clavo & 1944 \\
\hline El clavo & 1944 \\
\hline El crimen de Pepe Conde & 1946 \\
\hline El crimen de Pepe Conde & 1946 \\
\hline El crimen de Pepe Conde & 1946 \\
\hline El difunto es un vivo & 1941 \\
\hline El fantasma y doña Jacinta & 1944 \\
\hline El frente de los suspiros & 1942 \\
\hline Ella, él y sus millones & 1944 \\
\hline Eloísa está debajo de un almendro & 1943 \\
\hline Huella de luz & 1942 \\
\hline Intriga en el escenario & 1953 \\
\hline Intriga en el escenario & 1953 \\
\hline La Dolores & 1939 \\
\hline La rueda de la vida & 1942 \\
\hline La vida empieza a medianoche & 1944 \\
\hline Locura de amor & 1948 \\
\hline Pequeñeces & 1950 \\
\hline Tuvo la culpa Adán & 1944 \\
\hline Viaje sin destino & 1942 \\
\hline
\end{tabular}

Tabla 7: Referencias a fotogramas y foto fija.

Después de las propias producciones y de los registros sonoros de las obras a estudiar, es evidente que las partituras juegan un importante papel en el estudio de la música en el cine, de ayer y de hoy. Por desgracia, este material suele ser de difícil acceso para el investigador y en multitud de ocasiones sencillamente se ha perdido o destruido. La 
indiferencia, apatía y dejadez por parte de instituciones públicas y privadas en la conservación de nuestro patrimonio musical-cinematográfico es desgraciadamente elevada, pero si, además, nos referimos a este periodo cinematográfico los resultados son catastróficos.

Nos atreveríamos a asegurar que la mayor parte de las partituras compuestas en esta década ya no existen y un porcentaje alto de las que se conservan se encuentran en desvanes polvorientos y húmedos descomponiéndose y desapareciendo definitivamente. Iniciativas tomadas por herederos como los de Jesús García Leoz son dignas de elogio, debiendo cundir el ejemplo entre los demás, aunque reconocemos que si no existe un apoyo por parte de alguna institución, de la naturaleza que sea, que ayude con medio económicos o humanos, la labor puede ser sencillamente imposible e inviable para la mayoría.

Este fue uno de los principales motivos que nos condujeron a la creación de la base de datos MCE40. La pérdida de estas joyas de nuestra cultura cinematográfica y musical es ya casi una realidad y consideramos que esto debe subsanarse de algún modo.

Se comenzó a digitalizar toda partitura que llegó a nuestras manos con el fin de pasarlas a soporte digital para su conservación y almacenamiento. Por desgracia, a pesar de tener en estos momentos nada menos que catorce partituras completas digitalizadas, no se han incluido en la aplicación por posibles problemas jurídicos con la Sociedad General de Autores y Editores, que si bien no se preocupa de la conservación de dicho material, si lo hace en cuanto a los beneficios que de ellas se puedan obtener. Esta es la razón por la que tan solo se han incluido, partituras aparecidas en publicaciones de la época o libros a modo de fanzine y dos bloques musical pertenecientes a Deliciosamente Tontos (1942) y De mujer a mujer (1950) como se muestra a continuación.

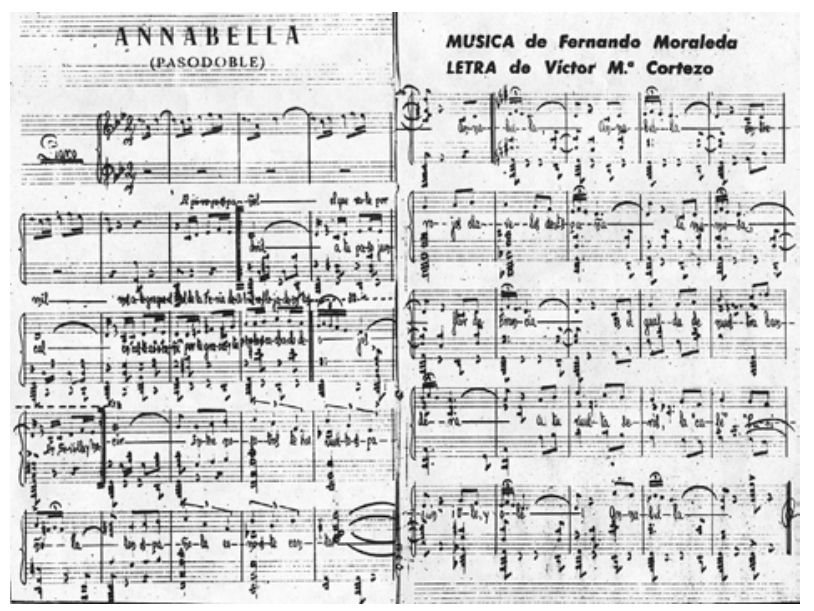

Imagen 16: Partitura de Annabella 


\begin{tabular}{|ll|}
\hline Título & Autor \\
\hline ¿Qué te pasa Trinia? & Manuel López-Quiroga Miguel \\
\hline Annabella & Fernando Moraleda Berber \\
\hline Canon & Jesús Guridi \\
\hline De mujer a mujer & Juan Quintero Muñoz \\
\hline $\begin{array}{l}\text { Deliciosamente } \\
\text { tontos }\end{array}$ & Juan Quintero Muñoz \\
\hline Ojos negros & Manuel López-Quiroga Miguel \\
\hline
\end{tabular}

Tabla 8: Referencias a partituras

La recuperación de los registros musicales originales resulta a día de hoy tarea baldía y destinada al fracaso, es por eso que se debe comenzar una tarea de reconstrucción al estilo y modo en que José Nieto está realizando su serie de grabaciones destinadas a rescatar del olvido a los grandes compositores de nuestro cine clásico. En los últimos quince o veinte años se han realizado escasamente cinco ediciones discográficas dedicadas a seis compositores de la época. Un promedio más bien bajo si tenemos en cuenta la gran calidad de música compuesta en aquellos tiempos por un número elevado de compositores.

Por otro lado, en los últimos años han aparecido en el mercado grabaciones que recogen parte del legado que nuestros protagonistas dejaron en el mundo de la canción. En concreto, hemos encontrado tres referencias importantes y a tener en consideración como documento imprescindible.

Estas fuentes, a la vez que nos permiten una audición distinta de aquella música, generan fuentes de consulta interesantes. Nos referimos en concreto a los libretos y notas que acompañan estas grabaciones. En el caso de las ediciones realizadas por José Nieto, el mismo director lleva a cabo comentarios de cierta envergadura consecuencia de su formación y conocimiento en la materia, al igual que su colaborador, Julio Arce, cuyos textos analizando la obra de Quintero, García Leoz y Parada son magníficos.

"La obra de estos músicos cinematográficos españoles tiene el valor añadido de haber sido creada en unas condiciones adversas. Carecieron de una formación específica que se vio compensada por su amor al cine y por la atención que mostraron a los grandes maestros americanos y europeos. Sufrieron la escasez de medios de una industria cinematográfica que consideraba la música como el último y uno de los menos importantes eslabones del producto artístico. Y tuvieron que realizar las mismas funciones que en otras industrias eran llevadas a cabo por un complejo y amplio equipo de profesionales: creaban la música, se encargaban de la orquestación, 
contrataban a los músicos, dirigían los ensayos y participaban en las mezclas de la banda sonora. ${ }^{56 "}$

No tan excepcionales pero, no por ello deben dejarse de lado, son los textos que acompañan las grabaciones de Joaquín Turina, a cargo de Carlos Colón Perales autor de una tesis doctoral sobre la obra cinematográfica del músico, y el libreto que acompaña la edición en caja de lujo de Melodías populares del cine español de los años 40.

También se incluyen referencias a obras de concierto de algunos músicos. La inclusión de estas obras radica en la necesidad de dar a conocer al investigador un conjunto más amplio del estilo y personalidad musical de estos compositores. A excepción de Cristóbal y Ernesto Halffter, la discografía existente de estas obras de concierto resulta prácticamente inexistente o de mayor dificultad, si ello es posible, que de las obras para cine. De ahí que se informe del material fonográfico disponible para su obtención.

A continuación mostramos un listado de las obras reseñadas en MCE40. Por motivos de derechos de autor, dichas piezas no se podrán escuchar en su totalidad, aunque sí se ha incluido un minuto de música de cada pieza. A pesar de todo, con la referencia dada el investigador podrá localizar con total seguridad la mayor parte de ellas.

\section{Material fonográfico}

\begin{tabular}{|c|c|c|c|c|}
\hline \multicolumn{5}{|l|}{ Augusto Algueró } \\
\hline Película & Forma & Titulo & Año & Referencia \\
\hline Campaña mañanera & Canción & Campana mañanera & 1942 & BMCD 2025 \\
\hline \multirow[t]{2}{*}{ Pensamiento } & Canción & Presentimiento & 1942 & BMCD 2025 \\
\hline & Canción & Soñar otra vez & & BMCD 2025 \\
\hline \multirow[t]{3}{*}{ Piruetas juveniles } & Canción & Lección de ritmo & 1943 & BMCD 2025 \\
\hline & Canción & $\begin{array}{l}\text { Mama, } \\
\text { hacer? }\end{array}$ & & BMCD 2025 \\
\hline & Canción & Idilio en el parque & & BMCD 2025 \\
\hline El obtáculo & Canción & ¡Alto el swing! & 1946 & BMCD 2025 \\
\hline
\end{tabular}

\section{Demón}

Película

Forma Titulo

Año Referencia

48 horas

Canción Mujer querida

1942 BMCD 2025

Canción Tu verás... Somos tres 1942 BMCD 2025

subidos en un árbol

\section{Campo, Fidel Del}

\begin{tabular}{lllll} 
Película & Forma & Titulo & Año & Referencia \\
\hline El 13.000 & Canción & Un sueño fue & 1941 & BMCD 2025 \\
& Canción & Piensa, mujer & 1941 & BMCD 2025 \\
Pimientilla & Canción & Quiero soñar & 1941 & BMCD 2025
\end{tabular}

\footnotetext{
${ }^{56}$ García LeOZ, J. (1999) José Nieto dirige la música de Jesús García Leoz [compact disc] Fundación Autor I
} SGAE / Karonte, JMBSP501. Pag. 5 


$\begin{array}{llll}\text { Canción } & \text { A la luz de la luna } & 1941 & \text { BMCD 2025 } \\ \text { Canción } & \text { Pimentilla } & 1941 & \text { BMCD 2025 } \\ \text { Canción } & \text { Canta, canta } & 1941 & \text { BMCD 2025 }\end{array}$

Casas Augé - Martínez Tudó

$\begin{array}{lllll}\text { Película } & \text { Forma } & \text { Titulo } & \text { Año } & \text { Referencia } \\ \text { Mosquita en palacio } & \text { Canción } & \text { Tu querer } & 1942 & \text { BMCD 2025 } \\ & \text { Canción } & \text { Pescar, pescar } & 1942 & \text { BMCD 2025 }\end{array}$

\begin{tabular}{|c|c|c|c|c|}
\hline \multicolumn{5}{|l|}{ Durán Alemany } \\
\hline Película & Forma & Titulo & Año & Referencia \\
\hline Música muchachos & Canción & Fuiste tú & 1941 & BMCD 2025 \\
\hline \multirow[t]{2}{*}{ Ritmo en la ondas } & Canción & Madrugada & 1942 & BMCD 2025 \\
\hline & Canción & Romance infantil & 1942 & BMCD 2025 \\
\hline \multirow[t]{2}{*}{ Boda accidentada } & Canción & Barrabás & 1942 & BMCD 2025 \\
\hline & Canción & Quimera & 1942 & BMCD 2025 \\
\hline El cochero tirolés & Canción & El cochero tirolés & 1942 & BMCD 2025 \\
\hline Yo no me caso & Canción & El placer de viajar & 1944 & BMCD 2025 \\
\hline Turbante blanco & Canción & Solamente & 1943 & BMCD 2025 \\
\hline \multirow{2}{*}{ Viviendo al revés } & Canción & Muchacho tímido & 1943 & BMCD 2025 \\
\hline & Canción & No entre sin llamar & 1943 & BMCD 2025 \\
\hline El difunto es un vivo & Canción & Pupupidú & 1941 & BMCD 2025 \\
\hline \multirow[t]{2}{*}{ Vaya música } & Canción & Noche del palmar & 1942 & BMCD 2025 \\
\hline & Canción & Orquídeas de plata & 1942 & BMCD 2025 \\
\hline $\begin{array}{l}\text { Es peligroso asomarse al } \\
\text { exterior }\end{array}$ & Canción & Tardes de Coímbra & 1946 & BMCD 2025 \\
\hline Eres un caso & Canción & El triquitruco & 1946 & BMCD 2025 \\
\hline El pobre rico & Canción & Arrullo de amor & 1942 & BMCD 2025 \\
\hline $\begin{array}{l}\text { Las tinieblas quedaron } \\
\text { atrás }\end{array}$ & Canción & Una chica con imán & 1947 & BMCD 2025 \\
\hline \multirow[t]{3}{*}{ Melodías prohibidas } & Canción & Soñaré & 1942 & BMCD 2025 \\
\hline & Canción & Yo siempre te querré & 1942 & BMCD 2025 \\
\hline & Canción & Triunfar, gozar & 1942 & BMCD 2025 \\
\hline
\end{tabular}

\begin{tabular}{lllll} 
Salinas & & & \\
Película & Forma & Titulo & Año & Referencia \\
\hline La sombra del hermano & Canción & No se lo que tengo & 1946 & BMCD 2025
\end{tabular}

Guridi, jesús

\begin{tabular}{lllrl} 
Película & Forma & Titulo & Año & Referencia \\
\hline La malquerida & Selección & La malquerida & 1940 & ENSAYO-EMY- \\
& Selección & Marianela & & S111
\end{tabular}




$\begin{array}{lrlll} & & & \\ \text { Amaya }-1111 & \\ \text { Mara } & \text { Tema Amaya } & 1952 & \text { ENSAYO-EMY- } \\ & \text { S- } 1111\end{array}$

\section{Turina, Joaquín}

\begin{tabular}{|c|c|c|c|c|}
\hline Película & Forma & Titulo & Año & Referencia \\
\hline El abanderado & Selección & El abanderado & 1943 & VND-1035 \\
\hline $\begin{array}{l}\text { Primavera } \\
\text { (cortometraje) }\end{array}$ & $\begin{array}{l}\text { Obra } \\
\text { Completa }\end{array}$ & Primavera sevillana & 1943 & VND-1035 \\
\hline Eugenia de montijo & Suite & Eugenia de montijo & 1944 & VND-1035 \\
\hline Luis candelas & Selección & Luis candelas & 1947 & VND-1035 \\
\hline Noche en blanco & Selección & Noche en blanco & 1948 & VND-1035 \\
\hline
\end{tabular}

Quintero Muñoz, Juan

\section{Película}

Deliciosamente tontos

Locura de amor

Mare nostrum

Pequeñeces

Alba de américa

\section{Forma Titulo}

Canción Vana ilusión

Canción Pensar en ti

Suite Locura de amor

Suite Mare nostrum

Suite

Suite
Pequeñeces

Alba de américa

\begin{tabular}{ll} 
Año & Referencia \\
\hline 1942 & BMCD 2025 \\
& BMCD 2025 \\
1947 & $460-574-2$ \\
1948 & $460-574-2$ \\
1949 & $460-574-2$ \\
1951 & $460-574-2$
\end{tabular}

Año Referencia

1941 BMCD 2025

\begin{tabular}{lllll} 
Galindo & & & & \\
Película & Forma & Titulo & Año & Referencia \\
\hline Pimientilla & Canción & Se va Covadonga & 1941 & BMCD 2025
\end{tabular}

\section{Rovira}

\section{Película}

Una conquista dificil

\begin{tabular}{ll} 
Forma & Titulo \\
\hline Canción & Creo en ti
\end{tabular}

\section{Año Referencia}

1941 BMCD 2025

\section{López-Quiroga}

\begin{tabular}{lllcl} 
Película & Forma & Titulo & Año & Referencia \\
\hline La hermana San Sulpicio & Canción & Viva sevilla & 1934 & 72438551672 \\
& & & 6 & \\
Goyescas & Canción & Maja y condesa & 1942 & 72438551672 \\
& & 6 & 72438551672 \\
& Canción & Olé catatún & 6 &
\end{tabular}

\begin{tabular}{lllll} 
Mostazo & & & & \\
Película & Forma & Titulo & Año & Referencia \\
\hline Morena Clara & Canción & Falsa moneda & 1936 & 72438551672 \\
& & 6 & 72438551672
\end{tabular}




\begin{tabular}{|c|c|c|c|c|}
\hline & & & & 6 \\
\hline & Canción & El día que nací yo & & 72438551672 \\
\hline & & & & 6 \\
\hline \multirow{8}{*}{ Carmen la de Triana } & Canción & Triana, triana & 1938 & 72438551672 \\
\hline & & & & 6 \\
\hline & Canción & Carceleras del puerto & & 72438551672 \\
\hline & & & & 6 \\
\hline & Canción & Los piconeros & & 72438551672 \\
\hline & & & & 6 \\
\hline & Canción & Antonio Vargas, Heredia & & 72438551672 \\
\hline & & & & 6 \\
\hline
\end{tabular}

\section{Evaristo}

Película

Forma Titulo

Año Referencia

Una conquista difícil

Canción Eternamente

1941 BMCD 2025

\section{Serramont}

Película

Forma Titulo

Año Referencia

Un enredo de familia

Canción Muchas muchacha

Canción Señora

BMCD 2025

Canción Ayer decías

BMCD 2025

Ruiz De Azagra

Película

Un marido a precio fijo

El $13-13$

\begin{tabular}{ll} 
Forma & Titulo \\
\hline Canción & Tipolino \\
Canción & Nena
\end{tabular}

\section{Rey, Martínez, Rivera}

Película

Nobleza baturra

\begin{tabular}{|c|c|c|}
\hline Forma & Titulo & \\
\hline Canción & Bien se ve & \\
\hline Canción & $\begin{array}{l}\text { La segadora } \\
\text { carretero }\end{array}$ & $\mathrm{y}$ \\
\hline
\end{tabular}

\section{Año Referencia \\ 1942 BMCD 2025 \\ 1944 BMCD 2025}

\begin{tabular}{|c|c|c|c|c|}
\hline \multicolumn{5}{|c|}{ Pedro Bonet Mir - V. Moro Lanchares } \\
\hline Película & Forma & Titulo & Año & Referencia \\
\hline Viviendo al revés & Canción & Galopando voy & 1943 & BMCD 2025 \\
\hline \multicolumn{5}{|l|}{ García Leoz, Jesús } \\
\hline Película & Forma & Titulo & Año & Referencia \\
\hline Balarrasa & Suite & Balarras & 1950 & JMBSP501 \\
\hline Surcos & Suite & Surcos & 1951 & JMBSP501 \\
\hline La sirena negra & Suite & La sirena negras & 1947 & JMBSP501 \\
\hline ¡Bienvenido, Mr. Marshall! & Suite & ¡Bienvenido, Mr. Marshall! & 1952 & JMBSP501 \\
\hline La duquesa del candil & Zarzuela & La duquesa del candil & 1949 & BMCD 7510 \\
\hline
\end{tabular}

\begin{tabular}{|c|c|}
\hline Año & Referencia \\
\hline 1935 & 72438551672 \\
\hline & 6 \\
\hline & $\begin{array}{l}72438551672 \\
6\end{array}$ \\
\hline
\end{tabular}


Parada de la Puente, Manuel

\begin{tabular}{lllll} 
Película & Forma & Titulo & Año & Referencia \\
\hline NO-DO & Tema & NO-DO & 1942 & Ref:700 \\
Raza & Suite & Raza & 1941 Ref:700 \\
Los últimos de Filipinas & Suite & Los últimos de Filipinas & 1945 & Ref:700 \\
El escándalo & Suite & El escándalo & 1943 Ref:700 \\
Maribel y la extraña familia & Suite & Maribel y la extraña & 1960 & Ref:700 \\
& & familia & &
\end{tabular}

\section{Granados, Enrique}

\begin{tabular}{lllll} 
Película & Forma & Titulo & Año & Referencia \\
\hline Goyescas & Ópera & Goyescas & 1916 & WD 71322
\end{tabular}

Tabla 9: Referencias a archivos sonoros

\section{Estructura de la tesis}

La presente tesis consta de cuatro capítulos. En el capítulo 1 se presentan de manera breve los hitos más significativos que nos permitirán reconstruir de forma sintética la historia de nuestro país en la década de los cuarenta y su repercusión en las primeras instituciones destinadas a dirigir y vigilar los caminos de nuestra cinematografía. En el capítulo 2, hemos realizado una aproximación a las ordenanzas jurídicas de la época, con la intención de facilitar la comprensión de la repercusión que las medidas tomadas tuvieron en la industria cinematográfica. Nos centraremos en los aspectos legislativos que más directamente afectan a la producción fílmica, entre los que destacaremos: la censura, las tasas arancelarias para la importación de material virgen, la importación de películas, las implicaciones del doblaje, los créditos y premios cinematográficos establecidos por ley, la regulación de la programación, la creación del Noticiario Cinematográfico Español (NO-DO). El capítulo 3 está dedicado a las características de la producción cinematográfica. La coyuntura política y jurídica fueron moldeando los engranajes de la industria que vio como sus universos temáticos y esquemas productivos fueron transformándose a lo largo de la década. En este sentido destacaremos como los géneros cinematográficos son dependientes de la política de clasificaciones seguida en la época. En el capítulo 4 se realiza una aproximación en torno a la música de cine y se recrea el panorama musical cinematográfico de los años cuarenta en nuestro país. El capítulo 5, está dedicado a los compositores del cine español, en el mismo se realiza un análisis en torno a la música de cine de la época, distinguiendo las tipologías musicales presentes en las películas de la década. También se aborda la naturaleza de la labor que realizaron los compositores y las limitaciones técnicas en la que ésta se desarrolló. El capítulo 6 está dedicado a mostrar la funcionalidad de la base de datos multimedia MCE40 desarrollada. La tesis se cierra con las conclusiones, la bibliografía utilizada y un conjunto de anexos. 
CAPÍTULO 1 CONTEXTO POLÍTICO 
Cualquier aproximación al cine de los años cuarenta en España, exige detenerse en el contexto político en el que éste se desarrolló. De manera breve, nos referiremos en este apartado a los hitos más significativos que nos permitirán reconstruir de forma sintética la historia de nuestro país en esta etapa y su repercusión en las primeras instituciones destinadas a dirigir y vigilar los caminos de nuestra cinematografía.

\section{El asentamiento de los estamentos franquistas}

Antes de la finalización del conflicto armado comienza por parte del bando sublevado una labor frenética por construir una estructura política y económica lo suficientemente fuerte y estable que favoreciera su consolidación, sin olvidar los aspectos sociales e ideológicos de los que harían uso.

Una vez establecido el gobierno en Madrid en 1938, comienza a crearse el entramado burocrático necesario para su funcionamiento, siendo operativo, en el bando Nacional, desde ese mismo instante. Este primer gobierno ${ }^{57}$ constituido el 30 de enero de 1938 bajo el mando, tanto en la jefatura del estado como en la presidencia del gobierno, por Francisco Franco. Es precisamente en este momento cuando la figura de Franco se sitúa en un lugar predominante y se establece un caudillaje que, según Francisco Sevillano Calero:

“... era prácticamente inexistente antes de la guerra y que tampoco hubo al respecto una ideación de gran calado por aparte de los teorizantes del Estado Nuevo, siendo más bien fruto de las circunstancias, al tiempo que la tradición y el carácter cristiano y providencial del carisma fueron elementos fundamentales en la legitimación que se hizo del caudillaje, rasgos que concordaban con el ideario militarista, conservador y "cristiano" del propio Franco. ${ }^{58 "}$

Pero si este momento es de vital importancia por lo que supone de potenciación de la figura del caudillo, no menos resulta la creación de la Falange Española, la FET y de las JONS, constituida a partir de la unificación de distintos sectores ideológicos y políticos, el 18 de abril de 1937 por el propio Francisco Franco.

"Esta organización va a tener durante la dictadura una papel importante, especialmente en este primer momento. Eso sí, la concentración de poder en la figura de Franco así como del gobierno, facilitó la labor de domesticar desde dichos poderes los componentes totalitarios fascistas de la Falange que desde sus mismos orígenes fue instrumentalizado por los conservadores y el propio

\footnotetext{
${ }^{57}$ Para consultar los gobiernos franquistas del periodo estudiado, ver ANEXO II.

58 Sevillano Calero, F. (1996) Dictadura, socialización y conciencia política. Persuasión ideológica y opinión en España bajo el franquismo (1939-1962), Alicante, Universidad de Alicante, Departamento de Humanidades Contemporáneas. Tesis Doctoral. Consultada on-line http://cervantesvirtual.com/FichaObra.html?Ref=3140 [mayo de 2003]. pp. 84.
} 
gobierno militar, sin olvidar que sirvió como apoyo para la creación de un primer proyecto político, inexistente cuando se produjo la sublevación militar de julio de 1936, aunque sí con unos objetivos claros sociales al pretender restaurar las estructuras tradicionales en peligro por las reformas llevadas a cabo por el Frente Popular en el último gobierno republicano ${ }^{59 "}$.

El ideario de esta agrupación ${ }^{60}$ tiene en su seno la base de la política del Nuevo Estado, si bien, la naturaleza dictatorial del primer franquismo:

“... convierte a los sectores fascistas y más reaccionarios de la Falange en un mero aparato burocrático dependiente del Estado con escasa penetración en la sociedad civil como consecuencia de la desnaturalización de un partido fascista por su necesaria adecuación al heterogéneo grupo de fuerzas que integraron el franquismo ${ }^{61}$."

Por otro lado, junto con la creación de Falange Española Tradicionalista, se crea la Delegación de Prensa y Propaganda, dependiente del Ministerio de la Gobernación, en manos de Ramón Serrano Súñer, durante la guerra. Ésta sería capitaneada por Dionisio Ridruejo de la sección fuerte de Falange, convirtiéndose tan solo un año más tarde en el Departamento Nacional de Cinematografía que pasaría a dirigir Manuel Augusto GarcíaViñolas. De este modo, se establecen las primeras instituciones destinadas a dirigir y vigilar los caminos de nuestra cinematografía durante los siguientes cuarenta años.

Ese mismo año, en virtud a la orden de 2 de noviembre de $1938^{62}$, la Junta Superior de Censura Cinematográfica comienza a funcionar en todo el bando Nacional:

\begin{abstract}
"Siendo innegable la gran influencia que el cinematógrafo tiene en la difusión del pensamiento y en la educación de las masas, es indispensable que el Estado lo vigile; en todos los órdenes en que haya riesgo de que se desvíe de
\end{abstract}

\footnotetext{
${ }^{59}$ Idídem. pp. 83.

${ }^{60}$ El ideario Falangista se resume en los 27 puntos expuestos a continuación, y extraidos de Menéndez Pidal, R. (1970) Gran enciclopedia del mundo, Vol. 8, Bilbao. pp. 520, "Fe en la suprema realidad de España. Concepción de ésta como una unidad de destino en lo universal. Voluntad de Imperio como plenitud histórica. Devolución de su plena dignidad al Ejército de Tierra, Mar y Aire. Aspiración de convertir a España en una gran potencia marítima y aérea. Participación de todo los españoles en el Estado a través de su función familiar, municipal y sindical. Intangibilidad de la dignidad, integridad y libertad humanas como valores eternos. Estímulo de la iniciativa privada compatible con el interés colectivo. Concepción de España en lo económico como un gigantesco sindicato de productores. Repudiación del Capitalismo y del Marxismo. Eliminación de la lucha de clases por cuanto todos los que cooperan a la producción constituyen una totalidad orgánica. Dedicación de la riqueza como primer destino a mejorar las condiciones de vida de cuantos integran el pueblo. Defensa por el Estado de la propiedad privada como medio lícito para el cumplimiento de los fines individuales, familiares y sociales. Tendencia a la nacionalización, mediante las corporaciones, de los grandes servicios públicos. Derecho al trabajo de todos los españoles. Deber del trabajo de todos los no impedidos. Elevación del nivel de vida del campo, vivero permanente de España. Reforma económica de la agricultura. Organización social de la agricultura. Repoblación forestal y ganadera. Apropiación por el Estado de las tierras adquiridas o disfrutadas ilegítimamente. Reconstrucción de los patrimonios comunales de los pueblos. Consecución, mediante una disciplina rigurosa de la educación, de un espíritu nacional fuerte y unido. Organización de la cultura en forma que no se malogre ningún talento por falta de medios económicos. Incorporación del sentido católico a la reconstrucción nacional. Aspiración a un orden nuevo, enunciado en los anteriores principios”

${ }^{61}$ CHUECA, R. (1977) El fascismo en los comienzos del régimen de Franco, Madrid, Fondo de Cultura Económica. pp. 29-60, citado en SeVILLANo CAleRo, F. (1996) Dictadura, socialización y conciencia política. Persuasión ideológica y opinión en España bajo el franquismo (1939-1962), Alicante, Universidad de Alicante, Departamento de Humanidades Contemporáneas. Tesis Doctoral. Consultada on-line http://cervantesvirtual.com/FichaObra.html?Ref=3140 [mayo de 2003].. pp. 86

${ }^{62}$ España. Órdenes del Ministerio del Interior. Boletín Oficial del Estado, 5 de noviembre de 1938, núm. 128
} 
su misión. La experiencia del sistema hasta ahora seguido aconseja introducir algunas modificaciones y completar las normas sobre la materia. En consecuencia, este Ministerio se ha servido disponer lo siguiente:

Artículo primero. - La Comisión de Censura Cinematográfica que incumbe al Estado, se ejercerá por medio de la Comisión de Censura Cinematográfica y por la Junta Superior de Censura Cinematográfica, ambas dependientes del Ministerio del Interior. ${ }^{63 "}$

Su labor es de control, por lo que todo producto cinematográfico debe pasar por su dictamen antes de ser comercializado. Su labor, comenzará incluso antes de la realización del filme, con la censura de los mismos guiones.

El 9 de agosto de 1939, poco antes del comienzo de la II guerra mundial, Franco lleva a cabo una nueva reforma gubernamental y se instituye el segundo gobierno de la dictadura. Esta primera remodelación del gobierno sufre grandes cambios, aunque tanto el titular de Industria y Comercio, Juan Antonio Suanzes Fernández, como el ministro de interior, que pasa a denominarse de la Gobernación, Serrano Súñer, se mantienen en sus puestos.

La subcomisión Reguladora de Cinematografía dependiente de Comercio e Industria comienza a funcionar. Serrano Súñer, conocido falangista de extrema derecha y simpatizante del movimiento Nazi, es destituido por Franco de su puesto en el Ministerio de Gobernación el 16 de octubre de 1940, colocando en su lugar al antifalangista Valentín Galarza Morante con la intención de que realizara una limpieza de falangistas en el seno de las instituciones gubernamentales. Galarza Morantes comienza a tomar medidas de distinto calibre dirigidas a la debilitación progresiva de la Falange, eliminando privilegios y relegando a miembros de dicha organización a puestos de menor importancia. De este modo, comienza Franco una "limpieza" de uno de los sectores más peligrosos para él, la FET. Comenzaba de este modo su estrategia política para mantenerse en el poder indefinidamente.

El 17 de octubre de 1940, Luis Alarcón de la Lastra es sustituido en la cartera de Industria y Comercio por Demetrio Carceller Segura. Esta nueva figura en el ejecutivo de Franco será el principal artífice y mentor de las medidas protectoras que en la industria cinematográfica española se llevarán a cabo durante la primera mitad de la década de los cuarenta.

Mientras todo esto acaecía en nuestro país, en Europa el devenir de la guerra sigue su curso y Alemania, a comienzos de 1941, tiene bajo su yugo a Polonia, Dinamarca, Noruega, Holanda, Bélgica y Luxemburgo. También se ha ocupado París (firmando el armisticio con el gobierno francés del mariscal Pétain) y ha comenzado la invasión de Rumania. Por su parte, Italia se ha lanzado a la conquista de Grecia y Franco, después de mantener un encuentro con Hitler en septiembre y otro posterior, en febrero de 1941 con Mussolini, decide mantener a España en una posición de no beligerancia, utilizando como excusa la precaria situación que vivía el país tras la guerra civil, circunstancia que proporcionaría a Franco una situación perfecta para dejarse arrastrar por los vientos que

\footnotetext{
${ }^{63}$ Idídem
} 
resultaran más favorables, como se demostró años más tarde. A pesar de todo, España envía a la famosa División Azul al frente ruso en apoyo de las fuerzas del Eje, algo que no será bien visto por los Aliados y tendrá sus posteriores consecuencias.

El 28 febrero de 1941, muere en su habitación del Gran Hotel de Roma, Don Alfonso XIII de Borbón, tras haber abdicado meses antes a favor de su hijo Don Juan. Y durante el resto del año, Alemania seguirá avanzando imparable por toda Europa, invadiendo Bulgaria, Yugoslavia y atreviéndose con Rusia.

En mayo de 1941 se producen dos acontecimientos importantes. Por un lado, se efectúa una nueva remodelación del gobierno, el día 20 de ese mismo mes. El tercer gobierno de la dictadura, no producirá cambios en las carteras de Gobernación ni de Industria y Comercio, manteniendo en sus puestos tanto a Valentín Galarza como a Carceller Segura.

Por otro lado, ese mismo día se crea la Vicesecretaría de Educación Popular de Falange Española Tradicionalista y de las JONS, pero hasta octubre ${ }^{64}$ de ese mismo año no se establece una organización concreta de este organismo, a cuyo frente coloca Franco a su pupilo incondicional Arias Salgado. La elección no pudo ser mejor, puesto que Salgado supo en todo momento manipular la información y orientarla en función de las necesidades del momento. Él fue uno de los responsables del cambio paulatino que sufrieron la directrices ideológicas del franquismo pasando de la derecha falangista a la vertiente más radical democristiana que se vivió a comienzo de los años cincuenta.

La entrada en el conflicto armado de los Estados Unidos tras el ataque sufrido en Peral Harbour, el 7 de diciembre de 1941, va a favorecer un cambio en el transcurso de la II guerra mundial en favor de los Aliados, que junto al desgaste, ya acentuado, de las tropas alemanas, después de dos años de conflicto, comenzaba a hacer mella en la moral de las tropas.

En 1942, la arriba citada Vicesecretaría de Educación Popular de Falange Española Tradicionalista y de las JONS, se convierte en la conocida Delegación Nacional de Cinematografía y Teatro. Casi al mismo tiempo, la Subcomisión Reguladora es sustituida por el SNE (Sindicato Nacional del Espectáculo), dependiente del Movimiento en un principio y posteriormente, casi tres años más tarde, del conocido Ministerio de Educación Nacional. Este Sindicato irá adquiriendo con el tiempo una importancia crucial para la vida de todos los trabajadores de nuestro país, puesto que si no se estaba afiliado a él, difícilmente se podía llegar a obtener un empleo. A pesar de ello, se intentó vender la idea como una alternativa a la lucha de clases, como podemos leer en estas declaraciones de Tomás Borrás, jefe del SNE:

"En el sindicato, como cumple a la verticalidad de su arquitectura, están presentes todos los elementos que integran la producción, desde el capitán de la Empresa, hasta la modestísima operaria de la limpieza. Todos, empresarios, artistas, técnicos y obreros tienen mandos, influyen por derecho propio en la marcha de este órgano regulador e impulsor de la Economía

\footnotetext{
${ }^{64}$ EsPañA, Falange Española, Tradicionalista y de las JONS organiza la Vicesecretaría de Educación Popular, 10 de octubre de 1941, Secretaria General del Movimiento, Boletín Oficial del Estado, 15 de octubre de 1941, núm. 288
} 
armonizados y jerarquizados para eliminar la lucha de clases, guerra permanente que no puede resistir la vida sana de ningún país y que fue creada con fines político-revolucionarios subversivos. Por el sindicato vertical, esa lucha de clases queda neutralizada y las aspiraciones y mejoras se adoptan al compás del progreso y de la resistencia de las empresas, para no matar la gallina de los huevos de oro, ni permitir el abuso del más fuerte sobre el que tiene que dar su trabajo. ${ }^{65,}$

El 3 de septiembre de 1942, como consecuencia tanto de la situación del país, como de las nuevas circunstancias en que se encuentra el conflicto europeo, Franco decide hacer nuevos cambios en el gobierno. En esta ocasión, si bien Carceller Segura mantiene su puesto en la cartera de Industria y Comercio, en el ministerio de la Gobernación se sustituye a Valentín Galarza por Blas Pérez González que mantendrá el puesto hasta bien entrados los años cincuenta.

\section{El aislamiento}

Durante los años 1943 y 1944 la guerra europea da un giro completo y Alemania e Italia comienzan a retroceder. Los Aliados cada vez más fuertes dan el golpe de gracia con el desembarco de Normandía.

Con este panorama internacional, donde los apoyos de Franco desaparecen, asistimos a una nueva crisis que tiene como consecuencia un nuevo cambio de gobierno. Esta vez se lleva a cabo el 18 de julio de 1945 y si bien la cartera de Gobernación sigue en las mismas manos, la de Industria y Comercio volverá a manos de Juan Antonio Suanzes Fernández, que ya fue encargado de este ministerio durante el primer gobierno franquista. En el momento en que se establece este quinto gobierno franquista, podemos afirmar que nos encontramos en un punto de inflexión dentro de la política nacional. Con los sucesivos cambios en las carteras ministeriales y en los puestos de gran responsabilidad de la administración, Franco ha conseguido, en 1945, reducir considerablemente la influencia de la Falange, trasladando el poder de éstos hacia los prohombres de los sectores democristianos que, en lo que queda de década, irán afianzando su posición así como el de la Iglesia en nuestro país.

Así pues, el ecuador de la década coincide con un punto de inflexión entre las dos últimas épocas que podrían definir este primer periodo del franquismo. La primera vendría definida por los gobiernos militares, la segunda por la fuerte presencia de la Falange y la tercera por las corrientes democristianas y católicas.

Ese mismo año, 1945, se firma la carta de las Naciones Unidas y al poco tiempo, esta institución condena el régimen franquista, tomando una serie de medidas económicas desfavorables para España y al año siguiente, Francia cierra la frontera con España. Estas

\footnotetext{
${ }^{65}$ BorRÁs, T. «El jefe del Sindicato Nacional del Espectáculo habla para RadioCinema». RadioCinema, 30 de julio de 1940. citado en Diez PuertAs, E. (2000) Historia del movimiento obrero en la industria española del cine. 1931 1999, Valencia IVAC. pp. 72.
} 
muestras de la comunidad internacional en contra de la dictadura franquista levantan el fervor patrio, impulsado a su vez por los medios de comunicación en manos del gobierno. A pesar de ello, en 1946 España firma un tratado comercial con Argentina, comenzando de este modo un acercamiento a América latina como posible mercado.

Ese mismo año, la Junta Superior de Censura Cinematográfica y la Comisión Nacional de Censura Cinematográfica se refunden en un solo organismo, que se denominará Junta Superior de Orientación Cinematográfica ${ }^{66}$, por la orden de 28 de junio, del Ministerio de Educación Nacional, cuyas funciones a desempeñar por la nueva institución serán las siguientes:

"1. Ser el órgano, supremo de carácter consultivo en materia de cinematografía y en tal concepto formular dictamen sobre los asuntos que le sean sometidos a su estudio, así como elevar a la Superioridad los informes y proyectos que estime convenientes para la mejor ordenación de la cinematografía española.

2. Proponer la condición de películas de interés nacional que establece la Orden de 15 de junio de 1944.

3. Determinar en su caso las películas que por su deficiente calidad artística no deben ser exportadas al extranjero.

4. Determinar en su caso las películas que por la misma razón citada en el apartado anterior, no puedan ser exhibidas en locales de primera y segunda categoría, como dispone la Orden de 13 de octubre de 1944 (R. 1944, 1407).

Autorizar o denegar el doblaje de las películas extranjeras y, en su caso, la exhibición de las mismas con rótulos en castellano. ${ }^{67 "}$

\section{La renovación}

Tanto 1947 como 1948 resultan años muy interesantes para España en diversos frentes. En 1947, el país es excluido del Plan Marshall presentado el 5 de junio pero, por otro lado, Brasil, Filipinas, Honduras y Nicaragua reanudan sus relaciones y sus Embajadores vuelven a Madrid.

Por su parte, Franco lleva adelante la Ley de Sucesión a la Jefatura del Estado, que es aprobada en referéndum por amplia mayoría, confiriendo a su persona la legitimidad que por el momento le faltaba para seguir en su puesto.

Durante 1947 se crean otras dos instituciones de gran interés para el desarrollo de la cinematografía en nuestro país.

\footnotetext{
${ }^{66}$ EspañA. Creando la Junta Superior de Orientación Cinematográfica, 28 de junio de 1946, Ministerio de Educación Nacional, Boletín Oficial del Estado, 19 de julio de 1946, núm. 200

${ }^{67}$ Idídem
} 
“... dependiente de la Dirección General de Cinematografía y Teatro se crea el Patronato de Experiencias y Divulgaciones Cinematográficas, que tiene por objeto desarrollar y dirigir las investigaciones y enseñanzas de carácter cinematográfico que se establezcan. ${ }^{68 "}$.

Dicho patronato fue una idea ya acariciada por los sectores falangistas de los primeros gobiernos franquistas. El mismo Serrano Súñer firmaba la orden de 21 de febrero de 1940 donde se fijaban las competencias y funciones del Departamento de Cinematografía, estableciendo, ya en aquel momento, lo que siete años más tarde se convertía en realidad:

“... de propia iniciativa y de acuerdo con los organismos competentes, previa

la aprobación superior, las bases en que se funden el futuro Instituto Cinematográfico Español, como escuela cinematográfica del Estado. ${ }^{69 ",}$

Ese mismo año, volviendo a los aspectos meramente políticos, el PCE renuncia definitivamente, tras la práctica desaparición de la resistencia maqui, a la lucha armada y Francia decide abrir nuevamente la frontera con España.

En el transcurso de los últimos años cuarenta, la situación internacional cambia y España empieza a ser mirada con buenos ojos. La ONU levanta definitivamente el veto contra España en 1950, hito que favorecerá el reconocimiento del régimen en el resto del mundo, trayendo consigo que en los siguientes años nuestro país fuese también admitido en la UNESCO (1952) y se firmará el Concordato con la Santa Sede en 1953.

\footnotetext{
${ }^{68}$ España. Creando el Patronato de Experiencias y Divulgaciones Cinematográficas, 18 de febrero de 1947, Ministerio de Educación Nacional, Boletín Oficial del Estado, 19 de febrero de 1947, núm. 50

${ }^{69}$ España. Orden fijando la competencia y funciones del Departamento de Cinematografía, pendiente de la Dirección General de Propaganda, 21 de febrero de 1940, Ministerio de la Gobernación, Boletín Oficial del Estado, 25 de febrero de 1940, núm. 56
} 
CAPÍTULO 2

CONTEXTO JURÍDICO 
Junto al entramado político destinado, sobre todo, a un mejor asentamiento de la figura de Franco en el poder y un reconocimiento internacional del nuevo régimen, se lleva a cabo una fuerte actividad legislativa dirigida a la creación de una serie de medidas de alto interés para la industria cinematográfica que, salvo excepciones poco afortunadas que se vienen arrastrando hasta hoy en día, fueron de gran ayuda al proporcionar medidas protectoras y de estímulo a la producción fílmica nacional.

El principal artífice de las reformas iniciales desarrolladas durante los primeros gobiernos franquistas fue Demetrio Carceller Segura, ministro de Industria y Comercio desde el 16 de octubre de 1940, quien sustituyó al militar Luis de Alarcón y Lastra, permaneciendo en dicho puesto hasta la creación del quinto gobierno franquista el 18 de julio de 1945 en que es sustituido en la cartera de Industria y Comercio por Juan Antonio Sánchez Fernández, responsable hasta la siguiente remodelación gubernamental realizada en 1951.

Así, puede afirmarse que estos dos hombres van a regir los caminos de la industria cinematográfica española durante la década de los años cuarenta y, en especial, Carceller Segura quien ideará una política proteccionista que, vista con el tiempo, no deja de sorprender por sus buenas intenciones e ingenuidad y que la inevitable interpretación de las leyes, el tráfico de influencias y las ansias de enriquecimiento de industriales ávidos de obtener beneficios, acabó por desvirtuar. A ello contribuyeron, también, los responsables políticos de la cartera del Ministerio de la Gobernación y del Ministerio de Educación Nacional, organismos de los que dependería, sucesivamente, la industria cinematográfica.

Antes de la llegada de Carceller, hay que hacer mención a los dos primeros ministros de la Gobernación, Ramón Serrano Súñer (padre de la censura franquista) y Valentín Galarza Morante (autor de la limpieza de falangistas efectuada en las instituciones gubernamentales).

A continuación vamos a realizar un recorrido por las disposiciones más directamente relacionadas con el cine, llevadas a cabo durante el periodo que abarca nuestra investigación. Para una mejor comprensión hemos ampliado el intervalo temporal a 1938, año en que se establece el primer gobierno franquista, sin haber terminado la guerra, porque ya en ese momento se toman algunas medidas jurídicas que van a repercutir directamente en las disposiciones posteriores.

Por otro lado, hemos decidido realizar una división de las ordenanzas en función de los temas abordados en las mismas, con la intención de facilitar la comprensión de la repercusión que las medidas tomadas tuvieron en la industria cinematográfica. Así pues, nos centraremos en los aspectos legislativos que más directamente afectan a la producción fílmica, entre los que destacaremos: la censura, las tasas arancelarias para la importación de material virgen, la importación de películas, las implicaciones del doblaje, los créditos y premios cinematográficos establecidos por ley, la regulación de la programación, la creación del Noticiario Cinematográfico Español (NO-DO). Asimismo nos ocuparemos de la incidencia que tuvieron para la industria española el Círculo de Escritores Cinematográficos y el I Certamen Cinematográfico Hispanoamericano para acabar refiriéndonos al Instituto Cinematográfico Español, la llamada Escuela de Cine. 


\section{La censura}

La censura se convierte en una de las herramientas fundamentales del régimen franquista. Por esta razón, no debe sorprendernos que una de las primeras medidas tomadas por Serrano Suñer fuese la promulgación de una orden ministerial que tuvo como objetivo regular todos los aspectos concernientes a la censura. Así pues, el Ministerio del Interior (después llamado de Gobernación) promulga el 20 octubre de $1938^{70}$, una orden ministerial en cuya entradilla podemos leer:

“... siendo innegable la gran influencia que el cinematógrafo tiene en la difusión del pensamiento y en la educación de las masas, es indispensable que el Estado lo vigile; en todos los órdenes en que haya riesgo de que se desvíe de su misión. La experiencia del sistema hasta ahora seguido aconseja introducir algunas modificaciones y completar las normas sobre la materia. ${ }^{71 "}$

En dicha orden se crean la Comisión de Censura Cinematográfica y la Junta Superior de Censura Cinematográfica que serían los organismos sobre los recaería la actividad censora. En los dos primeros artículos de la citada disposición podemos leer:

"Artículo primero. - La censura cinematográfica que incumbe al Estado, se ejercerá por medio de la Comisión de Censura Cinematográfica y por la Junta Superior de Censura Cinematográfica, ambas dependientes del Ministerio del Interior.

Artículo segundo. - La Comisión de Censura Cinematográfica estará integrada por el Jefe del Departamento de Cinematografía del Servicio Nacional de Propaganda como Presidente, y por cuarto Vocales designados por el Ministro del Interior a propuesta, respectivamente, del de Defensa Nacional, del de Educación Nacional, de la Jerarquía Eclesiástica y de la Jefatura del Servicio Nacional de Propaganda.

La Junta Superior de Censura Cinematográfica estará constituida por Presidente, Delegado del Ministro del Interior, y cuatro Vocales, nombrados también por él, a propuesta de las mismas Autoridades que los de la Comisión.

Tanto los Presidentes como los Vocales de ambos organismos tendrán designado un suplente para casos de imposibilidad de asistencia. La Junta y la Comisión tendrán su sede en el lugar en que radique el Ministerio del Interior. Dos funcionarios de éste actuarán como Secretarios. ${ }^{72 "}$

La delimitación de las funciones que tendrían estos organismos viene regulada a continuación:

"Artículo tercero. - Corresponde a la Junta Superior:

\footnotetext{
${ }^{70}$ Idídem.

${ }^{71}$ EsPaña. Órdenes del Ministerio del Interior. Boletín Oficial del Estado, 5 de noviembre de 1938, núm. 128

${ }^{72}$ Idídem.
} 
1. Censurar en única instancia los documentales y noticiarios.

2. Censurar en única instancia las producciones del Departamento de Cinematografía.

3. Censurar en segunda instancia o revisión las demás producciones cinematográficas.

Artículo cuarto. - Corresponde a la Comisión censurar en primera instancia las producciones cinematográficas no comprendidas en los apartados 1) y 2) del artículo anterior. ${ }^{73,}$

También en la citada orden se establecen los pasos a seguir, así como las tarifas de tasas a pagar por las empresas que presenten una película a la Comisión de censura. En el artículo diecisiete podemos leer:

"Los derechos de censura de la Comisión serán los siguientes:

Por rollo de cada una de las copias, 10,00 pesetas. En el caso de que se prohíba la película, sólo se cobrarán los derechos de censura sobre los rollos de una copia.

Por cada certificado que se expida 5,00 pesetas, independientemente del Timbre del Estado.

Los anteriores derechos de censura se dedicarán a atender las necesidades de proyección, material y personal de la Comisión y de la Junta Nacional de Censura.

La revisión y tramitación de apelaciones en la Junta Superior no devengará derechos. $^{74,}$

En diciembre de 1942 se reorganizan los servicios y organismos relativos a la censura cinematográfica creados anteriormente. La finalidad queda expresada en el prefacio de la orden ministerial:

"Debe presidir la constitución de estos Organismos un criterio de unidad, conforme al que es postulado en nuestro Movimiento, encaminado a la mejor eficacia del Servicio, reuniendo en un solo Organismo las funciones y competencias que venían estando dispersas en dos, aunque dejando subsistente otro Organismo superior a los efectos de recursos de revisión.

Igualmente se tiende con esta modificación a producir el menor retraso y entorpecimiento posible, dejando a salvo las garantías que corresponde a los intereses particulares, siempre respetables, pero subordinados al superior fin de la educación general, afectado de manera decisiva por un medio de tan extraordinaria difusión como es el cinematógrafo. ${ }^{75}$,

\footnotetext{
${ }^{73}$ Idídem

${ }^{74}$ Idídem.

${ }^{75}$ España. Orden Reorganizando los servicios de censura cinematográfica, 23 de noviembre de 1942, Vicesecretaría de Educación Popular, Boletín Oficial del Estado, 26 noviembre de 1942, núm. 330
} 
Más adelante, se abordan las competencias del aparato censor, entre las que se destacan:

“Compete a la Comisión:

- Censurar toda clase de películas, nacionales y extranjeras, sean de la clase que fueren y quienquiera que las haya producido, que hayan de proyectarse en territorio nacional.

- Censurar el material de propaganda que las Casas distribuidoras o propietarias de películas remitan con éstas a las salas de proyección."76

Mientras que a la Junta Nacional Superior se le atribuyen competencias en relación con los recursos de revisión sobre los acuerdos de la Comisión o de cualquier Organismo que haya ejercicio la censura cinematográfica. Se convierte, de este modo, en el órgano superior de apelación, aunque en la práctica no era usual proceder a revisar las decisiones de los órganos censores. Con la unificación de criterios y estructuración de los órganos censores, se pretendía conseguir rapidez en el trámite y mayor cohesión en los veredictos. Para lo cual, era de vital importancia la composición de la Comisión Nacional de Censura Cinematográfica. Según podemos leer:

"La Comisión Nacional de Censura Cinematográfica estará formada por un Presidente, nombrado libremente por el Vicesecretario de Educación Popular, y cinco Vocales, nombrados por el mismo, a propuesta unipersonal, respectivamente, del Ministerio del Ejército, de la Autoridad eclesiástica, del Ministerio de Educación Nacional, del Ministerio de Industria y Comercio (Subcomisión Reguladora de la Cinematografía), los cuatro primeros, y el quinto de ellos será Lector Censor de guiones del Departamento de Cinematografía de la Delegación Nacional de Cinematografía y Teatro.

La Junta Superior de Censura Cinematográfica estará formada por un Presidente, nombrado libremente por la Vicesecretaría de Educación Popular, y cinco Vocales, designados en forma análoga a los de la Comisión Nacional, y que podrá ser presidida por el Delegado Nacional de Cinematografía y Teatro, cuando lo estime oportuno. ${ }^{77 "}$

Hacemos notar que la obligatoriedad de someterse a la censura atañe a todas aquellas películas que se proyecten, privada o públicamente, sean españolas o extranjeras. Dos años más tarde se vuelve a revisar la orden ministerial y se realizan las siguientes matizaciones relativas a la obligatoriedad de presentar las películas ante la censura en versión original:

"La Comisión Nacional de Censura Cinematográfica determinará en todo caso sobre las películas extranjeras que se introduzcan en España, por importación

\footnotetext{
${ }^{76}$ Idídem.

${ }^{77}$ Idídem.
} 
temporal o definitiva rechazando cuantas se presenten en versión española sin autorización previa de doblaje. ${ }^{78,}$

Los asuntos referidos a la censura no acaban con esta última disposición. El 28 de junio de 1946 el Ministerio de Educación Nacional impulsa la creación de una nueva institución, con el propósito de unificar, aún más, los criterios utilizados por los censores. Se crea así, la Junta Superior de Orientación Cinematográfica.

"La misión de orientar la Cinematografía española, que en gran parte realizan los Servicios de censura cinematográfica, dependientes de la Dirección General de Cinematografía y Teatro, pone de manifiesto la necesidad de un organismo superior consultivo que asesore a la Dirección General sobre aquellas cuestiones que la alta orientación de la cinematografía plantea, y cuya falta ha venido supliéndose hasta el presente por los citados organismos censores.

Por todo ello parece aconsejable que, a la par que se confíe a una sola entidad la realización de las funciones indicadas, para así robustecer el criterio de unidad que debe presidir sus decisiones y simplificar también el despacho de los asuntos, convenga asimismo ampliar el campo de sus atribuciones $y$ elevar su rango e influencia. ${ }^{79}$,

La constitución de los tribunales de este nuevo órgano serán designados por el Ministro de Educación Nacional a excepción del Vocal representante de la Iglesia que será nombrado a propuesta del Ordinario diocesano. Entre las labores y funciones asignadas a esta Junta se encuentran:

"Proponer la condición de películas de interés nacional que establece la Orden de 15 de junio de 1944.

Determinar en su caso las películas que por su deficiente calidad artística no deben ser exportadas al extranjero.

Determinar en su caso las películas que por la misma razón citada en el apartado anterior, no puedan ser exhibidas en locales de primera y segunda categoría, como dispone la Orden de 13 de octubre de 1944 (R. 1944, 1407).

Autorizar o denegar el doblaje de las películas extranjeras y, en su caso, la exhibición de las mismas con rótulos en castellano.

Clasificar las distintas películas nacionales o extranjeras a los efectos que procedan.

Ejercer la censura de toda clase de películas nacionales y extranjeras que hayan de proyectarse en territorio nacional, así como la del material de

\footnotetext{
${ }^{78}$ ESPAÑA. Orden Rectificando la orden de 23 de noviembre de 1942 sobre censura de películas, 15 de diciembre de 1944, Vicesecretaría de Educación Popular, Boletín Oficial del Estado, 21 de diciembre de 1944, núm. 356,

${ }^{79}$ EsPaña. Orden Creando la Junta Superior de Orientación Cinematográfica, 28 de junio de 1946, Ministerio de Educación Nacional, Boletín Oficial del Estado, 19 de julio de 1946, núm. 200
} 
propaganda que las casas distribuidoras o propietarias de películas remitan con éstas a las salas de proyección. ${ }^{80 ",}$

De este modo quedan regulados los principales aspectos relacionados con la censura y el control de contenidos ideológicos en la década de los años cuarenta.

\section{Las tasas arancelarias}

Una de las primeras medidas de importancia tomadas para la protección de la industria cinematográfica, se centra en la imposición y aumento de las tasas arancelarias para la importación de material virgen o películas. El 23 de abril de 1941, el Ministerio de Industria y Comercio establece las primeras medidas a tomar.

La primera de ellas resulta ser de gran interés pues tiene como objetivo la intención de proteger nuestra industria, cargando con tasar arancelarias la importación de películas en beneficio de la producción nacional exenta de dichas tasas. Debemos recordar, que la base de la industria y comercio cinematográfico de nuestro país durante la II República (y por extensión, durante la dictadura), será la distribución de películas extranjeras y no la producción. Con esta carga de gravamen se pretende introducir cambios a esta dinámica de la industria aunque finalmente no se conseguiría lograr tal fin. Estas cargas impositivas estaban sujetas a una clasificación establecida por la Junta Clasificadora dependiente del Sindicato Nacional del Espectáculo, fiscalizando los largometrajes de primera categoría con 75.000 , los de segunda con 50.000 y los de tercera con 252.000 pesetas; quedando exentos de pago los noticiarios y las películas de corta duración o de complemento, a excepción de aquellas que el Sindicato Nacional del Espectáculo considerase que podría llegar a tener una vida comerciar de interés. Pocos años más tarde se introducirían modificaciones tendentes a derogar la exención de las películas de complemento por resultar esta medida perjudicial para la producción dentro de nuestras fronteras.

Deberían pasar tres años, hasta llegar al 19 de julio de 1944, para que se proceda a revisar y ampliar la ley de aranceles porque:

“... la producción cinematográfica nacional ha llegado a un grado de desenvolvimiento prometedor de grandes posibilidades, y ello exige que por el Estado se preste apoyo a la industrialización de esta vigorosa actividad española, utilizando al efecto el medio legítimo y racional de la protección arancelaria directa sobre las importaciones que hayan de realizarse. ${ }^{81 "}$

Con ello se vuelve a ver el interés que mostraron los primeros gobiernos franquistas por la creación, estabilización, asentamiento y consolidación de la industria cinematográfica española, promulgando leyes proteccionistas al respecto.

\footnotetext{
${ }^{80}$ Idídem.

${ }^{81}$ EsPaña. Ley, Clasificación arancelaria protectora de la industria nacional de cinematografía, 19 de julio de 1944 , Jefatura del Estado, Boletín Oficial del Estado, 21 de julio de 1944, núm. 203
} 
En esta misma ley, se establece una nueva tabla de aranceles dependientes éstos de la clasificación obtenida por la película en función de su calidad artística y técnica, como veremos más adelante. A continuación se transcribe la tabla de aranceles ${ }^{82}$ :

\begin{tabular}{|c|c|c|}
\hline \multirow{2}{*}{ PELÍCULAS CINEMATOGRÁFICAS } & \multicolumn{2}{|l|}{ TARIFA ORO } \\
\hline & Pesetas & Pesetas \\
\hline \multicolumn{3}{|l|}{ Partida 692 - Películas cinematográficas sin impresionar. } \\
\hline Peso neto $\mathrm{kg}$ & 4,50 & 1,50 \\
\hline \multirow{2}{*}{\multicolumn{3}{|c|}{$\begin{array}{l}\text { Partida } 692 \text { bis (Nota } 39 \text { bis).- Películas de largo metraje: } \\
\text { Impresionadas en negativo o positivo. Incluso sus bandas sonoras, la } \\
\text { columnas de efectos y las películas en tecnicolor: }\end{array}$}} \\
\hline & & \\
\hline De Primera categoría & 60.000 .00 & 30.000 .00 \\
\hline De Segunda categoría. & 40.000 .00 & 20.000 .00 \\
\hline De Tercera categoría... & 20.000 .00 & 10.000 .00 \\
\hline \multicolumn{3}{|l|}{$\begin{array}{l}\text { Partida } 692 \text { ter (Nota } 39 \text { bis).- Películas de corto metraje: } \\
\text { Por cada rollo de } 300 \mathrm{mts} \text { o o fracción: }\end{array}$} \\
\hline 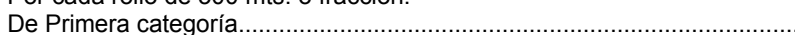 & 3.000 .00 & 1.500 .00 \\
\hline De Segunda categoría & 2.000 .00 & 1.000 .00 \\
\hline De Tercera categoría. & 1.000 .00 & 500.00 \\
\hline $\begin{array}{l}\text { Partida } 692 \text { cuart.- Bandas sonoras y columnas de efectos, cuando se } \\
\text { importen con separación de las películas a que correspondan, }\end{array}$ & & \\
\hline peso neto. Kg. & 75.00 & 25.00 \\
\hline
\end{tabular}

Tabla 10: Tabla de aranceles ${ }^{83}$

Como se observar, las imposiciones se dividen en dos subapartados. Por un lado, se fiscaliza la materia prima, pagando por su peso, el precio de la película; y por otro lado, por su clasificación de primera, segunda o tercera con una relación de 3:2:1, que se cumple tanto en la importación de largometrajes como de filmes cortos.

"Para determinar la categoría de la película, calificación que es totalmente independiente de su metraje, servirá de base el certificado de clasificación extendido por el Organismo formará parte, en representación del Ministerio de Hacienda, el Director general de Aduanas o funcionario en quien delegue. El documento de adeudo se hará constar el título de cada una de las películas importadas, que habrá de coincidir con el que conste en la licencia de importación y en el certificado de clasificación, cuyos documentos serán conjuntamente requisitos previos indispensables para que pueda ser autorizado el despacho. ${ }^{84 "}$

Todas las películas importadas quedan obligadas a pagar dichos aranceles estableciendo, con esta disposición, las normas y pasos a seguir, quedando exentas de esta obligación aquellos documentales de corta duración de interés netamente científicoeducativo que no vayan a tener una explotación comercial.

\footnotetext{
${ }^{82}$ Idídem.

${ }^{83}$ Ley, Clasificación arancelaria protectora de la industria nacional de cinematografía, 19 de julio de 1944, Jefatura del Estado, Boletín Oficial del Estado, 21 de julio de 1944, núm. 203

${ }^{84}$ Idídem.
} 


\section{La importación de películas}

En los primeros meses de 1943 se publica la primera medida importante referida a la importación de películas ${ }^{85}$. Con las medidas tomadas al respecto en estos primeros meses, se establecerían las bases de la estructura jurídica proteccionista y controladora de la industria cinematográfica española. El 18 de mayo se promulga la ley que se convierte en un pilar fundamental para el desarrollo creativo e industrial.

Comienza ratificando la orden del 28 de octubre de 1941, insistiendo en que:

“...la importación de películas se concederá única y exclusivamente a aquellas entidades o personas que produzcan películas de largometraje íntegramente nacionales, a los efectos económicos, y de una categoría técnica y artística suficientemente decorosa, a juicio de la Comisión clasificadora que a tal efecto nombra este Ministerio. ${ }^{86 "}$

Como podemos apreciar, se introduce un nuevo parámetro en el juicio de la Comisión Clasificadora, relacionada con aspectos técnicos y artísticos "decorosos". A partir de este momento comenzará a clasificarse las películas en tres categorías. Estar en una u otra implicará una amalgama de consecuencias a nivel de explotación, obtención de premios y de ayudas e ingresos por explotación de material importado que se convertirá, con las sucesivas leyes modificadoras, en el pilar central que sostendrá y moldeará, en cierto modo, la producción nacional como ya veremos más adelante. Así, las películas de producción nacional serán clasificadas dentro de las siguientes tres categorías:

- $\quad 1^{a}$ Aquellas películas que supongan un avance considerable en cualquier aspecto de la producción, sin que otro cualquiera de ellos haga perder la condición de muy buenas y merecedoras por tanto del mayor económico y protección.

- $\quad 2^{a}$ Aquellas películas que sin suponer un avance considerable en nuestra producción sean en su conjunto de una calidad suficientemente buena para poder con decoro traspasar nuestras fronteras, y que merezcan por tanto la protección del Estado.

- $\quad 3^{a}$ En esta categoría serían consideradas aquellas producciones que por su calidad artística o técnica supongan un descrédito de nuestra industria, no siendo merecedoras de apoyo alguno.

A la vista de la clasificación y coste de producción acordado por la Comisión Clasificadora, la Subsecretaría de Comercio, previo informe de su organismo competente, la Subcomisión Reguladora de la Cinematografía otorgará los permisos de importación correspondiente, teniendo en cuenta: la solicitud de los interesados y la operación que

\footnotetext{
${ }^{85}$ No equivocar con las medidas arancelarias ya establecidas desde 1941.

${ }^{86}$ EspañA. Orden Regulando la importación de películas, 18 de mayo de 1943, Ministerio de Industria, Subsecretaría de Comercio, Boletín Oficial del Estado, 24 de mayo de 1943, núm. de B.O.E. 124
} 
propongan, el precio, la calidad y la procedencia de las películas que se desea importar, los cupos existentes de diferentes países y la disponibilidad de divisas.

Como norma general, sujeta a las circunstancias que concurran, los beneficios de importación que este Ministerio concede ajustados a la categoría de la producción y a su valoración a estos efectos son los siguientes:

Por cada millón de pesetas de valor aprobado:

- Primera categoría, de tres a cinco películas, según su valor de explotación.

- Segunda categoría, de dos a cuatro películas, según su valor de explotación.

- Tercera categoría, ningún derecho.

A valores de producción superiores o inferiores al millón de pesetas corresponderá la parte proporcional de importaciones.

En casos especiales ${ }^{87}$ y si los contingentes de importación lo permiten, se podrá conceder algún aumento en el número de permisos, así como se autorizara la compensación directa con otra película de países de producción reducida, con quienes interese establecer relaciones cinematográficas y sea éste el único medio posible. ${ }^{88,}$

Años más tarde, dicha relación de «calificación - número de permisos de importación» llegará a igualarse con los de doblaje como da fe de ello Juan Mariné cuando hablamos sobre las importaciones con él:

“... en España, la legislación que hubo durante muchos años era que si la película era de tercera categoría no percibía ningún permiso; si la película era de segunda categoría se le daba un permiso de importación; y si la película era de primera categoría se le daban dos permisos, y con esto tu te podías ir bandeando. ${ }^{89 " ~ L a ~ r e l a c i o ́ n ~ d a d a ~ a q u i ́ ~ p o r ~ M a r i n e ́ ~ e s ~ e x a c t a m e n t e ~ i g u a l ~ a ~ l a ~ d e ~}$ concesión de licencias de doblaje publicada en la orden de 29 de julio de $1949^{90}$

Se agilizan los plazos necesarios para la aplicación de la presente orden y para ello, en su tercer artículo, punto c, se exige que:

“... en el plazo de veinte días, la Subcomisión Reguladora de Cinematografía emitirá informe relativo a esta producción, en el que hará constar los defectos que en ella pudiese apreciar. Las producciones que merezcan informes favorables tendrán prioridad a los efectos de suministro de material virgen para su realización. ${ }^{91 "}$

\footnotetext{
${ }^{87}$ Como explicaremos más adelante, este apartado consideramos que esta excepción va ha tener una repercusión muy importante pese a pasar inadvertida dentro del maremagno de esta orden.

${ }^{88}$ EsPaña. Orden Regulando la importación de películas, 18 de mayo de 1943, Ministerio de Industria, Subsecretaría de Comercio, Boletín Oficial del Estado, 24 de mayo de 1943, núm. de B.O.E. 124

${ }^{89}$ Entrevista con Juan Mariné, Madrid, 24 de julio de 2003

${ }^{90}$ España. Orden Permisos de doblaje a películas declaradas de Interés Nacional, 29 de julio de 1948, Ministerio de Educación Nacional, Boletín Oficial del Estado, 10 de agosto de 1948, mún. 223

${ }^{91}$ EsPaña. Orden Regulando la importación de películas, 18 de mayo de 1943, Ministerio de Industria, Subsecretaría de Comercio, Boletín Oficial del Estado, 24 de mayo de 1943, núm. de B.O.E. 124
} 
Pero la presente orden va más allá y regula el modo de pago, para controlar la posible evasión de divisas, así como la exportación. El Estado se preocupa claramente por recuperar, de algún modo, los fondos perdidos con la compra de cine al extranjero y material sensible, por lo que la medida, más que ayudar a las empresas lo que consigue es obtener más beneficio para las arcas del Estado. De este modo, la orden se expresa en estos términos:

"La importación de películas se realizará por pago de clearing, divisas o créditos facilitados o autorizados por el Instituto Español de Moneda Extranjera, o bien, de no ser esto posible, por compensación con la producción nacional realizada, bien entendido que de emplearse las dos primeras formas, la producción nacional al exportarse a todos los países, lo será con aportación total de su valor en divisas a España, y en el tercero de ellos sólo servirá de compensación hasta el valor del material que se importe, viniendo la diferencia en divisas al Instituto Español de Moneda Extranjera, así como las que resulten de exportaciones a los demás países que pudieran realizarse.

Las películas nacionales que hayan dado lugar a una importación deberán ser exportadas a cuantos países sea posible, y de no realizar estas exportaciones los interesados, podrán tomarlas a su cargo la Subcomisión Reguladora de la Cinematografía, correspondiendo los beneficios a los productores, pero sin que éstos puedan oponerse a las mismas. ${ }^{92 "}$

Trece meses más tarde, se amplia el espectro de clasificaciones destinadas a la importación de material extranjero con la creación de la conocida clasificación de «Interés Nacional». Esta nueva clasificación era otorgada especialmente a largometrajes españoles que demostraran un gran valor artístico, técnico y moral, aunque también podían tener acceso a esta clasificación cortometrajes y películas extranjeras (aunque en estos casos era difícil su concesión). A pesar de ello, la primera película importada que obtuvo el deseado "galardón" fue El hombre que vendió su Alma ${ }^{93}$ de 1941. Durante este periodo tan solo 6 largometrajes ${ }^{94}$ pertenecientes a Estados Unidos ${ }^{95}$, Reino Unido ${ }^{96}$ y México ${ }^{97}$ la obtuvieron. Entre las ventajas obtenidas por conseguir esta clasificación se encuentran:

\footnotetext{
92 Idídem.

${ }^{93}$ The devil and Daniel Webster (1941), dirigida por William Dieterle.

94 Datos obtenidos de: VV.AA. (1951) Anuario Cinematográfico Hispanoamericano 1950, Madrid, Sindicato Nacional del Espectáculo. pp. 673-675.

${ }^{95}$ Películas Norteamericanas:

El hombre que vendió su alma (R.K.O. Radio), estrenada el 5 de marzo de 1945.

Edison, el hombre. (M.G.M.), estrenada el 16 de noviembre de 1945.

La canción de Bernadette. (20th.Century Fox), estrenada el 8 de julio de 1946.

Qué bello es vivir. (Frank Capra), estrenada el 27 de marzo de 1948.

Juana de Arco. (R.K.O. Radio), estrenada el 1 de diciembre de 1949.

${ }^{96}$ Película inglesa:

Enrique V. (Two Cities Estudios), estrenada el 21 de octubre de 1946.

${ }^{97}$ Película mejicana:

Enamorada. (Panamerican F.), estrenada el 12 de abril de 1948.
} 
“Estreno en la época más conveniente de la temporada cinematográfica.

Prioridad en los reestrenos, con las condiciones establecidas en el inciso anterior.

Obligatoriedad de proyección mientras la película alcance el mínimo del cincuenta por ciento del aforo total del cine; se considerará no alcanzado este aforo si al realizar el cómputo de una semana los ingresos diarios no llegan a dicho porcentaje ${ }^{98}$."

Si bien, todo cuanto se ha visto hasta el momento está destinado a la protección y ayuda a nuestra cinematografía, todavía quedaba pendiente una buena regulación de los permisos de importación y exportación. Esta regulación no llega ser completa hasta 1945, año en el que se publican nada menos que seis órdenes ministeriales a tal fin. En las mismas se regula todo el proceso de importación y exportación, desde el visionado de películas antes de cerrar la compra, el doblaje, la reimportación, etc.

Las tres primeras datan del 13 de febrero de aquel año mientras que las otras tres son del 17 de febrero y del 3 de abril. En el primer caso, bajo el título "Normas para el visionado, por los importadores, de películas cinematográficas ${ }^{99 ",}$, se propone el entramado burocrático necesario para el acceso por parte del empresario del filme que desea importar con fines comerciales. Inicialmente podrán tener acceso a dicho visionado sin problema, siempre y cuando cumplimente adecuadamente los informes y se haga cargo de los gastos administrativos y de manipulación de los mismos. Solo en algunas ocasiones:

“... la Dirección General de Aduanas queda facultada para denegar la autorización de "visionado», siempre que razones fundadas lo aconsejen. ${ }^{100 "}$

La segunda orden, sobre importación y reexportación de películas extranjeras destinadas al doblaje ${ }^{101}$ ", deja abierta la puerta a un mercado altamente productivo y de posibilidades económicas muy fuertes. Nos referimos a la realización de doblajes para terceros países en otros idiomas, para lo que es imprescindible la importación y reexportación posterior de la producción de turno con el doblaje realizado.

"El indudable beneficio que ello puede suponer para la industria cinematográfica nacional aconseja facilitar, en el aspecto fiscal, las operaciones de doblaje. ${ }^{102 " ~ D e ~ e s t e ~ m o d o, ~ s e ~ a u t o r i z a, ~ " e n ~ r e ́ g i m e n ~ e s p e c i a l ~}$ de aplazamiento del pago de derechos arancelarios, la importación y subsiguiente reexportación de las películas extranjeras que se destinen al doblaje $^{103 "}$.

\footnotetext{
${ }^{98}$ España. Orden Estableciendo el titulo de «películas de Interés Nacional», 15 de junio de 1944, Vicesecretaría de Educación Popular, Boletín Oficial del Estado, 23 de junio de 1944, núm. de B.O.E. 175

99 EsPaña. Orden Normas para el "visionado» por los importadores de películas cinematográficas, 13 de febrero de 1945, Ministerio de Hacienda, Boletín Oficial del Estado, 15 de febrero de 1945, núm. 46

100 Idídem.

${ }^{101}$ ESPAÑA. Orden Sobre importación y reexportación de películas extranjeras destinadas al doblaje, 13 de febrero de 1945, Ministerio de Hacienda, Boletín Oficial del Estado, 15 de febrero de 1945, núm. 46

102 Idídem.

${ }^{103}$ Idídem.
} 
Estas ayudas económicas se complementan con algunas exigencias como la limitación del:

“... plazo máximo de permanencia en España de las películas importadas en las condiciones dichas será de seis meses, contados a partir de la fecha de la ultimación del despacho o de la terminación de los trabajos de doblaje, según las circunstancias que en cada caso concurran. En este mismo supuesto será obligada la intervención de las operaciones de doblaje por parte de los Servicios de Aduanas. ${ }^{104}$,

La tercera y última orden del día 13 de febrero expone las nuevas normas para la exportación temporal de películas cinematográficas ${ }^{105}$ que afectan a aquellas películas nacionales o nacionalizadas cuyos propietarios deseen exportar a Canarias, los puertos francos y posesiones de África. Inicialmente quedan exentas de pagar los aranceles correspondientes siempre y cuando no supere el año fuera de la península como se puede leer en las primeras líneas del primer artículo de la cintada ley:

“... los productores o industriales españoles que remitan películas para su proyección en Canarias, Posesiones Españolas del Norte de África en el extranjero, podrán reimportarlas en la Península, dentro del plazo de un año, sin pago de derechos arancelarios. ${ }^{106 "}$

Cuatro días más tarde, el 17 de febrero de 1945 se corrigen algunos errores cometidos en las órdenes precedentes. En dichas disposiciones se olvidaba establecer las normas para la reimportación de aquellas películas españolas exportadas al extranjero. Así pues, leemos:

“... las películas cinematográficas nacionales exportadas temporalmente para su explotación fuera del territorio español y desnacionalizadas por haber vencido, sin ser reimportadas, los plazos señalados en los respectivos documentos de exportación temporal y asimismo las copias obtenidas en el extranjero sobre películas cinematográficas nacionales exportadas temporalmente, no pueden beneficiarse de los derechos arancelarios anteriores. $^{107 "}$

También se penaliza, a su vez, el envío a terceros países de películas nacionales para la obtención de copias. Se trata, pues, de otra propuesta más para evitar la fuga de capital más allá de lo imprescindible, por las razones obvias de pobreza en que se encuentra nuestro país tras la Guerra Civil y el aislamiento internacional.

\footnotetext{
${ }^{104}$ Idídem.

105 ESPAÑA. Orden Normas para la exportación temporal de películas cinematográficas, 13 de febrero de 1945, Ministerio de Hacienda, Boletín Oficial del Estado, 15 de febrero de 1945, núm. 46

${ }^{106}$ Idídem.

107 EsPaña. Orden Sobre reimportación de películas exportadas en régimen temporal, 17 de febrero de 1945, Ministerio de Hacienda, Boletín Oficial del Estado, 22 de febrero de 1945, núm. 22
} 
Las últimas órdenes ministeriales son matizadas un par de meses más tarde mediante dos órdenes más, fechadas ambas el 3 de abril de $1945^{108}$. En la primera se aclara "la vida" (periodo de exhibición) de una película importada dentro de nuestro país:

"... la vida legal de las películas que se importan en España da lugar a pagos en divisas al exterior, y siendo norma corriente en los contratos de explotación de películas el período máximo de cinco años, tanto para aquellas que se ceden a porcentaje, las que se venden a precio fijo ${ }^{109 "}$.

De este modo, se establece dicho periodo de tiempo para la explotación comercial del producto en sí. Pasado esos cinco años, la película dejará de exhibirse para evitar la fuga de capital salvo que esté exenta de pagar dichos cánones. Por otro lado, solo en casos excepcionales, se podrá pedir la renovación de este plazo para lo que será necesario volver a pasar por todos los trámites como si de una película nueva se tratase, pagando de nuevo los aranceles e impuestos correspondientes.

La segunda orden ${ }^{110}$ se limita tan solo a aclarar puntos que pudiesen llevar a error en las tres órdenes del Ministerio de Hacienda promulgadas el día 3 de febrero y publicadas en el Boletín Oficial del Estado los días 13 y 17 del mismo mes. Pero han de pasar casi tres años para que se de solución al último punto relacionado con la importación. Nos referimos al caso de que el empresario se disponga a importar una película y tras realizar todos los trámites burocráticos necesarios a tal fin, se encuentra con la sorpresa de que ésta sea prohibida por la censura. Cuando se da esta circunstancia:

“... el importador de las películas extranjeras que hayan adeudado en firme los correspondientes derechos arancelarios, podrá solicitar de ese Centro directivo, antes de haber tenido efecto la exhibición de las mismas, que se acuerde la procedencia de la devolución de aquellos derechos, en el caso de que la proyección haya sido prohibida por los respectivos organismos oficiales encargados de la censura. ${ }^{111}$,

Las dos últimas disposiciones aparecidas con cierta relevancia en este apartado son, por una parte, la circular del 28 de diciembre de $1948^{112}$ que tan solo viene a llenar un vacío legal sobre las circunstancias que se deben dar para que una productora pueda interponer un recurso contra una clasificación dada; y por otra parte, la orden del 29 de octubre del año ${ }^{113}$ siguiente, que establece la obligatoriedad de especificar la correspondiente clasificación moral (tolerada o autorizada) en toda propaganda destinada al público, tanto en carteles, programas, anuncios, pizarras, etc.

\footnotetext{
${ }^{108}$ EsPaña. Orden Regulando plazo de exportación de películas extranjeras, 3 de abril de 1945, Ministerio de Industria y Comercio, 6 de abril de 1945, Boletín Oficial del Estado, núm. 96

${ }^{109}$ Idídem.

${ }^{110}$ ESPAÑA. Orden Aclarando e interpretando las ordenes de 13 y 17 de febrero ultimo sobre importación y exportación de películas, 3 de abril de 1945, Ministerio de Industria y Comercio, Boletín Oficial del Estado, 6 de abril de 1945, núm. 96

${ }^{111}$ ESPAÑA. Orden Devolución de derechos arancelarios de películas prohibidas por la censura, 22 de junio de 1948 , Ministerio de Hacienda, Boletín Oficial del Estado, 27 de junio de 1948, núm. 179

112 España. Circular Recursos de clasificación de películas, 28 de diciembre de 1948, Subsecretaría de Educación Popular. Dirección General de Cinematografía y Teatro, Boletín Oficial del Estado, 8 de enero de 1949, núm. 8

${ }^{113}$ ESPAÑA. Orden Clasificación de películas autorizadas o toleradas para menores, 29 de octubre de 1949, Ministerio de Educación Nacional, Boletín Oficial del Estado, 31 de octubre de 1949, núm. 304,
} 


\section{Las implicaciones del doblaje}

El doblaje se convirtió desde el comienzo de su aplicación en materia de discusión y debate. Desde un primer momento se alzaron voces a favor y en contra. Entre los primeros, citaremos a Wenceslao Peralta quien en un artículo titulado La importancia del doblaje en las películas aparecido en la revista Primer Plano considera beneficiosos los doblajes siempre que éstos se realicen con calidad. Así, cuando se refiere al doblaje de la película Margarita Gautier nos dice:

"... una de las obras maestras del cinema americano ésta no hubiera tenido en nuestro país la emoción y el éxito que alcanzó sin ese doblaje tan maravilloso. Las escenas de la muerte de Margarita, en su última entrevista con Armando, es algo que no se puede superar. ${ }^{114 "}$

En cambio, en contra se pueden apreciar dos claros planteamientos. Por un lado, se construye un discurso en el que se alude a los valores patrios y raciales, como se puede apreciar en la siguiente argumentación: "si hay un modo de amar y un modo de reír y un modo de morir español es porque hay un modo de ser español que se transparenta en nuestro propio lenguaje. (...) Tan monstruoso y tan insólito es someter nuestra palabra a la servidumbre de una psicología, desconectada totalmente con ella, que nadie aceptaba el doblaje sino como un procedimiento provisorio, experimental y excepcional inclinado a la desaparición. ${ }^{115 ",}$

Por su parte, el crítico cinematográfico Alfonso Sánchez consideraba el doblaje como una práctica nociva para nuestra industria. En el número 156 de Primer Plano, podemos leer que el doblaje era:

“... un sistema incompatible con el arte y que constituye un grave atentado contra la industria cinematográfica propia en beneficio de las exótica, puesto que si desaparece este elemento del idioma, al igualar la producción española con la extranjera, nuestras películas tendrán que dar la batalla de la competencia en condiciones de suma desventaja y sin contar con el apoyo más eficaz en su favor, algo agravado porque nuestros productores basan su negocio en la explotación de la película extranjera y solo utilizan la española como elemento de transacción mercantil, cortando de raíz toda ambición artística,... No hay, pues, ninguna razón seria, comercial o artística, que actúe a favor del mantenimiento de un sistema que tan catastróficas consecuencias tiene para el porvenir del cinema español, que es lo que a nosotros debe preocuparnos. ${ }^{116 "}$

\footnotetext{
${ }^{114}$ Peralda, W, «La importancia del doblaje en las películas», en Primer Plano, año II, número 52, 12 de octubre de 1941

${ }^{115}$ Extracto de un artículo citado a su vez por MONTERDE, J. E. (2001) «Hacia un cine franquista: La línea editorial de Primer Plano entre 1940 y 1945» en FERnÁNDEZ ColoRAdo, L.; Couto CANTERO, P. (coord..) (2001) La herida de las sombras. El cine español de los años 40, Madrid, Academia de las Artes y las Ciencias Cinematográficas en España / AEHC. pp. 75.

${ }^{116}$ Idídem. pp.75
} 
Por otro lado, en una conversación llevada a cabo con José Luis Borau, éste nos comentó que el doblaje se implantó obligatoriamente porque oficialmente se quería:

“... proteger los valores patrios, y en especial ir contra la contaminación de la lengua española. Esta era la razón político cultural, como quieras llamarla. Por mi parte, creo que el gobierno quería facilitar que el público fuese a ver películas españolas, no ya por las razones políticas, culturales o imperiales sino para reactivar la industria. El gobierno impone entonces el doblaje con la vana pretensión de apoyar al cine español. ¿Qué ocurrió? Que la gente puestos a ver una película hablada en español donde trabajaba Gary Cooper o una película hablada en español con Rafael Durán prefería siempre la película de Gary Cooper. ${ }^{117 ",}$

A las razones expuestas, anteriormente hay que añadir que el doblaje se convertiría en una herramienta efectiva de censura, como hemos podido ver en la orden del 15 de diciembre de 1944.

Después de buscar en diversas fuentes el BOE y el Aranzadi entre otras, nos ha sido imposible encontrar detalles precisos en torno a la famosa ley de obligatoriedad del doblaje a la que todo el mundo nombra, pero nadie nos indica con certeza su localización. Las fechas aportadas en distintos artículos periodísticos de la época y la bibliografía consultada al respecto no nos aportan datos precisos. Según nos han comentado documentalistas de las Cortes Valencianas que nos han ayudado pacientemente en la búsqueda, resulta especialmente difícil creer que exista tal ley si no aparece en ninguna de las citadas fuentes, BOE y Aranzadi, especialmente si tenemos en cuenta su importancia y repercusión. Por otro lado, no será hasta el día 31 de diciembre de 1946 cuando se promulgará una disposición por la que se crean y regulan las licencias o permisos de doblaje y en ningún caso se deroga o modifica ley $u$ ordenanza referente a una posible dobligatoriedad del doblaje. Esta ley saldrá publicada en el Boletín Oficial del Estado el 25 de enero de 1947 y plantea algunas paradojas interesantes. En ningún momento de la citada orden se hace referencia alguna a la ley de obligatoriedad del doblaje ni se comenta la necesidad de eliminar dicha disposición. Por el contrario, se establece una nueva situación por la cual, para doblar una película, a partir de ese momento se obliga a la empresa propietaria de la explotación del filme, a tener un permiso de doblaje para ello.

En cuanto a la nueva situación planteada por la presencia de los permisos de doblaje, ésta no va a variar considerablemente, puesto que se acaban concediendo prácticamente las mismas licencias de doblaje que de importación, con lo que resulta difícil pensar que las distribuidoras tuviesen arrebatos patrios en beneficio de la industria y del Estado Español que les hiciesen decidirse por perder dinero no doblando sus películas importadas. Por el contrario, esto no hizo nada más que empeorar la situación al crearse una coyuntura nueva que lo único que va a conseguir es aumentar el "mercado negro" de permisos y licencias de doblaje entre las distribuidoras afincadas en España.

Esto nos lleva a corregir un error muy típico y común: identificar licencia de doblaje con licencia de importación. Como se pude apreciar en una noticia aparecida en Primer

\footnotetext{
${ }^{117}$ Entrevista con José Luis Borau, Madrid, 25 de julio de 2003.
} 
Plano, este error comienza a generarse desde el mismo momento de la salida a escena de esta ley. Bajo el título: Reglamento del doblaje, se puede leer que "estos permisos (se refiere a los de doblaje) - que vienen a sustituir a los antiguos de importación - se concederán exclusivamente a los productores de películas españolas ${ }^{118 "}$.

\section{Reglamentación del doblaje} Queda suprimida la obligatoriedad que existía de doblar películas extranjeras al castellano

\footnotetext{
En el Boletin Oficial del Estado del día 25 de enero de 1947 se pu. blica una orden que deroga la del 23 de abril de $194 \mathrm{I}$, por la que se prohibía la exhibición de peliculas extranjeras que no estuvieran dobladas al castellano. Ahora podrán exhibitse esas peliculas en su idioma original, o bien dobladas, siempre que tengan permiso de doblaje. Estos permisos -que vienea a sustituir a los antiguos de importación de películas - se concerlerán única y exclusiramente a los productores de pellullo se conceneran daica y exclusivamente a los productores de pellculas espanias, quieves podrangeed importadot as $\mathbf{y}$ distribuidoras.

La concesión de estos permisos a los productores de películas nacionales se hará teni zndo en cuenta la calidad de sus pelíct 1's. para to cual se establecen tres categorfas. A la primera corresponden cuatio permisos de doblaje, o cinco, si la película es declarada de intetés na cional; a la segunda, dos permisos, $y$ a la tercera, ninguno.

Para las peliculas de corto metraje, sean de la indole que sean, rigen

las mismas reglas que para las antiriores.
}

Imagen 17: «Reglamentación del doblaje» en Primer Plano, año X, núm. 431.

Pero realmente, a lo largo de dicha ley, no se hace ninguna alusión a la fusión o cambio de nomenclatura para las licencias de importación, ni anuncia explícitamente la derogación de la obligatoriedad del doblaje, ni siquiera la nombra. Simplemente se da a conocer la aparición de la nueva licencia mediante el primer artículo en el que se dice:

"A partir del día $1^{\circ}$ de enero de 1947 las autorizaciones de doblaje al castellano de las películas extranjeras, destinadas a su exhibición en España, se concederán única y exclusivamente a aquellas personas o entidades que produzcan películas nacionales que por su calidad técnico-artística obtengan la aprobación de la Junta Superior de Orientación Cinematográfica. ${ }^{119 "}$

De hecho, si buscamos los datos referentes a las clasificaciones de los filmes y las concesiones otorgadas a los mismos, veremos que coexisten. Veamos algunos ejemplos en la siguiente tabla:

\begin{tabular}{|l|l|ll|ll|}
\hline Titulos & Año & \multicolumn{2}{l}{ Importación } & \multicolumn{2}{c|}{ Doblaje } \\
\hline Mare Nostrum & 1948 & $1^{\mathrm{a}}$ & 2 permisos & $1^{\mathrm{a}} \mathrm{A}$ & 4 permisos \\
Nada & 1947 & $1^{\mathrm{a}}$ & 2 permisos & $1^{\mathrm{a}} \mathrm{B}$ & 3 permisos \\
Confidencia & 1947 & $2^{\mathrm{a}}$ & 2 permisos & $1^{\mathrm{a}} \mathrm{A}$ & 3 permisos \\
Dos cuentos para dos & 1947 & $2^{\mathrm{a}}$ & 1 permisos & $2^{\mathrm{a}} \mathrm{A}$ & 1 permisos \\
\hline La cigarra & 1948 & $2^{\mathrm{a}}$ & 2 permisos & $2^{\mathrm{a}} \mathrm{A}$ & 2 permisos \\
\hline
\end{tabular}

Tabla 11: Ejemplo de coexistencia de los permisos de doblaje e importación

\footnotetext{
118 «Reglamentación del doblaje», en Primer Plano, año X, núm. 431, 16 de enero de 1949.

${ }^{119}$ España. Orden Concesión de permisos de doblaje, 31 de diciembre de 1946, Ministerio de Educación Nacional, Boletín Oficial del Estado, 25 de enero de 1947, núm. 25
} 
Lo que sí se establece, es la aplicación y concesión de dichas licencias de doblajes que, evidentemente, tienen relación con el mismo sistema empleado con la concesión de la licencias de importación. La concesión de las mismas estará, por tanto, ligada a la "calidad" de las películas realizadas por las productoras-distribuidoras nacionales, como se puede leer a continuación:

"La primera categoría comprenderá aquellas películas que supongan un avance considerable en alguno de los distintos aspectos de la producción o que posean, al menos en su conjunto el decoro y méritos suficientes para que sean objeto de aprecio y protección. Las películas a las que se declare de primera categoría tendrán derecho a la concesión de cuatro permisos de doblaje, y a cinco si obtienen la declaración de película de interés nacional.

La segunda categoría comprenderá aquellas películas que sin sobresalir del nivel medio de la producción cinematográfica española sean, no obstante, acreedoras a la protección del Estado. Las películas declaradas de segunda categoría tendrán derecho a dos permisos de doblaje.

Se consideran películas de tercera categoría aquellas producciones que por su calidad artística o técnica supongan un descrédito para la cinematografía española y no sean en consecuencia merecedoras de protección alguna. Las películas declaradas de tercera categoría no tendrán derecho a la concesión de ningún permiso de doblaje. ${ }^{120 "}$

Llevando tan solo seis meses de vida esta ley sufre su primera modificación. El 12 de junio de 1947 se promulga una orden por la que:

"Las películas declaradas en primera categoría tendrán derecho a la concesión de tres o de cuatro permisos de doblaje y tendrán asimismo derecho a obtener, según su calidad, uno o dos permisos de doblaje las películas que sean declaradas en segunda categoría. ${ }^{121}$,

Queda patente pues, que las autoridades se percatan rápidamente del riesgo que supone dejar abierta la puerta del doblaje y deciden bajar el porcentaje de dichas licencias. Esta tendencia bajista se vuelve a encontrar en la siguiente ley destinada a regular las licencias de doblaje que data del 29 de julio de $1948^{122}$. En esta ocasión el objeto de revisión son las concesiones a las películas catalogadas como de Interés Nacional que pasarán a obtener tan solo tres licencias. De todos modos, se aprovecha la ocasión para bajar más la demás categorías, de modo que las películas de primera percibirán dos y las de segunda tan solo una.

En este aspecto podemos afirmar que el gobierno del Régimen aboga claramente por ayudar a nuestra industria y para ello reducen en más de cincuenta por ciento las

\footnotetext{
${ }^{120}$ Idídem.

${ }^{121}$ España. Orden Modificando lo dispuesto en la orden de 31 diciembre 1946 sobre permisos de doblaje, 12 de junio de 1947, Ministerio de Educación Nacional, Boletín Oficial del Estado, 15 de junio de 1947, núm. 166

${ }^{122}$ España. Orden Permisos de doblaje a películas declaradas de Interés Nacional, 29 de julio de 1948, Ministerio de Educación Nacional, Boletín Oficial del Estado, 10 de agosto de 1948, mún. 223
} 
licencias concedidas para el doblaje a fin de potenciar el consumo del cine nacional frente al extranjero. Debemos recordar, que los porcentajes de alfabetización de la población española durante este periodo distaban mucho de los medianamente aceptables y la exhibición de largometrajes en versión subtitulada significaba cerrar la puerta a un fuerte sector de la población y, por tanto, del público objetivo al que pudieran ir destinadas las películas,

\section{Créditos y Premios Cinematográficos}

Siguiendo es espíritu proteccionista de los legisladores, el 11 de noviembre de $1941^{123}$ el Ministerio de Industria y Comercio establece una orden que regula los famosos créditos cinematográficos que nacen con la intención de ayudar a la producción nacional. Este apoyo se convirtió en piedra angular para el sostenimiento de nuestra cinematografía y su perdurabilidad, siendo el germen de las famosas subvenciones actuales que recibe nuestro cine, sin las que sería prácticamente imposible su existencia. Dichos créditos estaban exentos de intereses y podían llegar hasta una cuantía del $40 \%$ del montante total de la producción. La devolución de los mismos estaba ligada a un porcentaje de la recaudación durante su periodo de exhibición en las salas de cine hasta la cancelación de los mismos.

A la creación de los Créditos Cinematográficos hay que sumar la concesión de premios a la producción, con cantidades que oscilaban entre las 25.000 y las 400.000 pesetas. Como se puede apreciar en el segundo apartado de esta sección, "La entidad productora que obtenga uno de estos premios distribuirá el 20 por 100 de su cuantía entre los técnicos y artistas que, a juicio del Sindicato Nacional, se haya hecho a ello acreedores por su contribución al éxito artístico de la película." De este modo se pretendía premiar también el sector "obrero".

El tercer punto de interés publicado en la ley del 11 de noviembre de 1941 establece un concurso de guiones, con el fin de incitar y potenciar la creación de los mismos. Se establece un total de cinco premios con un montante total por cada uno de 50.000 pesetas. Estos guiones pasarían a estar depositados bajo la tutela del Sindicato Nacional del Espectáculo que potenciaría su posible realización.

La concesión de becas para la formación de miembros de la comunidad industrial cinematográfica es otra de las propuestas que se presentan. Con ella se pretende una mejor formación del personal humano y, de paso, obtener aquella información de los medios y procesos industriales que pudiesen ser útiles en la nueva formación de la industria. La obtención de estas becas estaba sujeta a una gran cantidad de requisitos y a un seguimiento exhaustivo de control de su aprovechamiento por parte del interesado.

\footnotetext{
${ }^{123}$ ESPAÑA. Orden Normas protectoras para la cinematografía, 11 de noviembre de 1941, Ministerio de Industria y Comercio, Boletín Oficial del Estado, 17 de noviembre de 1941, núm. 321
} 
El año 1945, con la intención de complementar los premios surgidos de la orden del 11 de noviembre de 1941, se crean los premios honoríficos de arte cinematográfico. Como se explica en el prefacio de la misma:

"... interesa al cine nacional que todos los elementos que intervienen en la realización de una película reciban periódicamente de los Organismos cinematográficos muestras inequívocas de sus actuaciones son valoradas con independencia del resultado que la labor total haya obtenido, ya que en muchos casos, al tener en cuenta solamente la totalidad de la obra, o pasan inadvertidos esfuerzos muy estimables o aparecen galardonadas intervenciones deficientes.

Ello exige a esta Vicesecretaría tomar medidas encaminadas a premiar y destacar aisladamente las intervenciones que con mayor acierto hayan tenido en la realización de películas nacionales los elementos cinematográficos más importantes, aquellos que realmente cuentan con una personalidad artística inconfundible. ${ }^{124 "}$

Se constituye las siguientes categorías que se otorgarán anualmente: un premio de honor a la mejor Dirección, dos premios de honor y dos de accésits a la mejor Interpretación femenina y masculina, premio de honor y accésit a la mejor Música y premio de honor y accésit a los mejores decorados. ${ }^{125}$

\section{La regulación de la programación}

La regulación de la programación en las sala de cine se convierte rápidamente, para las administraciones públicas, en una tarea necesaria para un mayor control de los contenidos y, sobre todo, como medida protectora de la industria productora nacional.

Antes de terminar el año 1941, el 10 de diciembre, un mes después de la publicación de la primera media protectora de nuestro cine, aparece una nueva orden del Ministerio de Industria y Comercio para regular la programación de películas en las salas de proyección. Esta ley proteccionista, con variaciones múltiples que han ido a peor, siguen existiendo en el panorama actual, con el famoso sobrenombre de cuota de pantalla. En este caso, se establece que:

“... en todos los locales de España que se dediquen a la exhibición cinematográfica deberá darse por lo menos una semana completa de proyecciones de películas españolas de largo metraje, por cada seis semanas de proyección de películas extranjeras de la misma categoría. ${ }^{126 "}$

\footnotetext{
${ }^{124}$ ESPAÑA. Orden Creando los premios anuales que se mencionan para estímulo de los elementos artísticos de la cinematografía, 23 de enero de 1945, Vicesecretaría de Educación Popular, Boletín Oficial del Estado, 29 de enero de 1945, núm. 29

${ }^{125}$ Idídem.

${ }^{126}$ ESPAÑA. Orden Regulando la programación de películas, 10 de diciembre de 1941, Ministerio de Industria y Comercio, Boletín Oficial del Estado, 13 de diciembre de 1941, núm. 347
} 
También se establece la obligatoriedad de incluir en los programas, películas de cortometraje de realización propia, en todos los cines de España, así como el calendario para la exhibición de películas de reestreno, y delimitar de algún modo la temporada, dando prioridad, a las producciones nacionales.

Esta ley se modifica tres años más tarde a través de la Orden del 13 de octubre de $1944^{127}$, corrigiendo algunos errores de bulto que era menester rectificar. Así, se establece una nueva proporción de exhibición entre películas importadas y propias de cinco a uno, quedando el texto de la siguiente manera:

"Art. $2^{\circ}$. Por cada cinco semanas de proyección de películas extranjeras se proyectará una semana de películas nacionales, entendiéndose que la película española se proyectará a continuación de la quinta semana de proyección de películas extranjeras.

Art. $3^{\circ}$. Si al finalizar la quinta semana de proyección de películas extranjeras, la que estuviese proyectándose debiera continuar en cartel por conveniencia de la Empresa o por exigirlo así el contrato establecido con la distribuidora, al retirar esta película la Empresa exhibidora además de proyectar la semana obligatoria de películas nacionales, deberá continuar proyectando producciones españolas durante un tiempo en que ningún caso será inferior al 50 por 100 de los días que hubiese excedido de la quinta semana de proyección de películas extranjeras.

Por el contrario, si al finalizar la semana obligatoria de proyección de películas nacionales, la que estuviese proyectándose debiera continuar en cartel por conveniencia de la Empresa o por explicarlo así el contrato establecido con la distribuidora, los días que excedan de proyección de esta película no se tendrán en cuenta a los efectos de ampliación del plazo de exhibición de cinco semanas para las películas extranjeras. La orden continúa especificando:

"Art. 40. En los cines en que se proyecte dos programas por semana, por cada dos semanas y media de proyección de películas extranjeras se deberá proyectar media semana de películas nacionales, siempre que dicha media semana esté incluido un día festivo.

Art. $5^{\circ}$. En los cines en que se proyecte tres programas por semana, por cada semana y media de películas extranjeras se deberá proyectar media semana de películas nacionales en la misma forma establecida anteriormente.

Art. $6^{\circ}$. En los cines en que se proyecte un programa cada día, por cada cinco programas de películas extranjeras deberá proyectarse un programa de películas nacionales.

Art. $7^{\circ}$. Cuando se trate de locales que celebren sesiones aisladas, por cada cinco películas extranjeras deberá proyectarse una película nacional. ${ }^{128,}$

\footnotetext{
${ }^{127}$ ESPAÑA. Orden Ampliando y modificando la orden de 10 de diciembre de 1941 sobre programación de películas, 13 de octubre de 1944, Ministerio de Industria y Comercio, Boletín Oficial del Estado, 15 de octubre de 1944, núm. 289

${ }^{128}$ Idídem.
} 
Queda así eliminado un resquicio legal utilizado por los exhibidores para programar las películas españolas en las peores fechas para perjudicar lo menos posible la exhibición de las producciones importadas, principal fuente de ingresos para las compañías españolas y extranjeras, cuya base de beneficios se encontraba, como ya se ha dicho, en la distribución de películas (especialmente norteamericanas) y no en la producción. Por otro lado, se aumenta la cuota de pantalla para las películas españolas y se mantiene la obligatoriedad de programar junto a la película larga una de corta duración así como los complementos correspondientes. Se prohíbe la programación de dos largometrajes seguidos, salvo que se trate de filmes cuya vida en las carteleras haya sido superior a dos años pero se deberá incluir igualmente los complementos pertinentes.

También se regulan otros locales susceptibles de proyectar películas junto con espectáculos en directo, y se relega a las películas de mala calidad, o de tercera categoría, a salas de condición menor, prohibiendo su exhibición en las de primera categoría.

\section{Otras reglamentaciones}

Entre 1944 y 1950, van a aparecer cuatro reglamentaciones del trabajo vinculadas al mundo del cine. Dos de ellas irán destinadas directamente a la industria cinematográfica mientras que las otras dos tendrán como objeto de atención los locales de espectáculos, entre los que se encuentran las salas de exhibición.

La primera en salir a la palestra data del 28 de septiembre de $1944^{129}$, y es llevada a cabo por Girón de Velasco, Director General de Trabajo. Esto se realiza pocos años después de la publicación del Fuero del Trabajo, donde éste dignifica al hombre y sirve a la patria. Cuatros años más tarde, diciembre de $1948^{130}$, vuelve a publicarse otro reglamento, prácticamente igual, tratándose más de una actualización de sueldos y matizaciones diversas que un cambio realmente significativo en las premisas principales. La presente Reglamentación trata esencialmente de constituir y clarificar por escrito todas las funciones propias de la industria, regulando como es menester los sueldos y las jerarquías. En cuanto a su, alcance, este queda reducido a los obreros y trabajadores en general, dejando de lado a empresarios y artista como podemos leer a continuación:

\section{"Artículo $1{ }^{\circ}$ Ámbito institucional \\ Las presentes Ordenanzas regulan las relaciones de trabajo en las Empresas de la Industria Cinematográfica. \\ A efectos de la aplicación de las presentes Ordenanzas, Se entiende por Industria Cinematográfica la que se dedica conjunta o separadamente a la producción, rodaje, elaboración y distribución de películas cinematográficas.}

\footnotetext{
${ }^{129}$ ESPAÑA. Orden por la que se aprueba la reglamentación nacional del trabajo en la industria de la cinematografía, 28 de septiembre de 1944, Ministerio de Industria y Comercio, Boletín Oficial del Estado, 6 de octubre de 1944, núm. 280

${ }^{130}$ España. Orden Reglamentación nacional del trabajo en la industria cinematográfica, 31 de diciembre de 1948. (Rectificada en fecha 28-5-1949), Ministerio de Industria y Comercio, Boletín Oficial del Estado, 24 de enero de 1949, núm. 24
} 
Se incluyen, por tanto, en la presente Reglamentación: a) Los llamados estudios Cinematográficos.

b) Los laboratorios que se dedican a las operaciones de revelado, positivado y montaje de películas cinematográficas.

Las Empresas productoras que editan películas cinematográficas.

Las Empresas distribuidoras dedicadas a la distribución de películas mediante compra, arrendamiento, préstamo o cesión gratuita.

Art. $2^{\circ}$, Ámbito personal.

Se regirán por las presentes Ordenanzas todos los trabajadores que actúan en la Industria Cinematográfica, tanto si realizan una función técnica o administrativa como si solo prestan su esfuerzo físico o de atención.

Se excluyen: a) Las funciones de alta dirección económica o artística, alto gobierno o alto consejo, características de los siguientes cargos $u$ otros semejantes: Director y Subdirector (general, técnico, de producción o películas), Gerente, Secretario y Administrador general, etc., así como los jefes de departamento en Empresas de varios ciclos de producción. b) Los actores que figuran en él «reparto» de una película. c) El personal estipulado por contrata a quien se encomiende algún servicio determinado (casas de modas, figuritas, sastres, etc.), sin continuidad en el trabajo, ni sujeción a jornada y sin que figure, por lo tanto, en la plantilla de la Empresa, ni en el contrato de la producción de la película. d) Los agentes comerciales que trabajen en la Industria Cinematográfica exclusivamente a comisión de una Empresa, con libertad de representar otras dedicadas a igual o distinta actividad. $^{131 "}$

Las otras dos grandes reglamentaciones se van a centrar en los locales de espectáculo, y por extensión, en los de exhibición cinematográfica. Estos reglamentos datan de diciembre de $1945^{132}$ y abril de $1950^{133}$ respectivamente, pero no suponen ninguna aportación a lo comentado en el apartado anterior.

También en este periodo se crea la Cámara de Directores Cinematográficos, dependiente de la Dirección General de Cinematografía y Teatro por la orden del 22 de octubre de $1948^{134}$. Este nuevo organismo tendrá como competencias:

- "Emitir informes de carácter exclusivamente técnico, artístico o literario sobre aquellos guiones cinematográficos que le sean a este efecto

\footnotetext{
${ }^{131}$ ESPAÑA. Orden por la que se aprueba la reglamentación nacional del trabajo en la industria de la cinematografía, 28 de septiembre de 1944, Ministerio de Industria y Comercio, Boletín Oficial del Estado, 6 de octubre de 1944, núm. 280

132 España. Orden Reglamento Nacional del Trabajo para Locales de Espectáculos, 31 de diciembre de 1945, Ministerio del Trabajo, Boletín Oficial del Estado, 22 de enero de 1946, núm. 22.

${ }^{133}$ España. Orden Reglamento Nacional del Trabajo para Locales de Espectáculos Públicos - Deportes, 29 de abril de 1950, Ministerio del Trabajo, Boletín Oficial del Estado, 15 de mayo de 50, núm. 135.

134 EsPaña. Orden Creación de la cámara de directores cinematográficos, 22 de octubre de 1948, Ministerio de Educación Nacional, Boletín Oficial del Estado, 28 de noviembre de 1948, núm. 333
} 
sometidos por la Dirección General de Cinematografía y Teatro para la oportuna concesión del permiso de rodaje correspondiente.

- Entender en los recursos de apelación promovidos por las productoras cinematográficas, como consecuencia de las denegaciones de los permisos de rodaje que tuvieran solicitados, siempre que dicha denegación haya sido motivada por razones de carácter técnico, artístico o argumental y literario.

- Informar las peticiones que se eleven a la Junta Superior de Orientación Cinematográfica, solicitando de ésta la concesión para alguna película de título de "interés nacional".

- Informar las peticiones de revisión que se eleven a la Junta Superior de Orientación Cinematográfica solicitando mejora de la clasificación otorgada por ésta, cuando se refieren a los efectos de concesión de permisos de doblaje exclusivamente. ${ }^{135 "}$

En cuanto a quienes formarán dichos órganos, se reserva el privilegio a directores de prestigio, siendo:

“... un requisito imprescindible el de haber dirigido cuando menos una película

de largo metraje que haya obtenido el primer premio en certámenes oficiales de carácter nacional o internacional, ${ }^{136, "}$

La presidencia se reserva al director más veterano que será nombrado presidente de la Cámara, siendo su secretario el Jefe de la Sección de Cinematografía de la Dirección General de Cinematografía y Teatro.

\section{El Noticiario Cinematográfico Español}

A finales de 1942 se hace público el nacimiento y obligatoriedad del noticiario cinematográfico que se dio en llamar NO-DO. En la orden de 17 de diciembre de 1942, se anuncia que:

“... a partir del día 1 de enero de 1943 no podrá editarse en España, sus posesiones y colonias ningún noticiario cinematográfico ni documental de este tipo que no sea el «Noticiario Cinematográfico Español No-Do». ${ }^{137 \text { " }}$

De este modo, se confiere prioridad y monopolio informativo dentro de las salas de cine a dicho noticiario. Este aspecto se acentúa con la prohibición, a todo operador o empleado que no esté contratado por NO-DO, a realizar tomas para el mismo u otros

\footnotetext{
${ }^{135}$ Idídem.

${ }^{136}$ Idídem.

${ }^{137}$ ESPAÑA. Orden Disponiendo la proyección exclusiva y obligatoria del noticiario "NO-DO», 17 de diciembre de 1942, Vicesecretaría de Educación Popular, Boletín Oficial del Estado, 22 de diciembre de 1942, núm. 356
} 
noticiarios. Se concluye con una disposición destinada a consolidar el monopolio de su distribución y exhibición cuando se anuncia que:

“.. el Noticiario Cinematográfico Español "No-Do» [...] se proyectará, con carácter obligatorio, en todos los locales cinematográficos de España y sus posesiones durante todas las sesiones de los mismos. ${ }^{138 ",}$

Con esta orden no solo nace el NO-DO. También una herramienta imprescindible de manipulación y propaganda, aunque, como bien plantean en su magnífico estudio sobre tan singular instrumento Rafael R. Tranche y Vicente Sánchez-Biosca:

“. la aparición del NO-DO no es un hecho casual ni espontáneo, sino fruto de una calculada operación política; sin embargo, su desenvolvimiento administrativo, su quehacer diario parecen abandonados al albur de los 'funcionarios de turno'. Nada de consignas ni directrices. Nada de órdenes emanadas de una instancia superior o paralela [...] en la línea del organigrama montado por Serrano Súñer y su equipo.

Y pese a ello, la irrefutable naturaleza autoritaria y autocrática del Régimen y la voluntad (plasmada en muy diversos órdenes) de inculcar en la población las bondades de su acción aumenta la confusión sobre la paradoja descrita. ${ }^{139 "}$

La aparición del NO-DO fue ampliamente refrendada y apoyada por la prensa de época. Son numerosos los artículos dedicados al Noticiario e incluso a sus creadores y trabajadores. Como ejemplo mostramos una doble página publicada por Primer Plano en la que, de un modo distendido y cercano al lector fuera de todo protocolo, Alfredo Marquerie entrevista a operarios del noticiario para dar una imagen fresca, aventurera, divertida y patriótica de su trabajo.

"De todas las gentes que trabajan con tanta alegría como entusiasmo en nuestro NO-DO, que entra en su tercer año de vida y ha popularizado en el mundo su anagrama, que lleva por todas partes la gracia de España y la actualidad cinematográfica universal mas viva y directa, los que se mantienen y se mantendrá siempre jóvenes son los operadores. Quizás sea ésta una virtud que da el oficio, arriesgado y dinámico, entre guerrero y deportivo, entre vitalista y heroico.

Días de jornada, largas noches sin sueño, riesgos y fatigas sin cuento, no hacen decaer jamás el ánimo de los operadores del NO-DO, siempre a la caza del bello fotograma de la noticia palpitante. ${ }^{140,}$

\footnotetext{
${ }^{138}$ Idídem.

139 Tranche, R. R.; SANChEZ-BIOsCA, V. (2001) NO-DO. El tiempo y la memoria, Madrid, Cátedra / Filmoteca Española (Serie mayor). pp. 179

${ }^{140}$ MARQUeIRE, A. «En el tercer año de NO-DO, los operadores, los del equipo sonoro y sus anécdotas», en Primer Plano, año VI, número 222, 14 de enero de 1945
} 


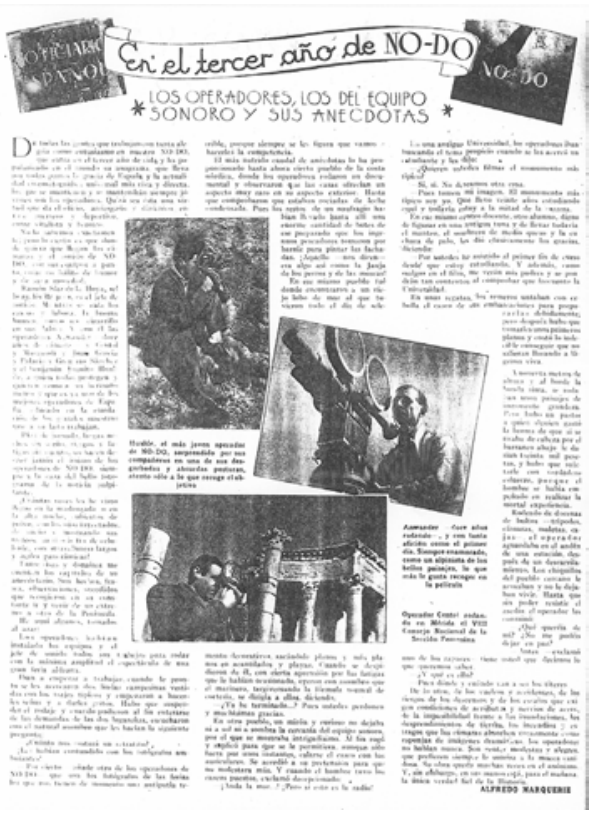

Imagen 18: «En el tercer año de NO-DO, los operadores, los del equipo sonoro y sus anécdotas», en Primer Plano, año IV, número 222

\section{El Círculo de Escritores Cinematográficos}

A mediados de 1945 se funda el Círculo de Escritores Cinematográficos. Dicha organización tiene como antecedentes el ya mencionado Círculo Cinematográfico Español (CIRCE) que se crea a comienzos de 1941, auspiciado por el vicesecretario de Educación Popular, Ricardo Soriano.

La duración de su actividad, a pesar del apoyo institucional aportado por su presidente, no llegó a cuajar y su repercusión fue más bien nula. Los propósitos del CIRCE, como se denominó a la asociación:

“... no podía ser más amplios y positivos: ciclos de conferencias, exposiciones, cursos técnicos, concursos de guiones y documentales, hemeroteca cinematográfica, biblioteca técnica, cinemateca de documentales españoles, archivo fotográfico, cine 'amateur', una editorial... en una palabra, el hogar espiritual del cinemista. ${ }^{141 \text { " }}$

La principal actividad y con mayor repercusión de cuantas efectuó, fueron sus ciclos de conferencias a cargo de eminentes personalidades del mundo del cine como,

\footnotetext{
${ }^{141}$ CABero, J. A. (1949) Historia de la cinematografía española Vol II. Madrid, Gráficas Cinema. pp. 485.
} 
Fernando Delgado, José Luis Sáenz de Heredia, Adriano del Valle, Miguel Pereyra, García Viñolas o Edgar Neville entre muchos otros.

Tras un periodo corto de actividades, sus puertas se cerraron al cabo de un año, pero volvieron a abrirse gracias otra vez a Ricardo Soriano, en 1943, aunque el destino no quiso que esta singular propuesta prosperase y a mediados de 1944 cerró sus puertas definitivamente.

De este modo llegamos a 1945, y el optimismo y fervor de "un grupo de intelectuales del séptimo arte ${ }^{142 "}$ presidido por Fernando Viola fundan en el verano de 1945 el Círculo de Escritores Cinematográficos, popularmente conocido como CEC.

En realidad se trataba de un nutrido conjunto de críticos de cine, periodistas y publicistas vinculados al mundo del cine, bien por trabajo, bien por afición, que se instituyeron según el siguiente manifiesto:

"El cine, como toda actividad artística, precisa ser estudiada con profundidad; su propia historia, de solo medio siglo lleno de lecciones, nos demuestra que sus avances más valiosos e importantes, en el orden espiritual y en el aspecto técnico, han sido obra de sus elementos intelectuales; escritores y artistas movidos por un intenso afán de perfección.

La tarea de los escritores especializados en los complejos temas del cine es esencialmente orientadora, en el sentido más diáfano de la palabra; por eso, y fieles a tan inexcusable y enaltecedor designio, hemos constituido el Círculo de Escritores Cinematográficos, con la alegre firmeza de cumplirlo plenamente. Con medios fundamentales para el desarrollo de nuestra misión, crearemos un cine-club en el que serán exhibidas, en ciclos normativos, las películas de mayor interés por su tema, por sus cualidades estéticas, por sus méritos de dirección o de realización, por su valor histórico; publicaremos un Boletín, fundaremos una Editorial e iniciaremos la ardua y tan necesaria empresa de organizar una Cinemateca, que con sus colecciones sirva de enseñanza teórica y práctica para el conocimiento detallado y completo del desarrollo de este arte; atentos también a los progresos evidentes del cine nacional e impulsados por el justísimo anhelo de su triunfo definitivo, estudiaremos sus diversas cuestiones en el lugar de nuestra fervorosa labor. Bosquejados los principales fines del Círculo de Escritores Cinematográficos, confiamos en la ayuda de cuantos comprenden y sienten el cine en su verdadero valor $y$ creen $y$ saben que nuestra Patria debe alcanzar en esta actividad uno de sus primeros puestos. ${ }^{143,}$

La creación de unos premios, seguida de ciclos de conferencias, publicaciones, apradrinazgos, etc., fueron algunas de sus principales actividades, cuya repercusión ha sido desigual a lo largo de su existencia, aunque en sus comienzos, se llegó a convertir en una de las instituciones o, mejor dicho, asociaciones de obligada referencia crítica. La principal y mayor repercusión de la actividad de esta asociación se materializaba anualmente con la

\footnotetext{
142 MÉndeZ-Leite, F. (1965) História del cine español Vol. I, Madrid, Rialp. pp. 485

${ }^{143}$ CABERO, J. A. (1949) Historia de la cinematografía española Vol II. Madrid, Gráficas Cinema. pp. 573-574.
} 
entrega de unos premios que se convirtieron en una especie de Oscars, acaparando titulares y publicidad, teniendo lógicamente una repercusión posterior en taquilla, aunque no conocemos datos fiables de esto. Las imágenes siguientes sirven de ejemplo del eco que la noticia de los premios del Círculo de Escritores Cinematográficos de 1947 tuvo en los medios de comunicación.

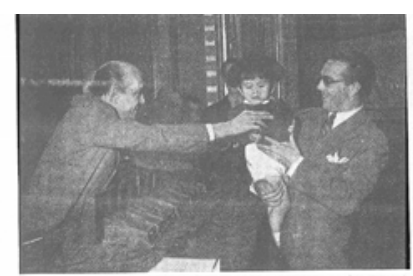

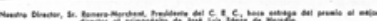
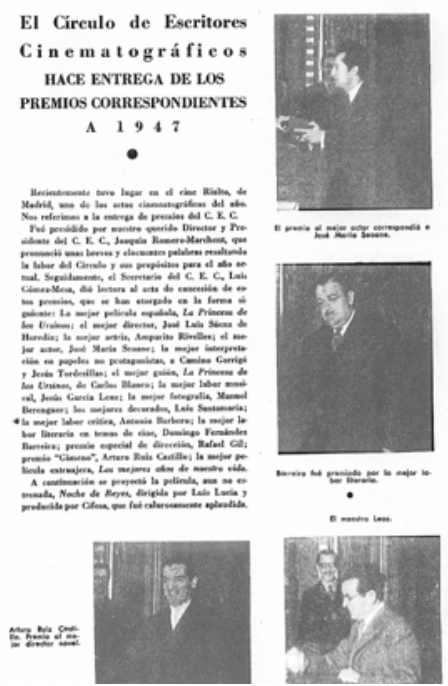
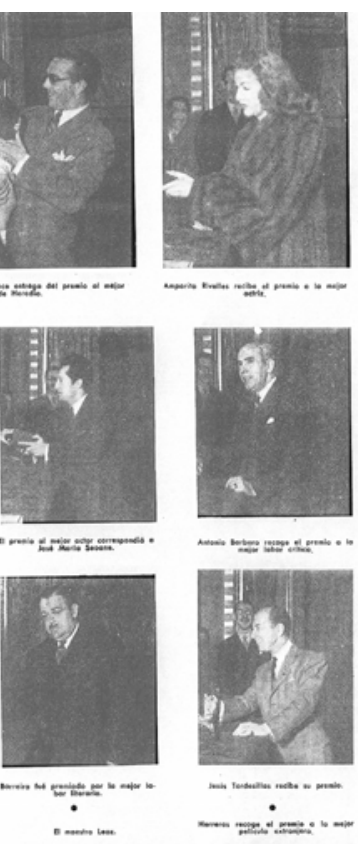

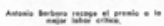
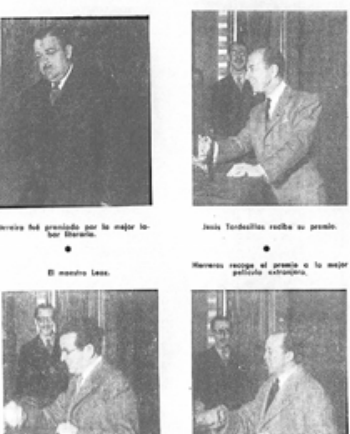

Imagen 19: «EI CEC hace entrega de los premios correspondientes a 1947», en RadioCinema, año IX, núm. 


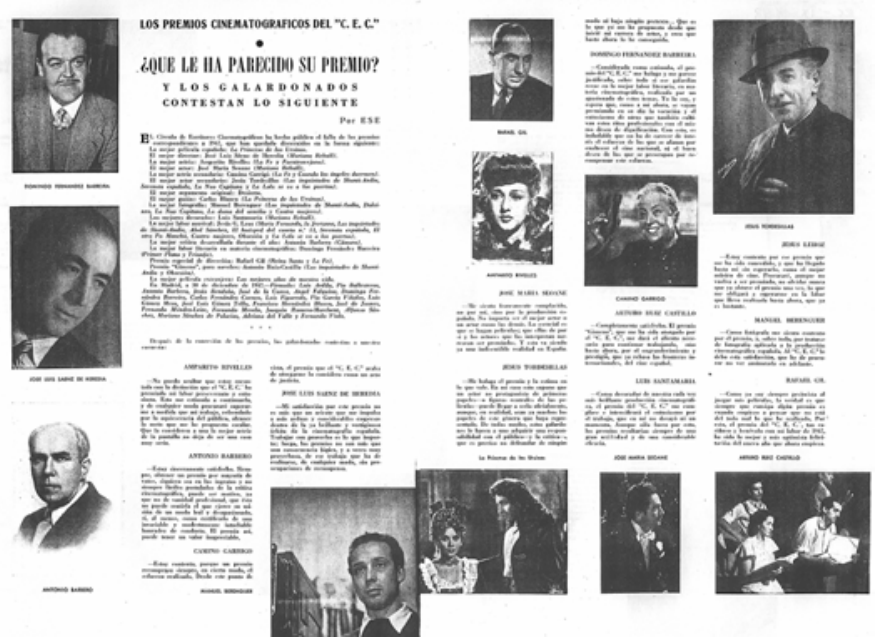

Imagen 20: «¿Qué le ha parecido su premio?», en RadioCinema, año IX, núm. 143

Debemos recordar que los miembros del Círculo en su mayoría pertenecían al mundo editorial y, por tanto, la publicidad y apoyo en los medios resultó crucial para el mantenimiento y prestigio del mismo. Entre las otras labores desempeñadas por el CEC, la creación de un cine-club se presentó como una oportunidad para visionar películas clásicas, difíciles de ver en salas comerciales, sin olvidar, la creación de una revista cuya línea editorial tenía como objetivo reflexionar sobre el arte del cinematógrafo.

\section{El Instituto Cinematográfico Español}

Durante toda la década van a ir apareciendo una multitud de instituciones y organismos que tendrán como función principal regular múltiples aspectos relacionados con la cinematografía. Ya hemos mencionado, anteriormente, la importancia y características de aquellos organismos encargados de la censura, ahora es el momento de centrar nuestra atención en la creación del Instituto Cinematográfico Español y las consecuencias que el mismo tuvo para la enseñanza reglada de los estudios de cine en España.

El 18 de febrero de 1947, a través de una orden ${ }^{144}$ del Ministerio de Educación Nacional se crea el Patronato de Experiencias y Divulgaciones Cinematográficas:

“... dependiente de la Dirección General de Cinematografía y Teatro, [...] que tiene por objeto desarrollar y dirigir las investigaciones y enseñanzas de carácter cinematográfico que se establezcan. ${ }^{145 ",}$

\footnotetext{
144 EsPañA. Orden Creando el Patronato de Experiencias y Divulgaciones Cinematográficas, 18 de febrero de 1947, Ministerio de Educación Nacional, Boletín Oficial del Estado, 19 de febrero de 1947, núm. 50

${ }^{145}$ Idídem.
} 
De este modo se hace realidad una idea acariciada al comienzo de la andadura franquista por Ramón Serrano Súñer y que quedó plasmada en la disposición del 21 de febrero de $1940^{146}$, fijando las competencias del Departamento de Cinematografía, en cuyo artículo cuarto dice:

"Corresponde igualmente al Departamento de Cinematografía establecer de propia iniciativa y de acuerdo con los organismos competentes, previa la aprobación superior, las bases en que se funden el futuro Instituto Cinematográfico Español, como escuela cinematográfica del Estado. ${ }^{147,}$

En junio de ese mismo año comienzan las actividades del Instituto de Investigaciones y Experiencias Cinematográficas con la creación a su vez de un ciclo de estudios dedicados al aprendizaje de técnicas cinematográficas en varias disciplinas de esta actividad.

La Escuela de Cine como se daría en llamar, y que harían famosa Berlanga y Bardem años más tarde, no gozó del beneplácito del mundo del cine que miraba con recelo esta iniciativa estatal. Como nos comentaba José Luis Borau:

“... en aquella época toda la profesión estaba en contra de aquella escuela porque, como decíamos nosotros, eran 'chusqueros'. La gente entraba, no de ayudante que eso es bastante lógico sino para llevar bocadillos, barrer el estudio, etc. y los que trabajaban, eran listos y constantes iban subiendo. Cuando apareció la Escuela los profesionales se burlaban mucho. Decian: pero si el cine no se aprende en las pizarras. El cine se aprende llevando bocadillos y pasando por todas las etapas que hay que pasar. ${ }^{148,}$

A pesar de todo, los primeros exámenes de ingreso a la Escuela tienen lugar en noviembre de ese mismo año, despertando un gran interés que obligó al Ministerio de Educación Nacional a subir el número de plazas iniciales hasta 109 alumnos.

La formación dada en la Escuela estaba divida en dos cursos estructurados del siguiente modo como testimonian esta selección de artículos pertenecientes al Reglamento de la escuela:

"Artículo 10.- Los cursos normales de enseñanza tendrán dos años de duración y estarán reservados a aquellos elementos que por propia disposición natural y por su cultura puedan aspirar a desempeñar los papeles principales y los puestos directivos de cualquier rama de la cinematografía nacional.

Artículo $2^{\circ}$.- Los cursos tendrán dos años de duración: año preparatorio y año de especialización.

Artículo $3^{\circ}$.- Las secciones que integran el I.I.E.C. son las siguientes:

\footnotetext{
${ }^{146}$ EsPañA. Orden fijando la competencia y funciones del Departamento de Cinematografía, pendiente de la Dirección General de Propaganda, 21 de febrero de 1940, Ministerio de la Gobernación, Boletín Oficial del Estado, 25 de febrero de 1940, núm. 56

${ }^{147}$ Idídem.

${ }^{148}$ Entrevista a José Luis Borau. Valencia, 17 de junio de 2003.
} 
- Producción (Organización de la producción)

- Realización artística (Asistencia y ayuda a la labor de dirección, guión, composición artística).

- Escenotecnia (Escenografía, decoración, vestuario, moblaje, maquetas).

- Interpretación (Actores y actrices).

- $\quad$ Acústica (Registro de sonido y especialidades anexas).

- Óptica y cámaras (Conocimiento y manejo de la cámara, iluminación, trucos).

- Sensitometría (métodos sensitométricos y técnicas de laboratorio).

La sección de Realización Artística encuentra su desenvolvimiento efectivo en el segundo año: por ello los aspirantes no serán admitidos directamente, sino aquellos alumnos que durante el primer año hayan demostrado, cada uno en su correspondiente sección, la capacidad, cultura y sensibilidad necesarias.

Artículo $4^{\circ}$.- Las materias que componen cada sección son las siguientes: Producción. Realización artística. Escenografía. Interpretación. Acústica. Óptica y cámaras. Sensitometría. Cultura general.

Artículo $5^{\circ}$.- El programa de cada una de las materias para el primer año (preparatorio) es el siguiente:

- Producción: Organización de la producción. Idiomas. Contabilidad.

- Realización Artística.

Segundo año:

- Escenografía: Escenografía cinematográfica. Materiales y construcción. Trucos y maquetas. Vestuario. Maquillaje.

- Interpretación: Dirección. Modales. Expresión y mímica cinematográfica. Teoría del actor cinematográfico y medios de expresión en el cine. Teoría del lenguaje. Educación física.

- Acústica: Teoría. Aplicaciones prácticas del registro de sonido. Doblaje y mézclas. Música. Sensitometría. Fonética experimental.

- Óptica y cámaras: Teoría. Aplicaciones prácticas con la cámara. Maquillaje. Fotografía. Sensitometría. Elementos de escenotecnia.

- Sensitometría: Teoría. Aplicaciones prácticas. Fotografía.

- Cultura general: Técnica y estética del cine. Historia del cine. Función social del cine. Historia del arte. Historia de la literatura española.

Artículo $6^{\circ}$.- Las materias correspondientes al segundo año (Especialización) son las siguientes: 
- Producción.

- Realización artística: Tratamiento del guión cinematográfico. El guión. Montaje. Ayuda a la dirección artística.

- Escenotecnia: Materiales y construcción. Trucos y maquetas.

- Interpretación: Dirección. Interpretación cinematográfica. Aplicación y prácticas. Educación física. Danza.

- Acústica: Aplicaciones prácticas de registro de sonido. Música.

- Óptica y cámaras: Aplicaciones prácticas con la cámara.

- Sensitometría: Aplicaciones prácticas de los métodos sensitométricos. Operaciones complementarias. Laboratorios. ${ }^{149,}$

Por otro lado, Fernando Méndez-Leite en su historia del cine nos informa sobre las instalaciones con las que contaba al comienzo de su andadura la Escuela. Según podemos leer:

“... un edificio levantado por el Instituto, situado dentro del recinto de la Escuela Especial de Ingenieros Industriales, destinado a laboratorio y salas de montaje y pruebas. Cuenta, además, con una nave de filmación o escenario" y "con cuantos elementos son precisos en el estudio cinematográfico moderno, tanto en lo que se refiere al laboratorio de revelado y sonido como a las salas de montaje, cámaras y demás instrumental y aparatos. ${ }^{150 "}$

Asimismo, dicha institución se plantea como plataforma para la investigación cinematográfica, y para ello coordina los trabajos de investigación llevados a cabo en las distintas especializaciones y becas con los organismos oficiales del Consejo Superior de Investigaciones. Entre las actividades a destacar, según la fuente antes cintada, se encuentra una filmoteca situada en el propio Instituto, que no pasaría de tener unos pocos títulos simbólicos.

La puesta en marcha de la llamada Escuela de Cine y las primeras promociones surgidas de sus aulas situarán al cine español en una nueva etapa.

\footnotetext{
149 «Reglamento de la Escuela de Cine», en CABERO, J. A. (1949) Historia de la cinematografía española Vol II. Madrid, Gráficas Cinema. pp. $600-601$.

${ }^{150}$ MÉndeZ-Leite, F. (1965) História del cine español Vol. I, Madrid, Rialp. pp. 521.
} 
CAPÍTULO 3 CONTEXTO CINEMATOGRÁFICO 
La coyuntura política, social, económica y religiosa, fueron moldeando con el transcurrir del tiempo los engranajes de una industria y por extensión, la producción, tanto en sus aspectos formales, estéticos y técnicos, como temáticos. Estos cambios están intimamente ligados a las propias transformaciones que las instituciones franquistas sufrieron con tal de conseguir la perpetuidad y estabilidad del régimen. Como ya hemos comentado, la paulatina transformación de éstas durante la década de los cuarenta resulta crucial para entender las transformaciones habidas en España. Este vaivén político repercutió directamente tanto en la sociedad como en el cine nacional que vio como sus universos temáticos y esquemas productivos, fueron transformándose a lo largo de la década.

A continuación realizaremos un seguimiento de la producción cinematográfica española de referencia, a partir de los datos que nos proporciona la base de datos elaborada en la presente tesis.

En la gráfica que mostramos a continuación, podemos visualizar la evolución de la producción general en nuestro cine desde 1939 a $1950^{151}$.

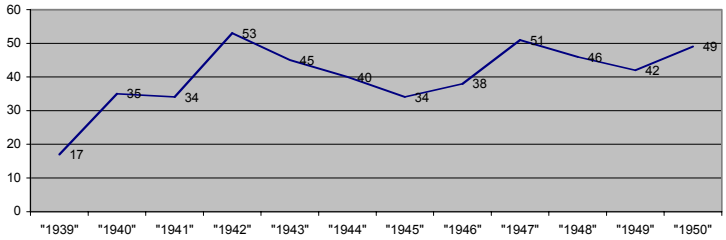

Gráfica 2: Producción de largometrajes desde 1941 a 1950

Podemos observar que la producción cinematográfica sufre vaivenes durante todo este intervalo de tiempo, con máximos que resultan a priori sorprendentes. Se comienza con una producción de diecisiete películas de largometraje al finalizar la guerra. Esta cifra se duplicará al año siguiente y se mantendrá en 1941 con una ligera bajada del $3 \%$. El año siguiente, 1942 supone el momento de mayor esplendor de toda la década, en cuanto a número de producciones desde 1939 a 1950 se refiere, con más de medio centenar de filmes. En los tres años posteriores a 1942, comenzará a notarse un decrecimiento considerable que se mantendrá hasta 1945 donde se llegan a realizan tan solo treinta y cuatro películas, cifra mínima sin contar los datos de 1939.

A partir de este momento se produce un nuevo empuje que supondrá una notable recuperación, alcanzando en 1947 la cifra de cincuenta y una películas (tan solo dos menos que en 1942). Esta cifra se mantiene estable durante la década estudiada, volviendo a

\footnotetext{
${ }^{151}$ Los datos pertenecientes a 1939 y 1940, a pesar de no ser del todo exáctos, servir de guía aproximada de cómo se comportó la industria en los dos años posteriores al periodo objeto del presente estudio.
} 
bajar, pero nunca por debajo de las cuarenta y dos producciones. En total se realizaron 484 largometrajes entre 1939 y 1950.

Los constantes altibajos que nos proporciona la gráfica, nos indica que los puntos máximos y mínimos están directamente relacionados con los acontecimientos históricos y con la acción legislativa emprendida por el gobierno franquista. Así pues, es lógico suponer que la baja incidencia de producciones en 1939 es consecuencia directa de la Guerra Civil que acababa de llegar a su fin a mediados de ese mismo año. Debemos recordar que la producción nacional durante la contienda, en lo referente a largometrajes de ficción, se paralizó prácticamente $o$ se desplazó su producción a terceros países mediante coproducciones, especialmente con Alemania e Italia, cuyos regímenes nazi y fascista eran afines al bando Nacional. Conocido es el caso de la película protagonizada por Imperio Argentina, Carmen, la de Triana, dirigida en su versión española por Florian Rey, cuyo rodaje se realizó en Alemania.

Como ya hemos comentado, finalizada la Guerra Civil, el 1 de septiembre de 1939 con la invasión alemana de Polonia daba comienzo la II Guerra Mundial que traería trágicas consecuencias para Europa. Como es de suponer, la industria cinematográfica, como toda actividad económica, se vio fuertemente influenciada. Puede pensarse, a simple vista, que como consecuencia del conflicto mundial la producción de películas debería haberse visto minada por un número considerable de circunstancias desfavorables (falta de material virgen y equipos apropiados, divisas, etcétera) pero lo cierto es que la realización de películas se cuadriplicó en tan solo dos años llegando a alcanzar cotas no superadas durante mucho tiempo.

\section{Etapas en la producción cinematográfica}

Con el fin de establecer una mayor comprensión de los cambios detectados en la producción cinematográfica, hemos establecido tres períodos claramente diferenciados.

El primero comprende desde el fin de la Guerra Civil hasta 1942 y lo denominaremos "Establecimiento de la Industria". Este periodo nos permite recoger las circunstancias que se producen en la industria cinematográfica, en su afán por retomar impulso recién terminada la guerra, pasando por la aparición de las primeras leyes proteccionistas que afectan al sector cinematográfico promulgadas en 1941, hasta finales de 1942 cuando la producción inicia su descenso en picado. Este periodo se caracteriza por una presencia importante de la gran comedia, de la comedia sofisticada, más receptiva a la influencia de las comedias Hollywodienses que a las de procedencia alemana e italiana ${ }^{152}$.

\footnotetext{
${ }^{152}$ Muy interesantes y clarificadoras resultan las investigaciones que sobre la comedia de CIFESA está llevando a cabo Aurea Ortiz, en su tesis doctoral, cuyos resultados esperamos ver pronto. Por el momento, podemos tener acceso a algunos datos presentados en el VIII Congreso de la Asociación Española de Historiadores del Cine, recientemente se ha publicado en Fernández Colorado, L.; Couto CANTERO, P. (coord..) (2001) La herida de las sombras. El cine español de los años 40, Madrid, Academia de las Artes y las Ciencias Cinematográficas en España / AEHC.
} 
El segundo periodo es el comprendido entre 1943 y 1947 y lo denominamos "Crisis de la industria". La producción baja en picado hasta el año 1945, coincidiendo con los avatares de la Segunda Guerra Mundial. Una vez terminada la guerra comienza un proceso de lenta recuperación que duró dos años, caracterizado por una reformulación que afecta tanto al estilo como a los temas tratados en nuestro cine. Nos encontramos en un momento de transición, donde la producción de comedias irá desapareciendo, mientras surge una avalancha de dramas.

El tercer periodo abarca desde 1948 hasta principios de la década de los cincuenta y lo llamaremos "Consolidación de la industria". La industria cinematográfica, con una legislación asentada comenzará a tener una mayor aceptación por parte del público nacional, especialmente a finales de los cincuenta. La producción se estabiliza y comienzan a surgir nuevos directores. Temáticamente, esta es la época donde surgen más temas de carácter histórico y religioso.

En resumen, a principios de la década de los cuarenta el cine nacional es, por un lado claramente de evasión y disfrute, y por otro de exaltación patriótica. Las aventuras épicas del ejército nacional con sus héroes así como las comedias alocadas de mujeres liberadas en ambientes ricos y sofisticados convivieron entre sí hasta 1943, año en que comenzará a bajar la producción de comedias y las películas épicas dejaron de gustar al público. Las primeras, "porque empezó a entrar una especie de pudor nacional y aquellas películas patrióticas, altisonantes y heroicas ya no gustaron ${ }^{153}$ ". Lo que no fue obstáculo para que a finales de la década, con las facciones más reaccionarias de los democristianos católicos fuertemente asentadas en las instituciones, el cine religioso e histórico de reminiscencias patrióticas tomara el relevo. Las segundas, casi dejaron de producirse, fundamentalmente porque los productores necesitaban obtener permisos de importación y las comedias no lo proporcionaban. Así pues, el drama se impone con una fuerza arrolladora, siendo al final de la década el principal género cinematográfico español.

\section{Los géneros en el cine español de los años cuarenta}

Uno de los aspectos más interesantes a la hora de abordar el estudio de la música de cine es observar la relación existente entre ésta y la diversificación de la producción cinematografía en géneros de ficción. Los géneros, como muy bien define Bordwell y Thompson:

\footnotetext{
“... se fundamentan básicamente en el establecimiento de un pacto con el receptor. En un musical, el público espera números musicales, ya sean integrados de forma realista en el contexto de la historia (como lo son los bailes de Fiebre del sábado noche [Saturday Night Fever, 1977] o presentados con motivaciones menos realistas como en El mago de Oz o en Un americano en París [An American in Paris, 1951]). Un género forma un conjunto de
}

\footnotetext{
${ }^{153}$ Entrevista a José Luis Borau, Madrid, 25 de julio de 2003.
} 
«reglas») para la construcción de la narración que conocen tanto el cineasta como el público. ${ }^{154 "}$

El cine español de la década de los cuarenta parece, como han puesto de manifiesto algunos autores, cortado por un mismo patrón ${ }^{155}$ lo que pone de manifiesto, en nuestra opinión, la existencia de una tendencia de la industria cinematográfica en la época que apuesta claramente por un cine de géneros. Por esta razón nos ha parecido de enorme interés dedicar parte de nuestro análisis a este aspecto, centrándonos en los dos géneros que más se desarrollaron durante la década, el drama y la comedia.

Según la definición encontrada en la Enciclopedia del Cine Español CINEMEDIA, drama es:

“... el género cinematográfico basado fundamentalmente en concitar en el espectador la emoción y la identificación con unos personajes sometidos, en medio de un mundo inmutable, a una acción continua que tiende hacia el desenlace. ${ }^{156 ،}$

No podemos salir de nuestro asombro ante una definición construida, básicamente sobre la ambigüedad. ¿Qué quiere decir "concitar al espectador la emoción y la identificación con los personajes"? ¿A caso no se busca siempre en todo relato que el espectador se identifique con los personajes y viva con ellos sus experiencias? ¿Y no resulta todavía más obvio el final de la definición, ya que en la misma lo que realmente se está haciendo es explicarnos una de las nociones básicas de todo relato clásico, el que la acción tiende necesariamente hacia un desenlace?

Pero si nos parece imprecisa y poco acertada la definición que se hace en dicha enciclopedia del género dramático, no lo es menos, cuando se refiere a otros géneros cinematográficos como la comedia $^{157}$, el suspense ${ }^{158}$ o el documental ${ }^{159}$. Dejando de lado las definiciones aparecidas en la mencionada enciclopedia multimedia y las particularidades de las mismas, el hecho cierto es que viene a poner de manifiesto la dificultad con la que nos encontramos cuando tratamos de acotar las características atribuidas a las distintas tipologías de géneros. $Y$ es que llegar a definir las características de un género no está exento de complicaciones, ya que es necesario tener en cuenta matices que van desde la percepción individual y social hasta de contexto histórico.

\footnotetext{
${ }^{154}$ BordWeLL, D.; THOMPSON, K. (1995) El arte cinematográfico. Una introducción. Barcelona, Paidós. pp. 81

155 “... en realidad resulta abusiva la pretensión de analizar el cine español de los años 40 bajo la pauta autoral o simplemente en función de actitudes muy diferenciadas,... debemos derivar la atención sobre ese cine español desde la figura del autor hacia los aspectos más generales, como puedan ser las tendencias temáticas, los géneros o el starsystem.”[VV.AA. (1995) História del cine español, Madrid, Cátedra (signo e imagen). pp.229]

${ }^{156}$ HuERTA, C. (1997) Enciclopedia de Cine Español : CINEMEDIA, [CD-Rom] Barcelona, Canal+ ; SGAE..

157 "La comedia es el género cinematográfico basado en la pintura de caracteres o situaciones por encima de la acción, cuya exposición es siempre fuente de enredos y desenlaces festivos o placenteros" en HUERTA, C. (1997) Enciclopedia de Cine Español : CINEMEDIA, [CD-Rom] Barcelona, Canal+ ; SGAE.

158 "El suspense es el estado de ansiedad creado en el espectador por medio de la presentación lo más intensa posible de las situaciones dramáticas, en la que es imprescindible que el público esté perfectamente enterado de lo que puede suceder, aunque no sepa cuando" en HUERTA, C. (1997) Enciclopedia de Cine Español : CINEMEDIA, [CD-Rom] Barcelona, Canal+ ; SGAE.

159 "El documental es un filme que pretende el tratamiento creativo de la actualidad e interpreta en términos sociales la vida de la gente tal como existe en la realidad" en HUERTA, C. (1997) Enciclopedia de Cine Español : CINEMEDIA, [CD-Rom] Barcelona, Canal+ ; SGAE.
} 
Por otra parte los géneros raramente se presentan aislados. Un relato puede, o mejor dicho, suele estar vinculado a varios géneros. Cuando hacemos referencia a una película como El hombre que mató a Liberty Vallance de John Ford, generalmente se dice de ella que es un western, porque transcurre en el Oeste, pero es mucho más que esto, es un drama en toda regla. El tema principal y los códigos con los que trabaja Ford en este filme se acercan más a estos últimos que al western. Lo mismo ocurre con algunas películas de Billy Wilder donde la frontera entre la comedia y el drama son en ocasiones difíciles de delimitar. De modo que, es complicado recurrir a la etiqueta de género, aún realizando un análisis pormenorizado de cada filme en cuestión. $Y$ es que como afirman Bordwell y Thompson:

“... la flexibilidad de las definiciones del género se muestra en la capacidad de los géneros para entremezclarse libremente,... el hecho de que los géneros puedan entremezclarse no quiere decir, sin embargo, que no haya fronteras entre ellos."

Así pues, los autores terminan diciendo que:

“... en vez de una definición abstracta, la mejor forma de identificar un género es reconocer cómo los cineastas y el público, en diferentes periodos históricos y lugares, han distinguido de forma intuitiva un tipo de película u otro. ${ }^{160}$ "

Nos parece acertado este argumento de base que aunque sigue sin resolver el problema de la indefinición de los géneros y sus límites, tiene en cuenta el contexto de producción y recepción de la obra fílmica.

Por ello, no es de extrañar que hayamos encontrado grandes diferencias en la asignación del género de las películas del cine español de la década de los cuarenta según la procedencia de las distintas fuentes consultadas. De todas ellas, CINEMEDIA es la enciclopedia que presenta un número nada desdeñable de títulos cuya asignación ponemos en entredicho después de haber realizado un laborioso trabajo de análisis. Así, títulos como El pobre rico (1942) resulta ser un drama cuando está bien claro y no hay ninguna duda que se trata de una comedia. Jack, el negro (1950) aparece como un filme de aventuras cuando es uno de los exponentes del cine policiaco nacional.

En nuestra base de datos hemos recurrido a la clasificación utilizada por la Filmoteca Nacional que lanzó en 1998 al mercado el segundo volumen del Catálogo de Cine Español de Películas de Ficción ${ }^{161}$. Se trata del resultado de un trabajo de documentación arduo y extenso en el tiempo cuyo propósito final es la catalogación del cine de ficción anterior a 1953, año en que se funda la Filmoteca y comienza a llevarse un control de nuestro patrimonio fílmico.

Este trabajo de documentación dirigido por Ángel Luis Hueso, recoge la información más precisa y cuidada de catalogación de nuestro cine desde 1921 a 1930 y 1941 a 1950. Precisamente, para nuestro trabajo, este último volumen nos ha resultado de

\footnotetext{
${ }^{160}$ BORDWELL, D.; THOMPSON, K. (1995) El arte cinematográfico. Una introducción. Barcelona, Paidós. pp. 81 - 82

${ }^{161}$ El primer volumen aparecido está dedicado al cine de ficción de 1921 - 1930 que en realidad se trata del segundo, puesto que el primero estará dedicado a la década de los diez y el tercero a la década de los treinta.
} 
gran ayuda, puesto que los datos aportados provienen, en su mayor parte, de las propias fuentes originarias, o sea, las películas.

El trabajo de adjudicación de un género a cada filme se plantea en los siguientes términos:

“... para determinar los géneros cinematográficos hemos observado un criterio muy amplio, dado que mayores especificaciones son siempre de difícil $y$ discutible exactitud. Para paliar esta indeterminación hacemos uso de los descriptores, tomados de los elementos más significativo de los argumentos. ${ }^{162 ",}$

Evidentemente, la Filmoteca Nacional también se encontró con el problema de los géneros. La asignación del género se hizo de forma intuitiva, quedando de este modo a merced de aquellos encargados de la labor, salvo en los casos donde la mezcla de géneros hacía difícil la designación de un único epígrafe. En estos casos, se recurre a los descriptores, palabras clave que describen la película.

Como hemos dicho, anteriormente, el género es un dato altamente arbitrario y sujeto a interpretaciones frente a otros datos referidos a la parte técnica o artística de la película. A pesar de ello, resulta necesario su estudio aunque éste pueda albergar fisuras, porque nos proporciona información de interés relativa a la producción e incluso en torno a la sociedad y cultura del momento.

De este modo, si tomamos como base las especificaciones que la Filmoteca Nacional nos aporta en el mencionado Catálogo de Cine Español de Películas de Ficción, nos encontramos con la siguiente relación de datos.

\begin{tabular}{|l|l|l|}
\hline Nombre & total & $\%$ \\
\hline Animación & 5 & $1,25 \%$ \\
Aventuras & 5 & $1,25 \%$ \\
Bélico & 6 & $1,38 \%$ \\
Biográfico & 4 & $0,92 \%$ \\
Comedia & 114 & $26,22 \%$ \\
Comedia dramática & 19 & $4,37 \%$ \\
Comedia musical & 5 & $1,25 \%$ \\
Drama & 166 & $38,18 \%$ \\
Espionaje & 4 & $0,92 \%$ \\
Fantástico & 3 & $0,69 \%$ \\
Histórico & 15 & $3,45 \%$ \\
Melodrama & 61 & $14,02 \%$ \\
Musical & 5 & $1,25 \%$ \\
Policiaco & 19 & $4,37 \%$ \\
Western cómico & 1 & $0,23 \%$ \\
\hline
\end{tabular}

Tabla 12: Listado de géneros. Fuente: Catálogo de Cine Español de Películas de Ficción

\footnotetext{
162 Hueso, A. L. (coord..) (1998) Catálogo de cine español 1941-1950, Fuenlabrada (Madrid), Cátedra / Filmoteca Española.pp. 13.
} 
En un primer momento nos encontramos con un total de quince géneros diferentes con una incidencia en el panorama cinematográfico del momento muy desigual dependiendo de la clasificación de géneros que se hace. Así, la animación, los filmes de aventuras, la comedia musical y el propio musical tienen una incidencia de tan solo el $1,25 \%$ cada uno del montante total de la producción que frente al $0,23 \%$ del western cómico, el $0,69 \%$ del fantástico y el $0,92 \%$ del biográfico y el espionaje, consigue superar la barrera del $1 \%$. El cine bélico, con un $1,38 \%$ se convierte en el género con mayor presencia dentro del grupo con menor incidencia en el panorama general.

A una distancia considerable, se encuentran el cine histórico, la comedia dramática y el policiaco con un $3,45 \%$, el primero y un $4,37 \%$ los dos últimos. Frente a estos porcentajes menores, se hallan los del melodrama, con un $14,02 \%$ y la comedia y el drama, con un $36,22 \%$ y un $38,18 \%$ respectivamente.

Como se puede apreciar en la tabla 1 la categorización de géneros propuesta resulta, en algunos casos, un tanto redundante ya que se distingue entre comedia, comedia dramática y comedia musical, diferenciando por otra parte el género musical. Asimismo se distingue entre aventuras, bélico e histórico y se separan el drama y melodrama. Se establece como género el western cómico y se distingue entre espionaje y policiaco.

De modo que, volvimos a centrarnos en las fuentes originarias, es decir, las películas y a considerar toda la documentación perteneciente a las mismas que pudiera arrojar luz sobre la correcta utilización de algunas de estas categorías, como la comedia dramática o el espionaje, dentro de otros apartados. Así, dentro del apartado de comedia incluiríamos las comedias dramáticas de aire sofisticado y sonrisas agridulces, o el western cómico $^{163}$ (que en nuestro país y en la década que nos ocupa, no deja de ser más que una rareza, teniendo mayor peso su vertiente cómica que las cánones y matices propios del género americano); la comedia musical, por su vertiente de números de baile y canciones decidimos incluirla dentro del musical; el espionaje, género poco habitual en nuestro cine, con tan solo cuatro filmes en diez años, por su cercanía y aspectos comunes con el policiaco, se ha fusionado con este último de mayor presencia y repercusión; y el melodrama, exaltación máxima del drama ha sido inevitablemente absorbida por este último.

Después de los ajustes necesarios, hemos obtenido esta nueva tabla de datos relativa a los géneros.

\footnotetext{
${ }^{163}$ El sobrino de Búfalo Bill (1944).
} 


\begin{tabular}{|l|l|l|}
\hline nombre & Total & $\%$ \\
\hline Animación & 5 & $1,25 \%$ \\
Aventuras & 5 & $1,25 \%$ \\
Bélico & 6 & $1,38 \%$ \\
Biográfico & 4 & $0,92 \%$ \\
Comedia & 134 & $30,82 \%$ \\
Drama & 227 & $52,21 \%$ \\
Fantástico & 3 & $0,69 \%$ \\
Histórico & 15 & $3,45 \%$ \\
Musical & 10 & $2,3 \%$ \\
Policiaco & 23 & $5,29 \%$ \\
\hline
\end{tabular}

Tabla 13: Listado de géneros en la Base de Datos MCE40

Los nuevos ajustes efectuados reducen a diez clasificaciones las quince que resultaban del primer acercamiento. La animación, el cine de aventuras, bélico, biográfico, histórico y fantástico se mantienen en la misma posición originaria sin variación alguna. Es cierto, que en alguna ocasión tuvimos la tentación de reunir en un mismo epígrafe el cine bélico, biográfico e histórico porque tienden de manera natural a entremezclarse, pero pronto desechamos esta idea por los matices existentes entre estos tres géneros. En el caso del cine biográfico gira, siempre, en torno a la figura de un personaje real, mientras que el género histórico, aunque tiene como protagonista una personaje real no presenta, necesariamente, la vertiente individualizada propia del biográfico, está más centrado en acontecimientos históricos y sociales. Por ejemplo, Agustina de Aragón es un filme histórico aunque la acción tiene como protagonista a la heroína aragonesa. Por otro lado, el cine bélico, más próximo al histórico que el biográfico, tiene una vertiente castrense que lo diferencia claramente de los otros dos.

Los géneros que sufren un cambio en nuestra base de datos son el drama, la comedia, el policíaco y el musical. El primero pasa de un $38,18 \%$ a un nada desdeñable $52,21 \%$, llegando a ser más de la mitad de la producción total. La comedia, de un $26,22 \%$ pasa a un $30,82 \%$, un segundo puesto en importancia que la hace merecedora de un estudio a parte, por las características propias del mismo. El musical dobla su proporción de cinco películas a diez producciones lo que se traduce a un simple $2,3 \%$ mientras que el policiaco se convierte en el tercer género más producido durante este período. 


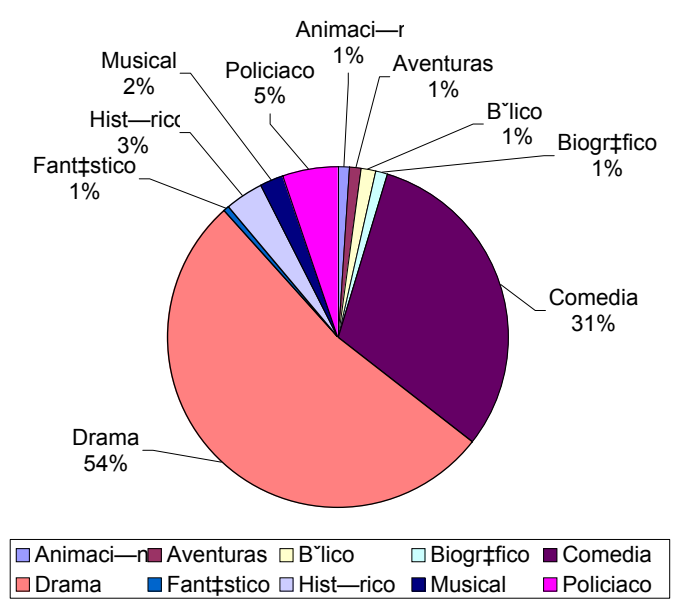

Gráfica 1: Distribución por géneros

En la gráfica anterior podemos observar con una mayor facilidad la presencia de cada uno de los géneros en la producción nacional de la década de los cuarenta. En ella se puede ver, con facilidad, la fuerte presencia del drama y la comedia frente al resto de géneros, que en algunos casos resulta ser meramente presencial o anecdótica.

Analizando todos estos datos, podemos afirmar que durante la década de los años cuarenta los dos géneros hegemónicos son el drama y la comedia. Estos datos ponen de manifiesto la repercusión menor del cine histórico y belicista. Estos dos géneros juntos no llegan ni siquiera a un $5 \%$ frente al $83 \%$ que sumarían la comedia y el drama.

La poca producción de musicales durante este periodo es otra de las constantes con las que nos hemos encontrado, poniendo de manifiesto que durante este periodo, hubo poca presencia de tonadilleras en nuestras pantallas. Es cierto que el público español de entonces tenía aprecio por la canción española pero también es cierto que la industria no pareció interesarse demasiado por ésta. La misma Imperio Argentina no llegó a realizar más que tres producciones, Goyescas, Bambú y La cigarra; ninguna de las cuales puede considerarse un musical en sentido estricto, ya que la presencia de canciones y bailes es meramente secundaria. Tan solo diez largometrajes en diez años se encuadran dentro de este género, número que resulta realmente escaso y poco representativo.

No ocurre así con el cine policiaco que aparece como el tercero en importancia, algo que por otro lado no debe sorprendernos si tenemos en cuenta que el cine negro siempre ha gozado del beneplácito de los espectadores. También debemos de tener en cuenta otro aspecto importante y que en multitud de ocasiones se olvida, la influencia del cine norteamericano tanto en nuestros cineastas como en el público. El mismo José Antonio Nieves Conde nos reconocía en la entrevista que tuvimos ocasión de mantener con él, la fuerte influencia que las películas de la Warner Bros tuvieron en él. Y, desde luego, es fácil de apreciar la influencia del cine americano cuando observamos las películas estrenadas en 
Madrid, dato éste, que se puede verificar con la lectura del tercer capítulo del Anuario de Cinematografía Hispanoamericana de 1950. De todos modos, esta influencia se podrá ver con más claridad en el apartado dedicado a la importación de películas extranjeras.

La animación es otro de los puntos a tener en cuenta. La realización de un largometraje de dibujos animados supone un gran esfuerzo humano, técnico y económico por lo que resulta sorprendente la realización de cinco películas de largometraje en diez años. No debemos olvidar que España durante este periodo está viviendo los efectos de la postguerra, cuyas consecuencias se ven agravadas por la Segunda Guerra Mundial. Si bien la industria había salido maltrecha por el conflicto armado, la recuperación de la misma durante la primera mitad de la década hizo posible la aparición de este tipo de películas en nuestro país. Aparición, por otro lado, que se veía venir si tenemos en cuenta los datos aportados por Victoriano López García ${ }^{164}$.

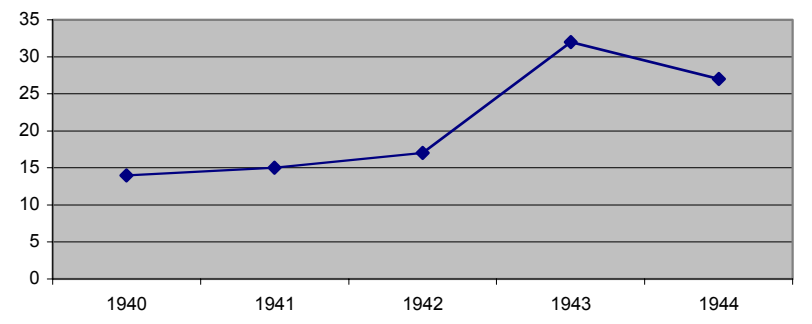

Gráfica 2: Producción de cortos de animación

\begin{tabular}{|l|llllll|}
\cline { 2 - 7 } \multicolumn{1}{c|}{} & 1940 & 1941 & 1942 & 1943 & 1944 & Total \\
\hline Animación & 14 & 15 & 17 & 32 & 27 & 105 \\
\hline
\end{tabular}

Tabla 14: Datos de la producción de cortos de animación

Si bien no hemos encontrado datos anteriores a 1940, tenemos los comprendidos entre este año y 1944. Los tres primeros años la producción de cortos de animación se estabiliza con una ligera subida anual de una o dos producciones más. Estos datos son bastante parecidos a los que aporta en su Historia del Cine, Fernando Méndez-Leite, cuando afirma que al comienzo de 1942 se producen 30 películas de cortometraje de dibujos animados ${ }^{165}$. Entre los datos proporcionados por Victoriano López y Méndez-Leite existe una discrepancia de dos producciones ${ }^{166}$.

\footnotetext{
164 LÓPEZ GaRcía, V. (1945) La industria cinematográfica española, Madrid, Asociación Nacional de Ingenieros Industriales. pp.11.

${ }^{165}$ MÉndeZ-Leite, F. (1965) História del cine español Vol. l, Madrid, Rialp. pp.421

${ }^{166}$ Dicha discrepancia no es significativa pero vamos a tomar como referente los datos proporcionados por López García.
} 
En 1943, coincidiendo con el apogeo generalizado de la producción en nuestro país, se consigue una cota nada desdeñable de 32 producciones, casi el doble que el año anterior, produciéndose una ligera bajada en 1944, coincidente también con la bajada de la producción general. A pesar de todo, se realizaron en cinco años la friolera de 105 cortometrajes de animación, una cantidad realmente llamativa, y que pone de manifiesto el asentamiento, de una parte del engranaje industrial cinematográfico dentro de este sector. Esto haría posible lanzarse a la aventura que supuso la realización del primer largometraje en color de dibujos animados de toda Europa ${ }^{167}$, Nos referimos a Garbancito de la Mancha estrenada en 1946.

Esta singular producción pronto acaparó la atención de los medios de comunicación y sirvió como ejemplo de ensalzamiento de la industria nacional ya que comenzó su realización 1944, año en el que se detecta un decrecimiento de la producción cinematográfica, lo que no supuso ningún impedimento para comenzar toda una campaña publicitaria en el momento, tal y como podemos apreciar en las siguientes páginas extraídas de la revista Primer Plano.
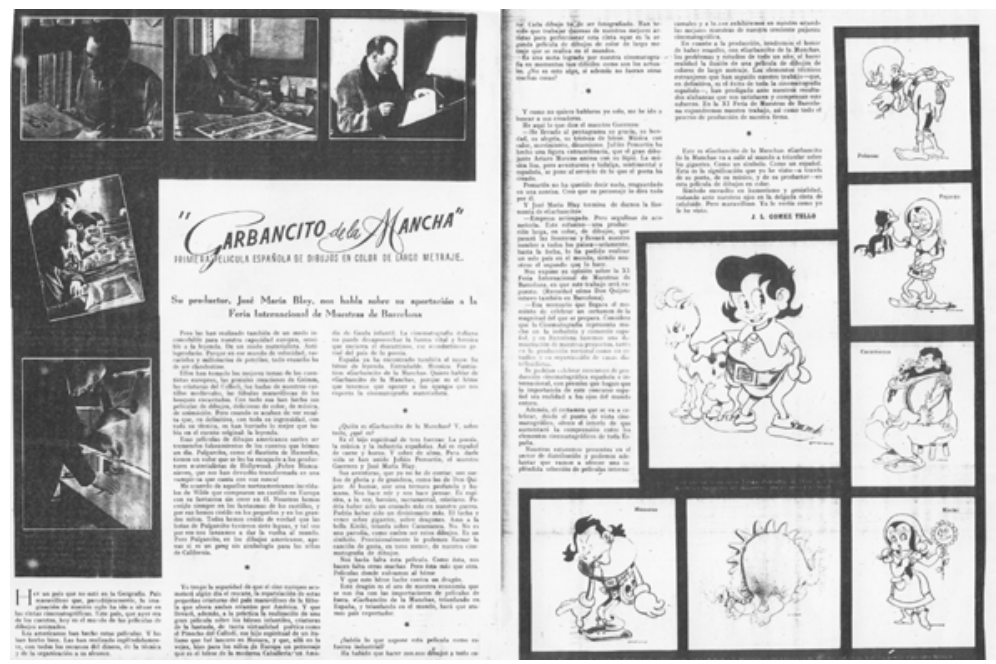

Imagen 21: «Garbancito de la Mancha» en Primer Plano, año IV, número 133

En las páginas de la revista podemos leer la opinión de José María Blay, productor de la película, cuando responde a la pregunta del esfuerzo de producción qué supone Garbancito de la Mancha.

"Ha habido que hacer 200.000 dibujos a todo color. Cada dibujo ha de ser fotografiado. Han tenido que trabajar decenas de nuestros mejores artistas para perfeccionar esta cinta «que es la segunda película de dibujos de color

\footnotetext{
167 CAstán Palomar, F. «Horas antes del estreno, con el director y los autores de Garbancito de la Mancha» en Primer Plano, año VII, número 291, 12 de mayo de 1946.
} 
de largometraje que se realiza en el mundo». Es una meta lograda por nuestra cinematografía en momentos tan difíciles como son los actuales ${ }^{168}$."

También se puede apreciar cómo se presentan a los personajes mediante dibujos de línea (puesto que fotogramas del filme por el momento no existen) y se muestra el modus operandis seguido por la productora a través de unas fotografías de los artistas trabajando en el proyecto.

Un año más tarde, en octubre de 1945 vuelve a aparecer una doble página en Primer Plano dedicada a esta producción. En esta ocasión centrada en una entrevista realizada al maestro Guerrero, autor de la música de la película.

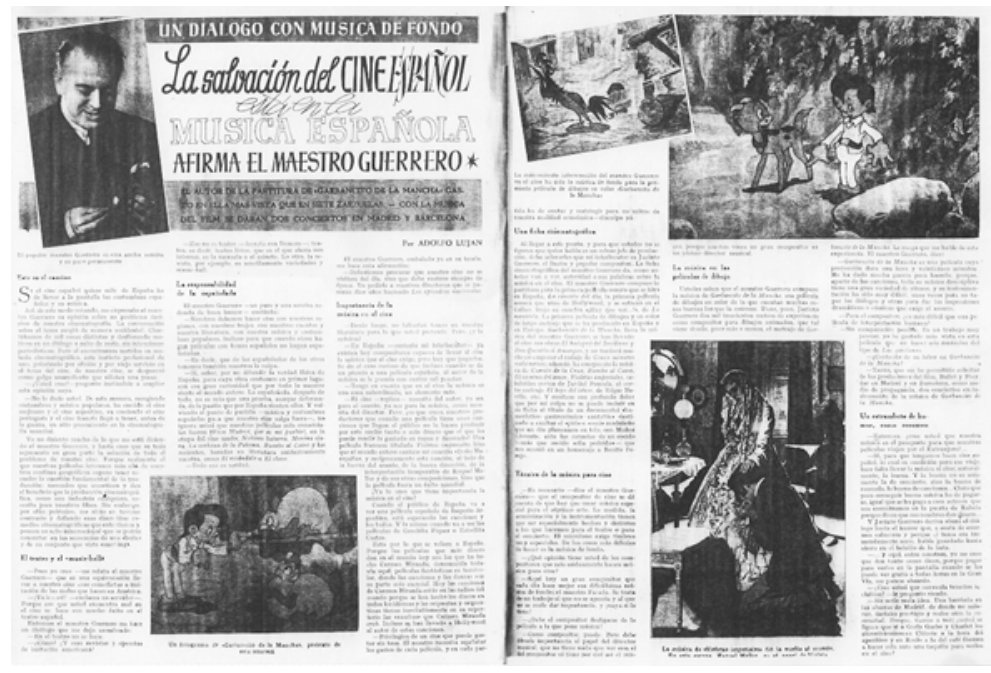

Imagen 22: «La salvación del cine español está en la música española», en Primer Plano, año VI, número 262

En primer lugar podemos percatarnos que, a pesar de tratarse de una entrevista con un enfoque generalista sobre la labor del maestro Guerrero en el cine y teatro, la presencia de imágenes de la producción de animación mencionada es importante y parte de la entrevista se centra en dicha obra. Es evidente que, la elección del popular compositor lírico para componer la música del filme no fue casual. De hecho, el autor de El huésped del Sevillano realizó una labor muy aplaudida en la época y su nombre se utilizó claramente como reclamo. En estas páginas, sin ir más lejos, se anuncia en el titular dos conciertos, uno en Madrid y otro en Barcelona de la música de la película, y al final del mismo, a la pregunta de si ha quedado contento con la labor desempeñada, el maestro responde:

"Tanto, que me he permitido solicitar a los productores del film, Ballet y Blay, dar en Madrid y Barcelona, como medio de propaganda, dos conciertos exclusivamente de música de Garbancito de la Mancha ${ }^{169 " .}$

\footnotetext{
${ }^{168}$ Gómez Tello, J. L. «Garbancito de la Mancha»; en Primer Plano, año IV, número 133, 2 de mayo de 1943.
} 
El apoyo dado por publicaciones como Primer Plano a este filme queda patente en este otro artículo aparecido unos días antes del estreno del filme. Nada menos que la primera y segunda páginas de la revista están dedicadas por completo al mismo.
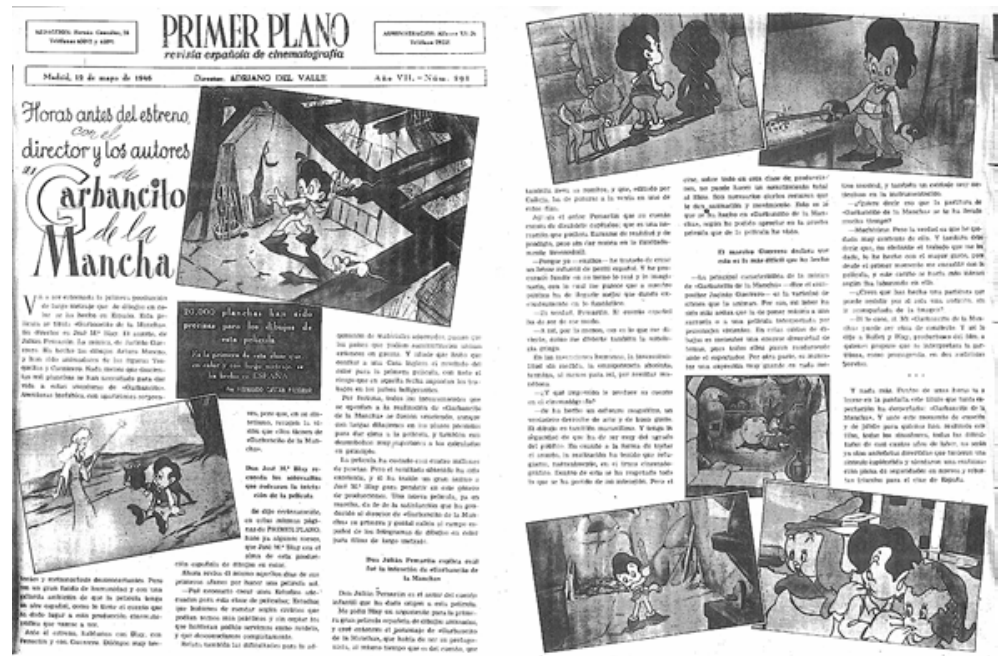

Imagen 23: «Horas antes del estreno con el director y los autores de "Garbancito de la Mancha"», en Primer Plano, año VII, número 291

En esta primera página nos encontramos con dos aspectos importantes. Por un lado, con una gran presencia gráfica que busca de forma rápida llegar al posible espectador mientras que, por otro lado, encontramos algunas declaraciones de interés que hacen alusión a la producción de animación.

De este modo, José María Blay, recuerda que:

“... fue necesario crear unos Estudios adecuados para esta clase de películas; Estudios que hubimos de montar según creíamos que podía sernos más prácticos y sin copiar los que hubieran podido servirnos como modelo, y que desconocíamos completamente. [...] también las dificultades para la adquisición de materiales adecuados, puesto que los países que podían suministrarlos ardían entonces en guerra. $Y$ añade que hubo que confiar a una casa inglesa el revelado en color para la primera película, con todo el riesgo que en aquella fecha suponían los trabajos en los países beligerantes. ${ }^{170 "}$

De este modo, a pesar de convertirse en toda una máquina publicitaria en sí, Garbancito de la Mancha fue el comienzo de una serie de largometrajes en color de

\footnotetext{
${ }^{169}$ LUJÁN, A. «La salvación del cine español está en la música española» en Primer Plano, año VI, número 262, 1 de octubre de 1945.

170 CAstán Palomar, F. «Horas antes del estreno, con el director y los autores de Garbancito de la Mancha» en Primer Plano, año VII, número 291, 12 de mayo de 1946.
} 
animación que fueron apareciendo en el firmamento cinematográfico nacional, con un intervalo de dos años entre ellas y consolidándose, por lo menos de puertas a fuera, los estudios catalanes de producción de animación, contribuyendo a potenciar un género atípico en nuestro país.

Para completar nuestra aproximación sobre los géneros en la producción española de los años cuarenta, es imprescindible mostrar las distintas fluctuaciones que se observan en cada género a lo largo de este periodo. Para ello hemos elaborado la siguiente gráfica a partir de los datos obtenidos en nuestra base de datos:

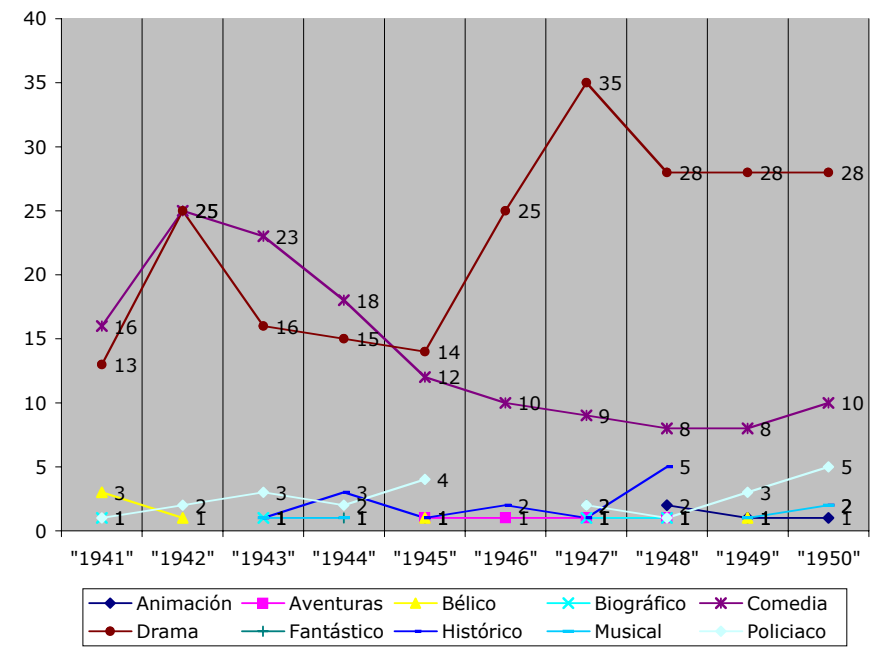

Gráfica 3: Producción cinematográfica por géneros

La producción cinematográfica varía a lo largo de los años cuarenta con altibajos que proceden, evidentemente, de múltiples factores que ya hemos comentado. Desde el término de la Guerra Civil, la producción de comedias y dramas comienzan un ascenso rápido y vertiginoso, con un notable predominio de la comedia frente al drama. Como podemos observar, en 1941 se realizan 16 comedias y 13 dramas. En 1942, año de mayor producción de la primera mitad de la década, nos encontramos con un empate técnico entre comedia y drama con 25 filmes cada uno. Al año siguiente, la producción comienza su caída pero sobre todo en el drama, con tan solo 16 películas frente a las 23 comedias. En 1944 se reduce la distancia entre ambas con tan solo 3 películas de diferencia, y en 1945 se produce un cambio muy significativo tanto a nivel de la producción en el número de películas realizadas, como de los géneros. En este año, el drama se coloca por delante de la comedia por primera vez desde el término de la guerra mientras que la comedia confirmará su tendencia hacia abajo, si bien, durante este año todavía no existe una diferencia grande entre ambos, algo que comenzará a observarse a partir de 1946 cuando se producen 25 dramas frente a tan solo 10 comedias, datos que se agudizarán al año siguiente con una diferencia mayor, de 26 películas. Tenemos que referirnos a 1946 para 
notar una ligera mejoría de la comedia pero el drama se mantiene de forma inequívoca como el género por excelencia de esta segunda mitad de la década.

El resto de géneros se mantienen en unos discretos niveles bajos y, además, su presencia en las pantallas españolas no es continua en ningún caso. Tal vez, el policiaco es el único que tiene una mayor presencia con la excepción hecha del año 1946 en la que no llegó a realizarse ningún título perteneciente a este género.

Para la creación de esta gráfica se han utilizado los datos obtenidos de la simplificación realizada y explicada anteriormente, por lo que consideramos importante, tanto en el drama como en la comedia ver como es la incidencia de los subgéneros que las conforman. De este modo obtenemos las siguientes gráficas:

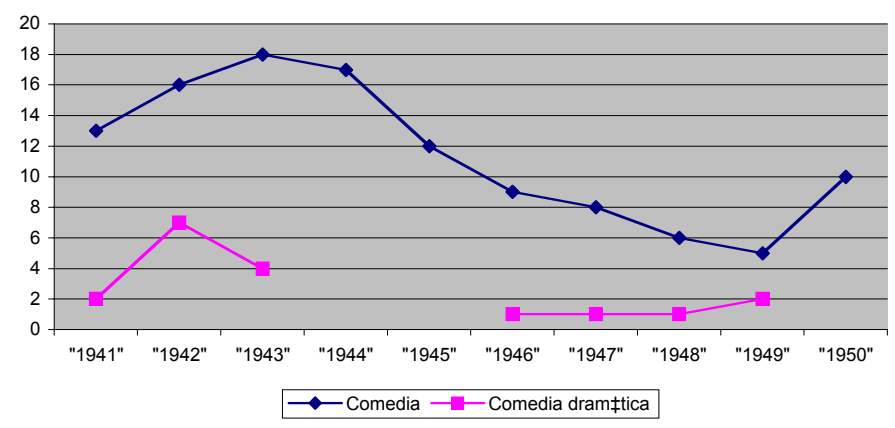

Gráfica 4: Producción cinematográfica: evolución de la comedia (1941 a 1950)

\begin{tabular}{|c|c|c|c|c|c|c|c|c|c|c|}
\hline & \multicolumn{10}{|c|}{ 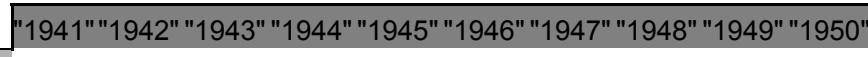 } \\
\hline Comedia & 13 & 16 & 18 & 17 & 12 & 9 & 8 & 6 & 5 & 10 \\
\hline Comedia dramática & & 7 & 4 & & & 1 & 1 & 1 & 2 & \\
\hline
\end{tabular}

Tabla 15: Datos de la evolución de la comedia (1941 a 1950)

Como se puede ver, la aportación de la comedia dramática es relativamente pequeña. Frente a los 18 títulos de comedia del año 1943 nos encontramos con 4 comedias dramáticas. En cambio, al año siguiente se puede observar como la realización de comedia dramática desaparece durante dos años para reaparecer de un modo tímido en 1946 con una única obra. El año en que se observa una distancia menor entre los dos subgéneros es 1949 donde tan solo hay una diferencia de 3 títulos entre uno y otro. Por norma general, la comedia dramática se nos presenta como algo anecdótico más bien. Sin una relevancia mayor. 


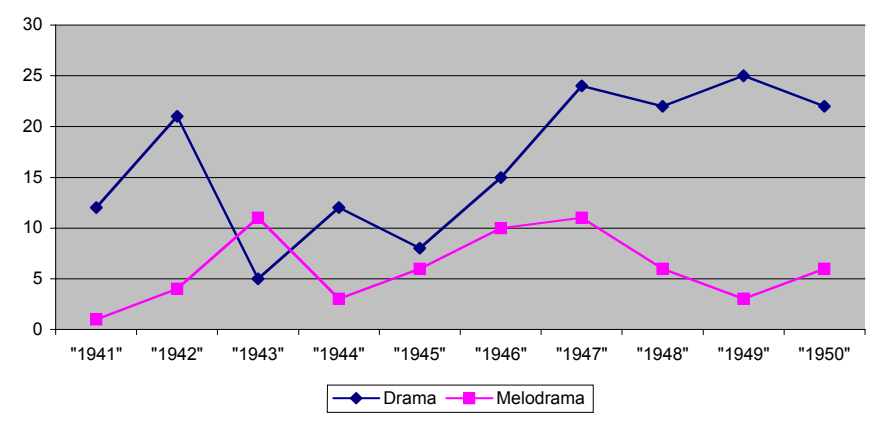

Gráfica 5: Producción cinematográfica: evolución del drama (1941 a 1950)

\begin{tabular}{|c|c|c|c|c|c|c|c|c|c|c|}
\hline & "1941" & "1942" & "1943" & "1944" & "1945" & "1946" & "1947" & "1948" & "1949" & "1950" \\
\hline Drama & 12 & 21 & 5 & 12 & 8 & 15 & 24 & 22 & 25 & 22 \\
\hline Melodrama & 1 & 4 & 11 & 3 & 6 & 10 & 11 & 6 & 3 & 6 \\
\hline
\end{tabular}

Tabla 16: datos de la evolución del drama de 1941 a 1950

La relación entre el drama y el melodrama es más cercana, como puede observarse en las gráficas anteriores, que entre la comedia y la comedia dramática. En primer lugar podemos ver cómo existe una extraña relación entre la evolución del melodrama y el drama al comportarse, casi durante todo el tiempo, de modo inverso. Es decir, que cuando se produce mayor número de dramas disminuye el número de melodramas y viceversa. Por ejemplo, en 1942 se terminan veintiuno títulos de dramas frente a cuatro melodramas, en cambio, al año siguiente del primero hay un total de cinco y del segundo once. Solo durante los años 1946 a 1947 esta dinámica se rompe y suben los dos géneros, para volver a comportarse de idéntico modo al ya comentado a partir de 1948 . Así, durante los años 1948, 1949 y 1950, se producen veintidós, veinticinco y veintidós filmes dramáticos respectivamente frente a los seis, tres y seis melodramas. Estos datos no hacen nada más que confirmar nuestras sospechas. Entre el drama y el melodrama no existen diferencias siendo en realidad la misma cosa, puesto que al subir la otra baja. En el caso del periodo comprendido entre 1946 a 1948, coincide con el auge del drama, con lo que es normal que los dos tuviesen un mayor crecimiento.

Después de observar pormenorizadamente estos datos ¿qué conclusiones podemos llegar a alcanzar de los mismos? Sin duda, el desarrollo de la II Guerra Mundial en Europa afectó de forma directa el desarrollo y recuperación de la actividad empresarial, industrial y económica de nuestro país que acababa de salir de una Guerra Civil, de modo que la situación era especialmente precaria. A pesar de ello, durante los primeros años de la contienda europea, en España se nota una ligera recuperación, como se puede observar en la producción cinematográfica. Esta recuperación coincide con el predominio del Eje en el conflicto armado, alcanzando su punto más alto en 1942, año en que comienza a girar la balanza a favor de los Aliados. Recordemos que en diciembre de 1941 y a raíz del ataque a Pearl Harbor, Estados Unidos entra a formar parte del conflicto y un año más tarde 
Alemania sufre dos fuertes reveses, uno en Stalingrado y otro en Egipto por no entrar en valoraciones a cerca del desgaste del ejército nazi y sus activos aéreos desde la Batalla de Inglaterra.

Como es de suponer, estos hechos repercuten directamente en nuestro país que mantenía fuertes vínculos económicos en el Eje, y algunos de ellos los seguirá teniendo después de la guerra, razón que influye directamente en la importación de material sensible entre otros. Esto provocará la tendencia bajista de los siguientes años hasta 1945, en que se alcanza un tope mínimo que coincide con el fin del conflicto en agosto tras la aceptación de la Declaración de Postdam por Japón y su firma el 2 de septiembre del mismo año.

\section{La incidencia de las clasificaciones en los géneros}

El nuevo régimen franquista se preocupa en cuanto se asienta en el poder por la industria cinematográfica y no sólo por lo que a contenidos se refiere. La creación de riqueza que supone la industria es uno de los principales alicientes. No es hasta noviembre de $1941^{171}$ cuando se promulgan las primeras leyes proteccionistas que permiten al Sindicato Nacional del Espectáculo poner en marcha el crédito cinematográfico que estaba exento del pago de intereses y llegaba a cubrir el $40 \%$ del total de la producción. Asimismo se establecían anualmente premios a películas y guiones por un montante nada desdeñable de 1.900 .000 a 2.800 .000 pesetas. Ambas acciones se acompañan con un plan de creación de becas para la formación de técnicos dentro de la industria cinematográfica.

Es precisamente durante este periodo inicial de Establecimiento de la Industria cuando tiene mayor auge la comedia. Por un lado, nada más terminar la Guerra Civil, la comedia es un tónico refrescante para una población que desea olvidar la tragedia vivida. Surge de este modo, un tipo de comedia muy característica de la época, en nuestra opinión de gran calidad y que gozaba de mucha popularidad. Como comenta Aurea Ortiz no se trataba de:

“...comedias folklóricas o «españoladas» sino de alta comedia, comedia sentimental, de enredo, de humor absurdo, comedias a lo Frank Capra y a lo Howard Hawks, intentos de screwball y comedias musicales. ${ }^{172,}$

¿Por qué entonces estas deliciosas comedias como Ella, él y sus millones, Tuvo la culpa Adán, Deliciosamente tontos o El hombre que se quiso matar, dejaron de realizarse masivamente para tender a una producción intensiva de dramas a partir de 1944? Para buscar la respuesta a esta pregunta volveremos a fijar nuestra mirada en el aparato legislativo puesto en marcha por el gobierno franquista.

\footnotetext{
${ }^{171}$ ESPAÑA, Normas protectoras para la cinematografía, 11 de noviembre de 1941, Ministerio de Industria y Comercio, Boletín Oficial del Estado, 17 de noviembre de 1941, núm. 321

172 ORTIZ, A. (2001) «La comedia española de los años cuarenta: Una producción diferenciada», en FERNÁNDEZ Colorado, L.; Couto CAntero, P. (coord..) La herida de las sombras. El cine español de los años 40, Madrid, Academia de las Artes y las Ciencias Cinematográficas en España / AEHC. pp.115.
} 
Junto a la orden ministerial del 11 de noviembre de 1941, a lo largo de ese mismo año y de 1942 irán surgiendo distintas leyes a favor de la industria que favorecerán el crecimiento y aumento de la producción. Pero coincidiendo con el cambio en el rumbo de la Guerra, el Ministerio de Industria (la Subsecretaría de Comercio) publica una nueva orden el 18 de mayo de 1943 por la cual se regula la importación de películas, de un modo más estricto.

En esta orden aparece por primera vez una clasificación de la producción nacional, que dará como consecuencia un giro a la misma. Se establece que solo podrán importar películas extranjeras aquellas empresas que desarrollen una labor de producción, es decir, aquellas productoras que se dediquen a realizar películas serán las únicas que podrán importar películas extranjeras, que era el mejor medio para obtener buenos beneficios económicos.

Pero el aspecto que realmente desempeñó una influencia crucial en el crecimiento del drama en perjuicio de la comedia está a nuestro entender en dos puntos clave. La clasificación en función de su "calidad" y, en función de ésta, los permisos de importación con los que eran obsequiadas las producciones nacionales. A continuación, debido a la importancia que creemos desempeñó dicha ley, reproducimos los dos puntos referidos a dicha clasificación y permisos.

En el punto cuarto de dicha ley, podemos leer:

“ a) Las películas de producción nacional serán clasificadas dentro de las siguientes tres categorías:

$1^{a}$ Aquellas películas que supongan un avance considerable en cualquier aspecto de la producción, sin que otro cualquiera de ellos haga perder la condición de muy buenas y merecedoras por tanto del mayor apoyo económico y protección.

$2^{a}$ Aquellas películas que sin suponer un avance considerable en nuestra producción sean en su conjunto de una calidad suficientemente buena para poder con decoro traspasar nuestras fronteras, y que merezcan por tanto la protección del Estado.

$3^{a}$ En esta categoría serían consideradas aquellas producciones que por su calidad artística o técnica supongan un descrédito de nuestra industria, no siendo merecedoras de apoyo alguno."

$Y$ en el apartado $6^{\circ}$, se especifica lo siguiente:

"A la vista de la clasificación y coste de producción acordado por la Comisión Clasificadora, la Subsecretaría de Comercio, previo informe de su organismo competente, la Subcomisión Reguladora de la Cinematografía otorgará los permisos de importación correspondiente, teniendo en cuenta: la solicitud de los interesados y la operación que propongan, el precio, la calidad y la procedencia de las películas que se desea importar, los cupos existentes de diferentes países y la disponibilidad de divisas. 
Como norma general, sujeta a las circunstancias que concurran, los beneficios de importación que este Ministerio concede son los siguientes ajustados a la categoría de la producción y a su valoración a estos efectos:

Por cada millón de pesetas de valor aprobado:

Primera categoría, de tres a cinco películas, según su valor de explotación.

Segunda categoría, de dos a cuatro películas, según su valor de explotación.

Tercera categoría, ningún derecho.

A valores de producción superiores o inferiores al millón de pesetas corresponderá la parte proporcional de importaciones.

En casos especiales, y si los contingentes de importación lo permiten, se podrá conceder algún aumento en el número de permisos, así como autorizarse la compensación directa con otra película de países de producción reducida, con quienes interese establecer relaciones cinematográficas y sea éste el único medio posible. ${ }^{173 "}$

En junio del año siguiente, se establece otra categoría, la denominada como de Interés Nacional. Esta categoría otorgaba privilegios que afectaban tanto a la concesión de licencias de importación como a la exhibición, siempre que se obtuviera la máxima clasificación en la primera categoría, tal y como se pude apreciar en este extracto de dicha orden:

"Artículo $1^{\circ}$. Las películas nacionales que reciben de la Delegación Nacional de Propaganda el artículo de películas de interés nacional serán diferentes a todos los fines de contratación en las salas de proyección cinematográfica enclavadas en territorio nacional.

Art. $2^{\circ}$. La preferencia establecida en el artículo anterior se referirá en todo caso a los siguientes extremos:

Estreno en la época más conveniente de la temporada cinematográfica.

Condiciones mínimas iguales a las que se hallen establecidas normalmente en el mercado cinematográfico.

Prioridad en los reestrenos, con las condiciones establecidas en el inciso anterior.

Obligatoriedad de proyección mientras la película alcance el mínimo del cincuenta por ciento del aforo total del cine; se considerará no alcanzado este aforo si al realizar el cómputo de una semana los ingresos diarios no llegan a dicho porcentaje. ${ }^{174,}$

\footnotetext{
${ }^{173}$ VV.AA. (1951) Anuario Cinematográfico Hispanoamericano 1950, Madrid, Sindicato Nacional del Espectáculo. pp. 708.

${ }^{174}$ EsPaña, Estableciendo el titulo de "películas de Interés Nacional», 15 de junio de 1944, Vicesecretaría de Educación Popular, Boletín Oficial del Estado, 23 de junio de 1944, núm. de B.O.E. 175
} 
Estas disposiciones que a simple vista parecen inocuas tuvieron una importancia crucial para los géneros. Como se puede apreciar en la siguiente tabla:

\begin{tabular}{|lllll|}
\hline Géneros & $1^{\mathrm{a}}$ & $2^{\mathrm{a}}$ & $3^{\mathrm{a}}$ & Interés Nacional \\
\hline Animación & 2 & & 1 & 2 \\
Aventuras & 1 & 1 & 3 & \\
Bélico & 2 & & & 2 \\
Biográfico & 2 & 1 & & 1 \\
Comedia & 16 & 54 & 18 & 3 \\
Drama & 67 & 61 & 27 & 23 \\
Fantástico & & 2 & 1 & \\
Histórico & 12 & & & 6 \\
Musical & 2 & 2 & & \\
Policiaco & 10 & 7 & 2 & 1 \\
\hline
\end{tabular}

Tabla 17: Asignación de calificaciones en función del género ${ }^{175}$

A las comedias solamente se le concedió la calificación de Interés Nacional en tres ocasiones lo que significa un $3 \%$ de la producción total de comedias, frente a los 23 dramas premiados con dicha calificación que suponía un $14 \%$ del total de ellas. Por otro lado, de primera categoría tan solo el $18 \%$ de las comedias la obtuvieron frente al $43 \%$ obtenido por el drama. Del resto de géneros cabe destacar los resultados obtenidos por los filmes bélicos e históricos, que consiguieron el $100 \%$ la calificación de primera.

Estos datos nos permiten afirmar que el reconocimiento de calificación de Interés Nacional para las comedias es muy reducido. De modo que, tras el primer año de aplicarse la orden de importación de películas, las productoras comenzaran a interesarse más por los dramas de cara a una mayor rentabilidad económica, ya que era más sencillo obtener la calificación y por lo tanto conseguir licencias para la importación de películas.

Así pues, la industria cinematográfica nacional comienza a interesarse en producir únicamente para obtener a posteriori los permisos de importación, doblaje y los créditos de ayuda, puesto que los beneficios generados por las películas en sí no eran muy elevados. La rentabilidad económica provenía fundamentalmente de la explotación de películas extranjeras, especialmente las norteamericanas que gozaban del favor del público.

Respecto a la no proliferación masiva de películas de corte histórico o belicista está relacionado con los altos costes de producción de estos géneros que exigían metrajes superiores, un mayor cuidado en la construcción de decorados y vestuarios, etcétera. De modo que los gastos eran muy superiores a los necesarios para producir un drama.

\footnotetext{
${ }^{175}$ Esta tabla ha sido confeccionada con los datos introducidos en la base de datos realizada en la presente tesis y cotejada con los aportados en VV.AA. (1951) Anuario Cinematográfico Hispanoamericano 1950, Madrid, Sindicato Nacional del Espectáculo, pp.674
} 
Por otra parte, las mayores productoras eran también distribuidoras y, por lo tanto, importadoras de películas. Los mayores beneficios, como hemos dicho anteriormente, procedían de las importaciones ${ }^{176}$ es de suponer entonces que la producción nacional se centrará en aquellos géneros que mejor aceptación tenían a la hora de recibir la calificación y por extensión los permisos de importación.

Desde otro punto de vista, encontramos unas declaraciones de José Luis Sáenz de Heredia en las que afirmaba, haciendo referencia a El escándalo y El destino se disculpa, que:

“... así como el drama está generalizado para todo el mundo, a todo el mundo se le muere la madre y a todo el mundo se le acerca la lágrima, ante una cosa graciosa, en cambio, no todo el mundo reacciona de la misma manera. El humor tiene menos clientela, por decirlo así, menos adictos, menos «tifosi» que el drama ${ }^{177 "}$.

Otro punto a observar en la gráfica es el resurgimiento de la producción a partir de 1945, lógica, por otra parte, si tenemos en cuenta que el final de la guerra en Europa supuso para España, en cierto modo, un respiro frente a las necesidades económicas. Durante los años posteriores a éste, se van a producir muchos cambios, tanto en la esfera política como social. La incorporación en los órganos de poder del estado, de las facciones católicas y la paulatina eliminación de los fascistas también puede verse como una más de las razones que motivaron la desaparición casi total de la comedia "sofisticada" de la primera mitad, al atentar la misma contra los valores como el matrimonio, el honor, etc.. y se potenciaran los dramas, especialmente de tinte literario, antes de que la censura comenzase a controlar con mano de hierro, como ocurriría en la década de los cincuenta y sesenta.

En el exterior, a pesar de las sanciones diplomática tomadas por las Naciones Unidas contra el Régimen franquista en 1946, y nuestra exclusión un año más tarde del Plan Marshall, muestra indicios de recuperación, especialmente gracias a la celebración de los Certámenes de Cinematografía Hispanoamericanas que tienen lugar en nuestro país. Estas convenciones dan como resultado el aumento de nuestras exportaciones a Cuba, Méjico y República Argentina. También, finalizada la guerra, comienzan a llegar hasta nosotros películas de la península Escandinava y hay un notable aumento de la presencia del cine norteamericano en nuestras pantallas como se puede observar más adelante.

Otro aspecto a tener en cuenta, es el gran número de adaptaciones literarias que se dan, especialmente dentro del drama, como es lógico, teniendo en cuenta su predominio, donde se aboga por un drama sobrio que rayaba en más de una ocasión en la inmoralidad pura y dura que, para sorpresa de todos, la primera censura de la época dejó pasar. José Luis Borau hace una lógica reflexión cuando comenta que:

“...durante la década de los cuarenta, los que hacian las películas eran los franquistas por lo que no había que temer nada y, por otro lado, el público,

\footnotetext{
${ }^{176}$ Esto es bien explicado en FANÉs, F. (1981) Cifesa, la antorcha de los éxitos, Valencia, Instituto Alfonso el Magnánimo.

177 Julio de Abajo de Pablos, J. E. (1996) Mis conversaciones con José Luis Sáenz de Heredia, Valladolid, Quiron Ediciones. pp. 42.
} 
socialmente hablando, eran los que habian ganado la guerra. Si había algún director que no lo era, se callaba y hacía otra cosa. lquino, por ejemplo, llegó hacer hasta alguna película patriótica aunque se centró en comedias... La Censura trabajó poco con ellos a no se que se atrevieran con temas espinosos como la Falange o cosas así, pero a Sáenz de Heredia, por poner un ejemplo, no se le ocurría hacer nada de eso. ${ }^{178 "}$

Esto desembocó a su vez, en que películas como El clavo o El escándalo disfrutaran de una gran aceptación entre el público que acudió a las salas cinematográficas, entre otras razones, por el puro morbo.

Así, la versión cinematográfica de El clavo (1944), resulta mucho más morbosa e inmoral que el relato originario de Pedro Antonio de Alarcón. En el filme, Blanca salva la vida, aunque tendrá que pagar por sus "pecados" mientras que en el relato, muere fulminada por la providencia, puesto que su delito debe ser castigado. Otros aspectos interesantes se refieren a la relación amorosa. Mientras que en el libro esta parte queda relegada a algo meramente anecdótico, en la película se convierte casi en el hilo conductor y principal motor de la acción, mostrando sin ningún tipo de recato una relación inicialmente impulsiva y pasional plenamente ilícita y sexual.

\section{Producir para importar}

Entre las causas que favorecieron el crecimiento de la producción cinematográfica hay que considerar, la intensa acción legislativa promovida por el recién instaurado gobierno franquista. La creación de una legislación proteccionista y de potenciación de la producción, fueron, sin duda, factores determinantes. Podría pensarse, en una primera instancia que este hecho constituyó el motor de una notable recuperación industrial del sector, cuando en realidad, la inflación en la producción cinematográfica que se manifiesta en la década, como afirma José Luis Borau, esconde el claro objetivo de obtener permisos de importación para comerciar con ellos:

“... se producía para luego comerciar con los permisos de importación, y el resultado en taquilla de la película ni se miraba, porque el productor ya había ganado mucho dinero con los permisos. ${ }^{179,}$

Las medidas legislativas tomadas inicialmente, con la vana finalidad de propiciar un aumento de la producción, se convirtieron rápidamente en un medio para obtener beneficios y no un fin en sí mismo. En palabras de Borau:

"El cine era la moneda de cambio para obtener unos permisos con los que luego se negociaba con las distribuidoras nacionales $y$, sobre todo, con las americanas. Estos permisos se vendian, y por cada uno te daban lo que

\footnotetext{
${ }^{178}$ Entrevista a José Luis Borau, Madrid, 25 de julio de 2003.

${ }^{179}$ Ibídem
} 
querías. Normalmente se comerciaba con distribuidoras americanas que pagaban verdaderas animaladas por estos permisos. ${ }^{180 "}$

Borau describe, en nuestra opinión, muy adecuadamente la situación, ayudándonos a entender la existencia de distribuidoras norteamericanas afiliadas a los grandes estudios norteamericanos, como la Columbia, la Fox o la RKO, que sin producir, pudieron seguir distribuyendo sus películas aferrándose a los resquicios legales que permitían el comercio de los permisos de importación y, posteriormente de los permisos de doblaje.

En efecto, la corrupción política así como la del propio funcionariado, permitieron un tráfico de influencias, de proporciones gigantescas, que favoreció el fracaso de unas leyes, que en esencia, podían haber resultado muy beneficiosas para el asentamiento de la industria cinematográfica en nuestro país. El fracaso del que hacemos mención viene avalado por las cifras y relaciones entre la producción nacional y la importada. Nos encontramos con años donde la relación de películas importadas y películas realizadas, en nuestro país, es desproporcionada y denota una falta total de control por parte de las autoridades, por lo que se refiere a la entrega de los permisos de importación, así como el buen uso de los mismos por parte de las productoras-distribuidoras. Los testimonios de Borau y Mariné nos ayudarán a clarificar la situación.

Juan Mariné, nos contó en la entrevista que tuvimos ocasión de mantener con él, que:

“... en España, la legislación que hubo durante muchos años consistía en que si la película era de tercera categoría no percibía ningún permiso; si la película era de segunda categoría se le daba un permiso de importación; y si la película era de primera categoría se le daban dos permisos, y con esto uno podía ir sorteando la situación. ${ }^{181 ”}$

Según Borau:

"...hubo un momento en que Levante Films, CIFESA, y unas cuantas productoras valencianas, se desplazaban a Barcelona a producir, porque en la ciudad condal habian estudios, laboratorios, puerto de mar, se encontraban materiales a mejores precios, etc., y en general, Barcelona proporcionaba una serie de ventajas que incitaban a producir allí. En cambio en Madrid, a parte de los estudios CEA, que no reunian condiciones adecuadas, los estudios estaban en Aranjuez, y esta ciudad estaba lejos y mal comunicada, resultando muy caro producir en ellos. Entonces hubo una serie de gobernantes que fueron a CIFESA y le dijeron que si trasladaba la producción a Madrid, ellos le darian hasta seis permisos de importación por película. Ellos iban a construir unos estudios que iban a ser los mejores y que se llamarían Sevilla Films. Esta gente estaba muy metida en el Régimen y estaban interesados en potenciar la producción en Madrid. El estudio de Barcelona le costaba a CIFESA 1200pts al día y el estudio de Sevilla Films, en aquel entonces, valía

\footnotetext{
180 Ibídem.

181 Ibídem.
} 
ya 7000pts diarias. CIFESA hizo sus número y se vino a Madrid, y la primera película que hicimos aquí fue Eloísa está debajo de un almendro. ${ }^{182 "}$

Las palabras de José Luis Borau están relacionadas con la censura de la película La Fe. Su testimonio nos dice:

"Una vez terminado este filme, la comisión episcopal, o quien fuese de la Iglesia, vio la película y se escandalizó y se hizo todo lo que estuvo en su mano para prohibir la misma. Cesáreo González aprovechó la situación de que la película contaba con todos los sacramentos legales para que no se prohibiese e hizo valer sus derechos y amistades ante el gobierno para que le resarciesen de algún modo. Entonces le dieron una barbaridad de permisos de importación, como 8 u 11, no lo sé..., desde luego muchos más de los que hubiese obtenido si la hubiesen calificado como de primera $A$. Le dieron todos aquellos permisos de importación para compensarle por las pérdidas de una película que, por aquellos días, costó nada menos que un millón y pico o dos. $^{183,}$

Esta política de premiar la producción, con permisos de importación, en función de la calidad del filme, tuvo sus consecuencias también en la tipología de cine realizado. Como veremos más adelante, la aparición de las clasificaciones hizo reducir drásticamente la producción de comedias y aumentar, significativamente, la de dramas. Como ya hemos apuntado, el sistema de clasificaciones premiaba con más facilidad un drama que una comedia y como el negocio estaba, claramente, en los permisos y no en los beneficios aportados por la película producida, es razonable que se produjese un éxodo considerable hacia un género más rentable económicamente que la comedia, es decir, el drama.

De todos modos, este aspecto también debe ser completado con un hecho que consideramos de primer orden. Desde el punto de vista de la taquilla, las comedias nacionales no podían competir con las magníficas comedias llegadas de Hollywood, como nos comentó José Luis Borau en nuestra entrevista:

"Pero debes de pensar en la gente de entonces. En aquellos días se estrenaban aquellas comedias americanas tan maravillosas como La fiera de mi niña. Además, los actores que aparecían en aquellas comedias eran tremendos. Además la gente decía que los actores españoles no sabian llevar un esmoking..., que si salían de históricos todavía pero con traje..., no. Y, además, en el cine de al lado, o a la semana siguiente, veían a Charles Boyer y no había comparación. ${ }^{184 "}$

Por otra parte, de los productores pocas pretensiones artísticas se podían esperar, aunque sorprende la gran cantidad de productoras que surgen en la década. En efecto, la multiplicidad de productoras existentes en este periodo llega a convertirse en un serio problema que impide identificar con claridad la importancia y evolución de cada una de ellas.

\footnotetext{
${ }^{182}$ Entrevista a Juan Mariné, Madrid, 24 de julio de 2003.

${ }^{183}$ Entrevista a José Luis Borau, Madrid, 25 de julio de 2003.

${ }^{184}$ Ibídem.
} 
A continuación presentamos una tabla con el listado completo de productoras y el número total de películas realizadas por cada una de ellas.

\begin{tabular}{|c|c|c|c|}
\hline Productora & Total & Productora & Total \\
\hline Agrupacine, Filmófono S.A. & 1 & Cinematográfica Madrileña S.A.,S.Huguet S.A. & 1 \\
\hline Alabama Films S.A. & 2 & Cinematográfica Vulcano S.A. & 1 \\
\hline Aladino Films & 1 & Cinemediterráneo S.A. & 1 \\
\hline Alhambra Films & 1 & Cinemediterráneo S.A., Cinéma de France & 1 \\
\hline Ángel Gamón & 1 & Colonial AJE & 3 \\
\hline Antonio de Obregón & 2 & C.O.P.C.E., Edgard Neville & 1 \\
\hline Antonio de Obregón y España Actualidades & 1 & Compañía Internacional Cinematográfica & 1 \\
\hline Ares Films & 1 & Concordia Films S.A. & 1 \\
\hline Arévalo para CIFESA & 1 & Consorcio Cinematográfico S.A. & 2 \\
\hline Ariadna Films, José Burriel & 1 & Constelación Films & 1 \\
\hline Arte Films S.A. & 1 & Cooperativa del Cinema & 1 \\
\hline Artes Films & 1 & Cumbre S.A. & 1 \\
\hline Aspa Films & 1 & CYE Films & 1 \\
\hline Aspa Films, CIFESA & 1 & Dayna Films & 1 \\
\hline Augusta Films para Helios Films S.A. & 1 & Diana Films & 1 \\
\hline Augustus Films & 1 & Distribuidores Asociados S.A. (D.A.S.A.) & 1 \\
\hline A. Campa y Com. Internacional Cinematográfica & 1 & Distribuidores Asociados S.A., Sevilla Films & 1 \\
\hline Aureliano Campa, para CIFESA & 1 & Duro Films, Stella Films & 1 \\
\hline Balet y Blay S.L. & 3 & E.C. IBERIA & 1 \\
\hline Ballesteros S.A. & 7 & E.C.E.S.A. & 1 \\
\hline Bascón Films & 1 & E.D.I.C.I. & 1 \\
\hline Benito López Ruano & 1 & Ebro Films & 1 \\
\hline Boga Films & 1 & Edgar Neville & 1 \\
\hline Boga S.A. & 2 & Edgar Neville para CIFESA & 1 \\
\hline C.E.A. & 1 & Edgar Neville para Salete-Jimeno & 1 \\
\hline C.E.A. Maroto & 1 & Ediciones Cinematográficas Cumbre & 2 \\
\hline C.E.A., CCFC. & 1 & Ediciones Cinematográficas Iberia & 1 \\
\hline C.E.A.-Alhambra Films & 1 & Ediciones Cinematográficas Kinefón & 4 \\
\hline C.E.A.-Alhambra Films S.L. & 1 & Ediciones Puigvert & 1 \\
\hline C.E.C & 1 & EDIMAN (EDICI, MANZANO) & 1 \\
\hline C.E.U. (Cinematografistas Españoles Unidos) & 1 & Elemsse Overseas Production, Chamartin & 1 \\
\hline C.E.U.S.A. & 1 & Emisora Films & 4 \\
\hline Campa para Balart & 1 & Emisora Films S.A & 1 \\
\hline Campa para CIFESA & 6 & Emisora Films S.A. & 21 \\
\hline Campa para CIFESA, UPCE & 1 & Emisora-Procisa & 1 \\
\hline Campa para Juca Films S.A. & 1 & Ernesto González & 1 \\
\hline Campa para Suevia Films & 1 & España Actualidades Asociadas & 1 \\
\hline Campa UPCE para CIFESA & 1 & España Films & 2 \\
\hline Campa-Olimpia Films & 1 & España Films para Filmófono S.A. & 1 \\
\hline Cancillería del Consejo de la Hispanidad & 1 & Estela Films S.A. & 1 \\
\hline Carmona para la Com. Inter.. Cinamatográfica & 1 & Estrella Azul, I.C.I. & 1 \\
\hline Casilla Films & 1 & Exclusivas Arajol & 1 \\
\hline Castilla Films & 1 & Exclusivas Diana & 4 \\
\hline Castilla Films S.L. & 1 & Exclusivas Floralva & 2 \\
\hline CEPICSA & 4 & Exclusivas Manzano & 1 \\
\hline César Cobián Producciones Cinematográficas & 1 & Exclusivas Muñoz-Amor & 1 \\
\hline C. Cobián-Prod. Aso. S.A. J. Lopes de Vilhena & 1 & Falcó Films & 1 \\
\hline Cétiga Films & 2 & Faro Films S.A. & 5 \\
\hline Cetro Films & 1 & Faro Films S.A., Filmes Lumiar & 2 \\
\hline Chamartín S.A. & 2 & Faro-Roptence & 1 \\
\hline Chapalo Films & 3 & Fernán Lara & 1 \\
\hline CIFESA & 33 & Fernando Mangrané & 1 \\
\hline
\end{tabular}

Tabla 18: Listado de productoras con número de películas realizadas entre 1939-1950. [PARTE I] 


\begin{tabular}{|c|c|c|c|}
\hline Productoras & Total & Productoras & Total \\
\hline CIFESA Producción & 1 & Filalico Flaquer para Nueva Films S.A. & 1 \\
\hline CIFESA, Campa & 1 & Film Océano & 1 \\
\hline CIFESA, / Hispania Artis Films S.A. & 1 & Filmófono S.A. & 2 \\
\hline CIFESA, Sovrania & 1 & Films Bassoli & 1 \\
\hline CIFESA, Sovrania, ICAR & 2 & Focofón, S.A. & 1 \\
\hline CIFESA, UPCE & 6 & Fono Roma & 1 \\
\hline CIFESA, UPCE / Hispania Artis Films S.A. & 1 & Galatea Films & 2 \\
\hline CIMA & 1 & Giralda Films & 1 \\
\hline CINECA & 1 & Goya Producciones Cinematográficas S.A. & 2 \\
\hline CINEDIA & 2 & Grupo de Producción & 4 \\
\hline Cinematográfica Madrileña S.A. & $\frac{2}{1}$ & Helios Films S.A. & 4 \\
\hline Hércules Excelsa & 1 & Peninsular Films, Lisboa Films & 2 \\
\hline Hércules Films S.A. & 5 & Peninsular Films, U.N.I.N.T.I. (produc. asociado) & 1 \\
\hline Hermic Films & 1 & Peña Films & 2 \\
\hline Hidalguia Films & 2 & Perseo Fiims S.A. & 1 \\
\hline Hidalguía Films & 1 & Perseo Films S.A. & 2 \\
\hline Hispania Artis Films S.A. & 5 & PROCINES S.A. & 3 \\
\hline Hispania Capa Films, C.B. Films & 1 & Producciones Acor & 2 \\
\hline Hispano Film Berlín & 1 & Producciones Boga S.A. & 2 \\
\hline Hispano Films S.L. & 1 & Producciones Campa & 2 \\
\hline Hispano Fim Berlín & 1 & Producciones Campa para CIFESA & 1 \\
\hline Hispano Imperial Films & 1 & Producciones Carabelas & 1 \\
\hline Horizonte Films & 2 & Producciones Cinematográficas Aladino & 1 \\
\hline Iberia Films S.A. & 1 & Producciones Cinematógráficas Alcázar & 1 \\
\hline Iglesias Films & 1 & Producciones Cinematográficas Castilla & 1 \\
\hline Imperator Films.- Ulargui & 1 & Producciones Cinematográficas Cumbre & 2 \\
\hline Intercontinental Films S.L. & 2 & Producciones Cinematográficas Daniel Falcó & 1 \\
\hline J. Films- España Films & 1 & Producciones Cinematográficas Españolas S.A. & 2 \\
\hline Joé Martínez Penas & 1 & Producciones Cinematográficas Huemir & 1 \\
\hline José Balart & 1 & Producciones Cinematográficas Kinefón & 1 \\
\hline Juan Montesinos & 1 & Producciones Cinematográficas Ritmo & 2 \\
\hline Juca Films S.A. & 1 & Producciones Cinematográficas Rosa & 1 \\
\hline Julio Elías & 1 & Prod. Cinematográficas Teodoro Busquets & 1 \\
\hline Jungla Films, Alsa & 1 & Producciones de Climent & 1 \\
\hline Lais S.A. & 2 & Producciones Hispánicas, Stella Films & 1 \\
\hline Lais, S.A. & 1 & Producciones Iquino & 3 \\
\hline Las Heras & 1 & Producciones Juan Montesinos & 2 \\
\hline Levante Films S.A. & 2 & Producciones Neville & 1 \\
\hline Levante Films S.L. & 3 & Producciones Orduña Films para CIFESA & 1 \\
\hline Manuel de Castillo-C.E.A. & 1 & Producciones Rosa & 1 \\
\hline Manuel de Lara Padín & 1 & Producciones Rosal & 1 \\
\hline M.de Lara Prod. Cinematográficas RIOBAR & 1 & Producciones-Ballesteros & 1 \\
\hline Manuel del Castillo & 5 & Productores Asociados S.A. & 1 \\
\hline Manuel del Castillo para P.B. Films & 1 & Productores Asuciados Huemir & 1 \\
\hline Manuel del Castillo, CIFESA & 1 & Radio Films & 1 \\
\hline Marta Films & 4 & Rafa Films & 3 \\
\hline Mercurio Films S.A. & 3 & Rey Soria Films & 1 \\
\hline Miguel García Rico, para Hércules Films S.A. & 1 & R. Gutiérrez, M. Torres, Pedro Bayona García & 1 \\
\hline Navrra Films & 1 & Ricardo Soriano Films & 2 \\
\hline Norte Films & 1 & Roptence S.A. & 3 \\
\hline Nueva Castilla & 1 & Roptence S.A. para Faro S.A. Films, Doperfilme & 1 \\
\hline Nueva Films S.A. & 1 & S.A.F.E. & 2 \\
\hline Nuevas Castilla & 1 & S.A.F.E., Escalera Film & 1 \\
\hline Olimpia Films & 1 & S.A.F.E., Secolo XX & 1 \\
\hline Onuba S.L. & 1 & S.O.C.E.F.S.A. & 1 \\
\hline Orbis Films & 1 & Sagitario Films & 4 \\
\hline Orduña Films, Columbia Films & 1 & Sagitario Films Ecesa & 1 \\
\hline P.B. Films & 1 & Sagitario Films Ercesa & 1 \\
\hline P.O.F. & 1 & Sagitario Films, ERCE & 1 \\
\hline Producciones Orduña Films para CIFESA & 1 & Sagitario Films, ERCESA & 1 \\
\hline
\end{tabular}

Tabla 19: Listado de productoras con número de películas realizadas entre 1939-1950. [PARTE II] 


\begin{tabular}{|l|l|l|l|}
\hline Productoras & Total & Productoras & Total \\
\hline Paloma Films & 1 & Selecciones Capitolio S.A. & 1 \\
\hline Paloma-Ares Films & 1 & Selecciones Capitolio, F. Granada & 1 \\
\hline Panorama Films & 1 & Selecciones Capitolio, S. Huguet S.A. & 1 \\
\hline Paro Films, S.A. & 1 & Sevilla Films Producción S.A. & 1 \\
\hline Pecsa Films & 9 & Sirena Filmes & 1 \\
\hline Pegaso Films & 4 & S.P.M., Productions Corlignion-Molinier & 1 \\
\hline Peninsular Films & 6 & Suevia Films & 28 \\
\hline Sur Films S.A. & 1 & UFISA & 6 \\
\hline Talia Films & 1 & UFISA, Bassoli-Ápia & 1 \\
\hline Taurus Films & 2 & UFISA, Film Basoli & 1 \\
\hline Terramar Films & 1 & Ulargui films & 1 \\
\hline Titan Films & 1 & Ultra Films & 1 \\
\hline Titán Films & 2 & UNIBA & 1 \\
\hline Trevor Films S.A. & 1 & Universal Films Española & 1 \\
\hline Trévor Films S.A. & 2 & Valencia Films & 7 \\
\hline UCESA & 2 & Victoria Films, Peña Films & 1 \\
\hline UFESA & 1 & Zenit-Helios Films S.A. & 1 \\
\hline
\end{tabular}

Tabla 20: Listado de productoras con número de películas realizadas entre 1939-1950. [PARTE III]

Tras esta larga relación de nombres y cifras podemos ver en primer lugar, el alto número de empresas creadas cuya vida activa no iría más allá de alguna que otra película de baja calidad lo que nos lleva a suponer por los testimonios que hemos recabado que nacían del capricho de empresarios adinerados que se introducían en la industria del cine con el objetivo de conseguir permisos de importación.

Como nos comentó Juan Mariné, en aquellos tiempos:

“... pasaba lo mismo que ocurre hoy en día. Si miras la producción actual española te darás cuenta que cada productora nace con cada película y muere con la misma. La productora nace con un nombre determinado. Se alquilan unas oficinas y se ponen unos muebles. Al acabar la película, la productora vende aquello, cierra las oficinas y desaparece. Luego, cuando hacienda va detrás para darle en "galletazo" se da cuenta de que no hay nadie. Es la única solución de sobrevivir, porque si esa productora continúa ahí sin producir, con empleados y gastos diversos se encontraría con que hacienda le está sacando la sangre. Así que la gente huye. Las grandes como CIFESA, Suevia Films, Roctence, etc., esos producían habitualmente y consiguieron organizar el negocio para que diera dinero pero la mayoría era tirar la piedra y marcharse porque sino hacienda se les iban a comer. ${ }^{185 "}$

A esto hay que sumar, en primer lugar, la supremacía de unas pocas productoras (que podríamos denominar Majors nacionales) como CIFESA, Suevia Films o Emisora Films con más de 20 producciones cada una y, en el caso de las dos primeras, con una gran cantidad de coproducciones a sumar a las suyas propias.

En segundo lugar, el otro gran problema que se plantea es la variación y cambio de nombre por parte de una misma empresa, bien por errata de las fuentes consultadas,

${ }^{185}$ Entrevista a Juan Mariné, Madrid, 24 de julio de 2003. 
bien por el cambio de denominación de la empresa originaria en otra porque esto aumentaba las opciones a la hora de conseguir permisos de importación.

El tercero y más interesante obstáculo es el motivado por las coproducciones. CIFESA fue un claro exponente, junto con Aureliano Campa de este tipo de actividad. Esta unión aparece en la lista con varios nombres, apareciendo nominalmente como diferentes entidades cuando en el fondo son las mismas.

Hemos intentado sin éxito discernir los aspectos anteriormente mencionados y después de un arduo trabajo de identificación los datos obtenidos son los siguientes:

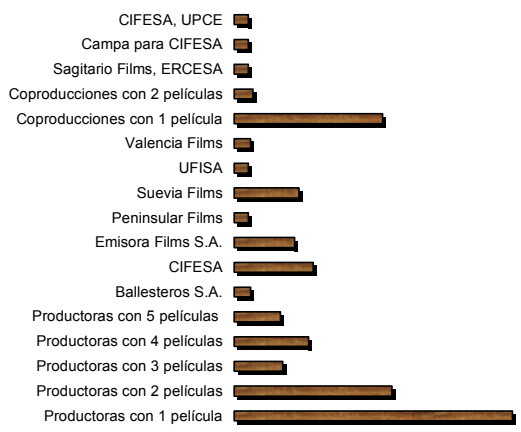

Gráfica 3: Productoras y coproducciones entre 1939 a 1950

\section{La importación de películas y su repercusión en la producción cinematográfica}

Como se ha ido reiterando a lo largo de las páginas anteriores, las primeras disposiciones promulgadas entre 1939 y 1941, dan un fuerte empuje a la producción con la creación de los créditos a la producción cinematográfica, y la imposición de fuertes aranceles para la importación de películas extranjeras, favoreciendo de este modo la industria autóctona, impulsando a ésta a producir un mayor número de películas para satisfacer la demanda interna del país. Estas películas, como podemos apreciar en la siguiente gráfica, se trata principalmente de comedias y dramas de rápida realización, siendo fácilmente amortizadas gracias a los créditos institucionales y la falta de competencia en las taquillas durante los primeros años de la postguerra. En la gráfica 3 que mostramos a continuación, podemos apreciar como era esta competencia: 


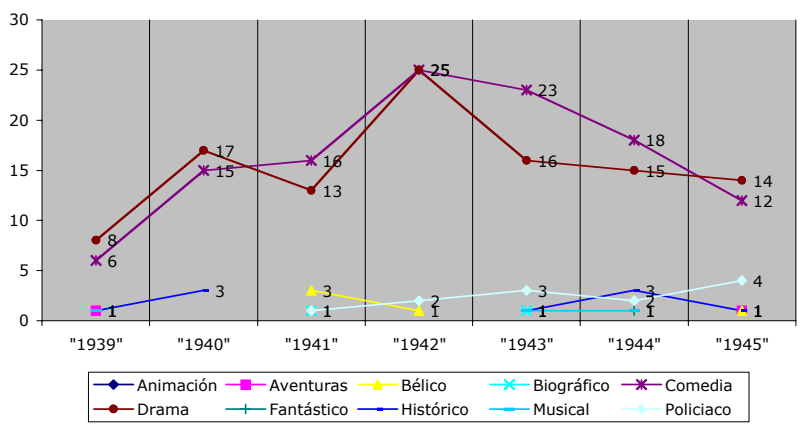

Gráfica 4: producción española por géneros (1939 a 1945)

Los parámetros abordados en la gráfica anterior están suficientemente comentados, pero debemos hacer hincapié, en el paralelismo existente entre la evolución del drama y la comedia durante estos años.

En la siguiente gráfica que mostramos a continuación podemos ver datos relativos a las películas estrenadas en Madrid, tanto importadas como nacionales.

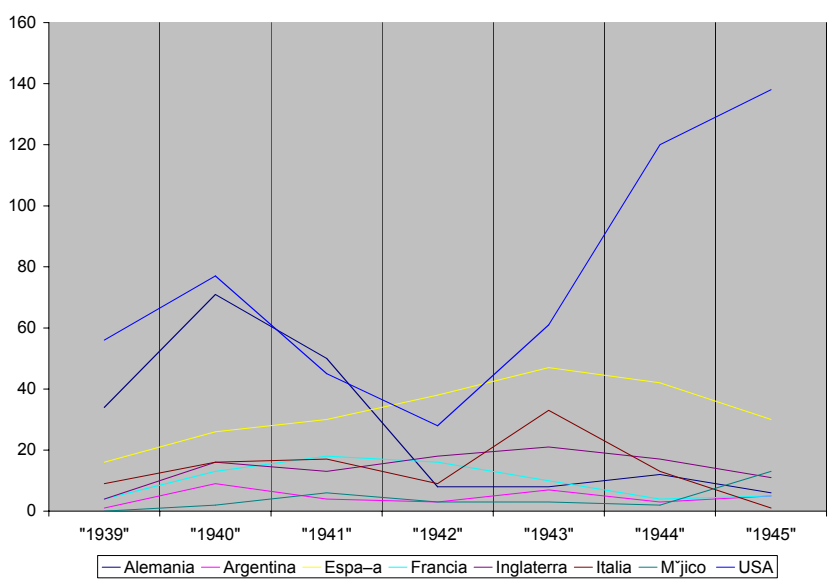

Gráfica 5: Películas estrenadas en Madrid por países de origen (1939 a 1945) 


\begin{tabular}{|llllllll|}
\hline PAIS & $" 1939 "$ & $" 1940 "$ & $" 1941 "$ & $" 1942 "$ & $" 1943 "$ & $" 1944 "$ & $" 1945 "$ \\
Alemania & 34 & 71 & 50 & 8 & 8 & 12 & 6 \\
\hline Argentina & 1 & 9 & 4 & 3 & 7 & 3 & 5 \\
\hline España $^{186}$ & 16 & 26 & 30 & 38 & 47 & 42 & 30 \\
\hline Francia & 4 & 13 & 18 & 16 & 10 & 4 & 5 \\
Inglaterra & 4 & 16 & 13 & 18 & 21 & 17 & 11 \\
Italia & 9 & 16 & 17 & 9 & 33 & 13 & 1 \\
Méjico & 0 & 2 & 6 & 3 & 3 & 2 & 13 \\
USA & 56 & 77 & 45 & 28 & 61 & 120 & 138 \\
\hline Totales & 125 & 230 & 183 & 123 & 191 & 213 & 210 \\
\hline
\end{tabular}

Tabla 21: Películas estrenadas en Madrid según su nacionalidad ${ }^{187}$.

Lo primero que queremos hacer notar es el bajo número de películas importadas durante estos años con relación al periodo republicano. Según los datos aportados por Vitoriano López:

“...en España se importaban, antes del 18 de julio de 1936, unos 550 títulos por año, existiendo una cierta producción propia, la cual se desenvolvía, como puede comprenderse, en desigual lucha con la extranjera, alcanzando, sin embargo, éxitos comerciales dignos de tenerse en cuenta. [...] Después de la guerra dicha importación se redujo considerablemente. ${ }^{188, "}$

La reducción de importaciones a la que hace referencia López García fue considerable como podemos apreciar en la tabla y gráfica anteriores, que corresponden al número de obras estrenadas en Madrid de procedencia extranjera.

Las razones que explican la disminución estarían vinculadas al problema que asolaba a la industria cinematográfica en aquellos momentos: la falta de divisas motivada por la falta de solvencia del emergente estado franquista. Evidentemente, el gobierno reducirá al máximo las importaciones y se decantará por incentivar el comercio económico con los países del Eje (Alemania e Italia) en los primeros años de la segunda guerra mundial, por razones indiscutibles de afinidad ideológica. Esta tendencia se ve truncada a partir del año 42, siendo las importaciones alemanas las más perjudicadas, reduciéndose en un $16 \%$. En cambio, las importaciones y el intercambio comercial con Italia seguirán, aunque tendrá subidas y bajadas espectaculares.

Otra razón para explicar la bajada de presencia de películas extranjeras en nuestra cartelera estaría en las medidas legislativas tomadas por los franquistas. Durante los

\footnotetext{
${ }^{186}$ Los datos de esta fila no coinciden exactamente con los de la producción propuesto por nosotros. Esto se debe esencialmente a que se trata de películas estrenadas, no producidas, parámetro con el que jugamos a lo largo de nuestro discurso.

${ }^{187}$ Datos obtenidos de: VV.AA. (1951) Anuario Cinematográfico Hispanoamericano 1950, Madrid, Sindicato Nacional del Espectáculo. pp. 345.

${ }^{188}$ LÓPEZ GARcía, V. (1945) La industria cinematográfica española, Madrid, Asociación Nacional de Ingenieros Industriales. pp. 15.
} 
primeros años, se lanza un paquete de medidas fiscalizando, mediante altos aranceles, las importaciones, obligando a más de un distribuidor a pensar más en el cine nacional que en el extranjero, a pesar de los altos beneficios que éste podía atraer, porque no debemos olvidar que si la presencia de películas de procedencia norteamericana, y de terceros países era elevada como afirma López García, los gustos del público español estarían fuertemente influenciados por la estética y modos de realización internacionales, con lo que la implantación de un cine netamente español, con características propias resultaba una empresa ardua y complicada.

Desde 1939 hasta 1942, la relación entre el estreno de películas alemanas y norteamericanas guardaba un delicado equilibrio con predominio germánico en más de una ocasión. Los resultados desfavorables para Alemania en varios frentes durante 1942 suponen el principio del fin para el III Reich y con ello la caída en picado de la producción nazi. Como consecuencia, la compra de películas alemanas bajó a mínimos históricos mientras que, a partir de ese mismo año, comienza a imponerse y ganar terreno en las salas de proyección los filmes procedentes de USA.

Junto a la bajada de las importaciones, hemos notado una subida de la fabricación de películas autóctonas debida esencialmente a las leyes proteccionistas promovidas por el gobierno, que imponían como requisito para poder importar un filme ser productor, tener en proyecto una película o haberla terminado, a la vez que se establecían los ya citados créditos a la producción cinematográfica. Estos créditos, a fondo perdido e interés cero supusieron una sangría para las arcas del Estado, al mismo tiempo que un aliciente para los empresarios. De este modo, sube como la pólvora el número de estrenos nacionales, pero como contrapartida, los títulos resultan ser producciones de bajo costo y resultados poco esperanzadores. Esta nueva coyuntura se convierte en un arma de doble filo. El aumento de la producción pone en marcha la maquinaria de una industria en ciernes, creando puestos de trabajo y películas realizadas de baja calidad que difícilmente eran exportables, lo que significaba que la recuperación de divisas se hacia difícil, por no decir imposible.

Con este panorama, la administración franquista pretende dar marcha atrás y frenar el proceso abierto con la ley de 1941. En el año 1945, Victoriano López García afirmaba que:

"Dicha disposición oficial trajo como consecuencia un aumento de la cantidad de las producciones españolas, las cuales servían como medio y no como fin, por lo que la mayor parte resultaron de baja calidad. ${ }^{189 "}$

Por ello, se establece la disposición del 18 de mayo de 1943. A partir de ese momento no se premiará solo la producción sino la calidad, tema este que supondrá un problema, pues los criterios a seguir por los diferentes organismos a la hora de establecer las clasificaciones de primera, segunda y tercera categoría fueron en más de una ocasión motivo de numerosos contenciosos administrativos por parte de los productores en busca de la mejor mención posible para obtener mayores beneficios de las licencias de importación. Esto acarreó, también, un cambio en la producción nacional como ya hemos

${ }^{189}$ Op. Cit. pp. 9. 
comentado cuando hemos hablado de los géneros. Ya que, la realización de comedias comienza un descenso brusco y continuo frente a la producción de películas dramáticas.

En la última gráfica también nos encontramos con otro resultado sobre el que debemos focalizar nuestra atención. Nos referimos a la bajada paulatina y conjunta de la producción de películas nacionales hasta 1945. Esta bajada creemos que está relacionada con la precaria situación que se vive en el país. El recrudecimiento del conflicto en Europa con la derrota del Eje no solo supone la pérdida de un suministrador de películas sino también de materias primas, energía, etcétera. Sin embargo, Victoriano López García nos dirá a propósito de este descenso que:

“... el número de realizaciones no se elevó, como a primera vista parece natural, a lo largo de los pasados años, a consecuencia de tender las casa productoras a realizar películas caras, las cuales precisan mayor número de días en su rodaje. Próximos anuncios de restricción en las importaciones, produjeron una baja general en los presupuestos de las películas y un menor número de las mismas, lo cual originó la crisis que actualmente atravesamos. 190 ”

La industria reacciona ante el "tirón de orejas" de la Administración con películas más caras como afirma López García, esto conlleva un mayor número de licencias de importación y por lo tanto se produce un aumento de la misma entre 1943 y 1945.

Félix Famés, por su parte, refiriéndose al caso CIFESA considera que ésta utilizaba como coartada las restricciones de energía eléctrica y la escasez de película virgen:

"Estas explicaciones de la empresa no parecen muy verosímiles. $Y$ esto por las razones siguientes: atribuir a las restricciones de 1944 y al efecto que estas tienes sobre las salas cinematográficas - reducción de los días de programación - una disminución de la demanda sería olvidar que este no fue el único año en que faltó la energía en España. Menos convincente resulta todavía la segunda explicación. Según las estadísticas oficiales, en el año 1944 fue el año, precisamente, durante el que más metros de cinta virgen se importaron desde 1939. ${ }^{191,}$

Más adelante, acaba concluyendo que las razones principales de la crisis estuvieron en la creación artificial de un mercado inexistente en nuestro país para conseguir una reactivación de la economía industrial en el sector. Este espejismo se vino y en 1943 llegó la crisis.

Para completar el análisis, vamos a centrarnos ahora en los presupuestos de las películas, que colegirán todos los anteriores:

\footnotetext{
190 Op. Cit. pp. 11.

${ }^{191}$ FANÉS, F. (1981) Cifesa, la antorcha de los éxitos, Valencia, Instituto Alfonso el Magnánimo. pp.128.
} 


\begin{tabular}{|l|l|l|l|l|l|l|}
\hline Años & 1939 & 1940 & 1941 & 1942 & 1943 & 1944 \\
\hline Pesetas & 620.000 & 800.000 & 900.000 & 1.250 .000 & 1.500 .000 & 1.900 .000 \\
\hline
\end{tabular}

Tabla 22: Presupuesto medio por película en pesetas

Como podemos apreciar en la tabla 8 el presupuesto medio para cada producción sufrió un aumento considerable, llegando a triplicarse en tan solo cinco años. En este periodo de tiempo, el capital no pudo crecer al mismo ritmo, entre otras cosas, porque el mercado español no supo, ni fue capaz, debido a las circunstancias coyunturales del momento, de crear un mercado fuera de sus fronteras para vender sus productos, algo que tampoco conseguirían, a pesar de las buenas intenciones, llevar a cabo productoras como CIFESA (antes de la guerra), Hispania Artis Films y Ballesteros (después de la misma) en Hispanoamérica.

Muchas causas explican la crisis en que se vio envuelta nuestra industria, pero lo bien cierto es que tras el término de la II Guerra Mundial, se abrió un nuevo periodo de cambios para nuestra cinematografía. La conclusión del conflicto trajo consigo un nuevo orden en Europa y el mundo entero, razones que llevaron al Gobierno a metamorfosearse para seguir subsistiendo. De pronto, nuestros amigos eran los norteamericanos y sus películas invadieron nuestros cines, convirtiéndose en fuertes competidores para nuestra producción que jugaba con mucha desventaja, tanto técnica como empresarialmente. Circunstancias que por desgracia parecen seguir existiendo en la actualidad.

La segunda mitad de la década se presenta sin muchos cambios como podremos apreciar en las siguientes gráficas:

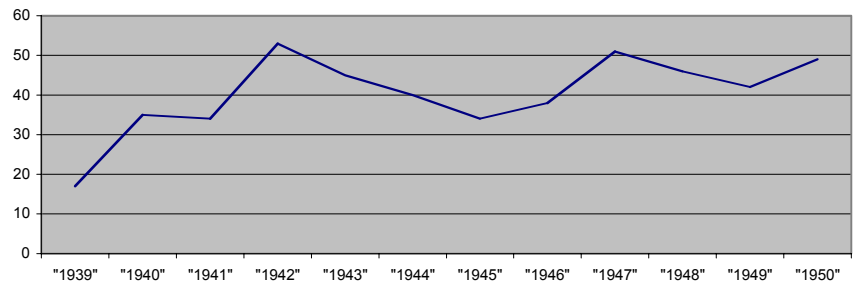

Gráfica 6: Producción de largometrajes (1941 a 1950)

Después de la crisis de 1945, nuestra producción vuelve a elevarse, manteniéndose las expectativas dentro de unos valores razonables. Así pues, la producción oscila entre las 51 y las 42 películas anuales, sin descender por debajo de las 40 . 


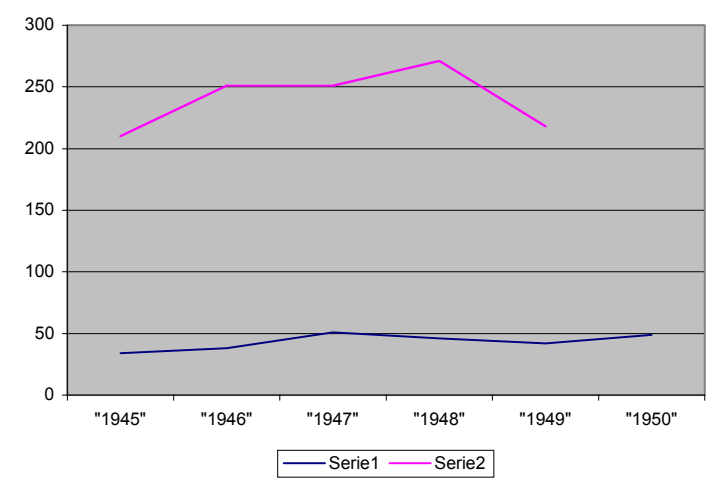

Gráfica 7: Producción nacional e internacional (1945 a 1950)

\begin{tabular}{|l|l|l|l|l|l|l|l|l|l|l|l|l|}
\hline Producción Nacional e importaciones $(1939 / 1950)$ \\
\hline Años & 1939 & 1940 & 1941 & 1942 & 1943 & 1944 & 1945 & 1946 & 1947 & 1948 & 1949 & 1950 \\
\hline Importación & 125 & 230 & 183 & 123 & 191 & 213 & 210 & 251 & 251 & 271 & 218 & - \\
\hline Prod. Nacional & 17 & 35 & 34 & 53 & 45 & 40 & 34 & 38 & 51 & 46 & 42 & 49 \\
\hline
\end{tabular}

Tabla 23: Producción Nacional e importación (1939 a 1950)

En cuanto a las importaciones, se produce un aumento muy significativo con respecto a las realizadas en el periodo de posguerra. Si las importaciones en aquel momento no llegaban a sobrepasar la barrera de las 200 películas y si lo hacían no era más de 30 puntos por encima, lo cierto es que en este segundo periodo, no baja de estas cifras, acercándose peligrosamente hasta las 300 películas. 1948 resulta ser el año de mayor número de importaciones, con la friolera de 271 producciones adquiridas. Estos datos resultan mucho más significativos si los comparamos con las cifras relativas a la producción propia. Resulta paradójico ver cómo los números no corresponden con aquellos que deberían resultar de la aplicación de las leyes proteccionistas. Recordemos que en 1943 quedaban fijadas una serie de normas que regularían las importaciones así como la exhibición en salas. Por las mismas, se establecía un baremo para otorgar licencias de importación que iban en función de la calidad de la producción española, concediendo como máximo cinco licencias a algunas películas de primera. Con una simple división podemos apreciar como esta correlación no se cumple. El porcentaje entre películas importadas y películas producidas es de cinco o seis frente a una, es decir, por cada filme español, se exhibían cinco o seis película importadas. ¿Esto quiere decir que todas nuestras películas obtenían la máxima calificación? Evidentemente, no. Más bien se da la situación contraria, los datos nos ofrecen un porcentaje alto de producciones a las que se le negaban los permisos de importación. De modo que ¿cómo puede explicarse la diferencia entre la producción y la importación? 
La respuesta creemos hallarla en un punto de la ley del que, sin duda, las productoras hicieron uso con el fin de obtener licencias, mientras el estado hacia la vista gorda ante la necesidad de abastecer un mercado en expansión. De este modo, al finalizar el apartado sexto de la orden de 17 de diciembre de 1942 se puede leer:

"En casos especiales, y si los contingentes de importación lo permiten, se podrá conceder algún aumento en el número de permisos, así como autorizarse la compensación directa con otra película de países de producción reducida, con quienes interese establecer relaciones cinematográficas y sea éste el único medio posible. ${ }^{192 ", ~}$

Esta cláusula deja la puerta abierta a múltiples interpretaciones quitando "validez" al artículo seis que especifica claramente las licencias que por clasificación se deben otorgar. Podemos justificar de este modo casos como los de El alarido de 1947 que pese a obtener la tercera calificación se le otorgó un permiso de importación y a Adversidad (1944) que en la misma situación obtuvo dos.

Pero pensar que el Régimen no se diera cuenta de ello sería una ingenuidad. La necesidad de abastecer el mercado, con más de 3200 salas en todo el país, hacía necesaria la permisividad de las instituciones y su consecuente consentimiento. Sin olvidarnos la posible repercusión de las leyes de cuota de pantalla ${ }^{193}$, que casualmente guarda relación con las películas importadas y las de realización propia. A esto, habría que sumar las concesiones realizadas bajo sobornos y tráfico de influencias que quedan ejemplificados en los casos aportados por José Luis Borau y Juan Mariné y comentados al inicio de este capítulo.

Pero ¿qué tipo de cine invadió nuestras pantallas? Los datos que tenemos dan una enorme presencia a la facturación made in USA, como hemos comentado. Si observamos la siguiente gráfica, podremos ver a simple vista como la invasión fue casi total tras la victoria Aliada en Europa. Pero esta gráfica lleva a engaño por la presencia de la línea desmarcada perteneciente a Estados Unidos. Como se puede observar, se muestra pormenorizadamente la presencia en nuestras salas de las películas en función de su nacionalidad y año. Según estos datos, la presencia del cine "americano" va disminuyendo paulatinamente frente al conjunto del cine europeo e hispano. Si bien en 1945 se proyectaban dos películas americanas frente a una del otro grupo, hacia finales de la década se había llegado a una paridad entre ambas, llegando incluso a superar el segundo grupo al coloso Hollywood.

\footnotetext{
192 España, Regulando la importación de películas, 18 de mayo de 1943, Ministerio de Industria, Subsecretaría de Comercio, Boletín Oficial del Estado, 24 de mayo de 1943, núm. de B.O.E. 124

${ }^{193}$ En la primera Orden de 10 de diciembre de 1941 [ESPAÑA, Orden, Regulando la programación de películas, 10 de diciembre de 1941, Ministerio de Industria y Comercio, Boletín Oficial del Estado, 13 de diciembre de 1941, núm. 347], se establecía una relación de una semana de proyección de películas nacionales frente a seis de cintas extranjeras. En una segunda Orden [ESPAÑA, Ampliando y modificando la orden de 10 de diciembre de 1941 sobre programación de películas, 13 de octubre de 1944, Ministerio de Industria y Comercio, Boletín Oficial del Estado, 15 de octubre de 1944, núm. 289] se pasa a la obligatoriedad de una semana de producción propia seguida por cinco de filmes importados.
} 


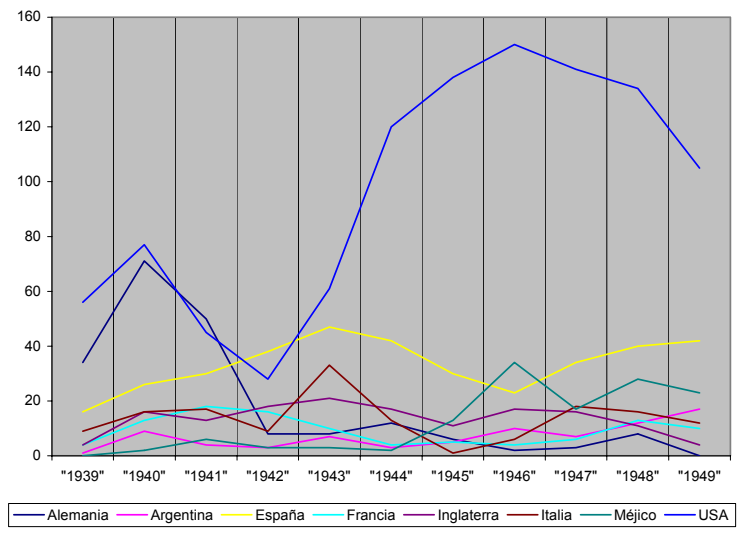

Gráfica 8: Películas estrenadas en Madrid por países de origen (1946 a 1950)

\begin{tabular}{|c|c|c|c|c|c|c|c|c|c|c|c|}
\hline PAIS ${ }^{194}$ & "193؟ & " "194 & " 194 & " "194 & " "194 & " "194 & "194! & "194 & " 194 & "194 & " "1949" \\
\hline Alemania & 34 & 71 & 50 & 8 & 8 & 12 & 6 & 2 & 3 & 8 & 0 \\
\hline Argentina & 1 & 9 & 4 & 3 & 7 & 3 & 5 & 10 & 7 & 12 & 17 \\
\hline Chile & & & & & & & & & & & 1 \\
\hline Cuba & 1 & 0 & & & & & & & & & \\
\hline Dinamarca & & & & & & & & & 1 & & \\
\hline España & 16 & 26 & 30 & 38 & 47 & 42 & 30 & 23 & 34 & 40 & 42 \\
\hline Francia & 4 & 13 & 18 & 16 & 10 & 4 & 5 & 4 & 6 & 13 & 10 \\
\hline Hungría & & & & & & & & 1 & 1 & & \\
\hline Inglaterra & 4 & 16 & 13 & 18 & 21 & 17 & 11 & 17 & 16 & 11 & 4 \\
\hline Italia & 9 & 16 & 17 & 9 & 33 & 13 & 1 & 6 & 18 & 16 & 12 \\
\hline Méjico & 0 & 2 & 6 & 3 & 3 & 2 & 13 & 34 & 17 & 28 & 23 \\
\hline USA & 56 & 77 & 45 & 28 & 61 & 120 & 138 & 150 & 141 & 134 & 105 \\
\hline Noruega & & & & & & & & & 1 & & \\
\hline Portugal & & & & & 1 & & 1 & 1 & 2 & & \\
\hline Suecia & & & & & & & & 2 & 2 & 7 & 3 \\
\hline Suiza & & & & & & & & 1 & 2 & 2 & 1 \\
\hline Totales & 125 & 230 & 183 & 123 & 191 & 213 & 210 & 251 & 251 & 271 & 218 \\
\hline
\end{tabular}

Tabla 24: Películas estrenadas en Madrid por países de origen (1939 a 1950)

¿Cómo se explica que se diera esta paridad? El cine de Hollywood nunca fue del agrado del Régimen franquista, aunque en un primer momento no presentó batalla contra

\footnotetext{
194 Datos recogidos de VV.AA. (1951) Anuario Cinematográfico Hispanoamericano 1950, Madrid, Sindicato Nacional del Espectáculo. pp. 345
} 
él. Son numerosos los artículos en Primer Plano que dan fe de este hecho. Se alaba incondicionalmente su factura pero se desprecian sus contenidos, muy alejados por otra parte, de los que hubiesen deseado el Estado. Una, pequeña, pero explícita, muestra de ello son las afirmaciones realizadas por José María Blay con respecto a la realización de dibujos animados:

"Los americanos han hecho estas películas. Y las han hecho bien. Las han realizado espléndidamente, con todos los recursos del dinero, de la técnica y de la organización a su alcance. Ellos han tomado los mejores temas de los cuentos europeos, las geniales creaciones de Grimm, las criaturas del Collodín, las hadas de nuestros castillos medievales, las fábulas maravillosas de los bosques encantados. Con todo eso han hecho sus películas de dibujos, deliciosas de color, de música, de animación. Pero cuando se acaban de ver resulta que, en definitiva, con toda su ingenuidad, con toda su técnica, nos han hurtado lo mejor que había en el cuento original: la leyenda. Esas películas de dibujos americanos suelen ser tremendos falseamientos de los cuentos que leímos un día. Pulgarcito, como el flautista de Hamerlin, tienen un valor que se les ha escapado a los productores materialistas de Hollywood. ¡Pobre Blancanieves, que nos han devuelto transformada en una vampiresa que canta con voz ronca. ${ }^{195 "}$

Por otro lado, no debemos olvidar que tras la derrota de Alemania, las fronteras comienzan a "abrirse" a nuevos mercados, o mejor dicho, el mercado español aceptó una llegada de trabajos de cineastas pertenecientes a países que hasta aquellos momentos no habían tenido cabida en España. Así, hacia finales de la década nos encontramos con estrenos de películas suecas, danesas y húngaras. Esta presencia más bien anecdótica no deja de parecernos significativa de los cambios surgidos a partir del fin de la guerra y la legislación nacional que facilitaban el comercio con países a los que podían exportarse nuestras películas.

Otra circunstancia importante fue la celebración del I Certamen Cinematográfico Hispanoamericano ${ }^{196}$ que tuvo lugar en el Ateneo de Madrid entre los día 27 de junio y 4 de julio de 1948 organizado por los gobiernos de España, México y República Argentina, con la colaboración de Cuba.

\section{Como expone Román Gubern:}

"... la finalidad -de éste evento- no era otra que la de romper el aislamiento político y cultural de la dictadura en los años en que el régimen estuvo sometido a las sanciones diplomáticas decretadas por la ONU en diciembre de 1946;:"197" pero como afirma Marina Díaz López, se intentó por parte de las autoridades franquistas no dotar a dicho encuentro de connotaciones políticas, "es notorio resaltar la intención conciliatoria que movía al Sindicato Nacional

\footnotetext{
195 Gómez TelLo, J. L. «Garbancito de la Mancha»; en Primer Plano, año IV, número 133, 2 de mayo de 1943.

${ }^{196}$ En el ANEXO IV, se recopila una crónica sobre el evento recogida en CABERO, J. A. (1949) Historia de la cinematografía española. Madrid, Gráficas Cinema. pp. 632-638.

197 GUBERN, R. «Pluralismo y comunidad en nuestras cinematografías», [en línea] en Centro Virtual Cervantes. http://cvc.cervantes.es/obref/congresos/zacatecas/cine/ponencias/gubern.htm [visitado el 25 de mayo de 2003]
} 
del Espectáculo, que era la de evitar cualquier matiz político en la reunión, y prueba de ello es la presencia de la delegación mexicana, país con el que se carecía de relaciones diplomáticas -que no se reemprendieron hasta 1976-. El acercamiento exigía tacto, y prueba de ello es que la cuestión preliminar se hizo recaer sobre el hecho de que no había conocimiento real de las tres cinematografías entre sí, por lo que la reunión se planteó como un "certamen"; es decir, concurso de películas. Así se manifestaba la intención de dotar al encuentro de un carácter primordialmente cultural y se salvaguardaba institucionalmente la pátina de hermanamiento hispano. ${ }^{198 "}$

Las consecuencias de este singular Certamen no se hicieron esperar. Durante su celebración se firmó un acuerdo de intercambio comercial e industrial con la República Argentina y se creó la Unión Cinematográfica Hispanoamericana (UCHA) cuya sede se abrirá en Madrid, con delegaciones en los países participantes en el evento, es decir, República Argentina, Méjico y Cuba. Asimismo se toman otros compromisos tanto institucionales como comerciales entre los que se encuentran:

1. La intención de eliminar el doblaje en las pantallas de dichos países.

2. La unificación de los aranceles aduaneros entre los países asistentes por parte de sus respectivos gobiernos.

3. La libre circulación del personal técnico y artístico.

4. Facilidades para la creación de fábricas de película virgen.

5. Facilidades para la circulación de publicaciones especializadas dentro de los países concurrentes.

6. La creación de una filmoteca (cinemateca) hispanoamericana.

7. La creación y concesión de unos premios.

El evento tuvo una gran repercusión en los medios, Primer Plano, RadioCinema, Espectáculo, Cámara, etc. Los distintos periodistas y colaboradores de estas publicaciones plasmaron el sentir nacional y las posibilidades que la creación de un "mercado único cinematográfico hispano" tendrían para nuestra maltrecha economía. Muestra de ello son las siguientes páginas donde con tono triunfalista y patriótico podemos cómo Martín Abizanda proclama:

"Imaginaos el gozo con que hemos escuchado vuestras voces fraternas en el Certamen Cinematográfico de Madrid. Ahora sabemos que estáis a nuestro lado para esta andadura, sin temor a las cadenas que el exotismo y la novedad nos pondrán en el camino. ¡Arriba pueblos de América! ¡Levantad vuestras banderas junto a la de España! Que esta cohesión lograda por el cine se extienda a otras ansías. Agradezcamos a la milagrosa teoría del celuloide el habernos deparado la ocasión y el recuerdo. Démosle al cine,

\footnotetext{
198 Díaz LÓPEZ, M. «Las vías de la Hispanidad en una coproducción hispanomexicana de 1948: Jalisco canta en Sevilla», [en línea] en (1999) Los límites de la frontera: La coproducción en el cine español, VII Congreso de la Asociación Española de Historiadores del Cine, pp. 146. citado en la página web: http://cvc.cervantes.es/actcult/cine/historia/coproducciones.htm
} 
patria: la patria hispana, joven y fuerte, igual a aquellas que, según el gran Leopoldo Marechal, es como un dolor que nuestros ojos no aprenden a llorar." 199

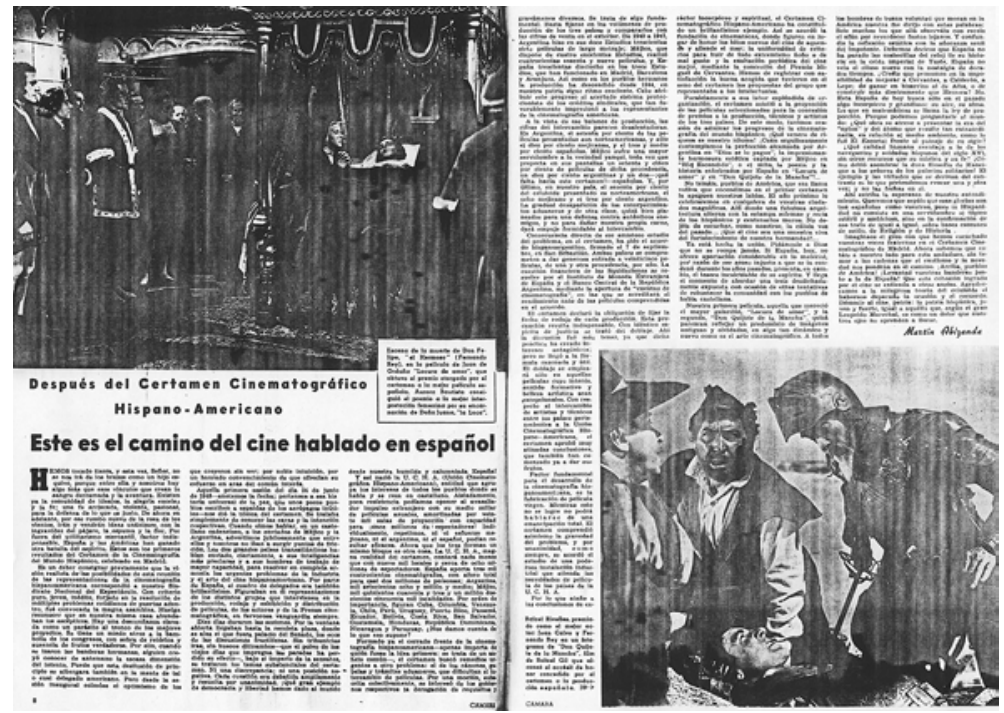

Imagen 24: «Este el camino del cine hablado en español» en Cámara, año VIII, núm. 140,

Poco se puede comentar de estas palabras, hablan por si mismas y nos proporcionan una idea bastante próxima de los delirios de grandeza de un sector de la prensa especializada.

Paralelamente durante el Certamen, se llegan a acuerdos bilaterales como el firmado entre ministro de Asuntos Exteriores, señor Marín Artajo, y el doctor don Pedro Radío, embajador de la República Argentina en España. En dicho acuerdo se establece:

"El intercambio de películas cinematográficas, con validez de un año, prorrogable automáticamente, mientras una de las naciones no lo denuncie con tres meses de antelación. Dicho acuerdo entra en vigor en septiembre de 1948, en el cual no se podrán aspirar a sus beneficios más que las películas producidas en España y la Argentina, debidamente calificadas por los organismos competentes de cada país. Se establece un régimen de permisos de importación por ambas naciones que se estipula en veinticinco, pudiendo ampliarse de común acuerdo. ${ }^{200 "}$

\footnotetext{
${ }^{199}$ ABIZANDA, M. «Este es el camino del cine hablado en español», en Cámara, año VIII, núm. 140, 1 de noviembre de 1948.

${ }^{200}$ CABERo, J. A. (1949) Historia de la cinematografía española, Vol. II. Madrid, Gráficas Cinema.. pp. 638.
} 
¿Afectó esto realmente a la importación de películas? La respuesta es, en nuestra opinión, claramente afirmativa. Como podíamos apreciar en la última tabla, hacia el final de la década se llega a una paridad de importación entre las películas hollywoodienses y el resto de producciones importadas, es decir, había tantas películas norteamericanas como la suma de todas las películas europeas y latinoamericanas. Una de las razones es el aumento en la llegada de material por parte de países de habla hispana, impulsado como es lógico, por los acuerdos comerciales alcanzados en este Certamen. Si seguimos observando, los acuerdos con la República Argentina son relativamente efectivos, con tan solo el aumento de dos películas importadas de aquel país. Por el contrario, la verdadera afluencia de cine de habla hispana se produjo con un incremento muy significativo.

En cambio, si tenemos en cuenta las exportaciones, podemos observar una notable mejora. En la siguiente gráfica se aprecia un fuerte aumento de las exportaciones a Hispanoamérica, y en especial a Cuba, país que se convertiría en el principal importador de nuestros películas con 24 y 23 producciones españolas en 1948 y 1949 respectivamente. Los acuerdos con la República Argentina parecen ser más bien desfavorables para nuestro país, puesto que van a menguar de un modo palpable las exportaciones a ese país. Méjico por su parte, comienza un ascenso que seguirá durante los siguientes años y se confirmará en el segundo Certamen Cinematográfico Hispanoamericano celebrado en mayo de 1950.

En conjunto esto supone un fuerte avance. Se incrementan las exportaciones a Latinoamérica en un $347 \%$, pasando de tan solo 15 producciones en 1944 a 52 largometrajes vendidos en 1949.

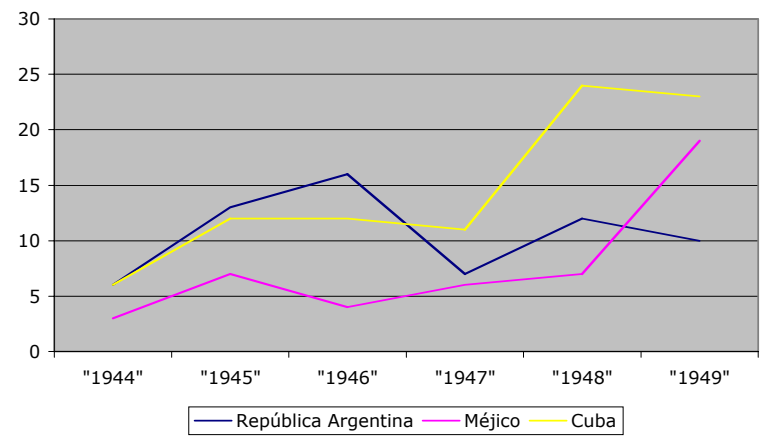

Gráfica 9: Películas españolas estrenadas en Hispanoamérica

\begin{tabular}{lllllll|} 
PAIS & $" 1944 "$ & $" 1945 "$ & $" 1946 "$ & $" 1947 "$ & $" 1948 "$ & $" 1949 "$ \\
Argentina & 6 & 13 & 16 & 7 & 12 & 10 \\
Méjico & 3 & 7 & 4 & 6 & 7 & 19 \\
Cuba & 6 & 12 & 12 & 11 & 24 & 23 \\
Total & 15 & 32 & 32 & 24 & 43 & 52 \\
\hline
\end{tabular}


Tabla 25: Películas españolas estrenadas en Hispanoamérica ${ }^{201}$

Como se ha podido ver, son muchas y muy variadas las causas que motivaron las distintas fases que conforman la consolidación de la industria cinematográfica española de los años cuarenta. Se mantuvo una política proteccionista favorable que consideraba al cine como instrumento de adoctrinamiento ideológico y como fuente de riqueza.

Los créditos a la cinematografía solo sirvieron para engordar los presupuestos (que lógicamente en nuestro mercado difícilmente se podrían amortizar), promoviendo la producción como única vía para poder comerciar con los permisos de importación. El aislacionismo al que España estuvo sometida durante el periodo posterior a la II Guerra Mundial, con la exclusión de la Naciones Unidas y del Plan Marshall, supuso un duro golpe para las exportaciones de nuestras películas, único modo de poder recuperar las divisas perdidas por el alto número de importaciones necesarias para abastecer al mercado interior. La creación en 1947 del Instituto de Experiencia e Investigaciones Cinematográficas, más popularmente llamada Escuela de Cine, pone de manifiesto la intención del gobierno franquista de consolidad una industria fuerte y sólida.

${ }^{201}$ Datos recogidos de VV.AA. (1951) Anuario Cinematográfico Hispanoamericano 1950, Madrid, Sindicato Nacional del Espectáculo 
CAPÍTULO 4

EL CINE Y LA MÚSICA 
Para comprender el objeto de nuestra investigación, la música de cine de los años cuarenta en España, es imprescindible realizar una pequeña aproximación contextual a la teoría musical de la época.

Desde el momento en que comenzó a escribirse música para el cine surgieron todo tipo de detractores y entusiastas adeptos que se posicionaron en contra o a favor, pero no será hasta mediados de los años treinta, cuando comienzan a aparecer estudios teóricos sobre la cuestión. Según el británico Russell Lack $^{202}$, el principal foco de debate generado en torno a la música cinematográfica durante la década de los treinta y cuarenta, se desarrolló en el seno de la Inglaterra Victoriana propiciado éste por la inclusión de un nutrido grupo de grandes sinfonistas post-románticos ingleses de reconocido prestigio internacional, con personalidades tan destacadas como Vaughan Williams, William Walton, Benjamin Britten, Arthur Benjamin o Arthur Bliss, entre otros. La dignificación de la música cinematográfica resultó ser su principal función y papel en la historia, junto a los magníficos trabajos musicales realizados para la gran pantalla, entre los que se encuentran el soberbio Hamlet (1948) de William Walton, la impactante partitura de Arthur Benjamin para El hombre que sabía demasiado (1934) o la memorable Things to Come (1939) de Arthur Bliss.

¿Y por qué era necesario dignificar la música cinematográfica? La música para cine desde sus inicios ha sido considerada por la mayor parte de compositores "serios" como una forma menor de música. La indiferencia que por ella se siente, aún hoy, es muy elevada y se sostiene sobre una serie de prejuicios inaceptables: que la música de cine al estar forzosamente subordinada a la imagen carece de interés; que no se puede escuchar fuera del ámbito para el que fue escrita $y$, lo que parece más importante para los detractores, carece de una estructura formal bien desarrollada. Lógicamente, la música de cine tiene dos imperativos de primer orden; el primero de ellos tiene que ver con la adaptabilidad a los tempos marcados por el filme. Y, el segundo, es que la música de cine es, por lo general, uno de los últimos eslabones en la cadena de producción del filme, lo que obliga a los compositores de música de cine a trabajar en condiciones de extrema dureza, agilizando los procesos de creación.

Según nos cuenta el maestro Cristóbal Halffter:

"La música y el cine son dos artes que están en el tiempo -expone - y que requieren su tiempo para desarrollarse, y cuando se hace una imagen sobre una música preexistente, el tiempo lo marca la música. Yo creo que eso es lo que se debe de hacer. Generalmente es al revés, es una imagen que tiene su tiempo, y el compositor se tiene que adaptar, el que se sabe adaptar sale a delante, y yo últimamente no sería capaz de adaptarme,... «mira aquí tienes que hacer música porque esta señora está llorando, y aquí sale un caballo, y después la señora se enamora del caballo». No, la música es totalmente abstracta, entonces cuando las imágenes, que son reales, se adaptan a la abstracción de la música, entonces vale la pena. Pero claro, esto supone que

\footnotetext{
${ }^{202}$ Lack, R. (1999) La música de cine, Madrid, Cátedra - Signo e Imagen.
} 
para hacer una película yo necesitaría un año de trabajo para hacer la música, y luego realizar el rodaje sobre él. Pero claro, esto no hay nadie que lo haga. Hay un ejemplo en la historia del cine muy ilustrativo, que es cuando Pabs, hizo Don Quijote, con Saliapi, le encargaron la música a Ravel, y Pabs, le pidió que compusiera tres canciones (que luego llevaron el nombre de Dulcinea), y Ravel se entusiasmó con la idea. Se puso a trabajar y cuando las tuvo fue a ver a Pabs y éste le dijo que la película ya se había estrenado hacía un año. Ravel tardó un año y medio en componer estas tres canciones, que por otro lado son una maravilla. ${ }^{203 "}$

La cuestión de la dependencia de la música de cine a las imágenes, sobre la que incide Halffter, ha sido durante mucho tiempo uno de los argumentos utilizados para argüir que no puede ser escuchada fuera de la pantalla. Pero todo esto no deja de resultar en realidad argumentos de segundo orden. La mayor parte de la música considerada "clásica" son piezas sacras, compuestas para la liturgia (católica, ortodoxa o protestante). De modo que, si se utiliza el mismo razonamiento ¿cómo se justifica el hecho de que dicha música pueda escucharse fuera del contexto litúrgico para el que fueron compuestas estas obras?

Algo similar ocurre con las óperas. En muchas salas de concierto no habilitadas para una escenificación operística se interpretan dichas obras en versión concierto. ¿No es, pues, un sinsentido interpretar esta música sin escenificación? Y ¿las piezas musicales compuestas para teatro, como el Peer Gynt de Edvard Grieg? ¿Por qué se realizan, constantemente, grabaciones discográficas de estas obras?

\section{El cine y la música de cine}

En 1936 se publica en Londres el primer estudio serio de referencia, que tiene por objeto la música de cine. Kurt London mantiene que:

“... la música que acompaña al cine aún lucha por encontrar su puesto bajo el sol. De modo casi invariable, la propia gente del cine la trata de manera superficial y no tiene muy clara su importancia; los músicos recurren a ella más por amor a los honorarios que por amor al arte, y es raro el que entre ellos muestra alguna simpatía por las nuevas formas. El público, por último, no se preocupa demasiado por la música porque nunca acierta a comprender la causa y los efectos de las ideas musicales en el cine ${ }^{204 "}$

En cuanto a la funcionalidad de la música en el cine, Raymond Spottinwoode ${ }^{205}$, es uno de los primeros teóricos que en 1935, trató de delimitar las funciones de la música en relación con el relato fílmico, distinguiendo cuatro parámetros esenciales:

\footnotetext{
${ }^{203}$ Entrevista con Cristóbal Halffter, Madrid, 18 de marzo de 1999.

${ }^{204}$ London, K. (1936) Film Music. London. pp. 125. citado en Lack, R. (1999) La música en el cine. Madrid, Cátedra, signo e imagen. pp. 151.

${ }^{205}$ Spottinxoode, R. (1997) A grammar of the film: an analysis of film echnique. citado en Lack, R. (1999) La música en el cine. Madrid, Cátedra, signo e imagen. pp. 150.
} 
En primer lugar, destaca la Imitación, es decir, cuando la banda sonora imita sonidos naturales o cualidades tonales del habla. En segundo lugar, menciona el Comentario, cuando la música ocupa la posición del espectador ofreciendo un comentario a menudo irónico de los sucesos que acontecen en la pantalla. En tercer lugar, la Evocación, es cuando la música revela algo acerca de los personajes; un ejemplo sería el leitmotiv. En cuarto lugar, Spottinwoode habla de la función de Contrastaste, esto es que la banda sonora contrasta intensamente con la imagen y crea un efecto concreto. En cuarto y último lugar, el autor se refiere al Dinamismo para señalar que la música contribuye, con la composición de los sucesivos planos, a acentuar el impacto de los cortes y el montaje.

Como se puede apreciar, aunque se trate de una división aparentemente sencilla, las funciones que propone Spottinwoode significan una clara visón del concepto musical para la imagen en movimiento. Estas cinco funciones plasman, sintéticamente, las posibilidades que la música tiene en un contexto fílmico.

Para Michael Chion:

"... se suele decir - que la música "sirve» al filme, que es utilizada como reparación, vínculo, aliño, parche y camuflaje. En un objeto constituido, por definición, por elementos ensamblados y mezclados, como es el filme, la música tiene en efecto una función de pegamento, de navaja multiusos, de pinza universal, de caja de herramientas y de medicamento milagroso [...]. La música une y separa, puntúa y diluye, confunde y retiene, asegura el ambiente, esconde los raccords de ruido o imágenes que no «funcionan» ${ }^{206 \text { “ }}$

Las palabras de Chion vienen a poner de manifiesto el sentido tributario de la música de cine con respecto a la imagen, pero inciden en las posibilidades cohesionadoras de la música en el contexto del relato fílmico.

José Nieto por su parte recuerda la inexorable sinergia que se produce entre música e imagen en movimiento desde la aparición del cine.

“... hay que señalar la enorme capacidad que la música tiene para transmitir todo tipo de emociones, así como para crear los más variados estados de ánimo y las atmósferas más sutiles. Esta extraordinaria cualidad, unida a lo universal de su lenguaje, constituiría por si sola razón suficiente para que, hace ahora cien años, se decidiera que la música fuese, aún antes que la palabra, compañera inseparable de las imágenes en movimiento. ${ }^{207}$ "

No será hasta la llegada de los textos de Teodoro Adorno y Hanns Eisler, de obligada referencia y lectura, cuando nos encontremos con reflexiones teóricas de carácter. Adorno y Eisler abordan diferentes aspectos del problema; desde un diagnóstico de la situación que les permite detectar las dificultades encontradas en la música de cine que se realizaba en la década de los cuarenta, pasando por el estudio de los diferentes modelos, tanto en el terreno de la praxis como en el de la teórica, hasta el planteamiento de la implantación de nuevos lenguajes musicales en el ámbito cinematográfico.

\footnotetext{
${ }^{206}$ Chión, M. (1985) La música en el cine. Barcelona, Paidos, colección cine. pp. 195.

${ }^{207}$ Nieto, J. (1996) La música para la imagen, la influencia secreta. Madrid, SGAE, pp. 29
} 
En un principio, Eisler, plantea la problemática que se desarrolla con la llegada del cine por la alienación que supone la asistencia, de un público mayoritariamente obrero, a las proyecciones de películas donde fundamentalmente se proporcionaba una diversión "enlatada". Con la introducción de la música en el espectáculo cinematográfico se trataba de ocultar o naturalizar la toma de conciencia de estar asistiendo a una grotesca exhibición donde las máquinas de proyección lanzaban en la pantalla una serie de "espectros" que se movían con una frialdad tan espeluznante que sólo la música era incapaz de evitar.

Tras este planteamiento, de índole sociológica, dirigen sus esfuerzos a abordar las problemáticas surgidas en la elaboración de la música de cine durante las dos décadas precedentes $^{208}$. Desde un principio se muestran muy críticos con la utilización excesiva y desafortunada de la música en los relatos fílmicos. Reivindican los diálogos, y el soundtrack $^{209}$ en general, y plantean la precaria situación en la que se encuentra la música en el medio cinematográfico.

En un primer momento, se centran en el diagnóstico de lo que denominan pequeños vicios adquiridos a lo largo de los años, como la innecesaria justificación de la música que se escucha en la pantalla, por directores faltos de una mirada crítica y analítica con respecto a los valores que puede aportar la música en el film. Era muy habitual por aquella época que, en escenas románticas, para evitar el silencio, se introdujese la música, siendo de obligada puesta en escena un tocadiscos, o cualquier objeto, que pudiese “justificar dicha existencia ${ }^{210 " ~ d e ~ u n a ~ f o r m a ~ s u p e r f l u a . ~ A s i ́ ~ p u e s, ~ c o n c l u y e n ~ d i c i e n d o ~ q u e: ~}$

“... resulta evidente que, en la medida en que esta costumbre dominante en los principios del sonoro tenga actualmente alguna vigencia, impide que la música se utilice de una forma verdaderamente constructiva y creadora de contrastes. La música se pone al nivel de la acción y queda convertida en un requisito, en una especie de mueble acústico ${ }^{211 " .}$

Prosiguen su argumentación atacando la ilustración musical fomentada en los estudios de Hollywood. De hecho, atacan especialmente la manera de actuar y "crear" bajo el famoso epígrafe hollywoodiense: birdie sings, music sings (si canta el pájaro, canta la música). No es que estén en contra de esta práctica, por el contrario opinan que es un método interesante y a tener en cuenta, pero consideran que la excesiva utilización de este recurso debería dosificarse más.

La utilización de este recurso por parte de los directores, productores y de los mismos músicos trae como consecuencia la propia anulación de su efecto, es decir, que la reiterada identificación de ciertos recursos expresivos de la música con determinados elementos visuales, con el tiempo sufre una codificación que provoca la antelación del espectador y los efectos son perjudiciales para el desarrollo del relato fílmico. Por otro lado, la función de la música como ilustración da lugar a la duplicidad innecesaria de los elementos visuales en el campo auditivo. Para los autores:

\footnotetext{
${ }^{208}$ Nos referimos a los años 30 y 40.

${ }^{209}$ Término anglosajón para definir la banda sonora de la película, es decir, música, sonidos y diálogos.

${ }^{210}$ Adorno, T. W.; Eisler, H. (1981) El cine y la música. Madrid. Fundamentos. pp. 27.

${ }^{211}$ Op. Cit.
} 
“... en el cine la imagen y el diálogo son extremadamente precisos y la música convencional no puede añadir nada a esta precisión, sino solamente quitarle algo, ya que los efectos que acaban estandarizándose permanecen siempre, hasta en las peores películas, por detrás de la impresión definida producida por la situación escénica ${ }^{212 " . ~}$

Esto les lleva, irreversiblemente, a hablar de los clichés y de su utilización en la musicalización de filmes. En su claro análisis, Adorno y Eisler, tras exponer que la sucesiva creación de películas donde se repiten las mismas escenas y situaciones provoca que la utilización de estos recursos (clichés) habitualmente empleados por la música de cine, de una forma estandarizada y poco creativa, lleva a la inevitable frustración por parte del músico y de los creadores; y conllevan, necesariamente, a la inexistencia de sorpresa en el público receptor.

La utilización de clichés en la música de cine provoca en numerosos casos, una utilización de la misma contradictoria, llegando en algunas ocasiones a ser altamente perjudicial para el sentido del relato. La utilización de la Fuga en Mi menor de J. S. Bach en numerosas películas de la década de los cuarenta, no deja de producir en el espectador una cierta sonrisa que contribuye a que éste se sienta expulsado del universo de ficción del relato. Mucho peor resulta, cuando en una película de época, es decir, situada en un entorno muy definido histórica y geográficamente, se acude a los clichés con la esperanza de crear el ambiente apropiado; al final lo que se consigue con esto, es un "pastiche" donde los anacronismos y sin sentidos dominan el universo de ficción evocado. Es evidente que Adorno y Eisler plantean no solo una utilización cuidadosa del «código» sino una reformulación del mismo.

Acabamos de mencionar el término «código», pero ¿qué entendemos, exactamente, por código? La respuesta la encontramos en palabras de José Nieto cuando establece que para poder llamar códigos culturales de nuestra civilización:

“... es fundamental no perder la condición de subjetividad de los códigos, ya que éstos no son sino un conjunto de señales, significados y reglas que se han ido estableciendo dentro de las diferentes comunidades culturales. Estos códigos permiten a sus miembros transmitirse conceptos, ideas y emociones; es decir, les permite comunicarse entre ellos, pero no siempre les servirá para hacerlo con gentes de otras colectividades. ${ }^{213}$ "

Pero el código siempre va unido al cliché musical que según Nieto no es más que una pieza de música compuesta con arreglo a una combinación de códigos que se corresponden exactamente con los de un patrón conocido, razón por la cual su efecto sobre el oyente también se conoce de antemano, o lo que es lo mismo, la utilización indiscriminada y mecánica conlleva a la vulgarización y perversión del código. Su utilización aberrante genera consecuencias contradictorias. Por un lado se consigue el efecto deseado en el público, pero por otra, la pérdida de riqueza en la construcción sonora de un filme

\footnotetext{
${ }^{212}$ Op. Cit. pp. 28-29.

${ }^{213}$ Nieto, J. (1996) La música para la imagen, la influencia secreta. Madrid, SGAE, pp. 90.
} 
puede ser tremenda, por no hacer alusión a las posibles desventajas que produce el hecho de que el espectador pueda adelantarse a los hechos.

La orquestación de las piezas también está sujeta a una estandarización, llegando a la vulgarización del cliché, lo que implica, la pérdida por parte de los efectos orquestales, de timbre, tono, etcétera y del presunto significante, para el que fueron creados, o con el que, con el tiempo se han ido asociando al mismo. Adorno y Eisler ponen como ejemplo el efecto del trémolo del arco sobre la zona del puente en los instrumentos de cuerda frotada. Lo que en un principio despertaba una inquietante tensión, identificada con la esfera de lo irreal, con el tiempo, en la música para cine, se ha convertido en un recurso desprovisto de sus connotaciones iniciales.

"En términos generales, los recursos musicales que, ya cuando nacieron, fueron planeados como estímulos, en vez de ser el resultado de una construcción, aún dentro de la música autónoma, han perdido más rápidamente su eficacia ${ }^{214}$ "

Se hace clara alusión a la imposición que sufren los directores musicales por parte de los grandes estudios de cine, especialmente Hollywood, que marcaban las líneas interpretativas de las piezas. Y claro está, la ejecución de las obras, su interpretación, no iba a ser menos. Incluso, la utilización del cliché, en la ejecución es todavía peor y más destructiva si cabe. En un principio la falta de dinámica en las grabaciones de la época estaba supeditada a razones de carácter técnico, de las que los compositores eran penitentes abnegados. Pero una vez subsanado este problema que llevaba consigo la interpretación exagerada y desproporcionada de la dinámica (de pianissimo a fortissimo), se pasó a una ejecución más estandarizada y monolítica en mezzoforte que se mantuvo por desgracia durante un gran periodo de tiempo en el cine clásico de Hollywood. Esta estandarización (cliché) del registro sonoro, trajo consigo la pérdida de la poca dignidad que le quedaba a la música de cine, así como el menoscabo que sufrieron las películas en las que el empobrecimiento de la música llevó a una considerable pérdida de su efectividad dramática en el contexto fílmico, motivada también por la falta de personalidad en la interpretación. Por ejemplo, Alfred Newman ${ }^{215}$, director musical de la 20th Century Fox durante más de cuatro décadas, estableció un tipo muy concreto de modismos en la dinámica de la cuerda, con grandes vibratos en la misma. Como consecuencia de ello, daba igual quien compusiese la música o para qué, toda acababa sonando igual.

"El sempiterno "espressivo" se embota completamente. Incluso los buenos momentos dramáticos se convierten en kitsch por culpa de un acompañamiento demasiado dulce o por la exageración de su dramatismo. Un estilo interpretativo "medio", objetivamente musical, que utilizase el "espressivo" en donde realmente estuviese justificado podría incrementar

\footnotetext{
${ }^{214}$ Adorno, T. W.; Eisler, H. (1981) El cine y la música. Madrid. Fundamentos. pp. 33.

${ }^{215}$ Waletzky, J. (1995) Musique de Films: le son de Hollywood [Documental para televisión], emitido por Canal Hollywood en otoño de 2001. En este documental se puden escuchar testimonios de músicos que trabajaron en la Edad de Oro de Hollywood, donde comentan estas y otras anécdotas respecto al modo de trabajar e interpretar la música en la década de los cuarenta en Estados Unidos.
} 
significativamente a través de su economía la eficiencia de la música de cine ${ }^{216 ",}$

El filósofo y el músico alemanes proponen entonces una composición objetiva, intentando subsanar estos errores, con la intención de establecer un nuevo método, así como, la renovación del lenguaje musical a utilizar por el compositor. De esta manera, comienzan estableciendo una correlación, entre los elementos auditivos y los visuales, necesaria para la correcta simbiosis de las partes y el correcto funcionamiento dentro de la narración fílmica.

En primer lugar, ponen de relieve que la música debe ser la necesaria; y no abrumar con su existencia permanente. No se debe utilizar para tapar agujeros ni porque sí, puesto que de ésta manera perdería efecto, dañaría gravemente al film y a sí misma. La procedencia de Eisler del mundo clásico musical y la influencia que para él tuvieron las enseñanzas de la Escuela de Viena y, especialmente, las de Arnold Shoenberg, se aprecian claramente en sus argumentaciones que, por otra parte, nos resultan próximas a las defendidas por Cristóbal Halffter. Especialmente cuando Eisler afirma que:

“... debe existir una relación entre la imagen y la música. Si los silencios, los tiempos muertos, los momentos de tensión o lo que sea, se rellenan con una música indiferente o constantemente heterogénea, el resultado es el desorden. La música y la imagen deben coincidir, aunque sea de norma indirecta o antitética. La exigencia que la naturaleza específica del film debe determinar la naturaleza específica de la música -o a la inversa, aunque este caso sea actualmente más bien hipotético, que la naturaleza de la música determine la naturaleza de las imágenes ${ }^{217}$ ".

Pero una cosa lleva a la otra y para poder componer una música adecuada para cada film, según Eisler, es necesario que la industria cinematográfica, especialmente la estadounidense, abandone y destierre la mala costumbre de planificar las películas pensando en los efectos sobre el espectador y, se plantee seriamente la necesidad de invertir el proceso. De este modo, defiende el autor, el producto ganaría en calidad y, en lo que respecta a la música, se podría conseguir lo que tanto se anhela, que la partitura esté creada para el film, con una naturaleza propia e intrínseca a la propia obra, que de otro modo sería difícil de conseguir, por no decir casi imposible.

Sin duda, la postura de los teóricos alemanes está muy lejos de la realidad y más cerca de la quimera, fundamentalmente, porque prevalece una visión del cine meramente artística, dejando de lado, en todo momento, que el cine es también un producto y forma parte de un engranaje industrial que debe dar beneficios. De modo que la propuesta de estos autores, aún resultando en todo momento interesante, no deja de parecernos una maravillosa utopía, especialmente cuando plantean un cambio en el lenguaje musical empleado en las películas, considerando que el lenguaje musical utilizado, heredero de la evolución musical occidental de la armonía y su posterior deconstrucción, necesita un tiempo mínimo para su desarrollo musical por lo que, su utilización en el cine no resulta

\footnotetext{
${ }^{216}$ Adorno, T. W.; Eisler, H. (1981) El cine y la música. Madrid. Fundamentos. pp. 35.

${ }^{217}$ Op. Cit. pp. 91.
} 
adecuada, al no poder aportar éste, las condiciones necesarias para componer correctamente las piezas. En nuestra opinión, la aproximación de los autores encierra, en gran medida, la voluntad de trasladar al mundo del cine conceptos de las salas de concierto.

De hecho, debemos tener en cuenta que las teorías de Adorno y Eisler son de finales de la década de los cuarenta, cuando Schoenberg, ya residía en los Estados Unidos de América y había alcanzado una gran popularidad. En este momento, los prelados de la Escuela de Viena alcanzan influencia y prestigio internacionales, teniendo su mejor momento en el año 1951, año del fallecimiento de su mentor. No es de extrañar, que el sistema elegido por los autores, sea el serialismo. Pero ¿por qué utilizar este lenguaje en vez de continuar con el clásico postulado musical post-romántico? Dejando de lado las claras motivaciones personales de Eisler, no deja de ser interesante el razonamiento que lleva a los autores del estudio a considerar el "dodecafonismo" como el lenguaje idóneo para una futura música cinematográfica. Para ello se aferran a la idea de las estructuras internas de una y otra. Cualquier melómano, sabrá que el sinfonismo tradicional, así como la música compuesta hasta el romanticismo para los conciertos, estaba fuertemente sujeta a unas formas musicales, siendo la sonata la protagonista indiscutible de todas y por extensión, la base de la mayoría de dichas formas musicales. Es por tanto, la forma musical, lo más importante a la hora de valorar una pieza sinfónica.

"La música tonal de los últimos doscientos años tiende hacia formas largas, desarrolladas. Únicamente puede tomarse conciencia de un núcleo tonal a través de las analogías, los desarrollos y las repeticiones, que exigen un cierto tiempo ${ }^{218 ",}$.

Así pues, el factor que ha proporcionado a la música clásica su carácter durante siglos, se convierte en su aplicación al cine en un lastre difícil de salvar. Por esta razón, la música nacida del dodecafonismo es para Eisler la posibilidad de futuro. El sistema serial, y en general la mayor parte de los lenguajes musicales aparecidos a lo largo del siglo XX, favorecen la creación de microestructuras de corta duración ${ }^{219}$, sin perder su dignidad musical, como lo haría la música tradicional.

"Es evidente -formula Eisler- la aptitud de la nueva música para la construcción de formas breves, precisas y consistentes que entran en materia inmediatamente $y$ que no necesitan de prolongaciones por motivos estructurales, [...] Al mismo tiempo, la mayor agudeza de las características musicales permite la mayor agudeza de la expresión, que resultaba imposible debido a la "estilización" de los esquemas musicales tradicionales". Y acaba concluyendo que la "ampliación de la escala expresiva (que proporciona la nueva música) no se limita solamente a los caracteres expresivos como tales, sino también, y especialmente, a sus variaciones. La música tradicional, al margen de la técnica de la sorpresa tal y como fue utilizada, por ejemplo, por Berlioz o por Strauss, necesita generalmente un cierto tiempo para el cambio de carácter. La exigencia de un equilibrio entre las tonalidades y los

\footnotetext{
${ }^{218}$ Op. Cit. pp. 58.

${ }^{219}$ Recordemos el Microcosmos de Bartok
} 
fragmentos simétricos impide colocar directamente seguidos, en función de su propia significación, los caracteres puros. En términos generales, la nueva música no se detiene en estas consideraciones. Puede construir sus formas mediante los contrastes más acusados ${ }^{220 " .}$

Todo esto, que nos parece extremadamente sugerente, no tiene en consideración, por parte de Adorno y de Eisler, los códigos que el espectador tiene asimilados tanto a nivel audiotivo como visual. Sin estos códigos, como ya hemos apuntado, aunque la música sea de una riqueza absoluta, el receptor no acabará de percibir adecuadamente los mensajes, de modo que la música puede perder su funcionalidad.

Por otro lado, la música serial, dodecafónica, así como la gran mayoría de las corrientes musicales del siglo XX como el concretismo, la música estocástica o la electroacústica, corrientes todas ellas posteriores al escrito de Adorno y Eisler, tienen un significante determinado incorporados al conjunto de códigos de nuestra sociedad, que resultan difíciles de asimilar a un profano en esta tipología musical. Por el contrario, diremos que son muy adecuados para crear suspense, desequilibrio, terror, etcétera.

Según Eisler, el espectador de cine se comporta de una forma pasiva, lo que sin duda, contribuye a la poca atención que éste le otorga a la música de cine ${ }^{221}$.

La educación del público receptor hacia el conocimiento de nuevos lenguajes musicales se convierte, pues, en el caballo de batalla de muchos compositores. $\mathrm{Y}$, si actualmente, podemos decir que las dificultades, en este sentido, son muchas; más complicado era en la década de los cuarenta. A pesar de todo, la música de cine, como ya hemos apuntado en varias ocasiones, ha sido el único tipo de música capaz de albergar y aglutinar diferentes estilos, tipos y lenguajes musicales siendo, al mismo tiempo, un instrumento de primer orden para transmitir y difundir la diversidad musical.

\section{La música de cine en España}

El conjunto de músicos que trabajaron asiduamente para la gran pantalla durante la década de los cuarenta, procedían en su mayoría del teatro musical y su formación técnica era de gran calidad. Una gran parte de compositores, por no decir su totalidad, tenían sus raíces en la música para la escena. Recordemos que en la década de los

\footnotetext{
${ }^{220}$ Adorno, T. W.; Eisler, H. (1981) El cine y la música. Madrid. Fundamentos. pp. 95 - 60.

${ }^{221}$ Sobre la pasividad del espectador de cine, Russell Lack, hace suyas las aportaciones del filósofo John Dewey en el sentido de que el individuo nunca es totalmente indiferente a una percepción, ya que para serlo de forma absoluta debe tomar una serie de decisiones para tal fin que implican cierto nivel de compromiso, de modo, que nunca puede hablarse de pasividad absoluta a nivel de percepción. Como el propio Lack afirma:"Aunque uno adoptara la actitud borreguil de un espectador que balancea la cabeza adelante y atrás y acompaña una típica canción de una típica película musical de los años treinta de Jessie Matthews, ¿sería ésta exclusivamente una actitud pasiva y resignada?. John Dewey respondería que no, que al menos los sentimientos de vergüenza y de miedo ante la condena social habrían sido deliberadamente superados para permitirnos cantar una sencilla canción popular"

DEWEY, J. (1987) Art as experience. Illinois, pp. 162. citado en Lack, R. (1997) La músic en el cine. Madrid, Cátedra, signo e imagen. pp. 157.
} 
cuarenta todavía existía un fuerte fervor popular por la zarzuela y el género chico ${ }^{222}$, así como por las piezas cortas de teatro como los entremeses. Nuestros compositores, en su mayoría adoraban el teatro pero éste no daba suficiente para comer, por lo que comenzaron a vincularse al cine. Problema del que se hace eco Joaquín Turina como uno de los grandes males de la música para el cine:

"...los compositores y profesores de orquesta se matan por meterse en un estudio de cine. Y esto ¿por qué?; pues porque es un negocio estupendo. La música de cine deja de pertenecer a las bellas artes para convertirse en un objeto de puro comercio. ${ }^{223}$ "

Autores como Moreno-Torroba, Daniel Montorio, Demon, Juan Quintero, Manuel Parada, Francisco Alonso y hasta García Leoz, entre otros muchos, se acercaron al teatro de un modo o de otro. Esta experiencia de componer para el espectáculo teatral favoreció, a nuestro entender, tanto el acercamiento al cine como su desenvolvimiento en este nuevo género musical de parte de una amplia mayoría de estos hombres, puesto que al fin y al cabo, estas dos "formas" musicales están íntimamente ligadas entre sí al mundo de la escena.

Fe de la importancia que llegó a tener para algunos compositores los géneros teatrales son sin duda las largas ausencias del mundo cinematográfico de parte de sus miembros, como Ruiz de Azagra, o la disminución en el número de producciones compuestas para el cine en determinados momentos, fruto de una mayor actividad teatral como ocurre en el caso de Juan Quintero Muñoz. En conversaciones mantenidas con Francisca Martos, viuda del maestro Quintero, nos comentó como fueron las incursiones de su marido en el teatro musical con los éxitos de Si Fausto fuese Faustina ${ }^{224}$ y Yola:

\footnotetext{
${ }^{222}$ Habitualmente se confunde e identifican ambos géneros aunque realmente no son lo mismo, puesto que el género chico se trata de una derivación de la zarzuela. A continuación recogemos unos estractos de dos artículos aparecido en la red que explica perfectamente las diferencias entre ambos géneros:

La zarzuela es una producción teatral en la que la declamación alterna con fragmentos musicales. Especie de término medio entre el teatro de comedia y la ópera, este género lírico representa una reducción de esta última a dimensiones más modestas, tanto en lo que afecta a la estructura musical como al contenido del libreto.

http://www.geocities.com/zarzuela_2000/zarzuela1.htm [página visitada el 2 de mayo de 2003].

La principal diferencia entre el 'género chico' y la zarzuela es el tiempo de duración y el número de actos. La zarzuela suele tener dos o tres actos y el 'género chico' solo uno.

Su nacimiento se sitúa en El Recreo (1867), un pequeño teatro de la madrileña calle la Flor.

La menor duración de las obras (menos de una hora) abarataba el coste de las localidades, llegando hasta las clases humildes que abarrotaron el teatro. Las recaudaciones aumentaron espectacularmente, así como la producción de obras.

Este fue el nacimiento del 'género chico', llamado así no por ser un teatro de menor calidad, sino por ser más breve. También se ha denominado, erroneamente, a la zarzuela en general 'género chico' en contraposición a la ópera.

Una de las mayores diferencias entre el 'género chico' y la zarzuela es el argumento. La zarzuela grande se basa en temas dramáticos o cómicos de acción complicada, 'el género chico' trata el teatro costumbrista, reflejando la vida cotidiana madrileña. Respecto a la música, esta es pegadiza, tarareable, hecha para servir al texto. Sus melodías van desde lo bailable, gracioso, hasta lo sentimental y amoroso. Toda su música está basada en el folklore español: boleros, jotas, seguidillas, soleás, pasacalles, fandangos, habaneras, valses, mazurcas, polkas y, por supuesto, el chotis.

http://www.geocities.com/Vienna/Strasse/3300/elgene.html [página visitada el 2 de febrero de 2003].

${ }^{223}$ TURINA, J. «Música de cine» Dígame, 6-X-1942.

${ }^{224}$ No equivocar con la película del mismo título que también musicó el maestro Quintero.
} 
"Juan trabajó varias veces con Sáenz de Heredia en comedias musicales para el teatro, siendo éste el libretista. Ello surgió porque ambos eran aficionados al teatro $y$, como veraneaban juntos en el Escorial, surgieron estos proyectos que fueron para Celia Gámez, a la que Juan acompañó cuando ella cantaba tangos a los diecisiete años. 225 "

Este interés por la lírica, el teatro y, en general, cualquier forma vinculada a las representaciones escénicas generarían, como consecuencia, un vínculo con la canción y sus intérpretes que desembocaría con el tiempo en la paulatina inclusión de las mismas figuras que tenían éxito en el teatro, dentro del cine. Ejemplos de ello lo tenemos en figuras como la joven Marujita Díaz, Rina Celi, o José Valero. En otros caso, el viaje fue en sentido inverso, y una figura como Imperio Argentina, pasó a convertirse en todo un símbolo nacional y en una de las cantantes más prestigiosas del momento, dejando el cine de lado y dedicándose más a sus giras, como denota su poca actividad para la gran pantalla y los numerosos artículos aparecidos en revistas y periódicos donde se narra sus éxitos dentro y fuera de España.

Salvo algunas excepciones que mencionaremos a continuación, lo cierto es que los compositores en nuestro país no mostraron, en general, una excesiva preocupación por los aspectos teóricos relacionados con la música de cine.

Las particularidades asociadas a la técnica de composición fueron, rápidamente, asimiladas de los grandes maestros de Hollywood a través de sus películas. Tan solo Joaquín Turina, y a cierta distancia, Jesús García Leoz, Duran Alemany, Rafael Martínez y Ruiz de Azagra, mostraron interés por los aspectos de reflexión teórica asociados a la música de cine. Del resto, podemos afirmar, que se consideran a sí mismos, artesanos de un oficio: compositor de música de cine. Este es el caso de Juan Quintero Muñoz, que supo asimilar la técnica y conjugarla con un innato talento para la melodía y el dramatismo que le valieron el respeto y reconocimiento del resto de profesionales de la música y del mundo del cine.

A diferencia de Adorno y Eisler, los autores españoles no se adentran en un análisis profundo y analítico de los problemas relacionados con la música de cine, sino que tan solo se plantean cuestiones prácticas y en el mejor de los casos se da alguna solución ellas.

Como ya hemos comentado en otro momento, el gran teórico de la música de cine en nuestro país es, Joaquín Turina. A lo largo de una serie de escritos publicados en periódicos y revistas ${ }^{226}$, reflexiona sobre la música cinematográfica desde distintas

\footnotetext{
${ }^{225}$ Entrevista con Francisca Martos, Madrid, 16 de marzo de 1999.

226 "La música en el cinematógrafo», El Debate, 22 de julio de 1927.

«La música en el cinematógrafo», El Debate, 5 de septiembre de 1928.

«El «cine» parlante», El Debate, 11 de agosto de 1929.

"En torno al problema de la música cinematográfica», Revista Nacional de Educación, año II, 1ª época, núm. 15, marzo de 1942, pp.67-70.

«Música de cine», Dígame, 6 de octubre de 1942.

"Cosas de cine», Dígame, 5 de septiembre de 1944.

"Cosas de cine y otras cosas», Dígame, 13 de febrero de 1945.

«El pinar cinematográfico», Dígame, 30 de julio de 1946.
} 
perspectivas. Desde la creación de un nuevo lenguaje musical más adecuado para el nuevo medio (pero sin decantarse por uno en concreto como hacen los autores alemanes), pasando por los problemas planteados en las mezclas de sonido y el poco respeto que hacia la obra del compositor se suele tener durante este proceso, hasta ahondar en la necesaria implicación del compositor en un porcentaje mayor del proceso de creación de la obra, como lo hacen los guionistas, directores de fotografía o los diseñadores artísticos. Tal vez una de las ideas principales y más visionarias propuestas por el músico sevillano es sin lugar a dudas la inclusión de la disciplina de música para cine en los conservatorios, como asignatura fundamental para una buena formación y preparación de los músicos para este medio, algo que en tan solo unos pocos conservatorios del país se ha puesto en marcha hace unos pocos años con fuertes y nada desdeñables deficiencias.

Así, pues, el maestro afirma que:

"Es preciso, pues, reglamentar la música para el cine con nuevos preceptos, con nuevos derroteros, ya que ni las formas sinfónicas, ni las dramáticas, se ajustan a su manera de ser. Ya comprendo yo que hay en las películas, como en las óperas, escenas en las que no ocurre nada y en que, por lo mismo, se concede gran libertad al músico. Pensando en ello, vamos a buscar una escala que, en proporción ascendente, nos muestre el panorama sonoro.

Escribir un fondo constituye lo más fácil para el compositor. La música podrá estar más o menos de acuerdo con el asunto, pero puede llevar una estructura sinfónica y gozar de mayor libertad, sin más contratiempo que los ruidos. Ya comprenderá el lector que esto de los ruidos es otra mentira muy grande, lo cual no quita para que estropee por completo un trozo sinfónico el trote de un caballo, el motor de un coche o los pitidos de una locomotora. Siguen, a continuación, los movimientos rítmicos, que deben ir subrayados por la música. Aquí se llega a la más completa exageración, haciendo del ritmo musical algo automático, mecánico y seco. Hasta un simple gesto se marca con un acento sonoro, rígido, que quita flexibilidad a la música. En cuestiones rítmicas hay que respetar, naturalmente, cuanto se refiere a danzas y escenas coreográficas. En este sentido he visto hacer maravillas en una película española, pero procediendo al revés, esto es, adaptando los movimientos de la pantalla a la música. ${ }^{227 "}$

Pero al igual que London ${ }^{228}$, Turina llama la atención sobre la instrumentalización de la música de cine como medio para obtener beneficios económicos. El compositor sevillano es consciente plenamente de esta situación cuando la describe con estas palabras:

\footnotetext{
"La música en el cine», Dígame, 10 de septiembre de 1946.

"El bandolero y los bailarines», Dígame, 17 de septiembre de 1946.

"“Cosas del cine, don Gabriel"), Dígame, 29 de septiembre de 1947.

Citados en, Colón Perales, C. (1984) La música cinematográfica de Joaquín Turina, Separata del «Boletín de Bellas Artes» $2^{a}$ época, núm. XII, Sevilla, Real Academia de Bellas Artes de Santa Isabel de Hungría, pp. 39-54.

${ }^{227}$ TURINA, J. «La música en el cinematógrafo», El Debate, 22 de julio de 1927.

${ }^{228}$ London, K. (1970) Film music, London, Faber and Faber.
} 
"Por regla general, las películas tienen corta vida, pero gran divulgación. La música está en ella tan arrumbada que la mencionan detrás del último tramoyista y lo críticos ni siquiera la nombran. No obstante, los compositores y profesores de orquesta se matan por meterse en un estudio de cine. $Y$ esto ¿por qué?; pues porque es un negocio estupendo. La música de cine deja de pertenecer a las bellas artes para convertirse en un objeto de puro comercio. Este es el terrible problema, no ya español, sino mundial. ${ }^{229 ",}$

Otro gran maestro de la composición y discípulo predilecto de don Manuel de Falla, Ernesto Halffter, tío de Cristóbal Halffter, también trabajó para el cine aunque no llegó a escribir sobre el tema. Eso sí, podemos encontrar algunas entrevistas realizadas al compositor con motivo del estreno de los proyectos cinematográficos en los que participó. En ellas transciende el interés de Halffter por un medio de experimentación tan bueno como era el cine para él.

"Yo siempre he sentido una gran atracción por el cine. He visto una serie de posibilidades y de experiencias que la llamada música de fondo en el cinema nos puede proporcionar... la música en el cine no es un género inferior. Puede y debe ser tan buena como la música sinfónica ${ }^{230 " .}$

Halffter continúa diciendo:

¿... todavía no nos hemos dado cuenta de las enormes posibilidades que el cine a abierto a la música,... porque el compositor ha encontrado en el cine una serie de vías de expresión que no tiene fuera del cine. Una especie de campo de ensayo. "Yo he conseguido efectos que tenía en mi mente, pero que no encontraban acomodo en una partitura fuera del lenguaje cinematográfico, es decir, en el lenguaje musical cinematográfico he encontrado la clave exacta para expresar lo que yo sentía y quería expresar, pero no encontraba acomodo. He tenido ocasión de probar mis propias ideas en la música que he compuesto para las películas, y por tanto de corregirme; porque unas veces me sirvió para ver que estaba en el buen camino (que la idea era buena y merecía desarrollarla) y otras veces, estaba cerca pero no era eso exactamente.. ${ }^{231 "}$

El entusiasmo del maestro Halffter hacia la música de cine fue corroborada en la entrevista que mantuvimos con su hijo, cuando éste nos contó lo feliz que era su padre trabajando para el cine:

“... le gustaba mucho, se encontraba muy a gusto hablando con profesionales del medio ${ }^{232}$ “

A pesar de encontrarnos con estos dos casos bien significativos, lo cierto es que pocos son los compositores clásicos que durante este periodo se sintieron atraídos por la música de cine. Años más tarde, una nueva generación de músicos, como Antón García

\footnotetext{
${ }^{229}$ TURINA, J. «Música de cine». Dígame, 6-X-1942.

230 "La personalidad musical de Ernesto Halffter». Sin firmar.

${ }^{231}$ Entrevista con Manuel Halffter, Madrid, 18 de febrero de 1999.

${ }^{232}$ Ibídem.
} 
Abril o Carmelo Bernaola trabajaron activamente poniendo música a películas, pero a pesar de ello, el mismo García Abril es reacio a hablar de este periodo de su carrera.

Otros compositores cinematográficos como fueron Ruiz de Azagra y Durán Alemany reivindicaron vivamente su labor para el cine y la importancia que esta disciplina podía ejercer sobre la producción final. Son significativas las palabras de Azagra cuando declara a RadioCinema que:

"El autor de canciones - explica- es el artífice que adorna con sus encajes musicales el rodaje de la película, y el autor de la música de fondo es parte integrante de los cimientos que sostienen la producción -y su confección-, es una labor ingrata y anónima, a la que no todos le dan la importancia que en realidad tiene. ${ }^{233}$,

Cinco años más tarde, el músico seguirá quejándose de esta circunstancia:

“...hasta ahora no se le ha dado toda la importancia que merece a la música de las películas, y se le ha regateado el aspecto, económico. perjudicando con ello la calidad de la sincronización. El caso es que en España hay autores que pueden hacer las cosas tan bien como puedan hacerlo los ingleses o los americanos. Ahora bien, lo que hace falta es que nos encarguen las cosas con tiempo y no nos obliguen a hacer la música de una película en cuatro días. ${ }^{234 \text { “ }}$

Por otro lado, su compañero y amigo, Durán Alemany, autor muy popular a principios de la década de los cuarenta, reflexiona sobre el mismo tema a la vez que hace una meditación de la importancia que las canciones tienen en la comercialización de una película.

“...la música influye mucho en el éxito de una película, tanto si es de tipo musical como si no lo es - y prosigue diciendo que,- en la película musical pueden ser las canciones o bailables, etc., lo que dé el éxito a la película; pero hay que tener en cuenta que las situaciones musicales tienen que ser bien llevadas, o si no, ya no lo encuentra lógico el público - para acabar concluyendo que.- puede ayudar al éxito de una película una buena música de fondo, no mucha ni muy densa, pero que subraye adecuadamente las situaciones de las escenas. Nada de poner música porque sí o porque una escena es larga. Aquí opino que tiene que tener completa libertad el músico, incluso más que el director, puesto que el director ve la película en literatura y el músico la ve más en público, o sea que se da más cuenta de la situación a comentar musicalmente. ${ }^{235,}$

Por otro lado, en RadioCinema acaba haciendo un llamamiento a la industria para que tomen en mayor consideración la labor de escribir música para cine:

“...hay que convencer a los productores para que no pongan obstáculos a nuestra labor, pues la música en el Cine es más importante de lo que parece.

\footnotetext{
${ }^{233}$ RadioCinema, año IV, número 80. 30 de septiembre de 1942.

${ }^{234}$ RadioCinema, año VIII, NN130. 1 de diciembre de 1946

${ }^{235}$ RadioCinema, año V, número 89. 30 de junio de 1943.
} 
Vea, vea la importancia en "Luz de gas»), en "La octava mujer de Barba Azulı.... 236 ",

Por su parte, Jesús García Leoz que había sido un músico presente en los ámbitos intelectuales de la República, en los que trabó amistad profunda, por ejemplo, con Rafael Alberti, vivió la guerra en Madrid y participó en las actividades de la Alianza de Intelectuales Antifascistas ${ }^{237}$, lo que le produjo algunos serios problemas al término de la Guerra Civil, realiza un retrato claro de la evolución de la música para la pantalla durante los años treinta y cuarenta así como un análisis de cómo debe ser la música para la imagen fílmica. En una conversación mantenida con el conocido periodista Castán Palomar, el maestro recuerda que:

"En principio -refiriéndose a los comienzos del cine sonoro en España,- existía una pueril inquietud por concertar los ruidos que correspondían a la acción. Esto era un tanto ingenuo, pero hubiera parecido una torpeza no estar atento a esas ruidosas peripecias de la película. Ahora, la música se ha hecho más independiente. Esto no quiere decir que se prescinda de la imagen. Sería absurdo. Pero hay que procurar que la música tenga valor propio y que no se quede en mero acompañamiento. Es más, a veces conviene que la música esté en contradicción con la imagen; de ese contraste pueden surgir efectos muy eficaces; así por ejemplo, una música superficial, en determinado instante, puede reforzar la emoción de un pasaje dramático. ${ }^{238 ”}$

En otro artículo publicado en Cámara, García Leoz expresa su opinión acerca de la gran facultad que tiene la música para transmitir sentimientos:

"El papel de la música, en el conjunto de cosas que constituye una película, es algo tan sutil, que sólo si faltara se notaría su trascendencia: la película sería insoportable. También acusa el espectador la presencia de la música si ésta es un desacierto. Pero estando bien, parece un hecho tan natural que ocupados los sentidos en la contemplación de las imágenes o en la audición de los diálogos, la presencia constante (de la melodía es ya un hecho desvaído, fuera del análisis. Hace falta como el celuloide, y eso se da por descontado. Es como cuando pide usted langosta a la americana: juzga el pescado, la salsa y el guiso, pero no comenta que hacen falta muelas y saliva para digerir. Sin embargo, aunque haya puesto unos ejemplos demasiado..., ¿cómo diría yo?, demasiado "orgánicos», la música de cine no sólo es una técnica, sino un arte pleno en el que cabe la obra creadora del más inspirado artista. $^{239 ",}$

Preguntado por las características que debe tener la música de cine, García Lehoz responde:

\footnotetext{
${ }^{236}$ A. «Música. Juan Durán Alemany», en RacioCinema, año V, número 93. 30 de octubre de 1943.

${ }^{237}$ P.O. «García Leoz, el gran músico de Olite, rescatado», en Diario de Navarra. Domingo, 17 de diciembre de 1995. pp. 60-61.

${ }^{238}$ Castán Palomar. F. «García-Leoz: Evolución de la música cinematográfica en veinte años de películas sonoras». Primer Plano, año $\mathrm{XI}$, número 577.

${ }^{239}$ GARCía LeOZ, J. (1946) «Como se hace la partitura de una película», en Primer Plano, año VII, número 315,27 de octubre de 1946 .
} 
"Dos principalmente, como en el teatro, aunque en el cine más acusadas: la primera, que la melodía ha de expresar la psicología del personaje, e incluso dar a entender lo que pasa dentro de él; la segunda, que ha de subrayar las situaciones dándoles de este modo su pleno sentido dramático o su gracia en plenitud expresiva. Así se hace, y la gente se ha habituado a ello de un modo natural.

¡Imagínese lo que sería la misma escena sin música! Pienso en la diferencia que va de un hombre enfurecido que levanta el puño y lo descarga sobre otro, a la misma acción acompañada por una melodía en crescendo terminada en un fortísimo,cortado en seco -y lo hablo un lenguaje extramusical para mejor comprensión-. Así se hace, repito, y sólo si faltara o estuviera mal, lo advertiría, para valorarlo negativamente, el público ${ }^{240 " . ~}$

Por último, plantea una estética de la música de cine, con un lenguaje moderno, sin copiar a los clásicos, dando origen a un estilo de género y forma musical específica para el cine. De este modo, a la pregunta de ¿cómo cree que debe ser la música cinematográfica? Contesta:

"Yo creo que debe ser una música moderna con todas las inquietudes y la, conquistas que la música ha logrado en nuestros días. Por ejemplo: Son modelo de músicas cinematográficas las escritos por Newman para Concierto macabro241 y La canción de Bernadette, y la de Rozsa para Recuerda. ${ }^{242 "}$ También "entiendo -sigue diciendo Leoz- que un músico bien dotado y formado, con criterios musicales de esta época, puede realizar plenamente en el cine toda su obra, toda su ambición vocacional, El cine ofrece a la inspiración del músico un campo mucho más amplio que el tan convencional del teatro. En el cine, la música no ha de servir al esquema rígidamente sonoro de la voz humana y a una acción limitada a desenvolverse en el reducido y falso mundo de un escenario. En un film de calidad, el músico tiene amplio campo para que su inspiración pueda alcanzar todos los variados matices de una verdadera sinfonía.

Música bucólica, dramática, lírica, descriptiva, simbólica... Soy un poco enemigo de la música de programa o literaria. Pero en el cine es muy distinto. Alli, quien explica todo es la Imagen que entra por los ojos. Y, por tanto, la música no tiene que explicar, sino subrayar, evocar, intensificar una emoción, expresar pensamientos de los personajes más que hechos. Preparar el clima espiritual del espectador..." Acaba reexponiendo que "es algo esencial, y cada día lo será más -replica vivamente Leoz-. Y conste que no hablo de las operetas fotografiadas, de que tanto se ha abusado desde la perfección de la sonoridad. Eso no es cine, sino otra cosa. Hablo de las películas dramáticas o divertidas; pero en el mejor sentido. La música, a mi entender, ha de decir, a veces, lo que un personaje no conviene que diga con la palabra y ha de

\footnotetext{
${ }^{240}$ Ibídem.

${ }^{241}$ Concierto Macabro (Hanovert Square) fue compuesta por Bernard Herrmann y no por Newman como afirma Leoz.

242 «La música en el cine para 1947», en RadioCinema, año VIII, №130. 1 de diciembre de 1946.
} 
conseguir evocar o enunciar el tema ambiental que el personaje o la acción requieren. Una cosa es esencial a la partitura cinematográfica. Esta puede tener los mismos valores musicales que una partitura sinfónica, con tal de que estos valores hayan sido concebidos y logrados al servicio de la imagen y no independientes de ella. En este sentido, yo cada día procuro dar al cine una música muy cinematográfica; pero con mayor hondura y más pureza. ${ }^{243 ،}$

${ }^{243}$ ANTÓN CABEZAS, J. «La música como elemento expresivo de la imagen» en CÁMARA, año VII, Nº97. 15 de enero de 1947. 
CAPÍTULO 5

LOS COMPOSITORES EN EL CINE ESPAÑOL 


\section{Tipologías musicales en las películas}

Una de las cuestiones que más suscita nuestro interés está relacionada estrechamente con la actividad que los músicos llegaron a desempeñar en la cadena de producción de la banda sonora, la naturaleza de la labor que realizaron y las limitaciones tecnológicas en la que ésta se desarrolló.

Algo, aparentemente, tan sencillo como definir cuál fue la actividad que desempeñó cada uno de los músicos y las diversas tipologías musicales presentes en cada película se torna en la actualidad un verdadero rompecabezas. Según los datos aportados por la Filmoteca Nacional ${ }^{244}$, en el apartado musical aparecer las siguientes funciones ${ }^{245}$ :

- $\quad$ Música de fondo, define la labor de componer la música original (o adaptada) de la película en general.

- Música y canciones, abarcaría la labor de componer la música de fondo más la partitura de las canciones que pudiesen escucharse en el film.

- Canciones, define la labor de escribir la música de las canciones. En este apartado no entrarían los responsables de escribir la letra.

- Dirección musical, precisa la tarea del músico encargado de dirigir a la orquesta durante las sesiones de grabación de la música.

- Colaboración, hace alusión a aquellos compositores que ayudan a otro en la labor de componer una banda sonora. En este apartado no se incluyen aquellos compositores que en la sombra se encargaban de la orquestación y arreglos diversos.

Esta clasificación aparentemente correcta, presenta algunas imprecisiones ${ }^{246}$ ya que dentro del apartado de canciones se incluyen muchas veces a poetas, como Rafael de León que colaboró en numerosas ocasiones con el maestro López-Quiroga. Por esta razón, en el proceso de elaboración de nuestra base datos, tomamos la decisión de introducir en la clasificación, con el fin de completarla y distinguir, en la medida que nos fuese posible, a los letristas de los compositores. La no inclusión de estos músicos en el apartado "canciones" como habitualmente se hace, viene dada por la posibilidad que nos reporta la distinción

\footnotetext{
${ }^{244}$ Hueso, A. L. (coord..) (1998) Catálogo de cine español 1941-1950, Fuenlabrada (Madrid), Cátedra / Filmoteca Española.

${ }^{245}$ Por otro lado, también se deben de tener en cuenta los siguientes funciones que hemos incluido nosotros con la intención de definir con mayor exactitud la actividad de los compositores.

Letra, delimita a aquellos profesionales (poetas, directores, etc.) que escribieron el texto de las canciones.

Música o canciones, se utilizará para aquellos casos en que exista duda sobre cual ha sido la labor real de un compositor.

Autor adaptado, se aplicará a aquellos autores cuya obra sirva de referencia para la composición de la música de fondo.

${ }^{246}$ En nuestra opinión, sería necesario que la administración dotará de personal y presupuesto adecuado a las instituciones y organismos encargados de la salvaguarda del patrimonio cinematográfico para que éstas pudieran revisar los datos disponibles, con el fin de proporcionar una información fidedigna de la función que los compositores, directores musicales, colaboradores y orquestadores que colaboraron con ellos tuvieron en la banda sonora de las películas realizadas en la década de los cuarenta.
} 
mencionada ya que nos permite distinguir a aquellos compositores centrados en componer música de fondo, de aquellos cuya producción fue eminentemente lírica. Este es el caso del maestro López-Quiroga, que a pesar de componer numerosos fondos musicales, su labor y presencia en el cine es especialmente significativa por sus canciones.

En cuanto a las clasificaciones de colaboración y dirección musical, se han mantenido en nuestra base de datos, pero a la hora de elaborar gráficas y obtener conclusiones, nos hemos dado cuenta que tienen una escasísima incidencia, ya que tan solo encontramos un registro en dirección musical y dos en colaboraciones.

Por otro lado, hemos detectado también alguna incorrección en la base de datos CINEMEDIA ${ }^{247}$ respecto a la participación de determinados compositores en las películas de referencia. No se hace distinción entre Juan Quintero Muñoz y Antonio Quintero Ramírez, del trío "Quintero-León-Quiroga"; se presenta a Granados como autor de Goyescas (1942), cuando en realidad es un autor adaptado, igual que ocurre con El huésped del Sevillano (1940). En la mayoría de ocasiones se incluyen varios nombres pero no se especifica que función desempeñaron, etcétera.

Para corregir todos estos datos hemos tenido que realizar un cuidado seguimiento de la actividad de los compositores, en especial de los más importantes, contrastando la información con publicaciones de la época, fundamentalmente revistas y con los datos que muy amablemente nos facilitaron los distintos herederos con los que tuvimos ocasión de conversar.

Como ejemplo, mostramos el caso particular del compositor Manuel LópezQuiroga que supuso un problema serio a la hora de asignar la autoría en cada una de las películas para las que trabajó. A continuación se muestra una tabla en la que se pueden apreciar los datos proporcionados por Filmoteca Nacional, con respecto al compositor mencionado.

\begin{tabular}{lll}
\hline Año & Título & Función \\
\hline 1940 & & \\
\hline 1941 & La Dolores & Canciones \\
\hline & El crucero Baleares & \\
& Pepe Conde & Música Fondo \\
& Sol de Valencia & Música y Canciones \\
& Torbellino & Música Fondo \\
1942 & & Canciones \\
& Correo de indias & \\
& Danza de fuego & Canciones \\
& Goyescas & Música Fondo \\
& La blanca paloma & Música y Canciones \\
& La culpa del otro & Música y Canciones
\end{tabular}

${ }^{247}$ Huerta, C. (1997) Enciclopedia del Cine Español CINEMEDIA [CD-Rom]. Barcelona, Canal+, SGAE. 


\begin{tabular}{|c|c|c|}
\hline & Los misterios de Tánger & Canciones \\
\hline & Los misterios de Tánger & Música Fondo \\
\hline & Madrid de mis sueños & Música y Canciones \\
\hline \multicolumn{3}{|l|}{1943} \\
\hline & Canelita en Rama & Música y Canciones \\
\hline & El triunfo del amor & Música y Canciones \\
\hline & La patria chica & Música y Canciones \\
\hline \multicolumn{3}{|l|}{1944} \\
\hline & Lola Montes & Música Fondo \\
\hline & Macarena & Canciones \\
\hline \multicolumn{3}{|l|}{1946} \\
\hline & El crimen de Pepe Conde & Música y Canciones \\
\hline & Embrujo & Música y Canciones \\
\hline \multicolumn{3}{|l|}{1947} \\
\hline & La Lola se va a los puertos & Canciones \\
\hline & La princesa de los Ursinos & Canciones \\
\hline & María de los Reyes & Música Fondo \\
\hline & Oro y Marfil & Música Fondo \\
\hline & Serenata española & Música y Canciones \\
\hline \multicolumn{3}{|l|}{1948} \\
\hline & ¡Olé torero! & Música y Canciones \\
\hline & Brindis a Manolete & Canciones \\
\hline & Jalisco canta en Sevilla & Música y Canciones \\
\hline & La cigarra & Música y Canciones \\
\hline \multicolumn{3}{|l|}{1949} \\
\hline & Filigrana & Música y Canciones \\
\hline & La duquesa de Benamejí & Canciones \\
\hline & Rumbo & Música y Canciones \\
\hline & Vendaval & Canciones \\
\hline
\end{tabular}

Tabla 26: listado de películas en las que participó López-Quiroga durante la década de los cuarenta. Datos proporcionados por la Filmoteca Nacional

A primera vista parece todo correcto excepto la duplicidad de Los misterios de Tánger (1942) que aparece dos veces, una para especificar su autoría en la música incidental y otra para las canciones. La solución en este caso parece sencilla a primera vista, bastaría con unificar las dos actividades en el epígrafe Música y Canciones. Pero aquí no acaban los errores, ya que el maestro López-Quiroga aparecía como autor de la música de Goyescas, dato erróneo, pues la autoría de la misma correspondería al maestro Muñoz Molleda, que a su vez adaptó la ópera homónima del maestro Granados. A partir de ahí comenzamos a repasar una por una todas las producciones, tras lo cual, nos pusimos en contacto con el hijo del compositor para solicitarle algunas aclaraciones al respecto.

Nuestra solicitud de información fue atendida rápida y atentamente por Manuel López-Quiroga Cavero. Por la claridad y contundencia de la misma, presentamos aquí en 
su totalidad el correo electrónico que recibimos a modo de respuesta, y que nos fue de gran utilidad para corregir los errores existentes.

"Estimado Sr. Roldán:

Después de leer su e-mail he recordado perfectamente el contacto que mantuvimos hace años acerca de su trabajo de investigación sobre la música en el cine español de los años 40.

Referente a las consultas que me hace, paso a precisarle:

EMBRUJO.- La música de fondo de la película es de Jesús García Leoz. En este film se incluyeron las canciones de Quiroga tituladas "Los niños de la Gabriela", "Pepa Bandera", "La Buenaventura", "La Niña de Fuego", "La rosa nueva", "La Salvaora", "Tú a mi no me quieres" y "Tu boca".

SERENATA ESPAÑOLA.- Los datos que tenemos dicen que la música de fondo es de Albéniz y Quiroga, incluyéndose además las canciones de mi padre tituladas "Junto al río", "Ay, España mía", "Más que el tesoro del moro" y "Coplas de la alegría".

MADRID DE MIS SUEÑOS.- En esta nos aparecen como autores de la música de fondo García Leoz y Quiroga. Están incluídas las canciones de mi padre tituladas "Doña Manuela" y "Madrid de mis ensueños".

LOLA MONTES.- No tenemos información veraz sobre esta película. Si es cierto que hay una canción de mi padre con el mismo título, que Conchita Piquer hizo muy famosa.

LA DUQUESA DE BENAMEJI.- La música de fondo es de Juan Quintero Muñoz. Se incluyeron las canciones de Quiroga tituladas "Bandolera" y "Serranas".

SOL DE VALENCIA.- La música de fondo es de Vicente Quirós. Contiene varias canciones de Quiroga que no puedo precisar.

GOYESCAS.- La música de fondo es de Granados (prácticamente basada en su ópera del mismo título). Hay dos canciones de Quiroga que Imperio Argentina popularizó: "Ole, catapum" y "Maja y condesa".

LA PATRIA CHICA.- La música de fondo es de Quiroga. Además son suyas las canciones incluídas, que se titulan "Adios, Sevilla", "España, madre querida", "No creas en el queré", "Mi Virgen Macarena es morenita", "Olé", "Tanguillo" y "Sevillanas con jota".

MACARENA.- No tenemos datos de esta película.

LA CIGARRA.- Según nuestros datos la música de fondo es de Quiroga, si bien hay música argentina de Francisco Lomuto. Están incluídas las canciones de Quiroga tituladas: "Ay, qué risa", "Castillitos en el aire" y "Nana". 
VENDAVAL.- La música de fondo es de Quiroga. En la banda sonora se incluyen las canciones de Quiroga tituladas: "Ay, calle del Sacramento", "Soledad Montero", "Lorito real" y "Y sin embargo te quiero".

Espero que toda esta información le sea de utilidad y le agradeceré que, una vez termine su trabajo de investigación, que considero muy interesante, me envíe una copia que leeré con mucho gusto.

Muy atentamente

Manuel López-Quiroga y Clavero ${ }^{248 "}$

Como se puede observar, los datos aportados transmiten una gran seguridad, tanto por el tono empleado, como por la sinceridad por parte de nuestro interlocutor al reconocer, cuando carece de los datos solicitados, su desconocimiento. Así pues, consideramos la información facilitada por Manuel López-Quiroga Cavero como una fuente de mucha fiabilidad, pero a pesar de ello encontramos algunas incorrecciones. Una de ellas ya ha sido comentada, la música de la película Goyescas; otra a destacar es la autoría de la música de fondo para el filme, Vendaval (1949). Según la Filmoteca, la partitura corresponde a Jesús García-Leoz mientras que en este correo electrónico se nos asegura que la obra es de López-Quiroga. Después de varias consultas realizadas y tomando como referencia el catálogo completo del músico de Olite, llegamos al convencimiento de que la música de fondo de esta largometraje se puede asignar con un elevado grado de certeza a Jesús García-Leoz.

Una vez concluidas las pesquisas descritas, la tabla anterior quedó reformulada de la siguiente forma:

\begin{tabular}{|c|c|c|}
\hline Años & Título & Función \\
\hline \multicolumn{3}{|l|}{1940} \\
\hline & La Dolores & Canciones $^{249}$ \\
\hline \multicolumn{3}{|l|}{1941} \\
\hline & El crucero Baleares & Música Fondo \\
\hline & Pepe Conde & Música y Canciones \\
\hline & Sol de Valencia & Canciones $^{250}$ \\
\hline & Torbellino & Canciones $^{251}$ \\
\hline \multicolumn{3}{|l|}{1942} \\
\hline & Correo de indias & Canciones $^{252}$ \\
\hline & Danza de fuego & Música Fondo \\
\hline
\end{tabular}

\footnotetext{
${ }^{248}$ López-Quiroga y Clavero, M.”RE. Solicitud de información acerca del maestro López-Quiroga” [e-mail]. 27 de mayo de 2003. Respuesta a dudas planteaas.

${ }^{249}$ Música adaptada de Tomás Bretón

${ }^{250}$ Música incidental de Vicente Quirós

${ }^{251}$ Música incidental de Ruiz de Azagra

${ }^{252}$ Música incidental de Muñoz Molleda
} 


\begin{tabular}{|c|c|c|}
\hline & Goyescas & Canciones $^{253}$ \\
\hline & La blanca paloma & Música y Canciones \\
\hline & La culpa del otro & Canciones $^{254}$ \\
\hline & Los misterios de Tánger & Música y Canciones \\
\hline & Madrid de mis sueños & Canciones $^{255}$ \\
\hline \multicolumn{3}{|l|}{1945} \\
\hline & Canelita en Rama & Música y Canciones \\
\hline & El triunfo del amor & Música y Canciones \\
\hline & La patria chica & Música y Canciones ${ }^{256}$ \\
\hline \multicolumn{3}{|l|}{1944} \\
\hline & Lola Montes & Canciones $^{257}$ \\
\hline & Macarena & Canciones $^{258}$ \\
\hline \multicolumn{3}{|l|}{1946} \\
\hline & El crimen de Pepe Conde & Música y Canciones \\
\hline & Embrujo & Canciones $^{259}$ \\
\hline \multicolumn{3}{|l|}{1947} \\
\hline & La Lola se va a los puertos & Canciones $^{260}$ \\
\hline & La princesa de los Ursinos & Canciones \\
\hline & María de los reyes & Música Fondo 261 \\
\hline & Oro y Marfil & Música Fondo \\
\hline & Serenata española & Música y Canciones ${ }^{262}$ \\
\hline \multicolumn{3}{|l|}{1948} \\
\hline & ¡Olé torero! & Música y Canciones \\
\hline & Brindis a Manolete & Canciones $^{263}$ \\
\hline & Jalisco canta en Sevilla & Música y Canciones \\
\hline & La cigarra & Música y Canciones ${ }^{264}$ \\
\hline \multicolumn{3}{|l|}{1949} \\
\hline & Filigrana & Música y Canciones \\
\hline & La duquesa de Benamejí & Canciones ${ }^{265}$ \\
\hline
\end{tabular}

\footnotetext{
${ }^{253}$ Música inspirada en la Ópera del mismo nombre de Jacinto Guerrero. Adaptación y música incidental de Muñoz Molleda. Canciones de López-Quiroga.

${ }^{254}$ Música incidental de Ruiz de Azagra

${ }^{255}$ Música incidental de García Leoz (y según las informaciones en colaboración con López-Quiroga.

${ }^{256}$ Música inspirada en la obra de Ruperto Chapí

${ }^{257}$ Música incidental de Manuel Parada

${ }^{258}$ Música incidental de Halpern García y Gordillo Ladrón de Guevara.

${ }^{259}$ Música incidental de García Leoz

${ }^{260}$ Música incidental de Ruiz de Azagra

${ }^{261}$ Música incidental de López-Quiroga y Guzmán Merino

${ }^{262}$ Música de Albeniz, adaptada por López-Quiroga. (aparece como director de orquesta García Leoz. Podría ser también autor de la música de fondo)

${ }^{263}$ Música incidental de Muñoz Molleda

${ }^{264}$ Música incidental de López-Quiroga. También se escucha música argentina de Francisco Lomuto.

${ }^{265}$ Música incidental de Juan Quintero Muñoz
} 


\begin{tabular}{ll} 
Rumbo & Música y Canciones \\
Vendaval & Canciones $^{266}$ \\
\hline
\end{tabular}

Tabla 27 listado corregido de películas en las que participó López-Quiroga durante la década de los cuarenta [corregida].

De este modo, llegamos a corregir cuatro registros con información errónea. Sol de Valencia (1941), con música de García-Leoz y canciones de López-Quiroga, al igual que se confirmaba esta misma relación en Vendaval (1949); pasando a ser compositor de canciones únicamente en las películas Goyescas (1942) y Embrujo (1946).

Una vez realizadas estas correcciones, pudimos realizar las gráficas correspondientes a las actividades y tipologías musicales realizadas por los compositores en el cine español de los años cuarenta. Como se puede apreciar en la siguiente gráfica, el $75 \%$ de los compositores centraban su actividad en la realización de música incidental o de fondo. El $13 \%$ desempeñaban la labor de composición de canciones, bien porque escribieron canciones originariamente para cada película, bien porque los productores adquirieron canciones a los compositores para ser incluidas en un determinado filme. Tan solo el $9 \%$ conjuga las dos facetas y un $3 \%$ son autores adaptados, con nombres tan populares y conocidos como el ruso Rimsky-Korsakov en Sucedió en Damasco (1942), el alemán Franz Lizt en Su excelencia el mayordomo (1942), Enrique Granados en Goyescas (1942) y El huésped del Sevillano (1940), o Isaac Albéniz Serenata española (1947) y Sinfonía del hogar (1947) entre algunos otros.

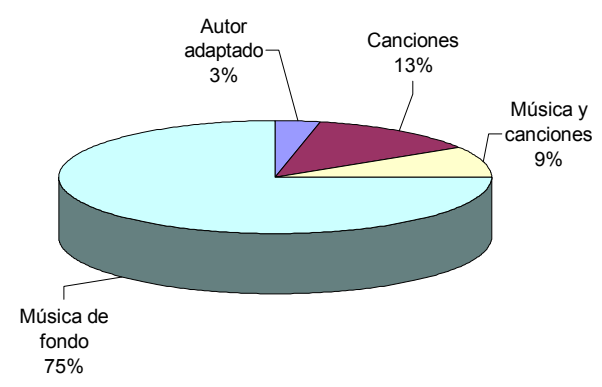

Gráfica 10: Actividad desempeñada por los compositores sobre la producción total (1939 a 1950)

Relación de compositores y actividad musical desempeñada

\footnotetext{
${ }^{266}$ Música incidental de García Leoz
} 
A continuación vamos a mostrar la relación completa de autores, tanto músicos como letristas, que trabajaron durante este periodo, indicando en la parte derecha, el número de obras realizadas en cada una de las funciones descritas anteriormente.

\begin{tabular}{|c|c|c|c|c|c|c|c|c|}
\hline Autor & 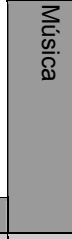 & 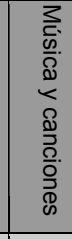 & 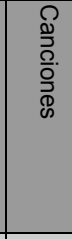 & 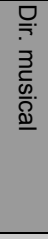 & $\begin{array}{l}\Omega \\
\frac{\delta}{\tilde{0}} \\
\frac{0}{0} \\
\frac{0}{0} \\
\frac{0}{0}\end{array}$ & $\begin{array}{l}\overline{0} \\
\overline{0} \\
0 \\
0 \\
0 \\
0 \\
0 \\
0 \\
0 \\
\overline{0} \\
\overline{0} \\
\overline{0} \\
\infty\end{array}$ & 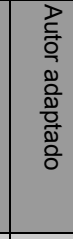 & 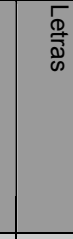 \\
\hline Cienfuegos & & & 1 & & & & & \\
\hline Marchiña & & & & & & 1 & & \\
\hline Matio & & & & & & 1 & & \\
\hline Palmita & & & 1 & & & & & \\
\hline Valerio & & & & & & & & 1 \\
\hline Aguilar, Santiago & & & & & & & & 3 \\
\hline Alar, Alberto & & & 1 & & & & & \\
\hline Albéniz, Isaac & & & & & & & 2 & \\
\hline Algueró Algueró, Augusto & & 1 & 1 & & & & & \\
\hline Algueró Dasca, Augusto & 2 & 2 & 1 & & & & & \\
\hline Alonso Misol, F. & & & & & & 1 & & \\
\hline Alonso Pesquera, José María & & & & & & 1 & & \\
\hline Alonso, Francisco & 2 & & & & & & & \\
\hline Álvarez García, Juan & 7 & & & & & & & \\
\hline Amadeus Mozart, Wolfgang & & & & & & & 2 & \\
\hline Anglás Gilabert, Antonio & & & & & & & & 2 \\
\hline Annovazzi, Napoleón & 2 & & & & & & & \\
\hline Arajol, Juan & 1 & & & & & & & \\
\hline Aredes, Segundo & & & 1 & & & & & \\
\hline Arniches, Carlos & & & & & & & & 1 \\
\hline Arribas, Fermín & & & & & & & & 1 \\
\hline Arrieta, Emilio & & & 1 & & & & & \\
\hline Aznar, Adolfo & & & & & & & & 1 \\
\hline Balcells Planas, José & 1 & & & & & & & \\
\hline Barbá, Rogelio & 1 & & & & & & & \\
\hline Beretti, Antonio & 1 & & & & & & & \\
\hline Bisbe Piqué, Joaquín & & & & & & & & 2 \\
\hline Bixio, Cesare Andrea & 1 & & & & & & & \\
\hline Blanco, Carlos & & & & & & & & 1 \\
\hline Bolaños Recio, Mariano & & & & & & & & 2 \\
\hline Bolaños Recio, Mariano & & & & & & & & \\
\hline Braña Martínez, Pedro & 5 & 1 & & & & & & \\
\hline Braña Martínez, Pedro & & & & & & & & \\
\hline Bretón, Tomás & & & 1 & & & & 2 & \\
\hline
\end{tabular}


CAPÍTULO 5: LOS COMPOSITORES EN EL CINE ESPAÑOL

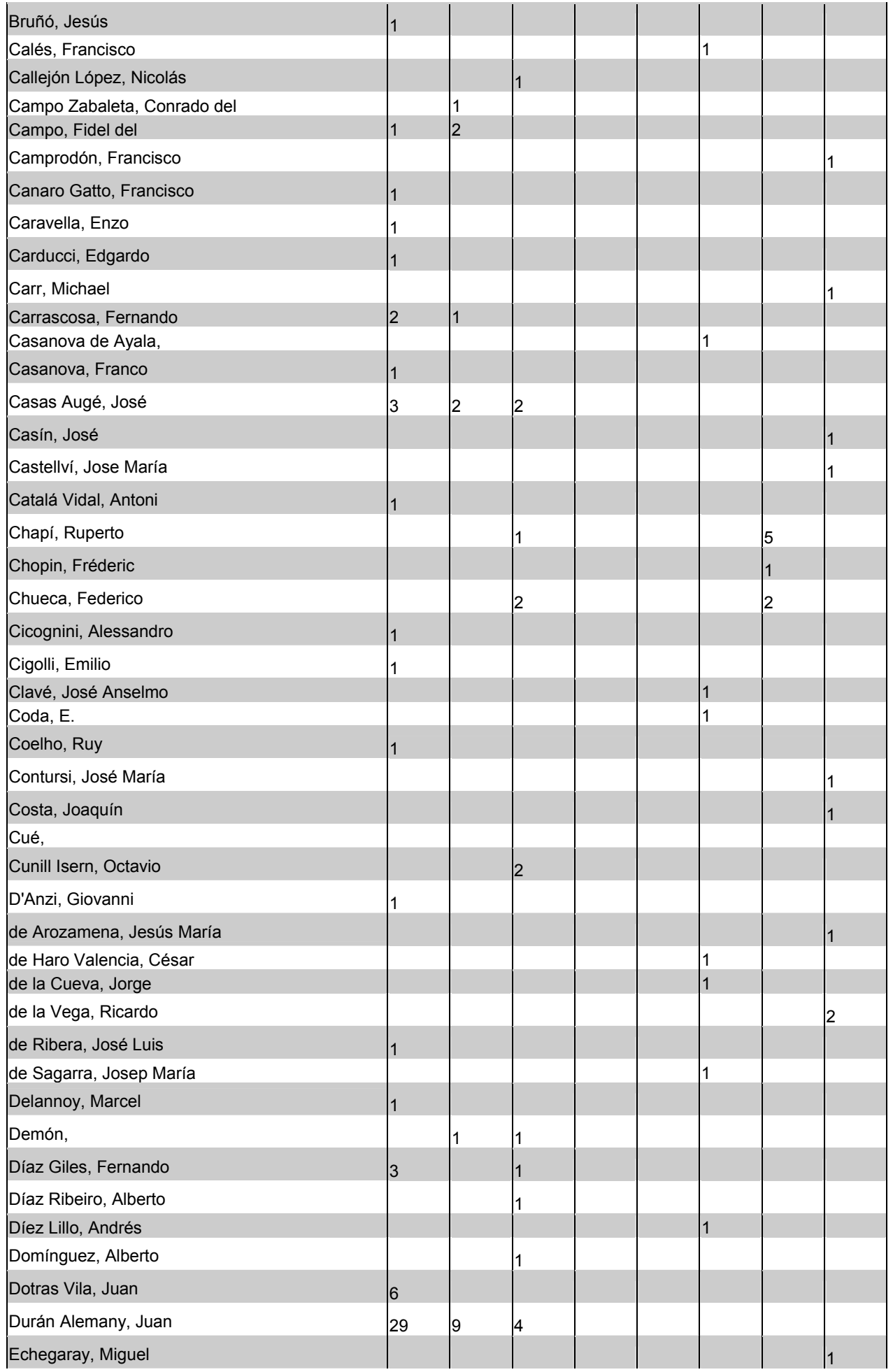




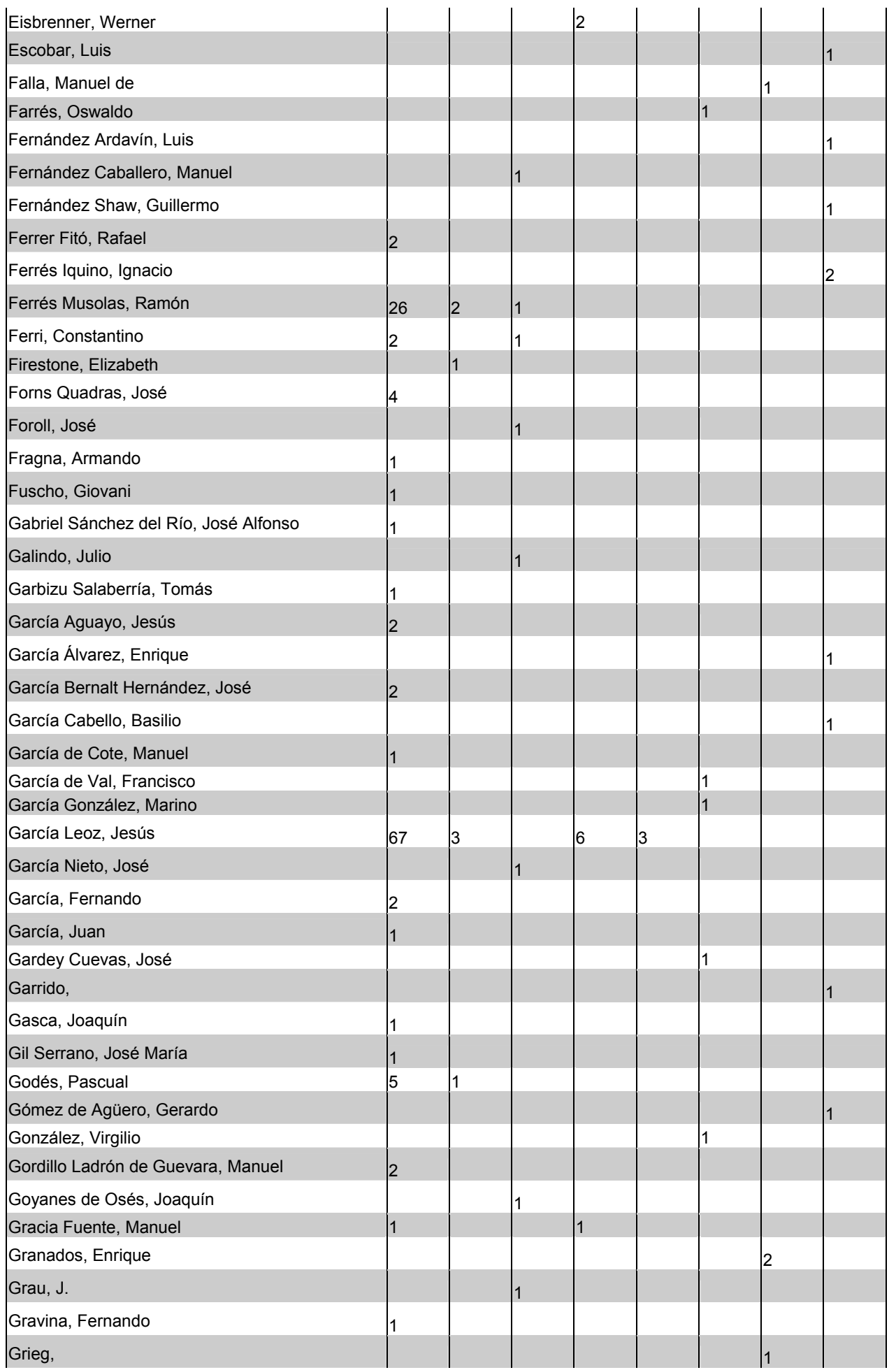


CAPÍTULO 5: LOS COMPOSITORES EN EL CINE ESPAÑOL

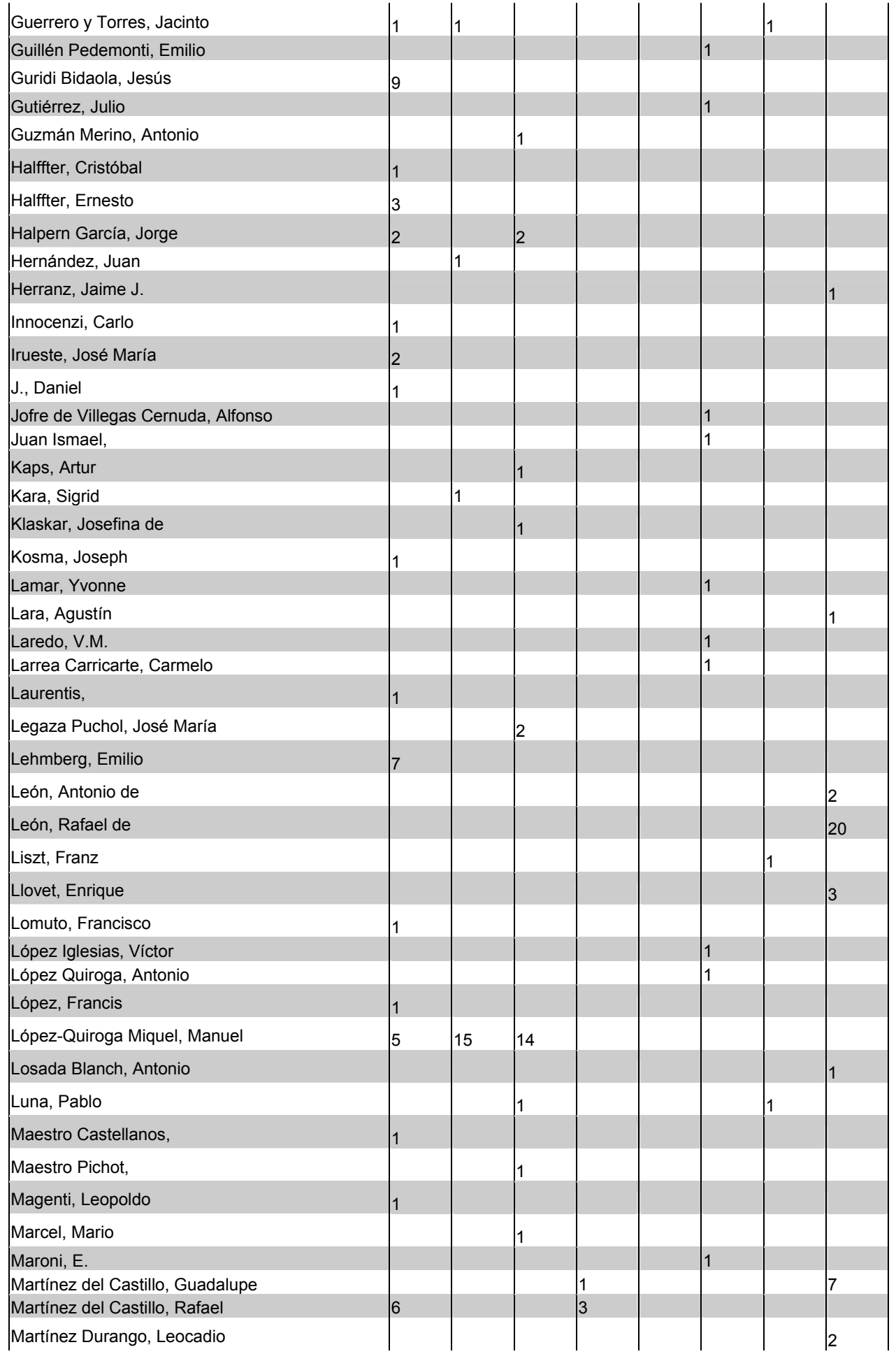




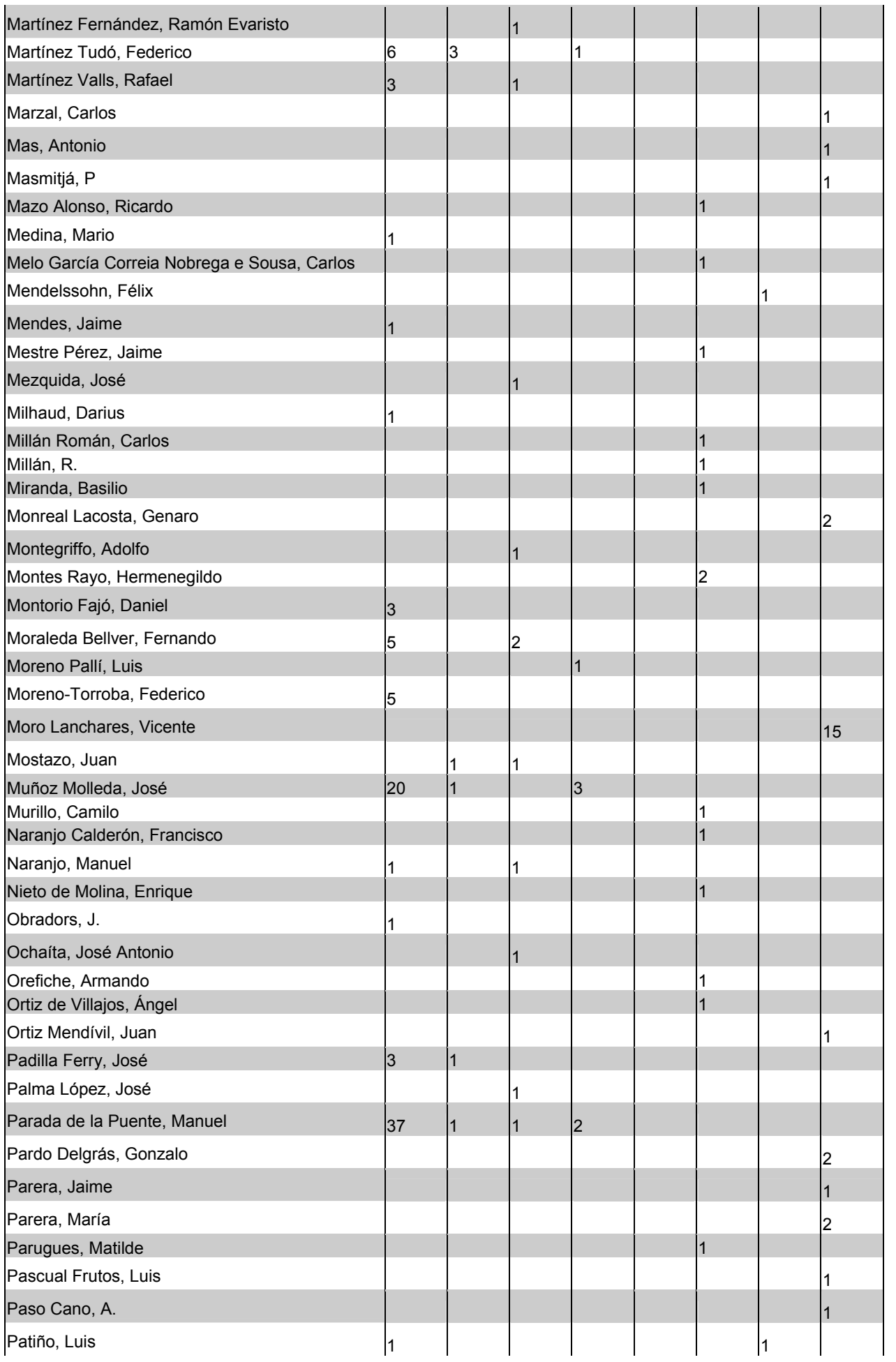


CAPÍTULO 5: LOS COMPOSITORES EN EL CINE ESPAÑOL

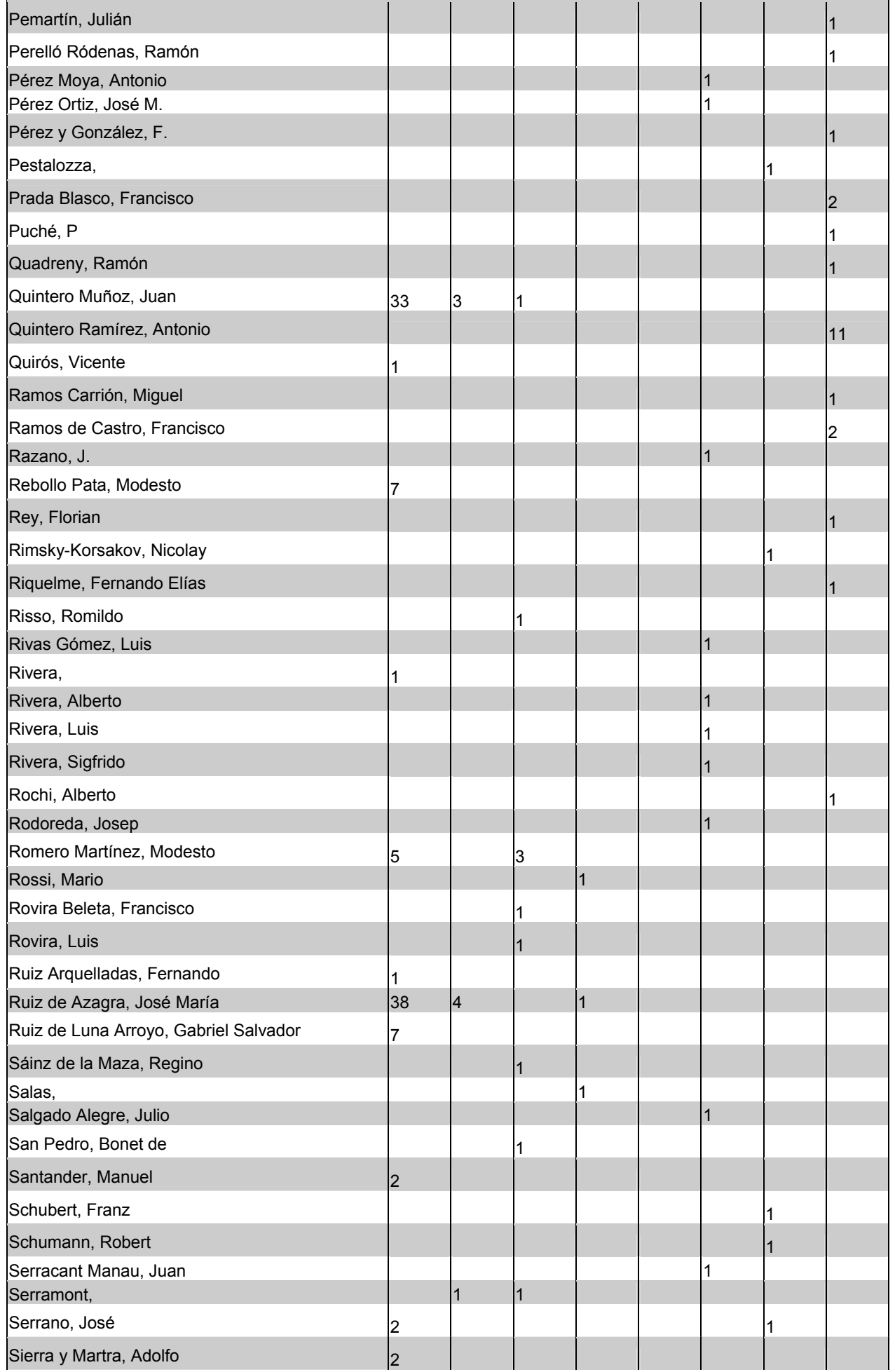




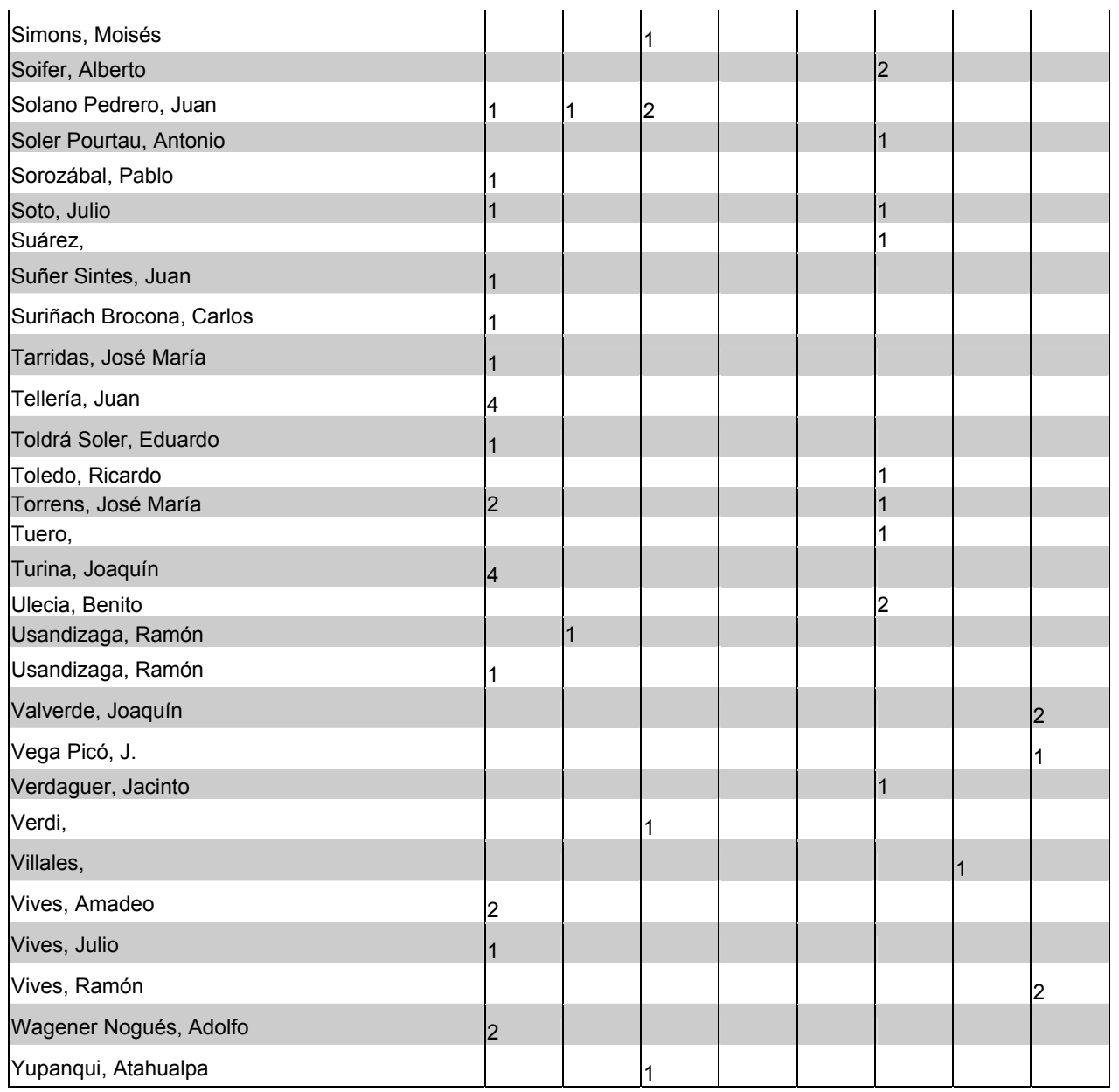

Tabla 28: Listado de autores con el número de producción realizadas y labor desempeñada

De la nómina completa, que asciende a 288 , tan solo 228 van a desempeñar actividad musical propiamente dicha. Los restantes 60 fueron letristas, poetas o directores de cine que participaron en la elaboración de alguna letra.

Sobre estos datos, se ha elaborado la siguiente gráfica en la que, con el fin de obtener unos porcentajes significativos en torno a los músicos que tuvieron una incidencia más activa en la música de cine de la década estudiada, hemos realizado la siguiente gráfica que nos permite observar la actividad desarrollada por aquellos músicos cuya producción superó las ocho películas. 


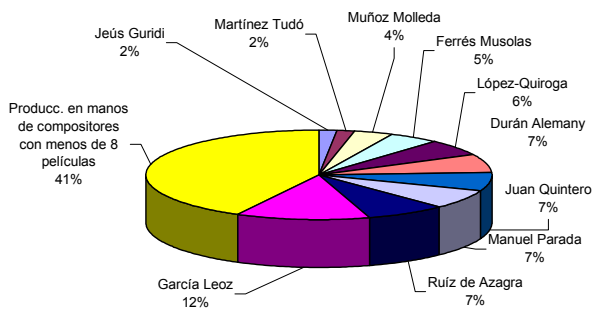

Gráfica 11: Compositores cuya producción es de ocho largometrajes o superior

En ella podemos apreciar que el $59 \%$ de la producción total fue encargada a tan solo diez compositores de los cuales, García-Leoz se muestra como el compositor con mayor número de partituras realizadas, un $12 \%$ del montante total, seguido de Ruiz de Azagra, Manuel Parada, Juan Quintero y Durán Alemany con un $7 \%$ cada uno. En una proporción menor, López-Quiroga, Ferrés Mussolas y Muñoz Molleda con un $6 \%, 5 \%$ y $4 \%$,cada uno de ellos; siendo tan solo de un $2 \%$ la producción de Jesus Guridi y Martínez Tudo respectivamente. El $41 \%$ restante recae en músicos cuya labor en el cine no resulta, por lo menos en este periodo, importante, con una producción menor a ocho títulos en los doce años considerados en nuestro estudio. Dentro de este sector, la proporción entre los compositores con una o más obras se puede visualizar en la gráfica siguiente.

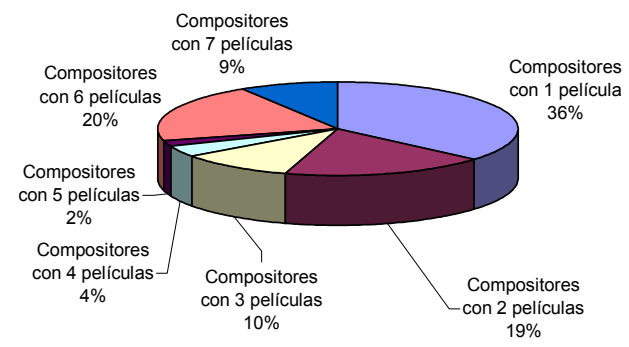

Gráfica 12: Compositores cuya producción es inferior a ocho largometrajes

La incursión por parte de músicos que no llegaran a mantener una relación estable o continua, con el cine es muy alta como podemos observar. El $55 \%$ del $41 \%$ del 
total pertenecen a este grupo ${ }^{267}$ mientras que los compositores con siete películas tan solo suponen un $9 \%$ del $41 \%$ del total.

De los datos obtenidos, podemos afirmar que la profesión de músico de cine estuvo acaparada por unos pocos compositores, García-Leoz, Ruiz de Azagra, Manuel Parada, Juan Quintero, Durán Alemany y López-Quiroga, que realmente tomaron la composición para el medio como una profesión, a la que dedicaron gran parte de su tiempo. La relación siguiente muestra estos compositores y las películas en las que trabajaron.

Pero, además de estos compositores que se especializaron en mayor o menor medida en la creación de música para la imagen, lo cierto es que durante la década de los cuarenta el ritmo de producción de la industria generó una gran demanda de música de cine, lo que creemos justifica el hecho de que numerosos compositores se pusieran a componer música para cine de forma eventual y anecdótica. Hemos mencionado que el $59 \%$ de la producción total recae en tan solo diez autores, mientras el $41 \%$ restante acabó en manos de compositores que podemos denominar casuales, ya que desarrollaron poca actividad relacionada con la música de cine. Estos datos ponen de manifiesto que muchos de los compositores que forman parte del $41 \%$ llegaron al cine por casualidad, por el afán de obtener beneficios económicos, o por pura casuística fraternal y familiar, es decir, como le ocurrió a Cristóbal Halffter:

"La razón de entrar en el cine la tuvo una tía carnal mía, la hermana de mi madre, que estaba casada con Luis Marquina, el director.

Por entonces era estudiante de música y él me propuso hacer la música de El capitán Veneno, propuesta que yo acepté encantado. ${ }^{268,}$

Esta situación es una circunstancia que se prolonga hasta nuestros días. El problema radica en los malos resultados obtenidos por unos músicos no profesionalizados y faltos de conocimientos y técnica.

Llegados a este punto debemos de realizar unas pequeñas matizaciones al respecto. Durante los primeros años del franquismo del ingente grupo de autores que se acercaron al cine de un modo fortuito, hubo un pequeño grupo de compositores de espléndida formación académica que se embarcaron en esta aventura con el suficiente éxito como para destacar y ser reconocido su trabajo a pesar de ser minoritario.

Algunos de ellos gozaban de un fuerte prestigio fuera de las pantallas como Jacinto Guerrero, Joaquín Turina o Ernesto Halffter. Este último, mantendrá con el cine una vinculación directa durante el resto de su vida, llegando a realizar la música para un número elevado de largometrajes y documentales, algunos de los cuales pasarán a la historia de nuestra cinematografía. A pesar de ello, el maestro Halffter, por ejemplo, fue duramente criticado por el trabajo realizado para Don Quijote de la Mancha (1947), obra que, si bien no

\footnotetext{
${ }^{267}$ En este grupo, a pesar de nuestros esfuerzos por subsanar el error, cabe la posibilidad de que haya nombres de letristas o poetas, pero en un porcentaje que consideramos más bien reducido. Como ya comentamos anteriormente, la información al respecto es confusa y difícil de cotejar, por lo que albergamos nuestras dudas sobre la fiabilidad exacta de estos datos finales, pero esperamos que en un futuro próximo se pueda llevar a cabo una ampliación de la investigación que de cómo resultado una aplicación cuyos contenidos sean definitivos en la medida de lo posible.

${ }^{268}$ Entrevista con Cristóbal Halffter, Madrid, 18 de marzo de 1999.
} 
resultó redonda lo cierto es que, denota un afán por la experimentación notable que no fue comprendido en su momento. Muestra de ello son sin duda las duras declaraciones de José Antonio Nieves Conde cuando recuerda las vicisitudes pasadas por el maestro Halffter en aquella ocasión:

"Don Quijote de la Mancha lo compuso su discípulo - se acababa de hablar de Manuel de Falla-, y hubo algún problema. Yo no intervine en esa película pero me lo contaron. Halffter tenía que sincronizar la música con la proyección. Se le pasaba el tiempo y no llegaba. Al final se puso nervioso y tuvieron que llamar a otro. ${ }^{269 "}$

Estas declaraciones no coinciden con las de don Manuel Halffter, hijo del aludido compositor, que si bien admite la existencia de algunos problemas, nos comenta que acabaron siendo resueltos:

"Alguna vez sí. Afortunadamente pocas y con buena solución, porque los directores eran personas comprensivas, flexibles, con una muy buena formación humanística y por lo tanto había posibilidad de dialogo. ${ }^{270 \text { " }}$

A nuestro entender, seguramente el maestro Halffter tuvo serios problemas con esta composición debidos a la complejidad de la obra pero dudamos seriamente que se llamara a otro compositor para terminar el trabajo de sincronización, máxime cuando hablamos de una primera figura cuya formación y capacitación no se pueden poner en duda, ya que no era la primera vez que trabajaba para el medio. Además el presupuesto debía ser, en aquellos momentos, muy ajustado para realizar un desembolso mayor contratando a otro músico. Por otro lado, según Ricardo Bayon, con quien conversamos en el año 1999, orquestador del maestro durante el trabajo de El Quijote, negó taxativamente las afirmaciones de Nieves Conde.

\section{Componer música para el cine en España}

Por los testimonios recogidos tanto en las entrevistas realizadas como en las revistas de la época, podemos afirmar que la labor de los compositores de música de cine, comenzaba ya con el guión cinematográfico antes de la realización del filme. De hecho, los compositores estaban inmersos en el proyecto desde el principio. Evidentemente, ninguno componía nada antes de ver el copión, pero sí iban creando y desarrollando el material temático, tímbrico y sonoro de la obra.

Según nos contó la viuda del Maestro Quintero, su marido:

“Él trabajaba primero con el guión, pero el trabajo más fuerte era cuando le mostraban el copión. Entonces había que afinar en todo con mucho cuidado.

[...]Muchas veces, cuando grabábamos, Juan me pedía que fuera con el

\footnotetext{
${ }^{269}$ Entrevista con José Antonio Nieves Conde, Madrid, 17 de marzo de 1999.

${ }^{270}$ Entrevista con Manuel Halffter, Madrid, 19 de marzo de 1999.
} 
ingeniero para ver si realmente sonaba lo que él quería, puesto que el ingeniero muchas veces no sabía el efecto que deseaba marcar Juan.

Por otro lado, la principal queja de Juan era del poco tiempo que le daban para componer. Había ocasiones en que tuvo que escribir una partitura en 15 días. Para él esto era muy poco tiempo porque se encargaba de todo, de componer, orquestar ensayar y dirigir la orquesta, sin olvidarnos de que también asistía a las mezclas. ${ }^{271}$ "

Manuel Halffter por su lado, en un segundo encuentro que mantuvimos con él, recordaba que su padre:

“... a medida que se iba metiendo en el argumento y valorando todas las posibilidades que podía ofrecer la trama desde el punto de vista musical, me acuerdo que hacía una selección de películas que se estuviesen exhibiendo en aquel momento e iba a verlas para ver como habian resuelto los problemas. Normalmente era películas americanas aunque también veía cine europeo, en especial francés o italiano. Todo esto lo hacía para documentarse ${ }^{272}$. Recuerdo que había dos compositores de cine que él

\footnotetext{
${ }^{271}$ lbídem.

${ }^{272}$ Estas declaraciones se convirtieron en un interrogante importante. Durante muchos años y hasta nuestros días, nos hemos dado cuenta de una curiosa circunstancia que se daba cuando veíamos películas clásicas norteamericanas y europeas de los años 30 y 40 por televisión, principal fuente de obtención de este tipo de cine para nosotros. Cuando visionábamos estas producciones en versión doblada nos dimos cuenta de la mutilación que la música y, por añadidura, el soundtrack sufría en el proceso de doblaje. Dicha mutilación se producía cuando los personajes hablaban. En ese momento la música y el sonido cambian radicalmente. El soundtrack se vuelve pobre, con pocos sonidos de fondo y muy localizados, con gran predominio del silencio, y con unos sonidos "artificiales". En cuanto a la música, cuando comenzaba el diálogo, ésta era modificada o cambiada, habiendo dos estilos en dicha manipulación del score original: en unos casos, la música era sustituida directamente por música clásica, con o sin sentido. Ejemplos de esto lo tenemos en El secreto tras la puerta de Frizt Lang, donde se sustituyó la magnífica música compuesta por Miklos Rozsa para los soliloquios de Joan Bennett, por el preludio del Tristán e Isolde de Richard Wagner, o en El fantasma y la señora Muir de Mankiewicz la música de Bernard Herrmann fue reemplazada por el Célebre adagio de Samuel Barber. Siguiendo una tónica similar, en películas como El sueño eterno de Howard Hawks, con música de Max Steiner, ésta se eliminó y se colocó en su lugar música de baile con ritmos jazzísticos.
}

El segundo modo de manipulación era mucho más elaborado, y consistía en reconstruir el score a partir de la música que se oía cuando los personajes no hablaban, es decir, se tomaba un fragmento anterior de la banda de audio y se repetía cuando comenzaban las disertaciones de los protagonistas, de este modo, se consigue una falsa ilusión, y menos dañina que la anterior, de continuidad musical. Ejemplos de este modelo son los doblajes realizados de Robín de los bosques de Michael Curtiz con música de Erich Wolfgang Korngold o parte del doblaje de Ciudadano Kane de Orson Wells con música de Bernard Herrmann.

La lista de títulos cuyas bandas sonoras fueron masacradas por los doblajes en España sería interminable. Por ello, nos sorprendió que los compositores españoles fuesen a ver como interactuaba la música narrativa y musicalmente en dichas películas cuando lo que oían era claro que no existía en su estado original. La respuesta a estas preguntas nos vino de la mano de Juan Mariné y su colaboradora, Concha Figueras, en la Escuela de Cine de la Comunidad de Madrid. Ella nos comentó que:

“... las distribuidoras lo que querían era gastar lo menos posible. Manipular les encantaba pero lo hacian en cosas fáciles como los títulos pero en sonido... ni se les ocurría..., los soundtracks se conservaban intactos y se hacía el doblaje encima." [José Luis Borau, entrevista, ver anexos]

Las razones planteadas por Mariné y Figueras nos parecieron razonables, por lo que tomamos una nueva hipótesis de interpretación. Los nuevos doblajes realizados por las televisiones, con la intención de actualizar dichos doblajes, no contaban con los soundtracks originales sino con el doblaje, donde la banda de sonidos y música no estaba separada de la de los diálogos, por lo que se debía recurrir a estas perversas estratagemas. Esto también explicaría que los compositores cinematográficos españoles fueran al cine a escuchar la música de las películas, puesto que realmente éstas sí conservaban el sonido original, pero nos surge otra duda: ¿hasta qué punto resulta rentable el redoblaje de casi la totalidad de películas de los años 40 y 50 importadas? Salvo en casos tan escandalosos de manipulación argumental como ocurrió con Mogambo de John Ford, no comprendemos hasta qué punto pudo ser justificable esta decisión, pero esto sería alejarnos de nuestro tema y dejamos abierto el interrogante para quien quiera tomar el relevo. 
admiraba mucho y que había películas que iba a ver más por ellos que por la trama en sí. Me refiero a Dimitri Tiomkin y George Antheil. Este último trabajó a las órdenes de Tiomkin como orquestador. Tiomkin le indicaba lo que quería y Antheil lo desarrollaba. Indudablemente, como la difusión y producción americana era mucho mayor que la europea en aquella época, por razones que todos conocemos, el número de ejemplos americanos de cómo se combinaba la música y la imagen era mayor que el europeo. ${ }^{273 "}$

Otro aspecto que no debe dejarse de lado son las declaraciones de Manuel Halffter sobre el modo de documentarse de su padre y que coinciden, en cuanto a modus operandis del compositor, con otros autores importantes de la época que solían ir al cine siempre y cuando se lo permitiese el trabajo y lo hacían, en su mayoría, para escuchar la música de sus compañeros de profesión, especialmente de los americanos, para asimilar y aprender la técnica que éstos empleaban. Según nos contaba en una conversación la viuda del maestro Quintero, a su marido:

"Le encantaba ver las películas americanas y fijarse en la música. Él lo que admiraba realmente eran los levmotives. El tema de amor, el del malo, el del bueno, etc. y luego cada uno de estos temas entraba en su momento concreto, cambiando constantemente la música. Y esto lo cogió muy bien, siendo una de las cosas que más gustaban de Juan" -siendo sus compositores favoritos-, "Max Steiner y Miklos Rozsa, entre otros muchos. ${ }^{274 "}$

José Antonio Nieves Conde, por su parte, nos amenizó relatándonos su colaboración con García Leoz en Balarrasa (1950):

“...se le pasaba un guión con las anotaciones pertinentes sobre la música.

Unas semanas más tarde nos reuníamos para hablar y ultimar los temas. La verdad es que se le daba muy poco tiempo. A Leoz esto no le preocupaba, pero durante el rodaje él ya sabía que es lo que iba a hacer. Venía a los rodajes, veía lo que se iba rodando. Y durante todo este tiempo iba trabajando. Por último, desde el momento en que se terminaba el copión hasta que se hacía el registro de la música se tenía una semana. Yo supongo que él ya lo tenía casi todo ultimado. ${ }^{275,}$

Estas afirmaciones son refrendadas por el maestro Leoz en varias entrevistas donde se le interroga sobre cómo se compone música para el cine. En una primera fase de preproducción, como afirmaba Nieves Conde, se trabajaba sobre el guión:

"Primero estudio un plan general con el guión: elijo los temas, los escribo libremente. Pero la labor del músico no empieza hasta que la película ha terminado de rodarse. A veces, la realización varía del guión proyectado; han

\footnotetext{
Por otra parte, no debemos tampoco olvidar, que, paralelamente a las industrias de producción y distribución, la industria del doblaje irá haciéndose un hueco importante en España, apoyada por una legislación que obligará, no solo a doblar las películas en español sino también a que dicho doblaje se realizara en nuestro territorio en la medida de lo posible.

${ }^{273}$ Tercer encuentro con Manuel Halffter, Madrid, verano de 1999.

${ }^{274}$ Entrevista con Francisca Martos, Madrid, 16 de marzo de 1999.

${ }^{275}$ Entrevista con José Antonio Nieves Conde, Madrid, el 17 de marzo de 1999.
} 
desaparecido escenas y han nacido otras, y lo más frecuente es la sorpresa de que determinados "planos» que leyendo el guión no tenían demasiado relieve, antes bien eran grises, luego, al realizarse, ganaron en belleza, alcanzaron una plasticidad que está pidiendo a voces música, mucha música y la mejor posible, y en cambio, se encuentra uno también sorprendido porque la escena que leída en el guión parecía relevante, luego, ya en imágenes, pierde el supuesto relieve. ${ }^{276 "}$

Durante este proceso, Leoz defiende el criterio que los músicos puedan tener para aportar nuevas ideas que repercutan en una mejora del film. Así en una entrevista publicada en Cámara afirmaba brevemente que:

"Si el autor del guión y el director logran un caudal de emociones visuales poesía para los ojos- el músico, según mi criterio, ha de conseguir efectos semejantes y equivalentes con su partitura ${ }^{277 "}$

Mientras que en Primer Plano se extendía más sobre esta cuestión:

"El músico, como todos los colaboradores, los intérpretes especialmente, puede proponer al director cuanto le parezca oportuno dentro de su colaboración. Si el director acepta la sugerencia, sin duda era buena y mejora la obra. Si, por ejemplo, hay una escena en que un automóvil va rodando por la carretera, y en el guión se señalaba como sonido el ruido del motor, al músico se lo puedo ocurrir que desaparezca ese ruido de motor, inexpresivo por vulgar, y su sustitución por unos compases rotundos y expresivos del drama moral que se está desarrollando dentro del coche, que el público, por el tema argumental, ya supone, y que osos compases musicales le afirman y aclaran definitivamente. Ahí tiene usted dos versiones sonoras de la misma escena, pobre la una, emocionante la otra, gracias a la música. ¡Ya ve usted si nosotros podemos aportar valores en la realización del cine cuando tenemos cariño e ilusión por él! ${ }^{278 ",}$

Una vez concluido el rodaje y realizado el copión, éste:

“... se proyecta rollo por rollo, y al término de la proyección se proponen los fondos y subrayados musicales. Los directores discuten, en general, poco. Se llega en seguida a un acuerdo. Entonces, el mismo rollo se pasa por la moviola para medir con precisión matemática la duración de cada escena ó fracción de escena. $Y$, entonces, ya no queda sino escribir. Luego, la partitura se registra mientras se proyecta la cinta, y con cuidado se logra que coincida en todo. ${ }^{279 \text { “ }}$

\footnotetext{
${ }^{276}$ GARCía LEOZ, (1946) «Como se hace una partitura para una película», en Primer Plano, año VII, núm. 315. Madrid, 27 de octubre de 1946.

${ }^{277}$ ANTÓN CABEZAS, J. «La música como complemento expresivo de la imagen» CÁMARA, año VII, Nº97. 15 de enero de 1947.

${ }^{278}$ GARCía LEOZ, (1946) "Como se hace una partitura para una película», en Primer Plano, año VII, núm. 315. Madrid, 27 de octubre de 1946.

${ }^{279}$ Ibídem.
} 
Por último, el compositor recuerda que su trabajo, aunque le apasiona, es muy duro y debe ser constante para poder realizar una buena labor y llegar a ser un profesional.

"A mí me gusta escribir música, y no me parece duro. Ahora, eso sí, hay que trabajar mucho; hay que consagrar la vida a la tarea. Yo trabajo todos los días. Madrugo. A las ocho de la mañana estoy componiendo y laboro intensamente hasta la tarde, hasta la hora de almorzar. Después alterno el trabajo con los deberes sociales y las expansiones. [...] Un profesional no puedo esperar a ver si la inspiración sopla o no. Hay que trabajar todos los días, y mucho. ¡Qué duda cabe de que tiros se está más inspirado que otros! Pero lo fundamental es ponerse a la labor. Las musas vienen pocas veces a buscarle a uno; en cambio, si se las llama con tenacidad son más asequibles y frecuentes, acaban por medio convivir con nosotros. Creadme: en la obra de un artista, incluyendo la inspiración, naturalmente, hay mucho de oficio. ${ }^{280 ",}$

En este sentido, consideramos necesario ahondar en un aspecto que pasa desapercibido, se trata de la existencia y vinculación de hombres en la sombra que trabajaban codo con codo para los compositores. Nos referimos a los orquestadores. $\mathrm{Si}$ bien hay músicos que no conciben realizar una obra y que la orqueste otro músico, como le ocurría a García Leoz o Cristóbal Halffter ${ }^{281}$, lo cierto es que la fuerte demanda de trabajo que algunos profesionales llegaron a tener hacía necesaria la colaboración de manos expertas que aligeraran la labor del maestro. Estos hombres normalmente realizaban tareas de orquestación y arreglos en función de las órdenes recibidas por los compositores responsables. En otros casos, llegaban a ser ellos mismos los que realizaban el trabajo aunque la "gloria" se la llevaran otros. En su entrevista, José Antonio Nieves Conde denomina a estos músicos como "prácticos", término que nos parece muy apropiado y que hemos asimilado.

\section{Los compositores y los prácticos}

Durante nuestra investigación, tuvimos el placer de conocer y entablar una conversación $^{282}$ con Ricardo Bayon, reputado arreglista, orquestador y compositor de nuestro cine. Olvidado en la actualidad, este hombre trabajó con los mejores músicos de nuestro cine, desde Manuel Parada hasta Antón García Abril o Ernesto Halffter. Ricardo Bayon es un claro ejemplo de práctico del cine español. Como el resto de profesionales que trabajaron a la sombra de otros compositores, a pesar arreglar y orquestar la partituras para el día de la grabación, rara fue la ocasión en que estos músicos llegaron a ser acreditados. Ni siquiera Bayon, con el gran prestigio que llegó a alcanzar tuvo tal reconocimiento, algo

\footnotetext{
${ }^{280}$ García LeOZ, (1946) «Como se hace una partitura para una película», en Primer Plano, año VII, núm. 315. Madrid, 27 de octubre de 1946.

281 “... la orquestación siempre la he hecho yo, no concibo que la haga otro." [Entrevista con Cristóbal Halffter, Madrid, 18 de marzo de 1999].

${ }^{282}$ Esta entrevista no ha sido transcrita por tratarse de una conversación informal, con giros constantes en el hilo conductor, lo que hace muy difícil su comprensión. Más adelante no negamos la posibilidad de llegar a realizar tal transcripción para que quede constancia de todas las anécdotas y situaciones que nos contó.
} 
que puede sorprender si tenemos en cuenta que este hombre llegó a trabajar no solo con los mejores de nuestro país sino también con grandes personalidades de la música del cine americano como George Antheil ${ }^{283}$ o Johnny Mercer ${ }^{284}$.

La labor de estos hombres era de lo más variada. Podían encargarse simplemente de transcribir las partituras del compositor a las partichelas de los intérpretes hasta "componer" ellos el score ${ }^{285}$ completo en función de unas pequeñas directrices dadas por el compositor principal. El propio Bayon nos contó algunos casos y comentó la calidad de los maestros de la época como Manuel Parada de la Puente del que afirmaba que "era un compositor muy serio y lo hacía muy bien ${ }^{286 ", ~ m i e n t r a s ~ q u e ~ d e ~ L e o z, ~ n o ~ d u d a b a ~ e n ~ a f i r m a r ~}$ que "era de los que más sabía de trucos de cine, además de ser muy competente ${ }^{287 "}$. Cuando se refería a Juan Quintero, recordaba inmediatamente a un práctico que colaboró asiduamente con el maestro, al que llamaba Santander. Este hombre, también gozaba de un gran reconocimiento dentro del oficio y fue, según Bayon, una pieza fundamental en el éxito de Juan Quintero.

En cuanto a las sesiones de grabación, Bayon nos contó que en muchas ocasiones se llegaba a la grabación tan solo con la partitura del director y que él se sentaba en una esquina con el papel pautado y una pluma para escribir las partichelas. Evidentemente, si durante la grabación había que retocar algún pasaje, mientras se tomaba el registro de un tema, él se encargaba de hacer las correcciones y tenerla preparadas para cuando se las solicitaran.

La figura de estos prácticos, no fue muy usual en los años cuarenta, aunque a medida que la industria del cine se va asentando comienzan a aparecer. De hecho, Ricardo Bayon comienza su andadura en el cine a mediados de la década de los cuarenta y fue uno de los veteranos. Por otro lado, el propio García Leoz fue el práctico, a su vez, de Joaquín Turina en varias ocasiones, llegando a figurar los dos en Eugenia de Montijo como coautores.

Normalmente, durante este periodo, los compositores se veían obligados en reiteradas ocasiones a realizar todas las tareas asociadas con la música. Así, según nos confesaba Francisca Martos, viuda de Juan Quintero:

"Recuerdo que por hacer una película Juan (mi marido) cobraba unas 5.000 ó 10.000 pts.

Como Juan estaba muy interesado en conseguir los mejores medios y el mayor número de músicos, acababa llegando a un acuerdo con la productora por el que él se encargaba de todo. Ellos le preguntaban que cuanto creía él que costaría hacer la música, a lo que Juan respondía, por ejemplo, con

\footnotetext{
${ }^{283}$ Antheil es el autor de la música de: Corsarios de Florida (1938), En un lugar solitario (1950), No serás un extraño (1955), Orgullo y pasión (1957), etc.

${ }^{284}$ Johnny Mercer fue sobre todo autor de canciones aunque también compuso bandas sonoras completas. Algunas de sus obras son: Jezebel (1938) [canciones], La bella de Nueva York (1952) [música de fondo], Siete novias para siete hermanos (1954) [canciones], etc.

${ }^{285}$ Término anglosajón que hace referencia a la música que se escucha en una película.

${ }^{286}$ Entrevista con Ricardo Bayon, Madrid, primavera de 1999.

${ }^{287}$ Ibídem.
} 
10.000 ó 12.000 pesetas. Entonces la productora le daba 20.000 '9 25.000

pesetas para que él se encargara de todo. De este modo todo salía mejor. ${ }^{288, "}$

El proceso de trabajo en la gestión de una partitura para una película en los años cuarenta no dista mucho de los procesos empleados hoy en día, si exceptuamos, claro está, los medios tecnológicos que han revolucionado el sector. Al igual que ocurre hoy, el compositor se reunía con el director que le proporcionaba el guión, con anotaciones de donde creía que iría música. Si había canciones en la película, éstas se componían antes para poder realizar los playbacks durante el rodaje, mientras que la música de fondo se dejaba para el final, una vez terminado el copión. Entonces se realizaban los últimos arreglos. Una vez concluida la partitura se grababa con la orquesta mientras se visionaba el film y por último se realizaban las mezclas. Dentro de todo este proceso, como acabamos de mencionar, el compositor también se encargaba muchas veces de la contratación de los músicos, de buscar un lugar para la toma del registro, etcétera.

Para terminar de aproximarnos al proceso de trabajo seguido por los compositores tendremos que hacer mención a dos condicionantes que de forma directa afectaron al desarrollo de su labor; por un lado, el tiempo limitado del que disponían los músicos para escribir la partitura y por otro, la falta de recursos técnicos y espacios apropiados para poder desarrollar adecuadamente su labor.

\section{Tiempo limitado para componer}

El tiempo dado a los músicos para componer era tan limitado como parece ser que sigue ocurriendo hoy en día. Muchos autores se veían forzados a componer grandes cantidades de música en un intervalo de tiempo reducido. El propio Manuel Parada, muy poco dado a aparecer en los medios, también se quejó asiduamente, aunque con tono muy conciliador, de la falta de tiempo:

“...el defecto más importante es el obstinado proceder de la mayoría de los directores y productores en lo que se refiere al tiempo que al compositor le conceden para componer la partitura. Nosotros, prácticamente, no podemos ni debemos escribir ésta hasta que no se haya terminado el montaje de la película. $Y$ desde este momento, casi siempre, suelen darnos la mitad o la tercera parte del tiempo que necesitamos para escribir sin agobios. ${ }^{289,}$

A pesar de todo, el maestro acaba siendo optimista y considera que:

“...la respuesta - a como debe solucionarse el problema- sale de la lógica deducción de la respuesta a la pregunta anterior: dándonos más tiempo. Salvo raras excepciones, nunca causaría esto ningún perjuicio. Pero... desde que se

\footnotetext{
${ }^{288}$ Entrevista con Francisca Martos, Madrid, 16 de marzo de 1999.

${ }^{289}$ «La música en el cine para el año 1947», RadioCinema, año VIII, número 130.
} 
rueda el último plano, la impaciencia por ver completa la película no "les deja" vivir. ¡Es natural! !90",

En palabras del propio Juan Quintero, el defecto mayor de la música de cine:

“... es la prisa con que hay que hacer las partituras. Cuando llega al compositor el "copión» para poder trabajar, siempre hay compromisos de estrenos tan próximos que tenemos que trabajar a marchas forzadas. ${ }^{291}$ ",

En estas mismas declaraciones, algo más adelante, el Maestro ceutí pone sobre la mesa otro de los grandes problemas con los que se encontraban los músicos. Las tomas de sonido y las mezclas, como se puede constatar cuando afirma que:

“...además se carece en los estudios de salas de registro de música acondicionadas especialmente, y los equipos de mezclas no son todo lo perfectos que nosotros desearíamos. 292 "

También se aviene a estas quejas Parada, que a pesar de contar normalmente de todos los medios existentes en aquellos momentos en España, al igual que sus compañeros de profesión era consciente de las grandes deficiencias que existían.

"El primer problema de esta índole - se refiere a dificultades técnicas- con la que tropezamos los compositores está, a mi juicio, en la inexistencia en algunos Estudios de salas especiales para la toma de música. Esto hace que las orquestas ejecuten en locales que no reúnen las condiciones acústicas necesarias para la realización de un trabajo depurado. Por otra parte, aún no se ha llegado a establecer un definitivo acuerdo entre el criterio del técnico de sonido y el del compositor, en lo que a registro musical se refiere. Cuando surge una discrepancia, entre ambos, debe prevalecer, lógicamente, el criterio del compositor, en beneficio de un mayor rendimiento artístico. ${ }^{293 ،}$

Esta última afirmación coincide con la información obtenida a través de nuestra reunión con José Antonio Nieves Conde, quién nos apuntó otro problema añadido. Nieves Conde nos comentó que, sobre todo durante la primera mitad de la década de los años cuarenta, el registro de la música se llevaba a cabo en cualquier parte de los estudios, sin existir un lugar creado para tal fin, lo que obligaba, en ocasiones, a desplazarse a salas de concierto o iglesias para grabar la música. Esto es lo que sucedió cuando García Leoz tuvo que grabar el Aleluya con el que arranca Balarrasa (1950).

"Para introducir la película, hizo una especie de cantata. Esta obra la registramos en una iglesia que ya no existe. En la iglesia del Buen Suceso, porque era el templo que mejor sonaba en Madrid según Leoz. Alli fuimos una mañana con el equipo de la Fol-Selgas. Durante una mañana nos dio tiempo para hacer tres tomas de sonido de la cantata lo más perfectas posibles. En

\footnotetext{
${ }^{290}$ Ibídem.

291 «La música en el cine para el año 1947». RadioCinema, VIII, № 130, 1 de diciembre de 1946.

292 Ibídem.

${ }^{293}$ GARCíA, P. «La música de cine. Una charla con el maestro Parada» Primer Plano, año V, número 216.
} 
aquel lugar se consiguió un sonido muy peculiar y característico de iglesia que resultó muy adecuado. En el plató no se hubiese conseguido nunca.

Años más tarde se habilitó un lugar para los registros sonoros en los estudios, pero hasta entonces la música se registraba como nosotros habiamos hecho siempre, en los estudios, en Chamartí, Sevilla Film... y estos registros se hacian con proyección.. ${ }^{294 "}$

Las mezclas, al igual que en la actualidad, acababan convirtiéndose en sesiones eternas, prueba de resistencia y diálogo, entre director, compositor, ingeniero de sonido y productor. Era, según hemos constatado, la parte más desagradecida del trabajo, aquella que menos gustaba, pero en la que los músicos podían llegar a perder mucho, prueba de ello son las palabras de Joaquín Turina cuando explica que:

"El ingeniero tiene facultad de hacer lo que quiera con la obra musical, hasta tal punto, que de un cuarteto puede hacer algo monumental y, por el contrario, meter en un rincón a una gran orquesta. Lo dicho significa que el ingeniero dispone a su placer de los primeros planos y de las lejanías. Si en el momento culminante, en la suprema emoción, al fin de un gran crescendo, tiene que hablar un locutor o hay un diálogo entre los personajes de la película, el pobre compositor ve con zozobra que su música se la llevan, arrastrada, a países muy lejanos. Con ser bastante grave cuanto he dicho, no pasa de ser un problema de intensidad; pero hay en la música de cine problemas más graves, de fondo y de forma. ${ }^{295 "}$

Según nos contaron todos los entrevistados, en estas sesiones el músico podía llegar a perder mucho si no estaba allí y "luchaba" de algún modo por el respeto a su obra, sin olvidarnos de la repercusión que podría llegar a tener la opinión del músico respecto a cómo debía ser insertada la música, puesto que ningún ingeniero de sonido tenía conocimientos de música suficientes para ello. Nieves Conde nos narró una anécdota de García Leoz muy significativa sobre esta situación.

"En una ocasión tuvo que desplazarse Leoz a Londres para terminar un trabajo de una coproducción. Cuando llegó a los estudios, se quedó de piedra cuando vio al técnico de sonido con la partitura delante para controlar las entradas de la música. Eso aquí en España ni pensarlo. ${ }^{296 "}$

Por otro lado, las deficiencias técnicas existentes para esta labor en nuestro país, también suponía un mayor esfuerzo. Manuel Halffter recordaba que cuando su padre:

\footnotetext{
${ }^{294}$ Entrevista con José Antonio Nieves Conde, Madrid, 17 de marzo de 1999.

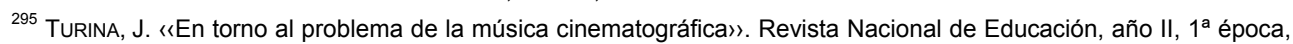
número 15. marzo de 1942. pp. 67-70.

Existe trascripción del artículo en las siguientes dos publicaciones:

IGLESIAS, A. (1982) Escritos de Joaquín Turina. Recopilación y comentarios. Mardrid. Editorial Alpuerto. pp. 233-235.

Colón Perales, C. (1984) La música cinematográfica de Joaquín Turina, Sevilla, Real Academia de Bellas Artes de Santa Isabel de Hungría.. pp. $42-47$.

${ }^{296}$ Entrevista con José Antonio Nieves Conde, Madrid, 17 de marzo de 1999.
} 
“... se metía en el Estudio, no salía de éste durante dos días. Probaba y probaba las mezclas hasta encontrar un punto de equilibrio con la moviola, pasando la película para delante, para atrás, para delante, para atrás, etcétera. $^{297 ",}$

Todo esto acababa desembocando en una circunstancia que ha envuelto a nuestro cine desde el comienzo de la era sonora. Nos referimos, concretamente, a los sistemas técnicos de sonido y su utilización.

\section{Recursos técnicos limitados}

Efectivamente, si la fotografía de nuestro cine en la década de los años cuarenta llegó a ser inmejorable; el sonido no pudo ser peor. De hecho, con el tiempo se convirtió en un mal endémico del que, por desgracia, nuestro cine no parece haberse repuesto en estos últimos sesenta años.

Las tomas de sonido directas eran complicadas y los resultados muy malos. Los micrófonos captaban todo menos lo que debían, produciendo un audio de muy baja calidad. Este problema fomentó que durante el rodaje no se tomara el sonido directamente y este trabajo se realizase en la postproducción, doblando a todos los personajes. Con ello se conseguía una mayor claridad en las voces y un control más exhaustivo de los planos sonoros. Un ejemplo de esto fue:

“...una de las primeras películas que se hicieron después de la Guerra, La tonta del bote. Ésta fue rodada muda con la extrañeza de todo el equipo, pero Gonzalo Delgras, su director, quería que se doblase después para que se entendiesen todos los diálogos, y así fue. ${ }^{298 ", ~}$

Por otro lado, en la entrevista mantenida con Nieves Conde, cuando se refiere a este tema, recordaba que si bien no se doblaba todo, si un porcentaje del total, especialmente el rodado en exteriores donde no se podía tener un control sobre el sonido ambiente.

"Antiguamente, cuando yo comencé con Rafael Gil de ayudante, se rodaba con sonido directo en los platós y lo que se doblaba eran las tomas de la calle o las que no habían salido bien en el plató. De esta manera se doblaba solo un $20 \%$ del total.

Más tarde, vino la manía que trajo Berlanga de rodar sin sonido. Y yo, la primera película que tuve que rodar sin sonido fue por obligación. Me encontré de pronto con que no había equipo de sonido....

\footnotetext{
${ }^{297}$ Entrevista con Manuel Halffter, Madrid, 19 de marzo de 1999.

${ }^{298}$ Entrevista con Juan Mariné y Concha Figueras, Madrid, 24 de julio de 2003.
} 
A pesar de ello, puse como condición para trabajar que aunque fuese un solo hombre, éste debía ir tomando los sonidos de referencia. De este modo cuando se doblara se podía uno apoyar en un sonido de referencia.

\section{$[\cdots]$}

Lo que hacían los montadores de aquella época, como Rojo, era pasar poco a poco imagen tras imagen y leían perfectamente los labios, siendo capaces de saber si el actor había dicho bien su papel o se había equivocado en lo más mínimo. Luego vino el magneto y eso complicó la cosa de mala manera. ${ }^{299 "}$

Como se puede constatar, la situación era grave si se tenía que recurrir a recursos como el anteriormente descrito, para poder conseguir buenos resultados. Durante la década de los cuarenta pugnan por el mercado del audio en el cine español numerosos sistemas de sonido, aunque tan solo unos pocos llegan a hacerse un lugar en el mercado nacional.

\begin{tabular}{|c|c|c|c|c|c|c|c|c|c|c|c|}
\hline \multirow{2}{*}{$\begin{array}{l}\text { Sistema de sonido }{ }^{300} \\
\text { Acústica S.A. }\end{array}$} & \multicolumn{10}{|c|}{$\mathrm{N}^{0} \mathrm{de}$} & filmes"1941""1942"'1943""1944""1945""1946""1947"'1948"'1949""1950" \\
\hline & 21 & & 2 & 4 & & & 1 & 2 & 3 & 3 & 6 \\
\hline Bittman & 2 & & 2 & & & & & & & & \\
\hline Breussing-Roptence & 32 & 3 & 7 & 4 & 2 & 5 & 2 & 2 & 4 & 4 & 2 \\
\hline British Acustic & 5 & & 2 & & & & & 1 & & & 2 \\
\hline Eurocord "N" & 14 & & & & 4 & 3 & & & 1 & 2 & 4 \\
\hline Klang Film Eurocord "N" & 5 & & 1 & 3 & 1 & & & & & & \\
\hline Laffón-Selgás & 6 & & 1 & 1 & & & 2 & 1 & 1 & & \\
\hline R.C.A. & 45 & 4 & 7 & 2 & 4 & 1 & 2 & 5 & 7 & 8 & 5 \\
\hline R.C.A. Alta Fidelidad & 3 & 1 & & 1 & & & & & & 1 & \\
\hline R.C.A. Ultravioleta & 27 & & 5 & 4 & 6 & 2 & 3 & 6 & & & 1 \\
\hline R.C.A. Ultravioleta, Alta-Fidelidad & 3 & & & 1 & & 1 & & & 1 & & \\
\hline Rivatón & 16 & 4 & 6 & 6 & & & & & & & \\
\hline Tobis Klang Film & 7 & 2 & 1 & & 1 & & 1 & & 2 & & \\
\hline Tobis Klang Film Eurocord "N" & 3 & 2 & 1 & & & & & & & & \\
\hline Western Electric & 6 & & 2 & & & & & 1 & & 1 & 2 \\
\hline Sistemas con una única referencia & & & & & & & & & & & \\
\hline
\end{tabular}

Tabla 29: Sistemas de sonido y su repercusión en la producción nacional (1941 - 1950)

\footnotetext{
${ }^{299}$ Entrevista con José Antonio Nieves Conde, Madrid, el 17 de marzo de 1999.

${ }^{300}$ En esta tabla faltan los datos de 275 largometrajes de los 484 que conforma nuestro corpus inicial. Tampoco se tiene datos de los años 1939 y 19440.
} 


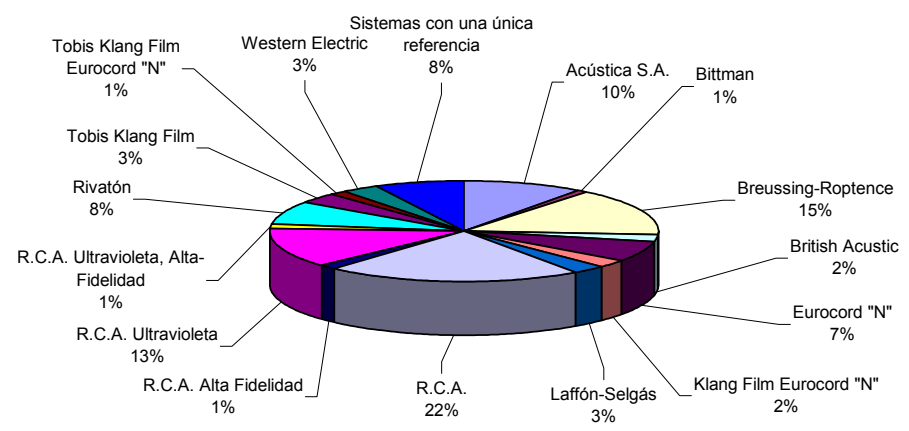

Gráfica 13: Sistemas de sonido y su repercusión en la producción nacional (1941 - 1950)

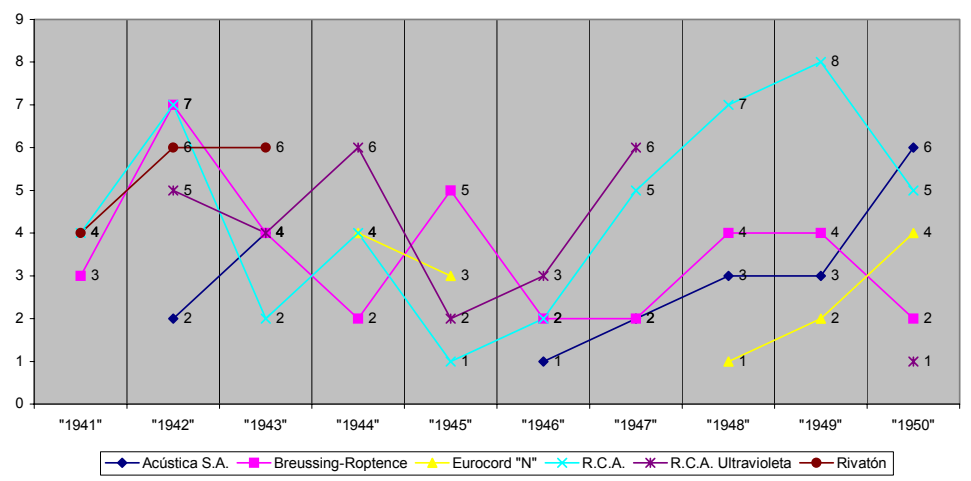

Gráfica 14: Repercusión de los 6 sistemas de sonido más extendidos por años (1941 - 1950)

Como se puede apreciar en las tablas y gráficas anteriores, durante los años cuarenta nos encontramos en la industria con una amplia gama de sistemas de captación del sonido. De todos modos, puede observarse sin problemas cómo la patente $R C A$ y sus ramificaciones ocupan un lugar predominante en el panorama del momento. Con cerca de un $36 \%$ de la producción total dependiente de este sistema, RCA se yergue como la patente más importante, seguida a una distancia prudencial por Breussing-Roptence con un $15 \%$ y Rivatón con $8 \%$ entre otras. Del resto, tal vez la única que merezca nuestra atención sea, Laffón-Delgas, sistema de patente española que llegó a traspasar fronteras y ser muy utilizado, especialmente en Francia. Según los textos encontrados sobre este singular sistema, los resultados obtenidos por la pantente española eran de gran calidad, pero en el mercado lo importante no es la calidad sino el marketing, rozón más que probables de la alta incidencia de este sistema en nuestra industria.

Las propiedades técnicas del sistema Laffón-Selgas quedaban claramente resumidas por Antonio Cabero: 
“... consisten en que el periodo propio de resonancia mecánica del oscilógrafo modulador de la luz, está situado en la zona infra-audible de la escala de vibraciones acústicas, y que el elemento móvil de dicho oscilógrafo está desprovisto de todo sistema mecánico de amortiguamiento de sus vibraciones. ${ }^{301 "}$
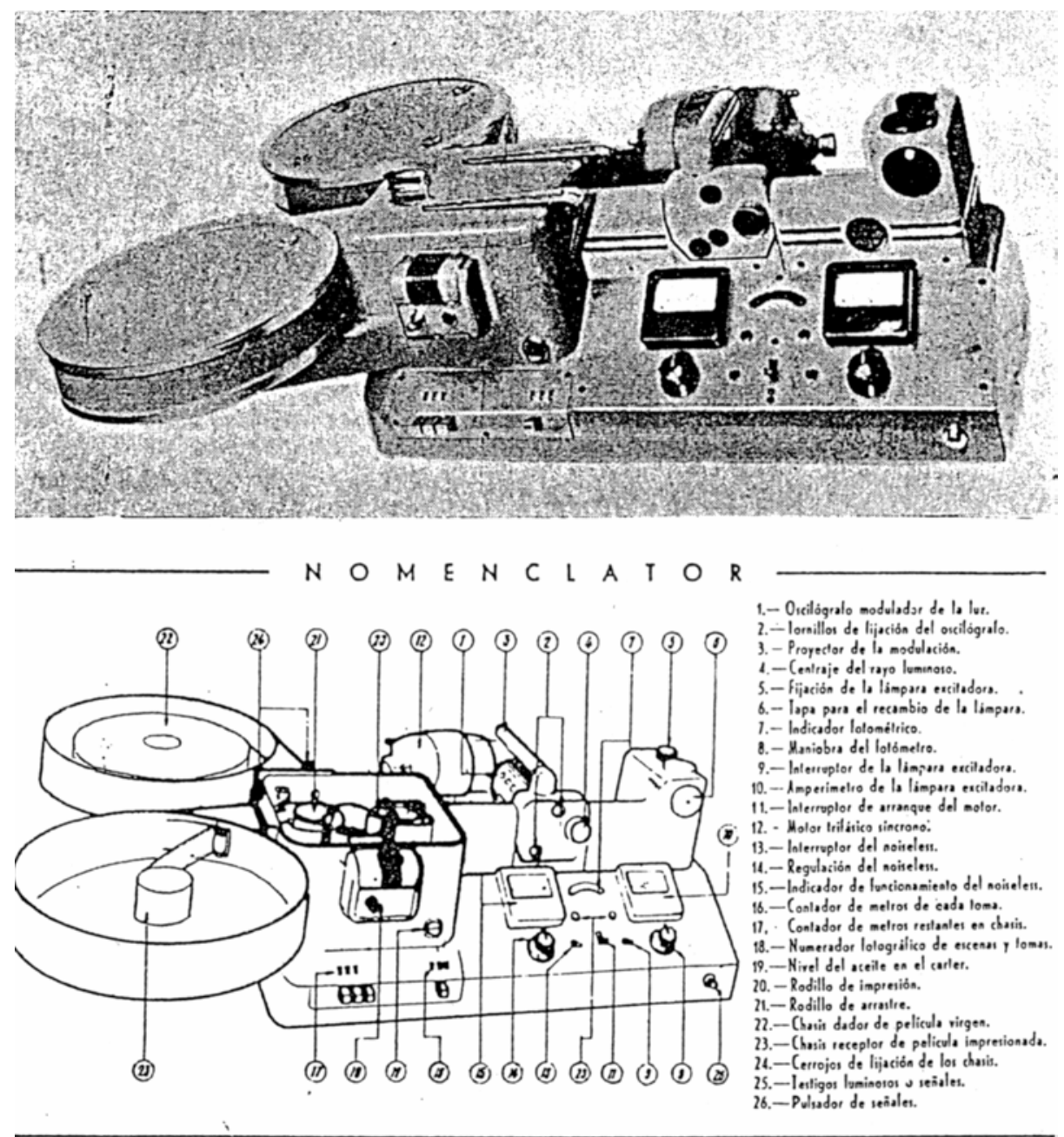

Imagen 25: Cámara de registro de sonido del Sistema Sonoro de Laffón-Selgas ${ }^{302}$

\footnotetext{
${ }^{301}$ CABERo, J. A. (1949) Historia de la cinematografía española. Madrid, Gráficas Cinema. pp. 378.

${ }^{302}$ Ibídem. pp. 377.
} 
En cuanto al sistema de sonido RCA, podemos apreciar cómo a partir de 1946 sufre una sustancial incorporación en la producción cinematográfica. Se convierte durante este periodo en todo un hito de la tecnología entre otras razones por el lanzamiento internacional, por parte de Walt Disney de su largometraje, Fantasía (1941). Este emblemático filme de animación atrajo la mirada de todo el mundo, convirtiéndose en toda una leyenda del séptimo arte, tanto por su realización y técnica como, y sobre todo, por los aspectos sonoros. Recordemos que esta película fue la primera realización de largometraje que utilizó un sistema de sonido estereofónico, para lo que fue necesario utilizar el sistema RCA.

Tal fue la influencia de esta película y la repercusión que desde el punto de vista comercial, trajo consigo la implantación de este sistema en la industria española. Durante los primeros años de la década encontramos algunos artículos dedicados a este sistema estereofónico y a sus ventajas. En el siguiente artículo podemos apreciar cómo se utilizó el nombre de Disney y Fantasía para promocionar el nuevo sistema:

"... los detalles técnicos del sistema de sonido "Fantasía», lanzado por la RCA y publicados en Better Theatres, indican que en principio, y contrariamente a lo que se predecía anteriormente, es casi idéntico al sistema Western Electric de estereofonía del sonido. Como éste, el sistema RCA emplea una película sonora distinta con tres canales e impresiones de sonido y un cuarto canal de control o instrucción. El sistema "Fantasía» de RCA ha sido empleado y lanzado por Wat Disney en su última película larga, que da su nombre al sistema, y su ingeniero de sonido, W. E: Gárrity, colaboró eficacísimamente en su perfeccionamiento. ${ }^{303,}$

Más adelante, el autor del artículo se centra en examinar más detenidamente los aspectos técnicos del producto norteamericano cuando dice:

"... la cabeza de sonido especial RCA está provista de dos lámparas de excitación y cuatro células fotoeléctricas, pus-pull que reciben la luz excitadora convenientemente dividida por medio de prismas. Tres de las células fotoeléctricas reproducen los tres canales de registro de sonido y música, y la cuarta el canal de control o «instrucción». Este canal de control consiste en un número de frecuencias puras registradas simultáneamente en un solo canal pus-pull, producido en la operación re-recording. Cada frecuencia representa, por su volumen, el volumen a reproducir por cada uno de los tres canales en trabajo, y se filtra y rectifica para emplearse en modificar el gridbias de una válvula amplificadora.

Cada canal de sonido está registrado con un volumen de unos $25 \mathrm{Db}$. El canal de control o «instrucción» puede modificar la amplificación de cada canal en unos $50 \mathrm{Db}$. más, haciendo la escala de volumen disponible de casi $75 \mathrm{Db}$. El total de potencia instalado en el Teatro Broadway (una sala para la cual, según las normas modernas, bastaba y sobraba con 100 vatios modulados), es de 320 voltios modulados, es decir, unos 160 vatios por cada canal.

\footnotetext{
${ }^{303}$ SÁINZ dE LA HoYA, R.: «Página Técnica». Primer Plano, año II, № 23.
} 
En el escenario del teatro hay tres equipos completos de altavoces, y cada equipo consta de ocho unidades de baja frecuencia, montadas en una bocina y cuatro unidades de alta frecuencia acopladas en una bocina multicelular. Uno de los equipos está colocado detrás del centro de la pantalla de proyección, y los otros dos a la izquierda y a la derecha del escenario, respectivamente. En la cabina de proyección hay tres juegos completos de amplificadores, que cada uno funciona independientemente de los otros y alimenta un determinado equipo de altavoces. ${ }^{304 "}$

Es un hecho que los sistemas de sonido fueron evolucionando, incorporando mejoras técnicas considerables. Pero, lo cierto, es que la industria cinematográfica tardaba muchísimo en incorporar estos sistemas al engranaje de la producción. El sistema LaffónSelgas rápidamente se haría un lugar en nuestra industria, de hecho fue utilizado por primera vez en la versión de 1935 de Currito de la Cruz, pero sobre todo en producciones de corta duración como documentales y noticiarios. Su repercusión en el ámbito del largometraje no será especialmente destacable, aunque durante la década de los cincuenta se utilizará ampliamente. El sistema de sonido RCA, por su parte, ira incorporándose a partir de 1946 a la industria cinematográfica.

Manuel Halffter nos recuerda cuánto debieron de sufrir los compositores de aquellos tiempos pretéritos:

"... en una época tan difícil en todas las realizaciones artísticas, humanamente él -su padre- contó con todos los medios que quiso. Las insuficiencias eran más de tipo técnico. Ahí si que se lamentaba él, como se lamentaba el director,... Él siempre se estaba quejando del sonido. "El sonido, el sonido, no se oye». El sonido era malo. Yo me acuerdo que en el cine siempre estabas preguntando "¿qué ha dicho?»,... Cuantas y cuantas partituras se malograron, en disco y en cine, por culpa de la baja definición de los medios técnicos, porque realmente no se podía dar una idea real de la calidad de lo que el autor había logrado con esa obra. Lo que quedaba era una impresión negativa. $^{305}$ "

\section{Dos tipologías musicales}

Todo el engranaje jurídico emanado de las circunstancias históricas y sociopolíticas del momento, repercutió de un modo muy directo en la realización de las películas y de forma indirecta en la tipología musical compuesta para el cine. Si durante los primeros años cuarenta, autores como Duran Alemany, Casas Auge y Ruiz de Azagra llegaron a convertirse en verdaderas estrellas del firmamento musical, especialmente barcelonés, con sus ritmos modernos y sincopados para las comedias; la segunda mitad de la década fue sin duda de los grandes autores dramático-sinfónicos como Manuel Parada,

\footnotetext{
304 Ibídem.

305 Ibídem.
} 
Juan Quintero y Jesús García Leoz. Una muestra de ello la encontramos en la existencia de grabaciones discográficas de las canciones de moda escritas para estas películas como la célebre Pu-pu-pi-dú, compuesta para El difunto es un vivo (1941)3 de Ignacio F. Iquino. Estos ritmos modernos tenían una marcada influencia de la música norteamericana y acababa denominándose piezas de jazz en general. No es una casualidad que este tipo de música se desarrollase casi y exclusivamente en Barcelona. "En Barcelona había unos concursos con distintas orquestas. Muchos músicos pertenecían al Jazz Club de Francia ${ }^{306 ", ~ l o ~ q u e ~ f u e ~ d e t e r m i n a n t e ~ p a r a ~ l a ~ c o n s t r u c c i o ́ n ~ d e ~ u n ~ e s t i l o ~ j a z z i ́ s t i c o ~ e n ~ l a ~ C i u d a d ~}$ Condal. Por otro lado, el bajo coste que suponía grabar en Barcelona frente a los altos precios de Madrid y la alta calidad de estos músicos, fueron factores determinantes para el desarrollo de estos modos musicales, a pesar de las reticencias mostradas hacia esta música por parte de críticos y políticos de las sectores más radicales como se puede leer en varios textos aparecidos en revistas de la época. A continuación reproducimos un fragmento del artículo Manuel Pastor, en la revista RadioCinema:

\begin{abstract}
"Poco a poco van desapareciendo las estridencias y desacordes del saxofón y del «jazz» como símbolo de lo excéntrico y ultramoderno, sin emotividad y sin delicadas expresiones, para dejar paso al gran género musical de los más renombrados maestros de la composición. ${ }^{307 "}$
\end{abstract}

Con la emigración de la producción cinematográfica hacia 1943 a los estudios madrileños por parte de las principales productoras nacionales como CIFESA y la paulatina desaparición de la comedia, que necesitaba de estas melodías, el relevo lo tomaron composiciones de carácter marcadamente sinfónico.

No queremos decir con ello que autores como Duran Alemany o Ruiz de Azagra dejaran de componer o García Leoz y Quintero no lo hicieran. Por el contrario, estos compositores, cuya formación musical había sido fuerte y de gran calidad, supieron adaptarse a todo tipo de estilos y géneros, aunque nunca llegaron a alcanzar la calidad del triunvirato formado por Jesús García Leoz, Juan Quintero y Manuel Parada dentro del sinfonismo. Estos tres músicos, supieron captar la técnica de la composición cinematográfica con una precisión absoluta. Cada uno de ellos supo imprimir su propio sello y estilo, no solo en la música que escribieron para cine sino también en su modus operandis, respecto a cómo musicar las imágenes, llegando a preocuparse por cuestiones teorico-técnicos en el caso de García Leoz.

El maestro Leoz, respetado y admirado en su tiempo pero relegado al olvido en la actualidad, no solo se presenta como el más prolijo de todos sino también el único que se plantea un debate sobre la teoría musical en el cine. Esto no debe sorprendernos si tenemos en cuenta la fuerte formación intelectual de la que gozaba el músico oliténse, sobrino del propio Joaquín Turina, con quien colaboró en varias ocasiones.

\footnotetext{
${ }^{306}$ Entrevista con Juan Mariné y Concha Figueras, Madrid, 24 de julio de 2003.

${ }^{307}$ PASTOR, M. «El cine y la música», en RadioCinema, año II, núm. 34. 15 de agosto de 1939.
} 
Lo bien cierto es que cada uno de los compositores mencionados evolucionó de un modo distinto, tanto musicalmente como en aspectos técnicos.

Si tenemos en cuenta el elevado nivel de producción de la industria y la consiguiente demanda de música de cine, lo que hizo necesario, la especialización profesional en este ámbito. Esta cuestión la comprendieron rápidamente autores como Juan Quintero Muñoz, Manuel Parada, Ruiz de Azagra o García-Leoz que supieron formular, cada uno de ellos, su propio estilo y método de trabajo, sin olvidar la composición para otros medios como el teatro musical, las formas de concierto o incluso la ópera ${ }^{308}$.

Como ejemplo nos proponemos analizar dos casos bien significativos como son Juan Quintero Muñoz y José Luis Ruiz de Azagra. A continuación presentamos, como muestra, dos análisis pertenecientes a largometrajes de la primera mitad de la década de los cuarenta en los que se pueden apreciar diferencias significativas en el método y estilo de composición así como en el concepto musical vinculado a las imágenes.

Para proceder a efectuar el proceso analítico hemos recurrido a la metodología desarrollada por Josep Luis i Falcó, dada a conocer a través de su página web, en el cual comienza planteando que:

“...hablar de cine, empleando términos visuales, resulta factible aun no visionando la película, ya que existe un lenguaje preciso, una terminología abundante que nos permite una comunicación verbal positiva. Pero hablar de cine utilizando términos auditivos comporta siempre una serie de riesgos, motivados por la poca precisión terminológica y la falta de un corpus global de términos delimitados y definidos que nos permitan comunicar de manera verbal los mil y un recursos que nuestro oído percibe ante una película. ${ }^{309 ",}$

Este es uno de los principales problemas con los que cualquier analista del audiovisual se encuentra. En su extenso artículo, Falcó comienza haciendo una distinción de matiz importante entre los que él considera música de cine (MDC) y banda sonora musical (BSM). En el primer caso se refiere a la música en sí, la que se puede escucha en el disco o mientras se ve la película, mientras que la segunda hace referencia a la música unida a las imágenes, por ello:

"El análisis de la BSM debe ser siempre audiovisual y no sólo auditivo; en caso contrario, insistimos, nos hallariamos ante el análisis, no de una BSM, sino de $M D C$. $^{310 "}$

Una vez establece la diferencia entre la música de cine y la banda sonora musical, pasa a definir los tres parámetros empleados para el análisis de la primera que son:

- La selección del bloque hace alusión directa a la música elegida para, tanto si se trata de una composición expresa como preexistente.

\footnotetext{
${ }^{308}$ García-Leoz murió cuando estaba completando su ópera Barataria con la que creó mucha expectativa en el mundo musical de la época.

${ }^{309}$ LLUIS I FALCÓ, J. «Método de análisis de la música cinematográfica»

http://usuarios.lycos.es/compositores/material2.html [Junio de 2000]

${ }^{310}$ Ibídem.
} 
- Estructura temática hace referencia a los temas o motivos empleados en la elaboración del bloque musical. En este caso nos encontraremos con dos posibilidades bien claras, pudiéndose tratar de bloques monotemáticos, o de un solo tema, o politemáticos, construidos por más de un tema.

- El carácter dominante de la pieza se refiere a aspectos de tipo anímico, físico y cultural, como por ejemplo cualquier pieza con un significante claro dentro de una cultura como puede ser en nuestras latitudes una de las marchas nupciales de Wagner o Mendelssonh.

Una vez definidos aquellos parámetros que afectan a la MDC, entra de lleno a tratar la BSM con el fin de plantear los parámetros a seguir en este otro caso.

"En primer lugar es necesario que tengamos claro que la BSM se divide, desde el punto de vista estrictamente cinematográfico, en "bloques", que a su vez se pueden dividir en temas ${ }^{311 "}$.

Una vez delimitados estos bloques, se debe de tener en cuenta a la hora de analizarlos su unión con la imagen. Así, se deben de tener en cuenta los siguiente aspectos:

- Función articuladora, define el origen de la música con respecto a las imágenes, es decir, si la música se crea después que las imágenes y debe supeditarse a ellas, o si por el contrario, son éstas las que se construyen después y están sometidas a la música, como es el caso de los músicales.

- Interacción semiótica, plantea la divergencia o no con las imágenes, o lo que es lo mismo, si las sensaciones y mensajes que envía la música son o no, afines a las imágenes.

- Ubicación en el montaje sitúa el bloque que se analiza en un lugar concreto de la narración, por ejemplos los títulos de crédito o una secuencia de montaje.

- Ubicación en la narración o forma narrativa, hace alusión a cómo está insertado el bloque en el discurso audiovisual, donde comienza y donde acaba, etec.

- Plano auditivo se refiere directamente al plano sonoro en que se encuentra la música con respecto al resto de elementos sonoros (ruidos, diálogos, etc.) que conforma la banda sonora.

- Los defectos que puedan alterar la percepción de la BSM deben de ser puntualizados, puesto que nos pueden aportar información que de otro modo pasaría desapercibida. Estos defectos pueden ser de producción (disminución del volumen, corte brusco, etc.) o bien de exhibición (doblaje, censura, etc.).

Con el fin de que el análisis sea lo más operativo posible hemos desarrollado una tabla de análisis músico-fílmico basándonos en las líneas abiertas por Josep Luis i Falcó, aunque hemos realizado algunas modificaciones, ya que los parámetros seleccionados por

${ }^{311}$ Ibídem. 
Falcó no resultan, a nuestro entender, suficientemente significativos para nuestros propósitos.

A cada bloque musical le hemos asignado una ficha como la que presentamos a continuación, donde se muestra un conjunto de parámetros que nos ayudarán a ir definiendo poco a poco el tipo de banda sonora realizada.

\section{BLOQUE 2}

\section{Ubicación:}

Inicio:

Fin:

Duración:

Estructura temática:

Forma narrativa:

Plano narrativo:

Plano sonoro:

Función semántica:

NOTAS

Tabla 30: Tabla de análisis músico-fílmico

En la franja superior se indicará el número de bloque musical que se intenta definir con la tabla y, a continuación, se presentarán los siguientes parámetros:

- Ubicación: indica el lugar donde se inserta el bloque musical, para lo que se enseña la o las secuencias donde se encontrará.

- Inicio / fin: se especifica el lugar exacto de comienzo y fin del bloque y si éste se funde con otro.

- Duración: en minutos y segundo (y si fuese posible en fotogramas).

- Estructura temática: se enumera en el orden de aparición (con las posibles repeticiones) de los temas o motivos que compone o hacen acto de aparición en el bloque.

- Forma narrativa: en este apartado se define como está estructurado el bloque con respecto al filme y qué formas musicales se pueden encontrar.

- Plano narrativo: nos referimos con este término a la clasificación archiconocida de música diegética o extradiegética, o lo que es lo mismo, música de fondo o música de pantalla, según el autor que se tome de referencia.

- Plano sonoro: define el nivel al que se encuentra el bloque dentro del soundtrack o mezcla final de audio (diálogos, sonidos y música).

- Función semántica: en este apartado se debe indicar el cometido que en cada momento tiene el bloque dentro de la narración audiovisual, es decir, lo que transmite y aporta al relato. Dentro de este apartado, definiremos esta función 
con los siguientes términos: Convergente, cuando la acción y la música llevan un mismo camino, o divergente, cuando la música no se dirige hacia el mismo lugar. Dentro de estas dos posibilidades, podemos encontrarnos con que la música transmita cualquiera de las siguientes sensaciones:

- Espacial

○ Física

○ Anímica

○ Social

$\circ \quad$ Cultural

- Histórica

- Etcétera

- Notas: nos servirá para aclarar posibles aspectos o completar aquellos, que por tratarse de excepciones, no han sido incluidos en la ficha general.

Una vez completada la ficha de cada uno de los bloques se puede, observando los resultados, llegar a conclusiones sobre la música de la película y estructura musical de la misma.

A continuación vamos a presentar los análisis de dos comedias de principios de la década de los cuarenta: El hombre que se quiso matar (1942) y Deliciosamente tontos (1943).

\section{Azagra: El hombre que se quiso matar (1942)}

El hombre que se quiso matar (1942) fue la primera película dirigida por Rafael Gil que contó en esta ocasión con Luis Lucia para el guión técnico y en el apartado musical a un veterano en el ramo, José Luis Ruiz de Azagra, quien ya llevaba por lo menos una veintena de películas realizadas.

Para el análisis que hemos llevado a cabo en esta ocasión, hemos utilizado la copia editada en vídeo VHS por la distribuidora DIVISA Ediciones en la colección "Clásico Español" aparecida en 1996. La presente copia tiene una duración de 67 minutos, a pesar de anunciar en el exterior de la carcasa una duración de 70 minutos.

Para la historia del hombre desdichado y derrotado que decide suicidarse, anunciando a los cuatro vientos su medida para poder aprovechar esta coyuntura y vivir los cuatro últimos días libre de los convencionalismos morales y sociales de la época, Ruiz de Azagra realiza una música sencilla aprovechando todos los convencionalismos que conoce como ya comentaremos más adelante.

Una vez más, como ocurre en la mayor parte de comedias de la época, nos encontramos con una película cuya proporción de música frente a la ausencia de ella es altamente significativa. Solo un $21 \%$ de la película contiene comentario musical, lo que 


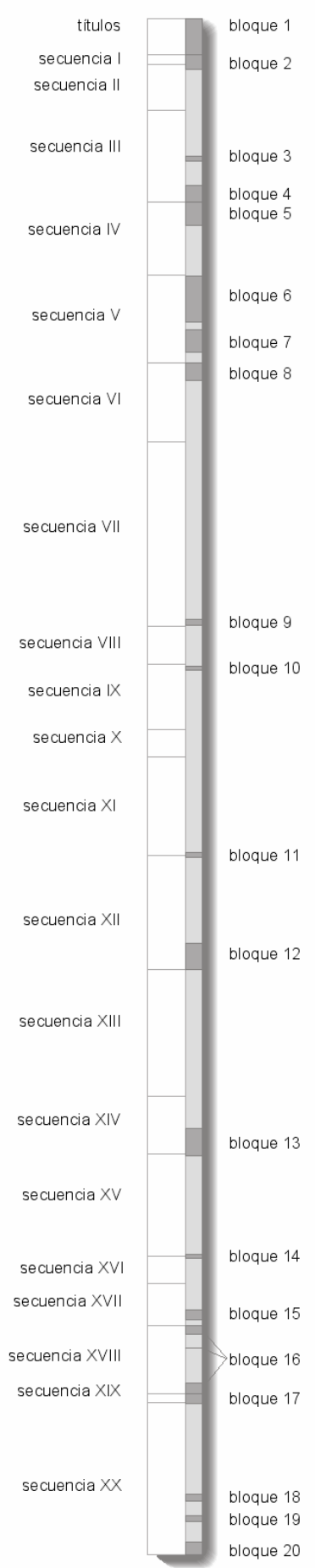

significa que el maestro Azagra solo compuso algo menos de un cuarto de hora. La colocación de la misma esta muy fraccionada, en 20 bloques musicales, siendo la duración de dichos fragmentos musicales de muy variada extensión, desde algunos que escasamente alcanzan los 4 segundos hasta los de 2 minutos de duración. Consigue de este modo que la música tenga una mayor efectividad al irrumpir en el soundtrack de la película.

Esta fractura de la música en microbloques repartidos a lo largo del metraje corresponde a una utilización poco preciosista de la misma y en cambio a una labor más elaborada por parte del director y el músico, buscando el aprovechamiento máximo de la música como elemento coextructurador del relato audiovisual. Nos referimos, a utilizar la música como un elemento más a la hora de crear el ritmo, la continuidad o el especio en el filme. A pesar de ello, existen algunos pasajes que consideramos no cumplen su función y por el contrario son antiproductivos y poco afortunados. Este es el caso del bloque 3 insertado en mitad de la secuencia III que creemos fue incluida para conseguir una mayor continuidad en el montaje pero que provoca un efecto nada deseable al transmitir la sensación del paso del tiempo y, por lo tanto, de la existencia de una elipsis narrativa donde no creemos que la haya en absoluto.

A pesar de todo, el audio de esta obra está bastante bien trabajado, existiendo una buena labor de sonido ambiente y con una riqueza sonora que en otras películas similares no hemos encontrado. Los planos sonoros están equilibrados y la música, cuando suena, se encuentra en los niveles adecuados, sin llegar a resultar excesivamente fuerte o molesta.

En este sentido debemos llamar la atención sobre las entradas y salidas de la música que resultan muy naturales, es decir, no está motivadas por una subida o bajada del volumen de la misma para hacer desaparecer la música. Esto quiere decir que los bloques fueron compuestos tal y como se escuchan en el filme sin una manipulación arbitraria o degradante en la mesa de mezclas. Esto reafirma nuestra opinión sobre los conocimientos y oficio del maestro Azagra.

En cuanto a la identificación de temas o motivos para una mayor interacción de los mismos en el relato, el compositor en esta ocasión trabaja esencialmente con tres temas principales y una serie de secundarios 0 
circunstanciales como veremos a continuación. Así pues, en el primer bloque nos presenta los dos temas más importantes, uno que hemos dado en llamar el tema del "Destino" y el tema de amor.

El tema del "Destino" se vincula a lo largo de la película al suicidio o momentos altamente dramáticos relacionados con el devenir que el protagonista ha trazado para él. Así, podemos escucharlo en todo su apogeo en el bloque 6 (después de leer la carta de su padre), en el número 7 y 8 (intentos de suicidio en las vías del tren o colgándose de la lámpara), etc. También aparece como pequeño motivo o fanfarria en otros bloques, a modo de aviso o puntuación como ocurre en los bloques 18 o 20 (momento en que Federico levanta el arma para pegarse un tiro o avisándonos de que van a tener, la pareja protagonista, un accidente con el coche).

El tema de amor está más estandarizado y se encuentra dentro de lo que se supone que debe ser un tema de amor dentro de los cánones del código musical de occidente. Se nos presenta el tema en la overtura de los créditos iniciales aunque realmente no hace su aparición hasta la segunda parte del bloque 12 (momento en que Irene comienza a interesarse por Federico). A partir de ese momento, cada vez que Irene y Federico se encuentren este tema estará presente.

El tercer tema de importancia en la partitura de esta película es aquel que hemos dado en llamar tema del "Fracaso". Dicho tema tiene su importancia por estar presente en todo aquel momento crucial que reafirma, de cara al espectador, las frustraciones de Federico y sus desilusiones, que le llevarán inexorablemente a los continuos intentos de suicidio. Se trata de una melodía fácilmente reconocible, de frase corta, y aire triste, melancólico, compuesta en tono menor. Comienza a escucharse en la secuencia IV, cuando Federico entra en su habitación después de ser abandonado por su novia Juanita (bloque 5) o bien cuando lee la misiva de su padre (bloque 6), etc.

El tema de la "Popularidad", más que un tema se pude decir que es un ritmo o motivo, que está emparentado a la expectación que en los medios de comunicación y la población tiene el morboso anuncio de Federico, bloques 9, 10 y 11.

El resto del material temático no tiene una identificación clara y se trata en la mayor parte de temas circunstanciales para subrayar la acción (como ocurre en el bloque 19 con el tema de la persecución) o las transiciones entre secuencias o escenas como los bloques 3 (ya comentado anteriormente) o el bloque 14 .

Existen por otro lado, tres piezas que se distinguen del resto de la partitura tanto por su lenguaje musical como por su utilización en el filme. Nos referimos a los dos pasodobles utilizados como música de pantalla (música diegética) y a la canción que entona un obrero y que escucha Federico a través de la ventana. El porcentaje de música de pantalla en la película es muy pequeño, reduciéndose a unos 2 minutos (el 14\% del total de la partitura).

La música de la película en su conjunto guarda un estilo propio tanto en la orquestación como en el lenguaje musical. Estas obras diegéticas rompen con el resto del trabajo pero al mismo tiempo no desentonan y realizan su función a la perfección. Así, el pasodoble que escuchamos en la secuencia $\vee$ (bloque 7) está perfectamente integrado con el fragmento orquestal que le precede y no solo se conforma el autor con ello sino que la 
unión entre ambos está bien conjuntada y preparada, sin tratarse de arreglos en la mesa de mezclas.

El pasodoble taurino funciona como tal en la secuencia de la plaza de toros (bloque 16) trazando una adecuada ambientación y la canción popular entonada por el obrero podemos afirmar que la pieza es meramente funcional.

Para concluir, afirmaremos que el modus operandis del maestro Azagra en esta ocasión fue construir una banda sonora con poca música, eligiendo su lugar y duración del modo más preciso posible para conseguir una mejor utilización y efectividad de la misma. Esto provoca la disgregación de la composición en una gran cantidad de bloques de pequeña duración situados en lugares estratégicos para suavizar cambios de secuencias, ayudar en la construcción del relato en el montaje, alcanzar mayor dramatismo en un momento concreto de una escena o simplemente para ambientar o situar la acción.

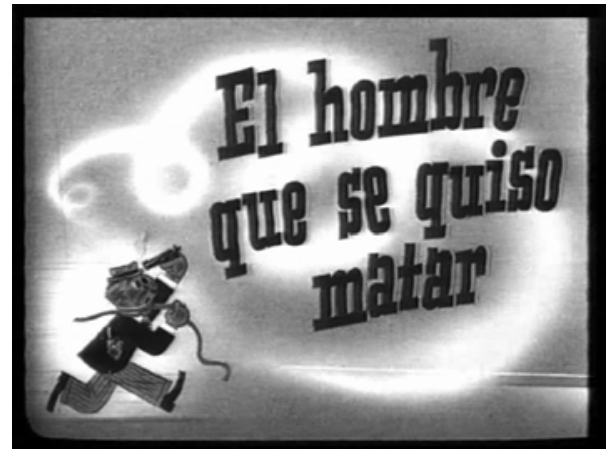

Fotograma 1: El hombre que se quiso matar (1942) Título en los créditos

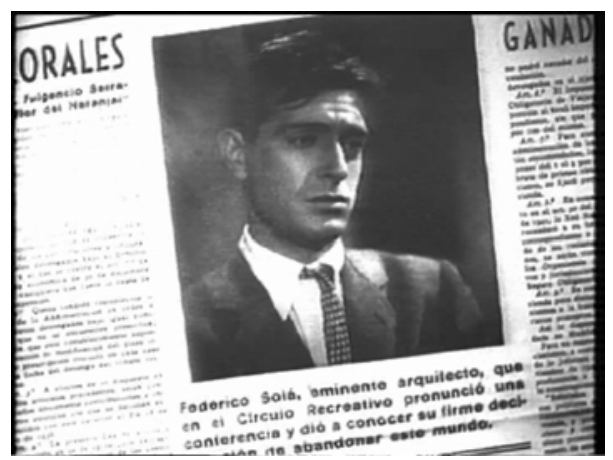

Fotograma 3: El hombre que se quiso matar (1942)

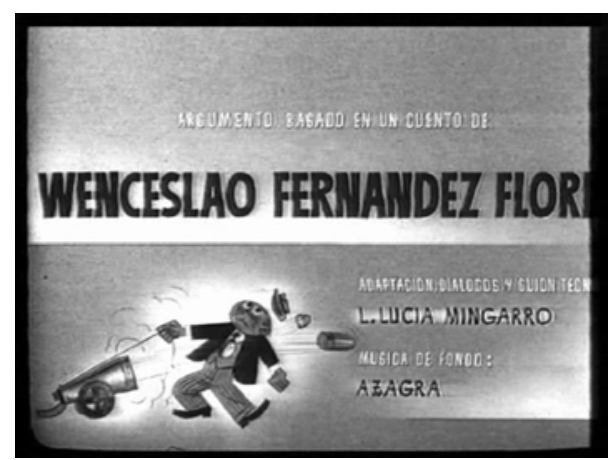

Fotograma 2: El hombre que se quiso matar (1942) créditos del compositor

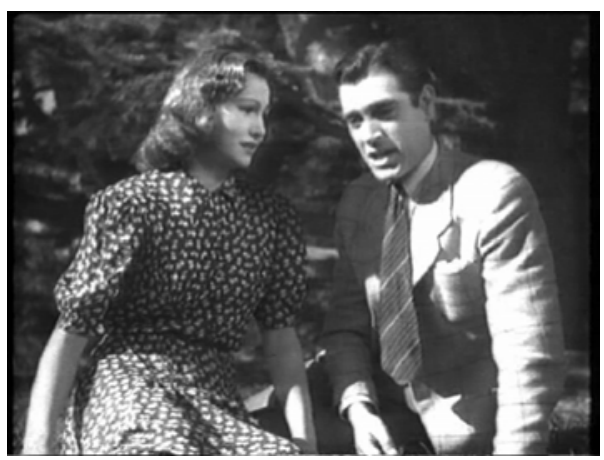

Fotograma 4: R. Yarza \& A. Casal en El hombre que se quiso matar (1942) 
El hombre que se quiso matar

\begin{tabular}{|c|c|c|c|c|c|c|c|c|c|}
\hline \multicolumn{3}{|c|}{ Dirección: } & \multicolumn{7}{|l|}{ Rafael Gil } \\
\hline \multicolumn{10}{|c|}{ Dato de producción: } \\
\hline \multirow{2}{*}{\multicolumn{3}{|c|}{ Producción: }} & \multicolumn{3}{|l|}{ CIFESA } & \multicolumn{2}{|c|}{ Prod. ejecutivo: } & \multicolumn{2}{|c|}{ Jesús Castro Blanco } \\
\hline & & Género: & Comedia & Color: & $\mathrm{B} / \mathrm{N}$ & Paso: & $35 \mathrm{~mm}$. & Metraje: & $2.200 \mathrm{mts}$. \\
\hline
\end{tabular}

\section{Datos artísticos:}

\begin{tabular}{|c|c|c|c|c|c|c|}
\hline Argumento: & \multicolumn{6}{|c|}{ Según el cuento homónimo de Wenceslao Fernández Flórez } \\
\hline Fotografía: & \multicolumn{2}{|c|}{ Isidoro Goldberguer } & Guión: & \multicolumn{3}{|c|}{ Luís Lucia (guión técnico) } \\
\hline Montaje: & \multicolumn{2}{|c|}{ Juan Serra Oller } & Diálogos: & \multicolumn{3}{|c|}{ Luís Lucia } \\
\hline Decorados: & \multicolumn{2}{|c|}{ Emilio Ferrer } & & & & \\
\hline Música: & \multicolumn{6}{|c|}{ Ruiz de Azagra, José María (Música Fondo) } \\
\hline \multicolumn{7}{|l|}{ Datos Técnicos: } \\
\hline Ayud. Sonido: & \multicolumn{2}{|c|}{ Jaime Torréns } & Regidor: & \multicolumn{3}{|c|}{ Jenaro Solsona Ronda } \\
\hline Script: & \multicolumn{2}{|c|}{ Remedios Sicilia } & Sist. de Son.: & \multicolumn{3}{|l|}{ R.C.A. } \\
\hline Ayute de Dir.: & \multicolumn{2}{|c|}{ Jesús Castro Blanco } & Maquillaje: & \multicolumn{3}{|c|}{ Luís Alcaraz } \\
\hline Operador: & \multicolumn{2}{|c|}{ Emilio Foriscot ( $2^{\circ}$ op.) } & Foto Fija: & \multicolumn{3}{|c|}{ Salvador Torres Garriga } \\
\hline Vestuario: & \multicolumn{2}{|c|}{ Casa Paquita } & Const. de dec.: & \multicolumn{3}{|c|}{ José Salvador } \\
\hline \multicolumn{7}{|c|}{ Datos de distribución: } \\
\hline Distribuidora: & \multicolumn{2}{|c|}{ CIFESA } & Laboratorios: & \multicolumn{3}{|c|}{ Cinefoto (Barcelona) } \\
\hline Estudios: & \multicolumn{2}{|c|}{ Kinefón (Barcelena) } & Fecha estr.: & \multicolumn{3}{|c|}{$16 / 02 / 1942$} \\
\hline \multicolumn{7}{|l|}{ Calificaciones: } \\
\hline \multicolumn{2}{|c|}{ Calificación del Estado: } & mayores 16 años & \multicolumn{3}{|c|}{ Permisos de importación: } & 1 \\
\hline \multicolumn{7}{|l|}{ Interpretes: } \\
\hline \multicolumn{2}{|c|}{ Intérprete } & Papel & \multicolumn{2}{|c|}{ Intérprete } & \multicolumn{2}{|c|}{ Papel } \\
\hline \multicolumn{2}{|c|}{ Acuaviva, José } & periodista & Alcáz & ar, Ángel & Bra & \\
\hline Aparici, & ente & portero del Círculo & Arbó & , Manuel & señ & rgüelles \\
\hline Bolas, $X$ & das & Gerardo, el huéspez & Casal & , Antonio & Fed & \\
\hline Castro Blanco & esús & tendero & Garrigó & , Camino & Jua & patrona \\
\hline Giner, José & món & catador & Hernández, & Eduardo & $\operatorname{limp}$ & \\
\hline López, & erto & Jorge & & las, Irene & Jua & \\
\hline Mascaró & edro & dueño del bar "Ámbar" & Mur & o, Eloísa & mac & rene \\
\hline Noya, Ale & ndro & fabricante & Palom & ero, José & port & rica \\
\hline Prad & José & presidente del Círculo & Pujac & las, José & don & \\
\hline Yarza, & osita & Irene Argüelles & & & & \\
\hline
\end{tabular}


Estructura.

\begin{tabular}{|c|c|c|c|c|c|c|}
\hline \multirow[t]{2}{*}{$\mathrm{N}^{0}$} & & \multirow{2}{*}{\multicolumn{2}{|c|}{ Tí́ulos de crédito }} & Personajes & \multicolumn{2}{|l|}{ acción } \\
\hline & & & & & & \multirow{4}{*}{$\begin{array}{l}\text { Bloque } 1 \\
\text { Bloque } 2\end{array}$} \\
\hline I & 1 & \multicolumn{4}{|c|}{ Vistas del pueblo mientras una voz en off nos pone en situación.. } & \\
\hline II & 1 & $\begin{array}{l}\text { Exterior } \\
\text { Día }\end{array}$ & Entrada "El Castor" & $\begin{array}{l}\text { Federico } \\
\text { Portero de la fábrica }\end{array}$ & $\begin{array}{l}\text { Federico sale apesadumbrado de la fábrica. El portero se pone a hablar } \\
\text { con él. Federico le comunica que le han despedido y que el puesto que } \\
\text { esperaba se lo han dado al hijo de uno de los jefes. }\end{array}$ & \\
\hline \multirow[t]{4}{*}{ III } & \multirow[t]{4}{*}{1} & \multirow{4}{*}{$\begin{array}{l}\text { Exterior } \\
\text { Día }\end{array}$} & \multirow[t]{4}{*}{ Paseo } & \multirow{4}{*}{$\begin{array}{l}\text { Federico } \\
\text { Juanita }\end{array}$} & \multirow{4}{*}{$\begin{array}{l}\text { Federico y Juanita (su novia) dan un paseo. Él acaba de terminar de } \\
\text { contarle sus desgracias. Ella le echa en cara su inutilidad. Él anuncia } \\
\text { que va a cambiar de carácter y de forma de ser. A partir de ese } \\
\text { momento decide ser un triunfador. } \\
\text { Se sientan en un banco y ella comienza a hacer planes para el fin de } \\
\text { semana pero él ya tiene otros. Una conferencia sobre el cemento } \\
\text { armado. Ella se enfada y decide abandonarle. }\end{array}$} & \\
\hline & & & & & & \multirow[t]{3}{*}{ Bloque 3} \\
\hline & & & & & & \\
\hline & & & & & & \\
\hline \multirow[t]{2}{*}{ IV } & 1 & $\begin{array}{l}\text { Interior } \\
\text { Día }\end{array}$ & Habitación de Federico & Federico & Entra en la habitación. Abre la ventana. Se sienta en la cama. & \multirow[t]{2}{*}{ Bloque 5} \\
\hline & 2 & $\begin{array}{l}\text { Interior } \\
\text { Día }\end{array}$ & Habitación de Federico & $\begin{array}{l}\text { Federico } \\
\text { Doña Francisca }\end{array}$ & $\begin{array}{l}\text { Entra doña Francisca, la casera, para pedirle el alquiler. Él informa a la } \\
\text { anciana que no puede pagarle porque no le han contratado. Ella le } \\
\text { perdona la deuda pero le pide que deje la habitación. Antes de irse le } \\
\text { entrega una carta. Sale. }\end{array}$ & \\
\hline \multirow[t]{5}{*}{$\mathrm{V}$} & 1 & $\begin{array}{l}\text { Interior } \\
\text { Día }\end{array}$ & Habitación de Federico & Federico & $\begin{array}{l}\text { Abre la carta que es de su padre. En ella éste le llama parásito y le } \\
\text { informa de que no le va a dar más dinero. } \\
\text { Federico decide quitarse la vida. } \\
\text { Escribe una carta de despedida. } \\
\text { Decide tirarse por la ventana, pero cuando lo va a hacer, el tendero de } \\
\text { abajo abre toldo frustrando el intento. Coge la carta y sale a la calle. }\end{array}$ & \multirow[t]{3}{*}{ Bloque 6} \\
\hline & 2 & $\begin{array}{l}\text { Exterior } \\
\text { Dia }\end{array}$ & $\begin{array}{l}\text { Calle solitaria junto a } \\
\text { vía de tranvía }\end{array}$ & $\begin{array}{l}\text { Federico } \\
\text { Limpiavías }\end{array}$ & $\begin{array}{l}\text { Federico casi es arrollado por el tranvía. Se da cuenta de las } \\
\text { posibilidades y se tumba a esperar que pase el tranvía pero pasa el }\end{array}$ & \\
\hline & & & & & $\begin{array}{l}\text { limpiavías y le hace levantar. Federico le pregunta que es más veloz, si } \\
\text { el tranvía o el tren, y el limpiavías le dice que el tren. }\end{array}$ & \\
\hline & 3 & $\begin{array}{l}\text { Exterior } \\
\text { Día }\end{array}$ & Vía de tren en el campo & $\begin{array}{l}\text { Federico } \\
\text { Maquinista del tren (más } \\
\text { tarde) }\end{array}$ & $\begin{array}{l}\text { Federico se tumba en la vía del tren a esperar que pase uno. } \\
\text { Pronto llega uno a toda velocidad, pero con la mala fortuna de que está } \\
\text { probando un invento para evitar atropellos y se salva. }\end{array}$ & \multirow[t]{2}{*}{ Bloque 7} \\
\hline & 4 & Exterior & Estación de tren & Federico & Llega el tren a la estación donde hay una gran multitud, una banda y & \\
\hline
\end{tabular}




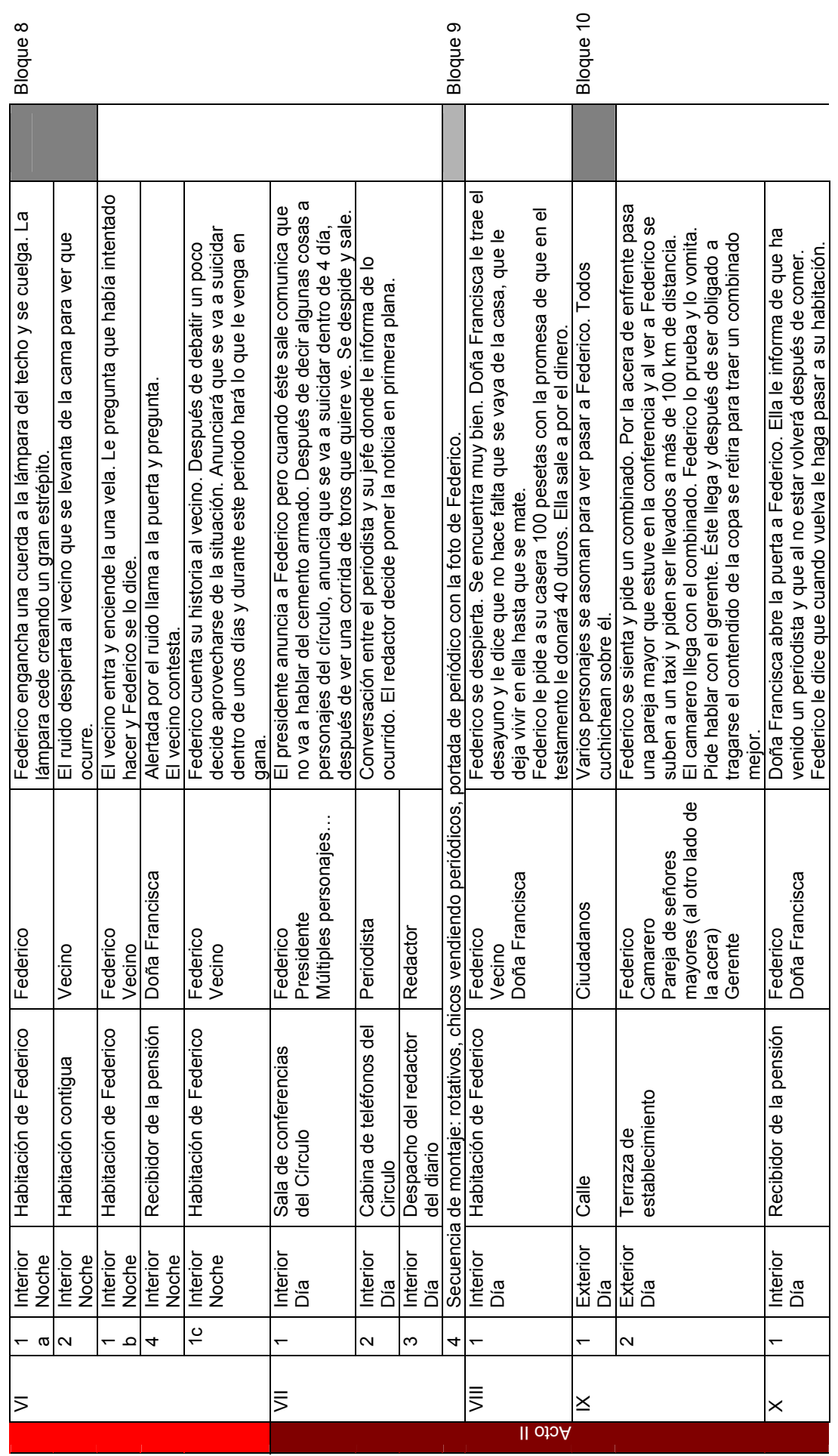




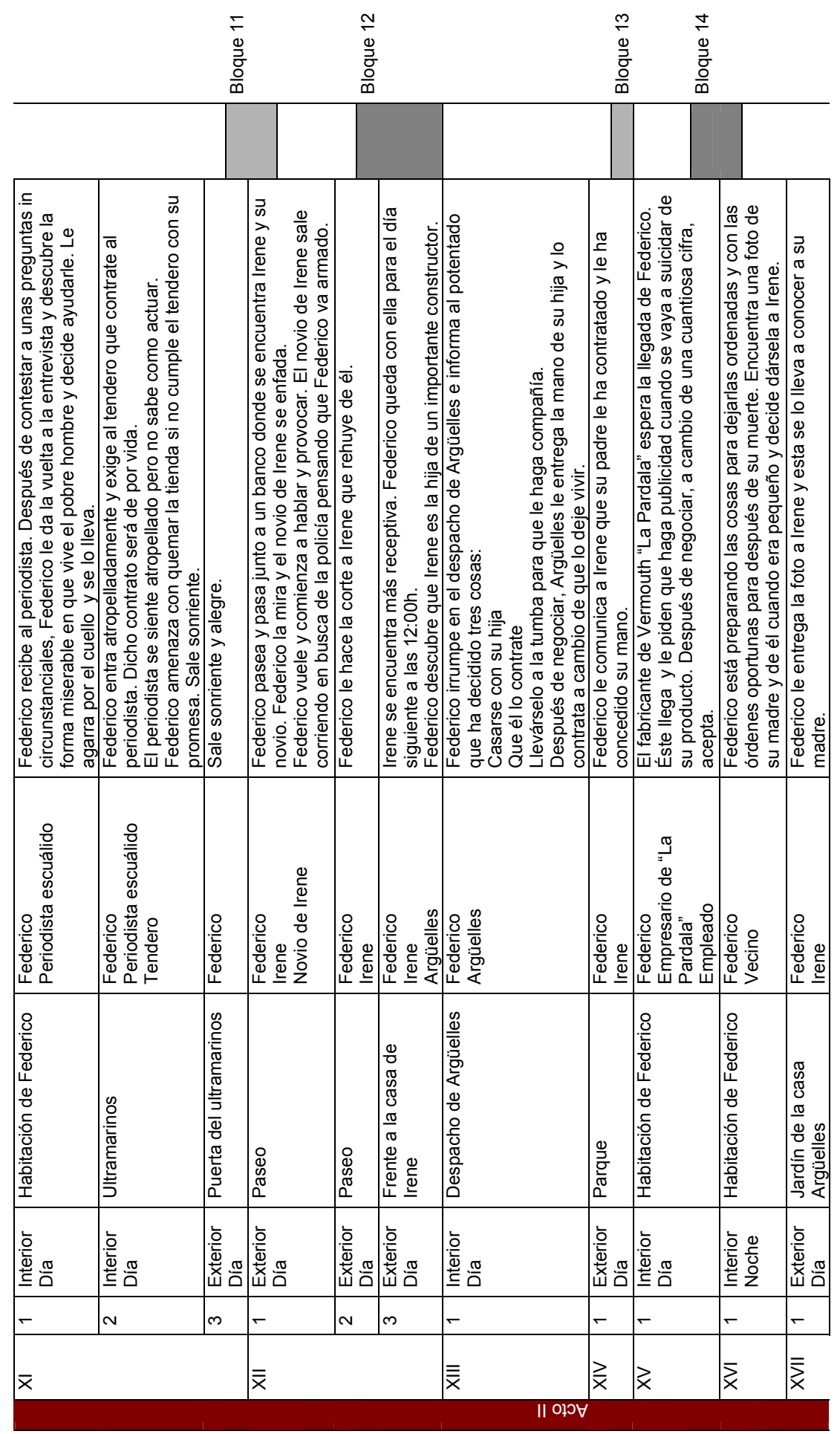




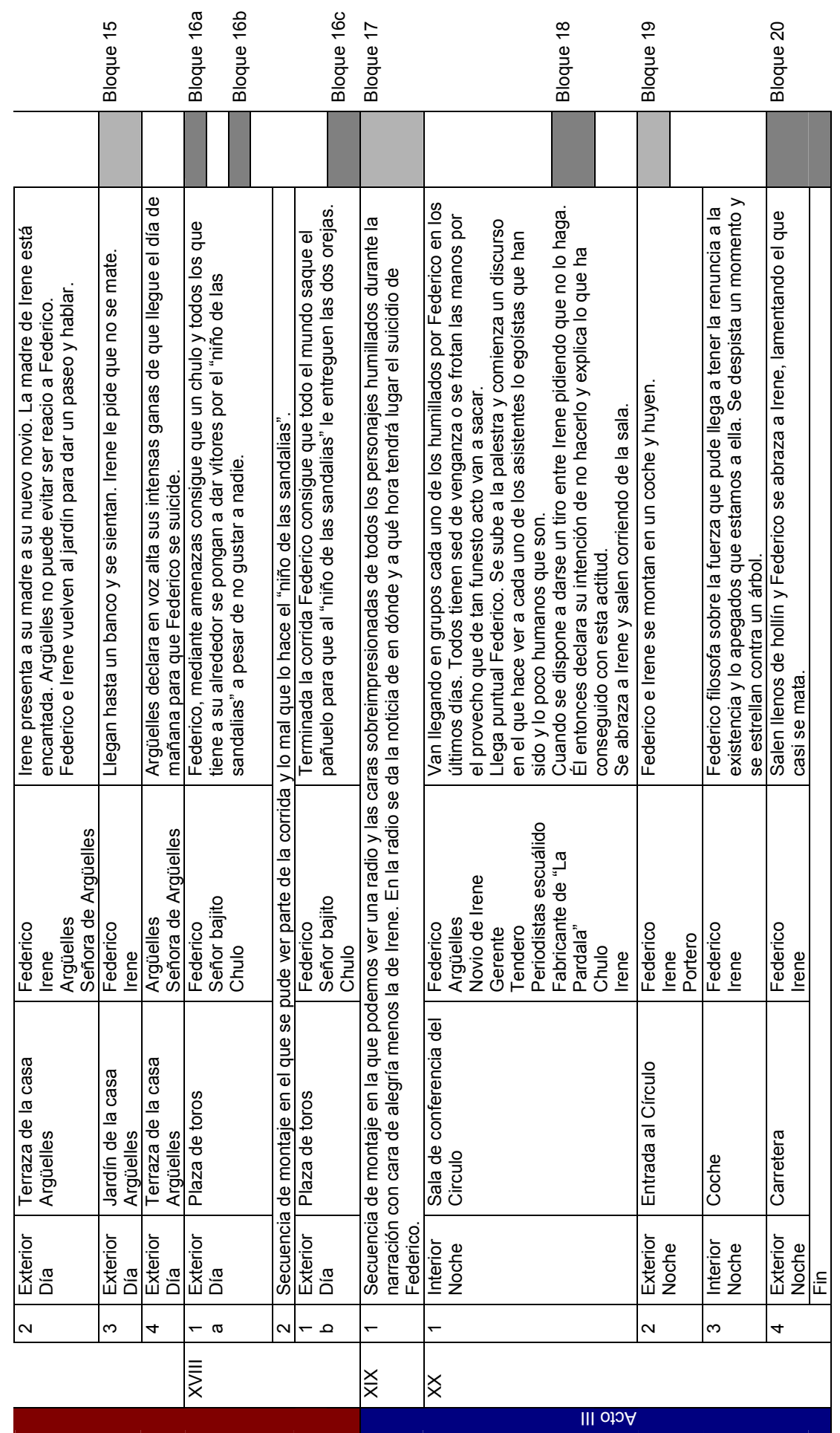


Fichas de análisis:

\begin{tabular}{|c|c|}
\hline BLOQUE 1 & \\
\hline Ubicación: & Títulos de créditos iniciales + escena $1+$ escena 2 \\
\hline Inicio: & Arranca con los títulos de crédito. \\
\hline Fin: & Finaliza con los mismos \\
\hline Duración: & 1'24" \\
\hline Estructura temática: & Tema del "Destino" \\
\hline & Tema de amor \\
\hline Forma narrativa: & Bloque a modo de overtura con los dos temas principales de la película. \\
\hline Plano narrativo: & Música de fondo (extradiegética) \\
\hline Plano sonoro: & Primer plano \\
\hline Función semántica: & Acompañamiento de créditos. \\
\hline & Presentación de los temas principales. \\
\hline NOTAS & $\begin{array}{l}\text { La pieza parece haber sido respetada al } 100 \% \text { a pesar de estar cortada al } \\
\text { principio, seguramente por razones del deterioro de la copia. }\end{array}$ \\
\hline
\end{tabular}

\begin{tabular}{|c|c|}
\hline BLO & \\
\hline $\begin{array}{l}\text { Ubicación: } \\
\text { Inicio: } \\
\text { Fin: } \\
\text { Duración: } \\
\text { Estructura temática: } \\
\text { Forma narrativa: }\end{array}$ & $\begin{array}{l}\text { Secuencias I y II } \\
\text { Arranca con el fundido a imagen después de los créditos. } \\
\text { Finaliza con la aparición en pantalla de Federico. } \\
39 \text { " } \\
\text { "Pueblo" } \\
\text { Está estructurado en dos partes. En la primera predominio del tema del } \\
\text { "Pueblo" y la segunda se trata de un fragmento sin tema reconocible con } \\
\text { progresión dinámica que acaba con un golpe de timbales. } \\
\text { Música de fondo (extradiegética) } \\
\text { Segundo plano } \\
\text { Convergente de tipo espacial en al primera parte y anímica en la segunda. } \\
\text { La pieza aunque fue compuesta para concluir con el golpe de timbales a la } \\
\text { aparición de Federico, en la mezcla se le bajó el volumen erróneamente por } \\
\text { respetar la voz en off. Esto produce un efecto desagradable. }\end{array}$ \\
\hline
\end{tabular}




\begin{tabular}{|l|l|} 
Ubicación: & Secuencia III \\
Inicio: & Cuando la pareja se dirige al banco para sentarse. \\
Fin: & Cuando está a punto de sentarse. \\
Duración: & $4 "$ \\
Estructura temática: & Transición 1 \\
Forma narrativa: & Mero arpegiado de subida y de bajada en el arpa. \\
Plano narrativo: & Música de fondo (extradiegética) \\
Plano sonoro: & $\begin{array}{l}\text { Segundo plano } \\
\text { Función semántica: }\end{array}$ \\
Nonvergencia física. \\
Ayuda a la transición. Resulta engañosa su utilización, puesto que según las \\
convenciones y el código occidental cuando se coloca una pieza de música en \\
un fundido a negro (aunque este sea motivado por la aproximación a la cámara \\
de un personaje) se produce una elipsis temporal que en este caso no existe. \\
Resulta desconcertante.
\end{tabular}

\section{BLOQUE 4}

Ubicación:

Inicio:

Fin:

Duración:

Estructura temática:

Forma narrativa:

Plano narrativo:

Plano sonoro:

Función semántica:

NOTAS
Secuencia III

Cuando Juanita abandona a Federico.

Cuando se produce el fundido a negro para finalizar la secuencia.

25"

"Abandono"

Tema circunstancial.

Música de fondo (extradiegética)

Segundo plano

Convergencia anímica. Enfatiza la desolación y ánimo del protagonista.

Convergencia física. Enfatiza el golpe del balón en la cara.

\section{BLOQUE 5}

\begin{tabular}{|c|c|}
\hline Ubicación: & Secuencia IV - escena 1 \\
\hline Inicio: & Arranca con el fundido a imagen. \\
\hline Fin: & Cuando Federico se aleja de la ventana a través de una bajada de volumen. \\
\hline Duración: & $57 "$ \\
\hline Estructura temática: & $\begin{array}{l}\text { "Fracaso" } \\
\text { canción popular }\end{array}$ \\
\hline Forma narrativa: & $\begin{array}{l}\text { Bloque en dos partes. La primera desarrollo del tema del Fracaso. La segunda } \\
\text { canción popular a capella. }\end{array}$ \\
\hline Plano narrativo: & $\begin{array}{l}\text { Música de fondo (extradiegética) (primera parte). } \\
\text { Música de pantalla (diegética) (segunda parte). }\end{array}$ \\
\hline Plano sonoro: & Segundo plano \\
\hline Función semántica: & Convergencia anímica (primera parte) \\
\hline NOTAS & Convergencia física, histórica y social.(segunda parte). \\
\hline
\end{tabular}




\begin{tabular}{|c|c|}
\hline BLO & \\
\hline Ubicación: & Secuencia V - escenas 1 y 2 \\
\hline Inicio: & Cuando Federico lee la carta de su padre \\
\hline Fin: & Cuando Federico se tumba en las vías del tranvía a esperar la muerte. \\
\hline Duración: & 2'06" \\
\hline Estructura temática: & "Fracaso" \\
\hline & "Dest \\
\hline & tem \\
\hline Forma narrativa: & $\begin{array}{l}\text { El bloque comienza con el tema del Fracaso acentuado por el “Destino".El resto } \\
\text { del bloque se trata de variaciones de este tema con adaptaciones para } \\
\text { conseguir la sincronización con elementos de la imagen como cuando el } \\
\text { protagonista arroja el papel o se levanta el toldo. Finaliza el tema con el tema } \\
\text { circunstancial del tranvía. }\end{array}$ \\
\hline Plano narrativo: & Música de fondo (extradiegética) \\
\hline Plan & Segundo y primer plano \\
\hline Función semántica: & $\begin{array}{l}\text { Convergencia anímica y física. Enfatiza especialmente la lucha interna del } \\
\text { personaje. }\end{array}$ \\
\hline NOTAS & $\begin{array}{l}\text { Con referencia al audio, nos engañan cuando el protagonista se tumba en las } \\
\text { vías. Oímos llegar el tranvía, con pitido incluido, cuando en realidad quien se } \\
\text { acerca es el limpiavías. }\end{array}$ \\
\hline
\end{tabular}

\begin{tabular}{|c|c|}
\hline BLOC & \\
\hline Ubicación: & Secuencia V - escenas 3 y 4 . \\
\hline Inicio: & Entra con el fundido encadenado de cambio de escena \\
\hline Fin: & $\begin{array}{l}\text { Cuando el presidente de la asociación protectora de animales le pide al } \\
\text { maestro que deje de tocar. }\end{array}$ \\
\hline Duración: & 1'02"' \\
\hline Estructura temática: & $\begin{array}{l}\text { "Destino" } \\
\text { pasodoble }\end{array}$ \\
\hline Forma narrativa: & $\begin{array}{l}\text { El tema del destino está perfectamente enlazado con el pasodoble, no parece } \\
\text { una unión echa en las mezclas sino realizada desde la partitura totalmente } \\
\text { sincronizado con las imágenes. }\end{array}$ \\
\hline Plano narrativo: & Música de fondo (extradiegética) (primera parte) \\
\hline & Música de pantalla (diegética) (segunda parte). \\
\hline Plano sonoro: & Primer y segundo plano \\
\hline Función semántica: & $\begin{array}{l}\text { Convergencia anímica y física. Se enfatiza por un lado la lucha interna del } \\
\text { protagonista y, por otro, se crea mayor tensión al potenciar la llegada del tren } \\
\text { al lugar donde se encuentra Federico. Por último, el desenlace de la escena es } \\
\text { más brioso gracias a la potenciación dramática que hace la música del rescate. } \\
\text { Convergencia socio-cultural e histórica. El pasodoble sirve inequívocamente } \\
\text { para situarnos en el contexto histórico social y cultural. } \\
\text { - }\end{array}$ \\
\hline
\end{tabular}




\begin{tabular}{l|l|} 
Ubicación: & $\begin{array}{l}\text { Secuencia VI - escenas 1 y } 2 . \\
\text { Inicio: }\end{array}$ \\
$\begin{array}{l}\text { Fin: } \\
\text { Duraciónca con el comienzo de secuencia. } \\
\text { Estructura temática: }\end{array}$ & $\begin{array}{l}53 \text { " } \\
\text { "Destino" } \\
\text { "Lampara" } \\
\text { Se escucha un primer momento el tema del destino para luego escuchar un } \\
\text { tema circunstancial que hemos dado en llamar "Lámpara". En el momento en } \\
\text { que cede la lámpara, se produce un silencio hasta que se escucha bien el } \\
\text { estrépito de la caída. }\end{array}$ \\
Plano narrativo: & $\begin{array}{l}\text { Música de fondo (extradiegética) } \\
\text { Segundo plano } \\
\text { Plano sonoro: }\end{array}$ \\
Función semántica: & $\begin{array}{l}\text { Convergencia anímica y física. Por un lado enfatiza la decisión del personaje. } \\
\text { Por otro lado, el silencio provoca una mayor inquietud y hace más efectiva la } \\
\text { entrada posterior de la música que resulta más dramática. }\end{array}$ \\
NOTAS &
\end{tabular}

\section{BLOQUE 9}

\begin{tabular}{|l|l|} 
Ubicación: & Secuencia VII - escena 4 \\
Inicio: & Con el primer plano de la escena de montaje. \\
Fin: & Con el último plano de la escena de montaje. \\
Duración: & 21 " \\
Estructura temática: & "popularidad" \\
Forma narrativa: & Tema rítmico sin apenas melodía. \\
Plano narrativo: & Música de fondo (extradiegética) \\
Plano sonoro: & Segundo plano \\
Función semántica: & $\begin{array}{l}\text { Convergencia anímica, física y temporal. } \\
\text { NOTAS }\end{array}$ \\
& $\begin{array}{l}\text { La música acompaña las imágenes de esta escena de montaje, } \\
\text { proporcionando mayor dinamismo y ritmo, asimismo aporta un mayor efecto del } \\
\text { paso del tiempo. }\end{array}$ \\
\hline
\end{tabular}

\section{BLOQUE 10}

\begin{tabular}{|l|l|} 
Ubicación: & Secuencia IX - escena 1. \\
Inicio: & Arranca con el comienzo de secuencia. \\
Fin: & Cuando aparece Federico seguido de niños \\
Duración: & $12 "$ \\
Estructura temática: & "popularidad" \\
Forma narrativa: & Reutilización del bloque 9 \\
Plano narrativo: & Música de fondo (extradiegética) \\
Plano sonoro: & Segundo plano \\
Función semántica: & Convergencia anímica. Enfatiza el frenesí popular morboso. \\
NOTAS & \\
\hline
\end{tabular}




\section{BLOQUE 11}

\begin{tabular}{l|l} 
Ubicación: & Secuencias XI y XII. \\
Inicio: & Comienza con el fin de la secuencia XI \\
Fin: & Finaliza con el comienzo de la secuencia XII. \\
Duración: & $14 "$ \\
Estructura temática: & "popularidad" \\
Forma narrativa: & Variación más lenta del tema popularidad. \\
Plano narrativo: & Música de fondo (extradiegética) \\
Plano sonoro: & Segundo plano \\
Función semántica: & Transición entre secuencias. \\
NOTAS & \\
\hline
\end{tabular}

\section{BLOQUE 12}

Ubicación:

Inicio:

Fin:

Duración:

Estructura temática:

Forma narrativa:

Plano narrativo:

Plano sonoro:

Función semántica: NOTAS
Secuencia XII - escenas 2 y 3.

Cuando ella le pregunta porqué se va a suicidad

Con el fundido a negro de cambio de secuencia.

1'48"

"Fracaso"

tema de amor

Bloque en dos temas bien diferenciados pero unidos musicalmente.

Música de fondo (extradiegética)

Segundo plano

Convergencia anímica.

La pieza está dividida en dos partes. En una primera parte, aquella en que Irene le pregunta el porqué de su decisión, se escucha el tema del Fracaso (vinculado desde el comienzo del filme a la decisión tomada) pero cuando la conversación entra en el terreno amoroso se introduce por primera vez el tema de amor.

\begin{tabular}{|c|c|}
\hline BLO & \\
\hline $\begin{array}{l}\text { Ubicación: } \\
\text { Inicio: } \\
\text { Fin: } \\
\text { Duración: } \\
\text { Estructura temática: } \\
\text { Forma narrativa: } \\
\text { Plano narrativo: } \\
\text { Plano sonoro: } \\
\text { Función semántica: } \\
\text { NOTAS }\end{array}$ & $\begin{array}{l}\text { Secuencia XIV } \\
\text { Cuando comienzan a tener una conversación seria sobre las intenciones de } \\
\text { Federico } \\
\text { Con el fundido a negro de cambio de secuencia. } \\
1 \text { ' } \\
\text { tema de amor } \\
\text { Música de fondo (extradiegética) } \\
\text { Segundo plano } \\
\text { Convergencia anímica. Potenciación de la escena amorosa. } \\
\text { El tema termina con bajada de volumen y corte brusco (seguramente de la } \\
\text { copia). }\end{array}$ \\
\hline
\end{tabular}




\begin{tabular}{|l|l|} 
Ubicación: & Secuencia XV y XVI. \\
Inicio: & Al finalizar la secuencia XV \\
Fin: & Al comenzar la secuencia XVI \\
Duración: & $12 "$ \\
Estructura temática: & Transición 2 \\
Forma narrativa: & Tema lúgubre, tal vez derivado del tema del destino. \\
Plano narrativo: & Música de fondo (extradiegética) \\
Plano sonoro: & Segundo plano \\
Función semántica: & Enlace entre escenas. \\
NOTAS & - \\
\hline
\end{tabular}

\section{BLOQUE 15}

\begin{tabular}{|l|l|} 
Ubicación: & Secuencia XVII - escena 3. \\
Inicio: & Al comenzar la escena 3 \\
Fin: & Al finalizar la escena 3, corte brusco. \\
Duración: & $20 "$ \\
Estructura temática: & Tema de amor \\
Forma narrativa: & \\
Plano narrativo: & Música de fondo (extradiegética) \\
Plano sonoro: & Segundo plano \\
Función semántica: & Convergencia anímica. \\
NOTAS & Se corta de modo brusco para acentuar todavía más la animadversión de \\
& Argüelles. \\
\hline
\end{tabular}

\section{BLOQUE 16}

\begin{tabular}{|c|c|}
\hline $\begin{array}{l}\text { Ubicación: } \\
\text { Inicio: } \\
\text { Fin: } \\
\text { Segunda parte: } \\
\text { Inicio tercera parte: } \\
\text { Fin: } \\
\text { Duración: } \\
\text { Estructura temática: } \\
\text { Forma narrativa: } \\
\text { Plano narrativo: } \\
\text { Plano sonoro: } \\
\text { Función semántica: } \\
\text { NOTAS }\end{array}$ & $\begin{array}{l}\text { Secuencia XVIII - escena } 1 \\
\text { Al comienzo de la escena 1a } \\
\text { En la conversación entre el presidente de los Faraones y Federico. } \\
\text { Antes de la salida del toro se escucha una fanfarria. } \\
\text { Con el paseíllo del "Niño de las alpargatas". } \\
\text { Fundido a negro de cambio de secuencia. } \\
37 \text { " / 5" / 30" } \\
\text { Pasodoble taurino } \\
\text { Fanfarria taurina } \\
\text { Temas de carácter popular } \\
\text { Música de pantalla (diegética) } \\
\text { Segundo plano } \\
\text { Función física e histórico-cultural. } \\
\text { Sirve de ambientación. }\end{array}$ \\
\hline
\end{tabular}




\begin{tabular}{|l|l|}
\hline BLOQUE 17 & \\
Ubicación: & Secuencia XIX \\
Inicio: & Con el fundido de entrada \\
Duración: & Con el fundido de salida. \\
Estructura temática: & $25 "$ \\
Forma narrativa: & Marcha fúnebre para la radio. \\
Plano narrativo: & Marcha nupcial de ritmo marcado. \\
Plano sonoro: & Música de fondo (extradiegética) \\
Función semántica: & Segundo plano \\
& Función física y anímica. \\
& Sirve como elemento unificador de la escena de montaje. \\
NOTAS & Acompaña el anunciamiento del final. \\
\hline
\end{tabular}

\begin{tabular}{|c|c|}
\hline BLOC & \\
\hline $\begin{array}{l}\text { Ubicación: } \\
\text { Inicio: } \\
\text { Fin: } \\
\text { Duración: } \\
\text { Estructura temática: } \\
\text { Forma narrativa: } \\
\text { Plano narrativo: } \\
\text { Plano sonoro: } \\
\text { Función semántica: }\end{array}$ & $\begin{array}{l}\text { Secuencia XX - escena } 1 . \\
\text { Cuando anuncia que se va dar un tiro } \\
\text { Cuando anuncia que no se va a dar un tiro } \\
18 \text { " } \\
\text { "Destino" } \\
\text { tema de amor } \\
\text { Fanfarria y tema melódico. } \\
\text { Música de fondo (extradiegética) } \\
\text { Segundo plano } \\
\text { Convergencia anímica y física. } \\
\text { Enfatiza con la fanfarria el momento trágico anterior al suicidio. } \\
\text { Con el tema de amor se redime el personaje y hace más fuerte la presencia de } \\
\text { Irene. } \\
\text { El tema de amor sirve a modo de resurrección. }\end{array}$ \\
\hline & \\
\hline
\end{tabular}

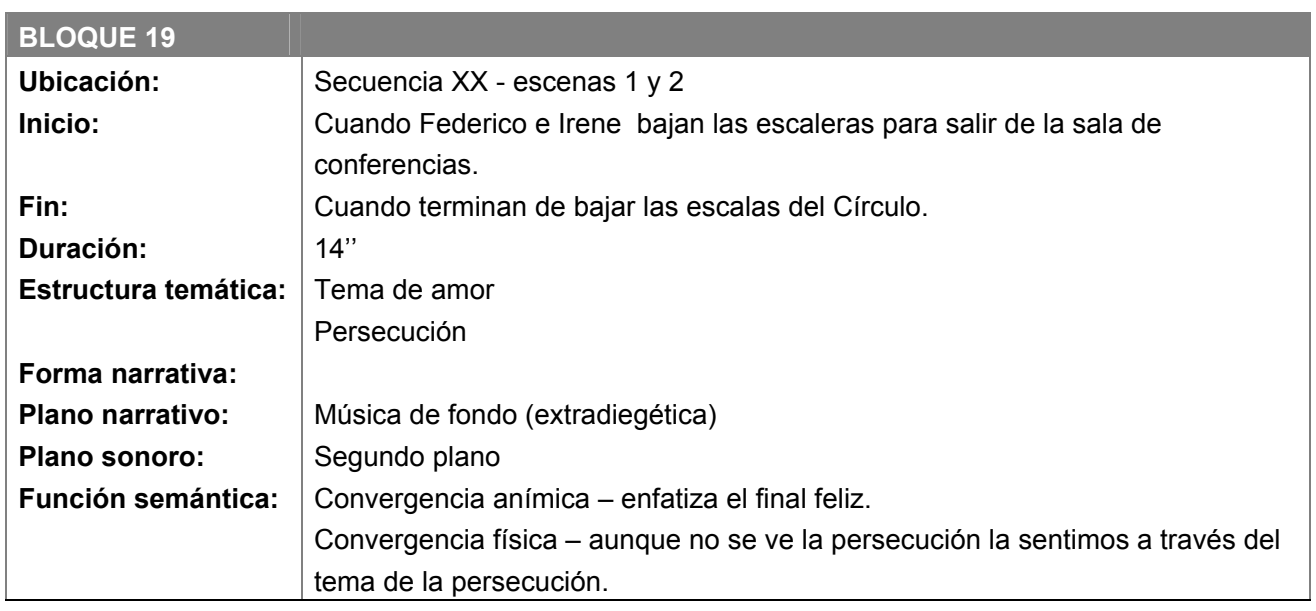




\begin{tabular}{|l|l|}
\hline BLOQUE 20 & \\
\hline Ubicación: & Secuencia XX -escena 3 y 4. \\
Inicio: & Comienza con la fanfarria del destino antes del golpe. \\
Fin: & Termina con el fundido de finalización del filme. \\
Duración: & 37 " \\
Estructura temática: & Fanfarria del "Destino" \\
Forma narrativa: & Tema de amor. \\
Plano narrativo: & $\begin{array}{l}\text { Música de fondo (extradiegética) } \\
\text { Plano sonoro: }\end{array}$ \\
Función semántica: & $\begin{array}{l}\text { Segundo plano } \\
\text { Función anímica } \\
\text { La fanfarria anuncia el accidente. }\end{array}$ \\
& $\begin{array}{l}\text { El tema de amor enfatiza el final feliz. } \\
\text { Sirve de elemento conclusivo. }\end{array}$ \\
NOTAS & La música continúa ya con la pantalla en negro durante unos segundo. \\
\hline
\end{tabular}

\section{Quintero: Deliciosamente tontos}

Deliciosamente Tontos (1943) fue una de las primeras películas de Juan de Orduña realizada para CIFESA, con música original de Juan Quintero Muñoz. Se trata de una obra menor del director al mismo tiempo que una película de aprendizaje para muchas de las personas implicadas en la elaboración de la misma.

Para el análisis recurrimos a una copia existente en el mercado videográfico editada por DIVISA Ediciones dentro de su colección Clásico Español, y puesta en circulación en formato VHS en 1996. El estado de la misma, a pesar de no estar todo lo bien que se desearía, es muy aceptable, tanto a nivel visual como sonoro, teniendo en cuenta.

La obra Juan Quintero Muñoz parece haber sido bastante respetada, aunque consideramos que en algunos bloques, como el número 12 insertado en la escena 41 y posterior secuencia de montaje, la música del maestro ha sufrido manipulación no controlada por su creador como veremos más adelante.

La primera conclusión que se extrae del análisis sonoro y musical del presente filme no es otra que la baja proporción de música presente en la narración, tan solo 30 minutos de música frente a 52 minutos de silencio.

Este aspecto se puede observar fácilmente en el gráfico de la derecha donde se presenta un diagrama en el que podemos apreciar la estructura de la película en secuencias y la inclusión de bloques musicales en al misma (marcados en gris oscuro).

Por un lado, la falta total de una planificación sonora de ruidos y sonidos ambiente resulta especialmente llamativa. Nos llama poderosamente la atención la inexistencia en multitud de escena de sonido ambiente, convirtiéndose el silencio casi en protagonista. Por otro lado, esta ausencia de ruidos es muy evidente cuando suena música, que sin 


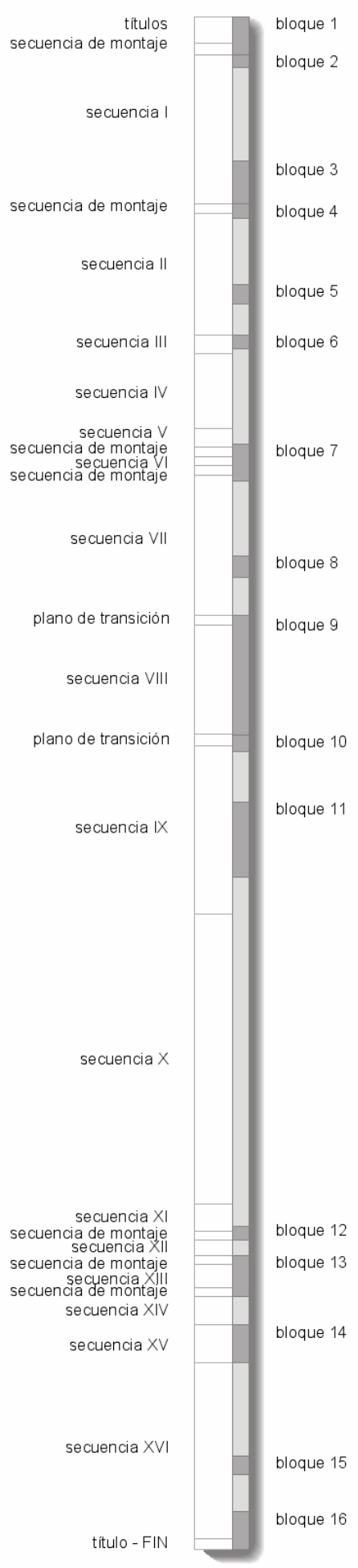

necesidad de encontrarse en un primer plano sonoro, no da esta sensación, debido a esta ausencia.

En cuanto a la diversidad temática, se puede observar que el mayor número de bloques están compuestos por un único tema musical, siendo casi una excepción aquellos bloques compuestos por más de un tema, o lo que es lo mismo, politemáticos.

A pesar de tratarse de una comedia, la música no pretende en ningún momento duplicar la información dada con las imágenes, evitando en todo momento las onomatopeyas musicales del mikeymausing ${ }^{312}$.

A nivel temático, nos encontramos con un grueso de temas que fueron creados para una única ocasión (Minué, tema bailable 1, etc.) que denominamos "temas circunstanciales" porque su única función es la de servir en ese único instante; frente a otros temas que funcionan a modo de leitmotives, como por ejemplo, "Pensar en ti" o "Vana llusión" vinculados de modo inequívoco a la historia de amor entre María y Ernesto, siendo el primero el genuino tema romántico del largometraje y con el que arranca y concluye la narración. Otro aspecto interesante de estas dos piezas es su procedencia o unión geográfica que pensamos está ligada a la procedencia de cada uno de los dos amantes; España (Pensar en ti), Cuba (Vana Ilusión).

El tema del viaje, se trata de un bloque del que existen dos versiones, una de larga duración y otra más corta. Este tema podría decirse que funciona como leitmotiv SE ESCRIBE CON E FINAL? asociado a los viajes $y$ desplazamientos de los protagonistas. Normalmente aparece en las secuencias de montaje que narran este tipo de eventos, ayudando narrativamente a entender dichas escenas y confiriendo un valor añadido al acortar el tiempo y el espacio.

El cuarto tema, utilizado más de una vez lo llamamos "Salvamento". Este tema, compuesto para la escena 20 , vuelve a hacer acto de presencia en la

\footnotetext{
${ }^{312}$ El mikeymausing hace referencia a aquella música descriptiva que duplica lo que vemos en pantalla en la partiura. Su nombre deriva de las primeras películas de Mikey Mause. Buenos ejemplos del la música mikeymausing son las partituras escritas para los cortometrajes que acabamos de nombrar del personaje de Disney o aquellas que se escuchan en los cortometrajes de la Warner (El correcaminos, etc.) o la Metro (Tom y Jerry).
} 
secuencia 41 y el montaje posterior, pero consideramos que se trata de un remiendo musical llevado a cabo en la mesa de mezclas sin la opinión del compositor, como medida drástica de última hora. Para realizar tal afirmación nos basamos en dos fuentes claras. Por un lado, la partitura manuscrita de la obra. En ella podemos ver cómo se corresponde claramente con la primera aparición del tema en la escena 20, donde emerge y desaparece de un modo natural. No ocurre así la segunda vez donde podemos apreciar el aumento forzoso del volumen y descenso del mismo en momentos no naturales de la pieza. En cuanto a la convergencia con la acción en este último momento, se puede ver y oír claramente que no existe, y por si esto no fuese suficiente, no hemos encontrado la partitura que correspondería a este bloque.

El otro tema utilizado de modo coherente es el que hemos denominado "Tema del viaje" que hace acto de aparición cada vez que se quiere constatar el paso del tiempo en el viaje o bien en la escena de montaje en las que se muestra el mismo. Otros temas como, "Salvamento" creado para la escena del salvamento del perro, es reutilizado para la escena de montaje del desembarco en España, algo que nos parece extraño. Al respecto opinamos que la pieza fue colocada en la fase de postproducción sin que fuese creada para tal lugar como se puede notar tanto en su duración, naturaleza del tema, ritmo, etc., que no concuerdan con la escena de montaje del desembarco.

Las marchas nupciales podemos considerarlas como temas circunstanciales en cuanto que son utilizadas en una única secuencia a lo largo de toda la película, pero las connotaciones semióticas, simbólicas y conceptuales que estas piezas tienen en nuestras latitudes confieren a dichos temas una importancia mayor de la que tendría de no ser así. Nos resulta, por otro lado, muy curiosa la utilización de las dos archiconocidas marchas nupciales de Wagner (Lohengrin) y Mendelsshon (Sueño de una noche de verano). La utilización de las dos nos parece aleatoria y seguramente surgida por la improvisación en la sala de montaje.

Al igual que las marchas nupciales, casi un $40 \%$ de la música que se escucha en la película tiene una justificación en pantalla, comúnmente llamada diegética, y a pesar del gran valor dramático que este tipo de música puede llega a tener, en el caso que nos ocupa, no se aprovecha tampoco este recurso por lo general, aunque en el bloque 13 nos encontramos con un caso muy especial e interesante que vuelve a demostrar el conocimiento del tema por parte de Juan Quintero y Orduña. En el momento en que María comienza a pensar en Dimas se comienza a escuchar la canción "Pensar en ti". De pronto, la melodía la torna en un silbido que más tarde descubrimos que lo produce en Ernesto. Aquí encontramos un caso en que la música pasa de ser no diegética a tener justificación en pantalla y acentuar los aspectos semánticos de la pieza.

Otro caso a tener en cuenta, son las canciones que suenan en la fiesta nocturna en el barco, donde podemos escuchar las dos canciones unidas al romance entre los protagonistas. En un momento determinado, Mari y Ernesto salen a cubierta y, a pesar de encontrarse fuera del salón, escuchamos más fuerte y claro que nunca la rumba "Vana Ilusión" que en un principio había funcionado en la escena anterior como música de diegética.

En cuanto a la planificación sonora así como la utilización de la música como elemento coestructurador del montaje nos hemos encontrado ante un caso que 
consideramos, cuanto menos, curioso. Si bien, Quintero y Orduña nos demuestran que no desconocen el poder unificador de la música en el bloque 7 , durante el resto de la película en contadas ocasiones vuelven a utilizarlo y vinculan el comienzo y final de pieza con el comienzo o final de secuencia, acentuando de este modo la división entre escenas y secuencias en vez de evitarlo. De este modo, al concluir la escena concluye la música. Esto nos ha llevado a pensar en que la planificación de la música se efectuaba en función de las escenas y no en función de un todo.

La falta de sonidos y ruidos en la banda sonora así como los sistemas de captación de los mismos, acentúan en grado sumo la inexistencia de variación en el plano sonoro. En esta película solo existen dos planos sonoros para cada uno de los elementos que forman el soundtrack.

En general se trata de una banda sonora muy desigual. Con una utilización torpe del recurso del leitmotiv así como de la utilización de la interrupción dramática del sonido. Recurso éste que por otro lado se utiliza en 4 ocasiones, aunque solo en una tiene un verdadero efecto dramático, en la última escena cuando Dima susurra al oído de María las palabras "... al fin solos", momento crucial puesto que es en ese preciso instante cuando ella toma su decisión de volver con el "salvaperros".

Para terminar, llamar la atención sobre la corta duración de los bloques musicales y su carácter heterogéneo tanto en estilo como en sus fuentes, encontrándonos con piezas sinfónicas junto a rumbas, piezas de jazz o bailables.

Como hemos podido observar, las diferencias en la estructura musical es bien diferente en función del compositor. Llegados a este punto debemos advertir que la elección de las dos películas que hemos utilizado como ejemplos no es en ningún momento casual. Se han elegido dos comedias próximas en la realización y que tienen como denominador común la misma productora. Por otro lado, aunque Deliciosamente tontos no responde al esquema musical que haría famoso a Juan Quintero, si es un ejemplo perfecto de partitura para comedia ligera realizada por el maestro en la que, como se ha podido apreciar, se distingue claramente el estilo del maestro aunque no se desarrolle en su máximo esplendor como ocurría en sus célebres dramas históricos como Locura de amor o Pequeñeces.

Una vez observados los dos análisis, podemos extraer las siguientes consideraciones:

- Juan Quintero asimiló el sistema basado en los leitmotives cinematográficos, originado en el drama musical wagneriano (salvando las distancias) y consolidado en Hollywood por Max Steiner. Con éste método, se acaba construyendo partituras pantacruélicas que nunca acababan, al estilo más puro del célebre vienés autor de Casablanca, pero para esta ocasión esto no se cumple. Se trata, como se acaba de decir, de una banda sonora relativamente corta (aunque más larga de lo que habitualmente eran).

- Ruiz de Azagra, por el contrario, más ecléctico, acaba creando un estilo basado en la puntuación de la acción, sin una utilización steinerniana del leitmotiv y prefiriendo la creación una partitura variada, muy fraccionada en pequeños bloques (que en ocasiones llegaban a durar tan solo cuatro 
segundos) y dirigidos esencialmente a una puntualización directa de la acción o los sentimientos.

Evidentemente, estas dos maneras tan diferenciadas de musicar un filme son la plasmación efectiva de una metodología en la labor compositiva bien diferenciada y con criterios diametralmente opuestos, no solo estéticos sino formales, que afectan a cómo la música interactúa con las imágenes. $Y$ a pesar de ser tan distintas, ambas cumplen su función de manera efectiva y solícita.

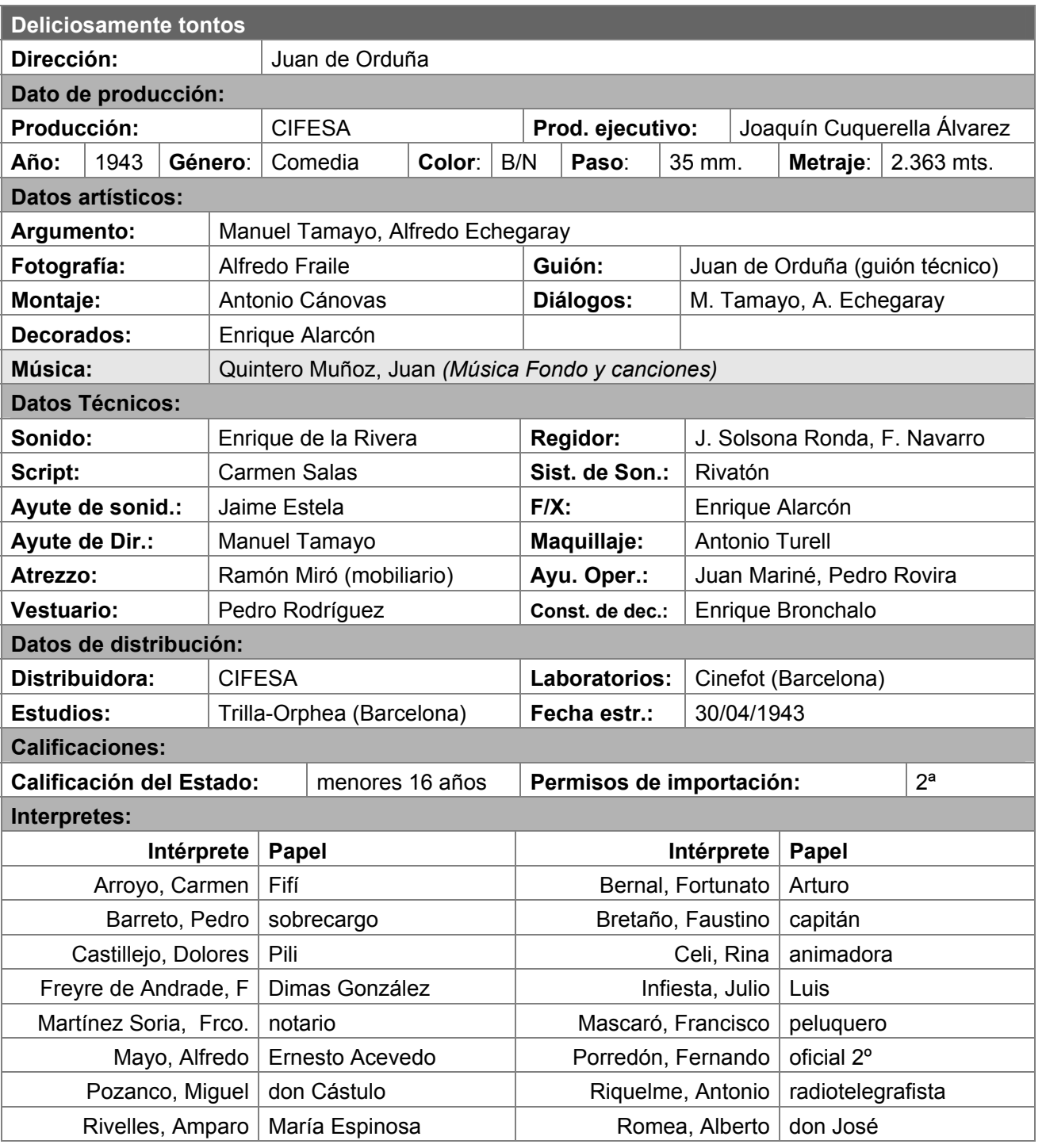


Estructura.

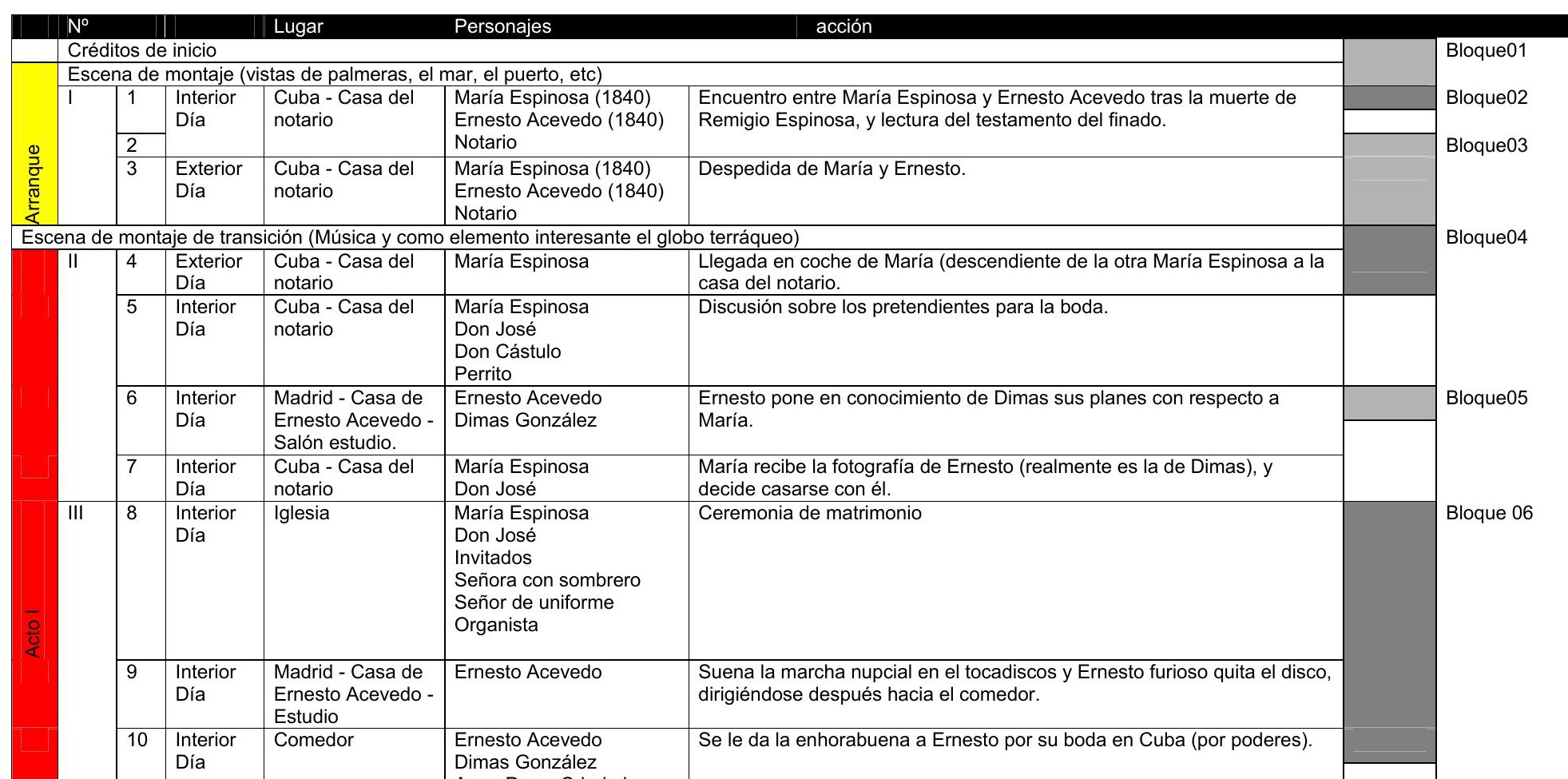




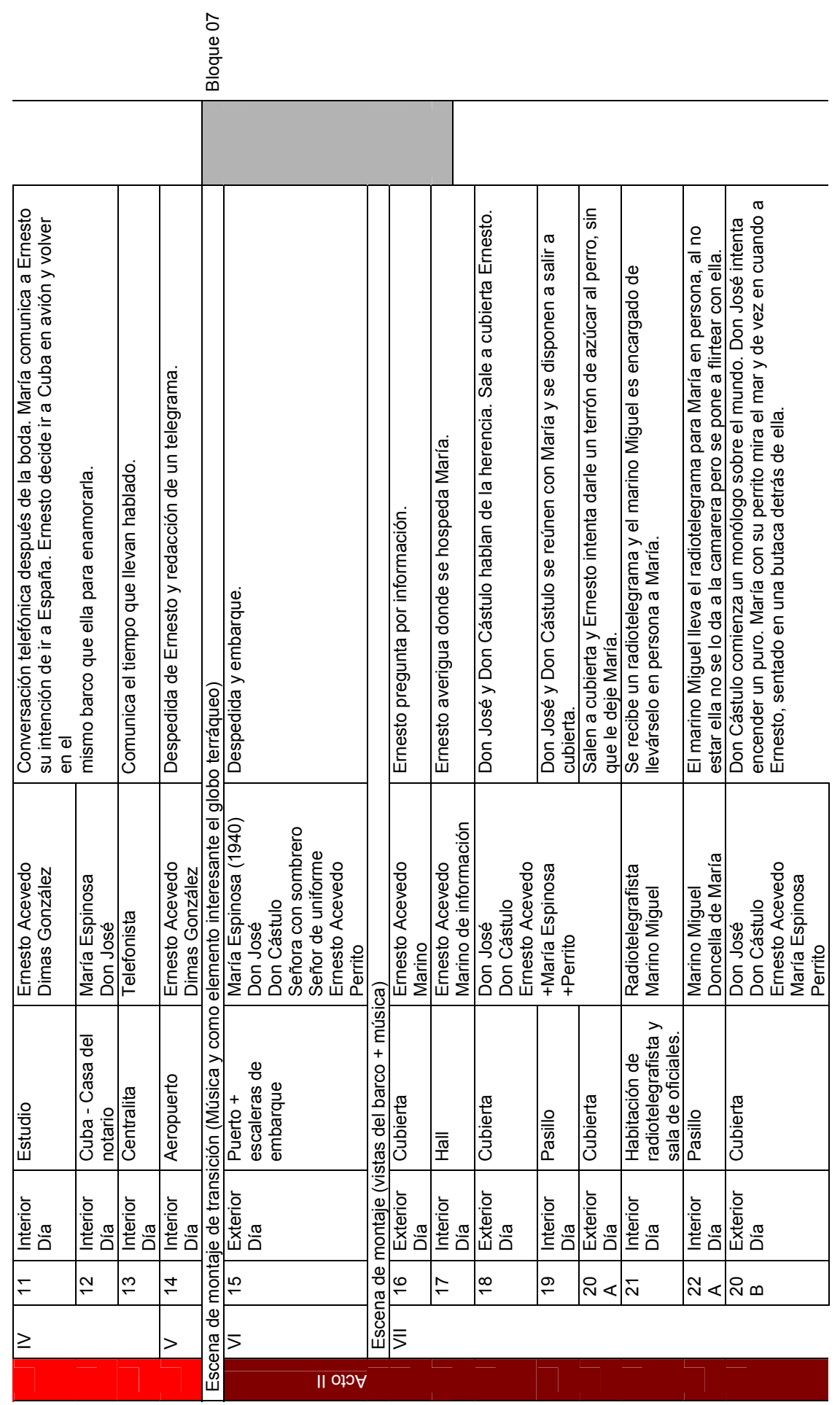




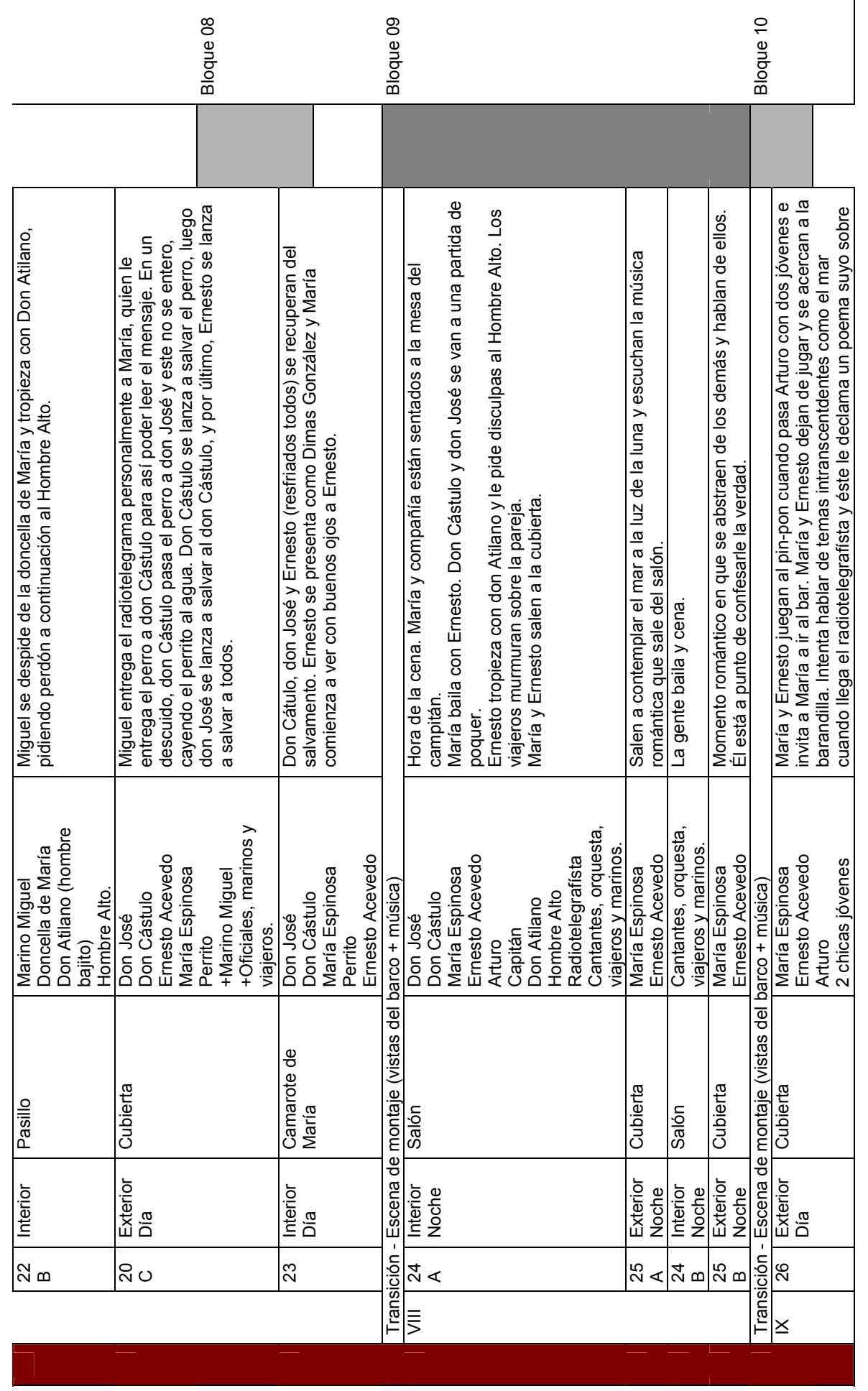




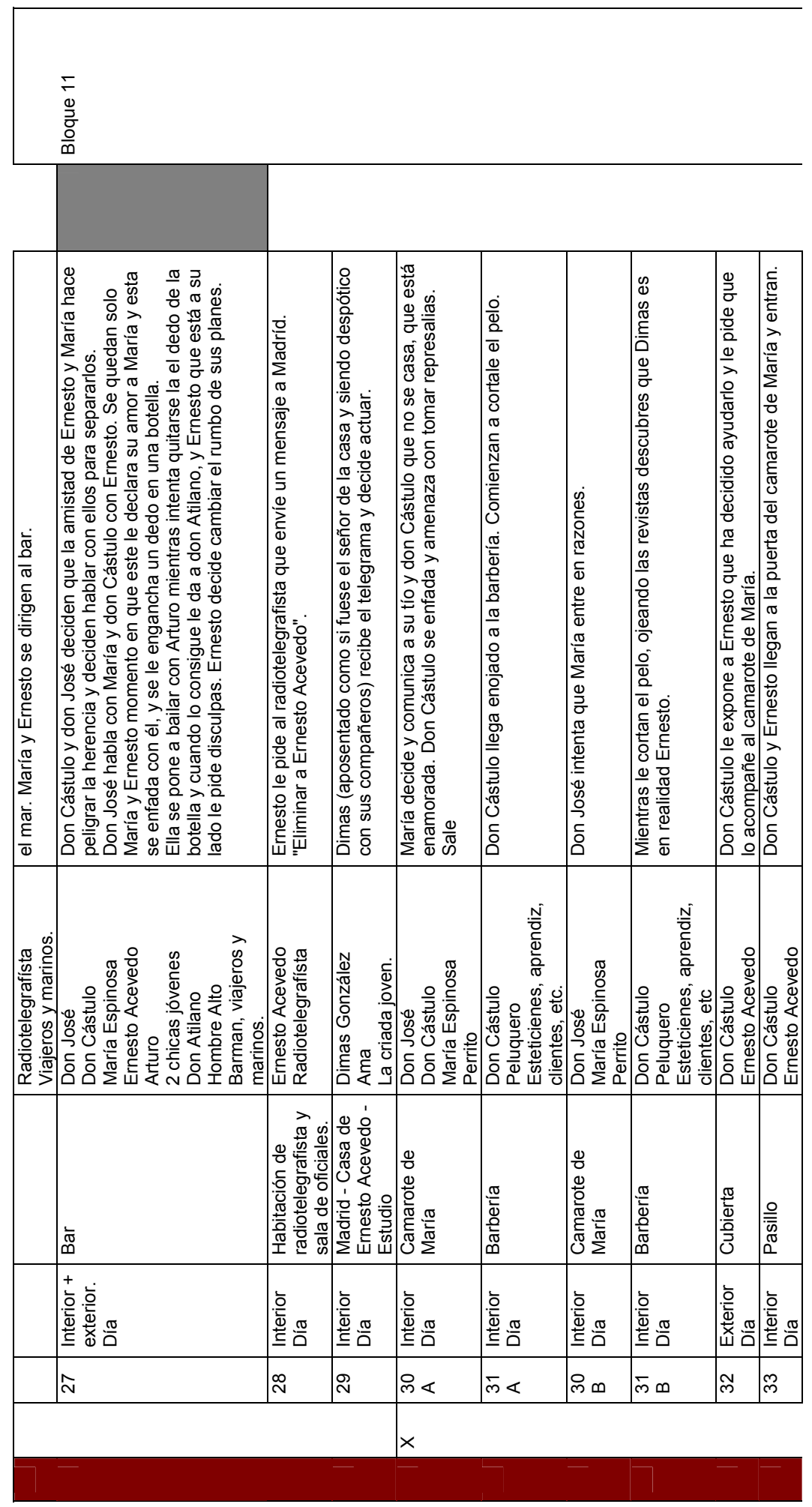




\begin{tabular}{|c|c|c|c|c|c|c|c|}
\hline 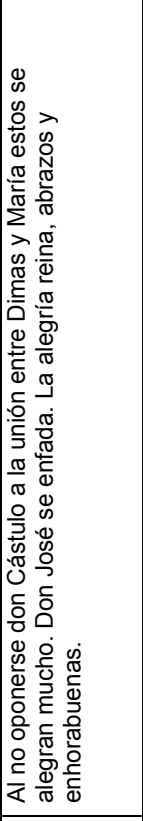 & 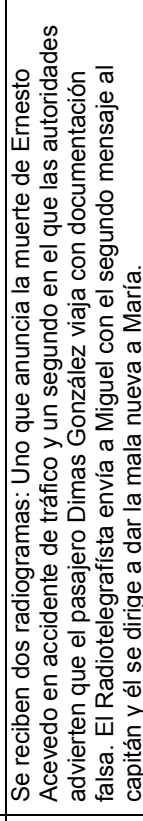 & 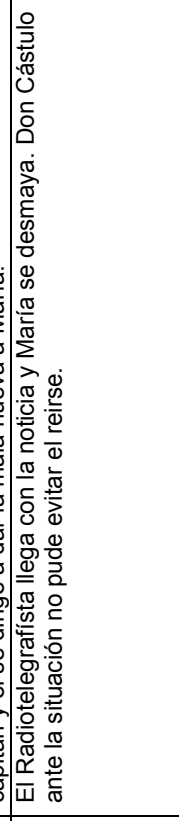 & 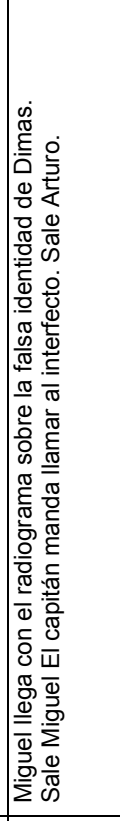 & 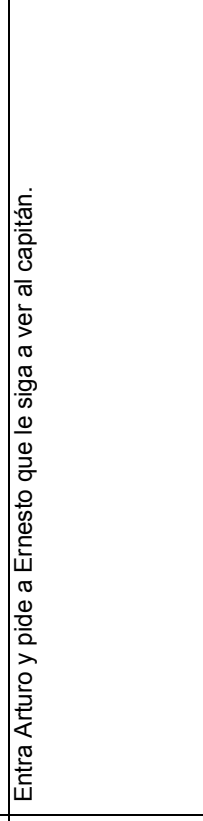 & 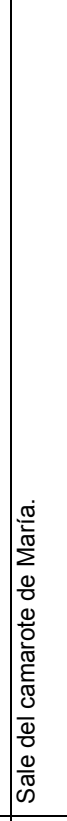 & 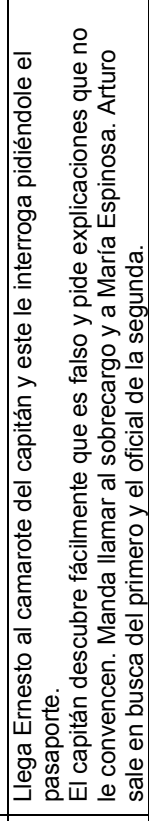 & 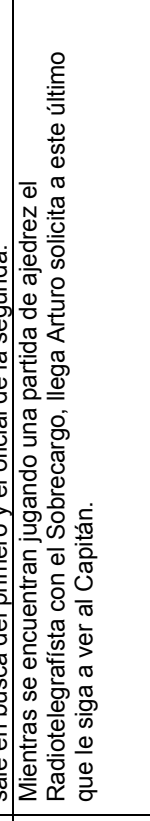 \\
\hline 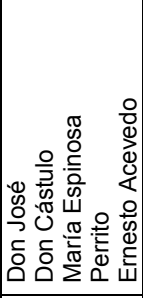 & 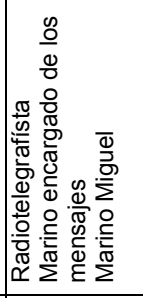 & 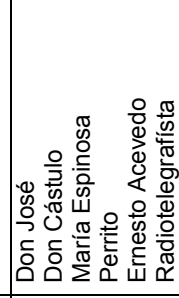 & 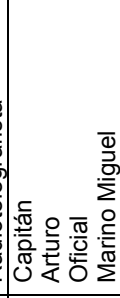 & 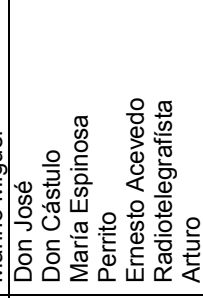 & 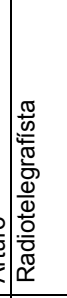 & 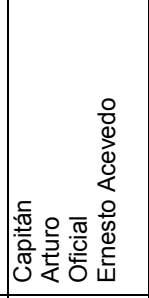 & 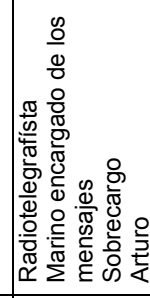 \\
\hline 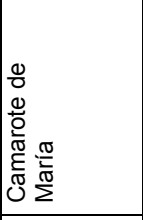 & 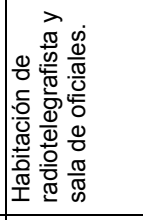 & 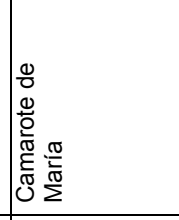 & 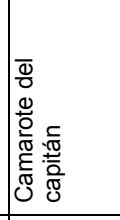 & 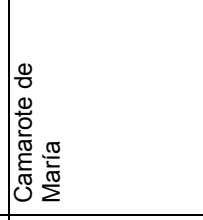 & 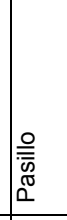 & 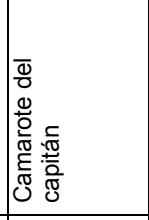 & 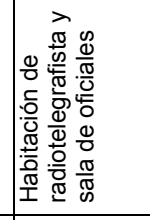 \\
\hline 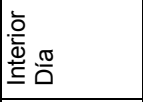 & 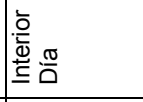 & & : & & 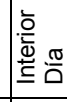 & 嗃 & סू \\
\hline m $<$ & m & ले & $\mathbb{m}_{\infty}<$ & mি & $\hat{m}$ & 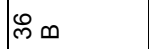 & m \\
\hline
\end{tabular}




\begin{tabular}{|c|c|c|c|c|c|c|c|}
\hline 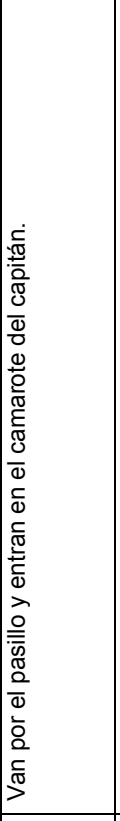 & 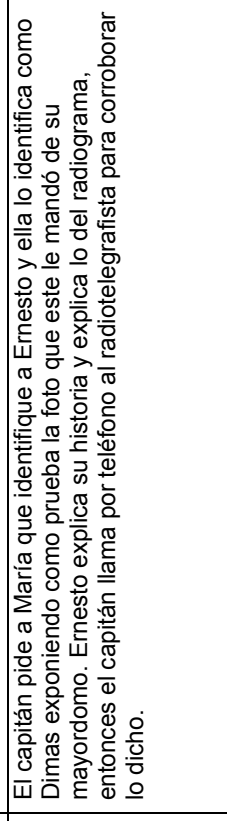 & 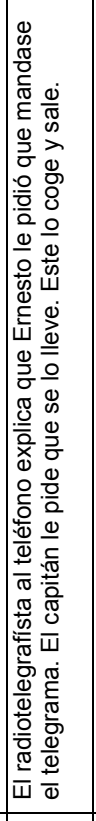 & 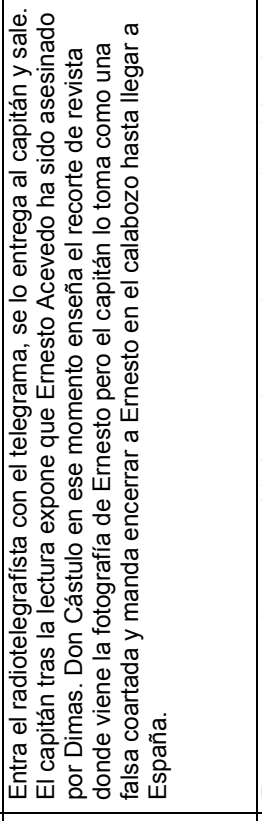 & 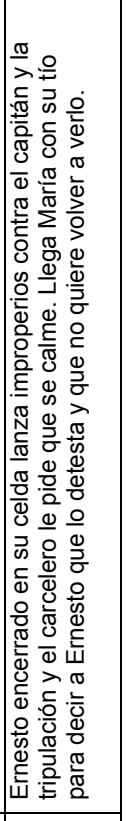 & 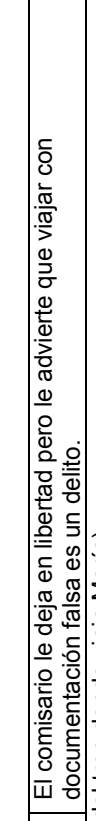 & 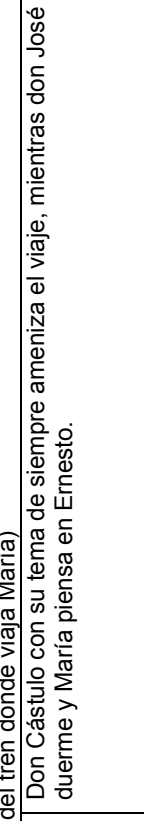 & 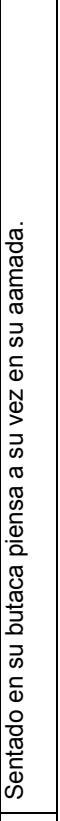 \\
\hline 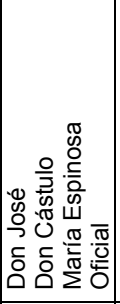 & 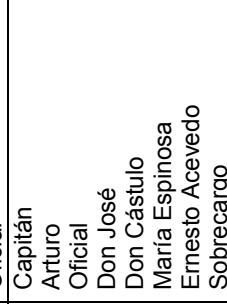 & 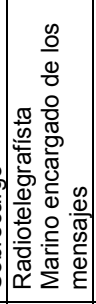 & 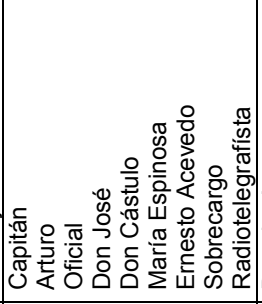 & 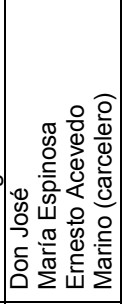 & 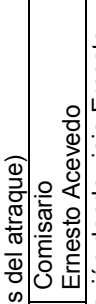 & 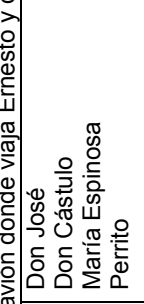 & \\
\hline 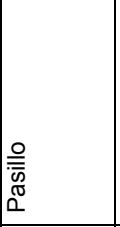 & 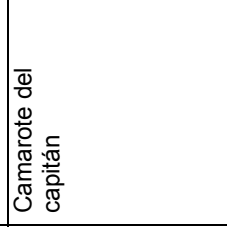 & 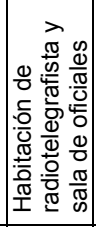 & 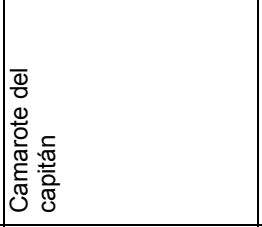 & \begin{tabular}{|l} 
N \\
O \\
$\frac{\pi}{\pi}$ \\
$\frac{\pi}{\pi N}$ \\
0
\end{tabular} & 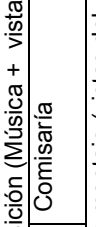 & 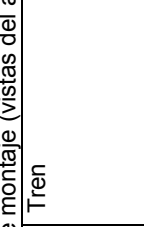 & $\mid \frac{\bar{\sigma}}{\bar{\alpha}}$ \\
\hline 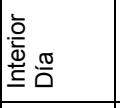 & 高 & 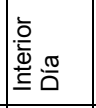 & 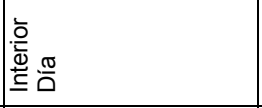 & 竞 & 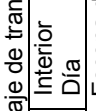 & 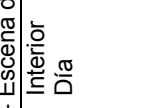 & 竞 \\
\hline প্ল & $\infty$ & \& & מים & $\bar{\forall}$ & 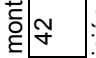 & : & 和 \\
\hline
\end{tabular}




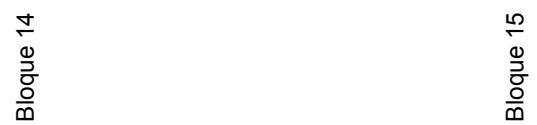

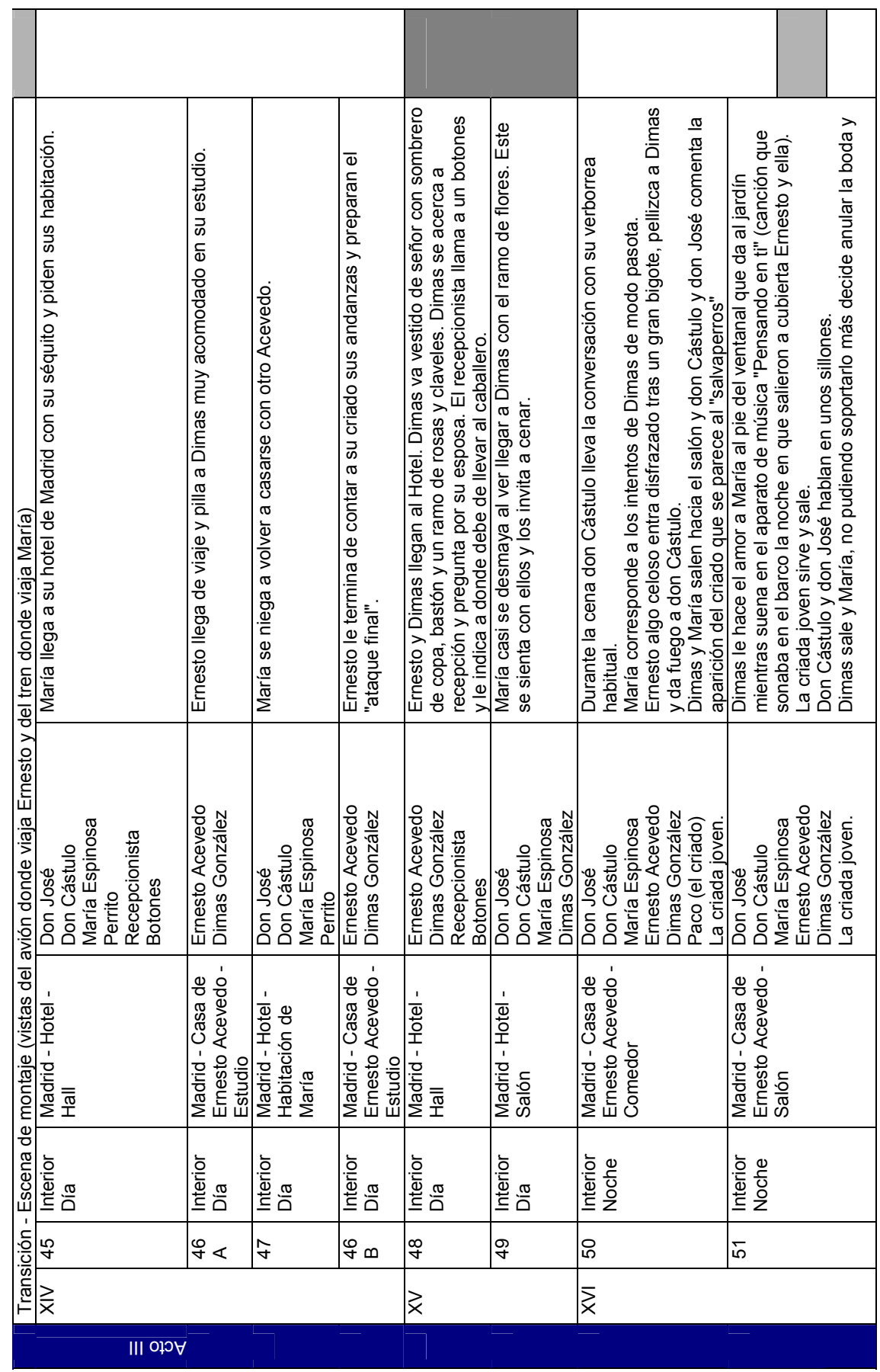




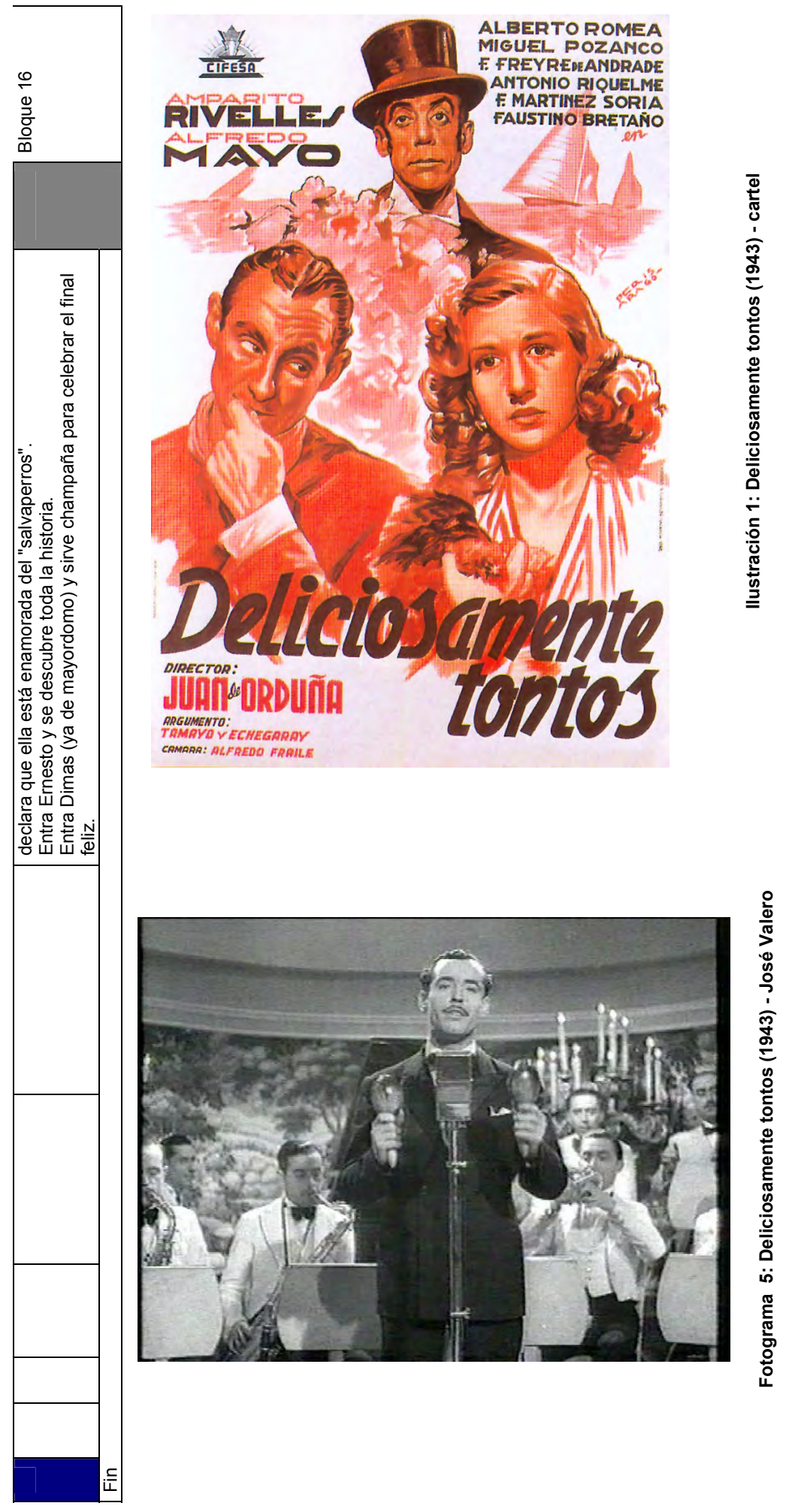


Fichas de análisis.

\begin{tabular}{|c|c|}
\hline Ubicación: & $\begin{array}{l}\text { Este primer boque está situado dentro de la construcción narrativa al comienzo } \\
\text { de la película, entre el logotipo de CIFESA y la primera escena, coincidiendo } \\
\text { con los títulos de crédito iniciales y una escena de montaje que nos sitúa la } \\
\text { acción en Cuba. }\end{array}$ \\
\hline Inicio: & Al arrancar la película después de la presentación de CIFESA. \\
\hline Fin: & Fundido con el bloque 2 simultáneamente a fundido encadenado. \\
\hline Duración: & 1 '24"' \\
\hline Estructura & Pensar en ti (versión orquestal). \\
\hline temática: & Vana ilusión (versión vocal) \\
\hline Forma narrativa: & Temas de amor entre Mari y Ernesto. \\
\hline Plano narrativo: & Música de fondo. \\
\hline Plano sonoro: & $\begin{array}{l}\text { Se encuentran en un primer plano sonoro, aunque al final del bloque se } \\
\text { produce un pequeño fundido para preparar un encadenado con el segundo } \\
\text { bloque. }\end{array}$ \\
\hline Semántica: & Música afín a las imágenes en el terreno histórico, local y cultural. \\
\hline Función: & $\begin{array}{l}\text { Acompañar los títulos de crédito e introducirnos en el lugar, época y ambiente } \\
\text { en el que comienza la historia. }\end{array}$ \\
\hline NOTAS & $\begin{array}{l}\text { La pieza se encuentra ya empezada al comenzar las películas. } \\
\text { Según nuestra opinión se trata de un fallo debido al mal estado de la copia con } \\
\text { la que trabajamos y no aun corte musical realizado a conciencia. }\end{array}$ \\
\hline
\end{tabular}

\section{BLOQUE 2}

\section{Ubicación:}

Inicio:

Fin:

Duración:

Estructura

temática:

Forma narrativa:

Plano narrativo:

Plano sonoro:

Semántica:

Función:

NOTAS
Se encuentra enlazado con el primer bloque y situado al comienzo de la primera escena del filme.

Surge mientras desaparece el primer bloque al mismo tiempo que podemos apreciar un fundido encadenado.

Desaparece al terminar la frase musical y justo antes de que hable primer personaje, el notario.

0 '16"

Caja de música

Tema circunstancial.

Música de pantalla.

Primer plano

Pieza afín - física.

Ambientar el despacho del notario.

A pesar de tratarse de una pieza diegético o de pantalla, la sonoridad es propia de la música de fundo de los títulos, teniendo un protagonismo sonoro total. 
Ubicación:

Inicio:

Fin:

Duración:

Estructura

temática:

Forma narrativa:

Plano narrativo:

Plano sonoro:

Semántica:

Función:

\section{NOTAS}

Comienza nada más empezar al escena 2 y se desarrolla durante la escena 3. Después de un fundido encadenada, al comenzar un travelling hacia atrás. Al comenzar el fundido encadenado que da paso a la siguiente escena de montaje.

2'20"

Minué

Tema circunstancial.

Música de fondo.

Plano secundario.

Pieza afín - anímica.

Pretende conceder un aire cursi a la decisión tomada por los protagonistas.

\section{BLOQUE 4}

Ubicación:

Inicio:

Fin:

Duración:

Estructura

temática:

Forma narrativa:

Plano narrativo:

Plano sonoro:

Semántica:

Función:
Escena de montaje (transcurso del tiempo) y la escena 4.

Sincronizado, a través de un toque de bombo y paltillo, con el comienzo de la primera imagen de la escena de montaje.

Sincronizado con la entrada de María (1940) en la casa del notario.

16 '23"

Tema popular (blues o jazz).

Tema circunstancial

Música de fondo

Primer plano.

Pieza afín-histórico-cultural.

Ayuda a pasar el tiempo a través de su frenético ritmo y nos sitúa en la actualidad (de cuando se estrenó).

NOTAS $-$

\section{BLOQUE 5}

\section{Ubicación:}

Inicio:

Fin:

Duración:

Estructura

temática:

Forma narrativa:

Plano narrativo:

Plano sonoro:

Semántica:

Función: NOTAS
Comienzo de la escena 6.

Surge a medida que aparece la primera imagen de la escena 6 que viene de un fundido encadenado con la anterior.

Concluye violentamente al ser apagada la radio.

1'28"'

Pieza clásica

Tema circunstancial

Música de pantalla

Segundo plano sonoro

Pieza afín - anímica

Acompañar y enfatizar los sentimientos amorosos del protagonista. 


\section{BLOQUE 6}

Ubicación: Inicio:

Fin:

Duración:

Estructura

temática:

Forma narrativa:

Plano narrativo:

Plano sonoro:

Semántica:

Función:

NOTAS
A lo largo de casi toda la secuencia III (escenas 8,9 y 10).

A mitad de fundido encadenado entre escena 7 y 8 .

Concluye cuando dejan de tararear la marcha nupcial los criados de Ernesto. 0'42"

Marcha nupcial (Lohengrin - Wagner) versión órgano.

Marcha nupcial (Sueño de una noche de verano - Mendelson) versión sinfónica Marcha nupcial (Lohengrin - Wagner) versión tarareada a capella.

Pieza circunstancial

Música de pantalla

Plano secundario

Pieza afín - cultural y física.

Acompañar el evento de la boda (en Cuba y España)

En la primera parte, con el cambio de plano hay un salto sonoro que puede estar debido a:

Que se editase así

Que falte algún plano o fragmento de uno de los dos implicados por la manipulación en la exhibición.

Por otro lado, cuando suena la marcha de Mendelson, se puede percibir sin problemas el ruido provocado por el disco al girar, creando una mayor ilusión sonora del lugar.

\section{BLOQUE 7}

\section{Ubicación:}

Inicio:

Fin:

Duración:

Estructura

temática:

Forma narrativa:

Plano narrativo:

Plano sonoro:

Semántica:

Función:
Comienza al finalizar la escena 14 y termina en la 17.

Al finalizar la escena 14

Al comenzar al escena 17

1 '27"

Tema del viaje

Tema orquestal vinculado a los viajas.

Música de fondo

Primer plano (aunque cuando hablan los personajes pasa a un segundo lugar)

Afín, anímica y física.

En esta ocasión sirva para:

Enlazar escenas

Ayuda en la construcción de la escena de montaje y transición.

Cuando la música está en primer plano, no se escuchan ni ruidos ni diálogos.

Las conversaciones de los protagonistas en la despedida y la sirena del barco son los únicos ruidos que se escuchan. 


\begin{tabular}{|c|c|}
\hline $\begin{array}{l}\text { Ubicación: } \\
\text { Inicio: } \\
\text { Fin: } \\
\text { Duración: } \\
\text { Estructura } \\
\text { temática: } \\
\text { Forma narrativa: } \\
\text { Plano narrativo: } \\
\text { Plano sonoro: } \\
\text { Semántica: } \\
\text { Función: }\end{array}$ & $\begin{array}{l}\text { Escenas } 20 \text { y } 23 . \\
\text { Comienza cuando se cae el perro al agua. } \\
\text { Mostrando al perro mojado en el camarote de María. Comienzo de escena. } \\
\text { 1'01" } \\
\text { Salvamento (presto). } \\
\text { Tema circunstancial (utilizado en dos ocasiones, esta es la primera). } \\
\text { Música de fondo } \\
\text { Segundo plano } \\
\text { Afín anímica y física. } \\
\text { Enlace de escenas } \\
\text { Enfatiza el dramatismo del momento. } \\
\text { Enfatiza el acto del salvamento. } \\
\text { La pieza arranca con una subida de volumen de la música y concluye de la } \\
\text { misma manera. } \\
\text { Se trata de una pieza donde predomina especialmente el ritmo frenético en la } \\
\text { cuerda y entra el viento metal cuando se lanza Ernesto a salvar al perro. }\end{array}$ \\
\hline
\end{tabular}

\section{BLOQUE 9}

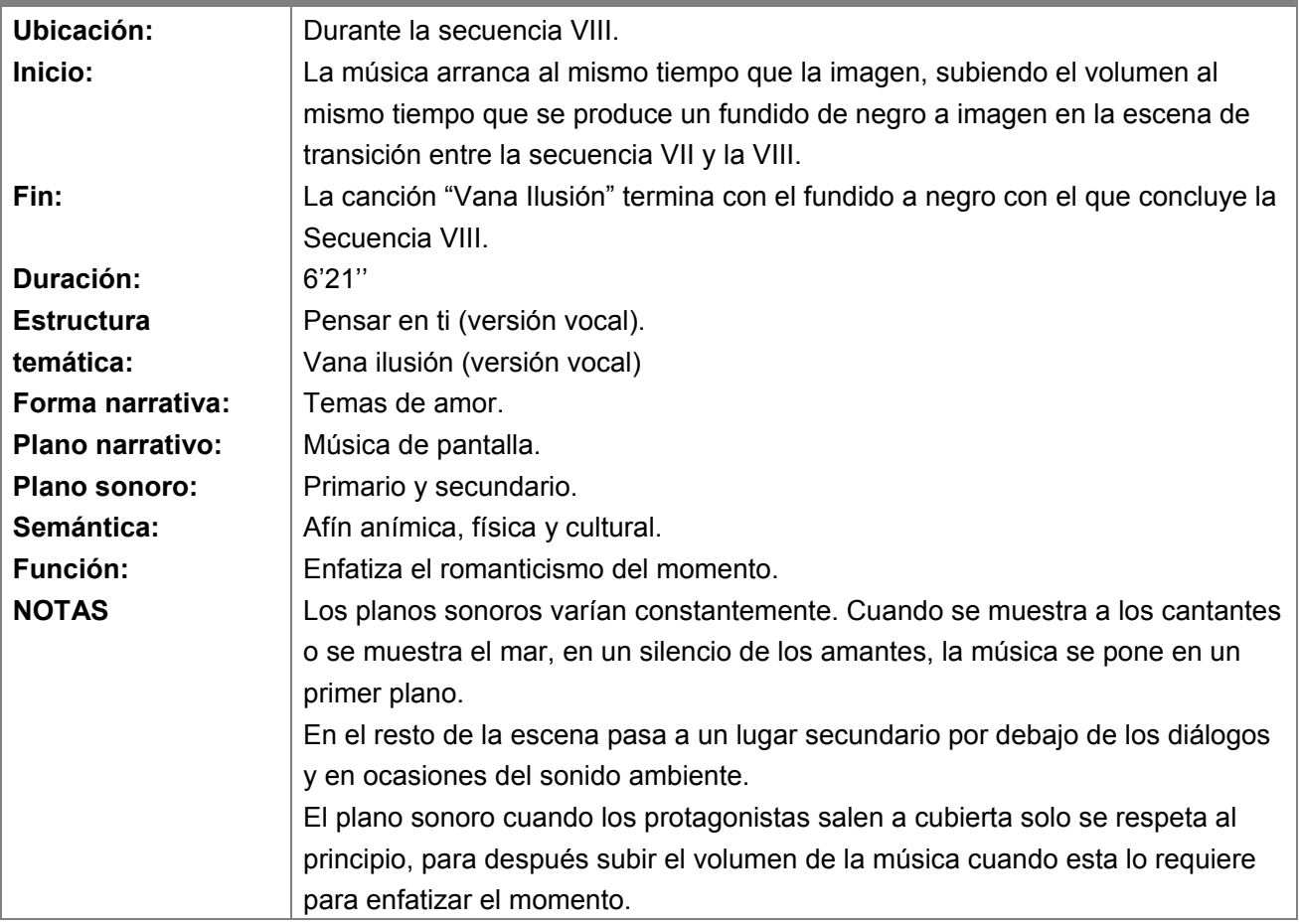




\section{BLOQUE 10}

\begin{tabular}{l|l|}
$\begin{array}{l}\text { Ubicación: } \\
\text { Inicio: }\end{array}$ & Transición y escena 26. \\
Fin: & La música arranca a su volumen con la pantalla en negro en la transición. \\
Duración: & Arturo y Mari. \\
$\begin{array}{l}\text { Estructura } \\
\text { temática: }\end{array}$ & 0'22" \\
Forma narrativa: & Tema del viaje. \\
Plano narrativo: & Tema orquestal vinculado al viaje. \\
Plano sonoro: & Música de fondo \\
Semántica: & Primario y secundario \\
Función: & Afín, física \\
NOTAS & Enfatiza el transcurrir del tiempo. \\
& La pieza parece un poco cortada al comienzo del bloque, pudiendo ser razón \\
de ello: & La grabación original era así \\
& Pérdida de algunos fotogramas por exhibición. \\
& Cuando la cámara se introduce en cubierta, pasa a un segundo plano y \\
paulatinamente va desapareciendo, aprovechando la finalización de la frase \\
musical, por lo tanto conclusiva. (No se trata de término de la pieza por bajada \\
de volumen sino por conclusión natural de la pieza).
\end{tabular}

\section{BLOQUE 11}

Ubicación:

Inicio:

Fin:

Duración:

Estructura

temática:

Forma narrativa:

Plano narrativo:

Plano sonoro:

Semántica:

Función:

NOTAS
Secuencia IX, escena 27.

Aparece bruscamente con el inicio de la escena 27

Concluye bruscamente al comienzo de la escena 28

4'57"'

Tema bailable 1 (Jazz)

Tema bailable 2 ( Jazz)

Tema bailable 3 (Jazz, al estilo Stephan Grapelli).

Temas circunstanciales.

Música de pantalla

Segundo plano (al final pasa a primer plano).

Afín, física.

Ambientación de escena (meramente funcional).

Tanto al principio como al final aparece y concluye la música de forma brusca.

En el caso de la salida en vez de terminar con el último fotograma de la escena

27 , la música se mantiene unos segundos en la escena 28 , pero consideramos que se debe más a un desajuste técnico del audio que a un enlace intencionado.

En cuanto al plano sonoro, la música se mantiene siempre en un segundo plano, salvo durante el baile de Mari con Arturo donde el volumen sube y pasa un primer plano, para volver a bajar cuando Ernesto piensa en voz alta. 
BLOQUE 12

\begin{tabular}{|c|c|}
\hline Ubicación: & Escena 41 y escena de montaje siguiente. \\
\hline Inicio: & Comienza la pieza cuando don José se despide y sale. \\
\hline Fin: & $\begin{array}{l}\text { Se baja el volumen de la pieza al mismo tiempo que se efectúa un fundido a } \\
\text { negro. }\end{array}$ \\
\hline Duración: & 0 '21" \\
\hline $\begin{array}{l}\text { Estructura } \\
\text { temática: }\end{array}$ & Salvamento (presto) \\
\hline Forma narrativa: & $\begin{array}{l}\text { Reutilización del tema creado para el salvamento del perro pero esta vez en } \\
\text { otro contexto. }\end{array}$ \\
\hline Plano narrativo: & Música de fondo \\
\hline Plano sonoro: & Transición a primer plano \\
\hline Semántica: & Afín física. \\
\hline Función: & Enfatiza el trasiego del desembarco. \\
\hline & $\begin{array}{l}\text { Funciona como enlace entre la escena } 41 \text { y la escena de montaje. } \\
\text { Agiliza el transcurrir del tiempo. }\end{array}$ \\
\hline NOTAS & $\begin{array}{l}\text { La pieza no concluye, sino que se le baja el volumen para que termine junto al } \\
\text { fundido a negro (sin crear enlace de escena) }\end{array}$ \\
\hline
\end{tabular}

\section{BLOQUE 13}

\begin{tabular}{|c|c|}
\hline \multirow{2}{*}{$\begin{array}{l}\text { Ubicación: } \\
\text { Inicio: }\end{array}$} & Escena de montaje, secuencia XIII, escena de montaje. \\
\hline & $\begin{array}{l}\text { Mediante elevación del volumen junto con el fundido encadenado entre la } \\
\text { escena } 42 \text { y la escena de montaje. }\end{array}$ \\
\hline Fin: & Mediante bajada de volumen entre la escena de montaje y la número 45 \\
\hline Duración: & 1'31" \\
\hline Estructura & Tema del viaje. \\
\hline temática: & Pensar en ti (versión vocal) \\
\hline & Pensar en ti (versión silbada) \\
\hline & Tema del viaje. \\
\hline Forma narrativa: & \\
\hline Plano narrativo: & Música de fondo \\
\hline Plano sonoro: & Primer y segundo plano. \\
\hline Semántica: & Afín, física primero, anímica después. \\
\hline Función: & Enlace de escenas \\
\hline & Transcurrir del tiempo \\
\hline & Enfatizar sentimiento amoroso y nostálgico. \\
\hline NOTAS & $\begin{array}{l}\text { Los temas se van fundiendo unos con otros, mediante la bajada y elevación del } \\
\text { volumen. }\end{array}$ \\
\hline & $\begin{array}{l}\text { En el caso de "Pensar en ti" (versión silbada) pretenden presentarla como } \\
\text { música de pantalla, pero a nuestro entender, aunque tenga justificación visual } \\
\text { en pantalla, en este caso el sonido (primer plano) da más sensación de tratarse } \\
\text { de música de fondo, aunque desde un punto de vista estricto sería de pantalla. }\end{array}$ \\
\hline
\end{tabular}




\section{BLOQUE 14}

\begin{tabular}{|c|c|}
\hline $\begin{array}{l}\text { Ubicación: } \\
\text { Inicio: } \\
\text { Fin: } \\
\text { Duración: } \\
\text { Estructura } \\
\text { temática: } \\
\text { Forma narrativa: } \\
\text { Plano narrativo: } \\
\text { Plano sonoro: } \\
\text { Semántica: } \\
\text { Función: } \\
\text { NOTAS }\end{array}$ & $\begin{array}{l}\text { Música de pantalla } \\
\text { Segundo plano. } \\
\text { Afín física } \\
\text { Ambientar la escena. } \\
\text { Aunque no tiene una justificación en pantalla directa, consideramos que se trata } \\
\text { de música de pantalla tanto por el tratamiento sonoro (segundo plano) como } \\
\text { por el lugar en el que se desarrolla la acción (donde es muy posible la } \\
\text { existencia de una pequeña orquesta que esté fuera de campo). }\end{array}$ \\
\hline
\end{tabular}

\section{BLOQUE 15}

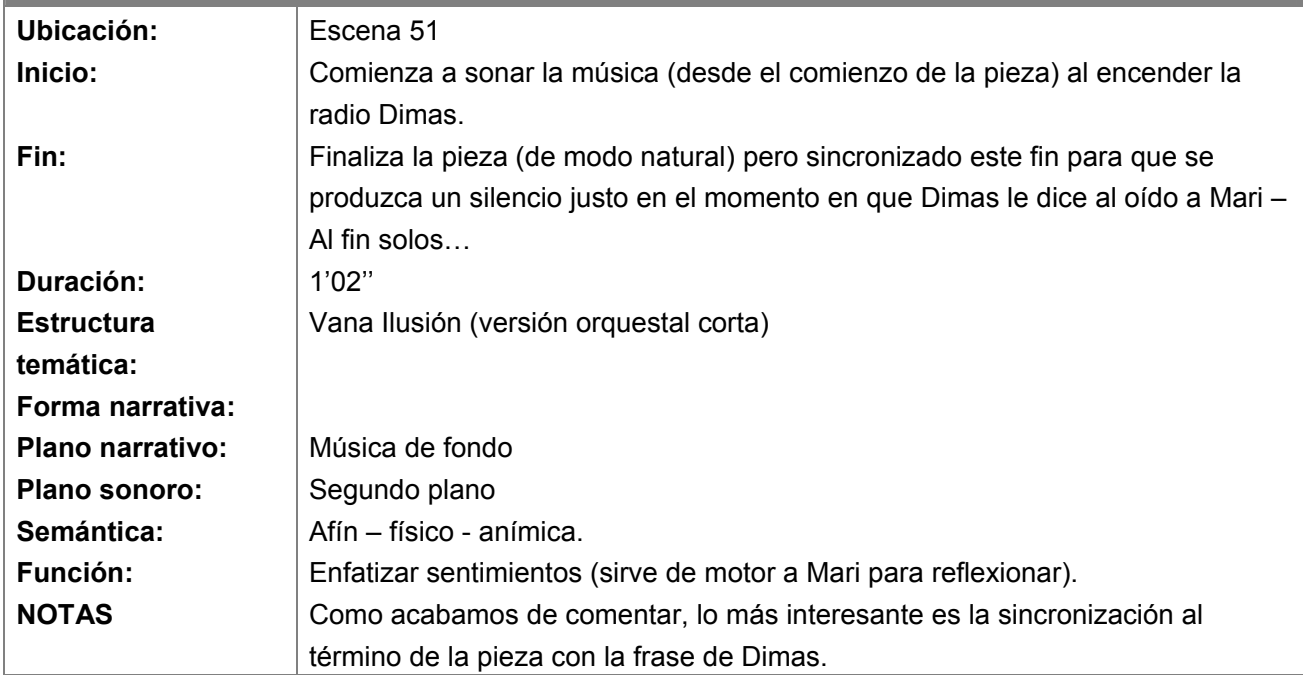


BLOQUE 16

\begin{tabular}{|c|c|}
\hline $\begin{array}{l}\text { Ubicación: } \\
\text { Inicio: } \\
\text { Fin: } \\
\text { Duración: } \\
\text { Estructura } \\
\text { temática: } \\
\text { Forma narrativa: } \\
\text { Plano narrativo: } \\
\text { Plano sonoro: } \\
\text { Semántica: } \\
\text { Función: } \\
\text { NOTAS }\end{array}$ & $\begin{array}{l}\text { Escena } 51 \\
\text { Arranca la pieza con la aparición de Ernesto tras la cortina. } \\
\text { Con final de la película } \\
2 \text { '07" } \\
\text { Tema circunstancial. } \\
\text { Pensar en ti (versión sinfónica) } \\
\text { Música de fondo } \\
\text { Segundo plano y transición a primer plano } \\
\text { Afín - anímica - física. } \\
\text { Conclusiva } \\
\text { Enfatizar sentimientos. } \\
\text { Se nota un corte en el audio en el cambio de un plano a otro pero } \\
\text { consideramos que se debe al estado de la copia estudiada, al igual que la } \\
\text { finalización brusca del tema Pensar en ti con la palabra fin impresa. }\end{array}$ \\
\hline
\end{tabular}


CAPÍTULO 6

BASE DE DATOS MULTIMEDIA MCE40 


\section{Objetivos}

La dificultad de obtener y acceder a las distintas tipologías de fuentes relacionadas con la música nos ha llevado a desarrollar una base de datos multimedia que reuniera todos los documentos de tipología diversa relativos a la música de cine de los años cuarenta y que han sido localizados durante nuestra investigación. El proceso seguido ha sido el que describimos a continuación. En primer lugar, y después de un exhaustivo trabajo de campo que nos ha permitido la recopilación de un total de 464 documentos, hemos procedido a la digitalización de los mismos. En segundo lugar, hemos elaborado las distintas fichas catalográficas teniendo en cuenta la heterogeneidad y particularidades de los mismos. El resultado obtenido ha sido un total de 1320 registros.

La base de datos multimedia MCE40 tiene como objetivo prioritario proporcionar funcionalidad y en nuestro caso, ha sido una herramienta de primer orden para proceder a realizar un análisis en torno a la música de cine de la época de referencia y por extensión al cine de la misma. Así pues, hemos simplificado enormemente todos los aspectos relacionados con el diseño gráfico de MCE40 distinguiendo con un color diferente el doble acceso a la información que permite la misma; azul para el Administrador, almagra para el Usuario.

Respecto a la navegación hemos optado por una estructura de naturaleza lineal que permitiera con facilidad la localización de los contenidos.

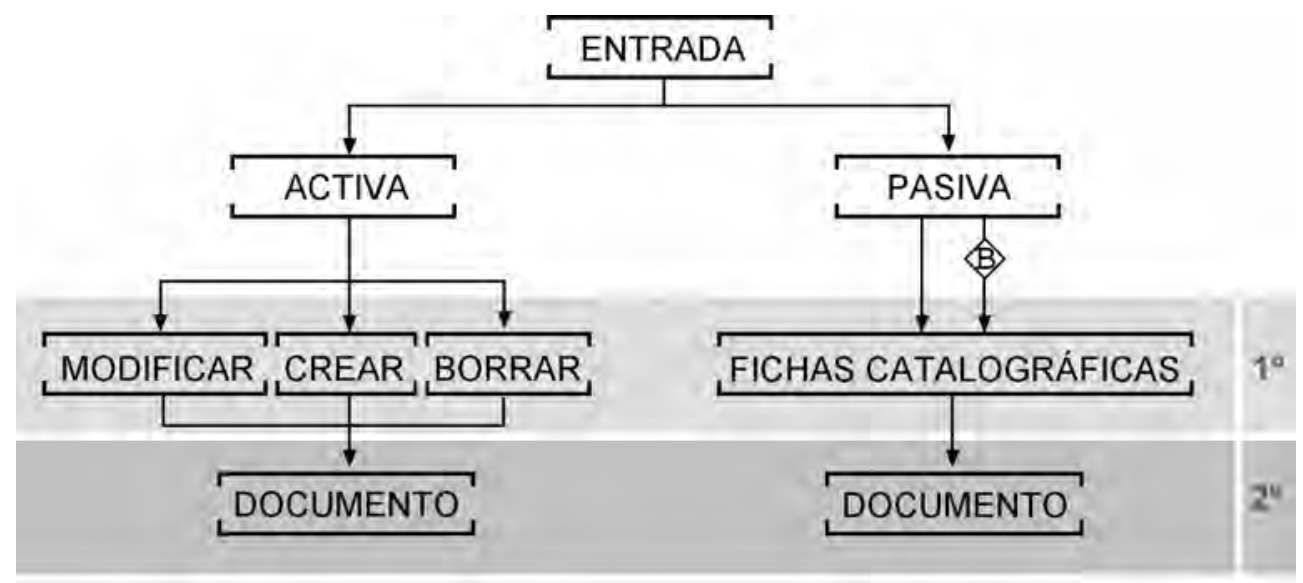

Gráfica 15: Esquema de navegación 


\section{Requerimientos de software y hardware}

El software utilizado para la implementación de la aplicación ha sido Microsoft Access después de cotejar otros existentes en el mercado, como FileMaker, de gran popularidad en entornos documentales, pero de poca difusión en otros contextos, lo que nos hizo decantarnos por la aplicación de Microsoft, muy popular y utilizada. El único escollo que alberga la utilización del presente software recae en su uso en entorno Macintosh ${ }^{313}$. Este obstáculo, no obstante, se puede salvar mediante la aplicación Virtual PC de Connectix Coorporations para Macintosh, simulador de PC donde puede funcionar tanto el Access como la aplicación desarrollada.

Su arquitectura básica se apoya en una plataforma que trabaja bajo los sistemas operativos de Microsoft Windows 95, Windows 98, Windows NT, Windows Milenium, Windows 2000 o Windows XP, siendo necesario tener instalado en el ordenador los programas Microsoft Access 2000, Adobe Acrobat Reader y Windows Media Player (o cualquier otro reproductor de audio mp3) para poder arrancar la Aplicación y aprovechar todas las posibilidades de la misma.

En cuanto a las necesidades de hardware, el ordenador requerido tiene que tener como mínimo las siguientes especificidades técnicas: $100 \mathrm{MB}$ libres de disco duro (o $1 \mathrm{Gg}$ si se incluyen en la instalación los documentos digitales), 32MB de memoria RAM siendo recomendable 64 o más, Procesador Pentium II, a $320 \mathrm{~Hz}$, Unidad óptica DVD-Rom y una resolución de pantalla mínima de 800×600 aunque se recomienda 1024×768 píxeles.

\section{Características y funcionalidad de MCE40}

Cuando se arranca la aplicación se abre el programa Microsoft Access y aparece una pantalla de bienvenida principal a la Aplicación.

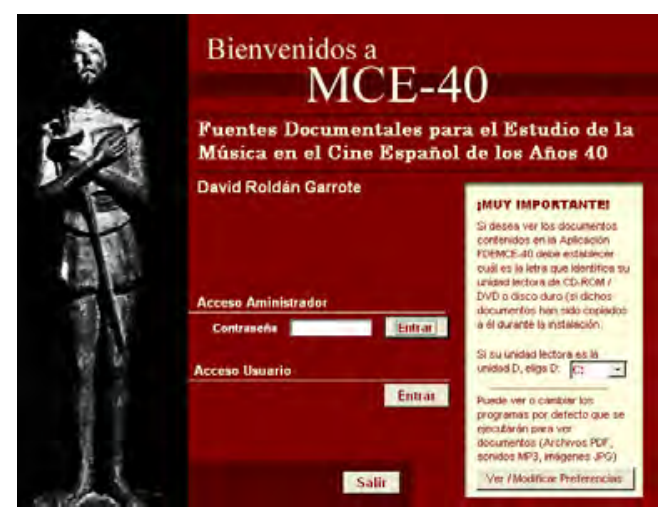

Imagen 1: Menú de bienvenida

\footnotetext{
${ }^{313}$ Microsoft no incluye en su Office para Mac el Access.
} 
Como podemos observar, a través de este Menú Principal, se tiene acceso a las dos modalidades de la misma (administrador o usuario), así como la posibilidad de designar la unidad desde la que se va a tener acceso a los distintos documentos, con el fin de evitar posibles fallos y errores en la visualización de los mismos por parte del programa. Esta opción se encuentra en la parte derecha y bastará con elegir la unidad desde la que se quiere leer los documentos.

También, mediante una pantalla de configuración podremos modificar las rutas de acceso a los programas subyugados a la Aplicación para la visualización de los archivos digitales. Si bien los documentos PDF no es recomendable abrirlos con otro programa que no sea el Adobe Acrobat Reader, los archivos de audio MP3 pueden oírse con innumerables programas, por lo que se ofrece al usuario la posibilidad de especificar con qué programa desea oír dichos archivos sonoros.

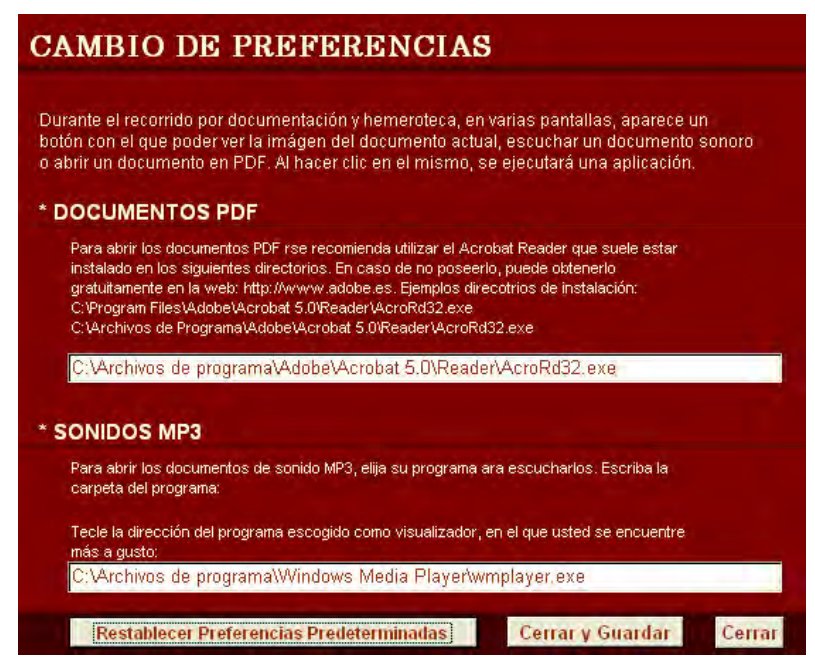

Imagen 26: pantalla de configuración de preferencias

En cuanto al modo de visualización, se ha optado por un software de lectura de archivos de libre acceso que se ha convertido, pese a no serlo, en un estándar por todos conocido. Nos referimos al Adobe Acrobat Reader. Todos los documentos digitalizados o transcritos han sido convertidos a la extensión PDF de Adobe y su programa Adobe Acrobat. Una vez abiertos los documentos deseados se podrá ampliar la imagen, reducir, imprimir, etcétera. Por tanto, si se desea tener acceso a dichos documentos es necesario tener instalado el software mencionado que se adjunta con la aplicación para su instalación. También se puede bajar del sitio web de Adobe gratuitamente, cuya dirección es: http://www.adobe.com/

Los archivos sonoros, por su parte, se pueden escuchar con cualquier reproductor de audio que admita mp3. MCE40 utilizará por defecto Windows Media Player, pero puede 
ser sustituido por el reproductor que se desee a través de la ventana de Cambio de preferencias que acabamos de explicar.

Por lo que respecta al acceso al administrador, este debe hacerse mediante la verificación de una clave de acceso personal ${ }^{314}$, que le permitirán la obtención de una serie de privilegios relacionados con la modificación de datos y la introducción de nuevos registros. Por otro lado, el acceso para usuarios está limitado a la simple consulta de los datos contenidos en las fichas catalográficas y a los informes que pueden generarse. Como es natural, los privilegios de escritura, modificación, etcétera propios del Administrador, quedan en este caso completamente anulados para evitar posibles manipulaciones indebidas por parte de los usuarios. En ambos casos, se tendrá acceso total a la visualización de los documentos incluidos en MCE40 para su examen y estudio.

Por último, se tiene la posibilidad de salir de la aplicación presionando el botón Salir, que cerrará tanto MCE40 como Microsoft Access.

\section{Modelos de acceso a la información}

La aplicación MCE40 ha sido diseñada teniendo en cuenta dos modelos de acceso diferenciados. Es decir, permite su utilización y manejo por parte de dos usuarios con intereses y funciones bien diferenciadas. Mediante una contraseña de identificación el Administrador realiza las funciones de gestor de la aplicación, pudiendo ver y modificar los contenidos de cada una de las fichas catalográficas y dar de alta a nuevos documentos. El Usuario, por su parte, puede visualizar el contenido de las fichas catalográficas, imprimir y elaborar informes de los documentos incluidos en MCE40, pero no puede modificar los datos existentes, ni introducir nuevos.

\section{Acceso a la información del Administrador}

El modelo de acceso a la información destinado al Administrador, se caracteriza porque permite la:

Creación de los mecanismos y espacios necesarios para la introducción de datos y documentos por parte del Administrador.

Creación de un espacio de visualización de los documentos disponibles en la aplicación por parte del Administrador y los Usuarios.

Creación de un espacio de visualización de las fichas catalográficas disponibles en la Aplicación.

Creación de un espacio de generación de informes y listados:

\footnotetext{
${ }^{314}$ la clave de acceso para el administrador en este caso es: cine40
} 
El diagrama de flujo de la información para el modelo de acceso Administrador:

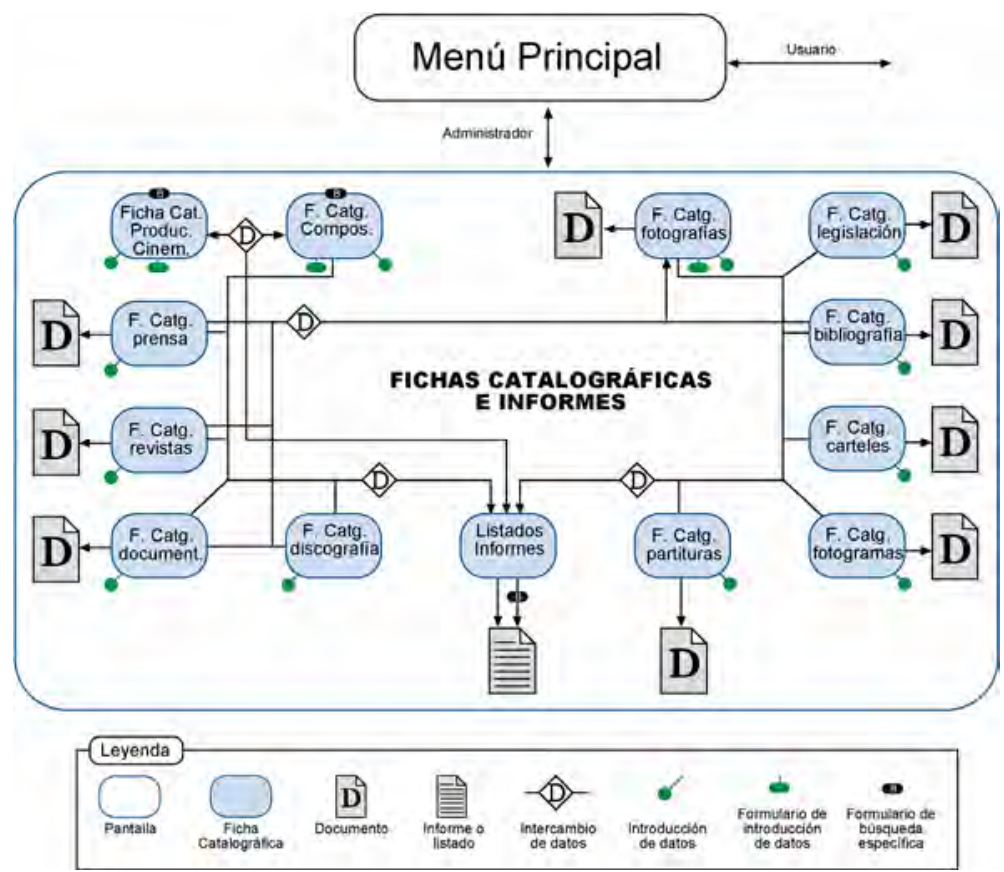

llustración 2: diagrama de flujo del recorrido del Administrador

El administrador es el encargado de mantener al día la información incluida dentro de la Aplicación. Su labor no solo está centrada en incluir nuevos registros y referencias sino de corregir aquellas entradas que no sean correctas. Por tanto, el administrador tiene total libertad para la manipulación de la información contenida pero no tiene acceso a la estructura de la aplicación ni a su diseño.

El acceso para el administrador comienza en el momento en que éste hace clic sobre el botón Entrar correspondiente al Administrador y la validación de la contraseña de entrada en el Menú Principal.

\section{Fichas Catalográficas e Informes}

Una vez se entra en el apartado denominado Fichas Catalográficas e Informes, tanto el administrador como el usuario tienen acceso directo a todas y cada una de las distintas tipologías de fichas creadas en función de la diversidad documental incluida.

Como se puede apreciar en la siguiente imagen, la pantalla con la que vamos a trabajar está dividida en tres partes bien delimitadas. En la parte superior nos encontramos con la cabecera de la Aplicación donde podremos leer el nombre de la misma. Debajo de esta zona nos encontraremos con los elementos puramente interactivos de MCE40. En el lado izquierdo el usuario encontrará una serie de botones que conforman el menú que permite acceder a las distintas tipologías de Fichas Catalográficas, documentales e 
informes, mientras que el lado derecho, de mayor extensión, se reserva para la consulta de las propias Fichas. El contenido de esta área irá variando en función del tipo de información que se haya seleccionando en la columna de la izquierda.

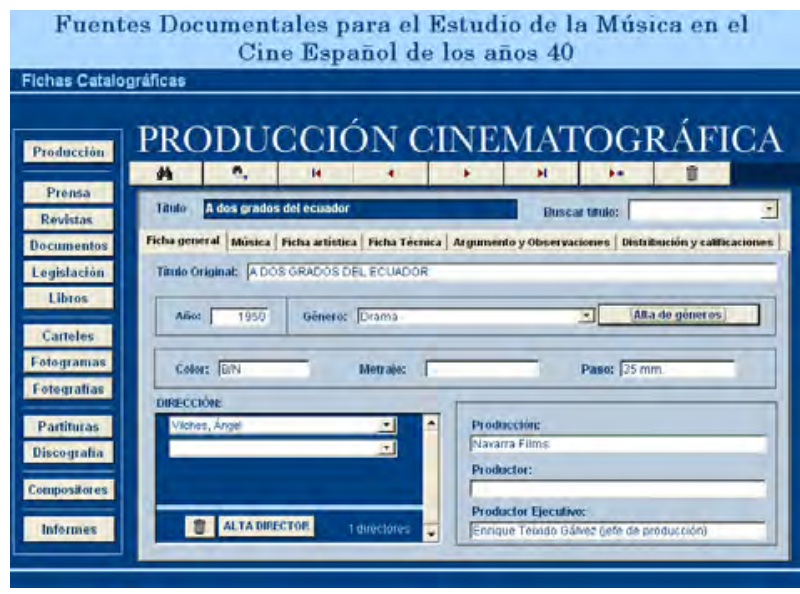

Imagen 27: Pantalla general de Fichas Catalográficas

En la columna de la derecha, se establece una jerarquía en los contenidos separándose unos de otros mediante una línea divisoria. Esta categorización se compone de: producción, documentación impresa y escrita, material gráfico, material musical, compositores e informes.

En el primero de todos, Producción, tan solo encontramos una categoría, la producción cinematográfica española de 1939 a 1950. Presionando en este botón se muestra la Ficha Catalográfica de Producción Cinematográfica.

El bloque siguiente, Documentación impresa y escrita presenta cinco accesos distintos en función de las distintas categorías creadas, estando presentes en este apartado: Prensa, Revistas especializadas, Documentos, Legislación y Bibliografía.

En el apartado Material gráfico se aúnan las Fichas Catalográficas de los documentos de carácter marcadamente gráfico: Carteles, Fotogramas, Fotografías.

El Material musical está compuesto por dos tipologías de documentos, por una parte las Partituras y por otro las grabaciones discográficas reunidas en Discografía.

Por último, en bloques separados se encuentran, las fichas de los Compositores, con información de los protagonistas de nuestra tesis y el acceso a distintos Informes generados para una posible impresión o consulta.

Como ya hemos comentado, la parte derecha del espacio está destinada a la visualización de las Fichas Catalográficas. Éstas a su vez, tienen un sistema de navegación interno que permite desplazarse entre los distintos registros pero no cambiar de tipo de ficha, algo reservado únicamente a la columna de botones de la izquierda que acabamos de 
comentar. Esta navegación es posible gracias a una banda horizontal situada en la parte superior y debajo del espacio asignado a la identificación gráfica de la tipología de la Ficha.

\section{PRODUCGIÓN CINEMATOGRÁFICA

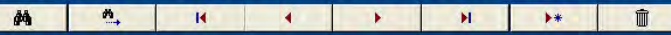

Imagen 28: barra de navegación de ficha

La banda de navegación está compuesta por ocho botones con representaciones icónicas cuyas funciones van desde la búsqueda hasta el avance y retroceso en los registros almacenados en MCE40. Los botones son: Buscar, Buscar siguiente, Ir a inicio, Registro anterior, Registro siguiente, Ir al final, Crear nuevo registro, Borrar registro.

El primer botón, Buscar, tiene como icono unos prismáticos y abre la ventana de búsqueda de Microsoft Access. Por tener un uso específico importante hablaremos de su funcionamiento más adelante, al igual que el siguiente botón que realiza una prolongación de la búsqueda.

El tercero, Ir a inicio, nos desplaza hasta la primera Ficha Catalográfica, mientras que el cuarto botón, Registro anterior, nos lleva a la ficha anterior a la que estamos viendo en el momento de presionar en él. Registro siguiente es el quinto botón que, como su nombre indica, no conduce hasta la Ficha Catalográfica siguiente, mientras que el botón, Ir al final, nos conduce a la última Ficha insertada en la Aplicación MCE40 dentro de la tipología catalográfica en la que estemos.

Crear nuevo registro, permite al Administrador crear una Ficha Catalográfica con los campos en blanco para introducir en ellos los datos pertinentes a un nuevo documento o referencia a incluir.

Borrar registro, permite eliminar toda una ficha completa con todos los datos.

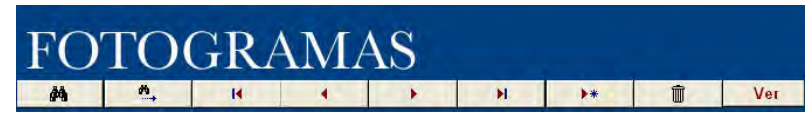

Imagen 29: barra de navegación de ficha (con botón de acceso a documentos gráficos)

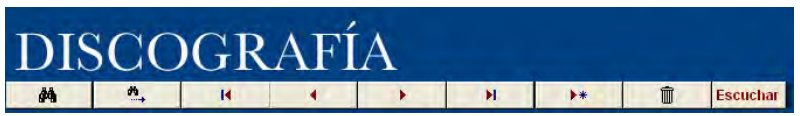

Imagen 30: barra de navegación de ficha (con botón de acceso a documentos sonoros)

Puede darse, y se da, el caso de existir más botones en esta barra. Normalmente tanto el Administrador como el Usuario se van a encontrar con uno más, dependiendo del tipo de ficha en que estén. Nos referimos principalmente a aquellos documentos que se 
encuentren digitalizados y contenidos en el soporte óptico que acompaña la presente aplicación. En estos casos se incluirá en la barra de navegación horizontal de la Ficha un botón con la palabra Ver para los documentos gráficos o escritos y, Escuchar para los sonoros.

Al presionar sobre el botón Ver, se abrirá un programa de visualización para mostrar el documento en cuestión y poder ser analizado por el investigador. Como se pude apreciar en la imagen siguiente, en la Ficha Catalográfica de Carteles podemos apreciar el botón Ver y sobre el mismo, la ventana del Adobe Acrobat Reader abierta con la imagen del cartel seleccionado. Esta opción aparece en las siguientes Fichas con acceso directo a los siguientes registros:

\section{Prensa}

Revistas especializadas

Documentos

Legislación

Carteles

Fotogramas

Fotografías

Partituras

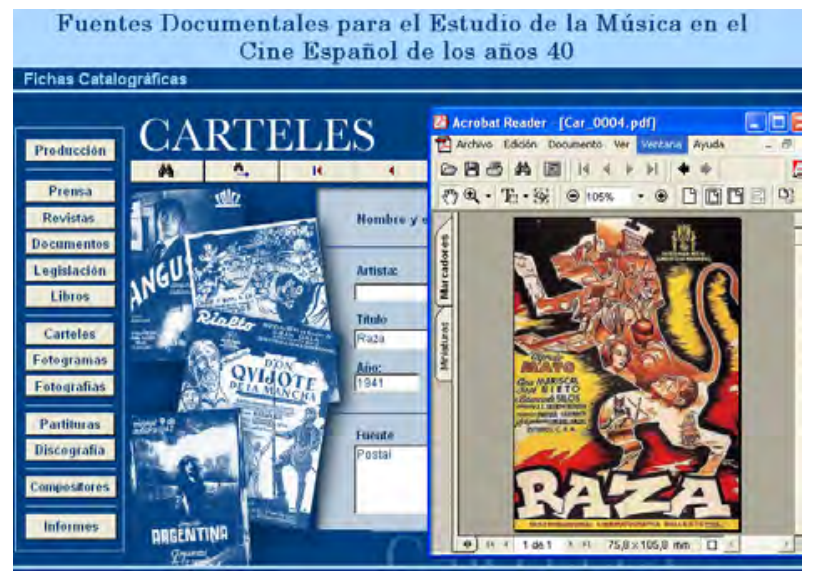

Imagen 31: Adobe Acrobat reproduciendo un cartel

En cuanto a la opción del botón Oír, éste se encuentra únicamente en la Ficha Catalográfica de Discografía y tan solo es funcional en aquellos registros donde se especifique un nombre y extensión de archivo digital enlazado por el Administrador. Siguiendo la normativa vigente sobre derechos de autor propiciada por la Sociedad General 
de Autores y Editores se ha decidido incluir tan solo unos segundos de las piezas seleccionadas:

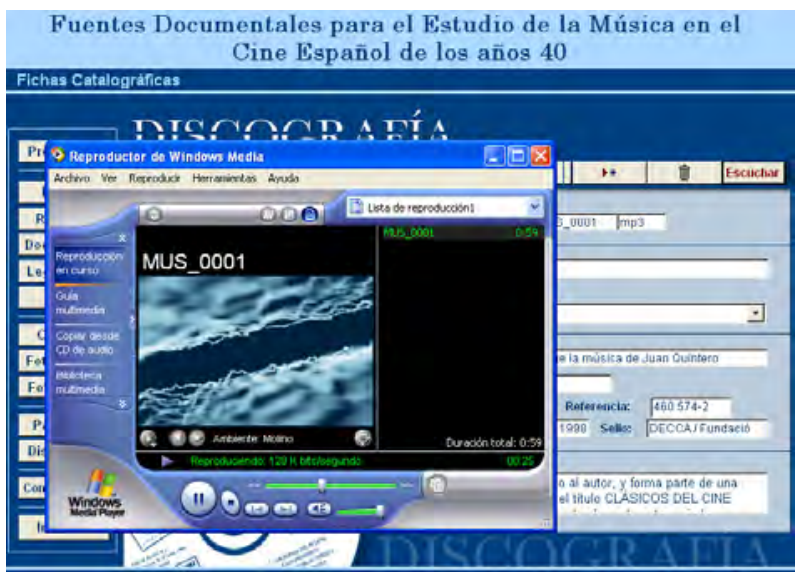

Imagen 32: Windows Media Player reproduciendo el tema principal de Locura de amor.

También se han tenido en cuenta las tipologías documentales para la creación de una nomenclatura y numeración adecuada a cada uno de los documentos aportados en la Aplicación MCE40. Dicha norma deberá ser seguida por el Administrador cuando éste genere un documento digital y lo incorpore a la Base de Datos. Esta norma se presenta en la siguiente tabla:

\begin{tabular}{|ll|}
\hline Tipo de documento & nomenclatura \\
\hline Prensa & PRE_0000 \\
\hline Revistas especializadas & RDP_0000 \\
\hline Documentos & DOC_0000 \\
\hline Legislación & LEG_0000 \\
\hline Carteles & CAR_0000 \\
\hline Fotogramas & FMG_0000 \\
\hline Fototeca & FTO_0000 \\
\hline Partituras & PAR_0000 \\
\hline Discografía & MUS_0000 \\
\hline
\end{tabular}

Tabla 31: Norma de nombramiento de los documentos digitales

Como se puede apreciar en la Tabla 1, el nombre del archivo está compuesto siempre por dos partes. La primera hace referencia directa al tipo de fuente o documento y consta de tres letras. A continuación sigue un "_" que sirve de división entre las dos partes, la textual y la numérica, para dar paso a esta última compuesta por cuatro dígitos. Esta 
numeración nos da un cierto margen en el almacenamiento de archivos, hasta 9999 por sección lo que hace un total de 79992 documentos susceptibles de poder ser incluidos utilizando este sistema, número que consideramos suficiente.

Debajo de la franja estudiada, se encuentra lo que podemos denominar la Ficha Catalográfica en sí. El tipo de Ficha que aparece por defecto cuando se abre MCE40 es el de la producción cinematográfica española correspondiente al periodo estudiado. A continuación nos vamos a encargar de describir una por una todas las Ficha Catalográficas contenidas en MCE40, así como sus particularidades.

\section{Producción Cinematográfica}

Como acabamos de comentar, la Ficha programada por defecto para que aparezca en primer lugar es Producción Cinematográfica donde encontraremos la información referente a cada una de las producciones de largometraje realizadas en España durante el periodo que va de 1939 a 1950.

Esta Ficha tiene en sí una estructura algo distinta al resto debido especialmente a las propias características de la documentación aportada y su extensión. Es por ello, que debajo de la barra de navegación horizontal podemos encontrar el nombre de la película a la que corresponden los datos que más abajo veremos y que debido a la gran cantidad de registros que deben incluirse en estas fichas se hizo necesaria una división de la información para poder visualizar correctamente de un modo más ordenado y estructurado que favorezca la localización de los datos buscados por el Usuario o Administrador.

En un primer lugar nos encontraremos con un campo en el que se podrá introducir el título de la película en cuestión. Junto a este campo encontramos un menú despegable con el nombre de Buscar título. Al desplegarse encontraremos todos los títulos introducidos hasta el momento y seleccionando uno de ellos, nos llevará directamente al registro de dicha película.

En cuanto a las subfichas, éstas se dividen en seis categorías denominadas: Ficha general, Música, Ficha artística, Ficha Técnica, Argumento y observaciones, Distribución y calificaciones. 


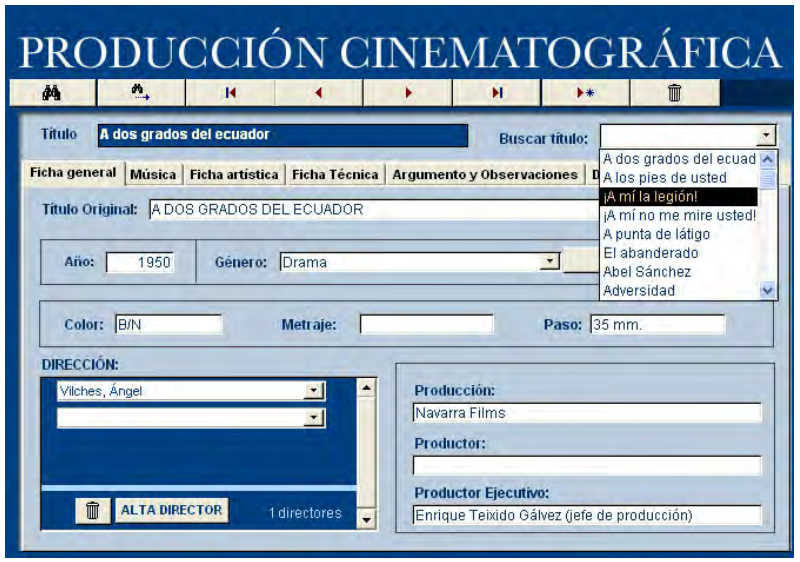

Imagen 33: Producción cinematográfica: menú de búsqueda

\section{Subficha general}

En la primera subficha se incluyen aquellos datos de interés inmediato que identifican de un modo rápido la película.

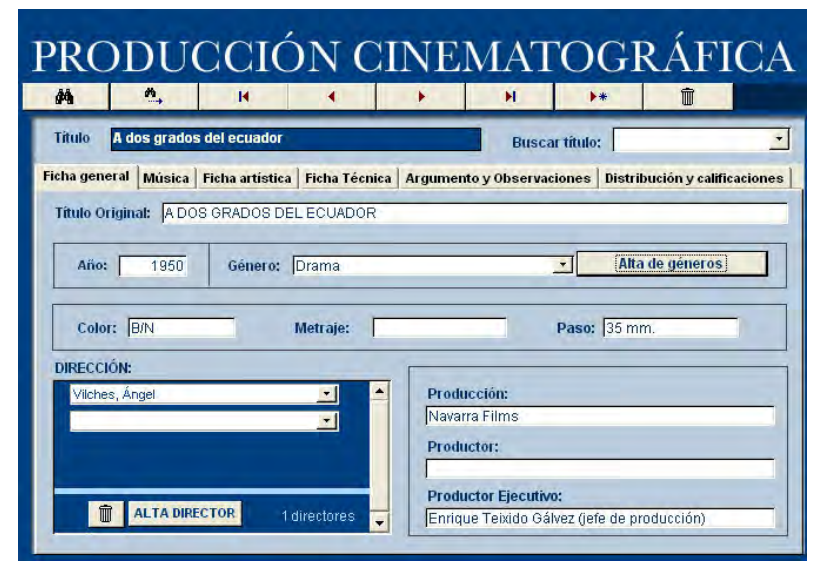

Imagen 34: Producción Cinematográfica: Ficha general (Administrador)

A continuación vamos a especificar cada uno de los parámetros y entradas incluidos en este apartado:

- Título original, se incluye por las posibles diferencias con el título que se puedan dar en aquellas películas coproducidas con otros países.

- Año, indica el año en que se realizó la producción, no el de su estreno, fecha esta última que se indica en la subficha de distribución. 
- Género, realiza una clasificación de los filmes en relación a unas categorizaciones preestablecidas. Como ya se comenta en el apartado dedicado la problemática de la asignación de género, no vamos a entrar en ella ahora sino tan solo recordar que se ha seguido el criterio de la Filmoteca Nacional con ligeras modificaciones de simplificación a la hora de designar los géneros. De todos modos, enumeramos a continuación cada una de las opciones a que tiene acceso el Administrador para asignar a una película un género:
- Animación
- Aventuras
○ Bélico
- Biográfico
- Comedia
- Drama
- Fantástico
○ Histórico
- Musical
○ Policiaco

Esta lista, para el Administrador no es cerrada. Junto al registro de Género, se encuentra un botón denominado Alta de géneros que al ser presionado se abre una ventana flotante con un miniformulario que hemos creado para la inclusión de nuevos géneros en MCE40, dando la posibilidad de describir también los parámetros que se establecen para dicho genero. 


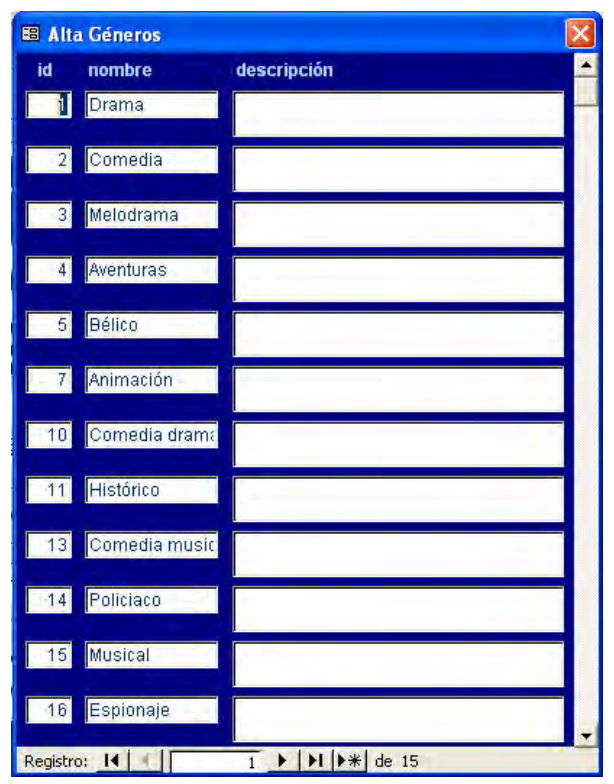

Imagen 35: Ventana de Alta de géneros

Color. En este apartado se indica si la película está realizada en blanco y negro o en color. En este último caso, que se da en contadas ocasiones, se pude especificar el tipo de película de color empleada al no estar reducido el campo a dos únicas posibilidades.

Metraje. En el presente registro se indica la duración de la cinta en metros de película.

Paso. El paso hace referencia al ancho de la película. Durante la década de los 40 el paso más habitual para el cine comercial era de $35 \mathrm{~mm}$ y para el cine amateur de 8 ó 16 $\mathrm{mm}$.

Dirección. Este apartado resulta algo especial. Como se puede apreciar en la captura de pantalla mostrada. Esta sección aparece en un recuadro de color azul marino y se divide en dos secciones. La parte superior contiene el o los nombres de los directores responsables del filme. El campo no es de libre inscripción, sino que para asignar un director éste antes debe ser dado de alta en la base de datos MCE40 para que el nombre aparezca en la cortina despegable del registro. Para dar de alta un nombre, se ha habilitado en la parte inferior del recuadro un botón, ALTA DE DIRECTOR. Pulsando este botón se abre una ventana flotante con tres campos: Nombre, Apellidos y Observaciones. 


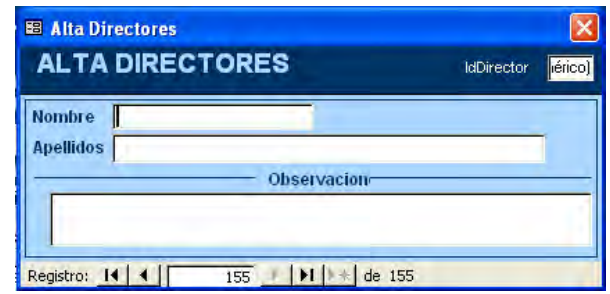

Imagen 36: Ventana Alta de directores

Una vez implementado el formulario, por lo menos con los dos primeros campos [Nombre y Apellidos] basta con cerrar la ventana para que se haya completado la operación de alta de un director. En la parte inferior de la ventana flotante se pueden observar los controles de desplazamiento entre registros. Estos se pueden usar en caso de querer modificar algún registro ya existente.

También en el recuadro de dirección, junto al enlace de ALTA DIRECTOR encontramos otro botón, esta vez con un icono que representa una papelera. Este sirve para eliminar un director ya asignado a una película, puesto que no sirve simplemente con seleccionarlo y presionar la tecla supr.. en estos casos lo mejor es colocar el cursor sobre el campo del director que queramos borrar y a continuación presionar el botón de la papelera.

En cuanto a este recuadro, tan solo queda indicar que junto a los botones que acabamos de explicar se indica en texto el número de directores asignados a cada película en cuestión. Si tan solo es uno, este se verá directamente pero si hay mas de uno, aparecerá una barra vertical al lado derecho para poder desplazar el registro visible hacia la parte superior y dejar de este modo espacio para los posibles registros ocultos.

Producción. En este apartado se indica el nombre de la productora o productoras responsables de la película.

Productor. Como su nombre indica, se especifica al productor de la cinta.

- Productor ejecutivo. Nombre del principal responsable de la producción o productor ejecutivo.

Música:

En esta segunda subficha se incluyen los datos relativos a los aspectos musicales de las producciones desde los compositores implicados en cada película hasta las canciones incluidas en la misma. 


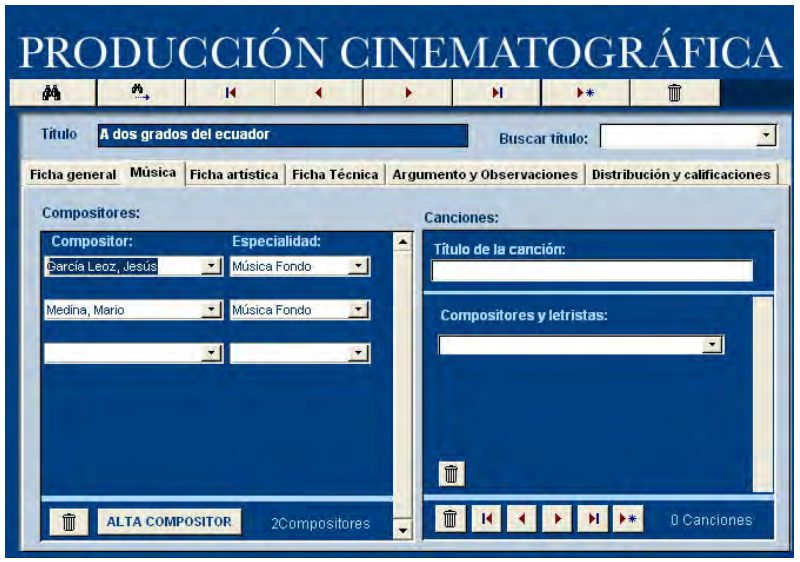

Imagen 37: Producción cinematográfica: Música (administrador)

- Compositores. Este apartado reúne unas condiciones especiales. En primer lugar, esta sección se comporta de un modo similar al de Dirección. El rectángulo se divide en dos espacios. El superior para los registros y el inferior contiene la botonería para las altas de registros, borrado de los mismos, etc.

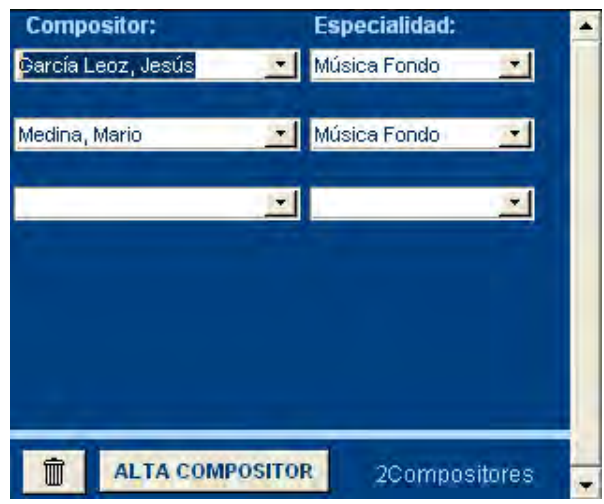

Imagen 38: Subformulario de compositores (Administrador)

En la parte superior, como el espacio de pantalla es limitado y en ocasiones el listado de músicos supera con creces dicho espacio, se ha habilitado una barra de scroll o desplazamiento vertical para estos casos. De todos modos, en la parte inferior del bloque se puede encontrar una referencia al número de registros incluidos en dicha película, es decir, se índica el número de compositores participantes en el proyecto que se está estudiando.

Para incluir un autor, éste debe estar antes dado de alta en MCE40. Para ello es necesario acudir a la botonería inferior del recuadro. En él, a parte de la papelera 
para eliminar un registro ya creado, clicando sobre el botón ALTA COMPOSITOR, se abre la ventana que mostramos a continuación.

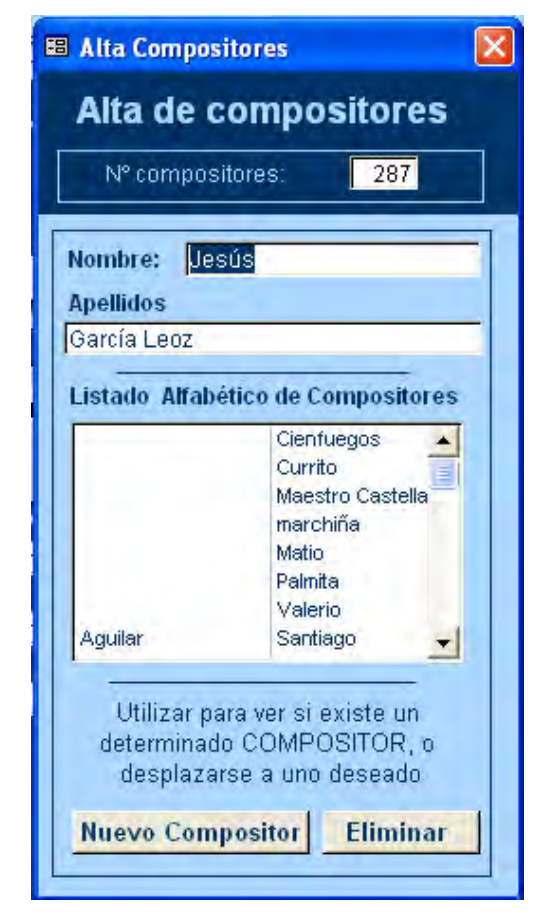

Imagen 39: Ventana de Alta de compositores

En ella, como se puede apreciar, nos vamos a encontrar con una primera sección en azul marino con el título de la ventana y el número de compositores dados de alta. El resto, de color azul claro está dividido en tres secciones. La primera contiene dos registros: Nombre y Apellidos. Estos sirven para introducir estos datos de un compositor nuevo o bien para modificar los ya existentes. A continuación aparece un listado con todos los registros de compositores incluidos hasta al momento con una barra de desplazamiento vertical a la izquierda. La última sección, tiene dos botones. El primero, Nuevo Compositor, nos lleva a un nuevo registro donde los campos de Nombre y Apellidos se quedan en blanco. El administrador aprovechará esta situación para introducir los datos pertinentes. Junto a este enlace se encuentra otro con el epígrafe Eliminar. Éste servirá para borrar un registro ya existente para lo que se elegirá un autor en la lista y se presionará sobre él. Una vez se hayan realizado todas las nuevas altas, basta con presionar sobre la cruz en la barra superior de Windows para cerrar la ventana y dar por finalizada la gestión.

En cuanto a los registros, no solo indican el o los compositores implicados sino su función dentro de la película. Debemos llamar la atención sobre el gran auge que la canción, en sus múltiples tendencias y estilos, tuvo en el cine en aquellos años. Es fácil 
encontrarnos con una o dos canciones, como ocurre hoy en día, que servían de promoción de la película. Estas canciones en la mayoría de los casos no eran compuestas por los compositores encargados de crear la música incidental del filme y se buscaba a especialistas en la creación de esta forma musical o se recurría directamente a incluir éxitos del momento presente o del pasado. Por otro lado, en ocasiones, como en el filme de Florian Rey, Goyescas, se adaptaba la música de un autor, en este caso la ópera Goyescas $^{315}$ del Maestro Granados o un compositor colaboraba con otro. Esto nos obliga necesariamente a incluir a todos estos autores, normalmente anónimos y hacer una evidente diferenciación entre quien escribía las canciones, quienes el score ${ }^{316}$ original, la idea musical, etcétera. Como ejemplo citaremos Correo de Indias, película de 1942 dirigida por Edgar Neville para CEPICSA; dentro del apartado de música nos encontramos con dos nombres. Por un lado, el maestro Muñoz Molleda, habitual colaborador de Edgar Niville y López-Quiroga. El primero, como puede verse fue el encargado de las canciones mientras que el segundo se especifica claramente como autor de la música de fondo. En otros casos, podremos encontrarnos con un gran número de autores que no se pueden visualizar juntos. En estos casos, mediante la barra de desplazamiento vertical se podrá tener acceso al listado completo.

El administrador podrá asignar solamente una serie de funciones a los compositores y tan solo una por línea de autor. Esto puede provocar algunos malentendidos en cuanto a la producción de algunos compositores en una primera vista, puesto que en una película pueden haber tenido dos funciones, por lo que en el listado de sus películas aparecerá esa misma película dos veces, una para cada función asignada.

Las funciones que aparecen cuando se despliega la cortinilla del registro son:

Dirección Orquestal, para el encargado de la dirección musical.

Música Fondo, para el autor del score, música incidental, de fondo o extradiegética.

Canciones, para los creadores de la música de esta forma musical.

Autor Adaptado, para los músicos cuya obra es utilizada por otros para la composición del score o de canciones.

Colaborador, para aquellos casos en que un compositor tan solo trabaja como apoyo a otro, realizando todo tipo de labores como los arreglos finales o la orquestación. El único ejemplo aparecido en este periodo de un modo claro es el de Jesús García Leoz en su colaboración con Joaquín Turina para Eugenia de Montijo.

Música y canciones, para aquellos autores que en una misma película se encargan de las dos facetas.

\footnotetext{
${ }^{315}$ No equivocar con las danzas españolas para piano del mismo nombre compuestas también por Granados y popularizadas por la pianista Alicia de Larrocha. De la Ópera solo se puede encontrar un registro sonoro en CD actualmente en el sello Alhambra con la Orquesta Nacional de España dirigida por otro histórico del momento, Ataúlfo Argental.

${ }^{316}$ Score: vocablo inglés que se utiliza para designar la música de fondo de las películas. Score no es lo mismo que Soundtrack, término utilizado para designar la banda sonora completa, mezcla de música sonidos y diálogos.
} 
Colaboración y canciones, para los casos posibles de apoyo aun primer compositor y realización de las canciones.

Letras, para los poetas, escritores, directores o guionistas que se implicaron en la creación de las letras de las canciones.

Letras o canciones, para los múltiples casos en que no ha sido posible determinar quienes eran los autores de las canciones o de las letras pero que aparecen como autores de las canciones.

Canciones. Este apartado tienes ciertas similitudes con el anterior. En el se pueden introducir los títulos de las canciones asociadas a cada filme y designar a los autores de cada una. El subformulario está dividido en tres zonas. La primera contiene el título de la canción. La segunda, los compositores y letristas autores de la obra. En este apartado, en la zona inferior encontramos un botón con el icono de la papelera. Este botón servirá para eliminar un registro de compositores ya asignado (bastará con colocar el cursor sobre el compositor y presionar el botón) La tercera zona es una franja destinada a botonería. En ella encontraremos una serie de iconos similares a los encontrados en la barra de navegación de la ficha principal. Estos botones son:

- Borrar: para eliminar una canción dada de alta.

- Ir a primera canción.

- Ir a canción anterior.

- Ir a siguiente canción

- Ir a última canción.

- Ir a nuevo registro.

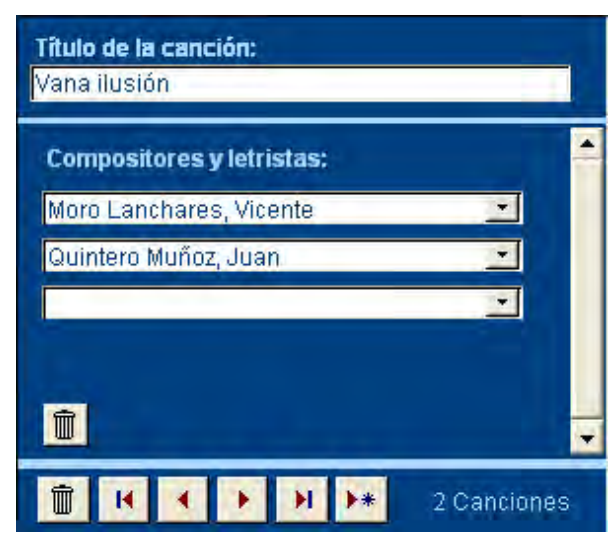

Imagen 40: subinforme Canciones (Administrador)

Junto a ellos encontramos en texto el número de canciones dadas de alta en cada película. Es importante resaltar que, para colocar un autor en este 
subformulario, será necesario darlo de alta anteriormente, para lo que es imprescindible ir al apartado de Alta compositor situado en el subformulario de Compositores y realizar los pasos ya descritos.

Ficha artística

En esta segunda categoría incluida dentro de la Ficha Catalográfica de Producción Cinematográfica, se encuentran los trabajos relacionados con las labores de marcado matiz artístico.

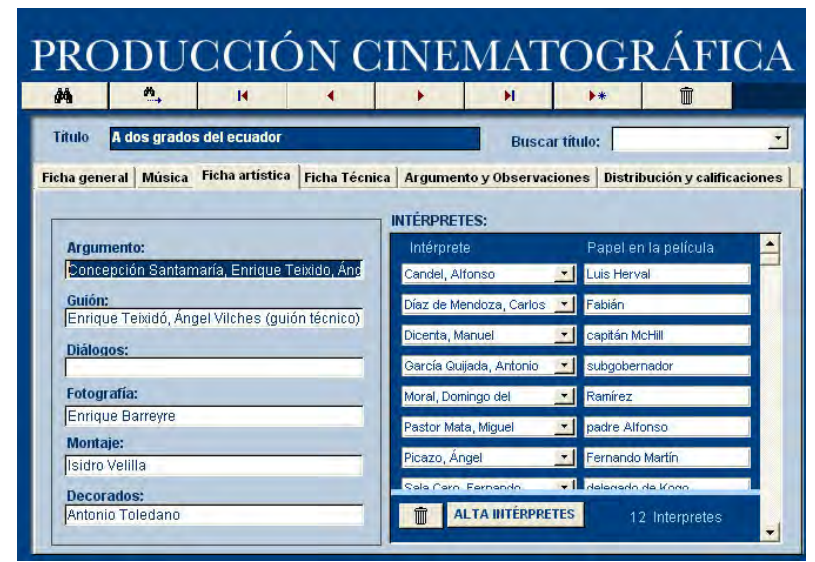

Imagen 41: Producción cinematográfica: Ficha artística (Administrador)

Como podemos observar en la imagen precedente, el área está dividida en dos partes bien diferenciadas. La sección de la izquierda contiene registros sencillos para actividades tan importantes como las vinculadas a la creación del guión, los decorados, la fotografía, etc., mientras que en la parte derecha se puede observar un recuadro similar a los ya explicados de Dirección y Compositores, pero en este caso, destinado a albergar el elenco artístico. Pero vayamos por parte y centrémonos primero en la parte izquierda.

En esta primera sección encontramos:

Argumento, que hace referencia al autor o autores de la idea original. También se pude dar el caso de ser una idea adaptada, en cuyo caso se especificará junto con el título de la obra teatral, novelística, etcétera y su autor.

Guión. En este apartado se destina para el responsable del guión final. En mucha ocasiones, sobre todo a principios de los cuarenta, se identifica también con el guión técnico.

Diálogos. Normalmente son los mismos responsables del guión y el argumento, pero en ocasiones, se requería de especialistas en la elaboración de textos ingeniosos o de cariz literario. 
Fotografía. Incluiría lo que hoy en día denominaríamos director de fotografía, responsable de la luz, el tono, las sombras, etcétera de la película.

Montaje. Contendrá los nombres de los responsables de la edición.

Decorados, o diseño de producción.

A la izquierda, podemos encontrar una ventana similar a las aparecidas en la subficha anterior destinada a albergar los datos concernientes al elenco artístico de intérpretes. Como se puede apreciar en la siguiente imagen, al igual que ocurría con los músicos, existen dos campos por línea. El primero incluye el nombre del artista y junto a él, se especifica el papel interpretado para la ocasión.

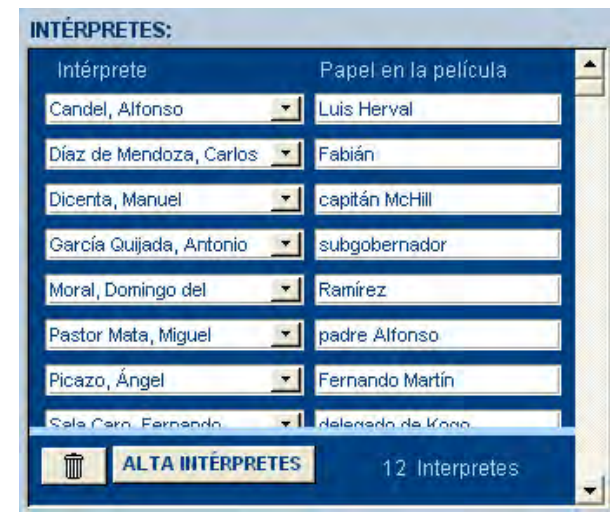

Imagen 42: subinforme Intérpretes (Administrador)

En la parte inferior del recuadro, como en los casos similares anteriores, se encuentran la botonería para la sección. El primero empezando por la izquierda es la papelera para borrar registros, mientras que el segundo abre una ventana de alta de intérpretes, Esta ventana contiene tres campos donde el administrador podrá introducir datos. Nombre, Apellidos y Observaciones para incluir cualquier información adicional que pueda interesar a nivel interno. En la parte inferior de la ventana, encontraremos los botones de navegación de registros, para poder desplazarnos de unos a otros.

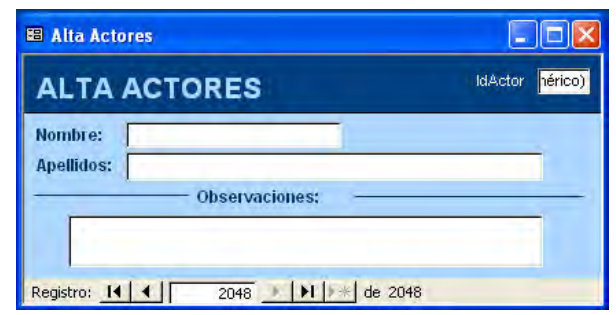

Imagen 43: Ventana Alta Actores 
Ficha técnica

La tercera subficha, Ficha técnica, como su nombre indica está destinada a albergar los nombres de los técnicos y ayudantes más importantes en la producción. Así, en ella podemos encontrar desde el Ayudante de dirección hasta la indicación del Sistema de sonido empleado. Para el Administrador, todos los campos son editables lo que quiere decir que puede escribir directamente en ellos.

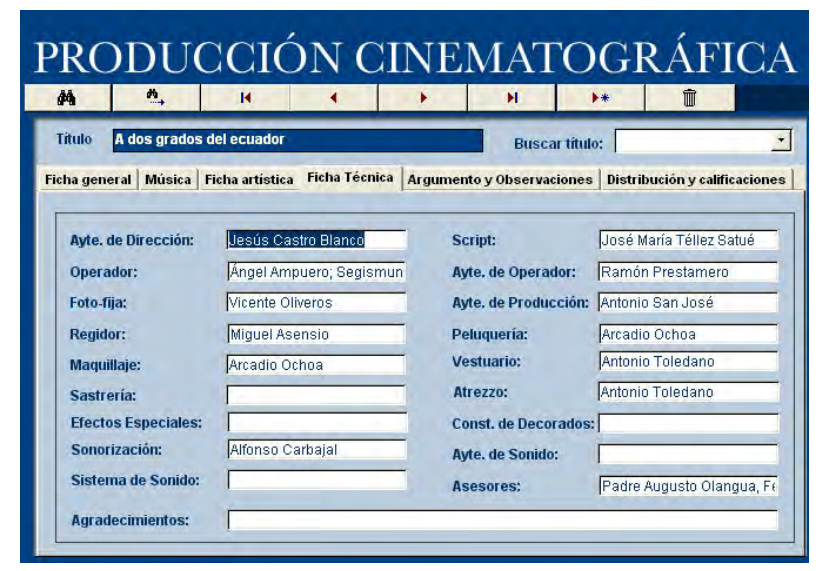

Imagen 44: Producción cinematográfica: Ficha técnica (Administrador)

Los campos especificados son:

Ayudante de Dirección.

Script; encargo de cuidar los detalles de continuidad y seguimiento del planning de rodaje.

Operador; encargado de cámara.

Ayudante de Operador; subalterno del cámara.

Foto-fija; fotógrafo de realizar las fotografías del rodaje y promoción del filme

Ayudante de Producción.

Regidor.

Peluquería.

Maquillaje.

Vestuario.

Sastrería.

Atrezzo. 


\section{Efectos especiales.}

Construcción de decorados.

Sonorización; Responsable de las mezclas finales de sonido

Ayudante de sonido; adjunto del encargado de sonido

Sistema de sonido.

Asesores; En algunos casos se pedía el asesoramiento de especialistas en algún tema para una mejor ambientación o diseño de producción, o del argumento. En este apartado se indica quienes hacen esa labor.

Agradecimientos.

En algunos casos, el espacio destinado para un determinado registro resulta insuficiente para la información contenida, entonces basta con cliclar sobre la información y desplazar el cursor emergente hacia la derecha, apareciendo paulatinamente todo el contenido incluido en dicho apartado.

\section{Argumento y observaciones}

La cuarta subficha, Argumentos y observaciones, está ocupada por dos grandes campos de texto. En el superior se incluye la sinopsis argumental de la película mientras que el inferior está reservado para matizaciones e información adicional de muy diversa idiosincrasia como premios, intervenciones especiales, etc.

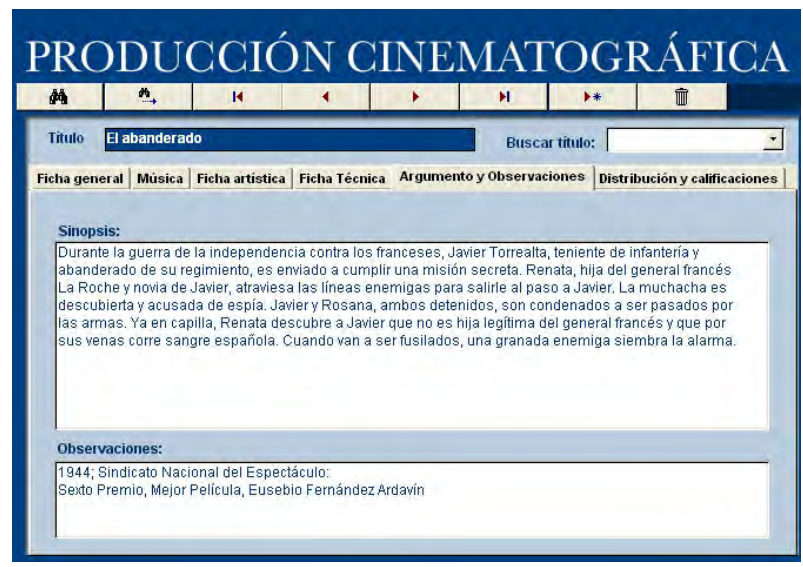

Imagen 45: Producción cinematográfica: Argumento y observaciones (Administrador) 
La mayor parte de los argumentos están extraídos del Catálogo del Cine Español, Películas de Ficción 1941-1950 317 realizado por la Filmoteca Española, otros de la Enciclopedia Multimedia CINEMEDIA ${ }^{318}$ y otros son de redacción propia.

\section{Distribución y calificaciones}

La quinta y última subficha, Distribución y calificaciones, presenta una distribución en tres partes. Las dos primeras están ligadas directamente con la distribución y conservación de la cinta mientras que la tercera y última se centra en las calificaciones obtenidas así como los permisos de importación y doblaje derivados de las primeras.

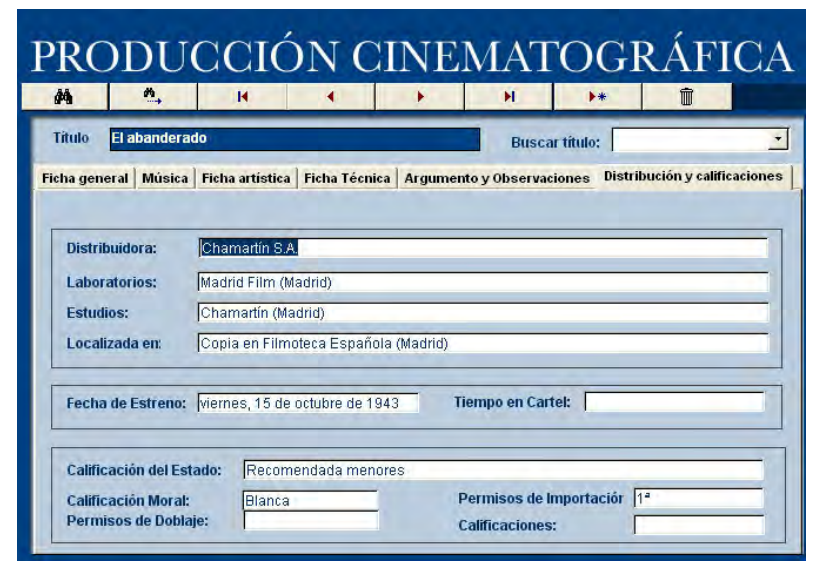

Imagen 46: Producción cinematográfica: Distribución y calificacioenes (Administrador)

Como se aprecia en la imagen, el primer bloque contiene tan solo cuatro campos:

Distribuidora; empresa encargada de su comercialización en aquel momento.

Laboratorios; compañía encargada del positivado de la película.

Estudios; talleres donde se realizó el rodaje de la cinta.

Depositada en; indica el la filmoteca, institución o empresa donde se encuentra en estos momentos la mejor copia para su conservación.

En un segundo bloque se plasman los datos referentes a su estreno y explotación inicial que muestran claramente su repercusión en el panorama cinematográfico del momento.

Fecha de estreno.

\footnotetext{
${ }^{317}$ Hueso, A. L. (coord..) (1998) Catálogo de cine español 1941-1950, Fuenlabrada (Madrid), Cátedra / Filmoteca Española.

${ }^{318}$ Huerta, C. (1997) Enciclopedia del Cine Español CINEMEDIA [CD-Rom], Barcelona, Canal +, SGAE.
} 
Tiempo en cartel; presenta el total de días o semanas que la película llegó a estar en cartel, el cine de estreno donde se llevó a cabo la premiere.

El tercer y último bloque dedicado a las calificaciones recoge las principales así como la referencia a los permisos de importación y doblajes concedidos por la administración. Estos campos en numerosas ocasiones carecerán de información. La razón de ello es variada, pero principalmente radica en las fechas de puesta en funcionamiento de alguna de ellas así como la no concesión de los permisos solicitados.

Cal. del Estado; Calificación otorgada por el gobierno para designar la calidad e interés de la cinta: Interés Nacional, de Primera, de Segunda o de Tercera.

Cal. Moral; Calificación moral otorgada por la iglesia. Principal división entre películas recomendadas para menores o no.

Permisos de doblaje; Número de permisos concedidos a la cinta para doblar películas extranjeras para su exhibición.

Permisos de importación; Número de licencias de importación para poder traer películas extranjeras a nuestro país para su explotación comercial.

Calificaciones; este campo se queda abierto para aquellas posibles calificaciones de tipo individual o de menor relevancia que pudiese llegar a tener una película.

\section{Prensa}

La Ficha Catalográfica de Prensa, contiene las referencias de aquellos artículos, críticas, entrevistas, noticias, anuncios, etc., aparecidas en publicaciones diarias no especializadas en cine. Normalmente el material obtenido dentro de esta tipología documental ha sido cedido por herederos de compositores de la época y extraídos de los principales diarios del país, dentro de sus secciones de espectáculos o sociedad.

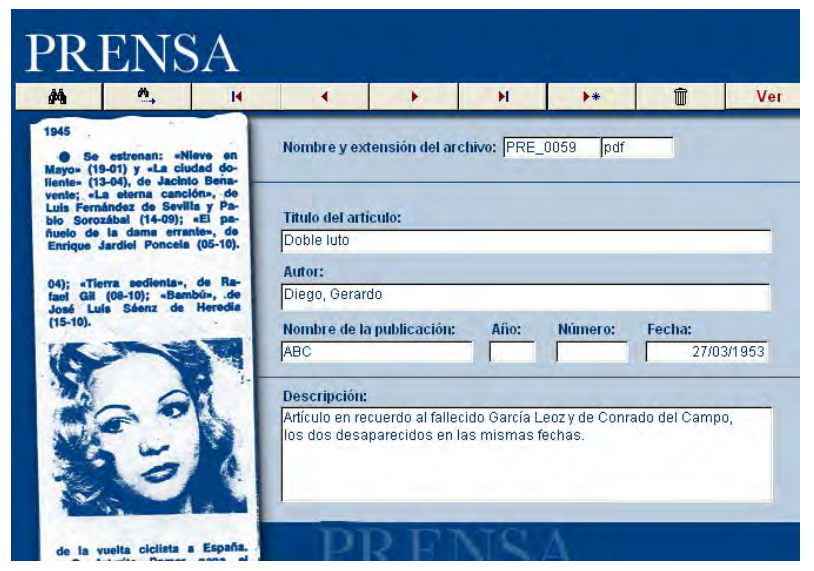

Imagen 47: Ficha de Prensa (Administrador) 
Vamos a aprovecharnos de la Ficha Catalográfica de Prensa para explicar someramente la estructura del resto de fichas dentro de MCE40. Como se observa en la imagen, el espacio de la Ficha se distribuye de un modo muy concreto y el esquema se seguirá para el resto de fichas.

En la parte superior de cada una de ellas se encuentra una zona destinada únicamente a grafismos con la inclusión del nombre de la Ficha Catalográfica. A esta zona, le sigue inmediatamente debajo, la banda de navegación interna de la ficha como ya se comentó al principio de esta sección.

En un primer vistazo, pueden verse dos zonas bien delimitadas. Una, en el lado izquierdo, de carácter gráfico destinado a una imagen significativa con respecto a la tipología documental a la que hace referencia la ficha y, otra, a la derecha donde se sitúa la información. La funcionalidad de la imagen incluida radica en que visualmente ayuda a ilustrar la sección.

En el margen derecho superior, aparecen los campos Nombre y extensión de archivo. Estos registros hacen referencia al nombre y extensión del archivo que contiene el documento original incluido en su versión digital dentro del soporte óptico. Es evidente que estos campos solo aparecerán en las fichas que contengan la referencia a documentos concretos aportados y no a referencias bibliográficas como es el caso de la ficha de libros.

Debajo de estos dos datos, se incluyen los registros necesarios para describir el documento y su origen, para poder situar adecuadamente dentro del contexto investigador el documento, así como la información necesaria en caso de querer acudir a la fuente primigenia.

Título del artículo digitalizado y contenido en el archivo adjunto

Autor del artículo o noticia incluido.

Nombre publicación o diario donde aparece impreso el artículo

Año de la publicación con respecto a su fecha de salida al mercado

Número de publicación o edición del diario.

Fecha de publicación y puesta en circulación.

Descripción que incluye un breve resumen sobre la noticia o artículo.

\section{Revistas Especializadas}

En la Ficha Catalográfica Revistas Especializadas se recogen todas las referencias encontradas tras el vaciado de varias revistas centradas en la industria cinematográfica, tales como Primer Plano, RadioCinema, Cámara. En estas publicaciones, a pesar de tratarse de revistas generalistas de cine, hemos llegado a encontrar casi una centena de artículos, entrevistas, críticas biografías, etc., sobre temas de música de cine y sus protagonistas. 


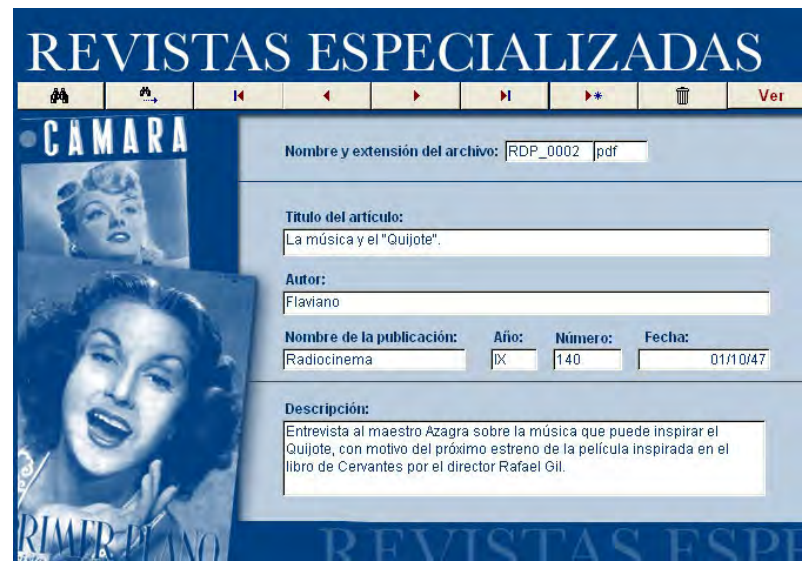

Imagen 48: Ficha Revistas especializadas (Administrador)

Los campos establecidos para la correcta clasificación de los documentos pertenecientes a esta categoría son:

Nombre y formato, como ya se comentó hacen referencia directa al archivo digital del documento contenido en el soporte óptico.

Título del artículo digitalizado y contenido en el archivo adjunto

Autor del artículo, entrevista, biografía, etcétera

Nombre publicación de la revista en donde aparece el artículo referenciado.

Año de la publicación con respecto a su fecha de salida al mercado

Número de publicación o edición del diario.

Fecha de publicación y puesta en circulación.

Descripción o breve resumen de tipo orientativo sobre la noticia o artículo.

En este caso, por las similitudes intrínsecas de las publicaciones periódicas, en nuestro caso entre la prensa diaria y las revistas especializadas, la estructura y campos incluidos en la misma son prácticamente iguales a las incluidas dentro de la Ficha Catalográfica de Prensa. A pesar de ello, se ha querido distinguir entre la prensa diaria y la especializada por las lógicas diferencias entre ambas tipologías documentales establecidas por la naturaleza de las mismas y el público al que iban destinadas.

\section{Documentos}

En esta sección se recogen documentos de diversa procedencia y tipología que tienen en común su unicidad, es decir, se trata de documentos únicos tales como correspondencia personal de los compositores, entrevistas no publicadas, y en general toda una amalgama de referencias variadas que nos ayudan a crear un retrato de la profesión y la labor creadora. Se trata, fundamentalmente de documentos inéditos cedidos por los 
herederos de los compositores. En MCE40 están digitalizados y se puede acceder a los mismos a través del botón Ver que abrirá los sucesivos archivos elegidos para su estudio.

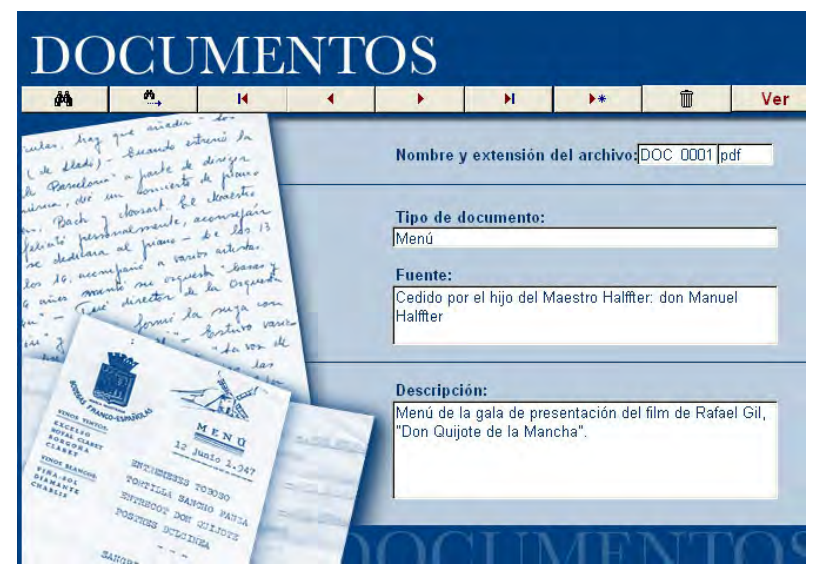

Imagen 49: Ficha Documentos (Administrador)

Siguiendo la tónica general presentada en la Ficha Catalográfica de Prensa, los primeros registros hacen referencia directa a la nomenclatura y extensión de los archivos digitales linkados a las fichas, por lo que es importante que el Administrador tome, tanto en esta ocasión como en el resto, con sumo cuidado la tarea de insertar adecuadamente el nombre del archivo y su extensión para evitar posibles problemas en visualización de los archivos.

El resto de la ficha se compone de tres campos. El primero de los cuales realiza una clasificación en función de una categorización creada para que el Administrador no se salga de ella. Esta categorización viene dada por las siguientes tipologías documentales:

Menú de cenas pertenecientes a celebraciones de gala con motivo de algún estreno. Estos menús solían estar personalizados e iban dirigidos a nombre del compositor y su familia.

Biografías y autobiografías escritas por los propios compositores o sus herederos a falta de notas biográficas de los Maestros en fuentes impresas como Enciclopedias, libros, etc.

- Catálogos de obras y filmografías de autores. Estos catálogos normalmente son de realización privada a petición de los interesados. En el caso de Manuel Parada de la Puente se sospecha que es una copia del catálogo de la obra guardada en la Biblioteca Nacional.

Curriculum vitae de compositores, algunos de ellos están escritos por los propios compositores con la intención de ser presentados en productoras para la obtención de algún trabajo. 
Fichas catalográficas de películas cedidas por herederos a modo de catálogo cinematográfico de sus progenitores.

Invitación a estrenos o celebraciones diversas con motivo del lanzamiento de alguna producción. Al igual que los menús suelen ser nominales.

Entrevistas inéditas llevadas a cabo para la investigación de la presente tesis doctoral, realizadas a personalidades del mundo cinematográfico y musical así como a los herederos y descendientes de los mismos.

Cartas, e-mails y correspondencia diversa que hemos mantenido con los herederos durante estos últimos cuatro años.

Los dos campos restantes que aparecen sirven para describir el documento aportado y su procedencia. Así, los registros son:

- Fuente, donde se especifica el origen de los documentos presentados, que en esta ocasión mayoritariamente serán cesiones para esta investigación por parte de herederos.

\section{Legislación}

En las Fichas Catalográficas de Legislación damos la referencia y datos necesarios para la localización de toda la legislación relativa a la industria cinematográfica española desarrollada entre 1938 a 1950.

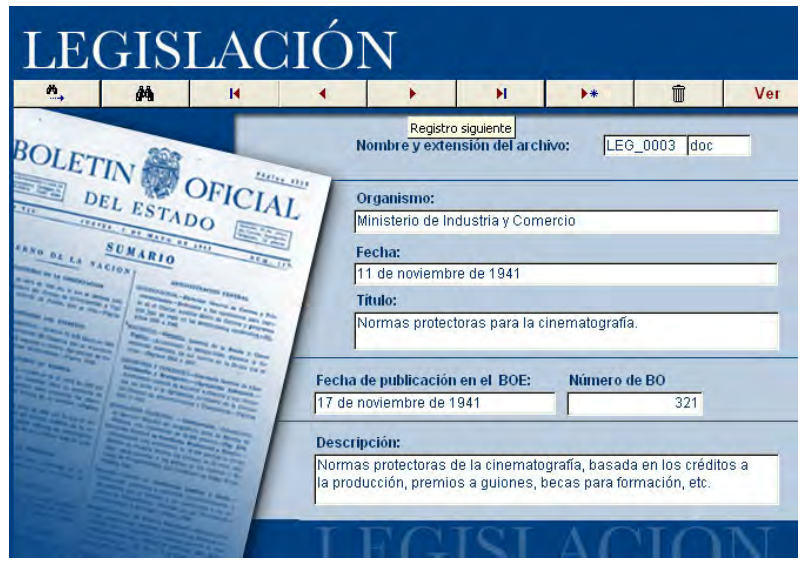

Imagen 50: Ficha Legislación (Administrador)

Encabezan los datos de la Ficha Catalográfica los ya mencionados campos que hacen referencia al nombre y extensión del archivo digital que contiene las leyes. A estos le siguen seis campos que consideramos suficientes para la designación y localización del documento original. 
Organismo o institución de que depende la promulgación de la ley u orden.

Fecha de publicación de la citada ley u orden ministerial.

Titulo descriptivo de la orden, ley o decreto.

Fecha de publicación en el BOE.

Número de BOE.

Descripción de la citada ley u orden donde se especifica de modo resumido y breve las principales características del citado documento.

En esta ocasión, a través del botón Ver se podrá tener acceso a cualquiera de las leyes, órdenes ministeriales, decretos, etcétera, en formato digital pero en una versión transcrita de las mismas ya que las fotocopias obtenidas de la Administración del Estado de los originales BOE de la época eran de muy mala calidad. De modo que hemos dedicado largas horas para descifrar parte de los textos jurídicos de referencia.

\section{Libros}

En la Ficha Catalográfica de Libros se incluye una amplia relación de referencias bibliográficas vinculadas al tema de estudio en cuestión. Libros de teoría musical, de música de cine, monografías de autores, historias del cine, catálogos, etcétera.

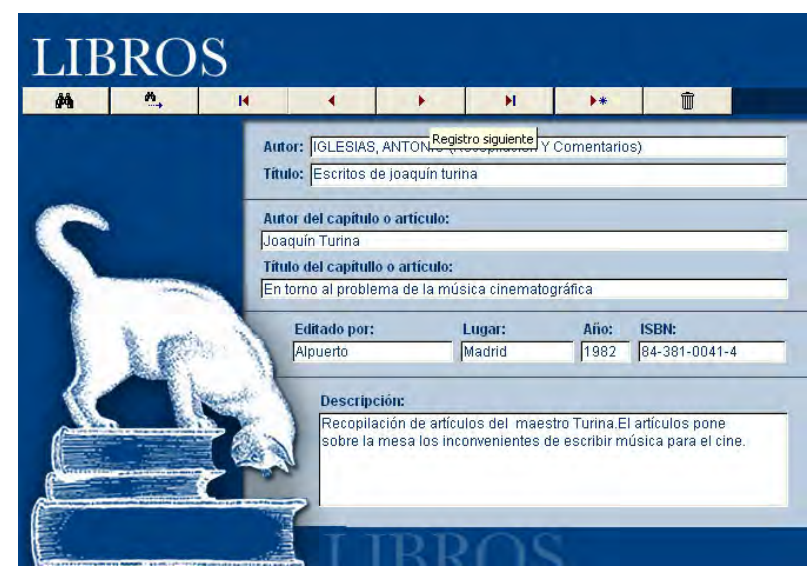

Imagen 51: Ficha Libros (Administrador)

Debido a que MC40 no pretende en ningún momento llegar a convertirse en un ejemplo de aplicación documental sino servir de herramienta para el estudio de la música de cine de los años cuarenta, hemos configurado una ficha sencilla con los datos suficientes. Estos datos son:

Título del libro o publicación, puesto que en ocasiones pueden ser actas de congresos o catálogos. 
Autor del capítulo, en el caso de que nuestro interés se encuentre solo en una parte de dicha publicación o actas que firmen varios investigadores o escritores.

Editado por, citamos la editorial que ha comercializado la edición que nosotros referenciamos.

Lugar o localidad de la edición.

Año de la publicación

ISBN. Se incorpora el mencionado número en aquellos casos que lo tengan o se haya podido obtener puesto que la inclusión de libros antiguos, carentes de dicho código de control hace imposible completar siempre este campo.

Descripción breve y resumida a modo orientativo sobre el contenido de la publicación o artículo.

La estructura de la presente Ficha varía en relación a las anteriores ligeramente. En este caso no se incluye el nombre de ningún archivo, puesto que los libros no se incluyen en MCE40 por motivos obvios. Al carecer de ellos, también se ha eliminado de la Ficha el botón Ver que da acceso a los documentos digitales.

\section{Carteles}

De inevitable referencia en todo estudio cinematográfico tanto por las aportaciones artísticas y estilística de los pintores, publicistas y creadores que desarrollaron su trabajo en esta disciplina, como por la información que este tipo de documentos aporta de un modo tangencial a nuestra investigación, yendo desde las jerarquías en la aparición dentro del cartel de los distintos profesionales que trabajan en filme hasta connotaciones de tipo moral que transciende en la propia iconografía gráfica.

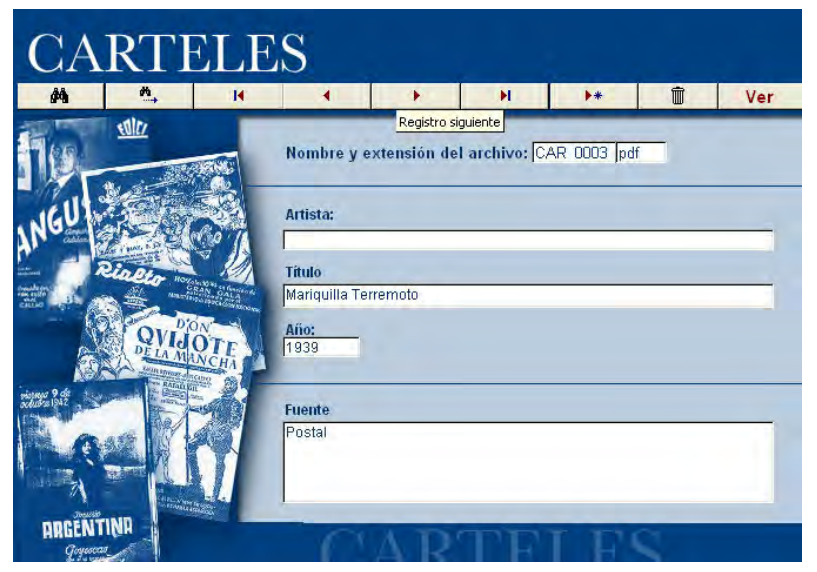

Imagen 52: Ficha Carteles (Administrador) 
Los carteles, de naturaleza gráfica, son incluidos en MCE40 en formato digital, siendo necesario incluir en la ficha el nombre del archivo como se hace en otras fichas de característica similares, mediante la introducción del nombre y extensión del mismo.

El resto de campos utilizados son:

Artista o creador de la obra gráfica. Se debe de tener en consideración que durante varias décadas, algunos de los mejores artistas de nuestro país trabajaron en esta disciplina y es justa la reivindicación de su obra y autoría.

Titulo de la película a la que pertenece el cartel.

Año de producción que coincide con el año de creación, al incorporarse únicamente versiones originales del momento.

Fuente, indica el origen de donde se ha extraído la imagen. Estas fuentes son de lo más variopinto. Desde revistas de programación televisiva hasta postales o carátulas de vídeo.

\section{Fotogramas}

La Ficha Catalográfica de Fotogramas, está destinada a organizar y clasificar todo el material fotográfico vinculado a producciones directamente. No incluimos en la misma fotografías de compositores dirigiendo la orquesta y similares, sino, únicamente, fotogramas extraídos de películas o foto-fija realizadas durante el rodaje y cedidas por particulares o entidades.

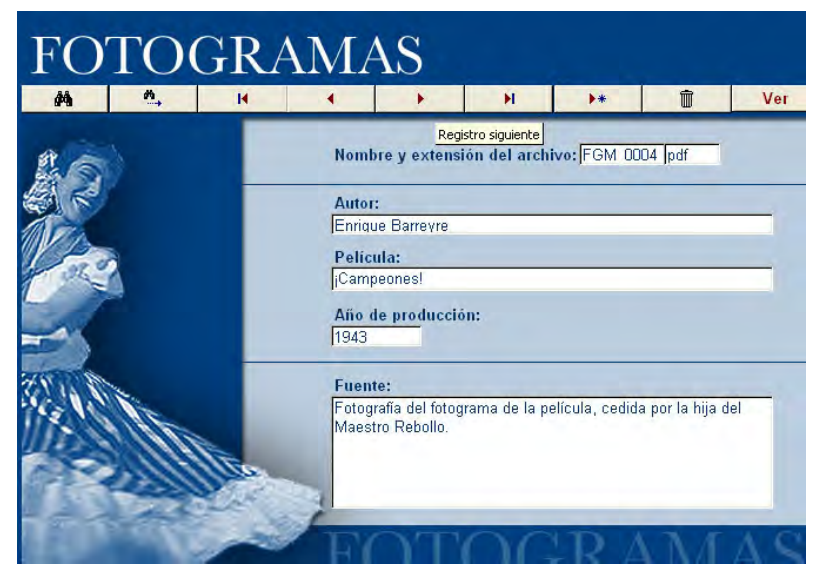

Imagen 53: Ficha Fotogramas (Administrador)

Para la designación estos documentos gráficos se han tenido en cuenta los siguientes parámetros: 
Nombre y extensión del archivo digital vinculado a la ficha con las imágenes catalogadas.

Autor de la fotografía. Por norma general se le atribuirá al director de fotografía o al responsable de Foto-fija acreditados a la producción salvo que tengamos información fidedigna de no ser así.

Titulo de la producción a la que pertenece el fotograma o foto-fija.

Año de la producción del filme.

Fuente, indica el origen de donde se ha obtenido dicha imagen. Al igual que los carteles, las fuentes son muy variadas y van desde la cesión por parte de interesados hasta la publicación en prensa y revistas especializadas.

\section{Fotografías}

Como complemento gráfico se presenta la Ficha Catalográfica de Fotografías con una colección de imágenes extraídas de diversas fuentes en las que los protagonistas de las mismas son los compositores y personas afines a los mismos. Estas imágenes, muchas de ellas inéditas, presentan el lado más humano de nuestros protagonistas y su ardua tarea creadora.

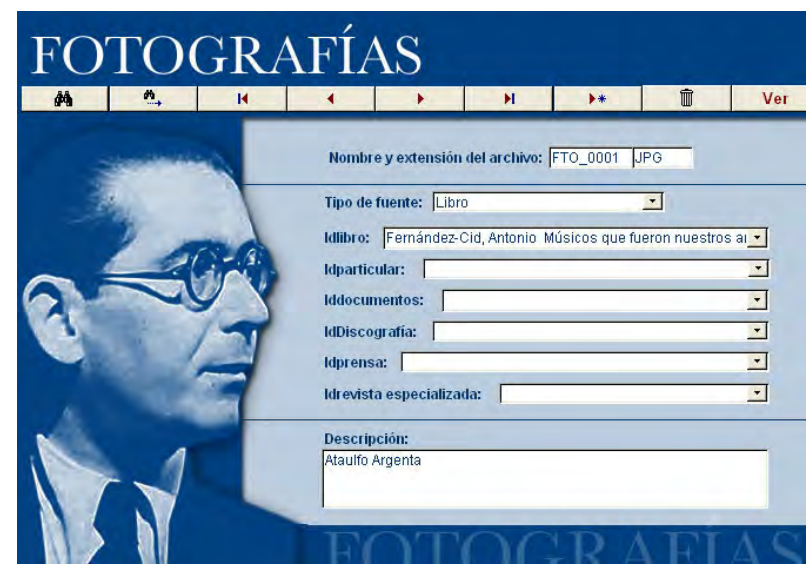

Imagen 54: Ficha Fotografías (Administrador)

En la versión para Administrador de esta ficha, los campos y visualización de los datos es totalmente distinta de la visión del Usuario. En este caso nos encontraremos con una serie de campos en los que el Administrador no podrá escribir libremente sino que deberé elegir entre los datos aportados en los campos despegables. Estos datos hacen referencia a documentos o libros que deben ser dados de alta en sus respectivas fichas para que aparezcan en esta. 
Por tanto, los campos que aparecen no se rellenarán nunca en su totalidad sino que se elegirá uno nada más, pues el resto hace referencia a otros documentos.

Los campos que nos encontramos son:

Nombre y extensión de los archivos digitales que albergan las imágenes.

Tipo de fuente crea una subcategoría de fuentes de donde se obtienen el material fotográfico porque el origen de todas estas imágenes es heterogéneo, tejido por los propios protagonistas y sus herederos así como publicaciones de distinto rango y características. El Administrador para tener acceso a estas subcategorías deberá desplegar la cortina del campo Tipo de fuente presionando sobre el triangulito situado a la derecha del mismo y presionando sobre la opción que interese para el caso. Las tipologías incluidas en este campo son:

Libro

Documento

Particular

Fuente

Grabaciones

Idlibro, nos da acceso a todos los libros registrados.

Idparticular, nos da acceso a un listado de las fuentes de los documentos inéditos aportados por particulares.

Iddocumentos, nos da acceso a un listado de los documentos inéditos dados de alta en la Aplicación.

Iddiscografía, es el listado de ediciones discográficas incluidas en la Aplicación.

Idprensa, muestra el listado de artículos de prensa recogidos.

Idrevistas especializadas recoge el listado de referencias extraídas de estas publicaciones periódicas.

Descripción de la imagen y su contenido.

La elección de la referencia de los campos que comienzan por id_dará a MCE40 la información suficiente para aportar al usuario una información mucho más detallada como se podrá ver cuando abordemos esta ficha en el itinerario de Usuario.

\section{Partituras}

Las partituras, como documento inédito y de difícil obtención resulta en todo momento una de las tipologías más interesantes de MCE40. Es por ello, que a pesar de las dificultades que pueden plantearse en la reproducción de este material sujeto a derechos de autor, se incluyen algunos fragmentos de partituras inéditas y otras aparecidas en revistas o catálogos de la época. Por ello, presionando el botón Ver, se podrá tener acceso a estas pequeñas joyas documentales, paro lo que será imprescindible que el Administrador 
haya introducido correctamente el nombre y extensión del archivo digital que contiene cada una de las partituras.

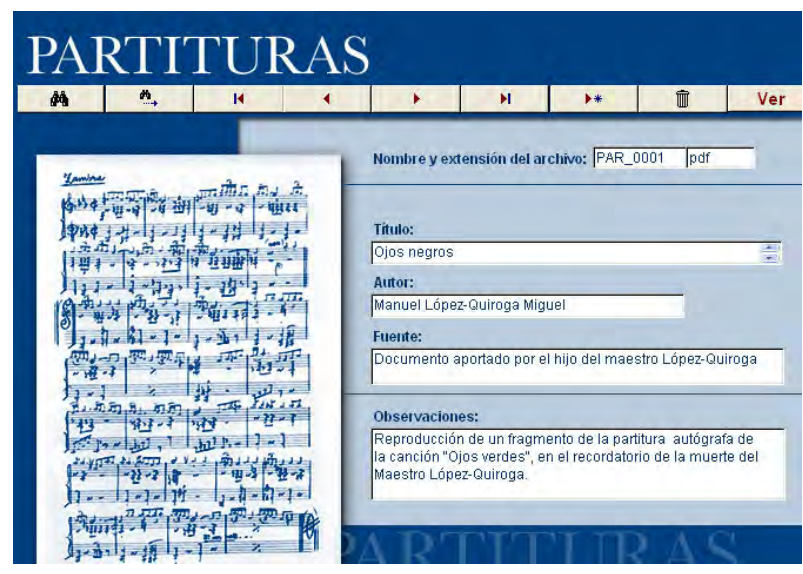

Imagen 55: Ficha Partituras (Administrador)

Los campos que nos ayudan a clasificar este material vienen conformados por los siguientes parámetros.

Titulo de la obra

Nombre del Autor o compositor de la pieza.

Fuente u origen de donde se ha obtenido la partitura o la persona o institución que nos la ha cedido temporalmente.

- Observaciones nos sirve como complemento a los campos anteriores para la clarificación de cualquier posible duda sobre el origen, características del documento, etc.

\section{Discografía}

La Ficha Catalográfica de Discografía recoge y aúna las referencias discográficas de los últimos veinte años. Al igual que se recogen las referencias a las ediciones, se puede, mediante el botón Oír reproducir una pequeña porción de las obras incluidas. Como la inclusión de todo este material resultaba imposible con una mínima calidad de sonido, tan solo se podrá escuchar aquellas piezas que tengan asignado un nombre y extensión de archivo. 


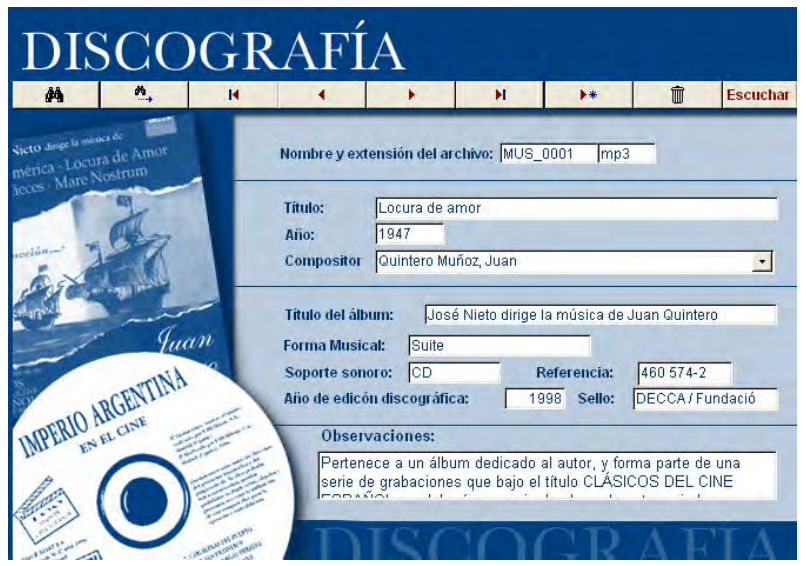

Imagen 56: Ficha Discografía (Administrador)

Como se puede apreciar en la imagen de la ficha superior, ésta se divide en tres partes cada una de las cuales hace referencia a aspectos diferentes de las obras. La primera se refiere al nombre y extensión del archivo de sonido adjunto. El segundo bloque hace mención a la obra en sí mediante los siguientes campos:

Titulo de la película a la que pertenece la pieza.

Año de producción que coincide con el año de creación

Nombre del Compositor de la obra. En este caso se trata de un campo despegable del que se debe elegir un nombre, por lo que los compositores deben estar dados de alta con anterioridad, a través de la ficha Compositores que veremos a continuación.

En el tercer bloque se presentan los datos relativos al álbum musical publicado comercialmente.

Título de álbum de la grabación discográfica presentado al mercado.

Forma musical en que se registró la pieza. Por norma general no se edita la música tal cual se escucha en el filme sino en forma de temas o suites así como canciones. Con el fin de hacer más sencilla la labor del Administrador y homogeneizar la información se han delimitado las formas musicales creando subcategorías, las cuales son:

Obra completa, que hace referencia a una posible edición del máster original de la grabación tal y como se escucha en la película.

Suite $^{319}$, grupo de melodías o temas recogidos en una pieza de mayor envergadura a modo de una sola pieza. Suite.

Selección, recopilación de unos pocos temas sin una idea de conjunto como en la

\footnotetext{
${ }^{319}$ No se debe identificar este tipo de suite con la denominación que recibe en el mundo de la música "clásica". En este caso se trata de una colección de danzas.
} 
Tema o bloque musical.

Canción, como pieza corta con letra y acompañamiento de voz.

Soporte sonoro o físico en referencia que se aporta, es decir, el formato en que ha sido publicado. Se establece, como en el caso anterior, tres tipologías de soportes posibles para que el Administrador pueda elegir.

- Vinilo, antiguos soporte denominados comúnmente como discos de música.

- $\quad$ Cassette, sistema de audio en desaparición como el vinilo perteneciente a la familia de sistemas de reproducción analógicas.

- $\quad C D$ o Compact Disc, es el soporte digital más extendido en los últimos diez años. Aprovechando su tirón se ha reeditado mucho material de música de cine, aunque por desgracia de música de cine español no demasiada.

Número de referencia discográfica del sello editor.

Año de edición discográfica y salida al mercado de la citada grabación. fonográfica.

Sello discográfico o empresa editorial encargada de su comercialización

Observaciones se reserva para introducir información adicional sobre la versión, anécdotas o curiosidades.

\section{Compositores}

La Ficha Catalográfica de Compositores recopila y muestra los datos de producción de cada uno de los protagonistas de esta tesis doctoral. Realmente esta ficha tiene más una funcionalidad de consulta que de introducción de datos como en el resto de Fichas mostradas hasta el momento. Salvo el último campo, Observaciones, donde el Administrador podrá introducir comentarios referentes a premios, seudónimos o curiosidades relativas al compositor en cuestión, en el resto de campos le está vedada la manipulación de la información.

A parte de esta posible actividad por parte del Administrador, en la barra de herramientas aparece el botón de nuevo registro. Éste abrirá la ventana de Alta de Compositores ya comentada en la Ficha Catalográfica de Producción Cinematográfica. A través de dicha ventana el Administrador, podrá interactuar de la misma manera para dar de alta un nombre nuevo. 


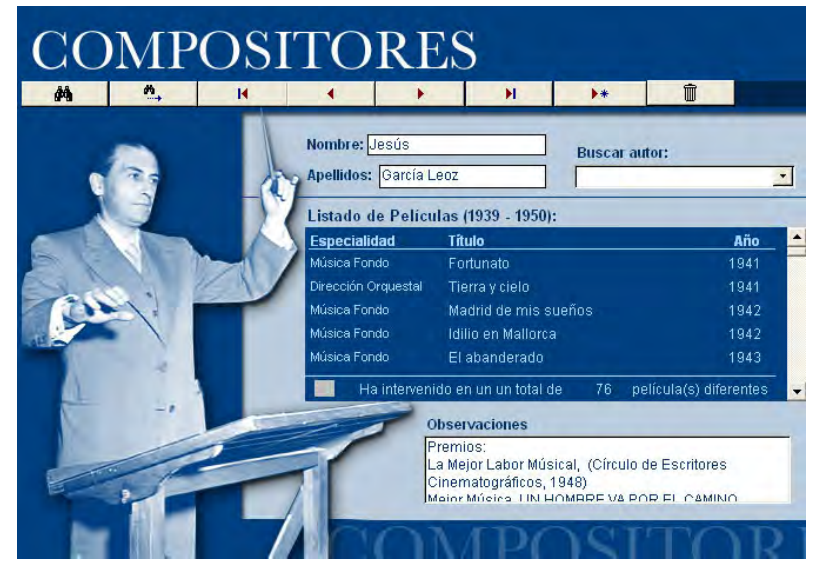

Imagen 57: Ficha Compositores (Administrador)

Como se puede apreciar en la imagen superior, la ficha muestra algunas características propias que a continuación vamos a describir.

En un primer bloque, se indica el nombre del artista y su apellido, junto a los que se encuentra un campo despegable con el listado completo de compositores dados de alta. Eligiendo uno de ellos, inmediatamente nos encontraremos en la ficha de dicho compositor.

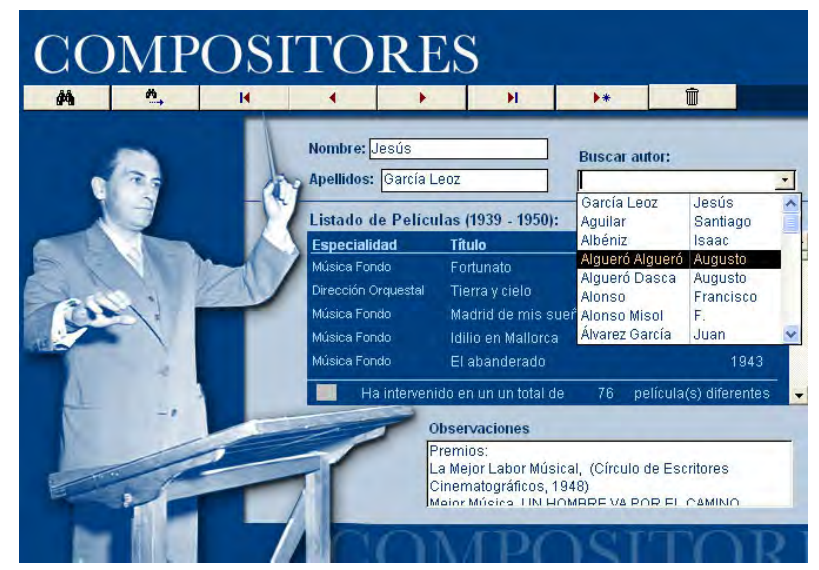

Imagen 58: Ficha Compositores con búsqueda desplegaba (Administrador)

En el segundo bloque, como se puede ver en la imagen precedente, aparece el listado de películas en las que participó el compositor elegido dentro de un rectángulo azul oscuro. En dicha área muchas veces no cabe toda la información existente. En esos casos se mostrará una barra desplazadora vertical en el lateral derecho y en la zona inferior aparecerán el número total de producciones asignadas. En este sentido cabe llamar la atención sobre el hecho de que en la lista, si un autor tiene dos funciones en una película, 
por ejemplo, música de fondo y dirección musical, esta producción se duplicará, puesto que se asigna por labores desempeñadas.

Es importante recordar que en esta lista tan solo aparecerán los títulos de las películas en las que participó el compositor dentro del periodo estudiado, es decir, entre 1939 y 1950. Todo título fuera de estas fechas no se encontrará en la lista.

\section{Informes}

Realmente esta pantalla no se trata de ninguna Ficha Catalográfica sino de una pantalla de acceso a informes y listados preexistentes de diversa consideración. Al igual que ocurría con la Ficha Catalográfica de Producción Cinematográfica, el acceso a los informes está distribuido en tres subfichas, una de Producción, otra de Música y una última de Documentación. Como se puede imaginar nuestro lector, esta sección es tan solo de consulta y por lo tanto, ni el Administrador ni el Usuario común podrán introducir nuevos informes o listados, tan solo consultarlos.

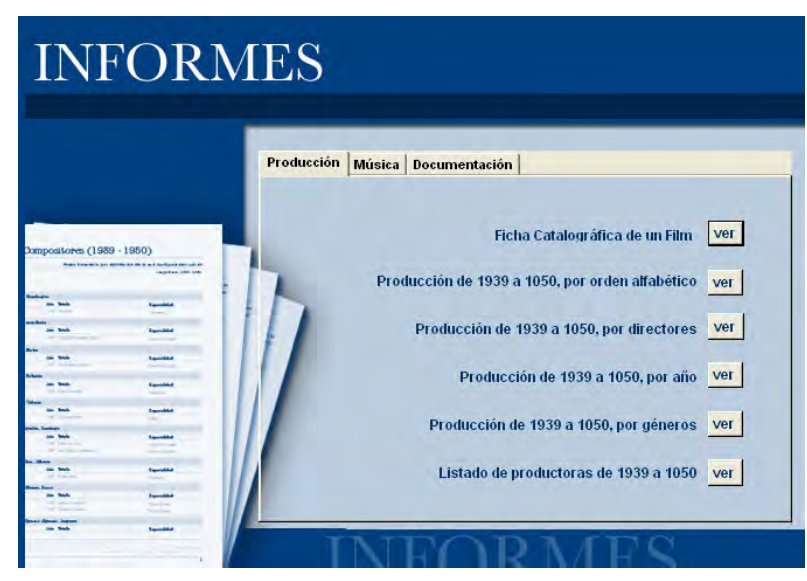

Imagen 59: Ficha Informes. Producción (Administrador)

A continuación vamos a exponer qué informes y como funciona la sección, comenzando por la subficha de Producción. En este caso nos encontraremos con un grupo de informes relativos a la producción cinematográfica atendiendo a varias facetas de la misma.

Ficha Catalográfica de un filme*

Producción completa por orden alfabético, donde se incluye en director de la producción y año de realización. producción.

Producción completa por directores, donde se incluye también el año de 
Producción completa por años, donde cada título irá acompañado de su director y año de realización.

Producción completa ordenada por géneros.

Listado de productoras por orden alfabético, junto con los títulos producidos.

La subficha de Música contiene un mayor número de informes y listados que proporcionan información detallada sobre la música de cine en España.

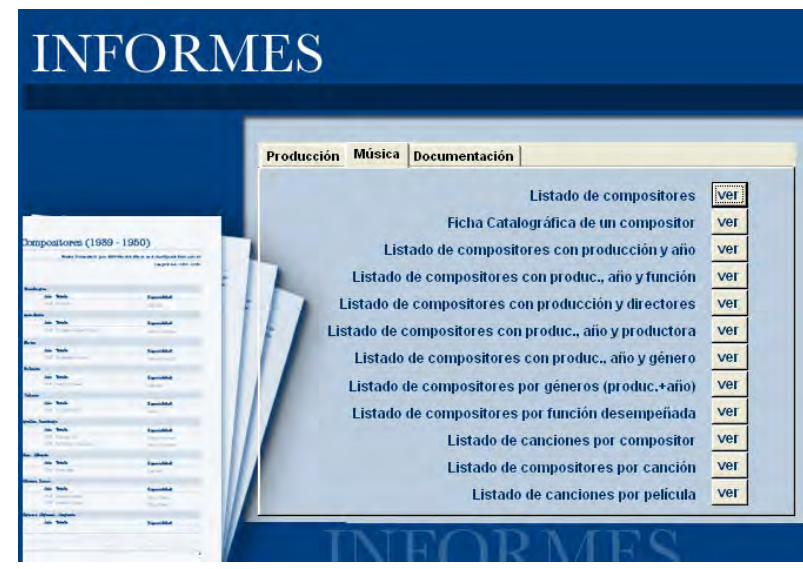

Imagen 60: Ficha Informes: Música (Administrador)

En este caso nos encontramos con los siguientes informes y listados:

Listado de compositores.

Ficha catalográfica de un compositor*

Listado de compositores con la producción realizada y año de producción.

Listado de compositores con la producción realizada, año de producción y función desempeñada.

Listado de compositores con la producción realizada y directores de la mismas.

Listado de compositores con la producción realizada, año de producción y productora.

Listado de compositores con la producción realizada, año de producción y género a la que pertenecen las películas. producción

Listado de géneros por compositores con la producción realizada y año de 
Listado de función desempeñada por los compositores, junto con la producción, año y nombre del mismo.

Listado de canciones por compositores.

Listado de canciones por películas y año

Listado de compositores por canciones.

En la tercera y última subficha, Documentación, nos encontraremos con listados e informes del material incluido con la aplicación.

\section{INFORMES}

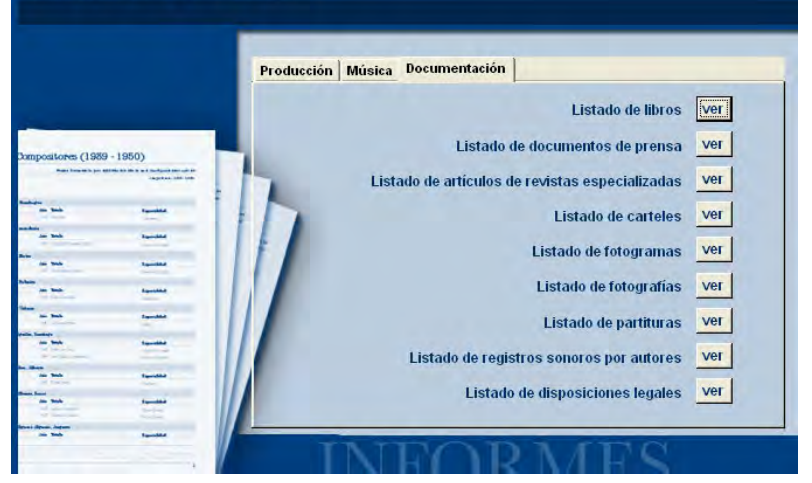

Imagen 61: Ficha Informes: Documentación (Administrador)

Los listados incluidos en esta ocasión son:

Bibliografía.

Listado de documentos de prensa

Listado de documentos de revistas especializadas

Listado de carteles

Listado de fotogramas

Listado de fotografías

Listado de partituras

Listado discográfico por autores

Listado de disposiciones legales. 
Los informes marcados con un $\left(^{*}\right)$ requieren de un paso intermedio. Cuando se presione el enlace, se abrirá una ventana con un formulario donde nos encontraremos un campo despegable en el que elegiremos, dependiendo del informe, la película o compositor del que deseemos el informe. A continuación presionaremos sobre el botón aceptar y se generará el informe deseado.

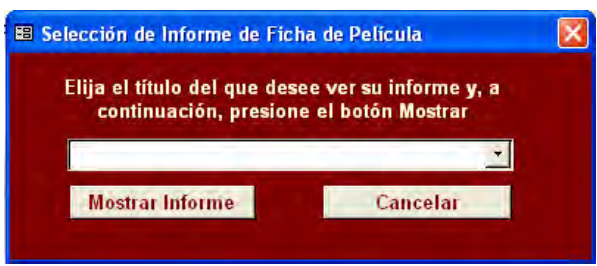

Imagen 62: Ventana Selección de Informe de una película

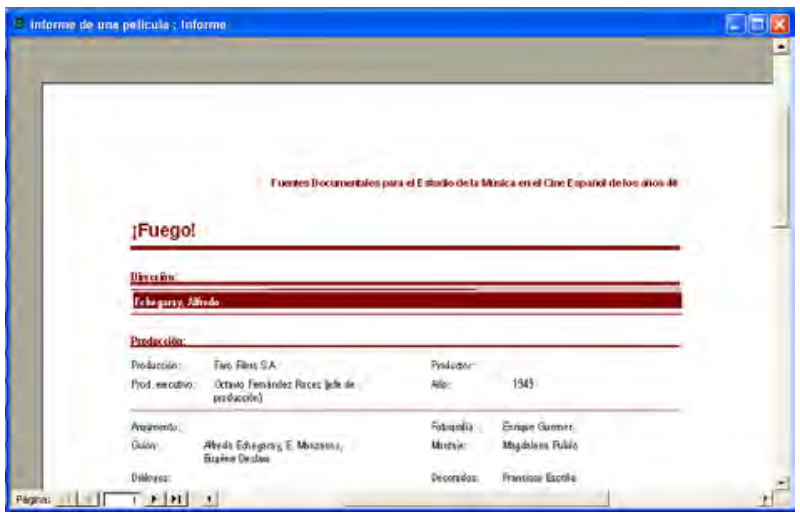

Imagen 63: Ventana de visualización de Informe

\section{Acceso a la información del Usuario}

Se ha desarrollado un modelo de acceso a MCE40 restringido para los Usuarios ${ }^{320}$ caracterizado por la:

Creación de un espacio de visualización de los documentos disponibles en la aplicación por parte de los usuarios.

${ }^{320}$ Tenemos la idea de someter este modelo de acceso a MCE40 a diversos tests de usabilidad de cara a una futura mejora del sistema para su implementación en un entorno web. 
Creación de un espacio de visualización de las fichas catalográficas disponibles en MCE40 por parte de los usuarios.

Creación de un espacio de generación de informes y listados.

El diagrama de flujo de la información para el Usuario es el que puede verse a continuación:

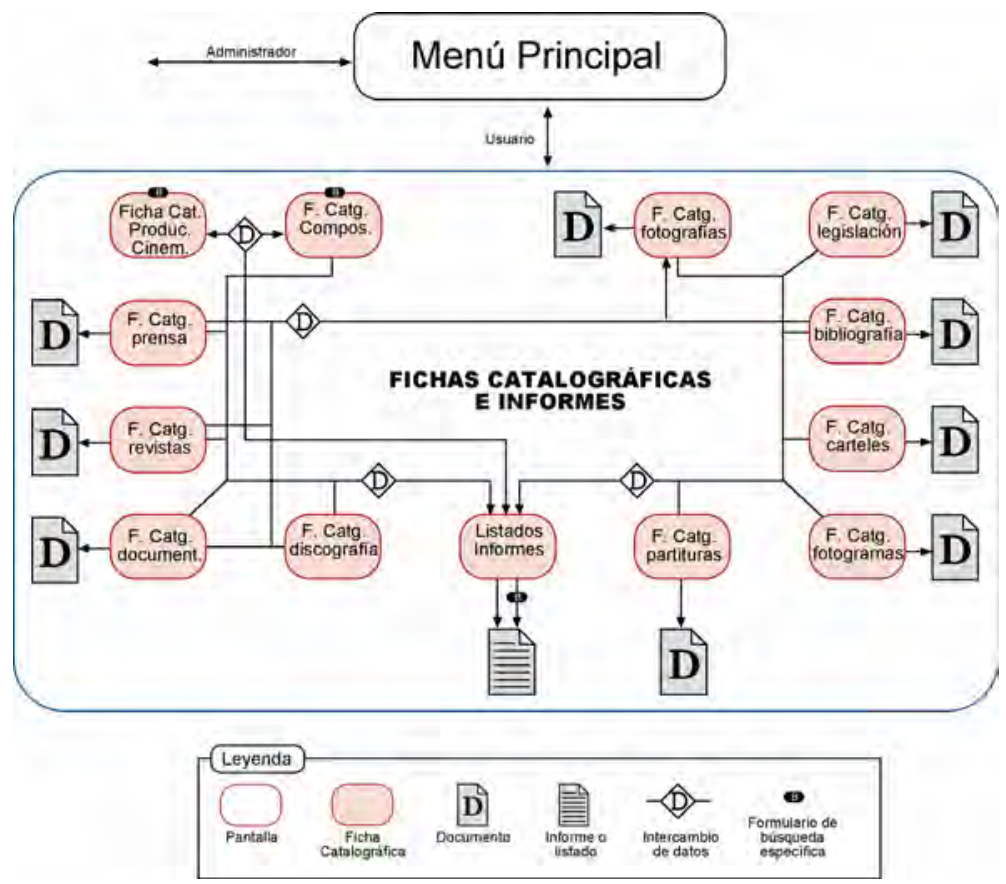

Ilustración 3: diagrama de flujo del recorrido del Usuario

El acceso para Usuarios comienza cuando se presiona el enlace correspondiente a dicha tipología de usuarios. Al contrario que ocurre con el Administrador, el Usuario no necesita de ninguna contraseña para tener acceso a las Fichas Catalográficas, aunque como ya comentamos anteriormente, no tendrá ningún tipo de privilegio, es decir, no podrá modificar ni insertar información en MCE40. Solamente tendrá acceso de consulta.

Al igual que pasaba con el Administrador, el Usuario deberá asignar en el menú principal la letra correspondiente a la unidad donde se encuentren los documentos, para que la Base de datos pueda localizar los archivos digitales cuando éstos sean solicitados por el Usuario durante su recorrido. 


\section{Fichas Catalográficas e Informes}

Una vez dentro de las Fichas Catalográficas e Informes, nos encontraremos con un entorno prácticamente igual que para el Administrador desde el punto de vista de la navegación y contenidos existentes.

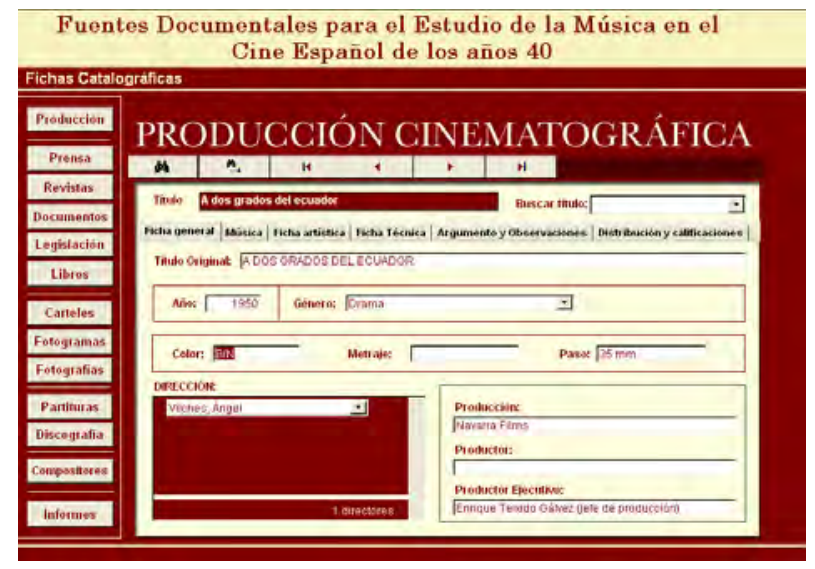

Imagen 64: Pantalla general de la Aplicación (Usuario)

La mayor diferencia existente entre ambos recorridos ha sido ya expuesta. Se trata de la facultad de insertar datos, por lo que todos los botones y enlaces existentes para tal fin en el recorrido de Administrador en este otro han sido suprimidos, así como la edición de los campos de las fichas.

El otro contraste se encuentra en los aspectos gráficos del entorno. Para diferenciar un recorrido del otro se ha optado por dar un tratamiento de color diferente. Esta es la razón que el Administrador se encontrará con un entorno de colores fríos, con un predominio del azul mientras que el Usuario se desenvolverá entre tonalidades cálidas con predominio del granate.

Al igual que ocurría con el recorrido para el Administrador, la pantalla con la que vamos a trabajar está dividida en tres partes bien diferenciadas. En la parte superior nos encontramos con la cabecera de MCE40 donde podremos leer el nombre de la misma. Debajo de esta zona destinada al nombre y grafismo localizamos los elementos puramente interactivos de la misma. En el lado izquierdo el Usuario encontrará una columna de botones a modo de menú para acceder a las distintas tipologías de Fichas Catalográficas documentales y de informes, mientras que el lado derecho, de mayor extensión, se reserva para la consulta de las propias Fichas. El contenido de esta área irá variando en función del tipo de información que se haya seleccionando en la columna de la izquierda.

En la columna de la derecha, se establece una jerarquía en los contenidos, exactamente igual que para el Administrador, separándose unos de otro mediante una línea divisoria. Esta categorización se compone de: producción, documentación impresa y escrita, material gráfico, material musical, compositores e informes. 
En el primero de todos, Producción, tan solo encontramos una categoría, la producción cinematográfica española de 1939 a 1950. Presionando en este botón, denominado Producción, se muestra la Ficha Catalográfica de Producción Cinematográfica.

El bloque siguiente, documentación impresa y escrita, presenta cinco accesos distintos en función de las distintas categorías creadas, estando presentes en este apartado: Prensa, Revistas especializadas, Documentos, Legislación, Libros.

El material gráfico se aúna las Fichas Catalográficas de los documentos de carácter marcadamente gráfico: Carteles, Fotogramas, Fotografías.

El material musical está compuesto por dos tipologías de documentos: por una parte las Partituras y por otro las grabaciones discográficas reunidas en Discografía.

Por último, en bloques separados se encuentran, las Fichas de los Compositores, con información de los protagonistas de nuestra historia; y una ficha de acceso a distintos Informes generados para una posible impresión o consulta.

Como ya hemos comentado, la parte derecha del espacio está destinada a visualización de las Fichas Catalográficas. Estas a su vez, tienen un sistema de navegación interno que permite desplazarse entre los distintos registro pero no cambiar de tipo de ficha, algo reservado únicamente a la columna de botones de la izquierda que acabamos de comentar. Esta navegación es posible gracias a una banda horizontal de botonería situada en la parte superior de las mismas y debajo del espacio asignado a la identificación gráfica de la tipología de la Ficha elegida.

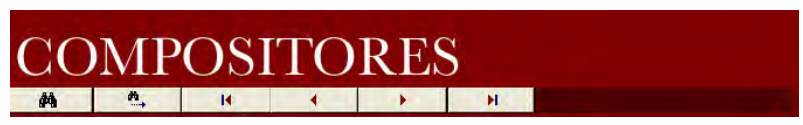

Imagen 65: Barra de navegación Usuario

La banda de navegación está compuesta en este caso por dos botones menos que para el recorrido del Administrador, por tanto tendremos seis botones con representaciones icónicas cuyas funciones van desde la búsqueda hasta el avance y retroceso en los registros almacenados en la Aplicación. Estos botones son: Buscar, Buscar siguiente, Ir a inicio, Registro anterior, Registro siguiente, Ir al final. Es decir, ha sido eliminado Crear y Borrar Registro, que permitía la inclusión de nuevas entradas.

Los dos primeros botones, Buscar y Buscar siguiente, cuyos iconos son unos prismáticos, van a servir al Usuario para localizar las fichas o datos que desee mediante la búsqueda de Microsoft Access. Por las mismas razones expuestas en el recorrido del Administrador, dejamos esta función para más adelante cuando tratemos el tema de las búsquedas.

El tercero, Ir a inicio, nos desplaza hasta la primera Ficha Catalográfica, mientras que el cuarto botón, Registro anterior, nos lleva a la ficha precedente a la que estamos viendo en el momento de presionar en él. Registro siguiente es el quinto botón que, como su nombre indica, no conduce hasta la Ficha Catalográficas siguiente, mientras que el 
botón, Ir al final, nos conduce a la última Ficha insertada en la Aplicación dentro de la tipología catalográfica en la que estemos.

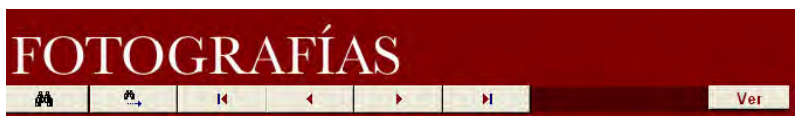

Imagen 66: Barra de navegación Usuario (con botón de acceso a documento gráfico)

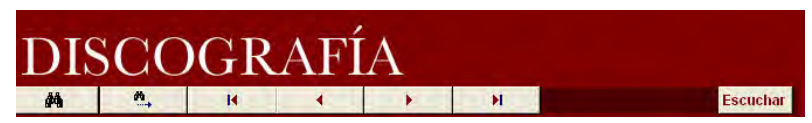

Imagen 67: Barra de navegación Usuario (con botón de acceso a documentos sonoros)

Puede darse, y se da, el caso de existir más botones en esta franja. Normalmente tanto el Administrador como el Usuario se van a encontrar con uno más, dependiendo del tipo de ficha en que estén. Nos referimos principalmente a aquellos documentos que se encuentren digitalizados y contenidos en soporte óptico de la presente aplicación. En estos casos se incluirá en la barra de navegación horizontal de la Ficha un botón con la palabra Ver para los documentos gráficos o escritos y, Escuchar para los sonoros.

Al presionar sobre el botón Ver, se abrirá un programa de visualización, Adobe Acrobat Reader, para mostrar el documento seleccionado y poder ser analizado por el investigador. Como se pude apreciar en la imagen siguiente, en la Ficha Catalográfica de Carteles podemos ver el botón Ver y sobre la misma, la ventana del Adobe Acrobat Reader abierta con la imagen del cartel seleccionado. Este botón tan solo existe en las siguientes Fichas con acceso directo a documentos, que son:

Prensa

Revistas especializadas

Documentos

Legislación

Carteles

Fotogramas

Fotografías

Partituras 


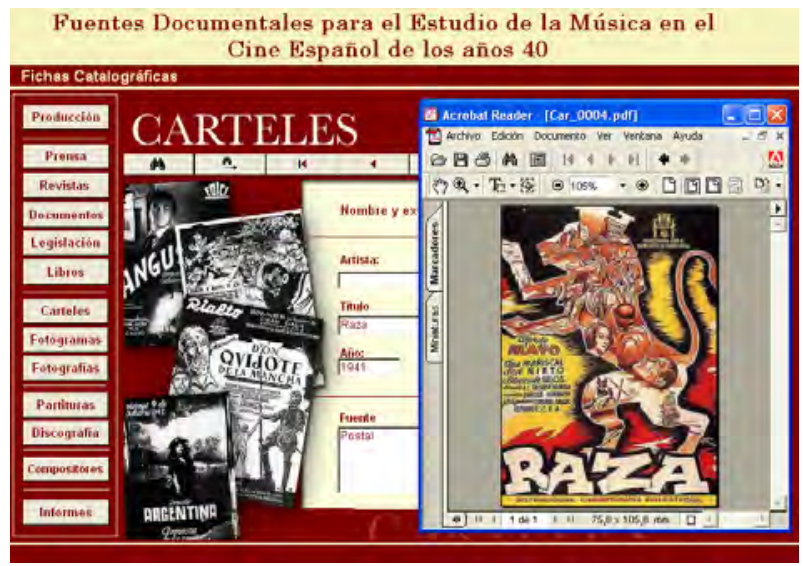

Imagen 68: Adobe Acrobat reproduciendo un cartel (Usuario)

En cuanto a la opción del botón Escuchar, ésta se encuentra únicamente en la Ficha Catalográfica de Discografía y tan solo es funcional en aquellos registros donde se especifique un nombre y extensión de archivo digital linkado por el Administrador, la duración de los mismos, como hemos dicho anteriormente, será solo de algunos segundos.

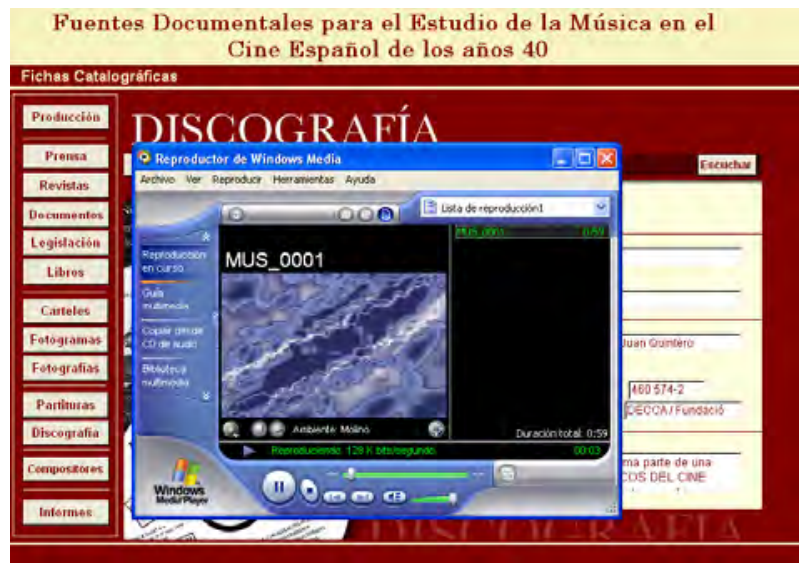

Imagen 69: Windows Media Player reproduciendo el tema principal de Locura de amor (Usuario)

También se ha tenido en cuenta las tipologías para la creación de una nomenclatura y numeración adecuada a cada uno de los documentos aportados en la Aplicación. A continuación se presenta una tabla con la especificación de la nomenclatura: 


\begin{tabular}{|ll|}
\hline Tipo de documento & nomenclatura \\
\hline Prensa & PRE_0000 \\
\hline Revistas especializadas & RDP_0000 \\
\hline Documentos & DOC_0000 \\
\hline Legislación & LEG_0000 \\
\hline Carteles & CAR_0000 \\
\hline Fotogramas & FMG_0000 \\
\hline Fototeca & FTO_0000 \\
\hline Partituras & PAR_0000 \\
\hline Discografía & MUS_0000 \\
\hline
\end{tabular}

Tabla 32: Nomenclatura de archivos digitales

Como se puede apreciar en el cuadro anterior, el nombre del archivo está compuesto siempre por dos partes. La primera hacer referencia directa al tipo de fuente o documento y consta de tres letra. A continuación sigue un (_) que sirve de división entre las dos partes, la textual y la numérica, para dar paso a esta última compuesta por cuatro dígitos. Este sistema, especialmente a través de su primera parte, puede servir de guía al Usuario sobre el tipo de archivo que puede visualizar, especialmente si decide introducirse de forma furtiva en las entrañas del soporte óptico directamente.

Debajo de la franja estudiada, se encuentra lo que podemos denominar la Ficha Catalográfica en sí. El tipo de Ficha que aparece por defecto cuando se abre la Aplicación es la de la Producción Cinematográfica Española del periodo estudiado. A continuación nos vamos a encargar de describir una por una todas las Fichas Catalográficas contenidas en MCE40 así como sus particularidades y similitudes.

\section{Producción Cinematográfica}

Como acabamos de comentar, la Ficha programada por defecto para que aparezca en primer lugar es Producción Cinematográfica donde encontraremos la información referente a cada una de las producciones de largo metraje realizadas en España durante el periodo que va de 1939 a 1950.

Esta Ficha tiene en sí una estructura algo distinta al resto debido especialmente a las propias características de la documentación aportada y su extensión. Es por ello, que debajo de la barra de navegación horizontal podemos encontrar el nombre de la producción a la que corresponde los datos que más abajo veremos y que debido a la gran cantidad de registros que debe incluirse en estas fichas se hizo necesaria una división de la información para poder visualizar correctamente y de un modo mas ordenado y estructurado que favorece la localización del dato o datos buscados por el Usuario o Administrador.

En un primer lugar nos encontraremos con un campo en el que se podrá introducir el título de la película en cuestión. Junto a este campo encontramos un menú despegable con el nombre de Buscar título. Al desplegarse encontraremos todos los títulos introducidos 
hasta el momento y seleccionando uno de ellos, nos llevará directamente al registro de dicha producción.

En cuanto a las subfichas, éstas se dividen en seis categorías denominadas: Ficha general, Música, Ficha artística, Ficha Técnica, Argumento y observaciones, Distribución y calificaciones.

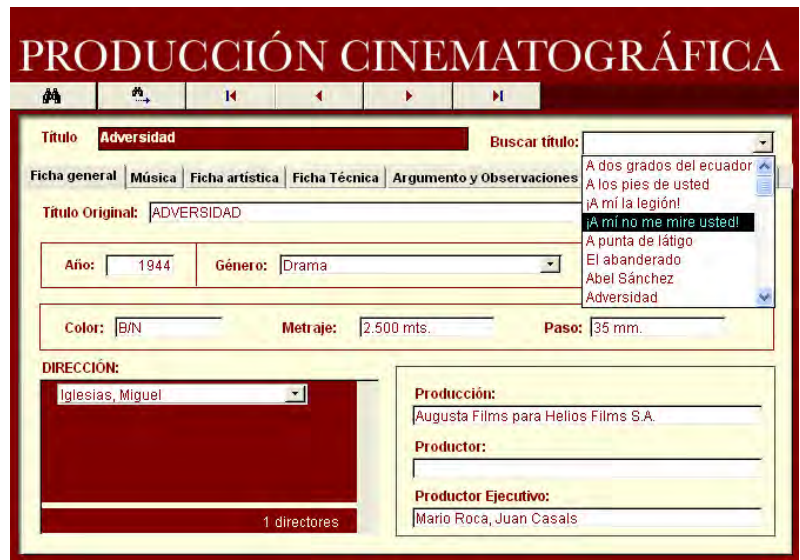

Imagen 70: Producción cinematográfica. Búsqueda de registro (Usuario)

En la primera se incluyen aquellos datos que identifican de un modo rápido la película.

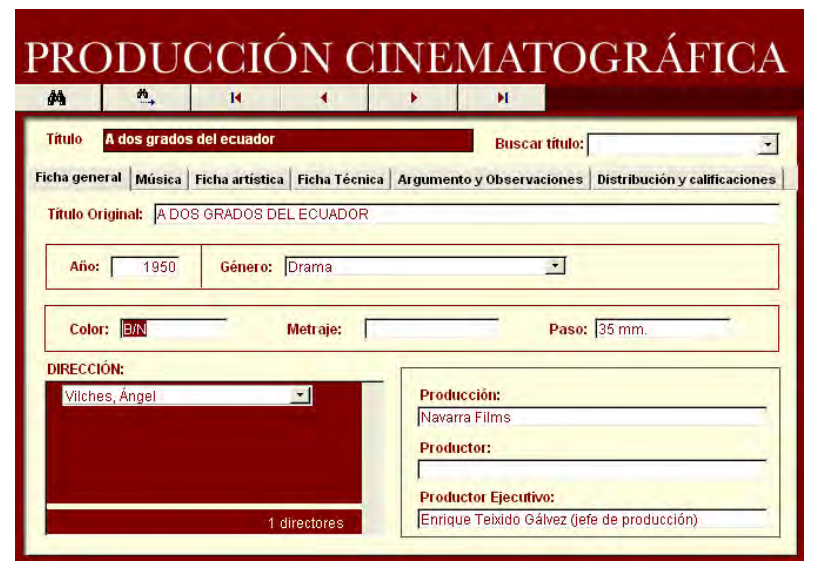

Imagen 71: Ficha Producción cinematográfica: Ficha general (Usuario)

A continuación vamos a especificar cada uno de los parámetros y entradas incluidos en este apartado: 
- Título original, se incluye por las posibles diferencias con el título general que se puedan dar en aquellas películas coproducidas con otros países.

- Año, indica el año en que se realizó la producción, no el de su estreno, fecha esta última que se indica en la subficha de distribución.

- Género, realiza un clasificación de los filmes en relación a unas categorizaciones preestablecidas. Como ya se comenta en el apartado dedicado la problemática de la asignación de género, no vamos a entrar en ella ahora sino tan solo recordar que se ha seguido el criterio de la Filmoteca Nacional con ligeras modificaciones de simplificación a la hora de designar los géneros comentadas sobradamente cuando hablamos de los distintos problemas planteados por el corpus elegido, quedando como lista definitiva la siguiente relación:

$\begin{array}{cl}\circ & \text { Animación } \\ \circ & \text { Aventuras } \\ \circ & \text { Bélico } \\ \circ & \text { Biográfico } \\ \circ & \text { Comedia } \\ \circ & \text { Drama } \\ \circ & \text { Fantástico } \\ \circ & \text { Histórico } \\ \circ & \text { Musical } \\ \circ & \text { Policiaco }\end{array}$

Color. En este apartado se indica si la película está realizada en blanco y negro o en color.

Metraje. En el presente registro se indica la duración de la cinta en metros de película.

Paso. El paso hace referencia al ancho de la película. Durante la década de los 40 el paso más habitual para cine comercial era de $35 \mathrm{~mm}$ y para cine amateu de 8 ó $16 \mathrm{~mm}$.

Dirección. Este apartado resulta algo especial. Como se puede apreciar en la captura de la pantalla que se muestra a continuación, esta sección aparece en un recuadro de color granate. Este recuadro se divide en dos secciones. La parte superior contiene el o los nombres de los directores responsables del filme.

En la parte inferior se indica en texto el número de directores asignados al filme de marras. Si tan solo es uno o dos, estos se verán directamente pero si hay mas, aparecerá una barra desplazadora vertical al lado derecho para poder desplazar el registro visible hacia la parte superior y dejar de este modo espacio para los posibles registros ocultos. 
Producción. En este apartado se indica el nombre de la productora o productoras responsables de la película.

Productor. Como su nombre indica, se especifica al productor de la cinta.

Productor ejecutivo. Nombre del principal responsable de la producción o productor ejecutivo.

Música

En esta segunda subficha se incluyen los datos relativos a los aspectos musicales de las producciones, desde los compositores implicados en el proyecto hasta las canciones incluidas en el mismo.

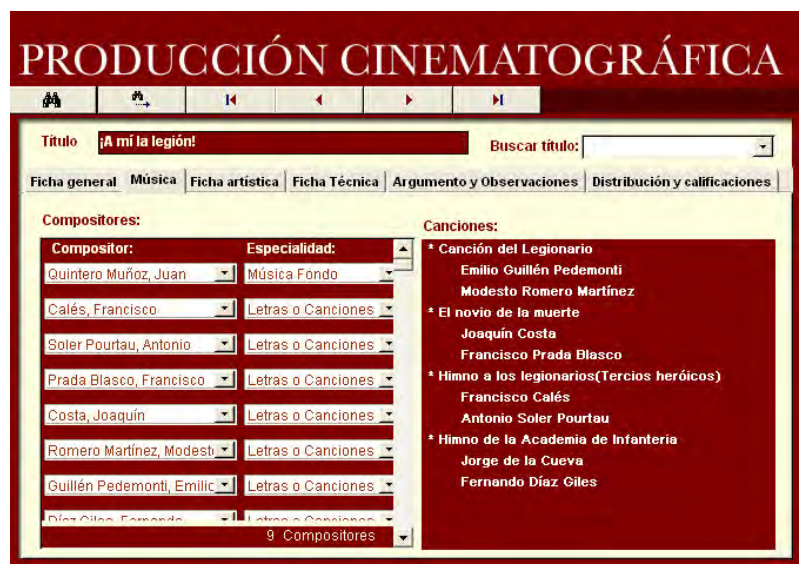

Imagen 72: Ficha Producción cinematográfica: Música (Usuario)

- Compositores. Este apartado como en la subficha anterior la dirección, reúne unas condiciones especiales. En primer lugar, esta sección se comporta de un modo similar al de Dirección. El rectángulo se divide en dos espacios. El superior para los registros y el inferior nos informa del número de registros incluidos en este apartado. 
Compositores:

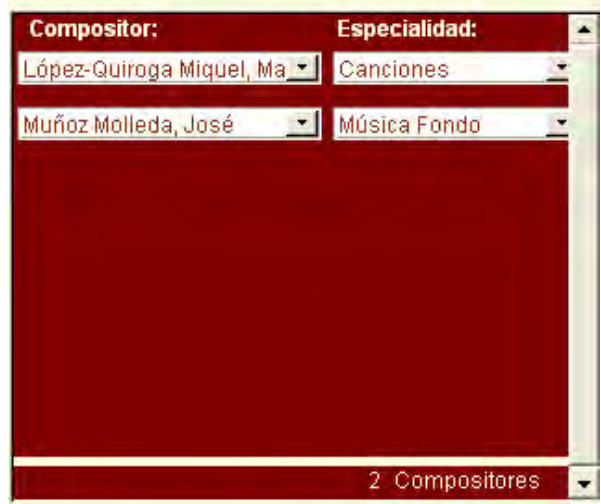

Imagen 73: Subformulario de compositores (Usuario)

En la parte superior, como el espacio de pantalla es limitado y en ocasiones el listado de músicos supera con creces dicho espacio, se ha habilitado una barra de scroll o desplazamiento vertical para estos casos. De todos modos, en la parte inferior del bloque se puede encontrar una referencia al número de registros incluidos en dicha película, es decir, se índica el número de compositores participantes en el proyecto que se está estudiando.

En cuanto a los registros, no solo se indica el o los compositores implicados sino su función dentro de la película. Debemos llamar la atención sobre el gran auge que la canción, en sus múltiples tendencias y estilos, tuvo en el cine en aquellos años. Es fácil encontrarnos con una o dos canciones que servían de promoción de la película. Estas canciones en la mayoría de los casos no eran compuestas, como hemos explicado anteriormente por los músicos encargados de crear la música incidental del filme, recurriendo a especialistas en la creación de esta forma musical. Así pues, las funciones que se han especificado y que el Usuario encontrará son:

Dirección Orquestal, para el encargado de la dirección musical.

Música Fondo, para el autor del score, música incidental, de fondo o extradiegética.

Canciones, para los creadores de la música de esta forma musical.

Autor Adaptado, para los músicos cuya obra es utilizada por otros para la composición del score o de canciones.

Colaborador, para aquellos casos en que un compositor tan solo trabaja como apoyo a otro, realizando todo tipo de labores como los arreglos finales o la orquestación.

Música y canciones, para los autores que en una misma película realizan las dos facetas.

Colaboración y canciones, para los casos documentados en los que un música ha colaboración con un primer compositor y realización de las canciones. 
Letras, para los poetas, escritores, directores o guionistas que se implicaron en la creación de las letras de las canciones.

Letras o canciones, para los múltiples casos en que no ha sido posible determinar quienes eran los autores de las canciones o de las letras pero que aparecen en distintas fuentes como autores de las canciones.

- Canciones. Este apartado es una consulta de los datos incluidos por el administrador en el subformulario correspondiente, por lo que el aspecto es muy diferente al de éste. El usuario se encontrará con un recuadro granate donde se visualizará un listado de las canciones que aparecen en dicha película. Junto a dichas canciones se incluye también el nombre de los autores de estas obras.

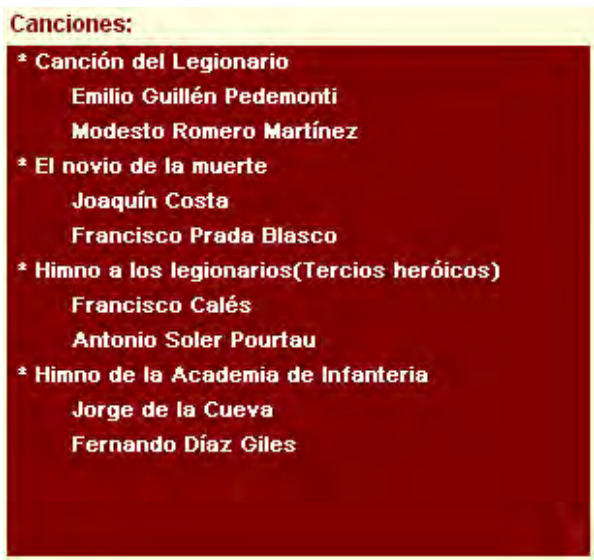

Imagen 74: Consulta de canciones (Usuario)

\section{Ficha artística}

En esta segunda categoría incluida dentro de la Ficha Catalográfica de Producción Cinematográfica, se encuentran los trabajos relacionados con una labor de marcado matiz artístico. 


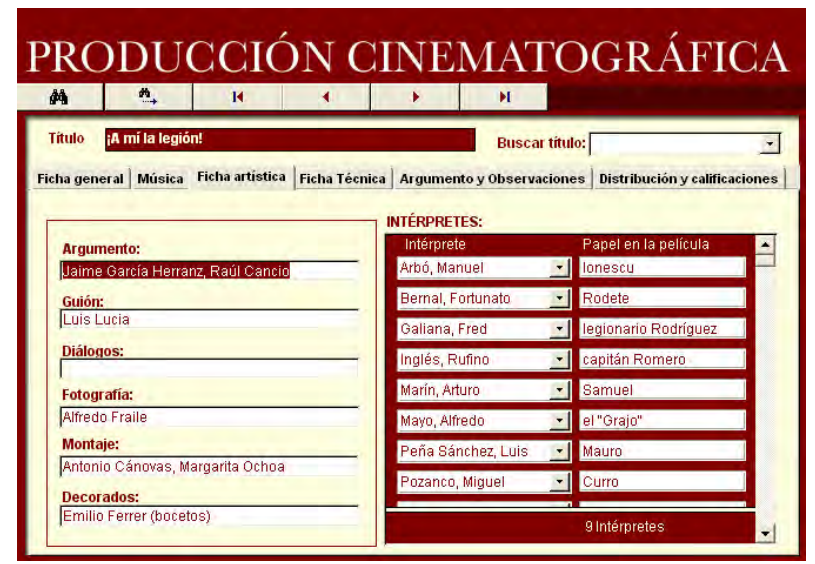

Imagen 75: Ficha Producción cinematográfica: Ficha artística (Usuario)

Como podemos observar en la imagen precedente, el área está dividida en dos partes bien diferenciadas. La sección de la izquierda contiene registros sencillos para actividades tan importantes como las vinculadas a la creación del guión, los decorados, la fotografía, etc., mientras que en la parte derecha se puede observar un recuadro similar a los ya explicados de Dirección y Compositores, pero en este caso, destinado a albergar el elenco artístico. Pero vayamos por parte y centrémonos primero en la parte izquierda.

En esta primera sección encontramos:

Argumento, que hace referencia al autor o autores de la idea original.

Guión. En este apartado se destina para el responsable del guión final.

Diálogos.

Fotografía. Incluiría lo que hoy en día denominaríamos director de fotografía, responsable de la luz, el tono, las sombras, etc., en la fotografía de la película.

Montaje. Contendrá los nombres de los responsables de la edición.

Decorados, o diseño de producción.

A la izquierda, podemos encontrar una ventana similar a las aparecidas en la subficha anterior destinada a albergar los datos concernientes al elenco artístico de intérpretes. Como se puede apreciar en la imagen siguiente, al igual que ocurría con los músicos, existen dos campos por línea. El primero incluye el nombre del artista y junto a él, se especifica el papel interpretado para la ocasión. 
INTÉRPRETES:

\begin{tabular}{|c|c|}
\hline Intérprete & Papel en la película \\
\hline Aleixandre, Margarita & $\Rightarrow$ sin especificar \\
\hline Alonso, Francisco & -1 sin especificar \\
\hline Bravo, Pepita & -1 sin especificar \\
\hline Cabañes, Carmen & + sin especificar \\
\hline Cabrera, Basilio & ㄱ sin especificar \\
\hline Calvo, Armando & t1 elvirrey \\
\hline Calvo, Juan & 드 currito \\
\hline Casas, Antonio & - sin especificar \\
\hline & 31 Intérpretes \\
\hline
\end{tabular}

Imagen 76: subinforme Intérpretes (Usuario)

En la parte inferior del recuadro, como en los casos similares anteriores, se encuentra un texto que informa del número de intérpretes dados de alta en la producción.

Ficha técnica

La tercera subficha, Ficha técnica, como su nombre indica está destinada a albergar los nombres de los técnicos y ayudantes más importantes en la producción. Así, en ella podemos encontrar desde el Ayudante de dirección hasta la indicación del Sistema de sonido empleado.

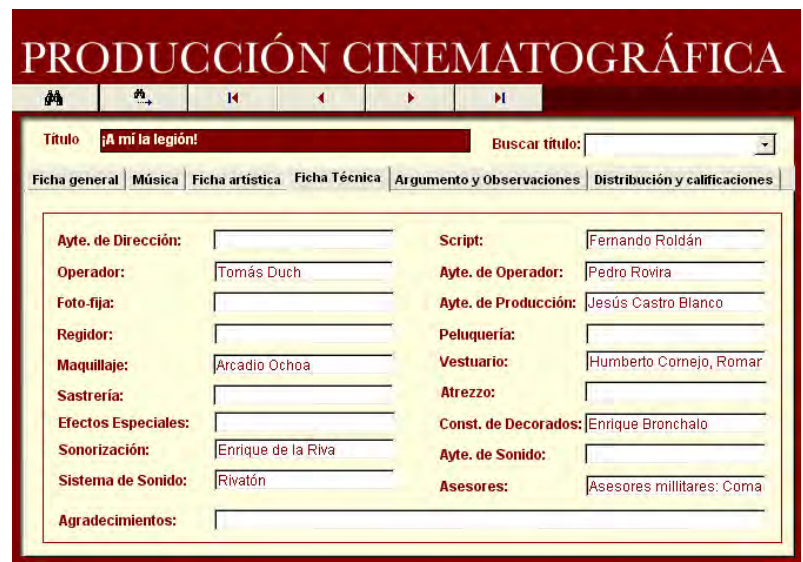

Imagen 77: Ficha Producción cinematográfica: Ficha técnica (Usuario)

Los campos especificados son:

Ayudante de Dirección. 
Script; encargo de cuidar los detalles de continuidad y seguimiento del planning de rodaje.

Operador, encargado de cámara.

Ayudante de Operador; subalterno del cámara.

Foto-fija; fotógrafo de realizar las fotografías del rodaje y promoción del filme

Ayudante de Producción.

Regidor.

Peluquería.

Maquillaje.

Vestuario.

Sastrería.

Atrezzo.

Efectos especiales.

Construcción de decorados.

Sonorización; Responsable de las mezclas finales de sonido

Ayudante de sonido; adjunto del encargado de sonido

Sistema de sonido.

Asesores; Se reúnen aquí los asesores que participaron en algún tema concreto, diseño de producción, argumento en cada película.

\section{Argumento y observaciones}

La cuarta subficha, Argumentos y observaciones, está ocupada por dos grandes campos de texto. En el superior se incluye la sinopsis argumental de la película mientras que el inferior está reservado para matizaciones e información adicional de muy diversa idiosincrasia como premios, intervenciones especiales, etc. 


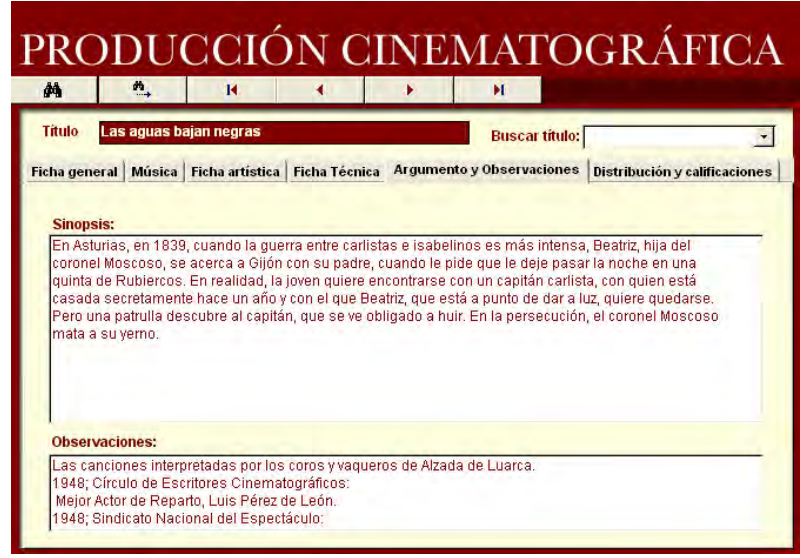

Imagen 78: Ficha Producción cinematográfica: Argumento y observaciones (Usuario)

\section{Distribución y calificaciones}

La quinta y última subficha, Distribución y calificaciones, presenta una distribución en tres partes. Las dos primeras están relacionadas con la distribución y conservación de la película, mientras que la tercera y última se centran en las calificaciones, permisos de importación y doblaje.

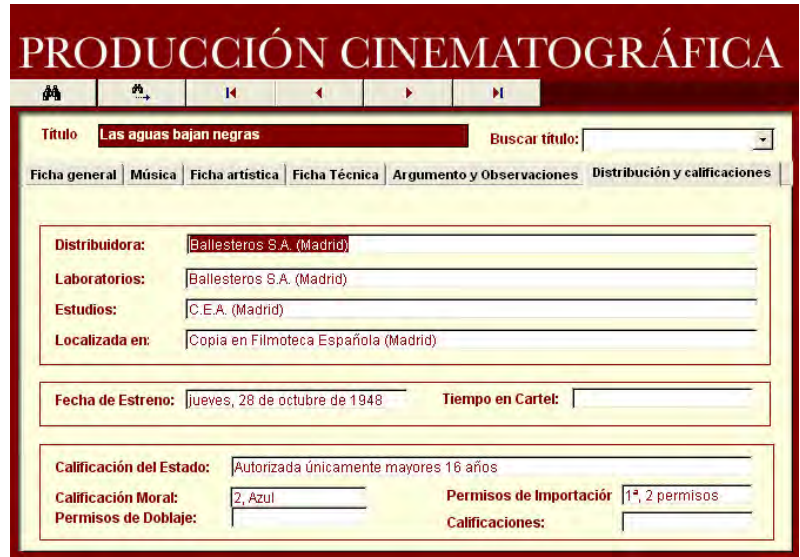

Imagen 79: Ficha Producción cinematográfica: Distribución y calificaciones (Usuario)

Como se aprecia en la imagen, el primer bloque contiene tan solo cuatro campos:

Distribuidora; empresa encargada de su comercialización en aquel momento. 
Laboratorios; compañía encargada del positivado de la película.

Estudios; talleres donde se realizó el rodaje de la cinta.

Depositada en; indica el la filmoteca, institución o empresa donde se encuentra en estos momentos la mejor copia para su conservación.

En un segundo bloque se plasman los datos referentes a su estreno y explotación inicial que muestran claramente su repercusión en el panorama cinematográfico del momento.

Fecha de estreno.

Tiempo en cartel; presenta el total de días o semanas que la película llegó a mantenerse en cartel en el cine de estreno principal donde se llevó a cabo la premiere.

El tercer y último bloque dedicado a las calificaciones recoge las principales así como la referencia a los permisos de importación y doblajes concedidos por la administración. Estos campos en numerosas ocasiones carecerán de información. La razón de ellos es variada, pero principalmente radica en las fechas de puesta en funcionamiento de alguna de ellas así como la no concesión de alguno de estos permisos.

Cal. del Estado; Calificación otorgada por el gobierno para designar la calidad e interés de la cinta: Interés Nacional, de Primera, de Segunda o de Tercera.

Cal. Moral; Calificación moral otorgada por la iglesia. Principal división entre películas recomendadas para menores o no.

Permisos de doblaje; Número de permisos concedidos a la cinta para doblar películas extranjeras para su exhibición.

Permisos de importación; Número de licencias de importación para poder traer películas extranjeras a nuestro país para su explotación comercial.

Calificaciones; este campo se queda abierto para aquellas posibles calificaciones de tipo individual o de menor relevancia que pudiese llegar a tener una película.

Prensa

La Ficha Catalográfica de Prensa, contiene las referencias de aquellos artículos, críticas, entrevistas, noticias anuncios, etc., aparecidos en publicaciones diarias y no especializadas en cine. 


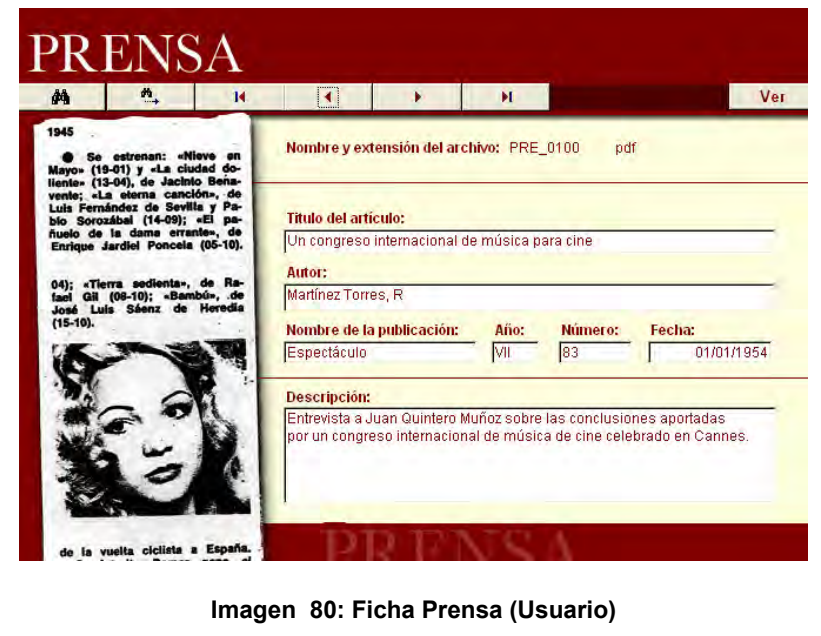

Como se observa en la imagen, el espacio de la Ficha se distribuye siguiendo el esquema comentado anteriormente para el Administrador.

\section{Revistas Especializadas}

En la Ficha Catalográfica Revistas Especializadas se recogen las referencias relativas a la industria cinematográfica encontradas en varias revistas de la época Primer Plano, RadioCinema, Cámara.

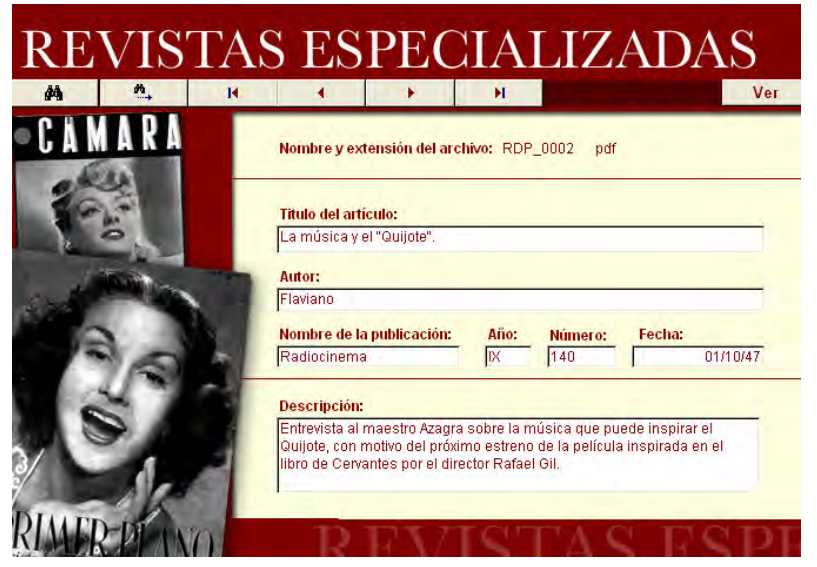

Imagen 81: Ficha Revistas especializadas (Usuario) 
Los campos establecidos para la correcta clasificación de los documentos pertenecientes a esta categoría son:

Nombre y extensión del archivo, como ya se comentó hacen referencia directa al archivo digital del documento contenido en el CD-Rom o disco duro.

Título del artículo digitalizado y contenido en el archivo adjunto

Autor del artículo, entrevista, biografía, etc..

- Nombre publicación de la revista en donde aparece el artículo referenciado.

Año de la publicación con respecto a su fecha de salida al mercado

Número de publicación o edición del diario.

Fecha de publicación y puesta en circulación.

Descripción o breve resumen de tipo orientativo sobre la noticia o artículo.

\section{Documentos}

En esta sección, como hemos comentado en la parte dedicada al acceso del Administrador se recogen documentos de diversa procedencia y tipología, tales como correspondencia personal de los compositores, entrevistas no publicadas, etcétera.

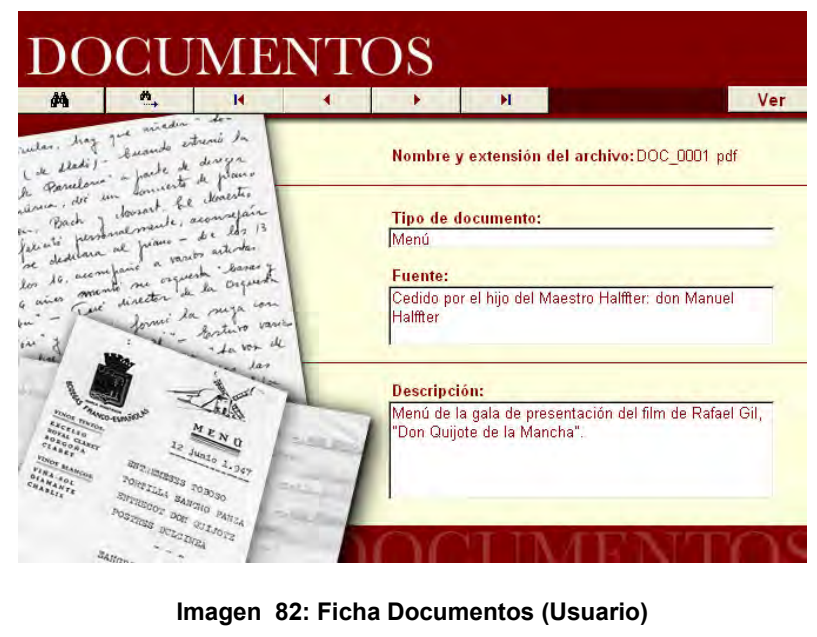

Los primeros registros proporcionan al usuario referencia directa a la nomenclatura y extensión de los archivos digitales. La ficha se compone de tres campos. El primero de los cuales realiza una clasificación en función de una categorización. Esta categorización recoge las tipologías documentales mencionadas anteriormente para el Administrador. 


\section{Legislación}

En las Fichas Catalográficas de Legislación el Usuario obtendrá datos relativos a la legislación desarrollada en la década de los cuarenta en torno a la industria cinematográfica.

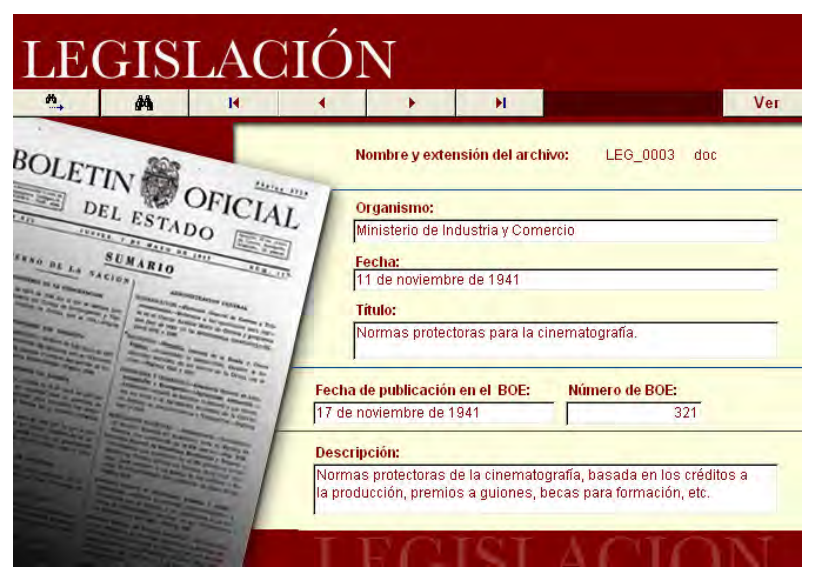

Imagen 83: Ficha Legislación (Usuario)

Encabezan los datos de la Ficha Catalográfica los ya mencionados campos que hacen referencia al nombre y extensión del archivo digital que contiene las leyes. A estos le siguen cuatro campos que consideramos suficientes para la designación y localización del documento original.

Organismo o institución de que depende la promulgación de la ley u orden

Fecha de publicación de la citada ley u orden ministerial.

Titulo descriptivo de la orden, ley o decreto.

Fecha de publicación en el BOE.

Número de BOE.

Descripción de la citada ley u orden donde se especifica de modo resumido y breve las principales características del citado documento.

En esta ocasión, a través del botón Ver el Usuario tendrá acceso a cualquiera de las leyes, órdenes ministeriales, decretos de la época. 
Libros

En la Ficha Catalográfica de Libros el Usuario tendrá acceso a una amplia relación de referencias bibliográficas relacionadas temáticamente con nuestro objeto de estudio, la música de cine, la teoría musical, monografías de autores, historia del cine, etcétera.

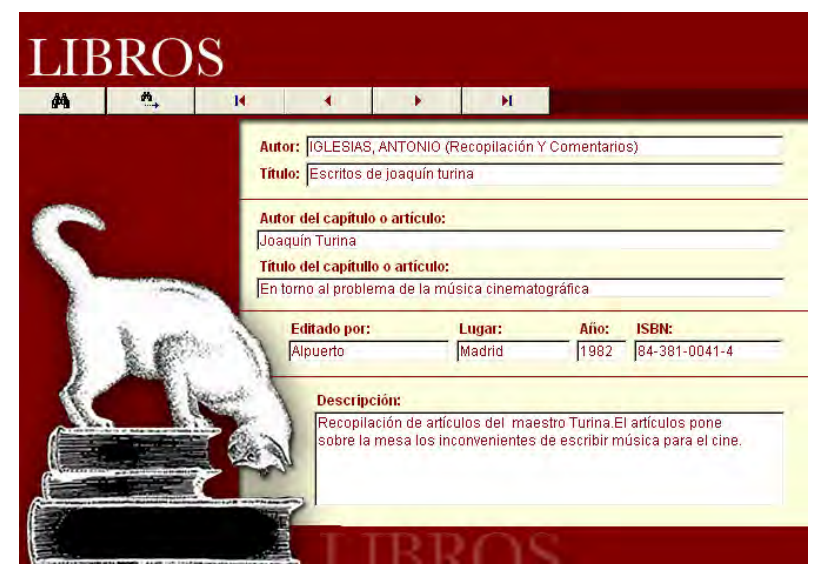

Imagen 84: Ficha Libros (Usuarios)

\section{Carteles}

EI Usuario podrá visualizar la Base de Datos relativa a carteles incluida en MCE40, obteniendo información relativa a la autoría de los mismos, título de la película a la que pertenece el cartel, año de producción y fuente de procedencia del mismo.

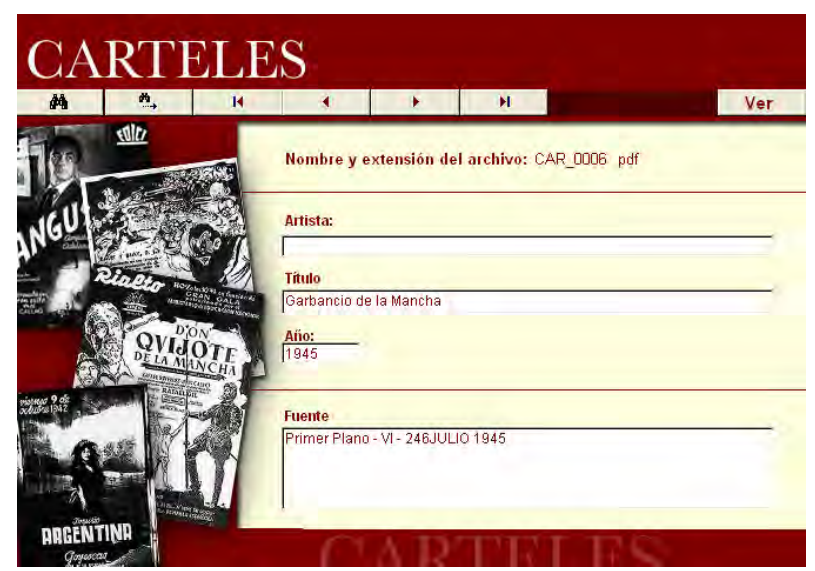

Imagen 85: Ficha Carteles (Usuario) 


\section{Fotogramas}

La Ficha Catalográficas Fotogramas, permite al usuario obtener información relativa al material fotográfico vinculado directamente a las películas, desde fotogramas de películas a fotografía realizadas durante el rodaje y que amablemente nos han sido cedidas para formar parte de MCE40.

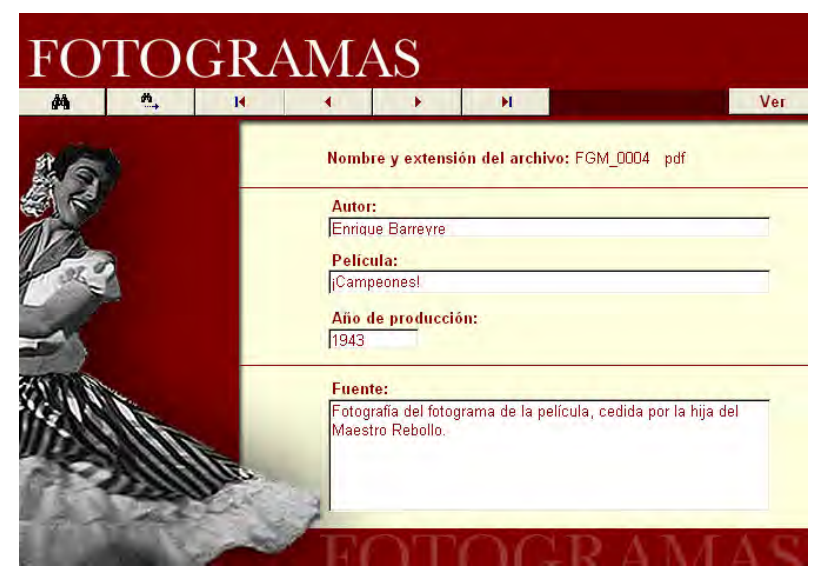

Imagen 86: Ficha Fotogramas (Usuario)

\section{Fotografías}

La Ficha Catalográfica de fotografías da acceso a una colección de imágenes inéditas procedentes de fuentes diversas cuyos protagonistas son los compositores de música de cine.

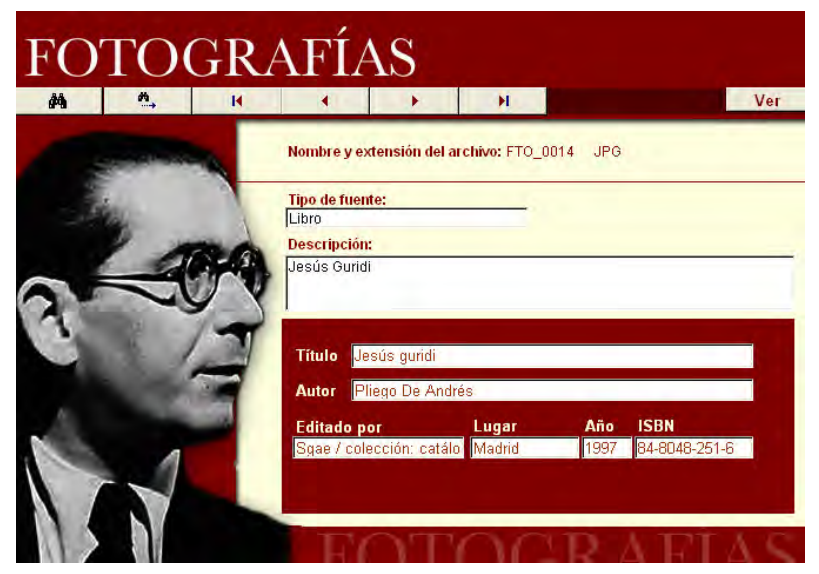

Imagen 87: Ficha Fotografías (Usuario) 
La presente ficha resulta ser un resumen-consulta de los datos aportados por el Administrador. Ésta es la razón por la que visualmente resulta tan diferente, como puede apreciarse en la imagen, existe un área situada en la parte inferior, un rectángulo rojo en el que los parámetros de catalogación variarán en función del tipo de fuente.

Evidentemente, los parámetros empleados en estos recuadros se transformarán en función de la tipología asignada por el Administrador en cada una de las fichas. A continuación presentamos la relación de campos establecidos en cada uno de los casos preestablecidos:

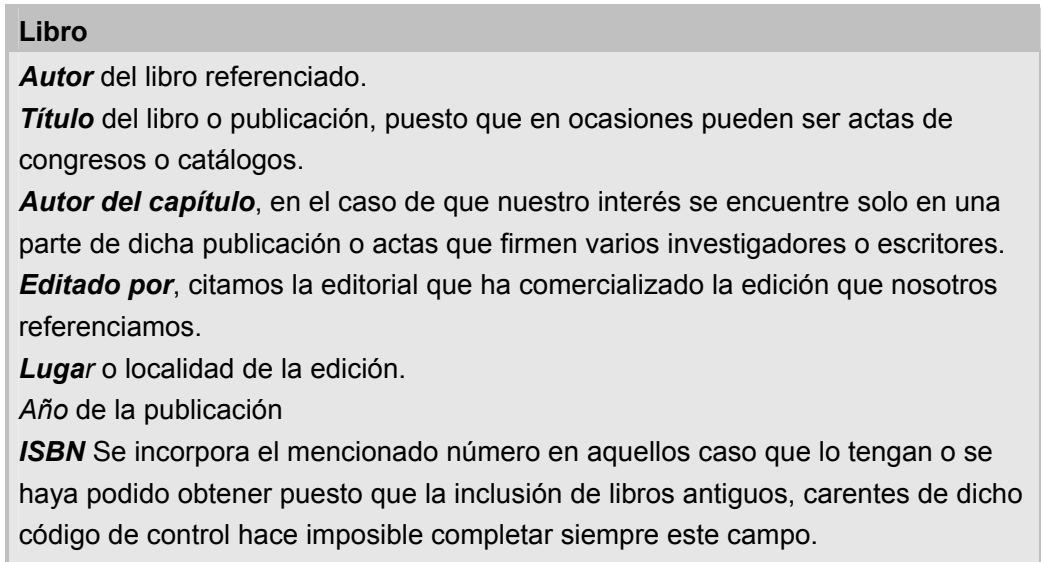

Tabla 33: Recuadro de la Ficha Fotografía ( fuente: libro)

\section{Prensa}

Nombre publicación o diario donde aparece impreso el artículo

Año de la publicación con respecto a su fecha de salida al mercado

Número de publicación o edición del diario.

Fecha de publicación y puesta en circulación.

Tabla 34: Recuadro de la Ficha Fotografía ( fuente: prensa)

\section{Revistas especializadas}

Nombre publicación de la revista en donde aparece el artículo referenciado.

Año de la publicación con respecto a su fecha de salida al mercado

Número de publicación o edición del diario.

Fecha de publicación y puesta en circulación.

Tabla 35: Recuadro de la Ficha Fotografía ( fuente: revistas especializadas) 


\section{Particular}

Fuente, donde se explica quién o qué ha proporcionado la imagen.

Tabla 36: Recuadro de la Ficha Fotografía ( fuente: particular)

\section{Grabaciones}

Título de álbum de la grabación discográfica presentado al mercado.

Forma musical en que se registró la pieza. Por norma general no se edita la música tal cual se escucha en el filme sino en forma de temas o suites así como canciones.

Soporte sonoro o físico en referencia que se aporta, es decir, el formato en que ha sido publicado.

Número de referencia discográfica del sello editor.

Año de edición discográfica y salida al mercado de la citada grabación.

Sello discográfico o empresa editorial encargada de su comercialización fonográfica.

Tabla 37: Recuadro de la Ficha Fotografía ( fuente: discografía)

\section{Partituras}

Las partituras, como documento inédito y de difícil obtención resulta en todo momento una de los recursos más interesante para los estudiosos de la música de cine. El Usuario pulsando el botón Ver, podrá tener acceso a estos documentos por lo que será imprescindible que el Administrador haya introducido correctamente el nombre y extensión del archivo digital que contiene cada una de las partituras para que éstas puedan verse adecuadamente. Además se proporciona información relativa a título de la obra, nombre del compositor, fuente de procedencia y observaciones en torno a las características del documento. 


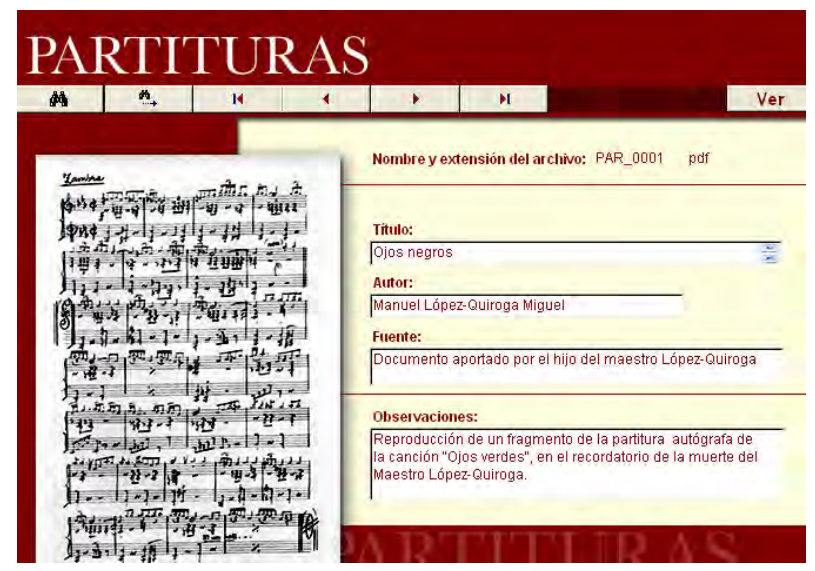

Imagen 88: Ficha Partituras (Usuario)

\section{Discografía}

El Usuario obtendrá referencia a las ediciones discográficas de las películas. Asimismo mediante el botón Oír puede reproducir un pequeño fragmento de las mismas.

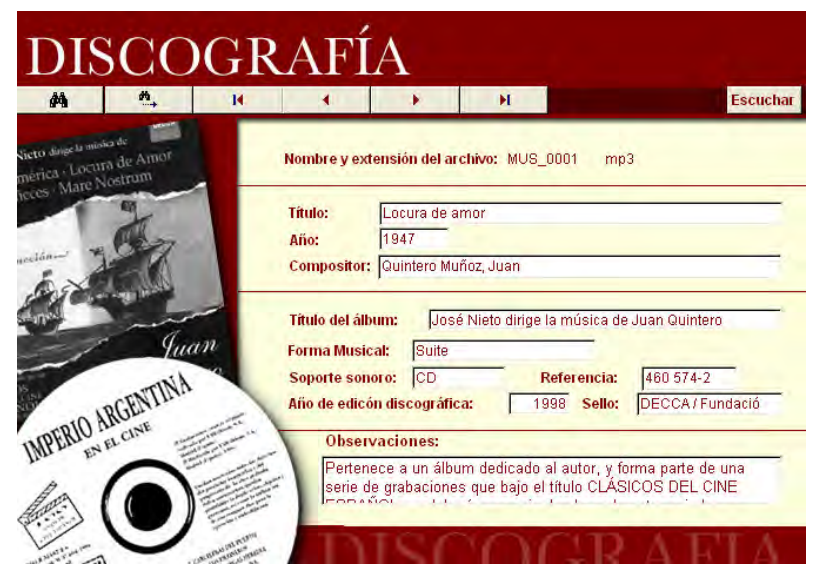

Imagen 89: Ficha Discografía (Usuario)

Los datos hacen alusión al nombre y extensión del archivo de sonido adjunto, título de la película, año de producción, nombre del compositor, título del álbum de la grabación discográfica, la forma musical de la pieza, soporte sonoro e información relativa a las siguientes categorías:

Obra completa, que hace referencia a una posible edición del máster original de la grabación tal y como se escucha en la película. 
Suite $^{321}$, grupo de melodías o temas recogidos en una pieza de mayor envergadura a modo de una sola pieza.

Selección, recopilación de unos pocos temas sin una idea de conjunto como en la Suite.

Tema o bloque musical.

Canción, como pieza corta con letra y acompañamiento de voz.

Número de referencia discográfica del sello editor.

Año de edición discográfica y salida al mercado de la citada grabación. fonográfica.

Sello discográfico o empresa editorial encargada de su comercialización

Observaciones se reserva para introducir información adicional sobre la versión, anécdotas o curiosidades.

\section{Compositores}

La Ficha Catalográfica de Compositores recopila y muestra los datos de producción de cada uno de los músicos. Como se puede apreciar en la imagen, la ficha muestra algunas características propias que a continuación vamos a describir.

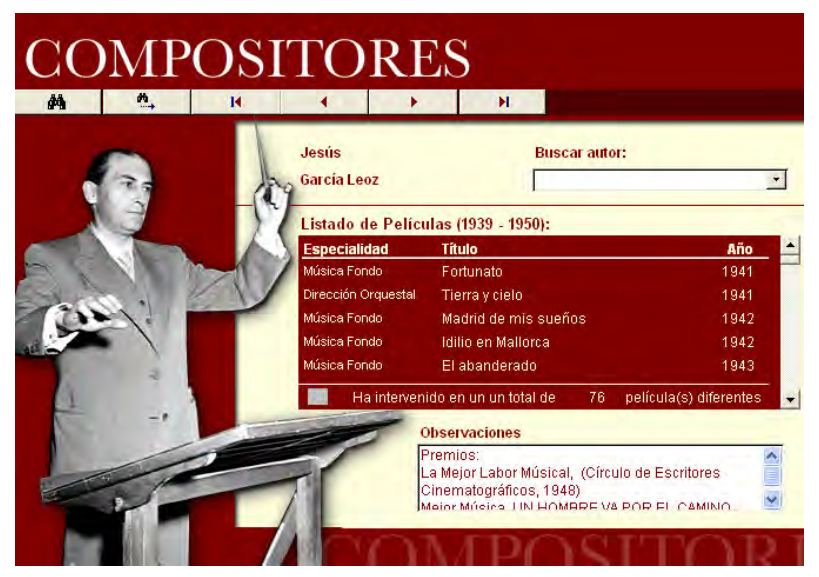

Imagen 90: Ficha Compositores (Usuario)

\footnotetext{
${ }^{321}$ No se debe identificar este tipo de suite con la denominación que recibe en el mundo de la música "clásica". En este caso se trata de una colección de danzas.
} 
En un primer bloque, se indica el nombre del artista y su apellido, junto a los que se encuentra un campo despegable con el listado completo de compositores dados de alta. Eligiendo uno de ellos, inmediatamente nos encontraremos en la ficha de dicho compositor.

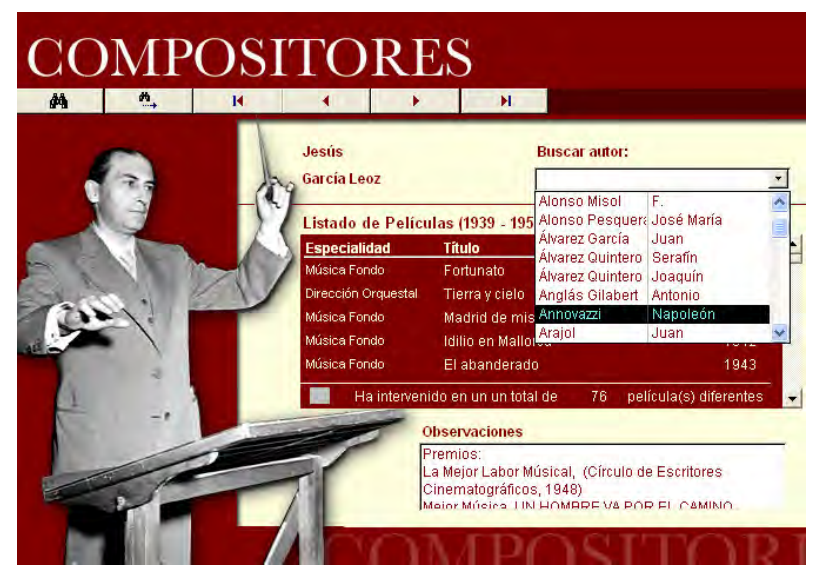

Imagen 91: Ficha Compositores: búsqueda (Usuario)

En el segundo bloque, como se puede ver en la imagen precedente, aparece el listado de películas en las que participó el compositor. Es importante recordar que en esta lista tan solo aparecerán los títulos de las películas en las que participó el compositor dentro del periodo estudiado, es decir, entre 1939 y 1950.

\section{Informes}

El usuario puede obtener informes y listados de diversa consideración. El acceso a los mismos sigue la distribución en tres subfichas, una de Producción, otra de Música y una última de Documentación. Ya hemos advertido, anteriormente que esta sección es exclusivamente de consulta, así que el Administrador y el Usuario tan sólo podrán obtener datos. 


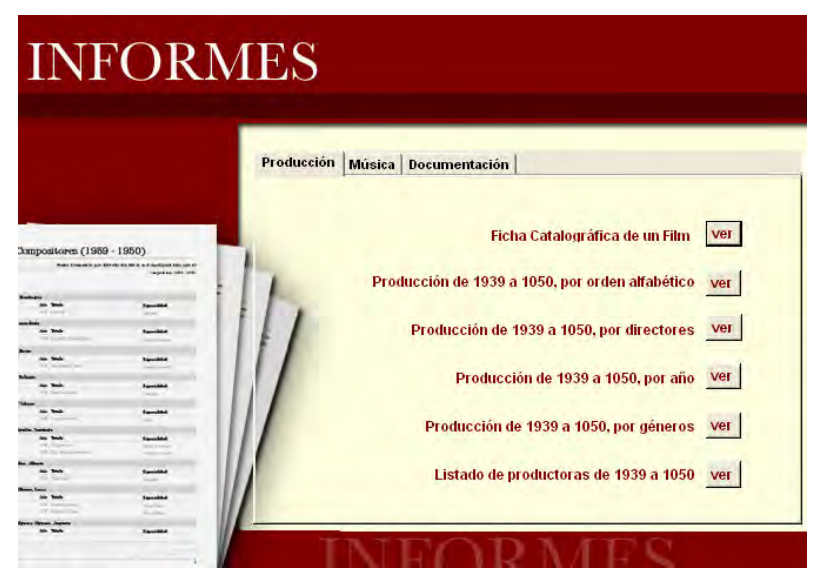

Imagen 92: Ficha Informes. Producción (Usuario)

En el caso de que el usuario desee obtener informes relativos a la Producción, éste podrá obtener datos en torno a la Ficha Catalográfica de un filme concreto, a la Producción completa por orden alfabético, donde se incluye en director de la producción y el año de realización, la producción completa de directores, donde se incluye también el año de producción, producción completa por años, donde cada título irá acompañado de su director y año de realización, producción completa ordenada por géneros y relación de productoras por orden alfabético, junto con los títulos producidos.

La subficha de Música contiene un mayor número de informes y listados dirigidos a proporcionar información sobre la música de cine español de los años cuarenta.

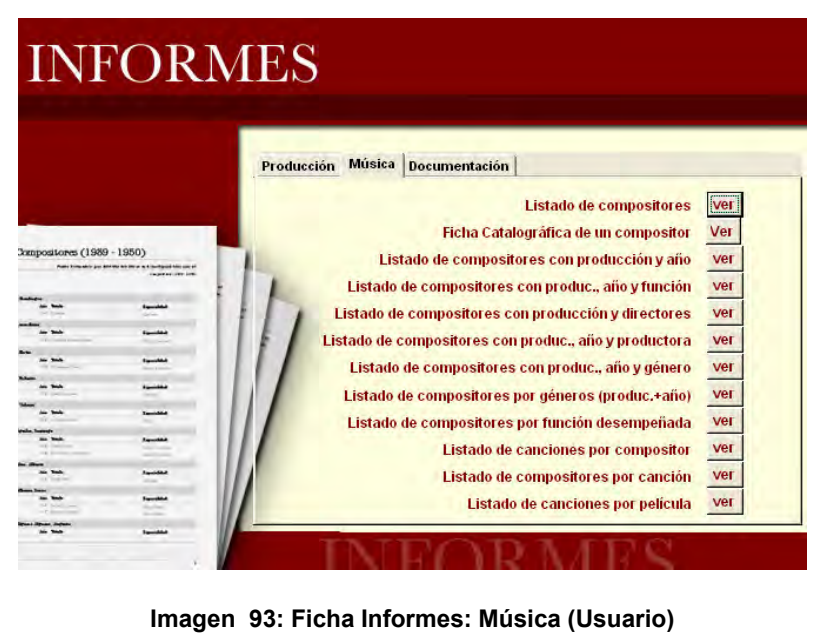

En este caso nos encontramos con los siguientes informes y listados: listado de compositores, ficha catalográfica de un compositor, listado de compositores con la 
producción realizada y año de producción, listado de compositores con la producción realizada, año de producción y función desempeñada, listado de compositores con la producción realizada y directores de la mismas, listado de compositores con la producción realizada, año de producción y productora, listado de compositores con la producción realizada, año de producción y género a la que pertenecen las películas, listado de géneros por compositores con la producción realizada y año de producción, listado de función desempeñada por los compositores, junto con la producción, año y nombre del mismo, listado de canciones por compositores, listado de canciones por películas y año, y listado de compositores por canciones.

En la tercera subficha, Documentación, nos encontraremos con listados e informes del material incluido con la aplicación. Los listados incluidos en esta ocasión son: bibliografía, listado de documentos de prensa, listado de documentos de revistas especializadas, listado de carteles, listado de fotogramas, listado de fotografías, listado de partituras, listado discográfico por autores, listado de disposiciones legales.

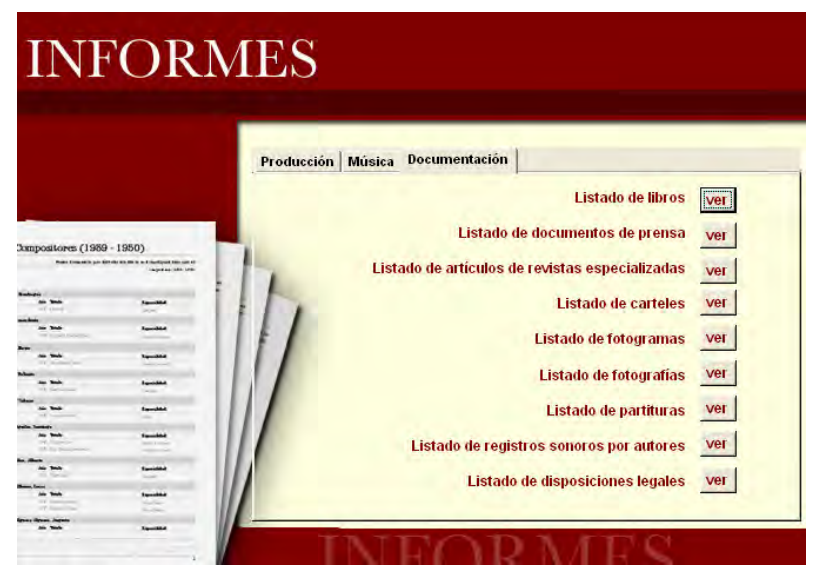

Imagen 94: Ficha Informes: Documentación (Usuario)

Algunos informes requieren de un paso intermedio. Cuando se presione el enlace, se abrirá una ventana con un formulario donde encontraremos un campo despegable en el que elegiremos, dependiendo del informe, la película o compositor del que deseemos obtener el informe. A continuación presionaremos sobre el botón aceptar y se generará el informe deseado. 


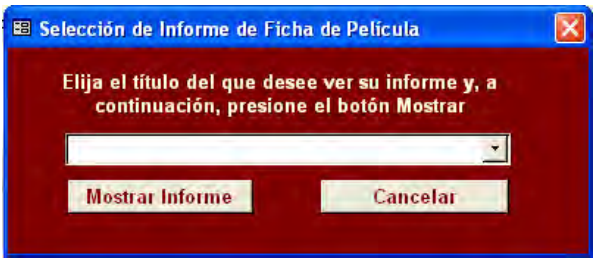

Imagen 95: Ventana Selección de Informe de una película

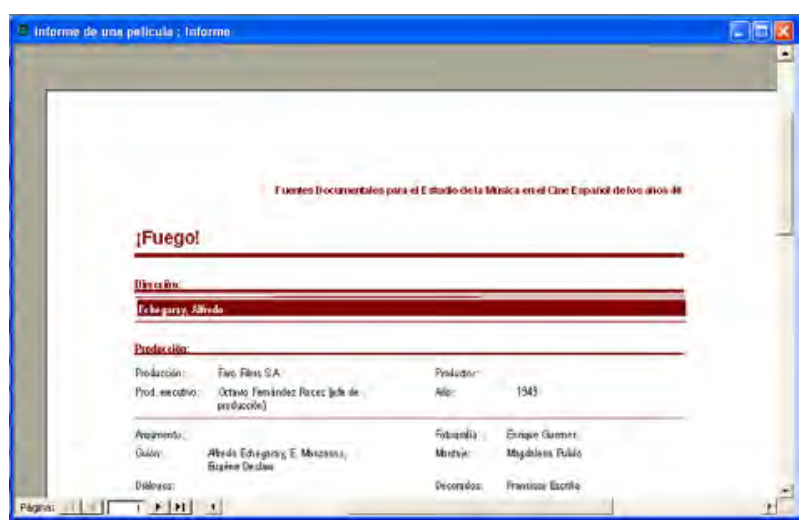

Imagen 96: Ventana de visualización de Informe 
CONCLUSIONES 
En el presente epígrafe vamos a exponer las conclusiones a este trabajo de investigación. Cómo se ha podido observar a lo largo de esta tesis, una de nuestras prioridades ha sido la búsqueda y recuperación de todo documento que pudiese arrojar luz sobre la música en el cine español de los años cuarenta.

Como resultado de nuestra investigación hemos reunido un conjunto de documentos de la época que nos han ayudado a tener una visión amplia del objeto de estudio propuesto. Durante cuatro años hemos podido comprobar de cerca la pasividad e indiferencia de las instituciones gubernamentales en relación con nuestro patrimonio cinematográfico. Una repercusión directa de esta lamentable situación, se plasma en la precaria situación en que se encuentran las filmotecas que se hemos visitado. Sin ir más lejos, la Filmoteca de Valencia tiene una gran deficiencia de personal y medios que hace prácticamente imposible que los funcionarios de la misma puedan dar un buen servicio. Las instalaciones de la misma son excesivamente pequeñas y la falta de presupuesto provoca situaciones tan terribles como que, a pesar de la donación a dicha entidad de grandes cantidades de material fílmico de gran valor, éste no puede ser catalogado, lo que supone que no pueda estar disponible para su consulta, además de estar expuesto al riesgo de perderse por estar almacenado sin las medidas adecuadas de conservación.

El material reunido proviene de múltiples lugares del territorio nacional fundamentalmente de particulares. En general se trata de documentos únicos, de carácter privado que han ido apareciendo a lo largo de nuestra investigación, algunos de ellos inéditos. Aunar todo este material, digitalizarlo y hacerlo accesible en una base de datos multimedia se convirtió en un primer objetivo a realizar.

Tras un largo trabajo de recopilación y recuperación en formato digital, se comenzó a introducir las referencias en la aplicación resultante, incluyendo en ella un montante de 464 documentos digitalizados y 31.469 registros que se distribuyen en doce categorías con un total de 1320 referencias, en las que se incluyen las fichas catalográficas de las películas, de los compositores y de los demás documentos localizados en nuestra investigación: revistas, prensa, legislación, carteles, fotogramas, fotografías, partituras, discografía y bibliografía.

A pesar de esta acotación de tipologías documentales, el diseño y la estructura internos de la base de datos, se ha realizado teniendo en cuenta que dicha estructura irá aumentando y se anexionarán en el futuro nuevos documentos, en función de las necesidades y posibilidades de continuidad que el devenir traiga.

La base de datos multimedia MCE40 nos ha proporcionado funcionalidad y ha sido una herramienta de primer orden para proceder a realizar un análisis en torno a la música de cine de la época de referencia y por extensión al cine de la misma.

Una vez creada la aplicación e introducido en la misma los documentos con sus correspondientes referencias y registros, se decidió llevar a cabo un análisis sobre el estado de la música de cine y por extensión a la cinematografía de la época.

La primera conclusión a la que llegamos tras cotejar los datos de producción, fue encontrarnos con el elevado número de producciones realizadas en un periodo histórico donde la economía del país se encontraba al borde de la ruina consecuencia de la guerra 
civil. La realización de más de cuatrocientos largometrajes de ficción en diez años, en plena posguerra, nos llevó a indagar las razones.

La contestación la encontramos cuando comenzamos a estudiar la legislación de este singular periodo histórico. Desde sus inicios, los gobiernos franquistas apostaron plenamente por las posibilidades de la industria cinematográfica nacional como medio de control y adoctrinamiento, pero también como medio para generar riqueza.

Desde la creación de los organismos que permitieron la instauración de la censura hasta una larga serie de normas legislativas tendentes a la protección de la producción propia se fueron introduciendo una serie de disposiciones que fueron modelando las características de la industria cinematográfica. Entre las disposiciones más importantes y con mayor repercusión en la producción cinematográfica, se encuentran los créditos a la producción, la clasificación de las películas en categorías, procedimiento éste que ayudaría a incentivar la producción a través de la concesión de permisos de importación para la explotación comercial en España de películas extranjeras, o el control de la programación en las salas de exhibición, como se conoce en la actualidad, las famosas cuotas de pantalla.

Esta legislación favoreció la creación y asentamiento de todo un aparato industrial en torno de la producción que en realidad no era más que un espejismo, puesto que, la verdadera naturaleza de dicha industria no se sostenía en la producción sino en la distribución de películas extranjeras, en especial, de las películas norteamericanas.

Esta peculiar situación provocó una inflación de la producción con películas de bajo presupuesto y de baja calidad en una proporción muy elevada. Las productoras apostaron por comedias sencillas, a imagen y semejanza de la alta comedia americana de Hawks o Lacaba, pero con unos presupuestos muy inferiores.

Cuando en 1943 se supedita la concesión de los permisos de importación a las calificaciones obtenidas por las producciones realizadas, esta tendencia se modifica rápidamente y se tiende hacia un cine más "serio". La industria apuesta entonces por el drama, como género de fácil realización con bajo presupuesto y que, por sus particularidades, resultaba fácil de ocultar las posibles deficiencias existentes. A raíz de esta circunstancia, el Departamento de Cinematografía concedía a estas películas mejores calificaciones, lo que implicaba mayores beneficios porque se obtenían más permisos de importación y de doblaje, por los que las distribuidoras americanas podían llegar a pagar cifras astronómicas.

Con la perspectiva que proporciona el tiempo, y tras analizar la época teniendo en cuenta los distintos puntos que acabamos de mencionar, se han establecido los siguientes periodos que dan cuenta de los cambios detectados en la producción cinematográfica.

El primero comprende desde el fin de la Guerra Civil hasta 1942 y lo hemos denominado "Establecimiento de la Industria". Este periodo nos permite recoger las circunstancias que se producen en la industria cinematográfica, en su afán por retomar impulso recién terminada la guerra, pasando por la aparición de las primeras leyes proteccionistas que afectan al sector cinematográfico promulgadas en 1941, hasta finales de 1942 cuando la producción inicia su descenso en picado. Este periodo se caracteriza por 
una presencia importante de la gran comedia, de la comedia sofisticada, más receptiva a la influencia de las comedias Hollywodienses que a las de procedencia alemana e italiana ${ }^{322}$.

El segundo periodo es el comprendido entre 1943 y 1947 y lo denominamos "Crisis de la industria". La producción baja en picado hasta el año 1945, coincidiendo con los avatares de la Segunda Guerra Mundial. Una vez terminada la guerra comienza un proceso de lenta recuperación que duró dos años, caracterizado por una reformulación que afecta tanto al estilo como a los temas tratados en nuestro cine. Nos encontramos en un momento de transición, donde la producción de comedias irá desapareciendo, mientras surge una avalancha de dramas.

El tercer periodo abarca desde 1948 hasta principios de la década de los cincuenta y lo llamamos "Consolidación de la industria". La industria cinematográfica, con una legislación asentada comenzará a tener una mayor aceptación por parte del público nacional, especialmente a finales de los cincuenta. La producción se estabiliza y comienzan a surgir nuevos directores. Temáticamente, esta es la época donde surgen más temas de carácter histórico y religioso.

En resumen, a principios de la década de los cuarenta el cine nacional es, por un lado claramente de evasión y disfrute, y por otro de exaltación patriótica. Las aventuras épicas del ejército nacional con sus héroes así como las comedias alocadas de mujeres liberadas en ambientes ricos y sofisticados convivieron entre sí hasta 1943, año en que comenzará a bajar la producción de comedias y las películas épicas dejaron de gustar al público. Lo que no fue obstáculo para que a finales de la década, con las facciones más reaccionarias de los democristianos católicos fuertemente asentadas en las instituciones, el cine religioso e histórico de reminiscencias patrióticas tomara el relevo. Las comedias casi dejaron de producirse, fundamentalmente porque los productores necesitaban obtener permisos de importación y las comedias no lo proporcionaban; así pues, el drama se impone con una fuerza arrolladora, siendo al final de la década el principal género cinematográfico español.

Como consecuencia de lo anteriormente mencionado, la tendencia en la música de nuestro cine va a sufrir una transformación inevitable tanto por lo que se refiere al estilo musical como a los aspectos comerciales.

Durante los años cuarenta un nutrido grupo de compositores se especializa y crea la profesión de músico de cine que compaginaban con el desarrollo de una importante labor en el teatro musical, la zarzuela o la canción. Manuel Parada se convirtió en un referente del teatro musical, especialmente a raíz de su nombramiento como Director Musical del Teatro Español. Jesús García Leoz por su parte, llegó a convertirse en un músico de prestigio tanto en el entorno de la industria del séptimo arte como en los ambientes musicales y melómanos de la villa y corte de Madrid. Otros como Moraleda, Ferrés Mussolas, Moreno-Torroba o el maestro Alonso desarrollaron carreras de éxito en la

\footnotetext{
${ }^{322}$ Muy interesantes y clarificadoras resultan las investigaciones que sobre la comedia de CIFESA está llevando a cabo Aurea Ortiz, en su tesis doctoral, cuyos resultados esperamos ver pronto. Por el momento, podemos tener acceso a algunos datos presentados en el VIII Congreso de la Asociación Española de Historiadores del Cine, recientemente se ha publicado en FERnÁNdez ColorAdo, L.; Couto CANTERO, P. (coord..) (2001) La herida de las sombras. El cine español de los años 40, Madrid, Academia de las Artes y las Ciencias Cinematográficas en España / AEHC.
} 
zarzuela y la dirección musical. Incluso un músico como Juan Quintero Muñoz, tal vez el más comprometido de todos con la música de cine, obtuvo renombrados éxitos teatrales que se llegaron a convertirse en todo un fenómeno social como fueron las obras Yola o $\mathrm{Si}$ Fausto fuera Faustina.

Cada uno de estos músicos fue elaborando un sistema de trabajo y de "teoría" musical muy personal y único, aplicado a las imágenes. Cada uno de ellos trabajaba y desarrollaba su labor casi de un modo individual, lo que les obligaba a experimentar cada uno por su cuenta, generándose de este modo una amplia variedad de modus operandis frente a la música de cine. Por otra parte, una amplia mayoría de los compositores tomaron como referencia a los grandes maestros del cine clásico de Hollywood como por ejemplo, Miklos Rozsa, Erich Wolfgang Korngold, Max Steiner, Alfred Newman o Bernard Herrmann. Lo cierto es que estos compositores eran muy diferentes entre sí y esto creemos que favoreció la heterogeneidad española.

En cuanto a la formación musical inicial, una parte de los compositores españoles se formaron en el conservatorio de Madrid bajo la experta mano del maestro Conrado del Campo, que transmitió su amor por el casticismo musical a sus discípulos. Mientras, en Barcelona, otro grupo de músicos se formó bajo la influencia de distintos clubes de jazz y de las múltiples orquestas de música "moderna" que se crearon en la ciudad Condal. Como es evidente, el estilo casticista y el jazz tienen pocos puntos de unión entre ambos pero se mezclaron y aunaron en distintos porcentajes en cada uno de estos compositores, dando como resultado un estilo personal y único en cada uno de ellos.

Estas diferencias fueron muy patentes en los primeros años de la posguerra. La producción de películas se dividió entre Madrid y Barcelona esencialmente. Mientras que en la ciudad del Manzanares se apostó por la producción de dramas, en la ciudad Condal se canalizó la misma hacia las comedias.

El casticismo se vio rápidamente fagocitado y fundido en los dramas, mientras que en Barcelona la comedia se encontró con un sustrato de músicos de gran calidad que introducirían estos nuevos ritmos en unas alocadas historias que parecían estar hechas para ellas. A su vez, se consiguió generar todo un mercado en torno de la música de cine y de sus autores. Por ejemplo, Juan Durán Alemany llegó a alcanzar gran popularidad por las canciones compuestas para películas como El difunto es un vivo o Boda Accidentada, de las que se realizaron ediciones discográficas. Por si esto fuese poco, Casas Augé o el mismo Durán Alemany en sus conciertos interpretaban su música para cine, algo que los músicos de Madrid no llegaron a realizar, o por lo menos no nos consta que lo hiciesen con la misma asiduidad.

Con el desplazamiento de la producción hacia Madrid y la puesta en marcha en 1943 de las clasificaciones de primera, segunda y tercera; y las concesión de los permisos de importación en función de la clasificación obtenida, la producción de comedia comenzó un descenso vertiginoso del que no se recuperó. Esta situación trajo como consecuencia la paulatina desaparición del jazz y de los ritmos "modernos" del panorama cinematográfico nacional a favor de un sinfonismo casticista, de influencias románticas e impresionistas que constituiría el mosaico musical de los últimos años cuarenta.

Otro de los aspectos que creemos importante destacar, es la falsa creencia de que los músicos de cine realizaban los trabajos en solitario. A excepción de unos pocos 
maestros, como García Leoz, la mayor parte de ellos contaban con colaboradores que hacían labores de orquestación y transcripción de partichelas. Este es el caso de Ricardo Bayon o el maestro Santander, eficientes y muy valorados en su tiempo y que trabajaron con todos los grandes compositores, no solo de los años cuarenta sino también de los cincuenta, sesenta y setenta. Por ejemplo, Santander trabajó en numerosas ocasiones con Juan Quintero Muñoz aunque no fuese nunca acreditado y Ricardo Bayon desarrollo una labor destacable junto a Manuel Parada, Ernesto Halffter, Antón García Abril.

Otro punto que nos ha parecido de cierto interés, especialmente por su actualidad, son las quejas mostradas por los compositores de la época alrededor de su labor en el cine. En esencia estas reivindicaciones parecen no haber cambiado en sesenta años, puesto que los músicos de ahora siguen quejándose de lo mismo, como hemos podido comprobar en diferentes entrevistas. En la actualidad se sigue reivindicando la obtención de beneficios en función de la explotación de la obra (algo que comenzó a gestarse a finales de los cuarenta), la falta de tiempo para componer (problema que nunca se solucionará por la propia idiosincrasia de los proyectos cinematográficos), y los escasos medios de que se dispone para la grabación de la obra y el posterior trabajo de mezclas donde ven su trabajo muchas veces manipulado a capricho del ingeniero de mezclas y el director del film.

Por lo que respecta a los aspectos relacionados con la teorización sobre la música de cine diremos que pocos son los compositores españoles que se adentraron en tales menesteres.

Joaquín Turina, puede ser considerado como el principal teórico que abordó el tema. Su fuerte formación humanística e intelectual, así como su amor por el cine, le llevaron a escribir un amplio número de textos acerca de los problemas que acechaban a esta disciplina en la época. El maestro se acercó en contadas ocasiones al nuevo medio con resultados desiguales, donde se plasman sus ideas de un modo práctico.

Por otro lado, Jesús García Leoz a pesar de seguir los pasos de su tío, Joaquín Turina, no llegó a plasmar literariamente su pensamiento conceptual sobre las funciones narrativas que la música puede llegar a ejercer en el relato cinematográfico. A pesar de todo, se han encontrado numeras entrevistas en que el maestro reflexiona en voz alta sobre los problemas de la música de cine y la necesidad de crear un lenguaje y forma musical nuevos para el cine.

El resto de compositores, en mayor o menor medida, no se preocuparon por la cuestión y simplemente llegaron a generar una técnica musical sustentada en el mejor de los casos, en la observación y la experimentación, sin un planteamiento teórico a priori. Esto no quiere decir que en el fondo no se teorizase ya que si recogemos y analizamos con detenido cuidado todas las fuentes consultadas, nos daremos cuenta que durante este periodo, tanto las publicaciones periódicas como sus lectores estuvieron interesados en la música de cine.

En definitiva, con nuestro trabajo hemos querido defender los siguientes puntos:

- En los años cuarenta nuestro cine ni llegó a ser homogéneo ni, muchísimo menos, su música lo fue. 
- La riqueza musical y técnica que se llegó a alcanzar en nuestro país no debe de envidiar a los resultados obtenidos en Hollywood.

- La industria siguió sosteniéndose en los pilares de la explotación y distribución de las películas importadas y no en la producción propia.

- Se crea un oficio nuevo: el compositor de cine.

- Estos compositores no trabajaron solos sino que tuvieron colaboradores que facilitaban y agilizaban el proceso de trabajo seguido.

- Se produce un fuerte impulso en la defensa de los derechos de autor. La mayor parte de estos músicos acabaron en los órganos de dirección de la SGAE a finales de los cincuenta y sesenta.

- Los mecanismos y métodos de composición, así como la utilización de la música dentro del relato cinematográfico se individualiza, creando cada compositor un sistema diferente con un estilo personal. Como ejemplo de esta circunstancia se han destacado dos casos muy característicos:

- Juan Quintero Muñoz basará la estructura de sus obras mediante el continuo juego entre distintos temas o leitmotivs cinematográficos asignados a personajes, situaciones o lugares, siguiendo el ejemplo de Max Steiner.

- Ruiz de Azagra construirá un discurso mucho más fraccionado. Prefiere centrar la atención mediante breves incisos musicales de puntuación, sin una profusa utilización del leitmotiv.

- Los compositores clásicos del cine americano son los principales ejemplos y puntos de referencia para los músicos españoles, a excepción de algunos compositores europeos de gran prestigio como Arthur Honegger (pero éste fue una excepción).

- Los principales problemas con los que se topaban los compositores eran:

- El escaso tiempo que se les concedía para realizar su labor

- Los malos y escasos medios de que disponían para registrar su música.

- Lo mal que era tratada su música en las mezclas finales del soundtrack.

- Aunque no hay una teorización escrita, la mayor parte de los compositores llegan a desarrollar sus propios modelos sobre cómo interactúa la música con las imágenes en el medio cinematográfico. 
BIBLIOGRAFÍA 
AbelLA, R. (1996) La vida cotidiana bajo el régimen de Franco, Madrid, Temas de hoy.

ABIZANDA, M. (1948) «Este es el camino del cine hablado en español», en Primer Plano, núm. 140.

ACKER, Y. (1997) Ernesto halffter. 1905 - 1989 músico en dos tiempos, Madrid, La residencia de estudiantes.

ACKER, Y.; SuÁREZ-PAJARES, J. (1995) Miguel asíns arbó, Madrid, Sgae / colección: catálogos compositores españoles.

Adorno, T. W.; EISLer, H. (1981) El cine y la música, Madrid, Fundamentos.

- (1994) Composing for the films, London, The athlone press.

Aguilar, Carlos; Gunover, Jaume: (1996) Las estrellas de nuestro cine, Madrid, Alianza editorial.

AguilaR, P. (1996) Memoria y olvido de la guerra Civil española, Madrid, Alianza.

Agramunt Lacruz, F. (1999) «Peris Aragó y CIFESA. Recuperación de uno de los grandes cartelistas del cine españolı, AGR Coleccionistas de cine, núm.3, Madrid, El Gran Caid S.L..

AlbeRICH, F. (1997) «Raza. Cine y propaganda en la inmediata posguerra.», VV.AA. Archivos de la Filmoteca, núm. 27, Valencia, Filmoteca de la Generalitat Valenciana.

Alonso, M.; García Estefanía, A. (1998) Conrado del campo, Madrid, Fundación autor / colección: catálogo de compositores.

Álvarez, R.; ARCE, J. C. (1996) La armonía que rompe el silencio. Conversaciones con Pepe Nieto, Valladolid, La Semana Internacional de Valladolid.

Amorós, A. (1991) Luces de candilejas, Madrid, Espasa Calpe.

Amoros I Isern, A. (1984) «Els Estudis Cinematografics Orphea», en Cinematograf. Vol.1.

ANÓNIMO, (1941) «La partitura de "Raza”, compuesta por el maestro Manuel Parada es interpretada por las Orquestas Nacional Sinfónica y Filarmónica, coaligadas», en El Alcazar, (31 de diciembre de 1941)

- (1949) «Es una lastima que en España no se hagan más películas musicales», en Primer Plano, núm. 594.

ANTEQUeRA, J. A. (1941) «La música en las películas», en Primer Plano, núm. 341.

ANTHEIL, G. (1990) Bad Boy of Music, Hollywood, Samuel French.

Aumont, J.; MARIE, M. (1983) Análisis del film, Barcelona, Paidós.

Aumont, J.; Berlanga, A.; Marie, M.; Vernet, M. (1985) Estética del cine: espacio fílmico, montaje, narración, lenguaje, Barcelona, Paidós.

Bazin, A. (1966) ¿Qué es el cine?, Madrid, Rialp. 
BeltrÁn Moner, R. (1984) La ambientación musical. Selección, montaje y Sonorización, Madrid, Instituto oficial de radio y televisión.

Benitez, J. M.; Carmona, L. M. (1996) Nombres de la banda sonora. Diccionario de compositores cinematográficos, Madrid, Stripper.

BernaOla, C.; GuRIDI, J. (1998) Bernaola - Guridi, Fundación Luis Cernuda [compact disc] ENSAYO-EMY-S-1111

Bernstein, L.; Gottlieb, J. (Ed.) (2002) Leonard Bernstein. El maestro invita a un concierto, Madrid, Ediciones Siruela.

BlAsco, R. (1981) Introdució a la historia del cine valenciá, Valencia, Ajuntament de Valencia.

BORAU, J. L. (coord.) (1998) Diccionario del cine español, Madrid, Alianza editorial.

BORDWELL, D. (1995) El significado del film. Inferencia y retórica en la interpretación cinematográfica, Madrid, Paidós.

- (1996) La narración en el cine de ficción. Barcelona, Paidós.

Bordwell, D.; Staiger, J.; Thompson, K. (1997) El cine clásico de Hollywood. Estilo y modo de producción hasta 1960, Barcelona, Paidós.

BORDWELL, D.; THOMPSON, K. (1995) El arte cinematográfico. Una introducción. Barcelona, Paidós.

Bosch I Hugas, J. (2001) Miklós Rózsa. La fidelidad a los orígenes, Barcelona, Associació Catalana per a la Difusió de la Música de Cinema.

BOSCH I HugAs, J.; ClAVER I BorRÀs, J. (2002) El spaghetti western y la revolución Morriconiana, Barcelona, Associació Catalana per a la Difusió de la Música de Cinema.

BRUCE, D. G. (1985) Bernard Herrmann: Film Music and Filme Narrative, Michigan, Ann Arbor / UMI.

BuRT, G. (1994) The Art of Film Music, Boston, Northeastern University Press.

Bustamante, E.; Zallo, R. (Ed.): Las industrias culturales en España. Madrid. Akal. 1988.

BYRnE, J. (1999) Microsoft Access 2000, Barcelona, Ediciones B, S.A.

CABero, J. A. (1949) Historia de la cinematografía española. Madrid, Gráficas Cinema.

- (1953) «Medio siglo de ensayos», en Revista Cine Mundo.

CABo, J. L. (1992) Cinematógrafos de Compostela (1900-1986), La Coruña, Xunta de Galicia.

Calvo MovelL, J. (1986) Cine y literatura. La adaptación literaria en el cine español, Valencia, Filmoteca Valenciana.

CÁnovas BelCHI, J. T. «La música y las películas en el cine mudo español. Las adaptaciones de zarzuelas en la producción cinematográfica madrileña de los años veinte»r, consultado

on-line

en 
http://cervantesvirtual.com/servlet/SirveObras/83699403184614000810046/p00000 01.htm\#l_1_[abril de 2003]

CAparRos Lera, J. M. (1977) El cine republicano español (1931-1939), Barcelona, Dopesa..

- (1981) Arte y Política en el Cine de la República, Barcelona, Universidad de Barcelona.

CARRoll, B. G. (1997) The Last Prodigy. A Biography of Erich Wolfgang Korngold, Porthland (Oregon), Amadeus Press.

CAstán Palomar, F. (1946) «Horas antes del estreno, con el director y los autores de "Garbancito de la Mancha"», en Primer Plano, núm. 291.

- (1949) «Evolución de la música cinematográfica en veinte años de películas sonoras», en Primer Plano, núm. 577.

CAstillejo, J. (1998) Las películas de Aurora Bautista, Valencia, Fundación Municipal de cine / Mostra del Mediterrani (Mitemas).

CAstro de PAZ, J. L. (1995) La Coruña y el cine I. 100 años de historia. 1896-1936, La Coruña. Vía Láctea Editorial.

- (2002) Un cinema herido: los turbios años cuarenta en el cine español (19391950), Barcelona, Paidós.

Cebollada, P.; Rubio Gil, L. (1996) Enciclopedia de cine español: cronología, Barcelona, Ediciones Serval.

CHIÓN, M. (1993) La audiovisión, Barcelona, Paidós, comunicación.

- (1985) La música en el cine, Barcelona, Piados.

- (1992) El cine y sus oficios, Madrid, Cátedra - signo e imagen.

CHUECA, R. (1977) El fascismo en los comienzos del régimen de Franco, Madrid, Fondo de Cultura Económica.

Colón Perales, C. (1981) Rota-Fellini (La música en las películas de Fellini), Sevilla, Anales de la Universidad Hispalense. Serie Filosofía y Letras, 58.

- (1984) La música cinematográfica de Joaquín Turina, Sevilla, Real Academia de Bellas Artes de Santa Isabel de Hungría.

- (1989) Fellini o lo fingido verdadero, Sevilla, Ediciones Altar.

- (1991) George Gershwin y Leonard Bernstein, Sevilla, Encuentros Internacionales de Música de Cine, Diputación de Sevilla.

- (1992) Europa en hollywood, Sevilla, Fundación Luis Cernuda.

- (1993) Introducción a la historia de la imagen visitada por la música, Sevilla, Facultad de ciencias de la información / Alfar, cuadernos de comunicación 10/11.

- (1993) Jerry Goldsmith, Sevilla, Fundación Luis Cernuda. 
- (1994) Para una periodización de la historia de la cinematográfica en los estados unidos (1895-1993), Madrid, Area 5, $\mathrm{n}^{\circ} 3$.

- (1995) John Barry, Sevilla, Fundación Luis Cernuda.

- (1997) "La música de la "Screwball Comedy"» en Nickel Odeon: Screwball Comedy núm.6, Madrid, Nickel Odeon Dos S.A.

Colón Perales, C.; Infante Del Rosal, F.; lombardo Ortega, M. (1997) História y teoría de la música en el cine, presencias afectivas, Sevilla, Alfar.

Company, J. M. (1985) Formas y perversiones del compromiso. El cine español de los años 40, Valencia, Eutopías / Documentos de trabajo.

Copland, A. (1992) Cómo escuchar la música, Madrid, Fondo de Cultura Económica.

CORTÉS, B.; LLORÉNS A.. (1989) La música en el cine, Valencia, Filmoteca valenciana.

Cuéllar Alejandro, C. A. (1998) Cine y música: el arte al servicio del arte, Valencia, Sevicio de Publicaciones de la UPV.

Cueto, R. (1996) Cien bandas sonoras en la historia del cine, Madrid, Nuer.

Cuevas, A. (1999) Economía cinematográfica, la producción y el comercio de películas, Madrid. Imaginógrafo. [Edición a cargo de Ramiro Gómez].

De Aranzadi, E. (1937-1952) Aranzadi. Repertorio cronológico de legislación, Pamplona, Editorial Aranzadi.

DE EsPAÑA, R. (1994) Directory of spanish and portuguse film-makers \& films, Trowbrigde, Flicks books.

De las Heras, A. (1941) «La música y los músicos en el cine», en Primer Plano, núm. 59.

De Santi, P. M. (1983) La música de Nino Rota, Bari, La Terza.

Del Amo, A. (Ed.) Catálogo general del cine de la Guerra civil, Madrid, Cátedra / Filmoteca Española.

Del Valle Fernández, R. (1966) Aspectos económicos del cine español. (1953-1965), Madrid, Ediciones y Publicaciones Populares. Servicio Sindical de Estadística.

Diez PueRTAS, E. (2000) Historia del movimiento obrero en la industria española del cine. 1931 - 1999, Valencia IVAC.

DíEZ, E. (1999) «Los acuerdos cinematográficos entre el franquismo y el Tercer Reich», VV.AA. Archivos de la Filmoteca, núm. 33, Valencia, Filmoteca de la Generalitat Valenciana.

Domínguez, A. (1987) I/ Encuentro Internacional de Música de Cine: Ennio Morricone. Musicografía, filmografía y discografía, Sevilla, Fundación Luis Cernuda.

EguIzÁBAL, R. (1999) «El cine a través del cartel publicitario», AGR Coleccionistas de cine, núm. 1, Madrid, El Gran Caid S.L..

EINSENSteIn, S. M. (1974) El sentido del cine, Buenos aires, Siglo XXI Ediciones s.a. 
- (2001) Hacia una teoría del montaje - volumen I, Barcelona, Paidós.

- (2001) Hacia una teoría del montaje - volumen II, Barcelona, Paidós.

ESPAÑA, Sobre la ordenación y defensa de la industria, 24 de noviembre de 1939, Jefatura del Estado, Boletín Oficial del Estado, 15 de diciembre de 1939, núm. 349

- Orden fijando la competencia y funciones del Departamento de Cinematografía, pendiente de la Dirección General de Propaganda, 21 de febrero de 1940, Ministerio de la Gobernación, Boletín Oficial del Estado, 25 de febrero de 1940, núm. 56

- Por la que se transfieren los servicios de prensa y propaganda a la Vicesecretaría de Educación de F.E.T. y de las JONS, 20 de mayo de 1941, Jefatura del Estado, Boletín Oficial del Estado, 22 de mayo de 1941, núm. 142

- Normas protectoras para la cinematografía, 11 de noviembre de 1941, Ministerio de Industria y Comercio, Boletín Oficial del Estado, 17 de noviembre de 1941, núm. 321

- Regulando la programación de películas, 10 de diciembre de 1941, Ministerio de Industria y Comercio, Boletín Oficial del Estado, 13 de diciembre de 1941, núm. 347

- Reorganizando los servicios de censura cinematográfica, 23 de noviembre de 1942, Vicesecretaría de Educación Popular, Boletín Oficial del Estado, 26 noviembre de 1942, núm. 330

- Disponiendo la proyección exclusiva y obligatoria del noticiario "NO-DO», 17 de diciembre de 1942, Vicesecretaría de Educación Popular, Boletín Oficial del Estado, 22 de diciembre de 1942, núm. 356

- Regulando la importación de películas, 18 de mayo de 1943, Ministerio de Industria, Subsecretaría de Comercio, Boletín Oficial del Estado, 24 de mayo de 1943, núm. de B.O.E. 124

- Estableciendo el titulo de "películas de Interés Nacional»,15 de junio de 1944, Vicesecretaría de Educación Popular, Boletín Oficial del Estado, 23 de junio de 1944, núm. de B.O.E. 175

- Ley, Clasificación arancelaria protectora de la industria nacional de cinematografía, 19 de julio de 1944, Jefatura del Estado, Boletín Oficial del Estado, 21 de julio de 1944, núm. 203

- Orden por la que se aprueba la reglamentación nacional del trabajo en la industria de la cinematografía, 28 de septiembre de 1944, Ministerio de Industria y Comercio, Boletín Oficial del Estado, 6 de octubre de 1944, núm. 280

- Ampliando y modificando la orden de 10 de diciembre de 1941 sobre programación de películas, 13 de octubre de 1944, Ministerio de Industria y Comercio, Boletín Oficial del Estado, 15 de octubre de 1944, núm. 289 
- Rectificando la orden de 23 de noviembre de 1942 sobre censura de películas, 15 de diciembre de 1944, Vicesecretaría de Educación Popular, Boletín Oficial del Estado, 21 de diciembre de 1944, núm. 356,

- Creando premios honoríficos al arte cinematográfico, 23 de enero de 1945, Vicesecretaría de Educación Popular, Boletín Oficial del Estado, 29 de enero de 1945, núm. 29

- Creando los premios anuales que se mencionan para estímulo de los elementos artísticos de la cinematografía, 23 de enero de 1945, Vicesecretaría de Educación Popular, Boletín Oficial del Estado, 29 de enero de 1945, núm. 29

- Normas para el "visionado» por los importadores de películas cinematográficas, 13 de febrero de 1945, Ministerio de Hacienda, Boletín Oficial del Estado, 15 de febrero de 1945, núm. 46

- Sobre importación y reexportación de películas extranjeras destinadas al doblaje, 13 de febrero de 1945, Ministerio de Hacienda, Boletín Oficial del Estado, 15 de febrero de 1945, núm. 46

- Normas para la exportación temporal de películas cinematográficas, 13 de febrero de 1945, Ministerio de Hacienda, Boletín Oficial del Estado, 15 de febrero de 1945, núm. 46

- Sobre reimportación de películas exportadas en régimen temporal, 17 de febrero de 1945, Ministerio de Hacienda, Boletín Oficial del Estado, 22 de febrero de 1945, núm. 22

- Regulando plazo de exportación de películas extranjeras, 3 de abril de 1945, Ministerio de Industria y Comercio, 6 de abril de 1945, Boletín Oficial del Estado, núm. 96

- Aclarando e interpretando las ordenes de 13 y 17 de febrero ultimo sobre importación y exportación de películas, 3 de abril de 1945, Ministerio de Industria y Comercio, Boletín Oficial del Estado, 6 de abril de 1945, núm. 96

- Aplicando a la producción cinematográfica la ley de 24 de noviembre de 1939 de ordenación de la industria nacional, 25 de enero de 1946, Jefatura del Estado, Boletín Oficial del Estado, 7 de febrero de1946, núm. 38

- Creando la Junta Superior de Orientación Cinematográfica, 28 de junio de 1946, Ministerio de Educación Nacional, Boletín Oficial del Estado, 19 de julio de 1946, núm. 200

- Concesión de permisos de doblaje, 31 de diciembre de 1946, Ministerio de Educación Nacional, Boletín Oficial del Estado, 25 de enero de 1947, núm. 25

- Creando el Patronato de Experiencias y Divulgaciones Cinematográficas, 18 de febrero de 1947, Ministerio de Educación Nacional, Boletín Oficial del Estado, 19 de febrero de 1947, núm. 50 
- Modificando lo dispuesto en la orden de 31 diciembre 1946 sobre permisos de doblaje, 12 de junio de 1947, Ministerio de Educación Nacional, Boletín Oficial del Estado, 15 de junio de 1947, núm. 166

- Devolución de derechos arancelarios de películas prohibidas por la censura, 22 de junio de 1948, Ministerio de Hacienda, Boletín Oficial del Estado, 27 de junio de 1948, núm. 179

- Salvando error, orden anterior, 22 de junio de 1948, Presidencia, Boletín Oficial del Estado, 1 de julio de 1948, núm. 183

- Permisos de doblaje a películas declaradas de Interés Nacional, 29 de julio de 1948, Ministerio de Educación Nacional, Boletín Oficial del Estado, 10 de agosto de 1948, mún. 223

- Creación de la cámara de directores cinematográficos, 22 de octubre de 1948, Ministerio de Educación Nacional, Boletín Oficial del Estado, 28 de noviembre de 1948, núm. 333

- Recursos de clasificación de películas, 28 de diciembre de 1948, Subsecretaría de Educación Popular. Dirección General de Cinematografía y Teatro, Boletín Oficial del Estado, 8 de enero de 1949, núm. 8

- Reglamentación nacional del trabajo en la industria cinematográfica, 31 de diciembre de 1948. (Rectificada en fecha 28-5-1949), Ministerio de Industria y Comercio, Boletín Oficial del Estado, 24 de enero de 1949, núm. 24

- Subasta de películas cinematográficas abandonadas, 6 de mayo de 1949, Ministerio de Hacienda, Boletín Oficial del Estado, 15 de mayo de 1949, núm. 135

- Eleva a orden ministerial la circular num. 262 de clasificación de películas importadas, 8 de septiembre de 1949, Ministerio de Hacienda, Boletín Oficial del Estado, 13 de septiembre de 1949, núm. 256

- Clasificación de películas autorizadas o toleradas para menores, 29 de octubre de 1949, Ministerio de Educación Nacional, Boletín Oficial del Estado, 31 de octubre de 1949, núm. 304,

EstiviLL, J. (1997) «El cine y el control de la juventud en España (1939-1945)», VV.AA. Archivos de la Filmoteca, núm. 25-26, Valencia, Filmoteca de la Generalitat Valenciana.

FANÉs, F. (1981) Cifesa, la antorcha de los éxitos, Valencia, Instituto Alfonso el Magnánimo.

FERnÁNDEZ BARREIRA, F. (1944) "Yo sé lo que costó levantar el cine español, hoy próspero»s, en Primer Plano, núm. 180.

- (1949) «José Iturbi, evolución de la música en la pantalla», en Primer Plano, núm. 445.

FERNÁNDEZ-CID, A. (1967) Músicos que fueron nuestros amigos, Madrid, Editora nacional. 
Fernández Colorado, L.; Couto Cantero, P. (coord..) (2001) La herida de las sombras.

El cine español de los años 40, Madrid, Academia de las Artes y las Ciencias Cinematográficas en España / AEHC.

GarCIA Escudero, J.M. (1962) Cine español, Madrid, Rialp.

Garcia Fernandez, E. C. (1985) Historia del Cine en Galicia (1896-1984), La Coruña, La Voz de Galicia.

Garcia Fernandez, E. C. (1985) Historia ilustrada del Cine Español, Barcelona, Planeta.

Garcia Fernández, E. C. (coord..): Memoria viva del cine español, Madrid. Academia de las Artes y las Ciencias Cinematográficas de España. 1998.

García LeOz, J. (1999) José Nieto dirige la música de Jesús García Leoz [compact disc] Fundación Autor / SGAE / Karonte, JMBSP501

García Leoz, J.; Serrano, J. (1998) La duquesa del Candil. Los Claveles [compact disc] Blue Moon, BMCD 7510

GASCA, L. (1998) Un siglo de cine español, Madrid, Planeta / Enciclopedias.

Gaudreault, A.; Jost, F. (1995) El relato cinematográfico. Barcelona, Paidós.

García de DueñAs, J.; GorostizA, J. (coord..) (2001) Los estudio cinematográficos españoles, Madrid, Academia de las Artes y las Ciencias Cinematográficas en España.

Gomez BeRMUdeZ DE CASTRO, R. (1989) La producción cinematográfica española. De la transición a la democracia (1976-1986), Bilbao, Mensajero.

GómeZ MESA, L. (1940) «Futuro de la película musical española», en RadioCinema, núm. 51.

- (1978) La literatura española en el cine nacional (1907-1977), Madrid, Filmoteca Nacional de España.

Gómez Tello, J. L. (1943) «Garbancito de la Mancha», en Primer Plano, núm. 133.

Gonzalez Ballesteros, T. (1981) Aspectos jurídicos de la censura cinematográfica en España, Madrid, Editorial Complutense.

GoRBMAN, C. (1987) Unheard Melodies, London, BFI Publising.

Granados, E (1987) Goyescas (Ópera en 3 cuadros) [compact disc] Alambra, WD 71322

Gubern, R. (1977) El Cine sonoro en la II República (1929-1936), Barcelona, Lumen.

- «Pluralismo y comunidad en nuestras cinematografías» consultado en Centro Virtual Cervantes, http://cvc.cervantes.es/obref/congresos/zacatecas/cine/ponencias/gubern.htm [visitado el 25 de mayo de 2003]

Hofstätter, H. H.; PIXA, H. (1972) Historia Universal Comparada - Tomo VI: del 1700 a nuestros días, Esplugas de Llobregat (Barcelona), Plaza \& Janes S.A. 
HuertA, C. (1997) Enciclopedia de Cine Español: CINEMEDIA, [CD-Rom] Barcelona, Canal+ ; SGAE.

Hueso, A. L. (coord..) (1998) Catálogo de cine español 1941-1950, Fuenlabrada (Madrid), Cátedra / Filmoteca Española.

IgLESIAS, A. (1982) Escritos de Joaquín Turina, Madrid, Alpuerto.

Jennings, R. (2003) Edición Especial Microsoft Access 2000, Madrid, Pearson Educación S.A.

Julio de Abajo de Pablos, J. E. (1996) Mis conversaciones con Juan Antonio Bardem, Valladolid, Quiron Ediciones.

- (1996) Mis conversaciones con José Luis Sáenz de Heredia, Valladolid, Quiron Ediciones.

LACK, R. (1999) La música en el cine, Madrid, Cátedra - signo e imagen.

LATORRE, J. M. (1989) Nino Rota. La imagen de la música, Barcelona, Montensinos.

Le'Peron, S. (1996) Musique de Films: Josep Kosma, [vídeo] Alternate Current Inc ; Les Films d'Ici ; La Sept/ARTE ;Imalyre ; France SUPERVSION

LLINÁS, F. (1989) Directores de fotografía del cine español, Madrid, Filmoteca Española.

Lluís I FAlCó, J. (1994) Gregorio García Segura. Historia, testimonio y análisis de un músico de cine, Murcia, Editora Regional Murciana.

- (1995) «Música y músicos en la Cataluña silente» en VV.AA. De Dalí a Hiichcocok, La Coruña, Asociación Española de Historiadores del Cine, Junta de Galicia.

- (1995) «Jacinto Guerrero: un compositor de antes y para el cine» en VV.AA, Jacinto Guerrero: de la zarzuela a la revista, Madrid, Fundación Inocencio y Jacinto Guerrero / SGAE.

LÓPEZ GaRcíA, V. (1945) La industria cinematográfica española, Madrid, Asociación Nacional de Ingenieros Industriales.

- (1972) Chequeo al cine español, Barcelona, Talleres Gráficos Casaló.

Lopez Garcia, V.; Martin Proharam, M. A.; Cuevas Puente, A. (1935) La industria de producción de películas en España, Madrid.

LÓPEZ YePES, A. (1992) Manual de documentación audiovisual, Pamplona, Eunsa.

- (1993) Documentación multimedia: el tratamiento automatizado de la información periodística, audiovisual y publicitaria, Salamanca, Universidad Pontificia de Salamanca.

- (1997) Documentación Informativa: Sistemas, redes y aplicaciones, Madrid, Síntesis.

LÓPEZ YEPES, J. (1995) La documentación como disciplina: teoría e historia, Pamplona, Eunsa. 
LÓPEZ YEPES, J. (Ed.) (2000) Teoria, historia y metodología de la documentación en España (1975-2000) [Recurso electrónico]: I Congreso Universitario de Ciencias de la Documentación, Madrid, 14-17 de noviembre: actas, Madrid.

London, K. (1970) Film music, London, Faber and Faber.

LUJÁN, A. (1945) «La salvación del cine español está en la música española», en Primer Plano, núm. 262.

MARQUEIRE, M. (1943) «En el tercer año de NO-DO, los operadores, los del equipo sonoro y sus anécdotas», en Primer Plano, núm. 222.

MARSÉ, J.; RABINAD, A. (Ed.) (1971) 1929-1940, la gran ilusión, Barcelona, Difusora Internacional.

- (1971) 1939-1950, años de penitencia, Barcelona, Difusora Internacional.

- (1971) 1949-1960, tiempo de satélites, Barcelona, Difusora Internacional.

MARtín AREAS, L. El cine: un espectáculo musical, Valladolid, Filmoteca / Obra Cultural de Caja Madrid.

MARTINEZ-BRETON, J. A. (1987) Influencia de la iglesia católica en la cinematografía española (1951-1962), Madrid, Harofarma.

Méndez-Leite, F. (1965) História del cine español, Madrid, Rialp.

MÉndeZ-Leite, F. (1999) «CIFESA: clarines y nubarrones», VV.AA. Nickel Odeon, núm. 15, Madrid, Nickel Odeon Dos S.A.

Micelı, S. (1997) Morricone: la música, el cine, Valencia, Fundación Municipal de Cine, Mostra de Valencia - Colección Mitemas.

MINGUET I BATLLORI, «J. M. La regeneración del cine como hecho cultural durante el primer franquismo (Manuel Auguto García Viñolas y la etapa inicial de "Primer Plano")», consultado on-line en http://cervantesvirtual.com/servlet/SirveObras/cine/83699405306814022010046/ind ex.htm [mayo de 2003]

MoRÁN, A. (1993) Joaquín Turina, Madrid, Sgae / colección: catálogos compositores españoles.

Moya LoRente, F. (1993) Los grandes músicos del cine, Barcelona, Royal Books.

NAscimbene, M. (1992) Nascimbene, mario: malgre moi, autobiografía de un músico de cine, Valencia, Fundación Municipal de Cine, Mostra de Valencia - Colección Mitemas.

Navarro Arriola, H.; Navarro Arriola, S. (2003) Música de cine: historia y coleccionismo de bandas sonoras, Madrid, Ediciones Internacionales Universitarias.

Newsom, J. (1985) David Raksin: a Composer in Hollywood, Washington, Library of the Congress.

Nielsen, J. (2000) Usabilidad, diseño de sitios Web, Madrid, Pearson Educación S.A. 
Nielsen, J. (2002) Usabilidad de páginas de inicio: análisis de 50 sitios Web, Madrid, Pearson Educación S.A.

NIETO, J. (1996) Música para la imagen, influencia secreta, Madrid, SGAE.

NúÑEz Polo, (1949) «Los films musicales» en Cámara, núm. 159.

OSKAM, J. (1991) «Censura y prensa franquista como tema de investigación», en Revista de Estudios Extremeños núm. 47, consultado on-line en http://www.geocities.com/Athens/Parthenon/4087/cens.htm [abril de 2000]

P. O, F. (1995) «García Leoz, el gran músico de Olite, rescatado», en Diario de Navarra, (17 de diciembre de 1995).

Pachón Ramírez, A. (1990) La música en el cine actual (1975-1990). Pepe Nieto, Badajoz, Tesis doctoral, Universidad de Extremadura, Departamento de Historia del Arte.

- (1992) La música en el cine contemporáneo, Badajoz, Diputación Provincial de Badajoz.

- La música en el cine actual: metodología e historiografía, Alicante, Biblioteca Virtual Miguel de Cervantes, consultado on-line en http://cervantesvirtual.com/servlet/SirveObras/01258968664922615765091/p00000 01.htm\#l_1_ [abril de 2003]

PADROL, J. (1988)Antón garcía abril, Sevilla, Fundación Luis Cernuda.

- (1998) Pentagramas de película. Entrevistas a grandes compositores de bandas sonoras, Madrid, Nuer.

Padrol, J.; Bodegas, R.; Calvo, F. (COORd.) Evolución de la banda sonora en España: Carmelo Bernaola, Madrid, Festival de Cine de Alcalá de Henares.

PAdRol, J.; VAlLs, M. (1986) Música y cine, Barcelona, Salvat, Biblioteca Básica Salvat, 99.

- (1990) Música y cine, Barcelona, Ultramar.

Palacios Mejía, L. A. (1990) Las funciones de la banda sonora en el cine, Barcelona, Publicaciones de la Universidad Autónoma de Barcelona - Microficha.

PAlmer, C. (1990) The Composer in Hollywood, London, Marion Boyars.

- (1982) Miklós Rózsa, Venecia, Ufficio Attività Cinematografiche dell' Assessorato alla Cultura.

- (1984) Dimitri Tiomkin. A Portrait, London, T.E. Books.

Parada, M. (2000) José Nieto dirige la música de Manuel Parada [compact disc] Fundación Autor /SGAE, Ref.: 700

PASTOR, M. (1939) «El cine y la música», en RadioCinema, núm. 34.

Peralta, W. (1941) «La importancia del doblaje en las películas», en Primer Plano, núm. 52.

Pérez Perucha, J. (1983) El cine de Luis Marquina, Valladolid, $28^{a}$ Semana Internacional de cine. 
- (1990) Mestizajes (realizadores extranjeros en el cine español. 1913-1973), Valencia, Fundación Municipal de Cine, Mostra de Valencia.

Pérez Perucha, J. (Ed.) (1997) Antología del cine español (1906 - 1995), Madrid, Cátedra / Filmoteca Española: Serie Mayor.

Pérez Perucha, J. (comp..) (1995) Huellas de luz, Madrid, Diorama.

Pineda Novo, D. (1991) Las folklóricas y el cine, Huelva, Festival de Cine Iberoamericano.

Pliego De Andrés (1997) Jesús Guridi, Madrid, Sgae / colección: catálogos compositores españoles.

Prague, C. N.; IRWIN, M. R. (1999) Access 2000, Madrid, Anaya Multimedia.

Prendergast, R. M. (1992) Film Music, a Neglected Art: a Critical Study of Music in Films, London, W. W. Norton \& Co.

Previn, A. (1991) No Minor Chords: My Days in Hollywood, New York, Double-day.

Quintero Muñoz, J. (1998) José Nieto dirige la música de Juan Quintero Muñoz [compact disc] Fundación Autor / SGAE / DECCA, 460 574-2 HC

QUISLÁNT, (1940) «La música en el cinema», en RadioCinema, núm. 51.

Ramírez, A.; Askeland, J. (2000) El (en) canto múltiple de la música popular en el cine. Funciones de la banda sonora en danzón y sur, Universidad de Bergen, Noruega, consultado on-line en http://www.svf.uib.no/media/audiovision/articul/Art3.html [enero de 2001]

Robinson, D. (1990) Music of the Shadows: the use of Músical Accompaniment Withsilent Film 1896-1936, Pordenone, Le Giornate del Cinema Muto.

RomagueRA I RAmIÓ, J. «La revista "Cine Experimental”: (Madrid, 1944-1946)», consultado on-line

en http://cervantesvirtual.com/servlet/SirveObras/cine/09593518542922648986691/ind ex.htm [febrero de 2003]

RózsA, M. (1982) Double Life, New York, Wynwood press.

RUIZ DE LUNA, S. (1959) La música en el cine y la música para el cine, San sebastián

RusselL, M.; Young, J. (2001) Bandas Sonoras, Barcelona, Océano.

SALA, R.; Álvarez, R. (2000) El cine en zona nacional, Bilbao, Mensajero.

SÁncheZ, B. (1990) 1896-1955. Del Cinematógrafo al Cinemascope. Primera vuelta de manivela para una historia del cine en La Rioja, Logroño, Consejería de Cultura.

SÁNCHEZ SÁNCHEZ, V. (1997) Tomás Bretón, Madrid, Fundación Autor / colección: catálogo de compositores.

SANZ DE Soto, E. (1989) «Cine español. 1940-1950», en Cine español, Madrid, Ministerio de Cultura.

Sempere, A. (2002) Roque Baños. Pasión por la música. Madrid, 15 Semana de Medina del Campo (Ocho y medio). 
Sevillano Calero, F. (1996) Dictadura, socialización y conciencia política. Persuasión ideológica y opinión en España bajo el franquismo (1939-1962), Alicante, Universidad de Alicante, Departamento de Humanidades Contemporáneas. Tesis Doctoral. Consultada on-line http://cervantesvirtual.com/FichaObra.html?Ref=3140 [mayo de 2003].

Simpson, A.; Robinson, C. (1999) La biblia del Access 2000, Madrid, Anaya Multimedia.

SMITH, S. C. (1991) A Heart at Fire's Center - The Life and Music of Bernard Herrmann, Los Ángeles, University of California.

SoRIA, F. (1991) Juan Mariné. Un explorador de la imagen, Murcia, Filmoteca Regional de Murcia.

StuCKENSChIMIDT, H. H. (1960) La música del siglo XX, Madrid, Ed. Guadarrama.

TÉLLEZ, E. (1996) «La composición musical al servicio de la imagen cinematográfica. El discurso musical como soporte del discurso cinematográfico», en Espéculo núm. 4, consultado on-line en http://www.ucm.es/info/especulo/numero4/cine_mus.htm [mayo de 1999]

- (1997) «El discurso musical como soporte del discurso cinematográfico. Análisis de ejemplos (I)»), en Espéculo núm. 6, consultado on-line en http://www.ucm.es/info/especulo/numero6/e_tellez.htm [mayo de 1999]

TÉLLEZ, J. L. (1989) «Notas para una teoría de la música dramática (I)», VV.AA. Archivos de la Filmoteca núm. 1, Valencia, Filmoteca de la Generalitat Valenciana.

- (1989) «Notas para una teoría de la música dramática (II)», VV.AA. Archivos de la Filmoteca núm. 2, Valencia, Filmoteca de la Generalitat Valenciana.

- (1990) «De historia y de folklore (notas sobre el $2^{\circ}$ período de CIFESA)», VV.AA. Archivos de la Filmoteca núm. 4, Valencia, Filmoteca de la Generalitat Valenciana.

- (1990) «Notas para una teoría de la música dramática (III)», VV.AA. Archivos de la Filmoteca núm. 5, Valencia, Filmoteca de la Generalitat Valenciana.

- (1990) «Notas para una teoría de la música dramática (IV): La ópera como dimensión pornográfica del texto musical», VV.AA. Archivos de la Filmoteca núm. 6, Valencia, Filmoteca de la Generalitat Valenciana.

- (1990) «Notas para una teoría de la música dramática (V)», VV.AA. Archivos de la Filmoteca núm. 8, Valencia, Filmoteca de la Generalitat Valenciana.

TORRES, A. M. (1994) Diccionario de cine español, Madrid, Espasa.

Tranche, R. R.; Sanchez-BIosca, V. (2001) NO-DO. El tiempo y la memoria, Madrid, Cátedra / Filmoteca Española (Serie mayor).

TURINA, J. (1942) «En torno al problema de la música cinematográfica», en Revista Nacional de Educación, año II, $1^{\text {a }}$ época, núm. 15. (marzo de 1942).

- (1942) «Música de cine», en Dígame, (6-X-1942). 
- (1987) Antón García Abril dirige la música cinematográfica de Joaquín Turina [vinilo] Fundación Luis Cernuda / Vinilo, VND-1035

Utrera, C. (1989) La música en el cine, Gran Canaria, Filmoteca Canaria - Ediciones Viceconsejería de Cultura y Deportes.

VIDAL, N. «Humor, música y... hermanos. (El cine de lquino en CIFESA)», VV.AA. Archivos de la Filmoteca, Valencia, Filmoteca de la Generalitat Valenciana.

VV.AA. (1951) Anuario Cinematográfico Hispanoamericano 1950, Madrid, Sindicato Nacional del Espectáculo.

- (1941) Anuario de cinematografía 1940, Madrid.

- (1942) Anuario de cinematografía 1941, Madrid.

- (1970) Gran enciclopedia del mundo, Bilbao, Durvan S.A. Ediciones.

- (1976) Gran diccionario enciclopédico, Esplugas de Llobregat (Barcelona), Plaza \& Janes S.A.

- (1982) Historia de la música en el cine, Barcelona, Discos Belter.

- (1989) La música en el cine, Gran canaria, Filmoteca Canaria.

- 1993) El paso del cine mudo al sonoro en el cine español, Madrid, Editorial Complutense / AEHC.

- (1995) História del cine español, Madrid, Cátedra (signo e imagen)

- (1995) Jacinto Guerrero: de la zarzuela a la revista, Madrid, Fundación Inocencio y Jacinto Guerrero / SGAE.

- (1995) El patrimoni cinematográfic a Catalunya, Barcelona, Fundació Instituo del Cinema Català.

_ (1996) Imperio Argentina en el cine [compact disc] EMI Gold, 724385516726

- (1997) Melodías populares del cine de los años 40 (caja de 2 compact disc + libro de 28 pags.) [compact disc] Blue Moon, BMCD 2025-2

- (1998) Diccionario del cine español, Madrid, Alianza Editorial.

- (1999) Nickel Odeon: Edgar Neville: 100, núm. 17, Madrid, Nickel Odeon Dos S.A.

- (2001) Nickel Odeon: El musical, núm.25, Madrid, Nickel Odeon Dos S.A.

- (2002) Bernard Herrmann, Las Palmas de Gran Canaria, Gobierno de Canarias SOCAEM. (Cuadernos de la Filmoteca Canaria)

WaletZKY, J. (1992) Music for the Movies: Bernard Herrmann, [vídeo] Alternate Current Inc ; Les Films d'Ici..

- (1995) Musique de Films: le son de Hollywood, [vídeo] Alternate Current Inc ; Les Films d'Ici ; La Sept/ARTE.

Xalabarder, C. (1997) Enciclopedia de la banda sonora, Barcelona, Ediciones B, grupo Z. 
ZWERIN, C. (1994) Music for the Movies : Toru Takemitsu, [vídeo] Alternate Current Inc ; Les Films d'Ici..

\section{Recursos}

Asociació Catalana per a la difusió de la música de cinema. [en línea]. Disponible en web: http://usuarios.lycos.es/ACDMC2/present.html

Bernard Herrmann: The Bernard Herrmann Society. [en línea]. Disponible en web: http://www.uib.no/herrmann/

Compositores cinematográficos en el estado español. [en línea]. Disponible en web: http://usuarios.lycos.es/compositores/

Gobiernos de España 1931-2003. [en línea]. Disponible en web: http://usuarios.lycos.es/alpheratz/pics/spain3.htm

Història del cinema. [en línea]. Disponible en web: http://www.xtec.es/ xripoll/

Historia y crítica del cine español, en Biblioteca Virtual Miguel de Cervantes. [en línea]. Disponible en web: http://cervantesvirtual.com/portal/LGB/cine_estatica.shtml

IVAC, la filmoteca. [en línea]. Disponible en web: http://www.ivac-lafilmoteca.es/ Jerome Moross, sitio oficial. [en línea]. Disponible en web: http://www.moross.com La Zarzuela. [en línea]. Disponible en web: http://www.geocities.com/Vienna/Strasse/3300/ Nino Rota. [en línea]. Disponible en web: http://www.ninorota.com

Portal Fuenterrebollo. [en línea]. Disponible en web: http://www.fuenterrebollo.com/Gobiernos/caudillo.html

\section{Bases de datos}

All Movie Guide, http://www.allmovie.com/

Ariadna, http://www.bne.es/esp/cat-fra.htm

A-V online, http://www.library.arizona.edu/indexes/links/avonline.shtml

AVM Audiovisuele Materialen, http://oclcpica.org/?id=2\&ln=uk

Baratz, http://www.baratz.es/baratz/

Baseline (Cinemascore), http://baseline.hollywood.com/

Broadway.com (Hollywood Media Corp.), http://www.broadway.com/index.asp

Cinefania, http://www.cinefania.com/

Cinema D’Europa, http://www.mediasalles.it/

Cineman Movie Reviews, http://www.minireviews.com/

CinemaSource: (Hollywood Media Corp.), http://www.cinema-source.com/ 
Comics and Animation Forum, http://forums.csi.com/gvforums/default.asp?srv=comic CSIC (CINE): Mediateca Científica del CSIC, http://www.asecic.csic.es/media.htm Delphi (Kansas City): A movie Area, http://www.amoviearea.com/

Efedata, http://efedata.efe.es/

Electronic Editions: the spokesman. Review and spokane chronicle, http://www.spokesmanreview.com

Film Video Canadiana, http://library.concordia.ca/collections/filmcanadiana.html

Filmoguía, http://www.filmoguia.com/

Forum des Images, http://www.vdp.fr/

Historic Films, http://www.historicfilms.com/index2.html

Hollywood Hotline, http://www.hollywoodhotline.com/

Hollywood.com: (Hollywood Media Corp.), http://www.hollywood.com/

Iberlex, http://www.boe.es/suscrip/iberlexinfo.htm

Instituto de la Cinematografía y de las Artes Audiovisuales (Filmoteca Española), http://www.cultura.mecd.es/cine/jsp/plantillaAncho.jsp?id=13

ISBN, http://www.mcu.es/bases/spa/isbn/ISBN.html

Japan on Films (Universidad de Michigan), http://www.umich.edu/ iinet/cjs/films/

Magill's Survey of Cinema, http://library.dialog.com/bluesheets/html/bl0299.html

Mapfre Lex, http://v2.vlex.com/es/site/default.asp

Mediasphere (NFB), http://mediasphere.nfb.ca/E/index.epl

Movies in depth, http://www.moviesindepth.com/period.htm

National Film Board (NFB) Film Collection, http://library.concordia.ca/collections/nfbfilm.html

Pariscope (Centre Serveur Duplex), http://www.pariscope.fr/

Prodav: actual DAVID, http://david.sdm.qc.ca/

Progra-4: (rtve), http://www.mercurialis.com/AV/rv18.htm\#4.

Radio Nacional de España (música), http://www.rtve.es/rne/areas/ar_docum.htm

Radio Nacional de España (palabra), http://www.rtve.es/rne/areas/ar_docum.htm

Tempus, http://www.ine.es/tempus2/tempusmenu.htm

Teseo, http://www.mcu.es/TESEO/teseo.html

The Anime and Manga Forum, http://forums.compuserve.com/gvforums/default.asp?SRV=Anime

The Internet Movie Database (IMDB), http://www.imdb.com/ 
BIBLIOGRAFÍA

TV Guide Movie Database, http://www.tvguide.com/movies/database/ 
ANEXOS 
ANEXOS I

ENTREVISTAS 


\section{José Luis Borau.}

Valencia, 17 de junio de 2003 / Madrid, 25 de julio de 2003

\section{Notas biográficas:}

José Luis Borau nace en Zaragoza en 1926, y tras cursar estudios de derecho decide dedicarse a la crítica cinematográfica. En 1957 ingresa en la Escuela de cine, concluyendo dichos estudios en 1961 con la película En el río.

Sus primeras películas no gozan del éxito necesario para proporcionarle la oportunidad de continuar con esta labor. Esto le mantendrá alejando de las cámaras durante casi una década.

Durante este periodo comienza una de sus labores más importantes y destacadas fuera del ámbito creativo, nos referimos a la enseñanza en la Escuela de cine. Por su clase pasarán algunos de los directores más respetados de la cinematografía española de los años setenta y ochenta como Pilar Miró, Manuel

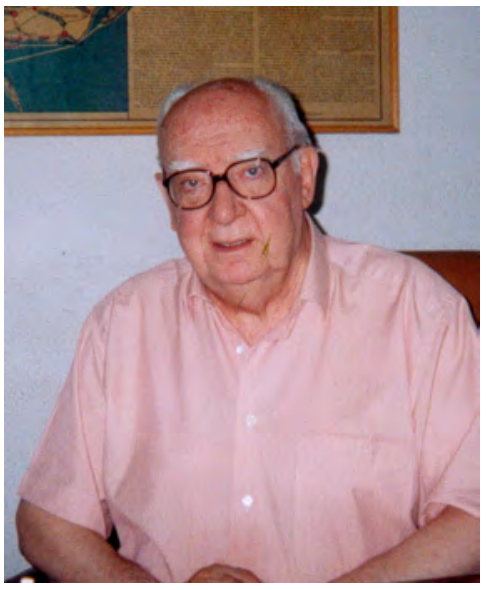

Imagen 97: José Luis Borau ${ }^{323}$ Gutiérrez Aragón, Antonio Drove, Iván Zulueta o Jaime Chavarri.

En 1966 decide fundar una productora y tres años más tarde llega a producir su primera película, Un, dos tres, al escondite inglés, de Iván Zulueta y Mi querida señorita, de Jaime de Armiñán, en 1971, película de la que también es coguionista y que considera prácticamente como suya.

A pesar de no tener en su haber un gran número de películas dirigidas, es considerado como uno de los directores más influyentes e importantes del cine español, habiendo trabajado también para la televisión en numerosos programas y series.

Su otra gran labor artística se engloba dentro de la literatura, terreno en el que ha destacado con numerosos libros y ensayos así como libros de consulta relacionados con el cine.

En 1994 fue elegido presidente de la Academia de las Artes y las Ciencias Cinematográficas de España, y el 21 de abril de 2002 ingresó en la Real Academia de Bellas Artes de San Fernando, con el discurso "El cine en la pintura".

\footnotetext{
${ }^{323}$ Foto: David Roldán. [25-07-2003]
} 
Entrevista:

Entrevistador: Nos podría hablar de la Escuela de Cine que se funda en $1947^{324}$.

José Luis Borau: Esa escuela desapareció hace muchos años. Se funda en el año 47/48 principalmente por unos ingenieros industriales que eran muy aficionados al cine como Victoriano López, o críticos como Carlos Serrano de Osma.

Inicialmente se albergan en un edificio que pertenecía a la Escuela de Ingenieros Industriales, y acaba llamándose Instituto de Investigaciones y Experiencias Cinematográficas.

Esta experiencia dura hasta el año $59 \ldots$

\section{Entr.: $\quad$... ¿No es el año en que usted entra?}

J.L.B.: No. Yo había entrado en el 57.

La primera promoción de aquella escuela fue la de Barden, Berlanga, Florentino Soria, Maeso, etc.

Yo entré más tarde, en 1957, manteniéndome en ella dos cursos. Entonces hubo una huelga de estudiantes provocando la paralización de toda la actividad.

En 1960, se reanudó de nuevo con el nombre de Escuela Oficial de Cinematografía y pasó a dirigirla en un principio José Luis Sáenz de Heredia, que era un director muy avenido régimen y nada sospechoso. Se debe de tener en cuenta que la Escuela siempre tuvo ciertos aires de lugar díscolo y poco adicto. Pero al hacerse cargo de la Escuela Sáenz de Heredia no pusieron impedimentos en volver a abrirla. Creo recordar que la idea de nombrar a Sáenz de Heredia como director vino de Patino, aunque no estoy seguro, y a mi entender fue una buena elección.

Ese mismo año, yo terminé mis estudios allí y cuatro años más tarde, en 1964, comencé a impartir mis primeras clases.

Para esta nuevo periodo, la escuela se traslada provisionalmente al antiguo edificio del Ministerio de Información y Turismo mientras se construye una escuela nueva que se inaugurará en el año 66 , aunque estos datos tendrás que comprobarlos.

\section{Entr.: Realmente nos interesa más la primera etapa. Nos referimos a su fundación} en los años 40 y los primeros años de actividad.

J.L.B.: El Instituto, que era como llamábamos todos, era un lugar donde había mucha afición y pocos medios, aunque esto de la falta de medios es relativo porque se rodaba siempre mucho, aunque nos quejábamos siempre.

Entr.: Esto enlaza con otra de las preguntas que nos interesaban. Después de una

\footnotetext{
${ }^{324}$ Esta primera parte de la entrevista tuvo lugar en Valencia, en la Casa del Libro, el 17 de junio de 2003.
} 
guerra civil y desarrollándose a nuestras puertas la II Guerra Mundial, la producción cinematográfica española es muy alta, incluso me atrevería a decir que mayor que la actual...

J.L.B.: Si. Se producían muchas películas a costa de malabarismos, aunque no tantas como ahora. No había negativo, resultaba caro y en muchas ocasiones llegaba de estraperlo.

Cuando se rodaba se intentaba no derrochar el negativo. Esto obligaba a realizar una única toma o a lo sumo dos. Eran tiempos de extrema pobreza en general y en nuestro país en particular.

Por otro lado, el Instituto tuvo la suerte de que en la primera promoción salió gente muy famosa, lo que ayudó a que fuese reconocida por la industria cinematográfica. Toda la profesión estaba en contra de aquella escuela, porque como decíamos nosotros, todos los que estaban en la industria eran "chusqueros". El cine español era "chusquero" en el sentido de que se entraba, no ya de ayudantes que es bastante lógico sino para llevar bocadillos, para barrer el estudio, etc., y los que trabajaban y eran listos iban subiendo.

Con esta coyuntura, cuando apareció la escuela, los profesionales se burlaban muchos y decían que el cine no se aprendía en las pizarras sino, llevando bocadillos y pasando por todas las etapas por las que había que pasar.

Aquello se vino abajo con el triunfo internacional de Barden y Berlanga. Pero curiosamente, después de ellos no hubo estudiantes con una relevancia suficiente como para mantener el efecto creado por los primeros. Esto hizo que otra vez toda la industria se pusiese en contra y dijera que «Barden y Berlanga bien, pero ¿quién ha salido después?». De este modo, aquel buen efecto inicial se perdió con el tiempo un poco.

Aún así, a la escuela fue mucha gente importante, como por ejemplo escritores. Ingresaron, se matricularon y algunos terminaron. Rafael Sánchez Ferlosio (aunque él lo dejó); Jesús Fernández Santos, que sí acabó; Mario Bargas Llosa, que obtuvo una beca desde Perú para ir a la escuela y luego otra para irse a París, etc., incluso algunos adeptos del régimen como García Serrano que era de la Falange...

$[\ldots]$

Entr.: Según la información aportada por Fernando Médez-Leite en su Historia del Cine Español, en la escuela se daban una serie de especialidades que a nosotros nos parece un tanto extrañas, ¿nos podría confirmar si dichos datos con ciertos?

Según el autor, las especialidades impartidas era: producción, realización artística, electroacústica...

J.L.B.: Eso era sonido.

Entr.: ... óptica y cámaras, escenografía, sensitometría e interpretación 


\section{cinematográfica.}

\section{¿Entonces son ciertos los datos?}

\section{J.L.B.: Si. ¿Montaje está?}

Entr.: No.

J.L.B.: Montaje también había, por lo menos cuando yo entré.

Entr.: Según la legislación aparecida a principios de los años 40, era necesario producir para importar películas. Según la calificación concedida por le gobierno, cada película podía llegar a tener un máximo de hasta 5 permisos de importación (pero esto era en casos contados). ¿Cómo es posible entonces que la relación entre películas importadas y producidas llegase a ser de 6 a $1 ?^{325}$

J.L.B.: Realmente de este tipo de cosas no te puedo decir mucho porque yo en el año 41 tenía 11 años, aunque ya tenía claro a qué me quería dedicar. Más adelante, cuando tenía algunos años más en el 46 ó 47 , siempre oí que todo el mundo hablaba de los permisos de importación.

Como tu bien has dicho, teóricamente era necesario producir para importar, por eso se crearon filiales de las productoras americanas en España como la Fox Film Española o RKO. Teóricamente estas empresas debían producir aquí pero en la realidad, salvo algún caso aislado, no llegaron a realizar ninguna producción.

Universal Film Española distribuía las películas de la Universal, pero producir aquí... nada de nada. Como siempre, "hecha la ley, hecha la trampa".

Una vez producida una película, esta se clasificaba y obtenía una serie de permisos de importación con los que más tarde se negociaba. Por ejemplo, siempre se comentó que este fue el origen de la fortuna de Cesáreo González.

Cesáreo González comenzó produciendo una película que se titulaba Polizón a bordo dirigida por Florian Rey en 1941. A pesar de ser gallego, algo muy importante por aquel entonces, y ser fiel al régimen, no era más que un productor del montón. La historia cambió en el año 46 cuando hizo una película que dirigió Rafael Gil titulada La Fe, inspirada en una novela de Palacio Valdés, y que fue prohibida a pesar de haber pasado la Censura.

Esto me hace recordar que hay tres casos en la historia de la censura en el cine español de los años cuarenta en los cuales, tras pasar todos los filtros reglamentarios de la Censura, éstas fueron prohibidas una vez terminadas por poderes ajenos a la Censura, lo cual hubiera sido suficiente, en teoría, como para que la ésta hubiese dimitido. Pero ahí no dimitía nadie. Estos tres casos fueron: El

\footnotetext{
${ }^{325}$ Esta segunda parte de la entrevista tuvo lugar en Madrid, en el despacho del señor Borau, el 25 de julio de 2003
} 
crucero Baleares, que produjo valientemente la RKO, Rojo y negro y La Fe.

En el caso de El crucero Baleares, fuel el Ministerio de Marina quien prohibió la película. El filme era malo, malo cinematográficamente hablando, pero pasó todos los filtros. Yo me acuerdo de haberla visto anunciada en los paneles de los cines donde se promocionaban los próximos estrenos, aunque no llegó a estrenarse allí en Zaragoza. No se si llegaría a estrenarse en Madrid. El caso es que cuando la vieron miembros del Ministerio de Marina montaron en cólera e hicieron todo lo posible para que se retirara y se prohibiese.

Esto mismo pasó con Rojo y negro, pero en este caso fue la Falange la responsable. Esta cinta también pasó todos los filtros de la Censura y después de su estreno, o una vez finalizada, la Falange hizo todo lo que estuvo en su mano para prohibirla.

Y el tercer y último caso cronológicamente hablando, fue $L a F e$. Una vez terminada la película, la comisión episcopal, o quien fuese de la Iglesia, vieron la cinta y se escandalizaron. Hicieron todo lo que estuvo en su mano para prohibirla.

Entonces, Cesáreo González aprovechó la coyuntura de que la película contaba con todos los sacramentos legales para que no se prohibiese e hizo valer sus derechos y amistades ante el gobierno para que le resarciesen de algún modo. De este modo consiguió que le dieran una barbaridad de permisos de importación, como 8 u 11 (no lo se), desde luego muchos más de los que hubiese obtenido si la calificación obtenida por la película hubiese sido de primera A. De este modo, le compensaron por las pérdidas de una película que por aquellos días costó nada menos que un millón y pico o dos. De pronto este hombre se encontró con permisos de importación por un valor de un millón de pesetas y se aprovechó de la circunstancia.

Estos permisos se vendían y por cada uno se podía llegar a obtener cifras millonarias. Normalmente se comerciaba con distribuidoras americanas que pagaban verdaderas animaladas por estos permisos. Supongamos que por cada permiso se obtenía dos millones. Por esa regla, el señor Gonzáles, que de pronto se encontró con tantos permisos de importación, hizo una tremenda fortuna. Si la película que había hecho le había costa un millón y medio, ahora tenía catorce o quince millones obtenidos tras la venta de los permisos. Aquello era una fortuna indescriptible. Ahí arrancó la fortuna como productor de Cesáreo González, porque debemos recordar que él ya tenía negocios en la hostelería y en algún que otro sitio.

¿Con todo esto a donde quiero ir a parar?, pues a que había películas que no se llegaban a estrenar, o que si lo hacían, al productor no le importaba si iban bien o mal, porque realmente lo que importaba eran los permisos de importación y el dinero que se podía llegar a sacar con ellos. Se producía para luego comerciar con los permisos de importación y doblaje, con lo que el resultado en taquilla del film ni se miraba porque el productor ya había ganado suficiente dinero con los permisos.

Este era el problema de los permisos de importación, aunque yo nunca he echado las cuentas... 
Entr.: Pues hay años en que había una relación de 6 películas importadas por cada una española.

J.L.B.: Pues eso. Chanchullos y manejos del Ministerio por una parte y, por la otra, favoritismos hacia algunas casas concretas, no solo españolas sino también americanas.

[...]

CIFESA, ya había empezado su andadura antes de la Guerra Civil, arrancando como gran negocio a partir de la firma de un contrato fabuloso con la Columbia antes de la Guerra. Por ese contrato, CIFESA se convertía en la distribuidora para España de las películas de esta productora americana, que tenía entre otras las películas dirigidas por Frank Capra.

Después de la Guerra, los permisos que obtenía CIFESA por la producción de largometrajes se aplicaron a sus clientes preferentes... como eran estos....

\section{Entr.: Según aquella legislación, tan solo se concedían permisos a la producción.}

J.L.B.: Bueno. Ten en cuenta que no vivíamos en un Estado de Derecho y todo eran excepciones. Por ejemplo, llegaba Cesáreo González al Ministerio y hacía lo que le daba la gana. El que no podía hacer lo que le daba la gana era el pequeño productor o el independiente. A estos sí se les obliga a cumplir la ley pero una gran productora como CIFESA, que era como la MGM española, hacía lo que quería e incluso imponía las calificaciones de las películas. Recuerda que García Escudero tuvo que dimitir porque se negó a darle la calificación de Interés Nacional a Alba de América...

\section{Entr.: Que se la concedió a Surcos...}

J.L.B.: Exacto.

Alba de América era un horror. CIFESA por aquel entonces comenzaba su decadencia y esta película es un ejemplo.

A pesar del gran éxito de Locura de Amor, CIFESA se lanzó a producir películas históricas pero cuando se estrenó esta otra película el público ya no estaba interesado.

\section{Entr.: Pero es que Locura de Amor no es una película histórica en sí...}

J.L.B.: Locura de Amor gustó porque era una película apasionada pero Alba de América era un rollazo tremendo. He de reconocer que a mi no me gustan estas películas históricas, aunque las he visto in situ, como se suele decir...

Con esta película comenzó a tambalearse CIFESA, pero a pesar de todo, ella todavía tenía la influencia suficiente para ser la responsable indirecta de la caída de García Escudero. 
Entr:: El nivel cultural de la gente en aquella década, con un alto nivel de analfabetismo, conllevaba que distribuir una película en versión original subtitulada era como relegarla al ostracismos...

J.L.B.: Me acuerdo que antes de la Guerra, la gente no quería ver películas subtituladas porque había que leer. En los cines se anunciaban las películas con un letrero donde se escribía «Hablada en español».

Al acabarse la Guerra, se obliga a doblar todas las películas. Oficialmente para proteger los valores patrios y en especial evitar la contaminación de la lengua española.

Esta era la razón político cultural o como quieras llamarla. Por mi parte, creo que el gobierno quería facilitar que el público fuese a ver películas españolas, no ya por razones políticas, culturales o imperiales, sino para reactivar la industria. El gobierno impone entonces el doblaje con la vana pretensión de apoyar al cine español. ¿Qué ocurrió? Que la gente puestos a ver una película hablada en español donde trabajaba Gary Cooper, o una película hablada en español con Rafael Durán, prefería siempre la película de Gary Cooper.

De hecho, a nosotros nos extrañaba que en países como Portugal, con un Régimen similar al nuestro, no se doblaran las películas.

\section{Entr.: Si, porque es contraproducente para la industria...}

J.L.B.: Claro. Todo esto fue una gran equivocación.

\section{$[\ldots]$}

En Italia, entre los años 38 ó 39, se hicieron bastantes películas españolas, surgiendo una situación muy curiosa. Algunos actores españoles resultaron ser muy populares en aquel país: Conchita Montenegro, Juan de Landa, etc.

Esto se debió a que los productores americanos cuando todavía no se había inventado el subtitulaje decidieron hacer versiones en varios idiomas europeos con la intención de obtener mayores beneficios. De todas las lenguas empleadas, la que más se utilizó fue la española, seguida de la francesa y la alemana. Al principio también se realizaron versiones en italiano pero consideraron, cosas que tienen en Hollywood, que era prácticamente igual al español y no merecía la pena realizar esta versión, así que se enviaba la versión española a Italia.

¿Qué ocurrió?. Pues que las producciones americanas que se veían en Italia a principios de los años treinta eran interpretadas por actores españoles, con lo que adquirieron mucha popularidad.

Esto provocó que, en 1938 con los acuerdos entre Franco y Mussollini, los italianos tuviesen mayor predicamento por los actores españoles y que muchos de aquellos filmes se hiciesen en versión italiana y española. Por ejemplo, El último Húsar, de Luis Marquina se hizo en español e italiano. Se llegaron a hacer muchas más que en Alemania donde tan solo se realizaron unas cinco películas, que además 
realizaba una productora nazi teóricamente hispano-alemana afincada allí.

\section{Entr.: Hay muchos técnicos italianos en el cine español de aquellos años.}

J.L.B.: No. Los técnicos italianos vienen a España después de la II Guerra Mundial, cuando las cosas comienzan a ir mal en Italia. Con los alemanes ocurrió lo mismo, aunque estos vienen antes, a principios de la década de los cuarenta, especialmente directores de fotografía como Guerner o Hans .

De todos modos, el aluvión de italianos que se produce vino controlado. La mayor parte de ellos venían contratados por productores españoles. La actriz Paola Bárbara y su marido el director de cine, María Denis, Adila Vally, etc.. También vino a España Vitorio de Sica con su mujer de entonces, María Mercader, pero se tuvieron que volver a Italia porque no encontraron a nadie que les produjera sus películas.

\section{Entr.: ¿Cómo era la visión u opinión del público sobre el cine español?}

J.L.B.: El cine español nunca gustó y en términos generales el cine español de los años cuarenta. Cuando sí gustó algo nuestro cine fue antes de la Guerra Civil. Me refiero a aquellas películas de CIFESA dirigidas por Florian Rey con Imperio Argentina y Miguel Ligero. Nobleza baturra o La verbena de la Paloma, fueron grandísimos éxitos.

Las películas americanas que se exhibían entonces eran las versiones españolas que se realizaban en Hollywood y que eran malísimas. Cada actor hablaba con un acento distinto. Se rodaban aprovechando los mismo decorados y hasta los mismos trajes de los actores americanos. Normalmente se rodaba por las noche 0 al finalizar el americano. Aquellas películas no llegaron a gustar nunca aquí.

Después de la guerra, el cine español era muy malo y no gustaba a la gente. Por otro lado, le habíamos dado a las películas extranjeras el arma del doblaje. La gente prefería ver a Rita Hayworth hablar en español que no a Maruchi Fresno, pero cuidado, eso no quita que hubiese grande éxitos.

Nada más terminar la Guerra Civil, se hicieron unas pocas películas patrióticas. Fueron muchas menos que en Alemania pero se hicieron, y estas películas tuvieron un éxito increíble. Recuerdo que Raza o Sin novedad en el Alcázar fueron éxitos tremendos.

\section{Entr.: ¿Raza tuvo tanto éxito?}

J.L.B.: Muchísimo. Eso lo he vivido yo. Luego ha habido historiadores que por razones políticas han dicho que no, pero eso no es cierto. Yo recuerdo que a mi familia y a mi nos costó conseguir entradas para ver aquella película. Otra película militar que también tuvo un gran éxito fue ¡Harka!, pero luego dejaron de gustar a la gente.

Esto de Raza lo he hablado en alguna ocasión con Julio Pérez Perucha que afirmaba que no había tenido éxito porque tan solo había estado dos semanas en 
estreno, pero hay que entender que dos semanas en cartel de estreno una película era mucho tiempo en aquel entonces. En Zaragoza, por poner un ejemplo, las películas estaban unos días. Las película buenas duraban una semana y las muy buenas a penas llegaban a dos semanas. Me acuerdo que no pude ver en aquel entonces Rebeca porque era muy pequeño y estaba prohibida para menores. Esta película estuvo ¡isolo dos semanas!!. A nadie se le ocurre decir que Rebeca fue un fracaso, todo lo contrario, fue un éxito fantástico.

Ten en cuenta que las películas no se reestrenaban como se hizo luego. Una película se proyectaba y si tenía relativo éxito se mantenía una semana, luego pasaba a cines de otra categoría y así hasta cuatro escalafones. Después desaparecían para siempre. Pero esto ocurría así si vivías en una ciudad suficientemente grande como era Zaragoza. Esto provocaba que la gente acabara hablando de memoria sobre las películas. En algunas ocasiones se reestrenaba algún film, y Raza fue uno de esos casos, no por motivos comerciales sino políticos, pero en esa segunda ocasión ya no tuvo éxito.

Luego había películas aisladas que tuvieron mucho éxito como La tonta del bote, el primer gran éxito del cine español de después de la guerra, que era un sainete. Este largometraje supuso el descubrimiento de dos actores muy malos pero que gustaron mucho, Josita Hernán y Rafael Durán.

\section{$[\ldots]$}

En el año 42 El escándalo fue algo tremendo. No parecía una película española aunque hoy la veas y sí lo parezca. Lo que pasaba es que estaba bien rodada según la ortodoxia clásica de aquel momento.

Hoy en día lees cosas que no entiendes... por ejemplo, Reina Santa. Esta película no fue ningún gran éxito. Lo que ocurrió con este filme fue que Cesáreo Gonzáles quiso "darse el pegote" de contratar a Madelane Carrol para el papel principal. Esta mujer, aunque británica, trabajaba mucho para Hollywood y era muy famosa en la década de los cuarenta. La idea de Cesáreo González era abrir nuevos mercados con esta película porque, todo sea dicho de paso, este hombre era muy ambicioso, algo que no es malo por otra parte. Madelane Carrol vino a España donde le hicieron los trajes y demás pruebas pero antes del comienzo del rodaje recibió un telegrama de los sindicatos de Hollywood advirtiéndola de que si rodaba una película española con Franco no volvería a trabajar allí. Evidentemente, no se lo pensó dos veces y sin rodar ni un solo plano se volvió. La prensa de la época y las voces patrióticas se alzaron para decir que no hacía falta, que mejor que se hubiese ido. Entonces como sustituta se llamó a Maruchi Fresno para que hiciese el papel principal.

Pero sobre todo recuerda que el cine español no gustaba a la gente. Siempre se ponían programas dobles donde se proyectaba una película española junto a otra extranjera, y esto hacía que se viera cine español. Los actores nacionales no gustaban salvo excepciones como la de Jorge Mistral, por el que se mataban las mujeres, o Aurora Bautista, que consiguió un éxito personal sin precedentes.

¿Sabes cuando gustó el cine español, hablando en términos comerciales e 
industriales? El cine español comenzó a gustar, y mucho, a finales de los años 40 y durante los cincuenta con las figuras comerciales que impulsó Cesáreo González como Joselito, Sarita Montiel, Marisol, etc.... sobre todo desde el 55 hasta el 70. Aquellas película fueron grandes éxitos.

Entr.: Durante la primera mitad de la década de los 40 se produce mucha comedia...

J.L.B.: Si. Sobre todo en Barcelona, aunque en Madrid también. En Barcelona CIFESA se asoció con Aureliano Campa. Se hicieron películas como Quién me compra un lío y otras protagonizadas por Mercedes Vecino o Amparito Ribelles.

\section{Entr.: ¿Tenían éxito?}

J.L.B.: No. Pasaban sin pena ni gloria. Pero serían buenos acuerdos de producción, películas muy baratas.

\section{$[\ldots]$}

Un cine de gran éxito fue el religioso pertenecientes a la corriente neocatolicista del momento, a finales de los cuarenta y principios de los cincuenta. Películas como San Judas, Sor Intrépida o Balarrasa fueron éxitos tremendos.

Entr.: Nuestra sensación era de que estas películas se hacían más por impulso de la administración que por el público que atraía a las salas.

J.L.B.: Más que promovidas eran favorecidas. Como tu sabes, la dictadura de Franco tiene muchas etapas y es un error confundirlas. Hay una primera etapa falangista o militar seguida de otra con un predominio de la democracia cristiana, que no era ni democracia ni cristiana, que fue a finales de los cuarenta principios de los cincuenta donde los ministros ya no eran falangistas. Durante ese periodo, la censura favoreció este tipo de películas en las clasificaciones, otorgándolas primeras categorías o de Interés Nacional.

Yo no creo que el gobierno se plantease qué tipo de cine se debía hacer, salvo tal vez nada más terminar la Guerra cuando el entusiasmos era general, porque los que no lo estaban, o habían muertos o callados por temor a las represalias. Pero la otra parte del país que había ganado, y eso es una verdad que parece que no se quiere ver ahora, estaba triunfante. Estos eran los que iban a ver aquellas películas.

Más tarde se dejó de ir porque empezó a entrar una especie de pudor nacional y aquellas películas patrióticas, altisonantes, heroicas ya no gustaban.

\section{Entr.: Algo que nos sorprendió fue las alusiones tan directas que Raza tenía sobre la Guerra Civil.}

J.L.B.: Ten en cuenta que una película en aquellos días que hablaba de la Guerra Civil proponiendo una reconciliación nacional al término de la misma no estuvo mal vista en un primer momento. 


\section{$[\ldots]$}

Un autor muy valorado hoy en día, Edgar Neville, que considero como uno de los grandes talentos de aquellos tiempos, no llegó a cosechar ningún gran éxito.

\section{Entr.: ¿Tampoco La torre de los siete jorobados?}

J.L.B.: Tampoco. Recuerdo que la vi en Madrid durante un viaje que hice con mis padres. Fue un fracaso de público. Las películas de este hombre no tuvieron éxito nunca. $\mathrm{Ni}$ Frente de Madrid, ni El marqués de Salamanca, que fue pagada por la RENFE. Incluso creo que algunas películas de Neville no llegaron a estrenarse. Recuerdo que hizo una película en Barcelona sobre una obra de Rusingnor, El señor Esteve, supongo que se estrenaría en Barcelona pero en Zaragoza no llegó a verse.

Solo tenían éxito las películas de Sáenz de Heredia, Rafael Gil y al final de los cuarenta las de Juan de Orduña.

\section{Entr.: ¿Juan de Orduña no tuvo éxito en su primera etapa?}

J.L.B.: Aquellas comedias como Deliciosamente tontos no estaban mal del todo pero no llegaron a atraer a los cines a mucha gente.

\section{Entr.: No es tan mala la película.}

J.L.B.: Pero debes de pensar en el público de entones. En aquellos días se estrenaban aquellas comedias americanas tan maravillosas como La fiera de mi niña. Además, los actores que aparecían en aquellas comedias eran tremendos. La gente comentaba que los actores españoles "no sabían llevar un esmoquin -decían que-, si iban de históricos todavía, pero con traje...”.

Esto se entiende si pensamos que después de ver a nuestros actores, en el cine del costado o a la semana siguiente veían a Charles Boyer o a todos aquellos actores tan elegantes que no había comparación posible.

\section{Entr.: El Quijote, ¿cómo lo recuerda?}

J.L.B.: El Quijote tampoco tuvo mucho éxito pero se le dio la calificación de Interés Nacional, por razones obvias, y CIFESA hizo un buen negocio. Por otro lado, era la primera ocasión que se veía en España una versión cinematográfica de esta obra puesto que, aunque se había exhibido la versión de Pabs antes de la Guerra en versión original, esta solo la había visto una minoría cinéfila.

Aquella película no estaba mal. Era una visión del Quijote un tanto ramploncilla pero en relación a lo que se realizaba estaba bien rodada, académicamente bien rodada y con seriedad dentro de lo que daba Rafael Gil y aquel cine.

Vuelvo a decir que el cine español de aquel entonces no gustaba, y cuando lo hacía la gente juraba que era porque no parecía española. 
Entr.: ¿La inclusión del nombre del compositor en el cartel podía llevar a la gente al cine?, ¿Eran conocidos los compositores?

J.L.B.: Gustaban las canciones pero los músicos españoles eran desconocidos para el gran público, en cambio cuando una canción pegaba, tanto en el cine español como en el extranjero, hacía ir al público a ver las películas.

La canción de las hermanas Andrews (aquella que decía "ooooooh, Aurora....") incluida en la primera película estrenada en España de los cómicos Adoc y Costello, Atrápame ese fantasma, hizo ir mucha gente al cine para verla (y oírla).

Otro caso similar, pero español, fue Los últimos de filipinas. La canción "Yo te diré" de Jorge Halpern fue uno de los elementos más importantes que influyeron en su éxito.

Entr.: ¿Los nombres de compositores como Parada, Quintero o Leoz no eran conocidos?

J.L.B.: Nada. La gente no se preocupaba de ellos ni de los guionistas...

\section{Entr.: ¿Y de los directores?}

J.L.B.: Si, un poco los aficionados. Tan solo el cinco por ciento de los espectadores españoles conocían los nombres de los directores.

Entr.: ¿Ni siquiera en casos como el de Ernesto Halffter cuando compuso la música del Quijote?

J.L.B.: Eso no llevaba a la gente al cine. Ten en cuenta que el público era mucho menos culto que ahora. Además, España era un país rural, algo que ahora no nos hacemos una idea.

\section{Entr.: ¿Por eso gustaban tanto las películas folklóricas?}

J.L.B.: Claro. Entonces había muchos más espectadores en general en los pueblos que en las ciudades. Películas de esas tan repugnantes folklóricas llegaban a tener éxito en los pueblos y conseguían hacer negocio, pero en las ciudades ya no iba la gente a verlas.

Pero el público de los pueblos no sabía ni siquiera que había un guionista o un director. Eso sí, si aparecía Estrellita Castro cantando "Mi jaca..." la gente aplaudía en la proyección.

\section{$[\ldots]$}

Los espectadores iban al cine por las estrellas y por nada más. Por ejemplo, el público no iba por los secundarios a pesar de ser lo mejor que tenía el cine español de aquella época, igual que tampoco lo hacía de la fotografía, una de las mejores 
cosas que teníamos.

Era un público muy primitivo aunque en las grandes ciudades teníamos nuestra cremita... hay gente que dice que en la época de la dictadura España era un lugar triste y oscuro. ¡Hombre!, era un país triste porque había mucha gente que sufría y las familias estaban desechas (empezando por la mía), pero la gente salía a la calle y se divertía todo lo que podía, se iba a verbenas, etc.. Era triste, en definitiva, porque era una sociedad triste, que no quería hablar de muchas cosas por miedo...

\section{Entr.: La Censura en los primeros años fue más flexible, ¿verdad?}

J.L.B.: Tuvo su lógica. Durante la década de los cuarenta los que hacían cine eran los franquistas por lo que no había que temer nada y, por otro lado, el público que iba a las salas, socialmente hablando, eran los que habían ganado la guerra. Si había algún director que no pensaba así, se callaba y hacía otra cosa. Iquino, por ejemplo, llegó hacer hasta alguna película patriótica aunque se centró en comedias...

La Censura trabajó poco con ellos a no se que se atrevieran con temas espinosos como la Falange o cosas así. Sáenz de Heredia, por poner un ejemplo, no se le ocurría hacer nada de eso.

Cuando la generación de directores se renovó con la primera promoción de la escuela de cine en los años cincuenta, comenzó el trabajo para la Censura. Llegó un momento que las películas las miraban con lupa y, diría más, las prohibían con lupa. De ahí viene ese estilo que tenemos todos los directores de nuestra generación de contar las historias con mucho simbolismo, sin que las cosas sean evidentes. Se perdió el hábito de hablar claramente de los temas.

\section{Entr.: Hay películas en los años cuarenta que resultan muy morbosas...}

J.L.B.: $\quad$.... es que no se enteraban.

Por ejemplo, en los años sesenta, Diferente, era una película homosexual y la Censura no se enteró. Ellos no se percataban... tan solo iban al argumento, a las cosas que se decían. 


\section{Cristóbal Halffter}

Madrid, 18 de marzo de 1999.

Notas biográficas:

Cristóbal Halffte nace en 1930 en el seno de una familia de compositores célebres. Aunque la procedencia de la familia es centroeuropea, el sentir y raíces de la misma es netamente española, habiéndose convertido en representante de nuestra música y cultura en el mundo entero.

Sobrino de Rodolfo y Ernesto Halffter, Cristóbal siguió los pasos de éstos y comenzó a estudiar música con su madre desde muy pequeño. Años más tarde, cuando contaba con veinte años, finaliza sus estudios en el Conservatorio de Madrid,

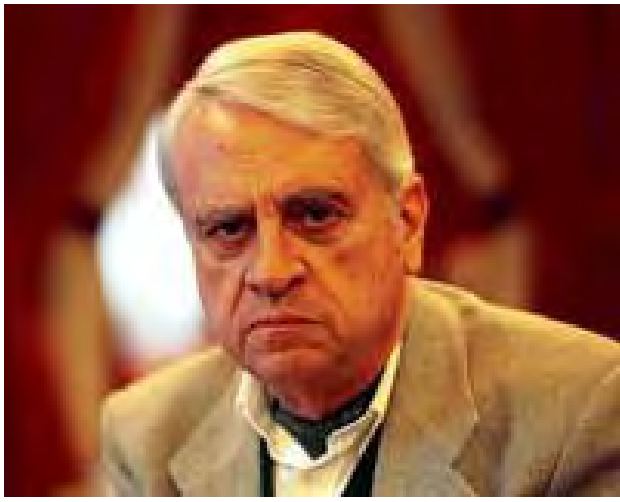

Imagen 98: Cristóbal Halffter ${ }^{326}$ donde tuvo como maestro a Conrado del Campo.

Un año antes comienza su singladura por el cine de mano de otro tío, en este caso político, Luis Marquina que le ofrece hacer la música de El capitán Veneno.

A pesar de ser un compositor poco dado a trabajar para el cine, tiene en su haber algunos títulos de interés como El beso de Judás (1954) (con una partitura disonante y muy contemporánea para la época), El extraño viaje (1964), Murió hace quince años o La pícara molinera (1954).

Cristóbal Halffter ha conseguido a lo largo de su carrera convertirse en el compositor español con mayor proyección internacional del momento. Premio Nacional de Música en dos ocasiones, miembro de la Academia Sueca desde 1989, Premio Europeo de Composición, etc. Sus obras son interpretadas regularmente en todo el mundo y en 1967 la O.N.U. le encargó una cantata en conmemoración de la proclamación de la Declaración de los Derechos Humanos.

En 1999 estrena su ópera El Quijote, en el Teatro Real de Madrid, obra encargada por el propio teatro y retransmitida por numerosas cadenas de televisión.

\footnotetext{
${ }^{326}$ Foto: Anónimo. Extraída de: http://www.larioja.com/portales/vino/premio.html
} 
Entrevista:

Entrevistador: Al igual que una gran parte de su generación, usted estudió con Conrado del Campo. ¿Cómo calificaría su aprendizaje con este maestro? ¿Hasta qué punto influenció tanto en usted como en su generación?

Cristóbal Halffter: Es muy difícil saber cual es la influencia de un gran maestro y compositor dentro de la música tradicional como fue Conrado del Campo, y menos yo, que soy el menos indicado para saberlo.

Entr.: Antes y durante la II República, su tío Rodolfo, realizó dos film (La traviesa molinera (1934) y La señora de Trevélez (1936), y su otro tío Ernesto, compuso la música para el film francés (Carmen). 20 años después, en 1945, realizó su primer film español (Banbu). ¿La experiencia de ellos influyó en su decisión de acometer la realización de la banda sonora de la película El capitán Veneno? ¿Qué otros motivos le llevaron a aceptar este trabajo? ¿Hasta qué punto influyó su tío Luís Marquina en la decisión?

C.H.: La razón de entrar en el cine la tuvo una tía carnal mía, la hermana de mi madre, que estaba casada con Luis Marquina, el director.

Por entonces era estudiante de música y él me propuso hacer la música de El capitán Veneno, propuesta que yo acepté encantado. En cuanto a la influencia de mi tío, Luis Marquina, se reduce a haberme dado la oportunidad de hacer la película.

Entr.: ¿Cómo resultó este primer encuentro con el medio cinematográfico?

C.H.: Fue estupendo y una experiencia muy bonita. Quedé muy satisfecho de cómo resultó.

Entr.: Como ya me comentó su mujer, usted utilizó el cine como un medio para la experimentación que le permitía escuchar relativamente rápido sus trabajos; pero supongo que el método de trabajo no es el mismo que para una obra de concierto. ¿Cómo era ese método de trabajo?

C.H.: Pues el método habitual. Hay piezas que se componen antes de comenzar la película porque se utilizan en play-back, y otras que se realizan ya terminada ésta. Porque claro, las escenas tienen un minutaje, y este depende del montaje que le dé el director. Una vez terminada la escena la música se adapta a las imágenes.

Entr.: ¿Se trabajaba sobre el guión o una vez terminada la película? ¿Trabajaba con el director de la película? ¿Acudía a los rodajes de los filmes?

C.H.: Sobre la copia final, claro. Evidentemente se tienen unas ideas anteriores, y se sabe donde va a ir música, pero escenas que se esperan largas luego acaban durando 
unos segundos y otras cortas se alargan incluso minutos.

Entr.: Para la tendencia de la época, El capitán Veneno, tiene muy poca música

C.H.: Marquina no era muy dado a poner mucha música.

Entr.: ¿Era una opción de él?

C.H.: $\quad \mathrm{Si}$, si. Siempre es una opción de él. Es una opción de compromiso entre el director y el compositor.

Entr.: No es una información contrastada (de hecho no he encontrado por el momento nada al respecto) pero en cierta ocasión me comentó una persona que le sonaba que usted también había producido en alguna ocasión alguna película o había estado relacionado con dicha tarea en algún momento ¿es eso cierto?. De ser cierto, ¿Cómo resulto la experiencia?

C.H.: No, nunca pasó por mi imaginación.

Entr.: ¿Se encontró en alguna ocasión con el problema de que su trabajo se viese rechazado por estar realizado en un lenguaje musical "demasiado moderno"?

C.H.: No, aunque los directores por lo general tienen un desconocimiento total de lo que es la música. Además la utilizan como un elemento similar a la hiedra por los arquitectos. Cuando les sale algo mal, plantan hiedra y lo esconden.

Pero volviendo al tema, como su gusto musical no es demasiado refinado, ... una escena que les ha salido mal (mal rodada y luego mal montada), se les ocurre meter una música grandiosa, wagneriana, y aquello lo que hace es estropearse más. Según mi experiencia en el cine, si una cosa de principio esta mal, sale mal siempre. Y cada vez es más evidente.

$[\ldots]$

Bueno, en general no he tenido problemas casi nunca, aunque, eso sí, me he tenido que amoldar al gusto del director.

\section{Entr.: ¿Con cuanto tiempo se disponía para la composición?}

C.H.: Siempre se dispone de muy poco tiempo, porque es el último trabajo que se realiza antes de las mezclas. Se van acumulando las perdidas de tiempo del rodaje, del montaje, del doblaje (porque entonces las películas no se hacían con sonido directo). Entonces llega un momento en que el productor dice que esto hay que terminarlo, y el último que le queda es la música...

Entr.: ¿Y con cuanto tiempo contaba para la grabación? ¿Se grababa la música viendo la película? 
C.H.: Si, si. Entonces se grababa con la película para poder sincronizar mucho mejor la música, aunque yo siempre lo que he visto muy bueno es adaptarse al metrónomo. Hoy en cambio se hace casi todo por medios electrónicos. La electrónica ha ayudado mucho a la música para imagen, abaratando mucho el producto final, pero se nota.

Entr.: Lo cierto es que en el cine español de las últimas décadas la música sinfónica es casi inexistente

C.H.: Por eso yo no estoy en este momento. No se si me alegro o no. Tal vez si me dan la oportunidad de hacer una película tal y como yo creo que hay que hacerla musicalmente, la aceptaría con mucho gusto. Pero creo que no es el momento. $Y$ cuidado, que con música de cámara se pueden hacer cosas impresionantes.

Entr.: La orquestación de la obra, ¿dependía del tipo de film, de los medios disponibles o de una decisión de carácter meramente artística? ¿Ésta, la orquestación, la realizaba siempre el compositor o por el contrario, debido al poco tiempo utilizado para dicha tarea, esta tarea recaía en otras personas? ¿Y la dirección de la obra delante de la orquesta?

C.H.: La orquestación siempre la he hecho yo, no concibo que la haga otro. En cuanto al tipo de orquestación, todo tenía su importancia.

Entr.: ¿Cuál llegaba a ser la duración media de la música compuesta para uno de sus filmes?

C.H.: Entre cincuenta minutos y una hora.

Entr.: ¿El capitán Veneno tenía mucho menos, no?

C.H.: Si. Algo más de media hora. Tenía un baile, una batalla. ¡Caray!, tenía sólo 19 años.

Entr.: ¿Ahora la haría de otra forma?

C.H.: Pues si.

Entr.: ¿Le pondría otro tipo de música?

C.H.: Seguramente, la experiencia da mucho.

Entr.: ¿Le asesoraron antes de escribir música para el cine de cómo funcionaba ésta con la imagen, es decir, en cuanto a la ubicación y el tipo de música que debía ponerse según la escena, lo que daríamos hoy en día en llamar la interacción narrativa de la música en el cine?

C.H.: No. 
Entr.: En cuanto al apartado económico y laboral. Los contratos, ¿le proporcionaban alguna libertad o control sobre le resultado final de su trabajo?

C.H.: No. En la mesa de mezclas era le director quien daba la última palabra. A pesar de todo, siempre he sido muy bien tratado.

\section{Entr.: ¿Con qué director se encontró más a gusto?}

C.H.: Con todos, aunque tal vez con Luis Marquina. León Klimovsky tenía mucha idea porque era músico.

\section{Entr.: ¿En qué situación se encontraban los derechos de autor por entonces?}

\section{C.H.: Mas o menos como ahora.}

Entr.: Encuentra mucha diferencia entre el método de trabajo de los años cincuenta a la última película que usted realizó.

C.H.: Pues si. Ahora hay muchas más facilidades. Las grabaciones son mejores. Las sincronías... pero creo que la música de cine ha evolucionado muy poco y al compositor sinfónico como yo no nos llaman para hacer música. En general, hoy en día no les interesa mi música a los directores por diferentes conceptos. Y a mi tampoco me interesa participar en ciertas películas que tienen un concepto muy anticuado.

Hay especialistas en música de cine, en música con imagen, que lo hacen muy bien, que lo hacen mucho mejor que nosotros para lo que piden los directores. Por ejemplo, Morricone.

Ahora bien, lo que piden los directores para mi no es el ideal de la música de cine. El cine es un arte que está en el tiempo pero demasiado industrializado. Hay demasiados intereses económicos por medio que privan al director y a quienes hacen la película de que eso se desarrolle realmente en el tiempo. Es decir, la música y el cine son dos artes que están en el tiempo y que requieren su tiempo para desarrollarse, y cuando se hace una imagen sobre una música preexistente, el tiempo lo marca la música. Yo creo que eso es lo que se debe de hacer. Generalmente es al revés. Es la imagen la que tiene su tiempo y el compositor se tiene que adaptar. El que se sabe adaptar sale a delante y yo últimamente no me adaptaría.

"Mira, aquí tienes que hacer música porque esta señora está llorando. Y aquí sale un caballo. Y después la señora se enamora del caballo".

No, la música es totalmente abstracta, entonces cuando las imágenes, que son reales, se adaptan a la abstracción de la música vale la pena. Pero claro, esto supone que para hacer una película yo necesitaría un año de trabajo para componer la música para luego realizar el rodaje sobre él. Pero claro, esto no hay nadie que lo haga. 
Hay un ejemplo en la historia del cine muy ilustrativo. Cuando Pabs, hizo Don Quijote, con Saliapi, le encargaron la música a Ravel. Pabs, le pidió que compusiera tres canciones (que luego llevaron el nombre de Dulcinea), y Ravel se entusiasmó con la idea. Se puso a trabajar y cuando las tuvo fue a ver a Pabs y éste le dijo que la película ya se había estrenado hacía un año. Ravel tardó un año y medio en componer estas tres canciones, que por otro lado son una maravilla. 


\section{Manuel Halffter}

Madrid, 18 de febrero de 1999.

\section{Notas biográficas:}

Don Manuel Halffter es el hijo y heredero de Ernesto Halffter.

Ernesto Halffter, discípulo predilecto y aventajado del maestro Manuel de Falla, nace en 1904, que tras la muerte de éste, se le encargará la finalización de la Atlántida, obra emblemática del maestro nacionalista.

Premio Nacional de Música y altamente respetado en los círculos musicales e intelectuales, su vinculación con el cine comienza ya en la era muda, componiendo la música para la película Carme de Feyder.

Casi veinte años más tarde retomará esta relación con las películas de Sáenz de Heredia, Bambú y el Don Quijote de la Mancha de Rafael Gil, a las que seguirán un nutrido número de títulos, algunos emblemáticos de nuestra cinematografía, que le hacen merecedor de un lugar destacado en el panorama musical-cinematográfico de nuestro país.

\section{Entrevista:}

La conversación arranca comentando un material que habíamos enviado de antemano a don Manuel sobre su padre y su tío, Rodolfo Halffter.

\section{Entrevistador: ¿Hay alguna publicación acerca de su padre?}

Manuel Halffter: Hay un catálogo que publicó la Residencia de Estudiantes el año pasado con motivo de la exposición que se realizó sobre mi padre, escrito por Yolanda Aker.

La exposición sobre mi padre se celebró en la Residencia de Estudiantes, de septiembre a noviembre de 1997. Con ese motivo se realizó un catálogo en el que se escribieron varios artículos originales, y luego una parte de filmografía, bibliografía, discografía, etc... con referencias y soportes informativos además de los artículos de Yolanda Aker, de Alberto Tarazona; en el que se consideraban varios aspecto de la vida y obra del maestro, muy ilustrado y que por la cantidad de datos que incorpora puede considerarse, realmente, como una aportación monográfica, a la poca bibliografía que hay sobre mi padre. Hay artículos, reseñas; pero no hay un estudio monográfico que englobe vida y obra, con su entorno familiar, compañeros de generación, los sitios donde vivió, etc...

Además, Yolanda Aker había publicado en una revista española de 
musicología, un artículo sobre la base de la correspondencia de Falla con mi padre y viceversa, donde se va comentando de los proyectos, como van evolucionando, sus vivencias con el editor, en el estreno de las obras, etc... . Y en Melbourne, donde ella estudió música, había publicado una tesis sobre la obra de piano de mi padre hasta 1939. Tesis apoyada y estimulada por un profesor que está muy interesado por la música hispana, y que quiere que exista en la universidad de allí (y lo está consiguiendo) un centro permanente, con partituras, que durante el curso se impartan clases sobre la materia y se den conciertos de cámara de compositores españoles actuales y no tan actuales.

Volviendo a La traviesa molinera, parece ser que no halla por lo menos localizada ninguna copia de esta película, y sin embargo, presenta varias curiosidades. Está considerada por la crítica como una película avanzada para su época, en el año 34. No era ése el cine que se hacía en España, está mucho más emparentada con otras cinematografías europeas y de Estados Unidos. Por tanto supone un salto en el futuro de lo que nos vamos ha encontrar en muchas películas de finales de los 30 y de los 40, sobre todo en Hollywood y la contribución de músicos clásicos que componen obras para el cine (obras de mucha importancia y valía), y que tienen la ocasión de ver en el cine el marco adecuado para desarrollar sus propias ideas y experiencias. En este caso, el que un compositor de la talla de mi tío fuera el autor de la música, representaba un "empuje" para la película. Y sin embargo, la otra característica es que no hemos podido encontrar copia alguna del film a lo largo del mundo.

La traviesa molinera tiene la particularidad de que figura como autor de la música mi tío, pero en realidad la compusieron los dos hermanos, mi tío y mi padre, lo que pasó es que estaban de acuerdo en que mi padre no figurara en los títulos de crédito. Mi tío Rodolfo trabajó varios temas musicales de la película en París con su hermano. Por aquel entonces, mi padre ya tenía más experiencia en música de cine que mi tío. Había tratado más con compositores que escribieron para cine en París como: Auirc, Poulenc, Honegger, etc.. Estos compositores ya habían ensayado en este medio y ellos estaban más identificados con la problemática de la música en le cine que en España. La valoraban de otra manera. Entonces mi tío, se trasladó a París para intercambiar ideas sobre la cuestión con mi padre.

\section{Entr.: ¿Cuál fue la razón de que La traviesa molinera la firmara sólo su tío?}

M.H.: En aquel momento, Rodolfo era el que iba a completar y a presentar la ilustración musical de la película. Él estaba en España donde Harry D'Abbadie D'Arrast vivía como productor y director. El guión era de Edgar Neville, y todo se desarrollaba en España. Mi padre estaba en París con otros temas, es decir, no podía involucrarse con la película para salir en los créditos con su hermano. Tampoco en aquel momento era un planteamiento que él se hubiera dado. Por lo tanto, tan solo ayudó 
a su hermano. Además, éste solicitó su ayuda para intercambiar impresiones de ideas que ya tenía.

\section{Entr.: ¿La primera película que firma su padre es Bambú?}

M.H.: No, la primera que firma mi padre es Carmen (1926), de Jacques Feyder, con Raquel Meller como protagonista principal. Se trata de una película muda y bastante larga (unas dos horas) para la que realizó una gran cantidad de música, en la que en las grandes ciudades donde se exhibía había una orquesta detrás de la pantalla, y en las otras se utilizaba un disco que parecía un neumático.

\section{Entr.: Fue la época donde comenzó a sincronizarse el sonido con la imagen, ¿no?}

M.H.: $\quad \mathrm{Si}$, la primera película sincronizada fue el Don Juan de Douglass Fairbanks ${ }^{327}$ aunque la cosa no se concretó al final, pero en quien se pensó para realizar la música de esta película fue mi padre. Por que Fairbanks pensaba que nadie era mejor que un español para ilustrar el Don Juan. Se puso en contacto con Falla, este estaba muy ocupado en otras cosas y le dijo que desde luego le encantaba la idea pero que no podía acometer este trabajo, pero que sin embargo, le recomendaba a su discípulo por antonomasia, que ciertamente haría un buen trabajo, y Fairbanks se puso en contacto con mi padre. Luego me faltan datos para saber como evolucionó el tema, prácticamente me atengo a lo que recuerdo que mi padre me contaba. No llegó a concretarse, bien porque mi padre no se encontraba libre en aquel momento, o bien se contrató a un compositor estadounidense por razones prácticas. Pero la idea de Fairbanks, que es lo importante, era que quería para esa película a un músico español.

Realmente eso es lo mismo que hace J. Feyder mas tarde. Con el tema de Carmen vuelve a suceder la misma historia. Se pone en contacto con Falla. Falla le dice "yo no puedo, aquí hay una persona que lo va a hacer muy bien", y después de algunos contactos, unas semanas después estuvo en París.

\section{Entr.: ¿Asistió al rodaje de la película?}

M.H.: Si, si.

Entr.: ¿En películas posteriores él continuó esta costumbre?, ¿Solía asistir a los rodajes?

M.H.: Siempre. Yo me acuerdo de haberlo acompañado a él a los Estudios cuando se estaban haciendo las películas. Y las mezclas. En aquella época era un ejercicio horrible, no sólo por la dificultad intrínseca del tema, sino porque estabas con el tiempo encima. Eso era así, se hacía ya con el calendario en mano diciendo que "la película tiene que estrenarse la semana que viene, es decir, tenemos tres días".

\footnotetext{
${ }^{327}$ En este momento, se refiere realmente a la película de principios del sonoro, Las aventuras de don Juan
} 
Entonces, se metían en el Estudio, y no salían de éste durante dos días. Hasta ir probando las mezclas y encontrar un punto de equilibrio con la moviola famosa, pasando la película para delante, para atrás, para delante, para atrás, etc... .

$[\ldots]$

Aquí, en esta filmografía, falta El amor Brujo (1949), de Antonio Román. La adaptación musical la hace mi padre, y vuelve a hacerla en el año 67 para El amor Brujo de Francisco Rovira Bétera. Tanto Román como Rovira Bétera estuvieron muy interesados en que la persona que realizara la adaptación de la obra estuviera muy identificado con la obra de Falla.

Por otro lado, hay un documental dirigido en el año 55 por Eugenio Martín. Eugenio Martín por aquella época todavía no estaba haciendo largometrajes. Se movía en cine-clubes, en la Universidad de Granada. El documental se llama Viaje romántico a Granada. Para esta película compuso una música con unos solos de guitarra que los interpretaba Regino Sáenz de la Maza. El documental es la descripción de un viaje, de un francés o centroeuropeo, que va recorriendo España con el inmenso deseo de llegar a Granada. Entra por el norte y corta transversalmente hasta llegar al Granada. Esto está ilustrado por los dibujos de Gustavo Doré que sirven de fondo. La película no tiene imágenes reales, ni de naturaleza ni de personas. Los ambientes y personajes están ambientados en los dibujos de Gustavo Doré.

\section{Entr.: En cuento al modo de trabajo de su padre, ¿trabajaba desde el guión o una vez terminada la película?}

M.H.: A él le gustaba estar desde el principio, desde que se comienza a rodar la película y durante el periodo de montaje. Desde el principio le gustaba intercambiar impresiones musicales con el director, es decir, acompañaba momento a momento la realización del film.

Realmente, él era un apasionado del cine y se encontraba muy a gusto hablando con profesionales del medio y, por otro lado, como decía él "todavía no nos hemos dado cuenta de las enormes posibilidades que el cine a abierto a la música, [...] porque el compositor ha encontrado en el cine una serie de vías de expresión que no tiene fuera del cine." Una especie de campo de ensayo. "Yo he conseguido efectos que tenía en mi mente, pero que no encontraban acomodo en una partitura fuera del lenguaje cinematográfico, es decir, en el lenguaje musical cinematográfico he encontrado la clave exacta para expresar lo que yo sentía y quería expresar, pero no encontraba acomodo. He tenido ocasión de probar mis propias ideas en la música que he compuesto para las películas, y por tanto de corregirme; porque unas veces me sirvió para ver que estaba en el buen camino (que la idea era buena y merecía desarrollarla) y otras veces, estaba cerca pero no era eso exactamente."

\section{Entr.: ¿En alguna ocasión tuvo algún problema?}

M.H.: Alguna vez sí. Afortunadamente pocas y con buena solución, porque los directores eran personas comprensivas, flexibles, con una muy buena formación humanística 
y, por lo tanto, había posibilidad de dialogo. A lo mejor, en el primer cambio de impresiones cada uno se quedaba con su idea, pero en posteriores reuniones llegaba a haber un punto de conciliación. ${ }^{328}$

\section{Entr.: Su padre trabajo en repetidas ocasiones con dos de los directores más refutados de los años $\mathbf{4 0}$ como son Sáenz de Heredia y Rafael Gil, ¿con cuál de los dos se sentía mejor trabajando?}

M.H.: $\quad$ Con los dos, igualmente. Lo mismo que en También hay cielo sobre el mar que fue de un director vasco. Película muy bien ambientada en los caseríos, con una música local basada en un estudio comparativo que hizo sobre las diferentes músicas regionales, para componer una partitura que se adecuara a toda la ambientación y trama de la película.

Curiosamente hay una escena donde se le ve a él. Es aquella en la que la protagonista cruza una calle y, en un piso bajo iluminado pero con una persiana entre abierta, hay como el perfil de alguien tocando el piano, y ese alguien era mi padre.

En Bambú Luís Peña cuando va a la casa del gobernador, mientras espera ser recibido por éste, ve un piano y no resiste la tentación de ponerse a tocar. Los planos de las manos tocando el instrumento son las de mi padre.

Me gustaría señalarte, aunque sea del 54, que Viaje romántico a Granada tenía un ballet. Esta música es el germen de otro ballet que él compuso con posterioridad.

Entr.: ¿Él tuvo todos los medios, tanto artísticos como técnicos, que quiso a la hora de grabar?

M.H.: En una época tan difícil en todas las realizaciones artísticas, humanamente él contó con todos los medios que quiso. Las insuficiencias eran mas de tipo técnico. Ahí si que se lamentaba. Como se lamentaba el director. Muchas veces, con Sáenz de Heredia o con Rafael Gil comentaban: "A ti lo que te gustaría sería estar en los estudios de la MGM. Imagínate lo que podríamos llegar a hacer." Y se imaginaban los dos en un diálogo de ciencia-ficción de lo que podrían hacer. Pero más que con la orquesta de la MGM, con los medios técnicos. Él siempre se estaba quejando del sonido. "El sonido, el sonido. No se oye". El sonido era malo. Me acuerdo que en el cine siempre estabas preguntando “¿qué ha dicho?”

Entr.: Cuando se disponía a grabar la música, ¿se grababa mientras se exhibía la película en una pantalla?

M.H.: En aquella época se utilizaba mucho el playback, por lo que esta música se debía de escribir antes de comenzar la película. En cuanto a la música de fondo, ya se tenían bocetos e ideas antes de empezar el rodaje. [...] y a la hora de grabar, se

${ }^{328}$ En esta declaración se refiere a Sáenz de Heredia y Rafael Gil. 
hacía con la película para sincronizarla.

\section{Entr.: ¿Y como era el trabajo en la moviola?}

M.H.: No te podría decir como era ese trabajo.

\section{Entr.: ¿Había posibilidad de realizar insertos sonoros en la partitura?}

M.H.: No, no había esta posibilidad.

$[\ldots]$

Cuantas y cuantas partituras se malograron, en disco y en cine, por culpa de la baja definición de los medios técnicos, porque realmente no se podía dar una idea real de la calidad de lo que el autor había logrado con esa obra. Esto producía una impresión negativa de la obra en el oyente.

Entr.: ¿Su padre nunca se planteo realizar una suite a partir de material cinematográfico?

M.H.: Que yo sepa nunca lo consideró seriamente.

Me estoy acordando ahora del caso de Bambú, donde existe por un lado una obra ya compuesta con anterioridad y arreglada para la película y, por otro lado, canciones escritas para el film que tuvieron posteriormente vida propia.

El resto de la conversación se comentan recortes de prensa diversos. 
Juan Mariné.

Madrid, día 24 de julio de 2003.

Notas biográficas:

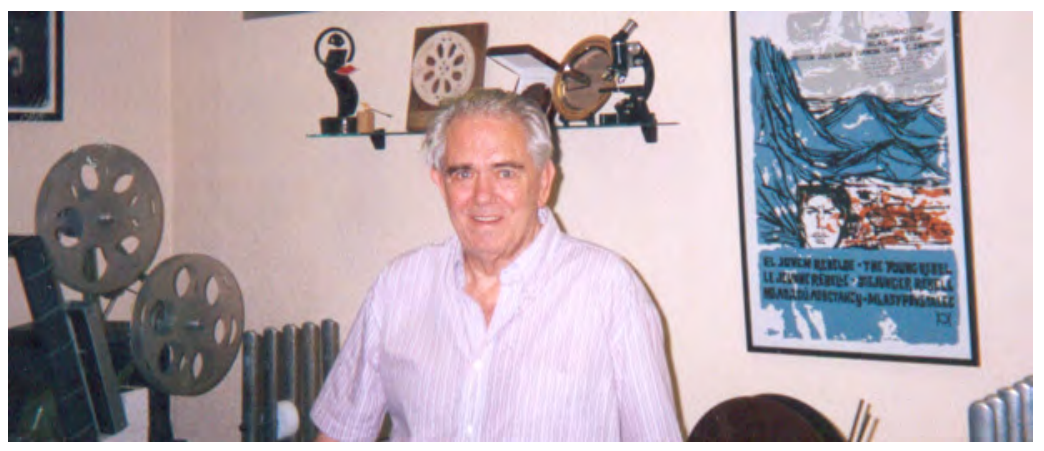

Imagen 99: Juan Marinés29

Juan Mariné nace en Barcelona en el seno de una familia vinculada con el cine en 1920. Cuando cuenta escasamente 14 años comienza a trabajar en el mundo del cine, realizando todo tipo de trabajos. En 1934 realiza su primera película como meritorio, habiendo de esperar ocho años hasta poder realizar su primer trabajo como segundo operador y tres años más para llegar a ser director de fotografía con Cuatro mujeres (1947).

En todo este periodo de tiempo, Mariné sufrirá todo tipo de penalidades por razones políticas e históricas, y se formará bajo la tutela de algunos de los directores de fotografía más prestigiosos de nuestro cine como Alfredo Fraile.

Su fuerte grado de autoexigencia le llevará a convertirse con los años en uno de los directores de fotografía más eminentes de nuestro cine, llegando a recibir numerosos homenajes y premios como el Premio Nacional de Fotografía (1966), la medalla de Oro al Mérito de Bellas Artes (1990), el homenaje del Círculo de Escritores Cinematográficos (1998) o como miembro de honor de la Asociación de Amigos de la Filmoteca Española.

En los últimos años fue abandonando paulatinamente su labor como director de fotografía y fue centrando su atención en la enseñanza y la restauración de películas mudas y antiguas así como la conversión de películas de formatos pequeños a $35 \mathrm{~mm}$. Esta labor la ha desempeñado tan magistralmente que le ha valido un fuerte reconocimiento por parte de gran parte de la comunidad cinematográfica, consiguiendo logros magníficos como la

\footnotetext{
${ }^{329}$ Foto: David Roldán [24-07-2003]
} 
restauración de las dos versiones de La aldea maldita de Florian Rey, Santander en llamas, o La reina joven.

Actualmente desarrolla una labor destacable dentro del entorno de la enseñanza en la Escuela de Cine de la Comunidad de Madrid al mismo tiempo que investiga y desarrolla nuevos métodos para la restauración y ampliación de negativo en dicha escuela.

\section{Entrevista:}

\section{Entrevistador: Su trabajo en el cine comenzó hacia el año 42 . ¿No es así?}

Juan Mariné: $\quad$ Nada de eso.

\section{Entr.: Los primeros datos que tengo son de Deliciosamente tontos como ayudante de fotografía.}

J.M.: $\quad$ Esa fue la primera película en la que rodé yo algunas escenas.

En El octavo mandamiento, de 1934, ya trabajé como meritorio.

En Amores gitanos, cuyo director de fotografía fue Adrián Porcher, comencé como meritorio y acabé como ayudante de foco. Fue una película bastante compleja en la que actuaba como boy Fernando Cortés.

Después fue Incertidumbre, en el año 35, de Sofía y Parellada. La fotografía volvía a ser de Porcher conmigo de ayudante.

Cuando estalló la Guerra, yo estaba rodando como ayudante una película que se titulaba El amor de mi vida que dirigió José Mayon y fotografía de Adrián Porcher. El rodaje de esta película se interrumpió por el conflicto.

Antes de acabar la Guerra se comenzó el rodaje de una película que se titulaba Molinos de viento donde fue a parar como ayudante de foto-fija de Godes. En aquel film debutaba una actriz de la que yo me hice muy amigo, María Mercader.

De esa película pasé a Aurora de esperanza, uno de los filmes más importantes realizados durante la Guerra de España, con Felix de Pomés.

$[\ldots]$

Recuerdo que en una ocasión, el Sindicato le montó un número a Ignacio Iquino por una película... . «¿Usted cree -le dijeron- qué se puede hacer una película con la gente que usted coge? ¿Cree de verdad que estos actores llegarán a ser algo en la vida? ¿Qué puede usted esperar de un hombre que se llama Francisco Martínez Soria? Este hombre no tiene presencia ni vale para nada...»

\section{Entr.: ¿Cómo se titulaba la película?}

J.M.: Paquete, el fotógrafo público número uno. Una de las primeras películas de Iquino. 


\section{$[\ldots]$}

... y con respecto a la actriz... «¿Usted cree - seguían- que esa mujer alta y desgarbada que no vale para nada podrá hacer algo?

-Bueno, estamos haciendo una película cómica.»)

¿Sabes quien era? Mary Santpere.

Iquino apostó por ella y dijo que era una gran actriz, y ella hizo cosas increíbles.

Me acuerdo que había situaciones de acción de alto riesgo en aquel largometraje como en aquella ocasión en que había que disparar con bala a un espejo junto a ella para romperlo. La mujer aguantaba lo que le echaban. Era increíble.

De ahí pasé a trabajar en el noticiario España al día que se hacía en Barcelona con un programa por semana y donde había que salir a rodar por ahí.

Por último me movilizaron para la Guerra y me enviaron al frente donde empecé como fusilero y acabé como fotógrafo junto a Enrique Lister, hasta que pasé a Francia junto al resto del ejército y fuimos encerrados en campos de concentración, de los que me escapé en varias ocasiones.

Más tarde volví a cruzar la frontera en dirección a España otra vez donde me cogieron y me encerraron en otro campo de concentración.

\section{Entr.: ¿Por qué los encerraron en Francia?}

J.M.: Porque allí no dejaban a la gente suelta. Además íbamos de militares. Algunos altos cargos eran más listos e iban preparados y, nada más pasar al frontera, se vestían de paisano para pasar desapercibidos.

Después de ser liberado del Campo de concentración en España, me obligaron a hacer de nuevo la mili y durante este periodo comencé a simultanear el servicio militar con las películas. Fue entonces cuando comencé a trabajar con CIFESA. La tonta del bote, Marijuana, Un marido barato, Legión de hombres, etc...

\section{Entr.: ¿En aquel periodo siempre como ayudante de fotografía?}

J.M.: $\quad$ Siempre, o de segundo operador.

\section{$[\ldots]$}

Yo comienzo como director de fotografía con Cuatro mujeres de Antonio del Amo. La sombra iluminada, La otra sombra, Aquellas palabras, El santuario no se rinde, El capitán Veneno donde aparece ya Sara Montiel.

\section{$[\ldots]$}

Recuerdo que yo le hice las primeras pruebas a Sarita Montiel. Entonces era una niña. Me le mandaron a mi cuando yo estaba haciendo Deliciosamente tontos. Era una niña que acababa de ganar un concurso en Valencia hecho por CIFESA. Era una niña con coletas que no podía hacer papeles de niña ni de mujer así que se 
decidió esperar, y creo recordar que debuta en un pequeño papel en una película hecha por un francés sobre la vuelta ciclista a España, cuando su representante era Enrique Herreros.

Entr.: Por lo que veo y en las películas en las que colaboró, usted debió conocer a Juan Quintero.

J.M.: Si. Él era muy amigo de Mur Oti que fue quien me lo presentó, pero no tuve mucho trato con él.

[...]

A Parada también lo conocí, y recuerdo que decía que con los derechos de autor que producía la cabecera del NO-DO se podía echar a dormir. Hay que tener en cuenta que en aquel momento en que había que pagar los derechos de autor de todo y en todos los cines de España, fuesen del tipo que fuesen (y el NO-DO se exhibía en todas partes) imagina la fortuna que sería.

\section{Entr.: Entonces, ¿era también amigo de Parada?}

J.M.: $\quad$ Bueno, yo en realidad del que llegué a ser un gran amigo fue de Jesús García Leoz y más tarde con quien trabajé mucho fue con Antón García Abril. Con Antón habré realizado tal vez 40 ó 50 películas.

Con Jesús García Leoz más que amigos éramos familia.

Entr.: Nos hemos encontrado con un número nada despreciable de artículos y entrevistas sobre Leoz en la prensa y revistas de la época, algo extraño para un compositor de cine...

J.M.: Jesús llegó a darle donosura a su cargo de música de cine. Por aquel entonces era una "cosa" que un hombre ponía música de fondo a una película y ahí estaba, pero hasta que no comenzaron a salir compositores americanos, franceses, italianos, etc... nada.

Él era un hombre extraordinario, de una humanidad... contar con Jesús en una película era decisorio.

Hubo un momento que para la concesión de los créditos concedidos por el Ministerio, era imprescindible presentar un grupo de trabajo prestigioso formado por los actores, guionistas y, evidentemente, los músicos. Cada nombre determinado tenía una cierta categoría. Dependiendo entonces del equipo que tu presentabas tenías unas ayudas u otras.

El gobierno por su parte vigilaba que esto se cumpliera porque había empresarios que hacían trampa. Presentaban un equipo que luego no era el que trabajaba en la película. A estos se les daba un buen "cogote" en la cabeza.

Yo me he encontrado varias veces con situaciones como tropezarme con gente y decirme...«¡Oye!, he visto que vas a trabajar en tal película.» y yo decirle que 
«no y que ni he hablado con ellos ni lo pienso hacer. Como saben que yo tengo una buena valoración dentro de los equipos técnicos abusan de esto».

Después se pidió que se entregase junto con la documentación el contrato firmado para conseguir las ayudas.

Volviendo sobre Jesús... era extraordinario. Llegó un momento en que él era el mejor, era el gran dios de las música en las películas españolas. Por otro lado, era una persona muy modesta y nada altisonante. Cuidaba mucho las relaciones públicas y era muy cariñoso. Asistía siempre que le invitaban a algo y la gente le apreciaba mucho.

Por otro lado, era un hombre que igual te hacía música de cine que una pieza de concierto, igual que Antón García Abril o el mismo Nieto. El otro día sin ir más lejos la academia le hizo un homenaje a Carmelo Bernaola, otro gran compositor. Se estrenó una sinfonía suya titulada sinfonía ambiental para cine, o algo así, que me recordó en esencia aquella gran película de Sam Wood, Nuestra ciudad. Una verdadera lección de cómo se debe narrar el cine.

[...]

¿Le conté una anécdota de Leoz?

\section{Entr.: ¿Creo recordar algo que me contó por teléfono?}

J.M.: Unos años después de morir Jesús, estaba yo rodando una película que se llamaba Un millón en la basura. Por motivos de trabajo entré en la iglesia de los Dominicos y cuando estaba en mitad del pasillo haciendo unas mediciones sobre la luz para ver que material me haría falta para el trabajo dentro de ella, veo venir hacia mi a Jesús García Leoz. Me quedé agarrotado.

Aquel hombre avanzaba más hacia mi y cuanto más cerca estaba más se sonreía. Yo estaba con cara de espanto. El hombre llegó hasta mi, me puso la mano en el hombro y yo creí caerme al suelo.

- Te veo muy serio- me dijo, y yo le contesté - Si, padre-. Él me preguntó si yo era amigo de Jesús, tras lo cual me dijo que él era uno de sus hermanos.

Aquel hombre era el Superior de los Dominicos que hay al costado del Bernaveu. Lo cierto es que nunca he visto dos hermanos tan iguales. No se si serían mellizos o qué, pero el parecido era asombroso.

Yo conocía a Esteban, su otro hermano, y no se si tendría algún otro.

\section{Entr.: ¿Pero Esteban no se parecía nada a Jesús, verdad?}

J.M.: No. Esteban era totalmente distinto. Esteban era como más navarro. Más bajito, más fuerte.

Luego yo seguí la amistad con la viuda que era encantadora y con sus hijos 
aunque ahora les he perdido la pista.

Entr.: Por desgracia, Azagra es un autor relegado al mayor de los olvidos posibles a pesar de ser el segundo autor más prolífico de la década después de García Leoz...

J.M.: $\quad$... el cine es un sistema de ruedas y engranajes que se mueven unos a otros aunque no lo parezca. Para poder llevar adecuadamente tu carrera debes intentar introducirte en el engranaje más adecuado, algo que yo intenté en su época, porque esto suponía estar en equipos que hacían mejores películas y se disponía de mejores medios, afán de superación, etc.

Había "ruedas" que lo único que pretendían era cumplir un fin, sin afán de continuidad. A esa rueda pertenecía el productor Aureliano Campa que siempre traía, como se dice vulgarmente, como "puta por rastrojo" a Ruiz de Azagra y a Emilio Foriscot (un operador). Ese era otro mundo.

A esa gente parece que no le daba nunca el aire, cuando en realidad la lista de trabajos realizados por estos hombres es increíble. Eran películas que pasaban sin pena ni gloria y que a veces ni se estrenaban.

Por desgracia, Azagra pertenecía a un tipo de gente que no supo desligarse de esta rueda.

Entr.: Durante la década de los años 40 , según la legislación existente, existía un tope para las importaciones de películas y éstas a su vez estaban sometidas a la producción nacional. Si examinamos la producción y la importación de películas extranjeras nos damos cuenta de que esta legislación no se cumplía. ¿Usted sabría decirnos qué era lo que ocurría?

J.M.: En España, la legislación que hubo durante muchos años era que si la película era de tercera categoría no percibía ningún permiso; si la película era de segunda se le daba un permiso de importación; y si la película era de primera categoría se le daban dos permisos. Con esto tu te podías ir "bandeando".

Pero hubo un momento en que Levante Films, CIFESA y unas cuantas productoras valencianas, iban a Barcelona a producir, porque en esta ciudad había estudios, laboratorios, puerto de mar, etc., teniendo en general tenía una serie de ventajas producir en ella. En cambio en Madrid, los estudios estaban en Aranjuez, si exceptuamos CEA (pero estos estaban muy mal). Aranjuez estaba lejos, mal comunicado y resultaba muy caro producir algo en ellos.

Ocurrió que hubo una serie de gobernantes que fueron a CIFESA y le propusieron trasladaba la producción a Madrid a cambio de obtener la productora un gran número de permisos de importación por título rodado. Ellos estaban construyendo unos estudios que iban a ser los mejores y que se llamarían Sevilla Films.

Estos hombres estaban muy próximos al Régimen y estaban interesados en potenciar la producción en Madrid. 
Por aquel entonces, el estudio de Barcelona le costaba a CIFESA 1200 pts al día mientras que Sevilla Films valía ya 7000 pts diarias ya. CIFESA hizo sus número y se vino a Madrid. Y la primera película que hicimos aquí fue Eloísa está debajo de un almendro.

Yo fui una de las tres personas que CIFESA se trajo aquí junto al maquillador Antonio Tudell, del teatro del Liceo de Barcelona, que era una enciclopedia. El Larousse del maquillaje. También vino Jaime Ventura, jefe eléctrico de los estudios Orfea de Barcelona que era rápido y eficaz. Los tres fuimos contratados fijos por CIFESA para trabajar a Madrid.

Aquí se estaba muy bien y cuando CIFESA tenía una película que no llegaba a primera, y le interesaba tenerla ahí, recibía a cambio cinco o seis permisos de importación. Pero llegó un momento en que cambió el gobierno. Aquel nuevo gobierno no tenía nada que ver con Sevilla Films y se eliminaron estos privilegios obteniendo el número de permisos que le correspondían.

CIFESA que había planteado una estrategia de mercado basándose en los permisos de doblaje e importación se vió forzada a reelaborar sus estrategias, y a pesar de que se trajo aquí a Madrid a Campa, la cosa ya no llegó a ser rentable como antes. A partir de aquel momento CIFESA fue dando tumbos hasta que desapareció.

Como es evidente, durante aquel periodo el entramado de Barcelona se derrumbó, puesto que no podían competir. Allí obtenían como mucho 2 ó 3 permisos mientras que aquí se llegaba a 5 ó 6 .

Esa fue la razón del desajuste que tu comentabas. Una serie de señores se trajeron la producción a Madrid a cambio de la concesión de más permisos soterradamente.

Entr.: La rescisión en 1946 de la "obligatoriedad" del doblaje abre la puerta a las películas en versión original subtitulada. ¿Había muchas películas subtituladas?

J.M.: Mira. Hoy la preparación de la gente es mucho mejor. Todo el mundo va al colegio. Muchos hacen segunda enseñanza. Hoy es muy difícil encontrar a alguien que no sepa leer, pero en aquel entonces había mucha gente. Estamos hablando de los años 40 y yo me acuerdo que $\mathrm{ml}$ madre apenas podía leer, y te estoy hablando de gente de ciudad ya no te cuento en los pueblos, donde a las niñas se las mandaba a cuidar cabras y a los niños a apacentar el ganado. Esa gente no sabía leer ni aprendieron y cuando se hicieron mayores, si la película era subtitulada, no podía ir a verla.

Ahora la cosa a cambiado mucho, incluso la gente conoce varios idiomas y se ha producido curiosamente el efecto contrario. Hay gente que prefiere ir a ver una película hablada en inglés porque está estudiando inglés y esas cosas.

$[\ldots]$

No era lo mismo un permiso de importación que uno de doblaje pero iban unidos, 
y se llegaba a pagar tantísimo dinero por el permiso de doblaje que te quedarías asustado.

\section{Entr.: Porque el comercio con los permisos era permitido, ¿verdad?}

J.M.: El negocio se solía hacer con los permisos. De hecho había empresas que hasta hipotecaban los permisos para hacer la película antes de tenerlos. Todo iba bien mientras le concedieran después el número de permisos que pensaban que se les iba a conceder. Si no era así venía el problema y se arruinaban.

Entr.: Observando el número de productoras existente durante el década de los cuarenta el número resultante se eleva casi a cien. ¿Es eso cierto?

J.M.: Ahí pasaba lo mismo que ocurre hoy en día. Si tu miras la producción actual española te darás cuenta que cada productora nace con cada película y muere con ella.

La productora nace con un nombre determinado. Se alquilan unas oficinas y se ponen unos muebles. Al acabar la película, la productora vende todo aquello y desaparece.

Luego, cuando hacienda va detrás para darle en "galletazo" se da cuenta de que no hay nadie.

Es la única solución de sobrevivir, porque si esa productora continúa ahí sin producir y dando el "cayo", con empleados y gastos diversos, se encontraría con que hacienda le está sacando la sangre. Así que la gente huye.

Las grandes como CIFESA, Suevia Films, Roctence, etc., aquellas si producían habitualmente y consiguieron organizar el negocio para que diera dinero pero la mayoría era tirar la piedra y marcharse porque sino hacienda se les iba a comer.

\section{Entr.: Y volviendo sobre los músicos... ¿Cómo era la labor de estos hombres?}

J.M.: Bueno... dependía de muchas cosas. En ocasiones se iba rodando la película y cuando se tenían fragmentos montados se les pasaba a los músicos para que estos tomaran sus notas. En otras, éstos preguntaban cosas o te llevaban a su casa como hacía Leoz, que una vez allí se sentaba al piano y te tocaba la melodía o te iba explicando como quería sincronizar la partitura con las imágenes. Muchas veces te presentaba múltiples opciones que había preparado. Después de hablar contigo se quedaba con la tu opinión hasta el día de la grabación que se presentaba con la partitura completa.

Recuerdo una anécdota muy divertida relacionada con el tema de los músicos... se estaban grabando los play back de una película que se llamaba Saeta del Ruiseñor de Joselito. Dirigía la orquesta el maestro Algueró. Joselito estaba cantando en el auditorio de Sevilla Films cuando de pronto Joselito hace parar toda la orquesta.

El maestro Algueró le preguntó que qué ocurría y Joselito le dijo - no se ha dado 
cuenta que ha entrado mal el segundo trompeta-...

¿Qué te parece?

\section{Entr.: Pues que Algueró debió sentirse violento.}

J.M.: Pues Algueró se vió obligado a darle la razón porque Joselito la tenía. Tu no sabes lo que era Joselito en aquella época. Te estoy hablando de un niño de 6 ó 7 años al que todos queríamos mucho. Era un chaval que lo había pasado muy mal. Era un joven que le gustaba hacer el bien a los demás y dar a los pobres, etc.

Me acuerdo de una ocasión en que llegamos a Mora de Rubielos para rodar unos exteriores. Nos hicieron salir al balcón del hotel donde nos esperaba una rondalla para cantar una jota. Al término de la misma todos aplaudimos menos Joselito. El maestro le dijo que aquello no le había gustado a Joselito porque no era lo suyo, y el niño le respondió que todo lo que era música era de él, porque la música se lleva dentro. Joselito le dijo que tenía engañada a esa pobre gente diciéndoles que para cantar una jota había que gritar y chillar cuando en realidad hay que cantarla con el corazón.

El director le respondió que era su opinión pero que no tenía importancia y Joselito le contestó que sin que sirviese de precedente, y sin cobrar, iba a cantar una jota a aquella pobre gente para que supiesen como había que cantarla.

Joselito desde el balcón cantón entonces una jota. En la vida he visto yo llorar a la gente de esa manera.

Joselito odiaba cantar y aquella vez fue la única, que yo sepa, que cantó por gusto propio. De pequeño, él junto a su familia vivían en Utiel. Su padre era peón caminero y su madre le ponía un delantal por la mañana, le cruzaba la vía y le decía - hijo mío, no vengas tarde esta noche-.

Aquel niño dejado de la mano de dios se vió obligado a cantar en cafés y lugares así para que le dieran de comer. Esto hizo que él identificaba cantar como una obligación necesaria para poder comer, llegando a odiarlo.

\section{$[\ldots]$}

Todo esto te lo cuento para que entiendas la anécdota con Algueró. Yo he visto entrar a Joselito en el despacho de Cesáreo González dando una patada en la puerta para abrirla y decirle al productor que a él no se le hacía esperar, que ellos trabajaban juntos y que además Cesáreo se llevaba el dinero. Si la película que iban a hacer es para los niños y ellos las prefería en color se iba a hacer en color. Me niego a que por ahorrarte algo de dinero se haga en blanco y negro.

Y la película se hizo en color.

En aquella época Joselito era muy importante. Era la época que por ir a cantar Granada al show de Ed Sullivan le dieron 40 millones de pesetas.

Entr.: ¿Me podría usted decir como era el tratamiento de las películas extranjeras a la hora de doblarlas, es decir, como era el proceso de manipulación de la 
música?

J.M.: No,no. Las películas venían con todo mezclado menos el diálogo en una película que se llamaba soundtrack, y de ahí se añadía y se doblaba el diálogo.

Entr.: ¿Entonces por qué se modificaba la música en el doblaje?

J.M.: Yo no tengo ninguna noticia de ello. ¿Qué película se modificó?

Entr.: Ciudadano Kane, El fantasma y la señora Muir, las películas de terror de la Universal, Eva al desnudo, etc... entre otras muchas.

J.M.: Juro que yo no me he enterado de esto. Es más. Cuando se hace un contrata con una película se exige que con ella venga el soundtrack.

Yo no he participado en aspectos de distribución así que no te lo puedo asegurar pero siempre he oído hablar del soundtrack y en España cuando una película se vendía fuera había que mandarla con su soundtrack.

\section{Entr.: ¿En los años cuarenta también?}

J.M.: Siempre. ¿Eso quien te lo ha dicho?

Entr.: Es algo que hemos notado nosotros y los hemos comentado con diversas personas que también se han dado cuenta. En películas de Frizt Lang de su etapa americana, por ejemplo, cada vez que hablan los personajes el sonido cambia...

Entra en el despacho la colaboradora de Juan Mariné, Concha, y se une a nosotros en silencio.

J.M.: Bueno, creo que lo que tu te imaginas es otra cosa. Lo peor que siempre ha habido en el cine español son los guiones y el sonido. Las malas instalaciones que había obligaría seguramente a los encargados de doblaje a que cuando entraran las voces bajar el volumen del soundtrack para que se pudiese entender bien los diálogos en las salas de cine.

De hecho, en el cine español se ha optado en muchos momentos por no rodar con sonido director y doblar después por lo mal que se tomaba el sonido aquí.

Una de las primeras películas que se hicieron después de la Guerra, La tonta del bote, fue rodada muda con la extrañeza de todo el equipo, pero Gonzalo Delgras, su director, quería que se doblase después para que se entendiesen todos los diálogos, y así fue.

Pero siempre se ha tenido el soundtrack por un lado y los diálogos por otro.

Así que eso es lo que tu notarás... 
Entr.: No. Hay un cambio de música total. Por ejemplo, en El secreto tras la puerta cada vez que la protagonista mantiene sus soliloquios desaparece la música de Rozsa y es sustituida por la muerte de amor de Isolde. En El fantasma y la Señora Muir se escucha el adagio de Samuel Barber, etc.

J.M.: ¿Tu sabes algo de esto? (dirigiéndose a Concha)

\section{Concha Normalmente los soundtracks se conservaban.}

J.M.: Concha desde niña ha trabajado en CIFESA, Filmoteca, etc., y de esto sabe mucho.

Concha Los soundtracks se conservaban intactos y se hacía el doblaje encima.

J.M.: $\quad$ El manipular el soundtrack suponía un gran gasto. Un gasto pantagruélico.

Concha Y aquí las distribuidoras lo que querían era gastar lo menos posible. Manipular les encantaba pero lo hacían en cosas fáciles como los títulos, pero en sonido... ni se les ocurría.

J.M.: $\quad$ Yo creo que te equivocas... serán casos aislados.

Entr.: Bueno, nosotros tenemos un buen fondo bastante amplio en vídeo y nos hemos encontrado con esta situación en muchísimas ocasiones, por no decir en casi todas.

Ahora que ustedes dicen esto se me ocurre que sean doblajes posteriores para vídeo o televisión...

J.M.: Ahora que tu vas por este camino te diré. Los doblajes que se hacian hace unos años, sobre todo los estudios metro, se notaba mucho que pertenecían a una vieja época, y muchas película se han redoblado. En esos casos ya no tenían el soundtrack.

Eso es televisión pero en el cine cuando se estrenaban... nada de eso.

Entr.: Según hemos constatado en revistas como Primer Plano y RadioCinema, se daba mucha importancia, sobre todo en la primera mitad de los años 40 , a la música "moderna".

J.M.: En Barcelona había concursos con distintas orquestas. Muchos músicos pertenecían al Jazz Club de Francia. Incluso me acuerdo que más adelante llegué a estar en el estreno de la primera guitarra eléctrica que se tocaba en España. Fue todo un espectáculo. Todos los asistentes al concierto en el Tíboli en pie.

Entr.: Pero a nivel institucional no estaban muy bien vistos, ¿no? 
J.M.: Tal vez, pero cuando había que grabar música para películas se iba a buscar a estos músicos porque eran los mejores.

Yo era muy amigo de Augusto Algueró padre. Este hombre llegó un momento que fue el "bacarrá" del cine español. Lo hacía todo él, pero eso fue más tarde, por la época de Las chicas de la Cruz Roja.

$[\ldots]$

Si a ti te interesa todo esto, te contaré algo que te interesará. Se hizo un intento basado en una película de Betty Boob en que ella cantaba su célebre canción mientras una boita iba saltando sobre la letra sobreimpresa en la parte inferior de la pantalla. Hubo una película de Rosita Moreno, De la sartén al fuego, donde salía esta mujer cantando una canción que decía...

“Después que te fuiste...."(canta)

... acompañando a las misma salía la famosa bolita para que la gente se animase a cantar con la actriz y eso tubo un éxito rotundo. La gente coreaba en los cines la canción y gustó mucho. Además recuerdo que fue una de las primeras películas en color que se hicieron en España.

Entr.: Hemos encontrado artículos en que se habla de "películas-concierto" al estilo de Fantasía. ¿Se llegó a exhibir películas de este tipo en España durante los años 40 ?

J.M.: No. Lo que si había, por lo menos en Barcelona, era conciertos de música de cine en el Hot Club de Barcelona del que yo era socio. Javier Cugat, por ejemplo.

Por otro lado, recuerda que había películas como las de los Hermanos Marx donde se intercalaban muchos números musicales, o Volando hacia Río o La alegre divorciada que eran mitad película mitad concierto.

Entr.: Aunque esto se va un poco del periodo que nos interesa, hemos encontrado material sobre la una películas que nos parece, cuanto menos, peculiar en el panorama cinematográfico español de los primeros años 50 . Nos referimos a Pársifal.

J.M.: Concha te puede hablar mucho de aquella película porque trabajó en aquella productora.

Se dice que la película, dirigida por Mangrané, estuvo supervisada por Serrano de Osma, pero eso no es cierto. En aquellos tiempos obligaban a un director a tener varios años de meritaje y tener un supervisor en la primera película. Por esto se puso a Serrano de Osma, pero de este hombre no hay nada en la película.

\section{Entr.: $\quad \mathrm{Y}$ ¿qué tal es la producción?}

J.M.: $\quad$ La película es digna. El film de un aficionado de los que van al Liceo de Barcelona y se llevan la partitura para seguirla durante la representación. Mangrané era un 
tipo de estos.

Concha Era un pseudo intelectual.

J.M.: $\quad$ Te diré que para mi, la película tiene la mejor fotografía en blanco y negro que he visto yo en una película española. Era de Cecilio Paniagua, un gran operador canario.

Concha Tienes que pensar que Huget en aquel tiempo compraba todas las películas de Godard, de la Nouvelle Vague, que no vendía ni un "chozo". Aunque no le daban dinero las compraba todas.

Se iba a Francia y se traía todo lo que podía. Además era una época en que la gente quería películas en color y estas eran en blanco y negro.

Pero volviendo sobre el Pársifal, se editó hace casi veinte años en vídeo, y a pesar de sacarlo del negativo, se trataba de un telecine muy malo y se veía mal. No se podía apreciar la fotografía tan buena que tenía.

J.M.: Era una película preciosa pero no tuvo el eco que debió tener. Era un largometraje para un público minoritario.

Entr.: Y Garbancito de la Mancha, ¿tuvo repercusión?

J.M.: No. Ninguna.

Entr.: Pero sí hubo industria de la animación, ¿no?

Concha Si, en Barcelona. 


\section{Francisca Martos}

Madrid, el 16 de marzo de 1999.

Notas biográficas:

Francisca Martos, Paquita como le gustaba que le llamaran, fue la mujer del maestro Quintero Muñoz.

Juan Quintero Muñoz nace en Ceuta en 1903 aunque a una edad muy temprana se desplaza a la península, permaneciendo en Madrid la mayor parte de su vida.

Desde muy joven se verá atraído por el mundo del espectáculo y su primer contacto con él será como acompañante de cantantes, como Célia Gámez, o como violinista en teatros.

Durante la Guerra Civil contrae matrimonio con Francisca Martos y conoce, a través de Guadalupe Muñoz Sanpedro a Juan de Orduña que se sentirá atraído de inmediato por su composición Suite Granadina que inspiraría a este último un documental con el mismo título y realizado a partir de la música del maestro Quintero.

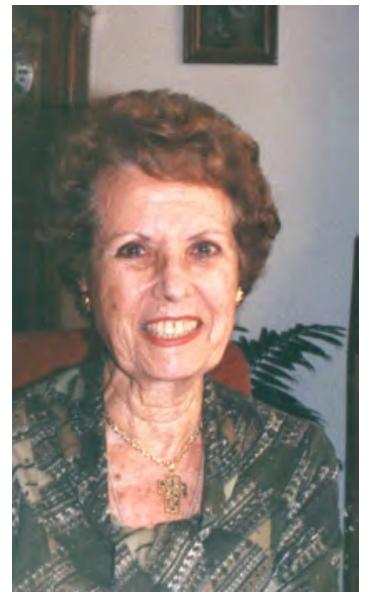

Imagen 100: Francisca Martos $^{330}$

A partir de este momento se convertiría en el compositor "oficial" de Juan de Orduña y posteriormente en el de Rafael Gil, lo que le granjearía una notable repercusión dentro del panorama cinematográfico español de la década de los cuarenta.

Durante aquellos años también desarrolla una labor exitosa en el teatro. Si Fausto fuera Faustina y especialmente Yola, se convertirán casi en fenómenos culturales del momento, dando una gran popularidad al maestro.

A partir de los años sesenta comenzará a reducir su presencia en la pantalla nacional a favor de una mayor actividad institucional como miembro de la dirección de la SGAE, todo ello motivado especialmente por una sordera que fue en aumento y que supuso un fuerte revés para él.

Muere en Madrid en 1980, dejando tras de sí un legado importante en el terreno de la música para la imagen de nuestro país.

\footnotetext{
${ }^{330}$ Foto: David Roldán [1999]
} 
Entrevista.

Entrevistador: Una de las primera cosas que me ha llamado la atención sobre el cine de la época, es la gran cantidad de cortometrajes que se realizaron, ¡Más de 1500! En la década de los cuarenta.

Paquita Martos: Entonces se hacian muchos documentales. Primero se ponía un documental, después el NO-DO, para terminar con la película. De hecho nosotros empezamos con películas pequeñas. Juan ya tenía unas cuantas cortas cuando comenzó a hacer películas largas.

Entr.: También me he encontrado con artículos dedicados al neorrealismo italiano en los años cuarenta, cuando teóricamente no había llegado a España esta corriente.

P.M.: En los cuarenta no había mucho producto español. Incluso no se doblaban las películas como ahora, habiendo grandes luchas de interés con el tema.

Entr.: La primera película que tengo apuntada de su marido, es La hermana san Sulpicio (1934)

P.M.: Él lo que hizo en aquella película fueron las sevillanas, porque la música de fondo la hizo el hermano de Florian Rey. En cuanto a las sevillanas, como Juan era andaluz se las pidieron a él.

Estas se conocen con el nombre de Sevillanas Imperio. Saura, en su película Sevillanas, las denominó simplemente como Sevillanas por Sevillanas, que canta Rocío Jurado.

Después cuando se hizo la versión de Carmen Sevilla, también se utilizaron las Sevillanas de mi marido.

Entr.: ¿Pero la partitura de la segunda versión era de él?

P.M.: $\quad$ Si, era de él.

Entr.: ¿Supongo que lo mismo ocurrirá con El novio de mama?

P.M.: Si.

Entr.: ¿Su marido conocía el trabajo de los compositores americanos?

P.M.: Si, le gustaba mucho. Le encantaba ver las películas americanas y fijarse en la música. Él lo que admiraba realmente, y creo que consiguió, era la utilización de los temas, los levmotives. El tema de amor, el del malo, el del bueno, etc. Utilizar estos temas mezclándolos y haciéndolos entrar en su momento, cambiando constantemente la música. Esto lo aprendió muy bien, siendo uno de los aspectos 
que más interesaban a Juan.

Yo desgraciadamente no pude ayudarle mucho, aunque en eso sí. Durante las sesiones de grabación me ponía con un cronómetro y en escenas corta de apenas unos segundos él me decía: "Paquita, cuando llegue esto tu ve diciéndome si falta mucho o poco". En función de mis indicaciones él iba alargando un poquito para que entrara el tema justo en el momento en el que tenía que entrar.

Él se hacía como un guión con números y después del ensayo me decía: "cuanto tiempo ha durado esto en el ensayo", y yo le decía "pues mira, esto lo justo, a esto le falta, a esto le sobra". Él a esto me respondía: "bien, ahora cuando vayamos a grabar, tu me vas indicando lo que me falta para que el efecto coincida con esto".

$[\ldots]$

Escribía la partitura primero al piano. Más tarde realizaba los ensayos, que los hacía por números.. Si se trataba de un fragmento que tenía que estar sincronizado con algún efecto, este se grababa a la vez que se veía la escena en una pantalla.

\section{Entr.: ¿Qué compositores americanos de cine eran los que más le gustaban a su} marido?

P.M.: Max Steiner, Miklos Rozsa, etc....

\section{Entr.: ¿Él trabajó con medios?}

P.M.: Cuando Juan empezó en el cine, él era muy pobre. Recuerdo que por hacer una película Juan (mi marido) cobraba unas 5.000 ó 10.000 pts.

Como Juan estaba muy interesado en conseguir los mejores medios y el mayor número de músicos, acababa llegando a un acuerdo con la productora por el que él se encargaba de todo. Ellos le preguntaban que cuanto creía él que costaría hacer la música, a lo que Juan respondía, por ejemplo, con 10.000 ó 12.000 pesetas. Entonces la productora le daba 20.000 '9 25.000 pesetas para que él se encargara de todo. De este modo todo salía mejor.

$[\ldots]$

Durante la guerra mi marido (que todavía era soltero) trabajaba en el Infanta Isabel donde había un teatro. Allí trabajaba con él Guadalupe Muñoz Sanpedro, que debido a los bombardeos se fue a vivir cerca de donde vivía mi marido. Durante este periodo oía mucho tocar el piano a Juan y ella se lo comentó a Juan de Orduña diciéndole: "en mi escalera vive un músico, un pianista, excelente que toca muy bien el piano".

Orduña, que era un gran aficionado a la música clásica quiso que le presentasen a mi marido para que le tocase piezas al piano. Y un buen día Guadalupe lo hizo. Por aquel entonces Orduña era sólo actor. $Y$ a partir de entonces tuvimos una amistad enorme. Siempre íbamos juntos a todos los sitios, a Barcelona, a los toros, a comer, etc. 
Por aquel entonces fue cuando empezó a escuchar la Suite Granadina, entusiasmándose con ella. Siendo por entonces cuando comenzó a hacer documentales, primero Ya viene el cortejo, y segundo la Suite granadina. Para este documental se inspiró en la obra de mi marido, y estructuróo y montó la película partir de la música de mi marido.

\section{Entr.: Entonces es de suponer que con el director con el que mejor trabajaría su} marido sería con Orduña

P.M.: Sí, sin duda alguna. Pero mi marido tenía mucho trabajo y no podía dar abasto, sobre todo por las producciones de CIFESA de donde le estaban llamando cada dos por tres para trabajar con Rafael Gil o con algún otro.

\section{Entr.: ¿Cómo trabajaba con Rafael Gil?}

P.M.: $\quad$ Era el mismo estilo. Le daba un guión donde le decía donde debía ir música o tal efecto.

Pero con el director que más a gustaba trabajar era con Orduña. Él (Orduña) decía, que cuando llegaba la grabación de la orquesta era el momento que más disfrutaba. El problema era el productor que siempre estaba con prisas y el trabajo había que hacerlo rápido. Me acuerdo que Juan, siempre se quejaba de esto y me decía, "a ver si un día me dejan hacer una película con el tiempo necesario".

Entr.: Eso sigue igual ahora. De hecho en el cine español tener una orquesta sinfónica puede ser casi un lujo.

P.M.: ¡Qué vergüenza!.

$[\ldots]$

Cuando terminó la guerra un músico cobraba unas cinco pesetas la hora. Incluso variaba según la ciudad. En Madrid costaba siete pesetas la hora mientras que en Barcelona sólo cinco, por lo que muchas veces se iban a grabar a Barcelona.

$[\ldots]$

Entr.: Retomando el tema que nos trae aquí. A la hora de componer, su marido trabajaba mucho sobre el guión o cuando el copión estaba terminado.

P.M.: Él trabajaba primero con el guión, pero el trabajo más fuerte era cuando le mostraban el copión. Entonces había que afinar en todo con mucho cuidado.

\section{Entr.: ¿Asistía a los rodajes?}

P.M.: $\quad \mathrm{Si}$, asistíamos mucho a los rodajes. Entonces todo era mucho más familiar, todos nos conocíamos y éramos amigos, ... me conocían y me querían, incluso los ingenieros de sonido. Muchas veces, cuando grabábamos, Juan me pedía que fuera con el ingeniero para ver si realmente sonaba lo que él quería, puesto que el 
ingeniero muchas veces no sabía el efecto que deseaba marcar Juan.

Por otro lado, la principal queja de Juan era del poco tiempo que le daban para componer. Había ocasiones en que tuvo que escribir una partitura en 15 días. Para él esto era muy poco tiempo porque se encargaba de todo, de componer, orquestar ensayar y dirigir la orquesta, sin olvidarnos de que también asistía a las mezclas.

\section{Entr.: ¿Cómo era el trabajo de las mezclas?}

P.M.: Bueno, yo ahí no puedo decir mucho porque este trabajo se hacía por las noches y era muy pesado, por lo que yo casi nunca fui.

\section{Entr.: ¿Quiénes estaban en estas sesiones?}

P.M.: $\quad$ Bueno, pues el director, el montador, el montador de sonido y el músico.

Cuando el trabajo era de Juan de Orduña, este siempre quería que se oyera la música lo más posible porque le gustaba mucho. Claro está, siempre y cuando no perjudicara a la película.

Entr.: Durante los años cuarenta ¿se planteó en algún momento la edición discográfica de fragmentos de música de cine, como por ejemplo la música de El clavo?.

P.M.: $\quad$ No. Por eso no tengo casi nada de mi marido.

Entr.: ¿En qué género se encontró más a gusto?

P.M.: A él lo que más le gustaba era trabajar en películas que le permitiese escribir muchas melodías. Especialmente le gustaba entregar dichas melodías a los violonchelos.

Entr.: ¿Él empezó como violinista y pianista?

P.M.: Él era sobre todo pianista y habría sido un gran intérprete de no haber tenido las manos tan pequeñas.

Entr.: ¿Su primer contacto con el cine lo tubo en salas cinematográficas como músico de cine mudo?

P.M.: Más que eso, era en los descansos donde él tocaba. También trabajaba en cabarets acompañando a cantantes y bailarines. Esto le dio mucha versatilidad porque te tocaba desde un tango, pasando por un waltz, hasta llegar a un nocturno de Chopin.

Me acuerdo que vino a España un cantante de tangos muy importante llamado 
Espaventa, y después de conocer a mi Juan ya no quiso que le acompañara nadie.

Entr.: Y dentro de este tipo de música, ¿cuál era la que más le gustaba?

P.M.: Le gustaba la buena música. Y en el único sitio donde le daban la oportunidad de componer a su gusto era en el cine. Algo que le molestaba mucho era no disponer de buenos cantantes en las comedias musicales para las que compuso la música.

Juan trabajó varias veces con Sáenz de Heredia en comedias musicales para el teatro, siendo éste el libretista. Esto fue gracias a que ambos veraneaban juntos en el Escorial a lo que habría de sumarse su afición por el teatro. Con el tiempo surgieron dos proyectos que fueron para Celia Gámez, a la que Juan acompañó cuando ella cantaba tangos a los diecisiete años.

$[\ldots]$

Y luego Celia le pidió a Juan que hiciera Si fausto fuera faustina.

Entr.: ¿El control definitivo de la parte musical lo tenía su marido?

P.M.: $\quad$ Mas o menos. Nunca tuvo problemas con ese tipo de cosas.

Entr.: ¿Qué teorías tenía sobre la utilización del silencio?

P.M.: Él consideraba que debía haber menos música y más silencio pero no hacían otra cosa que pedirle música a pesar de sus reticencias.

Entr.: ¿Era muy diferente el sistema de trabajo que tenía su marido en los años cuarenta de cómo trabajó después en los sesenta?

P.M.: Algo cambió, pero como siguió trabajando con los mismos directores, esto no supuso grandes cambios.

$[\ldots]$

Después le sobrevino una sordera bastantes años antes de morir. por eso en los últimos años ya no quería aceptar proyectos. Fue operado por Antonín Candela y quedó bien aunque tenía que estar siempre con el aparato.

$[\ldots$.

\section{Entr.: ¿Y los premios?}

P.M.: Obtuvo varios pero yo no me acuerdo.

\section{Entr.: ¿Cómo era su relación con los otros compositores?}

P.M.: La verdad es que estaba un poco apartado, pero conocía y era amigo de Guerrero, Moreno-Torroba, etc... 


\section{[...}

El resto de la conversación se desvía hacía la SGAE, así como comentarios sobre diversas fotos que nos iba enseñando. 
José Antonio Nieves Conde:

Madrid, 17 de marzo de 1999.

Notas biográficas.

Nacido en Segovia en 1911, José Antonio Nieves Conde lleva una vida más o menos fuera del mundo del cine hasta que asiste al rodaje de La aldea maldita de Florian Rey, momento éste que le cambiará la vida.

Decide dejar su trabajo en un banco y mudarse a Madrid para entrar en el mundo del cine. Durante unos primeros años escribe como crítico en Primer Plano y a mediados de la década de los cuarenta consigue realizar su primera película.

Amante incondicional del cine clásico americano, y en especial del cine de la Warner y del policíaco, Nieves Conde realiza una serie de películas donde este tipo de cine es una claramente influenciada en estilo y género.

En 1949 realiza Balarrasa, película religiosa que le encumbraría a la fama. Después de este singular éxito, lleva a la pantalla una historia cruda y realista sobre la desintegración de la familia, Surcos, film con el que tuvo muchos problemas de censura, especialmente religiosa.

En los años siguientes, seguirá desempeñando una ardua labor como director con resultados muy desiguales. Los peces rojos y El inquilino suponen otros dos títulos a resaltar. A mediados de los años setenta abandona la dirección dejando un legado indiscutiblemente importante.

En la actualidad es considerando un realizador destacado e importante del cine español y de su generación.

Entrevista:

Entrevistador: $\quad$ Algo que nos sorprendió mucho buscamos en Primer Plano, fue la abundancia de artículos sobre el Neorrealismo Italiano a finales de los cuarenta. ¿Usted se acuerda de cómo entró el Neorrealismo en España? ¿Antes de hacer Surcos, usted vio algo de los italianos?

J.A. Nieves Conde: Pues prácticamente no. Tanto mi mujer como yo éramos fundadores de la revista y nos conocimos allí. Lo que hacía la revista era lo que hacía las demás: copiar lo que se decía fuera. Creo que no había corresponsal en Italia sino una muchacha que se dedicaba a seguir lo que decían los americanos. Ella traducía al español de estas revistas americanas. Sabía muy bien inglés y había vivido en 
Inglaterra.

En realidad, la información que yo tenía sobre este tema se puede resumir en el visionado de una película que vimos en la embajada italiana, donde se proyectaban películas este país. Era un film de marinos, de donde se supone que arranca el Neorrealismo. De hecho Rosellini era el ayudante.

[...]

Por otro lado, Rosellini, según se supo por aquellos días, se matriculó en la escuela de cine por motivos políticos más que cualquier otra cosa.

En cuanto a nosotros, lo que teníamos era un conocimiento literario de lo que se contaba, pero en realidad de películas italianas lo que llegaba eran filmes oficiales, [...] como La corona negra, de Castellani, las películas de humor de De Sica; que poco o nada tenían que ver con el Neorrealismo.

\section{$[\ldots]$}

Ahora bien, que eso nosotros lo tomáramos como ejemplo es mucho decir.

\section{Entr.: Nos llamó la atención fue ver artículos a finales de los cuarenta de películas como El ladrón de bicicletas.}

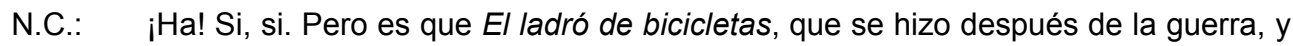
se importó a España tranquilamente como la cosa más natural del mundo. Creo que la distribuyó Chamartí. Por lo menos la primera vez que yo vi El ladró de bicicletas fue en una sala privada de Chamartí.

\section{$[\ldots]$}

Cuando pasaron la película en la sesión privada me contaron una anécdota de Alfonso Sánchez, aquel famoso crítico. Fue uno de los primeros en ver la película, y sin doblaje, como yo la vi. Cuando le preguntaron que qué le había parecido la película, y él contestó "joder, es una película sin importancia. Si lo único que tiene gracia es un niño que hace pis en una esquina". Más tarde cambió la cosa y dijo era cine, muy buen cine. No crea que es el primero.

\section{Entr.: En su cine hay una profusa utilización del silencio y una escasa presencia de la música.}

N.C.: $\quad$ En Surcos, por ejemplo, hablé con Leoz. El maestro era muy conocido antes de la guerra y tenía una amplia experiencia en el cine. Además, según me contaron, él antes de la guerra se dedicaba a ser un amanuense de la música. Como había entonces. y sigue habiendo ahora. Por ejemplo: Nino Rota. Usted veía una película de Nino Rota y en la dirección musical solía estar Carlo Savina. Estos músicos son más prácticos. Nino Rota casi no hacía nada, era Carlo Savina quien 
le acoplaba la música, la orquestaba y dirigía.

Luego hay otros músicos como uno con quien trabajé que me envió la música grabada hasta con los silencios. Le enviamos el copión a Roma, que era donde trabajaba, y él entonces acopló la música como creyó que era mejor, dejando los silencios donde le daba la gana. Cuando el copión vino de Roma. Vino el rollo de música completo con los silencios. A pesar de ello, tuve que alterar varios pasajes de la música. Más tarde me dijo que era una lástima que no se lo hubiéramos dicho antes.

En cuanto a Leoz, ya antes de la guerra había intervenido como "el práctico".

La primera película que yo hice con él, que ha desaparecido, se llamaba...

Entr.: ¿Llegada de noche?. Tenemos como primera colaboración entre los dos Llegada de noche.

N.C.: No. Llegada de noche es la tercera película. La primera es.... ¿cómo se llamaba?

$[\ldots]$

Leoz no intervino en la primera película....

Entr.: La primera película suya que tenemos apuntada es Vidas cruzadas, como guionista, y Senda ignorada como guionista y director.

N.C.: Senda ignorada, exactamente.

Entr.: La música la firma Jesús Guridi.

N.C.: Exactamente. Los productores de esa película era un grupo muy curioso. Estaban agrupados alrededor del diario YA, y uno de los socios era Gil Robles, el famoso político. Eran medio vascos y me preguntaron si tendría algún inconveniente en que hiciera la música el Sr. Guridi. Yo no puse ningún impedimento. En realidad no me lo había planteado todavía.

Yo de Guridi tenía información, puesto que era muy importante. Era un compositor muy dedicado al problema vasco a parte de ser un gran músico. Había hecho varias películas producidas por UFILMS. En parte me vi obligado a aceptar la colaboración de este hombre.

\section{$[\ldots]$}

Guridi solicitó la colaboración de un músico más práctico. Fue entonces cuando él me presentó a Leoz.

Para la segunda película, Angustia fui yo quien llamó directamente a Guridi. De hecho hay en esta película se dio una situación muy interesante. En un momento determinado del film en que la familia de uno de los protagonistas van a un concierto, probamos ha invertir el proceso, algo que nunca más volví a repetir. No hicimos la música sobre la película, si no que hicimos la película sobre la música. 
Le dije a Guridi: "me va usted a hacer la obra que suena en el concierto, que tiene una duración de unos siete minutos. Pero no quiero una música como la suya. No quiero algo clásico sino algo impresionista. Y se va a ir usted a ver tal película ${ }^{331 "}$ para orientarle.

Fue a ver la película y cuando nos vimos le pregunté que qué le había parecido. Me respondió que se trataba de una partitura con una fuerte influencia de la Escuela de Viena. [...] Al final acabó realizando una partitura en esa línea.

Se rodó la escena mientras se escuchaba la música. Con la partitura musical yo fui marcando los planos. De este modo, cuando se comenzó el rodaje de la película, en la calle y en los decorados, se tuvo en cuenta el tiempo que yo había marcado. Es algo que no he vuelto a hacer por el alto costo que suponía trabajar así, pero si he de ser franco, los resultados fueron extraordinarios.

Además, los músicos eran de verdad. Creamos un decorado que simulara el escenario donde tocaba la Orquesta Sinfónica, y trajimos a músicos de esta formación en vez de actores. El hermano de Florian Rey, dirigió la orquesta que se interpretaba mientras se grababa. Primero se rodó por bloques, y después en su totalidad, cosa que le extrañó mucho al director musical. Y la montadora tuvo que editar utilizando como base la música.

[...]

Las grabaciones de la música en las últimas películas que realicé costaron muchas más horas de estudio que las antiguas. Esto se debía a que ya no se hacía con la proyección. Uno llegaba a "tirarse" hasta dos días.

En la antepenúltima película que realicé le dije al músico: "no lo vamos a hacer así, usted va a hacer lo siguiente. Me va escribir una pieza que dure diez minutos como máximo". Una vez que la tuvo: "ahora, va a registrarse trompetas solo. Violines, solo.". De este modo se ahorró mucho tiempo y una grabación que tenía que haber salido por 250.000 pts tan solo costó 60.000 pts como máximo.

Cuando llegó el momento, todos esos bloque se mezclaron adecuadamente y se fueron insertandose en la película de un modo adecuado.

$[\ldots]$

Estas fueron las experiencias que yo tuve en el terreno musical. Algo que siempre me ha preocupado en el cine sonoro, ha sido el gran descubrimiento del silencio en el cine sonoro. El silencio como hecho dramático. $\mathrm{Y}$ como consecuencia de la música. Yo por principio no me gusta la música en el cine.

$[\ldots]^{332}$

Entr.: Orson Wells comentaba que lo que más le gustaba de Norte América era la profesionalidad de los técnicos de grúas, y otros. Que en Europa era muy

\footnotetext{
${ }^{331}$ Una producción americana con música tipo Miklos Rozsa

${ }^{332}$ la conversación se desvía hacia Kubrick y Orson Wells, y el sistema de producción Americano.
} 


\section{difícil de encontrar, sobre todo porque no se les pagaba lo suficiente.}

N.C.: $\quad$ Pero no es sólo por el dinero, sino porque son hijos y nietos de esa gente. Son unos profesionales que además tienen prestigio.

$[\ldots]$

La primera película que realicé con Leoz fue... Balarrasa.

\section{Entr.: ¿No cuenta en esto Llegada de noche?.}

N.C.: $\quad$ Pues no. No tenía nada que ver Leoz con aquella. Tal vez trabajara como práctico ya que recuerdo que había un número folklórico, aunque no me atrevo a decir ni que sí ni que no.

Balarrasa fue realmente aquella en que trabajó de un modo completo Leoz conmigo. Para introducir la película, hizo una especie de cantata. Esta obra la registramos en una iglesia que ya no existe. En la iglesia del Buen Suceso, porque era el templo que mejor sonaba en Madrid según Leoz. Allí fuimos una mañana con el equipo de la Fol-Selgas. Durante una mañana nos dio tiempo para hacer tres tomas de sonido de la cantata lo más perfectas posibles. En aquel lugar se consiguió un sonido muy peculiar y característico de iglesia que resultó muy adecuado. En el plató no se hubiese conseguido nunca.

Años más tarde se habilitó un lugar para los registros sonoros en los estudios, pero hasta entonces la música se registraba como nosotros habíamos hecho siempre, en los estudios, en Chamartí, Sevilla Film... y estos registros se hacían con proyección.

\section{Entr.: ¿Cómo trabajaba el guión con el músico?}

N.C.: En el mismo guión le hacía las anotaciones pertinentes. Aquí hay música, aquí no la hay, aquí hay duda. Después se hablaba de las características de la música. De hecho, en Surcos hay muy poquita música porque casi no marqué nada. Recuerdo que él mismo me preguntó: "¿es tan poca?". Si hubiese sido por mi le hubiera quitado toda salvo los títulos o algún que otro momento determinado. Él entonces escribió algo así como una "punta" con la idea musical de la película para acoplarla en los momentos decisivos. De hecho hay dos bloques más en que suena música que en el guión no estaban. Al ver el copión, la montadora sugirió que aquellas escenas debían ir con música, algo que por otro lado era cierto, y al final se puso música en ellos.

Surcos es una película que rodamos con sonido directo, incluso en la calle, con sus ruidos.

Me acuerdo que nos llevábamos un aparato de Chamartí para tomar el sonido. Registrábamos la escena en la calle y como había mucho ruido de fondo me llevaba a los actores hasta un portal y con el micro les decía que repitiese la escena con la misma entonación y ritmo. De esta forma la montadora tenía por un lado el sonido directo de la calle y por otro el sonido del plano a parte. Lugo le 
tocaba ir acoplando frase por frase.

\section{Entr.: Ahora las cosas son más sencillas con los nuevos médios.}

N.C.: Por eso es tan mala la música de estos chicos que hacen películas ahora. Primero, no se oyen las palabras, no se oye nada en la calle, los fondos se comen todo. Además, los actores de ahora hablan mal, no saben modular ni vocalizar, lo hacen todo de cualquier manera....

Antiguamente, cuando yo comencé con Rafael Gil de ayudante, se rodaba con sonido directo en los platós y lo que se doblaba eran las tomas de la calle o las que no habían salido bien en el plató. De esta manera se doblaba solo un $20 \%$ del total.

Más tarde, vino la manía que trajo Berlanga de rodar sin sonido. $Y$ yo, la primera película que tuve que rodar sin sonido fue por obligación. Me encontré de pronto con que no había equipo de sonido....

A pesar de ello, puse como condición para trabajar que aunque fuese un solo hombre, éste debía ir tomando los sonidos de referencia. De este modo cuando se doblara se podía uno apoyar en un sonido de referencia.

$[\ldots]$

Lo que hacían los montadores de aquella época, como Rojo, era pasar poco a poco imagen tras imagen y leían perfectamente los labios, siendo capaces de saber si el actor había dicho bien su papel o se había equivocado en lo más mínimo. Luego vino el magneto y eso complicó la cosa de mala manera.

Entr.: Recapitulando, a la hora de grabar la música ¿se proyectaba la película como en E.E.U.U., y se hacía simultáneamente?

N.C.: Efectivamente, el músico llevaba su partitura y lo que se controlaba era la duración. Él ya había visto el copión y por lo tanto ya tenía la idea de la duración. Luego, con la proyección se ajustaba totalmente. Había veces en que cuando lo grabábamos yo le decía a Leoz, "en esta escena no hay tensión", y él mismo corregía allí y le aumentaba la tensión sobre la proyección. Pero esto es lo que hacían los americanos como Steiner y los demás. Esta era una de las razones por la que la música nos llevaba dos o tres días. Por eso en las películas americanas de los años cuarenta y cincuenta, usted verá como la música de Miklos Rozsa prácticamente nunca se aparta de la imagen, y esto se conseguía tanto por estar escrito como luego grabando sobre la proyección. Porque no se crea que era tan fácil. Bronislau Kaper, uno de los grandes músicos americanos, hizo una cantata de toda una película, y se seguía.

$[\ldots]$

Entr.: ¿Cuánto tiempo se le daba a Leoz para componer la música? 
N.C.: Se le pasaba un guión con las anotaciones pertinentes sobre la música. Unas semanas más tarde nos reuníamos para hablar y ultimar los temas. La verdad es que se le daba muy poco tiempo. A Leoz esto no le preocupaba, pero durante el rodaje él ya sabía que es lo que iba a hacer. Venía a los rodajes, veía lo que se iba rodando. $Y$ durante todo este tiempo iba trabajando. Por último, desde el momento en que se terminaba el copión hasta que se hacía el registro de la música se tenía una semana. Yo supongo que él ya lo tenía casi todo ultimado.

Hay una anécdota muy curiosa, que me contó Rafael Gil, que le habían contado antes de la guerra. Alguien llamó a Falla para que compusiera la música de una película, y Falla dijo que él necesitaba dos años.

$[\ldots]$

Don Quijote de la Mancha fue compuesta por su discípulo ${ }^{333}$ y según tengo entendido tuvo algún problema. Yo no intervine en aquella película pero me lo contaron. Halffter tenía que sincronizar la música con la proyección. Se le pasaba el tiempo y se ponía nervioso, siendo incapaz de hacerlo él.

Los buenos músicos en el cine español no se han empleado nunca. Por ejemplo, hay una película española que se hizo antes de la guerra donde trabajó uno de los mejores compositores "nacionalistas" españoles, Turina. Él hizo la música de la versión sonora de La hermana san Sulpicio. Lo mejor de aquel film es el arranque con los títulos, con un plano que va a lo largo y largo de la sierra hasta terminar en el sanatorio. Turina era un músico extraordinario.

\section{Entr.: ¿Joaquín Turina estuvo relacionado con Leoz, no?}

N.C.: $\quad$ Creo que sí. La última película que yo hice con él fue Surcos...

\section{Entr.: Yo aquí tengo otra más con usted, El cerco al diablo.}

N.C.: Pero aquello fue una película por episodios que ha desaparecido. En ella hice una secuencia, Neville hizo otra,... una estafa de esas.

Él estaba cambiando ya su estilo musical. Estaba abandonando el "clasicismo" e iba hacia el "expresionismo vienés". Él me dijo: "en la próxima película que hagamos, voy a hacer este tipo de música". Llegué a darle el guión pero por desgracia murió...

\section{[...]}

Steiner y Rozsa, fueron los creadores de tipo de música cinematográfica que luego ha abandonado. Los italianos, por su parte, han caído en las manos de Nino Rota y Ennio Morricone... aunque este último tiene una particularidad muy curiosa. Él escribe una especie de libretto musical de la película. Que eso

\footnotetext{
${ }^{333}$ Antes de este párrafo se ha hablado de música y de la obra de don Manuel de Falla.
} 
normalmente no se hace.

$[\ldots]$

En otra ocasión, en una coproducción hispano-italiana, con Marisa Med, trabajé con Rizo Ortolani, que había hecho la música de esa película del taxi amarillo. Era un gran músico. Este ya trabajaba sin la proyección. Pero la segunda película que hicimos, por cierto muy mala, con Marisa Med y Silvia Cosima,... la música se le dio al hijo de un político italiano muy famoso [...] Éste hizo lo siguiente. Cuando terminamos, le enviamos el guión con las notas de costumbre, y él nos contestó que no nos preocupásemos, que haría lo que tenía costumbre y que si luego no estaba contento con su trabajo que hiciera lo que quisiese.

Después le enviamos el copión a Roma y cabo de los treinta días él nos envió un copión sólo musical con toda la sincronización terminada. Era un sistema muy cómodo para mezclar.

Con Luis de Pablo tuve algún que otro problema pero que resolvimos satisfactoriamente. Creo que fue primera película que él hizo para el cine. Le llamé para trabajar en El sonido de la muerte. Luis hizo pues el tipo de música que él hace, clásica-electrónica. Fue la primera vez que se puso música de ese tipo en una película española. El film no era gran cosa. Trataba de un monstruo, que aparecía y desaparecía.... La película fue realizada para exhibirse en la televisión americana. Lo curioso es que nos dieron un premio en un festival celebrado en Dresde.

Entr.: Aunque nos alejamos de nuestro cometido, ¿a usted le gustarán las películas de J. Tati?

N.C.: Hay gente que ha obtenido resultado muy buenos trabajando el sonido. Sobre todo las películas alemanas que llegaron al principio, que venían prácticamente con los efectos de sonido.

Recuerdo que cuando se programaban las películas en cine mudo. Una de las sesiones muy curiosa que pasaron en un cine de Segovia fue la de El capitán Blum. Se exhibió en casa Bona Plata, una distribuidora de Barcelona. Se proyectaba de la siguiente manera. Se oían efectos durante todo el largometraje pero cuando llegó el momento de la batalla, el telón se levantaba y se dejaba ver una maqueta de dos barcos, que escenificaba la batalla con petardos. Una vez terminada la contienda, continuaba la proyección de la película.

La primeras películas que yo vi en España de cine mudo recuerdo que eran alemanas, y la mayoría venían con disco. El principal problema con el que se encontraban a menudo era la sincronización con el ritmo de la proyección. ¿Y usted sabe cual fue la primera película sonora que se hizo en España?

Entr.: No se lo sabría decir con certeza. Creo recordar que hubo varios intentos y se componía mucho para las películas mudas. 
N.C.: En aquella época se escribía mucha música para cine. Para el Napoleón de Abel Gance, Darío Miló ${ }^{334}$ compuso una música increíble. Hace poco volví a ver la versión restaurada por Coppola y no me gustó lo que hizo el padre de él. Además, han caído en un problema, que también tuvo Nieto al hacer la banda sonora de La aldea maldita.

Se equivocó en una cosa y cuando se lo dije él se quedó sorprendido. Ninguno de los dos se dio cuenta de que la copia con la que habían trabajado estaba a 24 fotogramas por minuto mientras que la original era a 18 fotogramas por minuto. Por esta razón suelen durar menos las películas mudas....

De todas formas, la primera película sonora en España se dice que fue La puerta del Sol, pero no lo creo. De hecho esta película no llegó a terminarse. La música se puso más tarde. Yo creo que la primera proyección que se realizó en España con sonido fue en Burgos, con el sistema de Forest. Pero la primera película sonora, se rodó en los estudios de Londres, con el guionista Samuel Samuelson, el primer guionista de Hitchcock, con la música de Jacinto Guerrero.

Al respecto hay una anécdota muy curiosa sobre el trabajo en Londres que me contó Leoz. En una ocasión tuvo que desplazarse Leoz a Londres para terminar un trabajo de una coproducción. Cuando llegó a los estudios, se quedó de piedra cuando vio al técnico de sonido con la partitura delante para controlar las entradas de la música. Eso aquí en España ni pensarlo. Y eso que había aquí uno muy bueno, Alonso, que era pariente del músico Alonso.

[...]

En Italia no se registraba bien el sonido, por lo menos cuando yo trabajé con ellos. Cuando querían un buen trabajo, lo enviaban todo a Londres. Toda la parte sonora, se hacía en Londres. El recording, que es otra de las cosas que tampoco se hacían en España.

\section{$[\ldots]$}

A la hora del doblaje, en España, se ponían todos los actores en la misma banda, y luego se ajustaba. Mas tarde, cuando trabajé con Frade, lo que hacíamos era rodar en ingles, y actores como Puente lo que hacían era hablar lo que nosotros llamamos doble idioma, que no es otra cosa que el inglés aprendido al lo español. Luego se doblaba, pero cada actor en una banda. Cuando se tenían todas las bandas bien sincronizadas con la imagen, se acoplaban en una. Y para el doblaje también se utilizaba el sistema americano, por el cual, no se doblaba de frase en frase, sino de palabra en palabra.

\section{Entr.: Volviendo a García Leoz, ¿el trabajar durante la guerra en el bando republicano no le acarreó problemas?}

\footnotetext{
${ }^{334}$ La música original para el estreno del Napoleón realmente es de Arthur Honegger.
} 
N.C.: A él nunca, que yo sepa. En aquella época no se tuvo en cuenta esa clase de cosas. Se ha tenido mucho más en cuenta después.

Entr.: Las películas de Rafael Gil con Quintero como compositor tienen una gran cantidad de música. En este caso, ¿quién era el responsable de decidir la cantidad de música en un film?.

N.C.: $\quad$ Era de Gil. Le gustaba las películas con mucha música. En realidad como músico a mi no me gustaba mucho Juanito Quintero. Pero a pesar de ellos llegó a ser un gran técnico. Él construía por temas, y luego la introducción de la película era la reunión de los temas seis, siete y nueve, por ejemplo. Era un práctico muy curioso. Llevaba los tiempos marcados. $Y$ en realidad él hacía un tipo de música que suena a música.

\section{$[\ldots]$}

No se como llegaron a conocerse. Eso si, llegó un momento en que Juan Quintero se convirtió en el amo de la música de Madrid. El hecho de que Gil lo apoyara le hizo subir como la espuma. Además era un hombre que te preguntaba: "¿para cuando quiere la música?", y si tu le dabas tres días, él se presentaba a los dos días con toda la música hecha. Era un práctico y nunca perdías tiempo con él.

Yo asistía a los rodajes, como ayudante de dirección, tomando nota de aquello y esto. Recuerdo que siempre estaba la mujer de Juan Quintero, y que figuraba ella como coautora.

Entr.: Me entrevisté el otro día con ella y me contó más o menos como trabajaba con su marido.

N.C.: Ella siempre estaba sentada, muchas veces conmigo. Y lo máximo que hacía era indicarle a su marido si se había ido uno o dos segundo de lo establecido. Pero si soy sincero, la música de Quintero no me llamaba la atención.

\section{Entr.: ¿Y de Parada?}

N.C.: Lo de Parada tampoco lo he entendido. Tuve que hacer una película con él porque el productor era muy amigo de él. En realidad era una película muy divertida de rodaje...

\section{$[\ldots]$}

Entr.: Cuando usted realizó Surcos, se le dio la categoría de Interés Nacional, que posteriormente se le quitó...

N.C.: Fue una película que tuvo sus más y sus menos, aunque ya en el guión nos suprimieron la última secuencia. En ella los protagonistas montan en el tren y la chica escapa a la ciudad al mismo tiempo que llega una nueva familia. Cometí el error, y lo he lamentado mucho, de no haber rodado esta secuencia. Años más 
tarde tuve dinero e intenté rodarlo por mi cuenta, pero no fue posible.

Intente a toda costa que la censura me dejara aquel final, pero ni hablar. Me prohibían el guión si no suprimía esa secuencia. Gracias a Dios luego no se metieron en el rodaje y me dejaron hacer.

Cuando la película se terminó se le pasó a García Escudero que le gustó. Después, se sometió al tribunal y según me contó él mismo la mayoría de los componentes del jurado votaron en contra. El que salvó la película fue García Escudero.

Por otro lado, CIFESA pasaba por una profunda depresión y estaban desesperados porque le dieran a Alba de América algún premio. García Escudero dijo que no, que no se lo merecía, y esta decisión le costó el puesto a este hombre.

Más tarde cuando se votaron los premios sindicales, todos fueron en contra de la película, salvo alguien, tal ve García Escudero, de la Dirección General que la defendió recordando el éxito que el film estaba teniendo fuera de nuestras fronteras. A pesar de todo, la película quedó segunda detrás de un largometraje sobre María Tudor dirigida por Castillo.

En muchos sitios la Iglesia Católica puso la peor calificación moral posible. La película se estreno en el Palacio de la Prensa de Madrid mientras que en la iglesia de San Martín que se encuentra al lado, el cura en la misa de doce puso la película a parir. En cambio el obispo de Salamanca votó a favor porque había rodado Balarrasa en Salamanca y nos conocíamos. En este caso, él se preocupó de ver la película y dijo que no era para tanto, que con ponerla para mayores bastaba. $Y$ de esta forma hubo sitios donde se exhibió normalmente.

En cambio, en Roma pasó al circulo del Vaticano de cinematografía y les pareció perfecta. Incluso me enviaron una nota diciéndome que les había gustado mucho.

Me acuerdo que al pobre empresario, los amigos del bar le decían que cómo había permitido él que rodásemos esa película, si no le daba vergüenza. Y sobre todo lo que yo no perdono, eso lo tengo aquí clavado, es que quien más atacó la película fueron los profesionales. Gritaron a los cuatro vientos que no se podía hacer ese tipo de cine.

\section{Entr.: Nos sorprende mucho la diferencia entre Balarrasa y Surcos.}

N.C.: Eran dos películas muy diferentes. Recuerdo que cuando hice Balarrasa, Vicente Escrivá me contrató porque había visto una película mía titulada Angustia... de la que estoy muy orgulloso.. Aunque de la que más contento estoy de los resultados es de Los peces rojos. Es lo mejor que he hecho en mi vida y pasó inadvertida para público y crítica. Para mí es la película más en el estilo de la Warner, que era el que a mi más me gustaba.

\section{Entr.: Usted trabajó mucho el "cine negro" en los años cuarenta.}


N.C.: Bueno, en realidad Angustias en la primera película de cine negro que rodé. Construimos un decorado que era una casa entera, de arriba abajo. Me acuerdo que empleamos por primera vez un zoom. Entonces solo había uno en España y lo tenían los operadores del NO-DO que nos lo dejaron. Ahora ruedan con veinte cámaras y las llevan incluso en la mano. Nosotros que teníamos que rodar con una sola cámara, y para colmo con sólo 120 de obturación, frente a las cámaras francesas que llegaban a 180, y las norteamericanas olvidémonos. Era otro mundo. Ahora es mucho más fácil.

El otro día estaba viendo unas secuencias de Qué verde era mi valle de John Ford. ¡Qué encuadratura!, ¡Qué forma de mostrar las caras!. Eso que yo conseguí en Surcos, en Los peces rojos, o en Angustias, yo ya no lo he vuelto a ver en el cine español. Estos chicos de ahora, no saben hacer...

$$
[\ldots]^{335}
$$

Entr.: La película de Hitchcock, Rebeca, ¿tuvo una gran influencia en el cine de Rafael Gil, en películas como Eloisa esta bajo un almendro o El clavo, a nivel plástico?

N.C.: $\quad$ No. Ni creo que la viera. La película se estrenó en el cine Callao.

Recuerdo una crítica de una señorita que decía que era una película muy mala porque no tenía primeros planos. Pero hay una cosa muy curiosa alrededor Rebeca. Hay un film alemán que se hizo cuatro años antes que cuenta la misma historia. Algo que también ocurrió con El delator de Ford, de la que en Alemania existía una excelente versión muda, y fíjate que era buena la película de Ford.

$[\ldots]$

\section{Entr.: ¿Qué opina de Azagra?}

N.C.: $\quad$ Azagra era un músico que nadie se entendía de donde había venido. Igual que este otro, Quintero. Yo decía que era muy malo. Igual que el padre de lquino.

Entr.: ¿El trabajar con un músico de prestigio, como el maestro Parada, ayudaba a la hora de tener más medios en el registro?

N.C.: $\quad \mathrm{Si}$, a veces. Aunque no necesariamente.

Lo que se hacía era hablar con uno o dos músicos que tocaban en la orquesta sinfónica, y estos se encargaban de traer a los que se necesitasen para la grabación. Uno de ellos era Florian Martínez, el hermano de Florian Rey, que era primer violín de la orquesta sinfónica. La productora en definitiva se entendía con este individuo y arreglaban las cuentas.

\footnotetext{
${ }^{335}$ La conversación se desvía hacia multitud de derroteros que ahora no son el tema. Hablamos de cine clásico americano y nos contó una serie de anécdotas de W. Willer entre otros.
} 


\section{$[\ldots]$}

Hablando de Florian Rey. En realidad a él lo que le gustaba hacer era teatro.

$[\ldots]$

Primero fue actor de teatro, luego de cine, y después pasó a la dirección. La verbena de la paloma, fue realizada por él. En la época muda hizo grandes películas. De hecho, la primera versión de La hermana san Sulpicio era mucho mejor que las posteriores.

\section{$[\ldots]$}

A final de los años treinta dirigió Carmen, la de Triana, y lo curioso es que él no pinta nada en esa película. El productor era un tal Peterson, que había producido La muchachas de uniforme. El guión y la planificación fueron hechos en Alemania, y la dirección estaba dada a un director alemán llamado Lieberman. A Imperio Argentina le hicieron hablar en alemán, mientras que al resto de actores los cambiaron para la versión alemana. El sistema de rodaje, era que Lieberman, montaba la escena, con el decorado, las luces, y todo. Se rodaba, y después se lo pasaba a Florián Rey para que repitiese lo que había visto hacer, con los actores españoles. Por eso, cuando yo vi Carmen, la de Triana, con la planificación de seguridad, de encuadramiento, etc... supe que no era de Florián Rey.

Hay una anécdota al respecto. Florián Rey se llevó a un dibujante de Sevilla para hacer los figurines. El equipo alemán en Berlín le pidió que dibujase el vestuario de la protagonista, para lo cual, el dibujante les solicitó documentación. Al día siguiente, al dibujante lo acompañó un alemán que sabía hablar español al archivo de Berlín, donde se encontraron preparados cientos de dibujos de Gustavo Doré y otros autores del siglo XIX. Allí tenían de todo. El pobre dibujante me contaba que jamás había visto tanto material junto de aquel tipo, y según le dijeron tenían más.

\section{$[\ldots]$}


ANEXOS II GOBIERNOS FRANQUISTAS 


\begin{tabular}{|c|c|c|c|}
\hline \multicolumn{4}{|c|}{$1^{\circ}$ Gobierno del Estado Español: del 30 de enero de 1938 al 9 de agosto de 1939} \\
\hline Jefe del Estado & Francisco Franco Bahamonde & $(1892-1975)$ & militar \\
\hline Presidente del Gobierno & Francisco Franco Bahamonde & $(1892-1975)$ & militar \\
\hline $\begin{array}{l}\text { Vicepresidente y Asuntos } \\
\text { Exteriores }\end{array}$ & Francisco Gómez-Jordana y Souza & $(1876-1944)$ & militar \\
\hline Defensa Nacional & Fidel Dávila Arrondo & $(1878-1962)$ & militar \\
\hline Interior & Ramón Serrano Súñer ${ }^{336}$ & $(1901-)$ & \\
\hline Orden Público & Severiano Martínez Anido ${ }^{337}$ & $(1862-1938)$ & militar \\
\hline Justicia & Tomás Domínguez Arévalo & $(1883-1952)$ & \\
\hline Hacienda & $\begin{array}{l}\text { Andrés Amado y Reigondaud de } \\
\text { Villabardet }\end{array}$ & $(1886-1964)$ & \\
\hline Industria y Comercio & Juan Antonio Suanzes Fernández & $(1891-1977)$ & \\
\hline Obras Públicas & Alfonso Peña Boeuf & $(1888-1966)$ & \\
\hline Agricultura & Raimundo Fernández-Cuesta y Merelo & $(1896-1992)$ & \\
\hline Educación & Pedro Sáinz Rodríguez & $(1897-1986)$ & \\
\hline Organización y Acción Sindical & Pedro González-Bueno y Bocos & $(1896-19 .)$. & \\
\hline $\begin{array}{l}\text { Secretario General del } \\
\text { Movimiento }\end{array}$ & Raimundo Fernández-Cuesta y Merelo & $(1896-1992)$ & \\
\hline
\end{tabular}

\begin{tabular}{|c|c|c|c|}
\hline \multicolumn{4}{|c|}{$2^{\circ}$ Gobierno del Estado Español: del 9 de agosto de 1939 al 20 de mayo de 1941} \\
\hline Jefe del Estado & Francisco Franco Bahamonde & $(1892-1975)$ & militar \\
\hline Presidente del Gobierno & Francisco Franco Bahamonde & $(1892-1975)$ & militar \\
\hline Asuntos Exteriores & Juan Luis Beigbeder Atienza ${ }^{338}$ & $(1888-1957)$ & militar \\
\hline Gobernación & Ramón Serrano Súñer ${ }^{339}$ & (1901-) & \\
\hline Justicia & Esteban Bilbao y Eguía & $(1879-1970)$ & \\
\hline Ejército & José Enrique Varela Iglesias & $(1891-1951)$ & militar \\
\hline Aire & Juan Yagüe Blanco 340 & $(1891-1952)$ & militar \\
\hline Marina & Salvador Moreno Fernández & $(1866-1966)$ & militar \\
\hline Hacienda & José Larraz López & $(1904-1973)$ & \\
\hline Industria y Comercio & Luis de Alarcón de la Lastra ${ }^{341}$ & $(1891-1971)$ & militar \\
\hline Obras Públicas & Alfonso Peña Boeuf & $(1888-1966)$ & \\
\hline Agricultura y Trabajo & Joaquín Benjumea Burín & $(1880-1963)$ & \\
\hline Educación & José Ibáñez Martín & $(1898-1969)$ & \\
\hline $\begin{array}{l}\text { Secretario General del } \\
\text { Movimiento }\end{array}$ & Agustín Muñoz Grandes ${ }^{342}$ & $(1896-1970)$ & militar \\
\hline
\end{tabular}

\footnotetext{
${ }^{336}$ Asume el nuevo Ministerio de Gobernación tras la muerte de Martínez Anido el 24/12/1938, fusionando los ministerios de Interior y Orden Público.

${ }^{337}$ Fallece el 24/12/1938.

${ }^{338}$ Sustituido el 17/10/1940 por Ramón Serrano Súñer (1901-)

${ }^{339}$ Sustituido el 16/10/1940 por Valentín Galarza Morante (1882-1951) militar

${ }^{340}$ Sustituido el 27/6/1940 por Juan Vigón Suerodíaz (1880-1955) militar

${ }^{341}$ Sustituido el 17/10/1940 por Demetrio Carceller Segura (1894-1968)
} 


\begin{tabular}{|lll|}
\hline Sin cartera & Pedro Gamero del Castillo & $(1910-1984)$ \\
\hline Sin cartera & Rafael Sánchez Mazas & $(1894-1966)$ \\
\hline
\end{tabular}

\begin{tabular}{|llll|}
\hline 3 Gobierno del Estado Español: del 20 de mayo de 1941 al 3 de septiembre de 1942 & \\
\hline Jefe del Estado & Francisco Franco Bahamonde & $(1892-1975)$ & militar \\
\hline Presidente del Gobierno & Francisco Franco Bahamonde & $(1892-1975)$ & militar \\
\hline Asuntos Exteriores & Ramón Serrano Súñer & $(1901-)$ & \\
\hline Gobernación & Valentín Galarza Morante & $(1882-1951)$ & militar \\
\hline Justicia & Esteban Bilbao y Eguía & $(1879-1970)$ & \\
\hline Ejército & José Enrique Varela Iglesias & $(1891-1951)$ & militar \\
\hline Aire & Juan Vigón Suerodíaz & $(1880-1955)$ & militar \\
\hline Marina & Salvador Moreno Fernández & $(1866-1966)$ & militar \\
\hline Hacienda & Joaquín Benjumea Burín & $(1880-1963)$ & \\
\hline Industria y Comercio & Demetrio Carceller Segura & $(1894-1968)$ & \\
\hline Obras Públicas & Alfonso Peña Boeuf & $(1888-1966)$ & \\
\hline Agricultura & $\begin{array}{l}\text { Miguel Primo de Rivera y Sáenz de } \\
\text { Heredia }\end{array}$ & $(1904-1964)$ & \\
\hline Trabajo & José Antonio Girón de Velasco & $(1911-1995)$ & \\
\hline Educación & José Ibáñez Martín & $(1898-1969)$ & \\
\hline $\begin{array}{l}\text { Secretario General del } \\
\text { Movimiento }\end{array}$ & José Luis Arrese y Magra & $(1905-1986)$ & \\
\hline
\end{tabular}

\begin{tabular}{|c|c|c|c|}
\hline \multicolumn{4}{|c|}{$4^{\circ}$ Gobierno del Estado Español: del 3 de septiembre de 1942 al 18 de julio de 1945} \\
\hline Jefe del Estado & Francisco Franco Bahamonde & $(1892-1975)$ & militar \\
\hline Presidente del Gobierno & Francisco Franco Bahamonde & $(1892-1975)$ & militar \\
\hline Asuntos Exteriores & Francisco Gómez-Jordana y Souza ${ }^{344}$ & $(1876-1944)$ & militar \\
\hline Gobernación & Blas Pérez González & $(1896-1978)$ & \\
\hline Justicia & Esteban Bilbao y Eguía ${ }^{345}$ & $(1879-1970)$ & \\
\hline Ejército & Carlos Asensio Cabanillas & $(1896-1969)$ & \\
\hline Aire & Juan Vigón Suerodíaz & $(1880-1955)$ & militar \\
\hline Marina & Salvador Moreno Fernández & $(1866-1966)$ & militar \\
\hline Hacienda & Joaquín Benjumea Burín & $(1880-1963)$ & militar \\
\hline Industria y Comercio & Demetrio Carceller Segura & $(1894-1968)$ & \\
\hline Obras Públicas & Alfonso Peña Boeuf & $(1888-1966)$ & \\
\hline Agricultura & $\begin{array}{l}\text { Miguel Primo de Rivera y Sáenz de } \\
\text { Heredia }\end{array}$ & $(1904-1964)$ & \\
\hline Trabajo & José Antonio Girón de Velasco & $(1911-1995)$ & \\
\hline Educación & José Ibáñez Martín & (1898-1969) & \\
\hline
\end{tabular}

\footnotetext{
${ }^{342}$ Cesado $15 / 3 / 1940$. Sin sustituto

${ }^{343}$ Cesado 15/8/1940. Sin sustituto

${ }^{344}$ Fallece el 3/8/1944. Sustituido el 11/8/1944 por José Félix de Lequerica y Erquiza (1889-1963)

345 Sustituido el 16/3/1943 por Eduardo Aunós Pérez (1894-1969)
} 


\begin{tabular}{l}
$\begin{array}{l}\text { Secretario General del } \\
\text { Movimiento }\end{array}$ \\
\hline
\end{tabular}

\begin{tabular}{|c|c|c|c|}
\hline \multicolumn{4}{|c|}{$5^{\circ}$ Gobierno del Estado Español: del 18 de julio de 1945 al 18 de julio de 1951} \\
\hline Jefe del Estado & Francisco Franco Bahamonde & $(1892-1975)$ & militar \\
\hline Presidente del Gobierno & Francisco Franco Bahamonde & $(1892-1975)$ & militar \\
\hline Asuntos Exteriores & Alberto Martín-Artajo Álvarez & $(1905-1979)$ & \\
\hline Gobernación & Blas Pérez González & $(1896-1978)$ & \\
\hline Justicia & Raimundo Fernández-Cuesta y Merelo & $(1896-1992)$ & \\
\hline Ejército & Fidel Dávila Arrondo & $(1878-1962)$ & militar \\
\hline Aire & Eduardo González Gallarza & $(1898-1986)$ & militar \\
\hline Marina & Francisco Regalado Rodríguez & $(1881-1958)$ & militar \\
\hline Hacienda & Joaquín Benjumea Burín & $(1880-1963)$ & \\
\hline Industria y Comercio & Juan Antonio Suanzes Fernández & $(1891-1977)$ & \\
\hline Obras Públicas & $\begin{array}{l}\text { José María Fernández-Ladreda y } \\
\text { Menéndez-Valdés }\end{array}$ & $(1885-1954)$ & militar \\
\hline Agricultura & Carlos Rein Segura & (1897-19..) & \\
\hline Trabajo & José Antonio Girón de Velasco & $(1911-1995)$ & \\
\hline Educación & José Ibáñez Martín & $(1898-1969)$ & \\
\hline
\end{tabular}


ANEXOS III

LEGISLACIÓN 


\section{Ley sobre la ordenación y defensa de la industria ${ }^{346}$.}

La LEY de 24 de octubre de mil novecientos treinta y nueve, de protección a las industrias de interés nacional, es la primera y más fundamental disposición de las varias que habrán de dictarse para crear una economía industrial española grande y prospera, liberada de la dependencia extranjera, que revalorice las primeras materias nacionales.

El logro de esta legitima y perseverante aspiración del Nuevo Estado no podría alcanzarse con la rapidez y firmeza anheladas si la creación de estímulos no fuese acompañada de las oportunas disposiciones que regulen tanto la implantación como el desarrollo de las industrias, principales y secundarias, de la Nación, declarando la facultad de la Administración para condicionar, reglamentar y vigilar la producción fabril, obteniendo datos estadísticos que le permitan resolver los problemas de modo adecuado y permanente, en lugar de improvisar resoluciones, muchas veces inadecuadas y circunstanciales, sin seguridad de acierto, por carecer de las indispensables normas previsoras de ordenación y defensa industrial.

Para que las medidas de protección sean fructíferas, han de hermanarse en su aplicación con preceptos legales de la misma categoría, que ordenen, defiendan, orienten y disciplinen la producción, dentro de un plan orgánico de amplia tutela estatal que abarque todos los aspectos técnicos y económicos del fomento y progreso de la industria nacional.

En su virtud,

\section{DISPONGO:}

Artículo primero.- La industria, que, como instrumento de la producción, se considera parte integrante, del Patrimonio Nacional y subordinada al interés supremo de la Nación, se regirá por esta Ley.

\section{DEFINICIÓN Y CLASIFICACIÓN DE LAS INDUSTRIAS}

Articulo segundo.- A los efectos de la presente Ley, se entiende por industria toda actividad económica desarrollada con alguna de las finalidades siguientes:

a) Generación, transporte, transformación, distribución y aplicación de la energía mecánica, química, eléctrica o térmica.

b) Obtención de productos mediante operaciones manufactureras o fabriles que tengan por base procedimientos mecánicos, químicos, eléctricos o mixtos.

c) Presentación de servicios de utilización pública basados en alguna de las industrias comprendidas en los anteriores apartados.

Artículo tercero.- Las industrias se clasificarán en los grupos siguientes:

\footnotetext{
${ }^{346}$ EsPaña, Sobre la ordenación y defensa de la industria, 24 de noviembre de 1939, Jefatura del Estado, Boletín Oficial del Estado, 15 de diciembre de 1939, núm. 349
} 
A) Industrias para la Defensa Nacional.

Serán las que en tiempo de paz fabriquen normalmente material de guerra o elementos de aplicación inmediata a la misma.

B) Industrias Auxiliares para la Defensa Nacional.

Se considerarán como tales las que, fabricando en tiempos de paz materiales que no son de aplicación inmediata a la guerra, produzcan primeras materias o elementos indispensables para la fabricación de material de guerra, así como las que puedan fácilmente transformarse para producir elementos necesarios a la defensa de la Nación.

C) Industrias básicas para la Economía Nacional. Se incluyen en este grupo:

a) Las destinadas total o parcialmente a servicios públicos.

b) Las que produzcan artículos necesarios para la subsistencia, el vestido y la sanidad de la Nación.

c) Las de transporte y fabricación del material que utilicen.

d) Las que, atendidas las necesidades nacionales, puedan exportar productos manufacturados, total o parcialmente.

e) Las que sean calificadas por el Estado como tales, por que sirvan a la autarquía económica o afecte de manera sensible al comercio exterior, en cualquier modalidad o forma.

D) Industrias diversas.

Se incluirá en este grupo las no comprendidas en las anteriores.

\section{ORDENACIÓN E INSPECCIÓN INDUSTRIAL}

Artículo cuarto.- Como normas generales de la intervención del Estado para la ordenación industrial se establece:

a) No podrán instalarse nuevas industrias, trasladar ni ampliar las existentes sin la resolución favorable del Ministerio de Industria y Comercio, quien fijará los tramites y normas a seguir, según las necesidades nacionales. Los recursos administrativos que se presenten contra resolución adoptada en virtud de lo dispuesto en este artículo serán informados por el Consejo de industria y resueltos por el Ministro de dicho Departamento.

Para las industrias civiles comprendidas en el apartado A) del artículo tercero será perceptivo el informe previo de los Ministerios que tienen a su cargo la defensa de la Nación, según la industria de que se trate. Los Ministerios que tienen s su cargo la defensa de la Nación comunicarán al de Industria y Comercio las autorizaciones de instalación o ampliación de industrias que concedan dentro de su jurisdicción propia.

b) El Ministerio de Industria y Comercio otorgará las concesiones necesarias para las instalaciones industriales definidas en el artículo segundo de esta Ley, y regulará su inspección sobre las condiciones de seguridad y garantía que fijen los reglamentos. 
Cuando una industria de "interés nacional" o destinada a servicios públicos necesite para su instalación ocupar terreno de propiedad privada el Ministro de Industria y Comercio, por Decreto aprobado en Consejo de Ministros, acordará la expropiaciones indispensables que se ejecutarán cumpliendo los tramites reglamentarios. Corresponderá, a dicho Ministerio la imposición de servidumbres de paso necesarias en las instalaciones industriales, previa justificación en proyecto técnico aprobado al efecto.

Un Reglamento de Policía Industrial fijará las condiciones de seguridad y las del trabajo en los establecimientos e instalaciones industriales, clasificando aquellos con arreglo a su insalubridad, incomodidad, o peligro, y fijando las condiciones de emplazamiento que deben reunir.

c) El Estado podrá, en casos necesarios, fijar condiciones de producción y rendimiento, así como normas de tipificación de los productos industriales y obligará a que en los artículos manufacturados por la industria nacional conste, de manera indeleble que son de fabricación española.

d) Cuando la falta de competencia extranjera, por razones permanentes o circunstanciales, pueda crear para la producción española un verdadero monopolio en el mercado interior, el Estado impondrá las condiciones de venta de determinados artículos.

e) Si las empresas industriales no se encuentran en condiciones de sostener el precio de algún producto sometido a tasa, el Gobierno podrá inspeccionar sus libros e incluso designar personal técnico que lleve a cabo la valoración de su activo y pasivo para deducir la verdadera situación económica de la empresa.

Cuando del informe de la inspección efectuada resulte que el precio de venta señalado por el Estado es acertado, pero por deficiencias de administración, excesivos gastos, sobrecargas financieras o inflación en las aportaciones no pueda la sociedad hacer frente a sus obligaciones con dicho precio, se mantendrá éste, siempre que no sea inferior al corriente en el mercado internacional, procediéndose, si llega el caso, de acuerdo con lo que preceptúa el artículo tercero de la Ley de primero de septiembre del año en curso, sobre intervención de empresas industriales.

f) Se podrá conceder "Marca de calidad" para aquellos productos de fabricación nacional que satisfagan determinadas características de perfección.

g) Para efectos estadísticos, y con el posible respeto para cuanto pueda constituir secretos de fabricación, los industriales vienen obligados a facilitar los datos que la Administración de Estado necesite para la orientación, estudio y resolución de los problemas de la Economía Nacional.

h) La prestación de servicios públicos, a base de instalaciones industriales establecidas o por establecer, necesita expresa concesión administrativa para ello, en la que se fijarán las condiciones técnicas, modalidades, garantías del servicio, tarifas y sanciones aplicables.

i) Las empresas industriales dedicadas a servicios públicos, la incluidas en los dos grupos de Defensa Nacional, las que fabrican materiales que hay que importar por deficiencia de la producción nacional, cualquiera que sea su capacidad productiva y el numero de obreros que utilicen y todas las demás de carácter general que ocupen mas de 
doscientos obreros, en el caso de que por alguna causa, susceptible de ser prevista, se vean obligadas a interrumpir o disminuir sensiblemente sus actividades, lo participarán al Ministerio de Industria y Comercio, en la forma y con la antelación mínima de dos meses preceptuada en la Ley de primero de septiembre del año en curso, sobre Investigación de empresas industriales.

j) Se podrán fijar mínimos de existencia de materias primas a las empresas industriales concesionarias de servicios públicos.

k) Se exigirá una dirección técnica española responsable en las industrias de interés nacional y en las insalubres o peligrosas que por su importancia lo requieran, según clasificación que se insertará en el Reglamento correspondiente.

I) En cuanto sea necesario para la economía o Defensa Nacionales, podrán dictarse normas para el mejor aprovechamiento de la energía, materiales, residuos de fabricación y mano de obra.

m) Se fomentará la fusión o asociación de las empresas industriales, si así conviniera al Interés Nacional.

n) Cuando falte la iniciativa privada para el mejor aprovechamiento de la materias primas nacionales y de las fuentes de energía o se estime conveniente el establecimiento o coordinación de instalaciones industriales en forma que su realización pueda incrementar la producción nacional o la mejore, los servicios técnicos del Ministerio de Industria y Comercio, con el concurso de aquellos otros especializados en la materia de que se trate efectuarán el estudio pertinente. El Estado podrá ejecutar el proyecto o adjudicar su realización, previo concurso anunciado con la antelación suficiente, al mejor postor en relación con las condiciones que se fijen para el mismo.

o) En casos excepcionales, cuando lo exija el interés supremo de la Defensa o Economía Nacionales, el Estado por Decreto aprobado en Consejo de Ministros, podrán incautarse de las empresas industriales, procediendo al nombramiento de un Consejo de Incautación en la forma que previene la Ley de primero de septiembre ultimo.

Artículo quinto.- De manera especial, aplicable a las nuevas industrias, se establecen las condiciones siguientes:

a) El capital social activo será propiedad de españoles en sus tres cuartas partes, como mínimo. La cuarta parte restante, como proporciones máximas, podrán admitirse como inversión de capital extranjero, debiendo aportase en divisas cotizadas en España o en utillaje que no se obtenga en la producción nacional, valorando a los precios del mercado internacional.

Con independencia de la participación en el capital activo, prevista en el párrafo anterior, el Estado podrá autorizar a las empresas acogidas a los beneficios de esta Ley para concertar la adquisición de maquinaria herramental, patentes, privilegios y planos de procedencia extranjera necesarios para la implantación y desarrollo de la industria de que se trate, por su valor justamente apreciado, en moneda del país de origen y en forma de obligaciones de la Empresa, amortizables en un período no inferior a diez años, siempre que estas aportaciones no excedan del veinte por ciento del capital social. 
El Estado podrá garantizar al capital acciones suscritas por extranjeros, en divisas cotizadas en España o en utillaje, la extracción en las mismas divisas de un porcentaje de beneficio anual acordado de manera general, así como también las correspondientes a la amortización e intereses que se hayan establecido para las obligaciones a que se refiere el párrafo anterior.

b) En las industrias del grupo A) del artículo tercero el capital será íntegramente español.

c) En la decisión de los asuntos sociales, cualquiera que sea la forma jurídica de la entidad, las tres cuartas partes, al menos de los votos han de corresponder a españoles.

d) Los Directores, así técnicos como administrativos, gerentes y, en general, los administradores o apoderados legales, habrán de ser españoles. Sin embargo, en las Sociedades Anónimas podrán ser extranjeros, en proporción al capital suscrito, hasta una cuarta parte de los Consejeros, pero la Presidencia del Consejo y los cargos directivos, en todo momento, han de recaer en quienes tengan nacionalidad española.

Durante el período de iniciación de la industria podrá ser autorizada la admisión interina de una cuarta parte del personal técnico y administrativo especializado, no directivo, y por un plazo máximo de tres años. Trascurrido dicho plazo la proporción indicada deberá descender a la décima parte del personal afecto a cada una de la respectivas categorías y plantillas.

En todos los casos deberá ser cumplido previamente los requisitos establecidos, de manera general, para el trabajo de extranjeros en España.

Artículo sexto.- No se podrá transferir la propiedad de establecimientos o instalaciones industriales comprendidas en el grupo A) del artículo tercero, en cualquier forma que esté representada, a las personas naturales o jurídicas extranjeras.

En las demás industrias que no estén jurídicamente organizadas como Sociedades por acciones, podrán adquirir los extranjeros hasta la cuarta parte de la propiedad en las mismas.

En las industrias no comprendidas en el párrafo primero de este artículo que jurídicamente estén organizadas como Sociedades por acciones, cualquier misión de títulos de soberanía que se realice en lo sucesivo se dividirán en dos partes: una, igual a los tres cuartos de la emisión, que no podrá ser transferible a extranjeros; otra, igual al cuarto de la emisión que estará exenta de la expresada limitación. La condición de trasferible o intransferible a los extranjeros, de los títulos, se consignará en ellos de modo visible. La transmisión de títulos o participaciones en industrias a extranjeros, dentro de las condiciones de esta Ley se entenderá sin perjuicio de lo dispuesto en el número dieciocho del artículo primero de la Ley penal de delitos monetarios.

La transmisión de títulos o participaciones en industrias a extranjeros, con infracción de lo dispuesto en la presente Ley constituirá vicio de nulidad de la operación.

Articulo séptimo.- En casos excepcionales, el Estado previa deliberación en Consejo de Ministros, podrán variar las restricciones establecidas en los artículos quinto y noveno, en la extensión indispensable que permita la realización de proyectos industriales de extraordinario interés nacional. 
Artículo octavo.- En el grado de sus respectivas atribuciones, los jefes directos de las empresas son responsables ante el Estado del cumplimiento, con elevado espíritu de subordinación al interés nacional, de las disposiciones y orientaciones del Gobierno que en cada momento rijan para la industria responsabilidad que será exigida, subsidiariamente, en sus casos, a los Consejos, Juntas u organismos a quienes en grado superior pudiera corresponder.

\section{DEFENSA DE LA PRODUCCION}

Artículo noveno.- Solamente podrán acogerse a los preceptos de esta Ley las personas naturales o jurídicas que posean nacionalidad española.

Artículo décimo.- En todas las obras, instalaciones, servicios y adquisiciones en general, de cualquier clase, que se realicen con fondos procedentes del Estado, de la Provincia, de los Municipios, de los Organismos y Delegaciones del Movimiento, de los Monopolios, de las empresas concesionarias de servicios públicos o que disfruten de beneficios públicos o protección en cualquier forma administrativa, económica, o financiera, se emplearán exclusivamente artículos de fabricación española, justificada con el correspondiente Certificado del Productor Nacional y que otorgará el Ministerio de Industria y Comercio.

EL Ministro de Industria y Comercio, excepcionalmente, y previo informe de los Servicios Técnicos de la Dirección General de Industria, podrá autorizar adquisiciones en la industria extranjera mediante orden especial, en cada caso, cuando ocurra alguno de los motivos siguientes:

Primero.- Imperfección del producto nacional; para una finalidad determinada, taxativamente declarada después de efectuar los análisis ensayos o pruebas procedentes a petición de parte interesada.

Segundo.- Por reconocida urgencia que no pueda satisfacer la industria española, siempre que se demuestre por el organismo o entidad interesada en la adquisición, que no ha sido posible prever con indispensable antelación tal necesidad, que puede ser sustituido el producto por otro similar de mas rápida adquisición en la industria nacional.

Tercero.- Por no existir la producción nacional respectiva, no tolerándose que al amparo de esta excepción puedan establecer condiciones de concurso, arbitrarias, caprichosas, o excesivamente determinantes, que puedan excluir injustamente el producto nacional.

Las anteriores condiciones no son limitativas de las que por la índole especial de su misión y razones de urgencia, puedan, en determinados casos y circunstancias, establecer dentro de su jurisdicción propia los Ministerios que tienen a su cargo la defensa de la Nación.

Artículo duodécimo.- El empleo indebido de artículos extranjeros en los casos no autorizados originará responsabilidad en los Jefes de los Centros del Estado, de las Corporaciones, Organismos y Empresas, así como de los funcionarios que tengan a su cargo la recepción de obras o artículos y de los que autoricen la intervención del gasto o libramiento. 
Las sanciones económicas que deberán imponerse a los infractores del artículo décimo serán evaluadas en el duplo del precio medio de vente en España de la mercancía adquirida indebidamente en el extranjero, sin prejuicio de las sanciones administrativas que corresponda aplicar en cada caso al los funcionarios a los que alude el párrafo anterior.

Cuando las sanciones afecten a jefes de corporaciones o funcionarios dependientes de otros Ministerios, se adoptarán lo oportunos acuerdos en el Consejo de Ministros, a propuesta del de Industria y Comercio.

Artículo decimotercero.- Cada cinco años se publicará una edición del Catálogo Oficial de la Producción Industrial Española, que comprenderá la relación específica y detallada de los industriales españoles dotados de Certificado de Productor Nacional, con índices de las razones sociales y productos elaborados, y cuyo catalogo constituirá prueba documental en orden al cumplimiento de lo establecido en el artículo décimo de esta Ley.

Hasta tanto quede establecida la normal publicación de dicho catálogo, se formará anualmente por el Ministerio de Industria y Comercio relación de artículos para cuya adquisición se considere necesaria la concurrencia de la industria extranjera. Dicha relación se publicará en el mes de septiembre en el BOLETIN OFICIAL DEL ESTADO con recomendación de que se inserte en los de cada provincia, abriendo información pública a fin de que los industriales que se consideren perjudicados dirijan sus escritos de reclamación a dicho Ministerio, presentando pruebas a su alegación. De manera especial se pedirá informe sobre dicha relación a los organismos representativos de las distintas ramas de la Producción nacional y terminado el expediente, por Decreto acordado en Consejo de Ministros se aprobará la relación definitiva de dichos artículos, que será publicada en los Boletines Oficiales antes de primero de enero.

Esto no obstante, el Ministerio de Industria y Comercio, en los periodos intermedios podrá eliminar o incluir dicha relación por Orden Ministerial, artículos que se produzcan, o los que por cualquier circunstancia dejen de producirse en la industria nacional, oyendo igualmente a los organismos citados en le párrafo anterior.

Articulo decimocuarto.- La importación de materias primas, maquinaria, utensilios, productos y subproductos industriales vendrá condicionada a la posibilidad del suministro nacional o sustitución por otros similares, a cuyo efecto la Dirección General de Comercio y Política Arancelaria contará con los elementos necesarios de asesoramiento técnico, que le serán facilitados por la Dirección General de Industria.

Los Ministerios que tienen a su cargo la defensa de la Nación formularán directamente dichas peticiones para los materiales destinados a fabricaciones de guerra, dando cuenta, simultáneamente, en cada caso, a la Dirección General de Industria.

Articulo decimoquinto.- Las industrias del Estado y las de las Corporaciones y Organismos públicos no podrán competir ventajosamente con las particulares en la fabricación de artículos no relacionados con la defensa de la nación.

Articulo decimosexto.- El Estado podrá adquirir patentes de invención nacionales o extranjeras correspondientes a productos que no se fabriquen en España previo asesoramiento de los Centros Técnicos correspondientes. La puesta en práctica de dichas patentes será ofrecida, mediante condiciones anunciadas en concurso, a la Industria 
privada y en el caso de que no hubiera concurrencia y la necesidad nacional lo aconseje, el Estado podrá efectuar las instalaciones.

Artículo decimoséptimo. - Dentro del respeto a los Convenios Internacionales sobre la materia el Estado Español cuidará de todos los servicios concernientes a la Propiedad Industrial se articulen y desenvuelvan en forma de que los descubrimientos Técnicos Industriales patentados puedan alcanzar el mayor reflejo y valoración en el fomento y progreso de la Industria Nacional.

Artículo decimoctavo. - A los efectos del artículo anterior, el Registro de la Propiedad Industrial, dependiente de la Dirección General de Industria, se reorganizará mediante disposiciones del Ministerio de Industria y Comercio que modifiquen, en los necesario, los Decretos-Ley de veintiséis de Julio de mil novecientos veintinueve, Decreto de veintidós de Mayo Ley de dieciséis de septiembre de mil novecientos treinta y uno en orden a la dotación de personal técnico y nombramiento de Comisiones Mixtas que mejor convenga al interés nacional.

\section{INVESTIGACIÓN Y ESTUDIOS}

Artículo decimonono. - Se organizarán Laboratorios de investigación y ensayos industriales. En ellos se estudiarán nuevos procedimientos de fabricación para el aprovechamiento de materias primas nacionales y obtención de productos que hasta ahora son objeto de importación.

Se creará un órgano de información, elaboración y depuración de los datos que tienen relación con la vida económica del país, con la misión esencial de ordenarlos e interpretarlos en forma de previsiones, orientaciones y normas de conducta a seguir.

Las enseñanzas industriales serán objeto de especial atención del Estado. Se establecerán los grados y especializaciones necesarias para formar buenos Ingenieros, Directores de fábrica, Ayudantes, Jefes de talleres y obreros especializados. Con tal finalidad la intensificará la instalación de laboratorios y talleres de aprendizaje en los centros correspondientes a fin de que se completen los conocimientos teóricos con la prácticas de los mismos.

El Estado ayudará, en la forma conveniente, a los españoles que, careciendo de medios para ello aspiren a poner en práctica, en prueba Industrial nuevos procedimientos o elementos de fabricación que constituyan inventos, previo informe de los organismos técnicos oficiales.

\section{DISPOSICIONES GENERALES}

Artículo vigésimo. - Corresponde al Ministerio de Industria y Comercio la ejecución y desarrollo reglamentario de la presente Ley, a través de sus Organismos Técnicos.

En los Reglamentos respectivos se fijarán procedimientos rápidos de tramitación y las sanciones aplicables en los diferentes casos de infracción o incumplimiento de esta Ley. 
Artículo vigésimo primero. - Quedan derogadas cuantas disposiciones se opongan a lo dispuesto en la presente Ley, dada en Madrid a veinticuatro de noviembre de mil novecientos treinta y nueve. - Año de la Victoria.

\section{FRANCISCO FRANCO}

\section{Orden fijando la competencia y funciones del Departamento de Cinematografía, pendiente de la Dirección General de Propaganda ${ }^{347}$.}

IImos. Sres.: El desamparo oficial que ha padecido la vida cinematográfica española, ha impedido que los impulsos de la iniciativa privada lograsen un espectáculo cinematográfico digno de representar en el mundo nuestra naturaleza nacional.

Para establecer los principios a que deben someterse las actividades cinematográficas de España y para estimular esta producción y orientarla en el sentido que nuestra paz exige, se constituye en la Dirección General de Propaganda el Departamento de Cinematografía, según el articulado que más adelante se enumera, encargada de gobernar la vida cinematográfica en nuestro país y de ayudar a la iniciativa privada en toda sus manifestaciones considerables.

De acuerdo con ello, este Ministerio se ha servido disponer:

Artículo $1^{\circ}$. Corresponde a la Dirección General de Propaganda, y, bajo su dependencia, al Departamento de Cinematografía que se crea en virtud de la presente Orden, tramitar los permisos de rodaje como requisito previo a toda filmación cinematográfica que inicien las entidades españolas o extranjeras dentro del territorio nacional, cuya concesión autorizará el expresado Centro directivo, sin perjuicio de las facultades de revisión que corresponden al Ministerio, Subsecretaría de Prensa y Propaganda u otros organismos superiores.

Las normas a que deben someterse las solicitudes de tales permisos y la fecha en que comenzará a regir este requisito previo de rodaje se fijarán oportunamente.

Artículo $2^{\circ}$. A los efectos de la presente Orden, dependerán de la Dirección General de Propaganda, a través del Departamento de Cinematografía, aquellas instituciones o asociaciones cinematográficas que no tengan un carácter exclusivamente industrial o comercial o caigan dentro de las Organizaciones Sindicales del Estado y del Movimiento.

Artículo $3^{\circ}$. El Departamento de Cinematografía actuará de intermediario único, emitiendo su informe en cada caso, entre estas asociaciones y los órganos oficiales a que aquéllas pretendan dirigirse.

\footnotetext{
${ }^{347}$ Orden fijando la competencia y funciones del Departamento de Cinematografía, pendiente de la Dirección General de Propaganda, 21 de febrero de 1940, Ministerio de la Gobernación, Boletín Oficial del Estado, 25 de febrero de 1940, núm. 56
} 
Artículo $4^{\circ}$. Corresponde igualmente al Departamento de Cinematografía establecer de propia iniciativa y de acuerdo con los organismos competentes, previa la aprobación superior, las bases en que se funden el futuro Instituto Cinematográfico Español, como escuela cinematográfica del Estado.

Artículo $5^{\circ}$. La Dirección General de Propaganda, por su departamento de cinematografía, será el organismo competente para representar a España en sus relaciones con la cinematografía extranjera cuando se traten temas cinematográficos de su competencia nacional.

Artículo $6^{\circ}$. Corresponde al Jefe del Departamento de Cinematografía la presidencia de la Comisión de Censura Cinematográfica, conforme a la Orden de 2 de noviembre de 1938, y la propuesta de censor de guiones cinematográficos a la Sección encargada de este cometido, según O.M. de 15 de julio de 1939 (B.O. del 30).

Artículo $7^{\circ}$. La Dirección General de Propaganda, a través del Departamento de Cinematografía, acometerá directamente o por medio de las entidades adecuadas cuyo establecimiento promueva la producción de films de propaganda, noticiarios y documentales que tendrán a su vez un carácter informativo y formativo de la conciencia popular española, de acuerdo con las directrices políticas del nuevo Estado.

Artículo $8^{\circ}$. Se establecerá la necesaria coordinación del Departamento de Cinematografía que se crea, en su aspecto cinematográfico, con todas aquellas Secciones que dentro de los organismos del Estado y del Movimiento se constituyan para ejercer la propaganda cinematográfica de ellos.

Artículo $9^{\circ}$. El periodismo cinematográfico español estará sujeto, igualmente, de acuerdo con las normas establecidas por la Dirección General de Prensa, a la Dirección de Propaganda, y, por consiguiente, a su Departamento de Cinematografía en los aspectos que a ésta corresponden.

Artículo $10^{\circ}$. El Departamento de Cinematografía queda facultado para vigilar los proyectos privados de producción cinematográfica nacional o a producir en España, en cuanto afecten a materia de la competencia del mismo.

Dios guarde a VV. II. muchos años.

Madrid, 21 de febrero de 1941

SERRANO SÚÑER.

Por la que se transfieren los servicios de prensa y propaganda a la Vicesecretaría de Educación de FET y de las JONS, que se crea por la

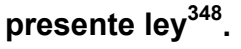

\footnotetext{
${ }^{348}$ Por la que se transfieren los servicios de prensa y propaganda a la Vicesecretaría de Educación de F.E.T. y de las JONS, 20 de mayo de 1941, Jefatura del Estado, Boletín Oficial del Estado, 22 de mayo de 1941, núm. 142
} 
Siguiendo el proceso gradual de revisión de la ley de treinta de enero de mil novecientos treinta y ocho que, con carácter provisional, organizo la Administración Central del Estado, procede ahora emplazar de manera adecuada los Servicios de Prensa y Propaganda en atención a la sustantividad de su significación doctrinal y política. No estimándose todavía conveniente su formal constitución en un Ministerio independiente, es oportuna su inserción en los órganos elaboradores de la doctrina política del Estado, por lo que se organizarán dentro del Partido mediante la creación de una Vicesecretaria que se llamará de Educación Popular.

En su virtud.

\section{DISPONGO:}

Articulo primero. - La organización de la Administración Central del Estado, establecida por la Leyes de treinta de enero de mil novecientos treinta y ocho, veintinueve de diciembre, se modifica en los términos que siguen:

Todos los Servicios y Organismos que, en materia de Prensa y Propaganda y sus respectivas competencias, dependían de las Subsecretaria de Prensa y Propaganda y del Ministerio de la Gobernación se transfieren a la Vicesecretaria de Educación Popular de la Falange Española Tradicionalista y de las J.O.N.S. que se crea por la presente ley.

Articulo segundo. - La Junta Política propondrá al Jefe Nacional de Falange Española Tradicionalista y de las J.O.N.S. la nueva estructura de los Servicios transferidos.

Articulo tercero. - Por el Ministerio de Hacienda se proveerá a la dotación de estos Servicios mediante las transferencias de los correspondientes créditos presupuestarios.

Articulo cuarto. - Esta Ley entrará en vigor el día de su publicación en el BOLETIN OFICIAL DEL ESTADO, quedando derogadas cuantas disposiciones se opongan a ella.

Así lo dispongo por la presente Ley, dada en Madrid a veinte de mayo de mil novecientos cuarenta y uno.

FRANCISCO FRANCO 


\section{Orden sobre las normas protectoras para la cinematografía ${ }^{349}$.}

Al objeto de dar aplicación adecuada a los fondos reunidos por el Sindicato Nacional de Espectáculo para protección y estímulo de la producción cinematográfica nacional, y estudiada por esta Secretaría Técnica la propuesta que a tal fin presenta el Sindicato Nacional del Espectáculo, he tenido a bien disponer:

\section{PRODUCCIÓN.- CRÉDITO CINEMATOGRÁFICO.}

Artículo $1^{\circ}$. Se instituye el Crédito cinematográfico nacional a través del Sindicato Nacional del Espectáculo, cuyo funcionamiento se ajustará a las siguientes normas:

a) Todo productor español de películas que desee acogerse a los beneficios que otorga el Crédito cinematográfico deberá presentar al Sindicato Nacional del Espectáculo el guión de la película que aspire a realizar, presupuesto total de la misma, plan financiero de la operación, relación del personal artístico y técnico que haya de intervenir y todos aquellos datos de carácter complementario que se estimen procedentes.

b) Del estudio de estos elementos por el Sindicato se deducirá la aprobación o denegación de un préstamo, que podrá ascender hasta el 40 por 100 del presupuesto total proyectado.

c) Una vez concedido el préstamo se hará éste efectivo, satisfaciendo el Sindicato semanalmente el porcentaje correspondiente a los pagos que deba efectuar el productor, contra presentación de los comprobantes de pago de dicho período semanal, debiendo estos pagos ajustarse en todo lo posible al plan de trabajo y presupuesto previsto.

d) La reversión del préstamo al Sindicato tendrá comienzo desde la explotación de la película, correspondiendo al Sindicato percibir en todas las liquidaciones mensuales el porcentaje concedido hasta la extinción y cancelación total del préstamo.

\section{PREMIOS A LA PRODUCCIÓN.}

Art. $2^{\circ}$. Por el Sindicato Nacional del Espectáculo, y previas las formalidades del caso, se concederán durante el mes de junio los siguientes premios a las mejores películas de producción nacional :

a) Dos premios de 400.000 pesetas y cuatro premios de 250.000 pesetas para las películas de largo metraje; cuatro premios de 25.000 pesetas para las películas de complemento.

b) La entidad productora que obtenga uno de estos premios distribuirá el 20 por 100 de su cuantía entre los técnicos y artistas que, a juicio del Sindicato Nacional, se haya hecho a ello acreedores por su contribución al éxito artístico de la película.

\footnotetext{
${ }^{349}$ Normas protectoras para la cinematografía, 11 de noviembre de 1941, Ministerio de Industria y Comercio, Boletín Oficial del Estado, 17 de noviembre de 1941, núm. 321
} 


\section{GUIONES}

Art. $3^{\circ}$. El Sindicto Nacional del Espectáculo abrirá un concurso de giones con arreglo a las siguientes bases:

a) Podrán concurrir al concurso de guiones, con uno o más originales, todos los españoles que así lo deseeen y los hispanoamericanos con residencia en España.

b) Los originales se presentarán escritos a máquina, en doble espacio, tamaño folio y en sobre cerrado, con el título y nombre del autor, debiendo enviarse con tres copias firmadas.

c) El plazo de presentación de guiones expirará el 31 de diciembre de 1941.

d) Los premios a conceder serán cinco, de pesetas 50.000 cada uno.

e) Los guiones premiados pasarán a ser propiedad del Sindicato por renuncia de sus autores a todo derecho sobre los mismos.

f) Los cinco guiones premiados serán facilitados, para su lectura, a las Casas productoras que lo soliciten, las que deberán hacerlo en el plazo de un mes, a partir de la fecha en que les sean entregados, y presentar las propuestas al Sindicato para su realización.

g) Estudiadas las proposiciones de las entidades productoras por el Sindicato Nacional del Espectáculo, éste cederá sus derechos de propiedad sobre cada uno de los guiones a la entidad o entidades que mayores garantías de buena ejecución ofrezcan para la más acertada realización.

\section{BECAS}

Art. $4^{\circ}$. El Sindicato Nacional del Espectáculo establecerá diez becas para perfeccionamiento de técnica cinematográfica en cada una de las siguientes especialidades : direcciones, operaciones, laboratorios, montaje, sonido, maquillaje, efectos especiales, películas culturales, noticiarios y organización de la producción.

La concesión de estas becas se efectuará con arreglo a las siguientes bases:

a) Estarán dotadas con una cantidad mensual equivalente a 5.000 pesetas de moneda española, más los gastos de viaje.

b) La duración será por seis meses, durante los cuales los becarios residirán en el punto que se le asigne y en armonía con las especialidades en aquellas naciones europeas más adelantadas en la técnica cinematográfica.

c) Podrán aspirar a estas becas todos los españoles afectos al Glorioso Movimiento Nacional que con anterioridad a la publicación de esta convocatoria hayan realizado trabajos cinematográficos e mayor o menor importancia y que demuestren una aptitud, conocimientos específicos y probable capacidad para la especialidad. 
d) Las solicitudes habrán de presentarse en el Sindicato Nacional del Espectáculo dentro del plazo de un mes, a partir de la publicación de la convocatoria, pudiendo aducir en ella cuantos méritos crean poseer y los títulos o documentos que acrediten estar comprendidos en las condiciones de la base anterior.

e) El Sindicato Nacional del Espectáculo procurará facilitar a los becarios la asistencia a los Centros de producción más importantes de la nación donde radiquen.

f) Los beneficiarios de las becas quedarán obligados a enviar mensualmente al Sindicato Nacional del Espectáculo información relacionada sobre las actividades que desenvuelvan.

g) El Sindicato Nacional del Espectáculo vigilará la asiduidad y aprovechamiento de los becarios, retirando la pensión a los que falten a la disposición anterior o no demuestren ser dignos del beneficio por comportamiento moral o profesional.

h) Ultimado el plazo de disfrute de la beca presentarán a su regreso una Memoria lo más amplia posible de los trabajos realizados.

i) Si de la Memoria presentada e información realizada por el Sindicato Nacional del Espectáculo se deduce que los becarios han realizado su período de estudio y perfeccionamiento con singular provecho, el Sindicato Nacional extenderá diplomas acreditativos de dichos extremos.

\section{Orden regulando la programación de películas ${ }^{350}$.}

Los laudables esfuerzos que vienen realizando las Empresas productoras no se corresponden con sus resultados prácticos, por el complejo de circunstancias que hacen difícil la explotación de nuestras películas. Aliviadas estas dificultades, es de esperar que esta industria alcance rápidamente el grado de esplendor que le corresponde. Para conseguir dicho fin, y decidido el Gobierno a fomentar la producción cinematográfica en su doble aspecto de fuente de riqueza y de vehículo para la difusión de nuestra cultura, este Ministerio, a propuesta de la Secretaría General Técnica, ha acordado disponer :

Artículo $1^{\circ}$. A partir del $1^{\circ}$ de enero próximo, en todos los locales de España que se dediquen a la exhibición cinematográfica deberá darse por lo menos una semana completa de proyecciones de películas españolas de largo metraje, por cada seis semanas de proyección de películas extranjeras de la misma categoría.

Art. $2^{\circ}$. A los efectos de la aplicación de esta Orden, el año cinematográfico se dividirá en dos periodos: en el primero, que comprenderá desde el $1^{\circ}$ de octubre hasta el 31 de mayo, se proyectarán películas españolas de riguroso estreno en cada local; el segundo,

\footnotetext{
${ }^{350}$ Regulando la programación de películas, 10 de diciembre de 1941, Ministerio de Industria y Comercio, Boletín Oficial del Estado, 13 de diciembre de 1941, núm. 347
} 
que abarcará desde el $1^{\circ}$ de junio hasta el 30 de septiembre, podrá dedicarse al reestreno de películas españolas proyectadas anteriormente en el mismo local.

Art. $3^{\circ}$. Con independencia de lo dispuesto en los artículos anteriores, y a partir de la misma fecha, todos los locales estarán obligados a complementar el programa de cada una de las sesiones con una película corta nacional de las llamadas de complemento.

Art. $4^{\circ}$. La Subcomisión Reguladora de la Cinematografía, o el Organismo que haya de asumir sus funciones, vigilará el exacto cumplimiento de esta Orden.

\section{Orden reorganizando los servicios de censura cinematográfica ${ }^{351}$}

La nueva estructura de los Servicios de Cinematografía y Teatro encuadrados en la Vicesecretaría de Educación Popular, y la experiencia conseguida en el transcurso del tiempo, aconseja introducir algunas modificaciones en los Organismos encargados de la censura cinematográfica, que tanta importancia revisten y tan delicda misión tienen confiada.

Debe presidir la constitución de estos Organismos un criterio de unidad, conforme al que es postulado de nuestro Movimiento, encaminado a la mejor eficacia del Servicio, reuniendo en un solo Organismo las funciones y competencias que venían estando dispersas en dos, aunque dejando subsistente otro Organismo superior a los efectos de recursos de revisión.

Igualmente se tiende con esta modificación a producir el menor retraso y entorpecimiento posible, dejando a salvo las garantías que corresponde a los intereses particulares, siempre respetables, pero subordinados al superior fin de la educación general, afectado de manera decisiva por un medio de tan extraordinaria difusión como es el cinematógrafo.

En consecuencia, esta Vicesecretaria de Educación Popular, de acuerdo con la Orden de 2 de noviembre de 1938 y Ley de 20 de mayo de 1941, se ha servido disponer lo siguiente:

Artículo $1^{\circ}$. La censura cinematográfica será ejercida por la Comisión Nacional de Censura Cinematográfica, y para los recursos de revisión por la Junta Nacional Superior de Censura Cinematográfica, que dependerán de la Vicesecretaría de Educación Popular, adscribiéndose a la Delegación nacional de Cinematografía y Teatro.

Art. $2^{\circ}$. La Comisión Nacional de Censura Cinematográfica estará formada por un Presidente, nombrado libremente por el Vicesecretario de Educación Popular, y cinco Vocales, nombrados por el mismo, a propuesta unipersonal, respectivamente, del Ministerio del Ejército, de la Autoridad eclesiástica, del Ministerio de Educación Nacional, del

\footnotetext{
${ }^{351}$ Reorganizando los servicios de censura cinematográfica, 23 de noviembre de 1942, Vicesecretaría de Educación Popular, Boletín Oficial del Estado, 26 noviembre de 1942, núm. 330
} 
Ministerio de Industria y Comercio (Subcomisión Reguladora de la Cinematografía), los cuatro primeros, y el quinto de ellos será Lector Censor de guiones del Departamento de Cinematografía de la Delegación Nacional de Cinematografía y Teatro.

La Junta Superior de Censura Cinematográfica estará formada por un Presidente, nombrado libremente por la Vicesecretaría de Educación Popular, y cinco Vocales, designados en forma análoga a los de la Comisión Nacional, y que podrá ser presidida por el Delegado Nacional de Cinematografía y Teatro, cuando lo estime oportuno.

Cada uno de los miembros de la comisión y de la Junta tendrá designado un suplente, nombrado en igual forma que el titular respectivo y que sustituirá a éstos en los casos de imposibilidad de asistencia.

Los titulares y suplentes de ambos Organismos percibirán la dietas de asistencia que se fijen por la Vicesecretaría de Educación Popular, que serán abonadas con cargo a su presupuesto.

La asistencia a las sesiones del Presidente y de estos Vocees o sus respectivos suplentes, por lo menos, es obligatoria, y sin que pueda celebrarse sesión en ausencia del Vocal representante de la Autoridad eclesiástica y su suplente.

Un funcionario de la Vicesecretaría de Educación Popular ejercerá el cargo de Secretario de ambos Organismos. Será suplido, en caso necesario, por otro funcionario encargado del servicio por el Delegado Nacional de Cinematografía y Teatro.

El personal administrativo y técnico de la Comisión que sea necesario pertenecerá igualmente a la plantilla de la Vicesecretaría de Educación Popular.

Las sesiones de la Comisión y de la Junta serán secretas y no podrán asistir a las mismas más que los componentes de dichos Organismos. En casos excepcionales y debidamente justificados, el Presidente de la Comisión y el de la Junta, respectivamente, podrán autorizar la asistencia a las sesiones a personas ajenas a aquéllas.

\section{Art. $3^{\circ}$. Compete a la Comisión:}

Censurar toda clase de películas, nacionales y extranjeras, sean de la clase que fueren y quienquiera que las haya producido, que hayan de proyectarse en territorio nacional.

Censurar el material de propaganda que las Casas distribuidoras o propietarias de películas remitan con éstas a las salas de proyección.

Art. $4^{\circ}$. Compete a la Junta Nacional Superior el conocimiento de todos los recursos de revisión sobre los acuerdos de la Comisión o de cualquier Organismo que haya ejercicio la censura cinematográfica.

Art. $5^{\circ}$. Todos los componentes de la Comisión y de la Junta tendrán voz en la apreciación general de las películas sometidas a censura, pero a la terminación del examen de aquéllas cada uno de los Vocales emitirá dictamen escrito y firmado con I resolución que considere prudente, teniendo en cuenta cada uno de ellos, exclusivamente, los puntos de vista propios de la representación que ostente, o sea: militar y de defensa nacional, el primero; moral y religioso, el segundo; pedagógico y de cultura, el tercero; económico, el cuarto; técnico, político y de educación popular, el quinto; este último ha de comprobar, 
además, en las películas de producción nacional, si la realización de las mismas se adapta al guión autorizado.

Los dictámenes de cada uno de los Vocales harán constar si proponen la prohibición total de la película o su total aprobación, o bien deben hacerse en ella algunos cortes que la hagan aprobable. Igualmente contendrán propuesta para el cumplimiento de los artículos $6^{\circ}$ y $8^{\circ}$ de esta Orden.

El Presidente, a la vista de los dictámenes emitidos por los Vocales y sin que pueda tomar decisión positiva en caso de algún dictamen negativo, aun cuando sí negativa ante dictámenes positivos, hará propuesta de resolución definitiva que, certificada por el Secretario, será elevada al Delegado Nacional de Cinematografía y Teatro. El Delegado Nacional expedirá el documento oportuno con la resolución de la Comisión.

Art. $6^{\circ}$. En la resolución definitiva elevada al Delegado Nacional de Cinematografía y Teatro se hará constar si la película es «recomendable» o simplemente «tolerada» para menores de dieciséis años, o si, por el contrario, sólo se autoriza para mayores de dicha edad.

Las Empresas cinematográficas, en toda clase de propaganda y por lo que se refiere a películas para menores, habrán de hacer mención obligatoria de la denominación con que haya sido clasificada; naturalmente y de acuerdo con la legislación vigente, cuando no se declara una película «tolerada» o «recomendable» para menores, no podrá permitirse a éstos, por las respectivas Empresas, su acceso a los locales.

Art. $7^{\circ}$. El programa de las sesiones que se titulan infantiles deberá componerse exclusivamente de las películas " recomendables " para menores

Art. $8^{\circ}$. Todas las películas que en la fecha de publicación de la presente Orden ostenten en el certificado de censura la denominación de autorizadas para menores de catorce años, se considerarán a no ser que las Empresas cinematográficas las sometan nuevamente a la Comisión, si a juicio de las mismas debe modificarse la clasificación que se les asigne.

Art. $9^{\circ}$. La Junta Nacional ejercerá sus funciones con procedimiento análogo al establecido por la Comisión.

Art. 10. El recurso de revisión ante la Junta Nacional Superior podrá ser interpuesto por cualquier autoridad o por el productor o distribuidor de las películas, abonando nuevamente en estos últimos casos el canon correspondiente de censura. El recurso será siempre razonado y se hará la petición por escrito al Delegado Nacional de Cinematografía y Teatro. Estos recursos de reposición pueden interponerse contra cualquier producción cinematográfica que se trate de representar.

Ninguna autoridad podrá suspender, por motivos de censura, la proyección de una película debidamente aprobada por la Comisión Nacional de Censura Cinematográfica. Sólo le compete la interposición del recurso de revisión. La Junta Superior no podrá, de oficio, proceder a la revisión de ninguna película.

Art. 11. El Delegado Nacional de Cinematografía y Teatro podrá, de oficio, cuando lo estime oportuno ordenar a la Junta Nacional Superior la revisión de cualquier producción cinematográfica. 
Art. 12. Los documentos que contengan las resoluciones de los Organismos de Censura, dados por la Delegación Nacional de Cinematografía y Teatro, si se refieren a noticiarios, habrán de ser entregados en el plazo máximo de cuarenta y ocho horas después de la presentación de las películas a la censura.

Todas las demás películas serán examinadas en el plazo máximo de quince días, sin que puedan ser reclamadas antes de los ocho días, a partir de su presentación.

Art. 13. Las solicitudes de censura serán dirigidas al Delegado Nacional de Cinematografía y Teatro y las películas deberán presentarse en el Registro de la Vicesecretaría tal y como hayan de proyectarse en público. Únicamente en casos excepcionales y por motivos debidamente fundados y razonados, podrá autorizar el Delegado Nacional de Cinematografía y Teatro que sean presentadas a censura cintas en su versión original, acompañadas, en estos casos, del texto que en el doblaje haya de hacerse en idioma español para su proyección al público. En dichos casos se abonarán triples derechos de censura, no eximiendo esta presentación, que se estimará previa, de la obligación de someterla a fallo definitivo, ante la propia Comisión una vez efectuado su doblaje en español.

Si los propietarios o alquiladores de películas hubiesen practicado en ellas algunos cortes antes de someterlas a censura, deberán acompañar a la solicitud los cortes verificados en una de las copias, que a su vez vendrán reseñados en aquélla.

La Comisión podrá reclamar los cortes de las demás copias de las películas.

Art. $14^{\circ}$. Las películas que sean prohibidas por la Comisión Nacional podrán someterse de nuevo a examen ante dicho Organismo, cuando los propietarios de aquéllas hubiesen transformado en material apto para la proyección mediante el nuevo pago de los derechos correspondientes.

Las películas así modificadas se considerarán como nuevas y seguirán para la censura la tramitación establecida para las películas aún no censuradas.

Art. 15. Cuando la Comisión o la Junta Superior acuerden la supresión de frases o escenas de una película, los propietarios o distribuidores quedan obligados a entregar los cortes de todas las copias en la Secretaría, donde se conservarán debidamente ordenadas por espacio de dos años, pasados los cuales procederá a su inutilización o destrucción.

No se entregarán las hojas de censura mientras todos los trozos no estén en poder de los Organismos de censura.

Art. 16. A la solicitud de censura, cuando se trate de películas importadas y en tanto no se establezca un régimen que permita hacer la revisión con anterioridad al abono de los derechos de importación, se acompañará necesariamente el documento original que acredite el pago o la exención de los derechos de Aduana correspondiente, así como una copia simple de dicho documento, que quedará unida al expediente. También deberá acompañarse el oportuno permiso de importación.

Cuando se trate de películas producidas en España se acompañará el certificado del laboratorio nacional que las hubiera positivado, acompañado también de su correspondiente copia. Asimismo deberá acompañarse el permiso del rodaje. 
A las solicitudes de los noticiarios y documentales deberá acompañarse, además, un índice o resumen de los asuntos que contengan.

En todo caso, en la solicitud de censura se expresará el número de copias de cada película, quedando también obligados los propietarios o alquiladores a declarar a la Comisión Nacional la importación, recuperación, estampación, en territorio nacional, de nuevas copias posteriores a las declaradas en la solicitud.

Art. 17. No podrá proyectarse ninguna película, de la clase que sea, en sesiones públicas ni privadas, si previamente no se obtiene el correspondiente certificado de censura.

Art. 18. Asimismo queda prohibido todo género de propaganda de películas de producción nacional sin la previa obtención del permiso de rodaje. Cuando se trate de películas extranjeras será necesario obtener con anterioridad el certificado de censura.

Art. 19. De acuerdo con el apartado $2^{\circ}$ del artículo $3^{\circ}$ de la presente Orden, al presentarse una película para su censura a la comisión deberá acompañarse toda la propaganda sobre la misma de carteles, fotogramas, fotografías, programas ilustrados, etc., los cuales no podrán exhibirse sin que ostenten el sello-contraseña de la Comisión Nacional de Censura. De los carteles murales o de aquellos otros reclamos que por sus dimensiones o peculiares características no sean fácilmente transportables, se presentará un diseño que los reproduzca exactamente en tamaño reducido.

La propaganda de las películas actualmente autorizadas deberá presentarse a la Secretaría de la Comisión en el espacio de sesenta días, a partir de la fecha de la publicación de esta Orden, para que sea sellada según se dispone en el presente artículo.

Art. 20. La vigilancia e inspección de todo lo relativo a censura cinematográfica corresponde a los Delegados provinciales de la Vicesecretaría de Educación Popular en las capitales de provincia, y a los Delegados locales en las demás poblaciones.

A cada película acompañará siempre su documentación en regla, que estará, en todo momento, sujeta al examen de las autoridades correspondientes.

Art. 21. Sin perjuicio de las responsabilidades en otro orden en que puedan incurrir, se castigarán con sanciones pecuniarias los siguientes actos: Primero, la proyección de películas o de parte de ellas censuradas y prohibidas; Segundo, la proyección con cortes, multinacionales o modificaciones que puedan alterar el fallo emitido con anterioridad por la censura; Tercero, las contravenciones a lo que se dispone en los artículos $6^{\circ}, 7^{\circ}, 8^{\circ}, 17,18$ y 19.

Las sanciones podrán imponerse a los propietarios, alquiladores, distribuidores, empresarios, gerentes responsables, por acción u omisión, bien sea intencionadamente o por negligencia, y serán abonadas en papel de pagos al Estado.

Art. 22. Los derechos de censura de los Organismos encargados de la misma serán los siguientes :

Por rollo de cada una de las copias, 10 pesetas. En el caso de que se prohiba la película, sólo se cobrarán los derechos de censura sobre los rollos de una copia. 
En los casos en que se solicite un nuevo certificado por extravío u otra cosa excepto por haber realizado una nueva copia de una película ya censurada, se cobrarán cinco pesetas por derechos de expedición.

Todos estos derechos se ingresarán por los interesados en la Administración de la Vicesecretaría de Educación Popular, de acuerdo con las normas establecidas para ello. esta Orden.

Art. 23. Quedan derogadas cuantas disposiciones se opongan a lo establecido en

\section{Orden disponiendo la proyección exclusiva y obligatoria del noticiario «NO- DO» ${ }^{352}$}

Creada la entidad de carácter oficial Noticiarios y Documentales Cinematográficos "No-Do", dependiente de esta Vicesecretaría, que editará y explotará cn carácter exclusivo el " oticiario Cinematográfico Español ", cuyo primer número aparecerá en los primeros días del próximo mes de enero, y siendo este Organismo el único que en el futuro podrá llevar a cabo el intercambio de noticias cinematográficas con el extranjero, esta Vicesecretaría de Educación Popular se ha servido disponer lo siguiente:

Artículo $1^{\circ}$. A partir del día 1 de enero de 1943 no podrá editarse en España, sus posesiones y colonias ningún noticiario cinematográfico ni documental de este tipo que no sea el " Noticiario Cinematográfico Español No-Do ".

Artículo $2^{\circ}$. Los noticiarios cinematográficos que hasta ahora venían editándose 0 que puedan editarse hasta esta fecha y que hayan sido puestos en explotación antes de la misma, podrán continuar su circuito normal de explotación hasta su finalización.

Art. $3^{\circ}$. A partir de esta misma fecha, ningún operador cinematográfico que no pertenezca a la entidad Noticiarios y Documentales Cinematográficos " No-Do ", o que trabaje debidamente autorizado por éste, podrá obtener reportajes cinematográficos bajo pretexto alguno. Igualmente ningún laboratorio podrá manipular película cinematográfica de este tipo que no haya sido rodada por los operadores autorizados anteriormente, debiendo dar cuenta inmediata a la entidad Noticiarios y Documentales Cinematográficos " No-Do" de cualquier encargo que se le hiciera en otro sentido.

Art. 4․ El Noticiario Cinematográfico Español "No-Do", que aparecerá en los priemeros días de enero próximo, se proyectará, con carácter obligatorio, en todos los locales cinematográficos de España y sus posesiones durante todas las sesiones de los mismos. esta Orden.

Art. $5^{\circ}$. Quedan derogadas cuantas disposiciones se opongan a lo establecido en

\footnotetext{
${ }^{352}$ Disponiendo la proyección exclusiva y obligatoria del noticiario « NO-DO», 17 de diciembre de 1942, Vicesecretaría de Educación Popular, Boletín Oficial del Estado, 22 de diciembre de 1942, núm. 356
} 


\section{Orden regulando la importación de películas ${ }^{353}$}

Con fecha 28 de octubre de 1941 el Ministerio de Industria y Comercio dispuso que la importación de películas cinematográficas impresionadas se concediera exclusivamente a las entidades o personas de nacionalidad española que, de acuerdo con las normas que con aquela fecha se hicieron públicas, produjesen películas enteramente nacionales de una categoría decorosa y de un coste no inferior a 750.000 pesetas. Las referidas normas establecían la posibilidad de llevar a cabo estas importaciones con anterioridad a la producción que las autorizaba, mediante la represetnación de un aval bancario que garantizaría su edición.

Transcurrido un año y medio desde esta fecha, variadas las circunstancias que entonces concurrían, apreciados los inconvenientes de que en las actuales adolecen las mismas y la necesidad de fijar de un modo más claro los requisitos que han de exigirse para conseguir la máxima eficacia en la protección y estímulo de la producción nacional, con la finalidad de elevarla a la altura que le corresponde, este Ministerio de Industria y Comercio ha acordado modificar las referidas normas, redactándolas de nuevo en la forma siguiente:

$1^{\circ}$. Las solicitudes aprobadas en principio por este Ministerio de acuerdo con las normas de 28 de octubre de 1941 y que no haya sido anuladas por haber entrado en período de tramitación o producción, serán resueltas con sujeción a las referidas normas, siempre que los interesados hagan uso de sus derechos en la forma en que han sido concedidos, en el plazo de tres meses, a partir de la fecha de la publicación de esta disposición, plazo que puede ser ampliado hasta un año, incluida en él la producción de la película ofrecida, si los motivos que impiden su resolución son ajenos a la competencia del interesado.

$2^{\circ}$. A partir de estas solicitudes, la importación de películas se concederá única y exclusivamente a aquellas entidades o personas que produzcan películas de largo metraje íntegramente nacionales, a los efectos económicos, y de una categoría técnica y artística suficientemente decorosa, a juicio de la Comisión clasificadora que a tal efecto nombra este Ministerio.

$3^{\circ}$. Los requisitos y trámites imprescindibles para que una película nacional tenga derecho en su día de disfrutar de los beneficios de importación que este Ministerio concede, son los siguientes:

a) Estar producida por la entidad o persona que reúna las condiciones legales exigidas para ejercer la industria de producción cinematográfica.

\footnotetext{
${ }^{353}$ Regulando la importación de películas, 18 de mayo de 1943, Ministerio de Industria, Subsecretaría de Comercio, Boletín Oficial del Estado, 24 de mayo de 1943, núm. de B.O.E. 124
} 
b) Presentar en la Subcomisión Reguladora de la Cinematografía, Organismo cinematográfico competente del Ministerio de Industria y Comercio, con veinte días, al menos, de anticipación a la fecha en que se piense iniciar cualquier adquisición de compromisos relativos a la producción que se pretenda realizar, el guión cinematográfico definitivo de la misma, acompañado, de un plan económico completo, relación de técnicos y artistas que se deseen emplear, así como la hoja de censura correspondiente.

c) En el plazo de veinte días, la Subcomisión Reguladora de Cinematografía emitirá informe relativo a esta producción, en el que hará constar los defectos que en ella pudiese apreciar, copia del cual será entregado al interesado, el cual podrá tenerlos en cuenta, realizando las modificaciones oportunas, presentándola de nuevo a informe, renunciar a la producción o, no obstante, insistir en realizarla: bien entendido que dicho informe será tenido en cuenta en su día por la Comisión de Clasificación, a los efectos oportunos.

Las producciones que merezcan informes favorables tendrán prioridad a los efectos de suministro de material virgen para su realización.

d) Una vez inscrita la película como acogida a estos beneficios, de lo cual se extenderá certificado al interesado, y concedido el material virgen necesario por la Subcomisión Reguladora de la Cinematografía, podrá iniciarse la producción, y durante su transcurso este Organismo queda facultado para supervisarla en todos los aspectos, haciendo las observaciones que estime oportunas, por escritos dirigidos al productor, que constarán igualmente en su día ante la Comisión Clasificadora.

e) Finalizada la producción, será sometidos visionado de la Comisión Clasificadora nombrada por este Ministerio, acompañándose resumen detallado por partidas del coste definitivo de la misma, quien a la vista de su resultado y de los informes y comunicaciones de la Subcomisión Reguladora de la Cinematografía antes citados, dictaminará la categoría que le corresponda y el valor de producción que se le asigne, que darán lugar a los beneficios de importación a que se haya hecho acreedora.

$4^{\circ}$ a) Las películas de producción nacional serán clasificadas dentro de las siguientes tres categorías:

$1^{a}$ Aquellas películas que supongan un avance considerable en cualquier aspecto de la producción, sin que otro cualquiera de ellos haga perder la condición de muy buenas y merecedoras por tanto del mayor económico y protección.

$2^{a}$ Aquellas películas que sin suponer un avance considerable en nuestra producción sean en su conjunto de una calidad suficientemente buena para poder con decoro traspasar nuestras fronteras, y que merezcan por tanto la protección del Estado.

$3^{a}$ En esta categoría serían consideradas aquellas producciones que por su calidad artística o técnica supongan un descrédito de nuestra industria, no siendo merecedoras de apoyo alguno.

b) El valor de producción será determinado según los resultados obtenidos a la vista de la calidad de los diferentes elementos que en ella intervinieron, teniendo en cuenta el resumen de gastos definitivo presentado por el interesado, pero aceptándose solamente 
aquellas partidas del mismo que se reflejan justificadas en la película visionada conforme a un plan de producción sensato y ordenado y a los precios normales de esta industria.

La decisión acordada será comunicada oficialmente a los interesados.

$5^{\circ}$. La Comisión Clasificadora queda constituida en la siguiente forma:

Presidente, el ilustrísimo señor Subsecretario de Comercio, Política Arancelaria y Moneda.

Vicepresidente, el Presidente de la Subcomisión Reguladora de la Cinematografía.

Vocales: un Vocal nombrado por la Vicesecretaría de Educación Popular; un Vocal nombrado por el Sindicato Nacional del Espectáculo; un Vocal nombrado por la Dirección General de Bellas Artes: un Vocal nombrado por la Academia de la Lengua: un Vocal nombrado por la Academia de Bellas artes.

Actuará de Secretario el Jefe de la Sección de Producción de la Subcomisión Reguladora de la Cinematografía.

El Presidente podrá recabar, si lo estima oportuno, el asesoramiento de otros elementos técnicos de la industria cinematográfica o personas competentes de este sector artístico.

$6^{\circ}$. A la vista de la clasificación y coste de producción acordado por la Comisión Clasificadora, la Subsecretaría de Comercio, previo informe de su organismo competente, la Subcomisión Reguladora de la Cinematografía otorgará los permisos de importación correspondiente, teniendo en cuenta: la solicitud de los interesados y la operación que propongan, el precio, la calidad y la procedencia de las películas que se desea importar, los cupos existentes de diferentes países y la disponibilidad de divisas.

Como norma general, sujeta a las circunstancias que concurran, los beneficios de importación que este Ministerio concede son los siguientes ajustados a la categoría de la producción y a su valoración a estos efectos:

Por cada millón de pesetas de valor aprobado:

Primera categoría, de tres a cinco películas, según su valor de explotación.

Segunda categoría, de dos a cuatro películas, según su valor de explotación.

Tercera categoría, ningún derecho.

A valores de producción superiores o inferiores al millón de pesetas corresponderá la parte proporcional de importaciones.

En casos especiales, y si los contingentes de importación lo permiten, se podrá conceder algún aumento en el número de permisos, así como autorizarse la compensación directa con otra película de países de producción reducida, con quienes interese establecer relaciones cinematográficas y sea éste el único medio posible.

$7^{\circ}$. El valor de las películas de importación a que dan derecho los referidos permisos será el normal de una película de buena calidad, es decir, que si se pretende importar una producción extranjera que por su excepcional mérito justifique un precio más 
elevado, será necesario hacer uso para ello de los permisos de importación necesarios para cubrir este precio.

$8^{\circ}$. La importación de películas se realizará por pago de clearing, divisas o créditos facilitados o autorizados por el Instituto Español de Moneda Extranjera, o bien, de no ser esto posible, por compensación con la producción nacional realizada, bien entendido que de emplearse las dos primeras formas, la producción nacional al exportarse a todos los países, lo será con aportación total de su valor en divisas a España, y en el tercero de ellos sólo servirá de compensación hasta el valor del material que se importe, viniendo la diferencia en divisas al Instituto Español de Moneda Extranjera, así como las que resulten de exportaciones a los demás países que pudieran realizarse. Se exceptúan los casos especiales de compensación con países de producción reducida fijados en el apartado $6^{\circ}$.

$9^{\circ}$. A los efectos del planteamiento de la operación que se proponga, podrá exigir la Subcomisión Reguladora de la Cinematografía cuantos datos estime oportunos, contratos legales y facturas originales y directas, e incluso el visado previo de las películas a importar.

10. Las películas nacionales que hayan dado lugar a una importación deberán ser exportadas a cuantos países sea posible, y de no realizar estas exportaciones los interesados, podrán tomarlas a su cargo la Subcomisión Reguladora de la Cinematografía, correspondiendo los beneficios a los productores, pero sin que éstos puedan oponerse a las mismas.

\section{Orden estableciendo el título de «películas de Interés Nacional»» ${ }^{354}$}

Importaría muy poco elevar el contenido técnico y artístico de nuestras producciones cinematográficas e imprimir en aquellas un sello inconfundible de personalidad española, si no se lograra simultáneamente amparar con visión amplia y equitativa las aportaciones materiales puestas al servicio de tal noble finalidad. Por eso, sin que las medidas destinadas a la protección de nuestro cine lleguen a lesionar respetables intereses creados al amparo de normas legítimas anteriores, urge corregir las diferencias existentes en la actualidad que pueden ser causa de que aquéllas modalidades protectoras no lleguen a alcanzar la gracia para que fueron creadas.

La construcción legislativa actual no ampara suficiente los esfuerzos nobelísimos hechos a favor de nuestra cinematografía, y son muchas las películas españolas que pudiendo alcanzar una riqueza técnica y artística mayor no la harán a causa de la imposibilidad de obtener posteriormente un trato de igualdad con respecto a las producciones extranjeras. Esto da lugar a que nuestra producción cinematográfica no se eleve en el ritmo que interesa a la cultura española para la divulgación de nuestras verdades raciales.

\footnotetext{
${ }^{354}$ Estableciendo el titulo de "películas de Interés Nacional», 15 de junio de 1944, Vicesecretaría de Educación Popular, Boletín Oficial del Estado, 23 de junio de 1944, núm. de B.O.E. 175
} 
Por otra parte, son muchas las películas extranjeras que, sin la intervención de ningún elemento español responden exactamente a las exigencias morales, sociales, y políticas de nuestro Estado. Estas creaciones cinematográficas no pueden quedar en su divulgación a merced de las vicisitudes comerciales más o menos admisibles a la estricta justicia.

Ante hechos y necesidades de tal naturaleza he tenido a bien ordenar lo siguiente:

Artículo $1^{\circ}$. Las películas nacionales que reciben de la Delegación Nacional de Propaganda el artículo de películas de interés nacional serán diferentes a todos los fines de contratación en las salas de proyección cinematográfica enclavadas en territorio nacional.

Art. $2^{\circ}$. La preferencia establecida en el artículo anterior se referirá en todo caso a los siguientes extremos:

a) Estreno en la época más conveniente de la temporada cinematográfica.

b) Condiciones mínimas iguales a las que se hallen establecidas normalmente en el mercado cinematográfico.

c) Prioridad en los reestrenos, con las condiciones establecidas en el inciso anterior.

d) Obligatoriedad de proyección mientras la película alcance el mínimo del cincuenta por ciento del aforo total del cine; se considerará no alcanzado este aforo si al realizar el cómputo de una semana los ingresos diarios no llegan a dicho porcentaje.

Art. $3^{\circ}$. Los títulos «película de interés nacional» no podrán otorgarse más que a las películas producidas en España cuyos cuadros artístico y técnico sean esencialmente españoles. También se considerará fundamental para la expedición de dicho título que la película contenga muestras inequívocas de exaltación de valores raciales o enseñanzas de nuestros principios morales y políticos. La concesión de estos títulos corresponderá al Excelentísimo Señor Vicesecretario de Educación Popular, a propuesta de la Delegación Nacional de Propaganda y previos los informes de la Sección de Cinematografía y Teatro y de la Comisión Nacional de Censura Cinematográfica, otorgándose o denegándose sin el ulterior recurso.

Art. $4^{\circ}$. Cuando alguna película extranjera contenga, a juicio de la Sección de Cinematografía y Teatro y de la Comisión Nacional de Censura Cinematográfica, valores artísticos, técnicos o políticos, de carácter excepcional dentro de las inspiraciones del Estado, se elevará automáticamente a la Delegación Nacional de Propaganda propuesta en el sentido de que se le otorgue el título de "Película de interés nacional». La Delegación Nacional elevará el oportuno dictamen el excelentísimo señor Vicesecretario de Educación Popular sobre dicha propuesta, y esta jerarquía resolverá en definitiva la concesión o denegación de dicho titulo.

Art. $5^{\circ}$. Las divergencias que surjan sobre la aplicación e interpretación de esta Orden, sobre los productores o distribuidores de las «Películas de interés nacional» y los propietarios de las salas de proyección, serán resueltas por la Delegación Nacional de Propaganda, previo el informe de la Sección de Cinematografía y Teatro, en el plazo de cinco días, a contar de la fecha de reclamación. Contra estas resoluciones podrá 
interponerse recurso ante el excelentísimo señor Vicesecretario de Educación Popular en el plazo de cinco días, contados desde la fecha de notificación.

Art. $6^{\circ}$. Las resoluciones que se dicten en virtud de esta Orden por la Delegación Nacional de Propaganda o por la Vicesecretaría de Educación Popular, no será obstáculo a las acciones de carácter civil que los interesados puedan ejercer ante los Tribunales ordinarios para solventar las cuestiones que surjan entre los mismos.

Art. $7^{\circ}$. La presente disposición comenzará a regir en primero de julio próximo.

\section{Ley de clasificación arancelaria protectora de la Industria Nacional de Cinematografía ${ }^{355}$}

La producción cinematográfica nacional ha llegado a un grado de desenvolvimiento prometedor de grandes posibilidades, y ello exige que por el Estado se preste apoyo a la industrialización de esta vigorosa actividad española, utilizando al efecto el medio legítimo y racional de la protección arancelaria directa sobre las importaciones que hayan de realizarse.

La clasificación arancelaria vigente, establecida en tiempos en los que la industria de la cinematografía no había llegado a manifestarse en nuestro país con vitalidad propia, resulta hoy tan insuficiente en su texto como absurda en la modalidad y cuantía del gravamen.

La adecuada protección arancelaria no sólo ha de favorecer a la producción nacional, sino que beneficiará asimismo a la de los países más adelantados, determinando automáticamente una selección natural, con preferencia para aquellas producciones cuyos merecimientos pueden considerarse como de mayor interés artístico y comercial.

Un discreto ordenamiento tributario, enlazado adecuadamente con un sistema aduanero que le complemente, puede afirmarse que ha de convenir a todos los intereses dentro de la relación armónica que los liga.

En su virtud, y de conformidad con la propuesta elaborada por las Cortes Españolas, dispongo:

Artículo $1^{\circ}$. A partir del día siguiente al de la publicación de la presente Ley en el Boletín Oficial del Estado se considerarán suprimidas las partidas 691 bis y 692 de los vigentes Aranceles de Aduanas en el texto y contenido actualmente tienen, sustituyéndose íntegramente por la clasificación que a continuación se detalla:

\footnotetext{
${ }^{355}$ Ley, Clasificación arancelaria protectora de la industria nacional de cinematografía, 19 de julio de 1944, Jefatura del Estado, Boletín Oficial del Estado, 21 de julio de 1944, núm. 203
} 


\begin{tabular}{|c|c|c|}
\hline \multirow{4}{*}{ PELÍCULAS CINEMATOGRÁFICAS } & \multicolumn{2}{|c|}{ TARIFA ORO } \\
\hline & \multirow[t]{2}{*}{ TARIFA $1^{\mathrm{a}}$} & TARIFA \\
\hline & & CONVENCIONAL \\
\hline & Pesetas & Pesetas \\
\hline \multicolumn{3}{|l|}{ Partida 692 - Películas cinematográficas sin impresionar. } \\
\hline Peso neto $\mathrm{kg}$ & 4,50 & 1,50 \\
\hline \multicolumn{3}{|l|}{ Partida 692 bis (Nota 39 bis).- Películas de largo metraje : } \\
\hline \multirow{2}{*}{\multicolumn{3}{|c|}{$\begin{array}{l}\text { Impresionadas en negativo o positivo. Incluso sus bandas sonoras, } \\
\text { la columnas de efectos y las películas en tecnicolor: }\end{array}$}} \\
\hline & & \\
\hline De Primera categoría & 60.000 .00 & 30.000 .00 \\
\hline De Segunda categoría................. & 40.000 .00 & 20.000 .00 \\
\hline De Tercera categoría. & 20.000 .00 & 10.000 .00 \\
\hline \multicolumn{3}{|l|}{ Partida 692 ter (Nota 39 bis).- Películas de corto metraje : } \\
\hline \multicolumn{3}{|l|}{ Por cada rollo de 300 mts. o fracción: } \\
\hline De Primera categoría. & 3.000 .00 & 1.500 .00 \\
\hline De Segunda categoría. & 2.000 .00 & 1.000 .00 \\
\hline De Tercera categoría. & 1.000 .00 & 500.00 \\
\hline \multicolumn{3}{|l|}{ Partida 692 cuart.- Bandas sonoras y columnas de efectos, } \\
\hline \multicolumn{3}{|l|}{ Cuando se importen con separación de las películas a que } \\
\hline correspondan, peso neto. Kg & 75.00 & 25.00 \\
\hline
\end{tabular}

Nota 39 bis.- Se considerarán como películas de corto metraje aquéllas cuya longitud no exceda de seiscientos metros, estimándose como de largo metraje las que pasan de expresada lontigud.

Para determinar la categoría de la película, calificación que es totalmente independiente de su metraje, servirá de base el certificado de clasificación extendido por el Organismo formará parte, en representación del Ministerio de Hacienda, el Director general de Aduanas o funcionario en quien delegue. El documento de adeudo se hará constar el título de cada una de las películas importadas, que habrá de coincidir con el que conste en la licencia de importación y en el certificado de clasificación, cuyos documentos serán conjuntamente requisitos previos indispensables para que pueda ser autorizado el despacho.

Art. $2^{\circ}$. Quedan exceptuadas de la aplicación del Régimen de Importación que por la presente Ley se establece, aquéllas películas cuyas licencias de importación se hayan concedido o puedan concederse como consecuencia de producciones cinematográficas nacionales cuyo permiso de rodaje esté expedido con fecha anterior a la publicación de la presente Ley.

Art. $3^{\circ}$. La excepción a que se refiere el artículo precedente prescribirá al año de la fecha en que haya sido clasificada la película nacional de que se trate.

Art. $4^{\circ}$. Podrán admitirse en régimen de suspensión del pago de derechos las importaciones de películas de exclusivo carácter científico o cultura que, sin utilización comercial alguna, obtengan la previa autorización del Ministerio de Hacienda. A este efecto 
será requisito indispensable que, con la conveniente antelación se presente ante la Dirección General de Aduanas la correspondiente solicitud, acompañada de los certificados que en apoyo de la petición aporte el solicitante. Por el expresado Centro directivo se interesarán de los Organismos competentes en la materia los adecuados informes, a fin de garantizar que las películas reúnen todas las circunstancias requeridas para el disfrute del régimen de que se trata. Las películas que disfruten de tal beneficio serán re-exportadas dentro del plazo que por el Ministerio de Hacienda se hayan fijado en la correspondiente autorización.

Art. $5^{\circ}$. Las películas que hayan de ser «visionadas» quedarán sometidas al régimen de intervención que se ejercerá por la Dirección General de Aduanas, cuyo Centro podrá delegar tales funciones en sus dependencias provinciales según en cada caso corresponda.

Art. $6^{\circ}$. Para las películas importadas previo el pago de los correspondientes derechos arancelarios, se expedirá por la Aduana respectiva un certificado acreditativo de su legal importación. La reproducción de este certificado habrá de proyectarse en la pantalla, precediendo a los preliminares de la película, sin cuyo requisito serán consideradas como fraudulenta.

Art. $7^{\circ}$. Queda derogado en su actual redacción el caso 17 de la disposición tercera de los vigentes Aranceles de Aduanas y, en consecuencia, las Ordenes ministeriales que en el mismo se mencionan.

No obstante, en caso suficientemente justificados, la Dirección General de Aduanas podrá autorizar en régimen especial de aplazamiento del pago de derechos arancelarios la importación de copias negativas de imagen y sonido, y de las positivas lavander, master prints, fine grain o similares. Tales concesiones llevarán aneja la obligación de depositar en metálico el importe de aquéllos derechos o bien la presentación de garantía bancaria suficiente a responder de los mismos, cuyos derechos se ingresarán en firme dentro de los treinta días siguientes a la fecha de expedición de la licencia de importación o al cumplirse el plazo de seis meses si antes no hubiera sido presentada.

Transcurrido este plazo se dará conocimiento en cada caso al Ministerio de Industria y Comercio, sin que pueda expedirse por la Dirección General de Aduanas el certificado de legal importación mientras aquél Ministerio no haya expedido la respectiva licencia de importación.

En el caso de que la licencia de importación fuera denegada por el Ministerio de Industria y Comercio, el importador, previa justificación oficial de tal extremo, así como de la re-exportación de la película de que se trate, podrá solicitar ante las correspondientes autoridades del Ministerio de Hacienda la instrucción de expediente de devolución de aquéllos derechos, cuya solicitud se tramitará con arreglo a legislación vigente sobre la materia.

Art. $8^{\circ}$. En el plazo de quince días a partir de la fecha de publicación de la presente Ley en el Boletín Oficial del Estado, el Departamento Nacional de Cinematografía, de la Vicesecretaría de Educación Popular expedirá certificación, a surtir efectos en la Dirección General de Aduanas, comprensiva de todos los premios de rodaje expedidos con anterioridad a la referida fecha de publicación. 
Art. 9 ${ }^{\circ}$. Quedan derogadas las disposiciones que se opongan a cuanto por la presente se dispone.

\section{Orden por la que se aprueba la reglamentación nacional del trabajo en la industria de la cinematografía ${ }^{356}$}

IImo. Sr.: Vista la Reglamentación Nacional del Trabajo en la Industria de Cinematografía propuesta por esa Dirección General con fecha de hoy, y en uso de las facultades atribuidas a este Ministerio, he acordado:

$1^{\circ}$ Aprobar la expresada Reglamentación con efectos a partir de primero de octubre próximo.

$2^{\circ}$ Autorizar a la Dirección General de Trabajo para dictar cuantas disposiciones y aclaraciones exija la aplicación de las citadas normas, extender sus preceptos a otras actividades, con las modificaciones que fuesen precisas, y acordar normas privativas, con carácter total o parcial, para las Empresas cuyas excepcional situación exija tales normas.

$3^{\circ}$ Disponer la inserción del mencionado texto en el BOLETíN OFICICIAL DEL ESTADO.

Lo que digo a V.I. para su conocimiento y efectos.

Dios guarde a V.I. muchos años.

Madrid, 28 de septiembre de 1944.

\section{GIRÓN DE VELASCO}

\section{REGLAMENTACION NACIONAL DEL TRABAJO EN LA INDUSTRIA DE CINEMATOGRAFIA}

\section{CAPITULO PRIMERO}

\section{Extensión}

Artículo $1,{ }^{\circ}$ Ambito institucional

Las presentes Ordenanzas regulan las relaciones de trabajo en las Empresas de la Industria Cinematográfica.

A efectos de la aplicación de las presentes Ordenanzas, Se entiende por Industria Cinematográfica la que se dedica conjunta o separadamente a la producción, rodaje, elaboración y distribución de películas cinematográficas.

\footnotetext{
${ }^{356}$ Orden por la que se aprueba la reglamentación nacional del trabajo en la industria de la cinematografía, 28 de septiembre de 1944, Ministerio de Industria y Comercio, Boletín Oficial del Estado, 6 de octubre de 1944, núm. 280
} 
Se incluyen, por tanto, en la presente Reglamentación: a) Los llamados estudios Cinematográficos.

b) Los laboratorios que se dedican a las operaciones de revelado, positivado y montaje de películas cinematográficas.

Las Empresas productoras que editan películas cinematográficas.

Las Empresas distribuidoras dedicadas a la distribución de películas mediante compra, arrendamiento, préstamo o cesión gratuita.

Art. $2^{\circ}$, Ambito personal.

Se regirán por las presentes Ordenanzas todos los trabajadores que actúan en la Industria Cinematográfica, tanto si realizan una función técnica o administrativa como si solo prestan su esfuerzo físico o de atención.

Se excluyen: a) Las funciones de alta dirección económica o artística, alto gobierno o alto consejo, características de los siguientes cargos u otros semejantes: Director y Subdirector (general, técnico, de producción o películas), Gerente, Secretario y Administrador general, etc., así como los jefes de departamento en Empresas de varios ciclos de producción. b) Los actores que figuran en él $<<$ reparto $>$ de una película. c) El personal estipulado por contrata a quien se encomiende algún servicio determinado (casas de modas, figuritas, sastres, etc.), sin continuidad en el trabajo, ni sujeción a jornada y sin que figure, por lo tanto, en la plantilla de la Empresa, ni en el contrato de la producción de la película. d) Los agentes comerciales que trabajen en la Industria Cinematográfica exclusivamente a comisión de una Empresa, con libertad de representar otras dedicadas a igual o distinta actividad.

Art. $3^{\circ}$, Ambito territorial.

Las presentes Ordenanzas de Trabajo serán de aplicación en todo el territorio nacional. Se entenderán comprendidas en este concepto, no solo las provincias de la Península e Insulares, sino también las plazas de Soberanía del Norte de África.

Art. $4^{\circ}$, Ambito temporal.

Las normas de esta Reglamentación empezarán a regir a partir del día señalado en su Orden aprobatoria y no tendrán plazo señalado de validez.

\section{CAPITULO II}

\section{Organización del trabajo}

Art. $5^{\circ}, 1$ 1) La organización práctica del trabajo, dentro de las normas y orientaciones de esta Reglamentación y de las disposiciones legales es facultad exclusiva de la Empresa, que responderá de su uso ante el estado.

2) No obstante, los sistemas de racionalización, mecanización o división del trabajo que se adopten no podrán nunca perjudicar la formación profesional que el personal tiene el derecho y el deber de completar y perfeccionar con la práctica diaria: y tampoco ha de olvidarse que la eficacia y el rendimiento del personal y, en definitiva, las prosperidad de la 
Empresa, dependen de la satisfacción que nace, no solo de una retribución decorosa y justa, sino de que las relaciones todas de trabajo y, en especial, las que sean consecuencia del ejercicio de la libertad que se reconoce a las Empresas, estén asentadas sobre la justicia.

Art. $6^{\circ}$, Con objeto de establecer la debida jerarquía en los distintos órdenes de la producción, la Empresa procurará organizar sus servicios, de forma que los jefes de cualquier categoría vengan obligados a transmitir las instrucciones de la Dirección y las sugerencias del personal por conducto jerárquico concretamente reglamentado, a fin de que nunca se desvirtúen su contenido y finalidad.

\section{CAPITULO III}

Del personal

\section{Sección Primera}

\section{Clasificación}

Art. $7^{\circ}$, Disposiciones genéricas.

Las clasificaciones de personal consignadas en la presente Reglamentación son meramente enunciativas y no suponen la obligación de tener provistas todas las plazas enumeradas si la necesidad y volumen de la industria no lo requiere.

Sin embargo, desde el momento mismo en que existía en una Empresa un trabajador que realice las funciones especificadas en la definición de la categoría profesional determinada, habrá de ser remunerado, por lo menos, con la retribución que a la misma asigne esta Reglamentación.

Son asimismo, enunciativos los distintos cometidos asignados a esta categoría o especialidad, pues todo trabajador de la industria está obligado a ejecutar cuantos trabajos y operaciones le ordenen sus superiores, dentro de los generales cometidos propios de su competencia profesional. siguientes:

Art. $8^{\circ}$, El personal de la Industria Cinematográfica se clasificará en los Grupos

$1{ }^{\circ}$ Técnicos.

$2,{ }^{\circ}$ Artistas.

$3,{ }^{\circ}$ Administrativos.

$4,{ }^{\circ}$ Subalternos.

$5,^{\circ}$ Obreros.

Art. $9^{\circ}$, Técnicos. - Este Grupo Comprende:

JEFES TÉCNICOS:

Jefes de Departamento.

Jefes de Sección Técnica. 
Técnicos especializados.

Operadores de Sonido (Estudio).

Operador Jefe de Cámara (Profesionales).

Decorador (Producción).

Montador (Producción o Estudios).

AYUDANTES DE TÉCNICOS:

Segundos operadores de Cámara (Producción).

Caracterizador (maquillador).

Ayudantes de Dirección Artística, Técnica y de Producción.

Constructor Realizador de decorados.

Jefe electricista.

Jefe de Cabina.

Ayudante de Cámara, Sonido, Montaje y Laboratorio.

AUXILIARES TÉCNICOS:

Secretarios de rodaje (Producción).

Fotógrafos de Fotofija (Producción).

Programista (Distribución).

Auxiliares de Director Artístico: a) Avisador, b)Retocador (Ayudante maquillaje). c) Dibujantes (Distribución, Estudios y Producción).

Operador de cabina (Estudios).

Auxiliares de cámara, sonido, montaje y laboratorio.

Art. 10 Artistas.

Comparseria.

Figuración.

Actores de doblaje.

Art. 11 Administrativos.

Jefe de sección administrativa.

Jefe de escenario (Jefe de plató o escenarios).

Jefe de negociado.

Viajante ( distribución).

Oficiales de primera.

Oficiales de segunda. 
Auxiliares.

Aspirantes.

Art. 12. Subalternos.

Encargados de almacén.

Conserje.

Porteros y ordenanzas.

Guardas y serenos.

Recadistas y botones.

Encargada de camerinos.

Camarera.

Mujeres de limpieza.

Art. 13. Obreros.

Capataz encargado de taller o laboratorio.

Profesionales o de oficio (Oficial primero, segundo y tercero).

Aprendices.

Peones.

\section{SECCIÓN SEGUNDA}

\section{Definiciones}

Art. 14. Personal Técnico.

Jefes Técnicos. - Comprende este subgrupo al personal que desempeña la jefatura con la responsabilidad consiguiente dentro del ciclo completo de producción o de una película determinada.

Jefes de Departamento. - Comprende esta categoría a los que, bajo las ordenes inmediatas del director técnico subdirector, están al frente de un ciclo de producción o elaboración, con responsabilidad de orientar, distribuir y dar unidad a los trabajos del personal a sus ordenes.

Jefes de Sección Técnica. - Se incluyen en esta categoría a los que, dependientes del jefe de Departamento, orientan y dan unidad a los trabajos integrantes de una Sección determinada (Decorado, Doblaje, Cámaras, Montaje, Iluminación, etc.).

Técnicos especializados. - Es el personal que, a las ordenes del jefe de la sección correspondiente, realiza las funciones propias de su especialidad dentro del rodaje de una película.

Se distinguen las siguientes especialidades: a) Operadores de Sonido Comprende esta categoría el personal que, especializado en sonido, es responsable ante el 
Jefe de la Sección correspondiente del registro de sonido y una determinada película encomendada a su trabajo. b) Operador jefe de la Cámara. - Es responsable, a las ordenes del Director de la película, de la iluminación y de la impresión de las escenas componentes de la misma a el encomenda. c) Decorador. - Abarca esta categoría al personal especializado que trabaja, cuida y vigila de los detalles del decorado de una determinada película para el perfecto rodaje de la misma. d) Montador. - Es el personal de producción que a las ordenes del director de la película secciona y articula las diversas verificadas en el rodaje, dándoles unidad y ritmo.

B) AYUDANTES TÉCNICOS. - Comprende este subgrupo a los que, a las ordenes de los jefes de Sección, realiza las funciones técnicas que aquellos les encomiendan, dentro de su respectiva especialidad.

Segundos Operadores de Cámara. - Son los técnicos fotógrafos que, a las ordenes con el operador - Jefe, le ayudan en las funciones encomendadas al mismo, sin la responsabilidad directa impuesta al primero.

Caracterizador (Maquillador). - Es el técnico que según el contenido de la película, caracteriza al personal que en ella figura antes de su actuación.

Ayudante de Dirección Artística, Técnica o de Producción. - Es el Personal que a las ordenes del director de la película, del Director Técnico o del de Producción, realiza las funciones preparatorias y auxiliares del rollo conjunto de la película.

Constructor realizador de decorados. - Es el técnico que, es consonancia con las indicaciones del director de la película ateniéndose a las limitaciones económicas del Productor, proyecta decorados para las diversas escenas del rodaje.

Jefe electricista. - Es el que dependiente del jefe de Sección Técnica Electrica,. Ejecuta sus ordenes, cordinando los servicios del personal y asumiendo la responsabilidad de su recta aplicación.

Jefe de Cabina. - Es el que, con el titulo legal correspondiente asume los estudios toda la responsabilidad de toda la producción de la película.

Ayudante de cámara, Sonido, Montaje y laboratorio. - comprende esta categoria a los que ayudan en sus funciones técnicas al jefe de cámara o laboratorios, al operador de sonido o al montador. Queda incluido en esta categoria el ayudante operador de grúa.

\section{AUXILIARES TÉCNICOS:}

Secretarios de rodaje. - Abarca esta categoria al personal encargado de tomar nota de cuantas advertencias técnicas dicte el director de la película con el fin de plasmar la realización futura en las escenas en el momento del rodaje definitivo.

Fotógrafos de foto fija. - Se entiende por tales los técnicos fotógrafos que toman las escenas indicadas por el director de la película o por el productor para los fines que crea necesarios. 
Programista. - Es el personal de Distribución que bajo la Dirección del jefe de sucursal regula en las Empresas las distribuidoras la distribución de películas con fijación de la fecha de proyección, teniendo a su cargo igualmente el movimiento de copias.

Auxiliares de dirección Artística. - Son los que a las órdenes del director de la película, del director de producción o de sus ayudantes plasman y realizan en sus diversos oficios las instrucciones dadas por aquel. Se incluyen en esta categoria al: a) Avisador c) Retocador y c) Dibujante.

Operador de cabina. - Integra esta categoria el personal que con inicial título legal el jefe de cabina trabaja a sus ordenes en la proyección sin la responsabilidad consiguiente de la jefatura.

Auxiliares de cámara, sonido, montaje y laboratorio. - Comprende esta categoria al personal auxiliar en encomendar los materiales y mecánicos de los ayudantes de cámara, sonido, montaje y laboratorio tales como repaso y empalme de películas etc.

Art. 15. Personal Artístico. - Es el que interviene con su voz o con su figura en el rodaje o impresión de las películas.

Comparseria. - Comprende el personal Artístico que interviene en las escenas de una película, sin papel que figure en su "reparto".

Figuración. - Abarca al personal que forma los conjuntos de la película, siempre que estos sean superiores a cincuenta personas, en cada una de las diversas escenas.

Actores de doblaje. - Son los artistas que tienen por misión reproducir en idioma nacional los diálogos en las películas nacionales o importadas del extranjero. A efectos de retribución, se distinguirán tres categorías, según doblen papeles de actores de reparto de primera o segunda, o de simple comparsería con breves intervenciones orales.

Art. 16. Personal administrativo

Es aquel que desempeña funciones burocráticas de contabilidad u otras análogas.

Jefe de Sección Administrativa, Comprende esta categoría al personal que con los conocimientos exigidos por el Reglamento de régimen interior, asume, bajo la dependencia directa de la Dirección, Gerencia, o Administración el mando y responsabilidad de un sector teniendo a sus órdenes el personal que requieran los servicios.

Jefe de Escenario. - Es el que asume la responsabilidad de la asistencia y vigilancia de todo el personal ocupado en el rodaje.

Jefe de Negociado. - Comprende esta categoria a los que tienen a sus órdenes uno o más Oficiales y dirigen el trabajo de estos en alguno de los Negociados $u$ Organismos inferiores que la Empresa tenga establecidos, o establezca para el mejor cumplimiento de sus fines.

Viajantes. - Abarca esta categoría al personal de distribución que a las órdenes del Gerente o Jefe de Sucursal hace las rutas de antemano señaladas, sometiendo a su aprobación cuantas contratas realice con las fechas señaladas para su proyección.

Oficial de Primera. - Es aquel que tiene a su cargo un servicio determinado dentro del cual ejerce iniciativa y posee responsabilidad con o sin otros empleados a sus órdenes y 
que lleva a cabo, en particular las siguientes funciones: Cajero de cobro y pago sin firma ni fianza: taquimecanógrafo en un idioma extranjero: Transcripción en libros de cuentas corrientes, diario, mayor y responsables, etc.

Oficial de Segunda. - Es el empleado que, con iniciativa y responsabilidad restringida, efectúa funciones auxiliares de estadística y contabilidad coadyuvantes de las mismas, transcripción en libros y demás trabajos similares, taquimecanografía en idioma nacional 100 palabras 300 pulsaciones.

Auxiliares. - Se considerará como tales a los empleados que sin iniciativa y responsabilidad se dediquen dentro de la oficina a operaciones elementales administrativas $y$, que en general, a las puramente mecánicas inherentes al trabajo de aquella. Quedan incluidas las telefonistas.

Aspirantes. - Se entenderán por tales, dentro de la edad de 14 a 20 años, trabajen en labores propias de oficina, dispuestos a iniciarse en las labores peculiares de estas.

Art. 17. Personal subalterno. - Es el que realiza funciones de limpieza y vigilancia de las dependencias y recintos, cobros y pagos, así como otras de carácter elemental, con el fin de facilitar la labor de los empleados y elementos directivos.

Encargado de almacén. - Es el que ha de despachar los pedidos de los almacenes, recibir las mercancías, distribuirlas y ordenarlas en los estantes registrando los libros el movimiento de material que haya habido durante siendo responsable de sus funciones ante la Empresa.

Conserje. - Tendrán la mencionada categoria el que, al frente de los Ordenanzas, Porteros, Recadistas, Botones y mujeres de limpieza, cuidan de la distribución del trabajo y del ornato y policia de las distintas dependencias.

Porteros y Ordenanzas. - Son los que tienen a su cargo la vigilancia de los locales de las oficinas, la copia a prensa de los documentos, el franqueo y la recogida y entrega de correspondencia y la ejecución de los encargos y recados que se les encomienden.

Guardas y serenos. - Son los que realizan funciones de vigilancia y cuastodia de las distintas dependencias, cumpliendo sus deberes con sujección a las disposiciones señaladas por las Leyes que regulan el ejercicio de la misión que les esta asignada.

Recadistas y botones. - Son los subalternos mayores de 14 años y menores de 20 que realizan funciones similares a la de los ordenanzas.

Encargada de camerinos. - Comprende esta categoria al personal femenino que vigila y cuida de la asistencia y orden de los camerinos.

Camarera. - Es la que auxilia y ayuda a la encargada en los menesteres que requieren sus funciones.

Mujeres de limpieza. - Se entiende por tales las que se ocupan del aseo y limpieza de las oficinas y dependencias de las Empresa.

Art. 18. Personal obrero. - Es el que ejecuta trabajos de orden mecánico y material. 
Capataz encargado de taller o laboratorio. - Se considera como tal a aquel que al frente de un grupo de operarios y bajo la dependencia correspondiente trabaja, vigila y cuida de la asistencia y disciplina del personal a sus órdenes y de los detalles de la recta aplicación de las ordenes recibidas en lo que se refiere a la ejecución de obras y trabajos.

Profesionales o de oficio. - Comprende esta categoria a los obreros que después de un aprendizaje realizan trabajos de un oficio tales como electricidad, pintura, albañilería, carpintería, conducción de vehículos etcétera. Las definiciones específicas son las que constan en las respectivas reglamentaciones.

Los operarios de estos oficios quedarán clasificados en la siguiente forma:

Oficiales primeros. - Son aquellos que poseyendo uno de los oficios detallados anteriormente, lo practican y practican con tal grado de perfección que no solo les permite llevar a cabo trabajos generales del mismo, sino aquellos otros que suponen especial empeño y delicadeza. Tendrán esta categoria los conductores de turismo o de camiones, a quienes se exige carné especial.

Oficiales segundos. - Integran dicha categoria los que sin llegar a la especialización exigida para los trabajos perfectos, ejecutan los correspondientes a un determinado oficio con la suficiente corrección y eficacia, tendrán, asimismo, esta categoria los conductores de turismo o camión con carné de primera y segunda y los montadores de fotograbado.

Oficiales terceros. - Son aquellos que habiendo realizado el aprendizaje de un oficio no han alcanzado todavía los conocimientos prácticos indispensables para efectuar los trabajos con la corrección exigida a un Oficial de segunda...

Aprendices. - Son los obreros de más de 14 años y las obreras de más de 16 que ingresan en el trabajo para iniciarse en la práctica de la operaciones de la producción y con objeto de adquirir la preparación necesaria para el ejercicio de las labores de la misma.

Peone. - Son los mayores de 18 años que ejecutan trabajos para los cuales no se requiera preparación alguna ni conocimiento teórico - práctico de ninguna clase, pues la índole de su trabajo consiste exclusivamente en la aportación de su esfuerzo físico y no exige otra condición que la atención debida a la voluntad de llevar a cabo aquello que se le ordene, se consideran dos categorías: 1) Serán "peones de primera" los que unen al trabajo realizado una cierta responsabilidad y atención especial, 2) Serán "peones de segunda" los mozos de carga y descarga.

\section{SECCION TERCERA}

Ingresos, accesos, plantillas y escalafones

Art. 19. El ingreso del personal técnico y administrativo y oficinas habrá de verificarse mediante concurso, oposición, cuyas condiciones se determinarán en el reglamento de régimen interior, de acuerdo siempre con las normas contenidas en esta Reglamentación.

Las admisiones de personal que habrán de efectuarse, de acuerdo con las disposiciones vigentes en materia de colocación, se considerarán provisionales durante un 
periodo de prueba variable según la índole de la labor a que cada trabajador sea destinado y que en ningún caso podrá exceder del que señala en la siguiente escala:

Para el personal técnico.........................4 meses.

Para el personal de propaganda ............6

Para el personal de oficinas.................. "

Para el resto del personal.....................1

Durante este periodo tanto el trabajador como el Empresario podrán, respectivamente, desistir de la prueba o proceder al despido, sin previo aviso sin ninguna de las partes tenga por ello derecho a indemnización.

En todo caso el trabajador tendrá derecho al percibido, durante el periodo de prueba de la retribución correspondiente a la categoria profesional del trabajo encomendado.

Transcurrido el plazo referido el trabajador pasará a figurar en la plantilla de la Empresa, según lo perceptuado en el artículo 26 y el tiempo que cada trabajador hubiere servido en calidad de prueba le será computado a efecto de los aumentos periódicos por tiempo de servicios que establecen la presente Reglamentación.

El período de prueba de que queda hecho mérito no es de carácter obligatorio y los patronos podrán, en consecuencia, proceder a la admisión de su personal con renuncia total o parcial a su utilización.

Art. 20. Ascensos. - Grupo 10: El nombramiento del personal que integra los tres subgrupos será de libre elección o contratación de la Empresa entre los que posean los títulos correspondientes.

Art. 21. Grupo $2^{\circ}$ : Todo su personal será libremente nombrado por la Empresa de entre el alistado Censo profesional.

Art. 22. Grupo $3^{\circ}:$ 1) La Empresa proveerá las vacantes de jefes de Sección Administrativa entre jefes de Negociado y Oficiales primeros mediante pruebas de aptitud cuyas condiciones se fijarán en el reglamento de régimen interior.

En las categorías de jefes de Negociado, Oficiales y Auxiliares el ascenso se hará mediante prueba de aptitud y entre el personal de categoria inferior y personal subalterno u obrero de la propia Empresa.

A falta de personal apto de la misma Empresa, podrán cubrir las vacantes de las categorías consignadas en el párrafo anterior con personal ageno a otras Empresas o en paro que reúnan las condiciones que fije el reglamento de Régimen Interior, según lo preceptuado en el artículo 19 de esta Reglamentación.

Los aspirantes, previo examen de capacitación, pasarán a la categorĺa de Auxiliares al cumplir la edad de 20 años siempre que haya vacante de esta categorla; en caso contrario, optarán entre marcharse de la Empresa o percibir dentro de ella la mitad de 
la diferencia, siempre que no desempeñe funciones de categoria auxiliar, en cuyo caso cobrarán la diferencia integra.

Art. 23. Grupo 4: Los Conserjes serán nombrados por la Empresa de entre los porteros y Ordenanzas. Las plazas de estas últimas categorias se proveerán, dentro de las Empresas, entre sus trabajadores que hayan sufrido examen o alguna incapacidad y no tengan derecho a subsidio o pensión; como así mismo entre quienes no pueden desempeñar otro oficio o empleo con el rendimiento normal a causa de defecto físico, enfermedad o edad avanzada. El restante personal de este Grupo será de libre elección de entre el personal de esta Empresa.

Art. 24. Grupo 50: 1) El porcentaje mínimo de oficiales de primera y segunda de los oficios determinados en el artículo 26 de estas ordenanzas se designarán por libre elección de la Empresa entre los integrante de la categoria profesional de oficiales, que en prueba de aptitud demostrarán la capacidad señalada en el contenido de la funciones fijadas de cada oficio. En caso contrario, podrá la Empresa sacar las vacantes a oposición libre entre el personal ajeno a la misma. 2) Los Aprendices serán de libre elección de la Empresa pasando a oficiales de tercera, si hay vacantes, en caso contrario, optarán por salir de la Empresa o cobrar la mitad de la diferencia.

Art. 25. 1) El Reglamento de régimen interior establecerá los exámenes y pruebas de aptitud y exigirá los méritos o títulos precisos para asegurar la capacidad profesional, así como las condiciones físicas y psíquicas necesarias para todos los ascensos. Así mismo fijará la puntuación de los méritos a considerar en los mismos, debiéndose computar la antigüedad en la Empresa como mérito preferentemente en igualdad de circunstancias.

Estas pruebas de capacidad deberán orientarse de tal forma que no exijan grandes esfuerzos de memoria, siendo más bien de carácter práctico, y se refieran preferentemente a los trabajos o funciones que vayan a desempeñarse.

El Tribunal que juzgará las pruebas de aptitud. Exámenes de capacidad, concursos de ingresos y ascensos, serán presidido por el Jefe de la Empresa o un representante de éste, quien estará asistido por dos Vocales de igual o superior categoria de la vacante o puesto de nueva creación que haya de proveerse; uno de ellos será libremente designado por la Empresa y el otro elegido por éste de una terna de su personal, que a tal fin presentará el Sindicato correspondiente.

Art. 26. Plantillas. 1) Todas las Empresas vienen obligadas a formar e insertar en el Reglamento de régimen interior la plantilla general del personal adscrito a la industria o talleres sujetos a estas Ordenanzas, sometiéndolo a la aprobación de la Delegación de Trabajo, si son provincias, y a la Dirección General de Trabajo, si son Empresas nacionales.

Establecerán el número total de empleados que debe comprender cada categoria profesional sin que pueda y deberse el que actualmente existe.

Las Empresas mixtas que abarcan, dentro de sus actividades, las distintas industrias señaladas en el apartado tercero del artículo primero tendrán las plantillas separadas del personal obrero adscrito a cada ciclo de producción.

En la plantilla del Grupo Administrativo se guardarán los siguientes porcentajes, en relación con el mismo total del Grupo: 
Jefes y Oficiales, el 40 por 100.

Auxiliares, el 60 por 100.

4) Los porcentajes del Grupo obrero en la categoria de Oficiales, serán como mínimo, en relación con el número total de los mismos, que integran la Empresa:

Oficiales de primera, el 20 por 100.

Oficiales de segunda, el 30 por 100.

Oficiales de tercera, el 50 por 100.

La Empresa especificará en su plantilla el carácter de su personal permanente o temporal.

Se entiende por personal permanente, el que tiene un trabajo fijo y continuado, sin limitación de tiempo.

Es personal temporal, el contratado para realizar una labor determinada en una película, etc., acabada la cual cesa su contrato de trabajo y su relación con la Empresa.

Art. 27. Escalafones. 1) La Empresa formará el Escalafón de su personal de acuerdo con la clasificación en grupos y categorías que establecen las Secciones primera y segunda del capitulo III.

El personal de Empresas de reducido volumen de fabricación que desempeñe funciones de varias categorías, recibirá también una clasificación de categoria determinada en el Escalafón en grupos y categorías, recibirá también una clasificación de categoria determinada en el Escalafón y plantilla, que se fijará atendiendo con equidad y justicia a los cometidos que en tiempo que en tiempo e importancia ocupa preferentemente sus actividades.

Un ejemplar del Escalafón será remitido a la Delegación de Trabajo o a la Dirección General de Trabajo, según los casos.

La Empresa publicará el Escalafón para conocimiento del personal, el cual tendrá un plazo de diez días, a partir de dicha publicación, para reclamar ante la misma Empresa sobre el lugar que le haya sido asignado. En caso de ser denegada la reclamación podrá acudir en el plazo de quince días ante la Delegación de Trabajo, donde formulará las alegaciones que estime oportunas, resolviéndolo en el plazo de diez días, y pudiendo recurrir ante la Dirección General de Trabajo en los diez días siguientes a la notificación.

\section{CAPITULO IV}

Del aprendizaje y formación profesional

Art. 28. Inspirándose en los criterios que orientan la doctrina y legislación social del Nuevo Estado, las Empresas que integran la Industria de Cinematografía, pondrán el máximo interés en la formación de aprendices, admitiéndoles para los oficios auxiliares y los propios de esta Industria de Cinematografía, pondrán el máximo interés en la formación de aprendices, admitiéndoles para los oficios auxiliares y los propios de esta Industria, en la 
proporción que fija la Orden de 23 de septiembre de 1939 de aplicar las enseñanzas oportunas para su mayor rapidez de perfeccionamiento profesional.

Art. 29. El aprendizaje en la Industria Cinematográfica durará cuatro años.

Art. 30. 1) La edad mínima de ingreso en la categoria de Aprendices para los oficios de la Industria Cinematográfica será la de catorce años para todo el personal.

El número de aspirantes del Grupo tercero no pasará del 15 por 100 del total que compone el escalafón del personal administrativo.

El número total de aprendices del Grupo quinto nunca podrá exceder del 25 por 100 del número de profesionales o de oficio que trabajen la Empresa.

Se les reservará el 80 por 100 de las vacantes que se produzcan en la categoria de Oficiales terceros, siempre y cuando hayan sido declarados aptos en la prueba de aptitud regulada por el artículo 25. En otro caso, podrán optar entre salir de la Empresa o cobrar la mitad de la diferencia.

\section{CAPITULO V}

Retribución

\section{SECCIÓN PRIMERA}

Principios generales

Art. 31. La remuneración del personal que actúe en la Industria Cinematográfica podrá establecerse sobre la base de salario fijo o de otro sistema de retribución que estimule al personal en la producción, aumentando su rendimiento y eficacia.

Art. 32. La retribución que se fija en el presente Capítulo se entenderá sobre jornada completa, pudiendo hacerse abono por semanas o meses.

Art. 33. 1) Los sueldos y salarios señalados en estas Ordenanzas se entienden mínimos y con carácter de ingreso garantizado en los casos en que la retribución sea de solo comisión o compuesta de sueldo y comisión.

2) En los oficios en los que no se consigne el sueldo o salario de mujer se entenderá que tienen éstas la misma retribución que los varones.

Art. 34. Con independencia de la retribución mínima que se marca, se establecen aumentos periódicos por tiempo de servicios a favor del personal administrativo y subalterno.

\section{SECCIÓN SEGUNDA}

Art. 35. A los efectos de fijación de sueldos y jornales del personal que presta sus servicios en la Industria Cinematográfica, se considera zona única todo el territorio nacional. 


\begin{tabular}{|c|c|}
\hline PERSONAL & SUELDO / Pts. \\
\hline Técnicos & Semanal \\
\hline Jefes de Departamento & 500 \\
\hline Jefes de Sección Técnica & 500 \\
\hline \multicolumn{2}{|l|}{ Técnicos especializados: } \\
\hline Operadores de sonido (Estudios) & 500 \\
\hline Operador-Jefe de Cámara (Producción) & 500 \\
\hline Decorador (Producción) & 500 \\
\hline Montador (Producción) & 500 \\
\hline Montador (Estudios) & 350 \\
\hline \multicolumn{2}{|l|}{ Ayudantes de Técnicos } \\
\hline Segundos operadores de Cámara (Producción) & 450 \\
\hline Caracterizador (Maquillador) & 400 \\
\hline Ayudante de Dirección Artística, Técnica y de Producción & 375 \\
\hline Constructor Realizador de Decorados (Estudios) & 325 \\
\hline Jefe Electricista & 325 \\
\hline Jefe de Cabina & 225 \\
\hline Ayudante de Cámara & 200 \\
\hline Ayudante de Sonido & 200 \\
\hline Ayudante de Montaje & 175 \\
\hline Ayudante de Laboratorio & 175 \\
\hline \multicolumn{2}{|l|}{ Auxiliares Técnicos } \\
\hline Secretario de rodaje (Producción) & 250 \\
\hline Fotógrafo de Foto-Fija (Producción) & 250 \\
\hline Programista (Distribución) & 200 \\
\hline \multicolumn{2}{|l|}{ Auxiliares de Dirección Artística: } \\
\hline Avisador & 200 \\
\hline Retocador (Ayudante de Maquillaje) & 200 \\
\hline Dibujantes (Distribución, Estudios y Distribución) & 150 \\
\hline Operador de Cabina (Estudios) & 125 \\
\hline Auxiliares de Cámara, Sonido, Montaje y Laboratorio & 100 \\
\hline Artistas & Diario \\
\hline Comparsería & 35 \\
\hline Comparsería con traje de etiqueta & 45 \\
\hline Comparsería con intervención oral & 60 \\
\hline Figuración & 25 \\
\hline Actores de Doblaje de $1^{\mathrm{a}}$ & 100 \\
\hline Actores de Doblaje de $2^{a}$ & 75 \\
\hline \multirow[t]{2}{*}{ Actores de Doblaje de $3^{a}$} & 50 \\
\hline & Semanal \\
\hline Actores de Doblaje (Personal fijo) & 350 \\
\hline Administrativos & Mensual \\
\hline Jefe de Sección Administrativa & 1.150 \\
\hline Con cuatro quinquenios de 70 pesetas mensuales & \\
\hline Jefe de Escenario (Jefe de Plató o Escenario) & 1.150 \\
\hline Con cuatro quinquenios de 70 pesetas mensuales & \\
\hline Jefe de Negociado & 1.000 \\
\hline
\end{tabular}




\begin{tabular}{|c|c|}
\hline Con cuatro quinquenios de 60 pesetas mensuales & \\
\hline Viajante (Distribución) & 600 \\
\hline Dieta mínima, 40 pesetas diarias. Comisiones libres. & \\
\hline Oficiales de $1^{a}$ & 750 \\
\hline Con cinco quinquenios de 30 pesetas mensuales & \\
\hline Oficiales de $2^{\mathrm{a}}$ & 600 \\
\hline Con cinco quinquenios de 40 pesetas mensuales & \\
\hline Auxiliares & 400 \\
\hline Con cinco quinquenios de 35 pesetas mensuales & \\
\hline Aspirantes: & \\
\hline De 14 a 16 años & 200 \\
\hline De 16 a 18 años & 225 \\
\hline De 18 a 20 años & 275 \\
\hline Subalternos & \\
\hline Encargado de Almacén & 600 \\
\hline Conserje & 450 \\
\hline Porteros y ordenanzas & 400 \\
\hline Guardas y Serenos & 400 \\
\hline Recadistas y Botones & 200 \\
\hline Encargada de Camerinos & 275 \\
\hline Camarera & 275 \\
\hline Mujer de limpieza & 2 pts. las dos \\
\hline Con cuatro quinquenios de 0,300 pesetas diarias & $\begin{array}{c}\text { primeras horas y } \\
1 \text { pts. las } \\
\text { restantes. }\end{array}$ \\
\hline Obreros & Diario \\
\hline Capataz encargado de taller o laboratorio & 24 \\
\hline Profesionales o de oficio: & \\
\hline Oficial $1^{a}$ & 19 \\
\hline Oficial $2^{\mathrm{a}}$ & 17 \\
\hline Oficial $3^{a}$ & 14 \\
\hline Aprendices: & \\
\hline Primer año & 3,50 \\
\hline Segundo año & 5,50 \\
\hline Tercer año & 8,75 \\
\hline Cuarto año & 10 \\
\hline
\end{tabular}

\section{SECCIÓN TERCERA}

Casos especiales de retribución

Art. 36. Trabajos de categoria superior. 1) El Personal de la Industria Cinematográfica podrá realizar trabajos sencillos de la categoria inmediata superior a aquella en que esté clasificado, no como ocupación habitual, sino en casos excepcionales de necesidad perentoria en la industria. 
Durante el tiempo de esta prestación los interesados cobrarán la remuneración asignada a la categoria desempeñada circunstancialmente, pasando en definitiva a ella si se prolongara por un periodo superior a dos meses.

Art. 37. 1) Los Viajantes de Distribución disfrutarán, cuando estén de viaje, dietas mínimas de 40 pesetas, con derecho a billetes de primera en ferrocarril además de las comisiones y participaciones que libremente pueda concederles la Empresa.

El Modelista y Pintor escenógrafo, por la especialidad de su trabajo artístico, cobrará sobre el jornal de Oficial primero un aumento diario de 5 pesetas.

Art. 38. Acoplamiento del personal con capacidad disminuida.- Con objeto de mantener en el trabajo, sin llegar al despido, a aquel personal que por deficiencia de sus condiciones físicas y psíquicas o por otras causas no se halle en situación de dar un rendimiento normal en su categoria, se podrá acordar su pase a otro trabajo.

\section{SECCIÓN CUARTA}

Aumentos periódicos por tiempo de servicio

Art. 39. Los quinquenios señalados en el cuadro de Sueldos y Salarios se computarán en cada categoria en razón del tiempo servido en la misma devengándose a partir del primer día del mes siguiente al que se cumpla. Los que asciendan de categoria no podrán sufrir pérdida en sus haberes respetándoles el sueldo alcanzado en la categoria inferior, y lo mantendrán en la nueva hasta tanto sea rebasado por acumulación al sueldo que asignado a este de los quinquenios que en la misma se vayan devengando.

\section{CAPITULO VI}

\section{Jornada Horas Extraordinarias y Vacaciones}

Art. 40. Jornada y horario. - 1) Dada la índole especial del trabajo en la Industria Cinematográfica la jornada legal de 8 horas diarias y 48 semanales no será de aplicación al personal técnico o artístico de producción contratado a plazo corto y fijo a base de un tanto alzado por su intervención en la totalidad o partes semanales de una película correspondiente y a pagos totales o escalonados, y que se deberán detallar en el contrato respectivo.

2) Del personal de Estudios quedan igualmente exentos de la jornada legal el jefe de escenario y todo el Grupo Técnico, con las únicas siguientes excepciones, Operador de cabina, Ayudantes, Auxiliares de cámara, Sonido y montaje y Fotógrafos de foto fija, y en los Laboratorios los Ayudantes y Auxiliares.

Todo el restante personal queda sometido a la jornada legal de 8 horas diarias y 48 horas semanales, si otra excepción que la del turno de noche que, cuando existan por acumulación de trabajo, circunstancias excepcionales con necesidades técnicas, aunque sea su turno único o aunque la Empresa solo trabaje a dos turnos, serán de 7 horas diarias y 42 semanales. 
Se entenderá por turno de noche el comprendido entre las veintidós horas y las seis horas y respecto a el habrán de cumplirse las disposiciones vigentes sobre trabajo de mujeres y niños.

Queda en todo caso excluidos del régimen de jornada legal el trabajo de los viajantes así como el de los porteros que disfruten de casa - habitación y el de los guardas que tengan asignado el cuidado de una zona limitada con casa - habitación dentro de ella siempre y cuando no se les exija una vigilancia constante.

En cuanto a los Porteros y Guardas y Vigilantes no comprendidos en el caso anterior podrán trabajar hasta un máximo de 72 horas a la semana los hombres, y 60 las mujeres con el abono de las que excedan de 48 a prorrata de su jornal - hora.

Respecto al Horario, las Empresas someterán a la aprobación de la Inspección Provincial de trabajo de su demarcación el correspondiente a su personal en general sometido a jornada legal, coordinándolo en los distintos servicios para el más eficaz rendimiento, siendo facultad privativa de la Empresa organizar los turnos y relevos y cambiar aquellos cuando lo crea necesario o conveniente, sin más limitaciones que las fijadas en esta reglamentación y la obligación de obtener permiso de la inspección cuando signifique cambio de horario.

El horario y régimen de trabajo del restante personal que actúa en una película lo fijará y hará público la Empresa con una anticipación mínima de 12 horas; debiendo en todo caso darse al personal exento de jornada legal y una hora como mínimo para el almuerzo y ocho horas continuas de descanso nocturno.

Art. 41. Horas extraordinarias. 1) Para el personal exento de la jornada legal no se computarán horas extraordinarias debiéndose, en todo caso, pagar proporcionalmente al contrato estipulado los días o semanas que excedan de las consignadas en el contrato como plazos de su actividad en la película.

2) El restante personal, previa obtención de la autorización pertinente, expedida por la respectiva Delegación de Trabajo, dentro de los límites señalados por la Ley de Jornada Máxima, podrá trabajar en la Industria Cinematográfica, horas extraordinarias abonadas con los recargos establecidos por aquella ley. El número de estas, dada la particularidad de la Industria podrá aumentarse sobre el tope máximo señalado por la Ley previa autorización para cada película de la delegación de Trabajo.

Art. 42. Vacaciones. 1) El régimen de vacación retribuida del personal será el siguiente: Subgrupo $1^{\circ}$ de Técnicos, 25 días naturales y 30 a los tres años; Subgrupos $2^{\circ}$ y $3^{\circ}$ de Técnicos y los Grupos $2^{\circ}$ y $3^{\circ} 15$ días naturales de entrada y 20 días naturales a los tres años de servicio en la Empresa; Personal Subalterno y Obrero, 10 días naturales. 2) Del anterior escala, y de acuerdo con la Ley de 6 de diciembre de 1940 y disposiciones posteriores, se exceptúan el personal de menos de 21 años, para el cual la vacación será de 20 días consecutivos cualquiera que sea su categoria y grupo al que pertenezca siempre que estos días sean para ir a campamentos, cursos o viajes etc. 
3) El personal que cese en el transcurso del año, por causas que no le sean imputables, tendrá derecho a la parte proporcional de la vacación, según el número de meses trabajados, computándose como mes completo la fracción del mismo.

Las vacaciones serán concedidas preferentemente en verano, y se otorgarán de acuerdo con las necesidades del servicio procurando complacer al personal en cuanto a la época del disfrute dando preferencia al más antiguo.

\section{CAPITULO VII}

\section{Enfermedades Licencias y Excedencias}

Art. 43. 1) Además de lo que se establece en el Reglamento de la Ley del Seguro de Enfermedad aprobado por Decreto de 11 de noviembre 1943, en relación con las indemnizaciones en tiempo de enfermedad y respetando las condiciones más beneficiosas que para el personal estuvieren establecidas en virtud de normas de trabajo, usos y costumbres locales o concesión espontánea de los empresarios, se reservará durante un año el puesto de trabajo al personal que contraiga enfermedad no profesional.

2) En este caso, quien ocupe la vacante temporalmente producida tendrá la condición de eventual durante el citado plazo, sin otro derecho cuando se le despida que el percibo de una indemnización correspondiente al despido normal.

3) Si el trabajador fijo no se reincorpora a su puesto en el plazo aludido, el eventual, previo examen de aptitud, adquirirá los derechos correspondientes al personal de plantilla de su categoria y computándoseles, a los efectos de los aumentos por tiempo de servicio, el período en que actuó en calidad de eventual o suplente.

Art. 44. 1) Las Empresas concederán las licencias que soliciten, siempre que no excedan en total de diez días al año y medie causa justificada, tal como fallecimiento de los padres cónyuges, hijos, nietos o hermanos, matrimonio del empleado, alumbramiento u otra de análoga naturaleza. Los Reglamentos interiores concretarán las causas y la duración de las licencias que se deba conceder por cada una de ellas.

2) En casos extraordinarios y debidamente acreditados, estas licencias se otorgarán por el tiempo que sea preciso, según las circunstancias; pero deberán convenirse las condiciones en que se concedan, pudiendo acordarse el no percibo de haberes e incluso el descuento del tiempo extraordinario de licencias, a efectos de antigüedad.

En ningún caso las licencias podrán descontarse de las vacaciones.

Art. 45. Todo el personal pasará a la situación de excedencia forzosa transcurrido el periodo que por enfermedad se señala en el artículo 43 de esta reglamentación.

En esta excedencia, el personal se someterá a los reconocimientos periódicos que determine la Empresa, causando baja definitiva al final del periodo máximo de cinco años.

Este personal en situación de excedencia forzosa al reingresar, tendrá derecho, siempre que hubiera vacante, a ocupar el puesto que reglamentariamente la corresponda en el escalafón o en otro caso, cuando se produzca. 
2) El personal femenino que contraiga matrimonio podrá solicitar el pase a la situación de excedencia voluntaria con carácter indefinido, reservando a la interesada, si quedase viuda o el marido se incapacitase para el trabajo, el derecho de preferencia al reingreso en la categoria que tenia cuando se produjo la excedencia, si hubiera vacante en la misma, o, en otro caso, en la primera que se produzca, siempre y cuando que la interesada tenga menos de cincuenta años cuando haga uso del derecho que se le reconoce.

\section{CAPITULO VIII}

Faltas, sanciones y premios

Art. 46. 1) En el Reglamento particular de cada Empresa se establecerá la forma de premiar la conducta, rendimiento, laboriosidad o condiciones sobresalientes del personal.

2) Los premios podrán consistir en viajes o bolsas de estudios, cantidades en metálico, sobresueldos, etc., y llevarán anejas la concesión de puntos o preferencias para el paso de unas a otras categorías.

3) En el fondo de premios se ingresará, en todo caso, el importe de las multas que se impongan al personal y el de las economías que la Empresa pueda hacer como consecuencia de la aplicación de sanciones.

Art. 47. Faltas del personal y sus sanciones. 1) Las faltas, aparte la de puntualidad, cuya especial naturaleza exige un régimen particular, se clasificarán en leves, graves y muy graves.

2) Son leves: Las faltas que sean calificadas por la Empresa en su Reglamento interior.

3) Son graves: Las cometidas contra la disciplina en el trabajo o contra el respeto debido a los superiores, compañeros o subordinados.

La falta de aseo, que produzca queja justificada de los compañeros de trabajo.

El quebrantamiento o violación de secretos o la reserva obligada, sin que se produzca gran perjuicio a la Empresa.

Simular la presencia de otro empleado, fichando o firmando por él; ausentarse sin licencia del centro de trabajo, fingir enfermedad o pedir permiso alegando causas no existentes y otros actos semejantes que puedan proporcionar a la Empresa una información falsa.

4) Son muy graves: El trabajo para otra actividad de Cinematografía, sin autorización de la propia.

Los malos tratos de palabra y obra o la falta grave de respeto o consideración a los jefes o sus familiares, sí como a los compañeros y subordinados.

El fraude, hurto o robo, tanto a la Empresa como a los compañeros de trabajo. 
La deslealtad, el abuso de confianza y, en general, los actos que produzcan prejuicio grave a la Empresa.

La enumeración de las faltas que anteceden no es limitativa, sino simplemente enunciativa.

El Reglamento del régimen interior habrá de completarla, señalando, además, las circunstancias que determinen el cambio de calificación de la falta y clasificando las de consideración o respeto debido al público.

El abuso de autoridad por parte de los Jefes será considerado siempre como falta muy grave. El que lo sufra deberá ponerlo inmediatamente en conocimiento del Jefe de la Empresa, que ordenará la inmediata instrucción de expediente.

Art. 48. 1) Las sanciones que procederá imponer en cada caso, según las faltas cometidas, serán las siguientes:

Por faltas leves:

Amonestación verbal.

Amonestación por escrito.

Multa hasta de un día de haber.

Por faltas graves:

Disminución o perdida total del período de vacaciones.

Multa no superior a la séptima parte de la mensualidad.

Recargo hasta el doble de los años que la vigente Reglamentación establece para los aumentos por tiempo de servicios.

Inhabilitación temporal, por plazo no superior a cuatro años, para pasar a categoria superior.

Represión pública.

Por faltas muy graves:

Pérdida temporal o definitiva para pasar a categoria superior.

Despido.

2) Dentro de los límites fijados, y teniendo muy en cuenta su experiencia y características, cada Empresa determinará en su Reglamento particular la gradación de las faltas y sanciones.

3) Las sanciones que en el orden laboral puedan imponerse se entienden sin prejuicio de pasar el tanto de culpa a los Tribunales cuando la falta cometida pueda constituir delito, o de dar cuenta a las autoridades gubernativas, si procede.

Art. 49. El retraso de más de cinco minutos del personal obligado a firmar o fichar a la entrada se sancionará con multas de 10 por 100 del haber de un día; en el caso de que estas faltas se repitan en el mismo mes más de tres veces, la multa será del 20 por 100 por 
cada falta a partir de la cuarta, y medio día de haber a partir de la séptima, la repetición de esta falta más de diez veces en el mismo mes será considerada como falta muy grave.

Art. 50. Tramitación. - 1) Corresponde al Jefe de la Empresa la facultad de imponer las sanciones por faltas leves, graves o muy graves, sin otra excepción que la de despido, que se reserva a la Magistratura de Trabajo, ante la cual formulará aquél la correspondiente propuesta.

2) No será necesaria la previa instrucción de expediente en los de faltas graves o muy graves. El Reglamento interior determinará los trámites y plazos del expediente, cuya duración no podrá exceder de dos meses, sobre la base de que sea oído el inculpado y de que se le admitan cuantas pruebas proponga en su descargo; asimismo concretará dicho Reglamento los casos de faltas muy graves en que la Empresa podrá acordar, como medida previa, la suspensión de empleo y sueldo por el tiempo que dure diez días.

3)Las sanciones graves o muy graves que imponga la Empresa al personal serán recurribles ante la Magistratura del Trabajo en el término de diez días.

4)Tanto en el caso de recurso como en el de propuesta de despido, el Magistrado de Trabajo resolverá por auto, dentro del plazo de diez días, a la vista del expediente de la Empresa y con audiencia del interesado, que podrá aportar las pruebas que a su derecho convengan.

La resolución que dicte la Magistratura será inapelable y hará la oportuna declaración sobre la suspensión de empleo y sueldo que, como medida previa, hubiera acordado la Empresa en la tramitación de los expedientes en las faltas muy graves.

Cuando la Magistratura no dé lugar al despido, la Empresa quedará en libertad para imponer cualquier otra de las sanciones señaladas para faltas muy graves.

Art. 51. 1) Las Empresas anotarán en los expedientes personales de sus empleados las sanciones por faltas graves o muy graves que se les impusieren, pudiendo anotar también las no incidencias en faltas graves.

2) El Reglamento Interior podrá determinar los cargos y condiciones en que la conducta y actuación del sancionado posteriores a la falta, anulen estas notas desfavorables.

3) La Empresa deberá dar cuenta al Sindicato de toda sanción impuesta por falta grave o muy grave.

Art. 52. Sanciones a las Empresas. 1) Las Delegaciones de Trabajo podrán sancionar a las Empresas que incumplen la presente Reglamentación con multas de 500 a 5000 pesetas o proponer a la Dirección General que eleve la cuantía hasta 25000 , en casos de reincidencia, o cuando así lo aconsejen las naturaleza y circunstancias de la falta o de los infractores. Cuando la sanción fuera impuesta por el Delegado de Trabajo, cabrá el oportuno el oportuno recurso ante la Dirección General, que deberá interponerse en el plazo de diez días hábiles, contados desde el siguiente al de la notificación de aquella.

2) En estos casos, la Dirección General de Trabajo, además de imponer la sanción económica, podrá proponer al Ministro el cese de los Jefes, Directores generales o miembros del Consejo de Administración responsables de la conducta de la Empresa, y el 
Gobierno, a propuesta del Ministro de Trabajo, acordar su inhabilitación temporal o definitiva para ocupar aquellos cargos u otros semejantes o de Jefatura en cualquiera Empresa.

Art. 53. Cuando en un establecimiento, sucursal, etc., se falte reiteradamente a las prescripciones de este Reglamento o de las Leyes reguladoras del trabajo, el Director que esté al frente incurrirá en falta muy grave, y aparte la sanción económica que a la Empresa pueda imponerse, según lo dispuesto en el apartado anterior, podrá ser también inhabilitado temporal o definitivamente para ocupar puestos de dirección o de Jefatura en cualquier actividad; esta resolución deberá adoptarse por el Ministro de Trabajo, a propuesta del Director general.

\section{CAPITULO IX}

Del Reglamento de régimen interior de las Empresas

Art. 54. 1) Todas las Empresas sujetas a las presentes Ordenanzas vendían obligadas, en el plazo de tres meses, contados desde el siguiente día al de la inserción de estas normas en el BOLETÍN OFICIAL DEL ESTADO, a redactar un proyecto de Reglamentación, adaptando las reglas de ésta a la peculiar organización de trabajo.

2) En dichos Reglamentos interiores se detallarán especialmente las materias referentes a turnos de trabajo, plantillas, recargo abonable por horas extraordinarias trabajadas, régimen de ascensos y de premios y sanciones, medidas de seguridad e higiene implantadas de las condiciones mínimas obligatorias o regla específica de organización.

3)El proyecto se presentará por triplicado ante la Dirección General de Trabajo si la Empresa desenvuelve sus actividades en más de una provincia, y ante la correspondiente Delegación de Trabajo si únicamente tuviera fábricas en una misma provincia.

4)Tanto la Dirección General como las Delegaciones adoptarán el acuerdo que proceda en el término de un mes, contado desde la emisión de informe por la Delegación Sindical Local o alguna dependencia oficial cuando esto último se creyera conveniente; el documento se entenderá aprobado por la táctica si no recayera resolución en el plazo señalado.

5)Contra la decisión dictada se dará recurso en el plazo de quince días hábiles, contados a partir de la notificación de aquélla, el cual recurso habrá de presentarse ante la misma Autoridad que se hubiera pronunciado, y será dirigido al Ministerio si primeramente hubiera intervenido la Dirección General de Trabajo o a esta Dirección si hubiera actuado una Delegación.

6) Para resolver el recurso formalizado dispondrá el Organismo competente de otros quince días laborables.

Las Empresas que incumplan la obligación que este artículo les impone serán sancionadas por la Dirección General de Trabajo con multa de 500 a 10000 pesetas, atendidas su importancia industrial y económica. 


\section{CAPITULO X}

\section{Disposiciones varias}

Art. 55. Gratificaciones especiales. 1) A fin de que los trabajadores de la Industria Cinematográfica puedan solemnizar las fiestas que conmemoran la Natividad del Señor, de tan honda raigambre espiritual y española, las Empresas de Trabajo abonarán a todo su personal una gratificación de Navidad equivalente a quince días de haber.

2) Con ocasión de la fiesta de la Exaltación del Trabajo (18 de julio), las Empresas concederán a todo su personal una gratificación equivalente a quince días de haber

3) A estos efectos, se entenderá como haber, el sueldo o retribución base establecido en esta Reglamentación con los aumentos en la misma señalados por años de servicios.

Art. 56. Al personal que hubiera interesado en el transcurso del año se le abonará la gratificación prorrateando su importe en relación con el tiempo trabajado en la Empresa, para lo cual la Tracción de semana o de mes se computará como unidad completa.

La gratificación de Navidad será pagada en día laborable inmediatamente anterior al 23 de diciembre; la de 18 julio, el día anterior.

En caso de despido justificado del trabajador, este perderá el derecho a que se le haga efectiva la parte proporcional de gratificación que de otra forma correspondería.

Art. 57. Las Empresas podrán contratar la prestación de servicios de personal técnico especializado para funciones de alto asesoramiento científico, cuyos servicios de pura investigación y consulta no se realice de modo continuo en la Empresa. Este personal no constará en plantilla ni se regirá por estas ordenanzas.

Art. 58. Cesión o traspaso de una Empresa. - 1) La Empresa que jurídicamente o de hecho continúe el negocio de otra se hará cargo de sus plantillas y de todo su personal, que se someterá al régimen adquirente o conservará el suyo propio, según cual de ello responda mejor a las normas y orientaciones de la presente Reglamentación, no solo en cuanto a capacitación sino a retribuciones; en caso de duda resolverá Delegación o la Dirección General de Trabajo, según la extensión territorial de las Empresas fundidas.

2) En ningún caso y por ningún concepto la Empresa adquirente podrá despedir personal antiguo ni nuevo, y cuantas reorganizaciones intente, se realizarán sobre la base de mejorar o al menos mantener la situación de unos y otros tan solo previa solicitud justificada, podrá amortizar las vacantes que ocurran.

3)El personal de nuevo ingreso, aunque sea destinado a establecimientos de la empresa adquirida se someterá en todo caso al régimen del adquirente.

4)Se evitará siempre mantener duplicidad de regímenes en establecimientos que realmente formen una Empresa.

Art. 59. Respecto a las condiciones más beneficiosas. - Por ser condiciones mínimas las establecidas en la presente Reglamentación de Trabajo, habrán de respetarse; las que vengan implantadas por disposición legal o costumbre inveterada cuando, 
examinadas en su conjunto, resulten más beneficiosas para el personal, tanto en lo relativo a remuneración como a lo referente a otras materias por lo tanto si en algún caso la actual retribución, incluido el sueldo o salario, más el plus de ecaristia de vida, es superior al establecido en esta Reglamentación, a de ser respetado en lo que exceda así como se han de conservar las jornadas en vigor siempre que supongan un beneficio para el personal, aplicándose en toda su integridad lo referente a estas materias al personal de nuevo ingreso.

Art. 60. Aplicación de la Legislación general. - En lo no previsto o regulado en la presente Reglamentación del Trabajo serán de aplicación las normas que sobre la materia respectiva quedan establecidas por la Legislación de tipo general.

\section{DISPOSICIONES ADICIONALES}

\section{Plus por cargas familiares}

En atención a las cargas familiares del trabajador, sin distinción del Grupo profesional en que este encuadrado, se establece un plus que habrá de regirse por las reglas que a continuación se detallan y que tendrán el carácter de extraordinario.

Este plus familiar representará cada semestre el 10 por 100 de la nómina de cada Empresa, correspondiente a las 6 mensualidades, y habrá de repartirse por el sistema de puntos en la siguiente proporción.

\begin{tabular}{|c|c|c|c|}
\hline & & 5 & puntos \\
\hline & & 6 & “ \\
\hline “ & 2 & 7 & “ \\
\hline “ & 3 & 8 & “ \\
\hline “ & 4 & 10 & “ \\
\hline “ & 5 & 13 & " \\
\hline “ & 6 & 16 & “ \\
\hline " & 7 & 19 & “ \\
\hline “ & 8 & 22 & “ \\
\hline “ & 9 & 25 & “ \\
\hline “ & 10 & 30 & “ \\
\hline “ & 11 & 35 & “ \\
\hline " & 12 & 40 & “ \\
\hline " & 13 & 45 & “ \\
\hline “ & 14 & 50 & 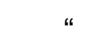 \\
\hline “ & 15 & 55 & " \\
\hline
\end{tabular}


Los trabajadores viudos de uno y otro sexo percibirán los puntos que les correspondan con arreglo al número de hijos, sin que pierdan en consecuencia, los 5 que se asignan a los casados, aunque para ello será imprescindible que tengan algún hijo. Si fueran viudos y careciesen de hijos, o los que tuvieren no diesen derechos a puntos solo percibirán el importe de tres puntos.

A los efectos de la escala especificada en el apartado 2) de esta disposición adicional, solo se computarán los hijos legítimos, los legitimados y los adoptivos cuya adopción se hubieran tramitado con arreglo a la ley, menores en todos los casos de 23 años, varones o hembras solteros, solteros que no estén colocados, no cobren sueldo o retribución alguna. También se computarán aquellos que, aún excediendo de dicha edad límite, se hallen totalmente imposibilitados, con tal que esta incapacidad les impida la realización de toda clase de trabajo, y aquellos hijos que percibieran retribución derivada de contrato de aprendizaje, aunque en este caso de excepción se limita esta a los aprendices que no hallan cumplido 17 años de edad.

Para cobrar los puntos por razón de matrimonio es requisito indispensable que la unión sea legítima.

El personal casado, pero separado de hecho de derecho de su consorte perderá los 5 puntos asignados por matrimonio pero no los que pudieran pertenecerle por los hijos que conserve bajo su patria potestad, siempre que reúnan las condiciones señaladas en el apartado 4).

Los hijos que, aún siendo menores de 23 no vivieran en el domicilio de sus padres por cualquier causa bien fuera temporal o definitivamente no dan derecho a puntos.

El personal accidentado, enfermo, con permiso o en vacaciones continuará percibiendo su plus familiar mientras siga cobrando remuneración.

En caso de que marido y mujer trabajen ya en la misma, ya en diferente actividad, se percibirá el plus familiar por el esposo aunque se le deducirán los 5 puntos por razón de matrimonio. Si no haya establecido el plus de cargas familiares en la rama donde el marido trabaje, se cobrará un plus de la mujer con el mismo descuento de los referidos 5 puntos.

Por importe de la nómina sobre el que hay que calcularse la cuantía global del plus familiar se entenderá la totalidad de las cantidades abonadas, según disposiciones legales, en el semestre que sirve de base por la respectiva Empresa, el personal sujeto a la Reglamentación eso es, no solo los sueldos o jornales sino las gratificaciones señaladas en esta reglamentación y horas extraordinarias con sus recargos.

Para efectuar el reparto de cada Empresa se determinarán, en primer lugar las pesetas que correspondan a cada punto; a tal efecto se dividirá la cantidad a que ascienda el 10 por 100 de la nómina del último semestre por la suma total de puntos que resulte de aplicar al personal la escala de apartado 2) de la presente adicional.

La cantidad que por cargas familiares corresponda percibir a cada uno de los que tengan derecho resultará de multiplicar el cociente de la división antes expresada por el número de puntos que se le reconocen en la escala, según sus circunstancias. 
Las cantidades asignadas por cargas familiares, y que pagarán mensualmente, no sufrirán alteración durante el transcurso del semestre, cualquiera que sean las modificaciones que las familias experimenten.

Las cantidades que corresponden a los trabajadores que causen baja o a las que dejen de pagarse por cualquier circunstancia incrementarán la cantidad que por este concepto haya de distribuirse en el siguiente semestre.

El personal que ingrese después de iniciado un semestre y por tanto, no hubiera podido computarse los cálculos distributivos, percibirá, sin embargo, este en idéntica cuantía a la del personal restante, a cuyo efecto la Empresa anticipará su reintegro al calcularse el importe del plus que haya de distribuirse en el semestre siguiente.

La falsedad en las declaraciones juradas y la falta en dar cuenta de las modificaciones familiares que se produzcan durante el semestre motivarán la imposición de sanciones, que se establecerán en el Reglamento de Régimen Interior y que podrá llegar incluso a la pérdida del plus durante todo un año.

Para entender en cuanto se relacionan con el plus de cargas familiares en cada Empresa se constituirán una comisión, integrada por el empresario de las mismas, su representante legal o persona en quien delegue y cuatro representantes de los trabajadores designados por la Empresa, previa propuesta en tema de Sindicato, que procurará figuren en las listas diversas categorías profesionales. Esta Comisión podrá ser renovada anualmente por iniciativa de la Empresa o Sindicato.

El plus por cargas familiares regulado en esta disposición adicional no será computable para la fijación de cuotas de los seguros sociales, conforme a lo prevenido en la Orden de Trabajo fechada el 7 de marzo 1942.

\section{DISPOSICIÓN TRANSITORIA}

En el plazo de dos meses, a contar de la publicación de estas Ordenanzas, todas las Empresas de Cinematografía harán el encuadramiento en los distintos grupos señalados en esta Reglamentación de todo el personal existente en la actualidad.

A este efecto, deberán atender a la capacidad y condiciones del individuo que se trate de encuadrar, así como a ñas funciones que éste realice, siguiendo las normas directrices de esta Reglamentación.

Los que no se consideren debidamente clasificados tendrán derecho a un examen de capacitación ante el Tribunal, cuya constitución se fija en el artículo 26.

Contra esta clasificación podrá reclamar el personal, ante la Delegación del Trabajo, en el plazo de quince días, a partir de la fecha en que le haya sido comunicada.

Madrid, 28 de septiembre de 1944 - El Director general de Trabajo, Francisco Ruiz Jarabo. 
ORDEN de 3 de octubre de 1944 por la que se dispone que la Secretaria Técnica del Instituto Nacional de Medicinal, Higiene y Seguridad del Trabajo se divida en dos secretarias.

TImo. Sr: Al proyectar el desarrollo de los servicios que comprenderá el Instituto

\section{Orden ampliando y modificando la orden de 10 de diciembre de 1941 sobre programación de películas ${ }^{357}$}

Con el fin de reglamentar debidamente las medidas de protección a la industria cinematográfica nacional, dictadas por Orden de este Ministerio de fecha 10 de diciembre de 1941 (Boletín Oficial del Estado del día 13), conforme aconsejan los resultados obtenidos durante el tiempo que ha estado en vigor dicha disposición.

Este Ministerio, a propuesta del Sindicato Nacional del Espectáculo, previo estudio de la Junta Sindical de Cinematografía, y de conformidad con el informe emitido por la Subcomisión Reguladora de la Cinematografía, ha acordado ampliar y modificar la referida Orden de 10 de diciembre de 1941 en la siguiente forma:

Artículo $1^{\circ}$. Las películas que sean clasificadas en tercera categoría por la Junta Clasificadora del Ministerio de Industria y Comercio no podrán ser estrenadas en locales clasificados en primera categoría.

Art. $2^{\circ}$. Por cada cinco semanas de proyección de películas extranjeras se proyectará una semana de películas nacionales, entendiéndose que la película española se proyectará a continuación de la quinta semana de proyección de películas extranjeras.

Art. $3^{\circ}$. Si al finalizar la quinta semana de proyección de películas extranjeras, la que estuviese proyectándose debiera continuar en cartel por conveniencia de la Empresa o por exigirlo así el contrato establecido con la distribuidora, al retirar esta película la Empresa exhibidora además de proyectar la semana obligatoria de películas nacionales, deberá continuar proyectando producciones españolas durante un tiempo en que ningún caso será inferior al 50 por 100 de los días que hubiese excedido de la quinta semana de proyección de películas extranjeras.

Por el contrario, si al finalizar la semana obligatoria de proyección de películas nacionales, la que estuviese proyectándose debiera continuar en cartel por conveniencia de la Empresa o por explicarlo así el contrato establecido con la distribuidora, los días que excedan de proyección de esta película no se tendrán en cuenta a los efectos de ampliación del plazo de exhibición de cinco semanas para las películas extranjeras.

Art. $4^{\circ}$. En los cines en que se proyecte dos programas por semana, por cada dos semanas y media de proyección de películas extranjeras se deberá proyectar media

\footnotetext{
${ }^{357}$ Ampliando y modificando la orden de 10 de diciembre de 1941 sobre programación de películas, 13 de octubre de 1944, Ministerio de Industria y Comercio, Boletín Oficial del Estado, 15 de octubre de 1944, núm. 289
} 
semana de películas nacionales, siempre que dicha media semana esté incluido un día festivo.

Art. $5^{\circ}$. En los cines en que se proyecte tres programas por semana, por cada semana y media de películas extranjeras se deberá proyectar media semana de películas nacionales en la misma forma establecida anteriormente.

Art. $6^{\circ}$. En los cines en que se proyecte un programa cada día, por cada cinco programas de películas extranjeras deberá proyectarse un programa de películas nacionales.

Art. $7^{\circ}$. Cuando se trate de locales que celebren sesiones aisladas, por cada cinco películas extranjeras deberá proyectarse una película nacional.

Art. $8^{\circ}$. Los empresarios exhibidores quedarán exentos de responsabilidad en el cumplimiento de esta Orden cuando en el mercado no existan películas nacionales disponibles, para lo cual, y con una anticipación de quince días a la fecha en que deben programar la película nacional, deberán solicitar del Sindicato Nacional del Espectáculo el oportuno certificado, o, en su caso, alguna de las películas nacionales que figuren en la lista de disponibles que al efecto llevará el mencionado organismo.

Art. $9^{\circ}$. Quedan prohibidos en todos los locales de exhibición los programas de dos películas largas, debiendo estar constituidos dichos programas por una película de largo metraje, el material corto obligatorio y los complementos que se precisen para completar el programa.

Art. 10. Solamente se permitirán programas dobles de películas largas siempre que dichos programas se constituyan por los complementos obligatorios y dos películas que lleven en explotación un tiempo superior a veinticuatro meses.

Art. 11. En los cines que se celebren variedades como fin de fiesta no podrá proyectarse más que una película larga, además de los complementos obligatorios. Dichos programas mixtos tendrán que tener siempre la autorización previa del Sindicato Nacional del Espectáculo.

Art. 12. La obligatoriedad de proyección de películas nacionales en la forma que se establece en esta Orden comenzará a regir desde la fecha de publicación de la misma. En cuanto a la prohibición de programas dobles, entrará en vigor dentro del plazo de seis meses, con la excepción de los locales enclavados en la ciudad de Barcelona, en los que deberá cumplirse a partir de la primera temporada cinematográfica siguiente a la publicación de esta Orden. 


\section{Orden rectificando la orden de 23 de noviembre de 1942 sobre censura de películas $^{358}$}

Previsto y autorizado excepcionalmente el artículo 13 de la Orden de esta Vicesecretaría, de fecha 23 de noviembre de 1942, el dictamen de la Comisión Nacional de Censura Cinematográfica sobre películas en versión original o directa, ha demostrado la práctica que los importadores de películas extranjeras eluden en muchos casos dicho trámite no obligatorio, con graves perjuicios para los intereses, al hacer inversiones en películas que no pueden ser proyectadas.

Todo ello exige a esta Vicesecretaría rectificar dicha disposición de 23 de noviembre de 1942, de tal manera que, sin perjuicio para los importadores cinematográficos, todas las películas extranjeras pasen a la Comisión Nacional de Censura antes de que los interesados comiencen a realizar inversiones en ellas.

En su virtud, dispongo:

Artículo $1^{\circ}$. La Comisión Nacional de Censura Cinematográfica determinará en todo caso sobre las películas extranjeras que se introduzcan en España, por importación temporal o definitiva rechazando cuantas se presenten en versión española sin autorización previa de doblaje.

Art. $2^{\circ}$. Los derechos de censura se establecen en el artículo 13 de la Orden de 23 de noviembre de 1942 para las películas en versión directa u original serán reducidos, en el caso de aprobarse la película de los que hayan de obtener a tenor del artículo 22 de dicha disposición.

Art. $3^{\circ}$. Quedan sin efecto las disposiciones que se opongan a la presente Orden.

\section{Creando los premios anuales que se mencionan para estímulo de los elementos artísticos de la cinematografía ${ }^{359}$}

Interesa al cine nacional que todos los elementos que intervienen en la realización de una película, reciban periódicamente de los organismos cinematográficos muestras inequívocas de que sus actuaciones son valoradas con independencia del resultado que la labor total haya obtenido, ya que en muchos casos, al tener en cuenta solamente la totalidad de la obra, o pasan desapercibidos esfuerzos muy estimables o aparecen galardonadas intervenciones deficientes.

\footnotetext{
${ }^{358}$ Rectificando la orden de 23 de noviembre de 1942 sobre censura de películas, 15 de diciembre de 1944 , Vicesecretaría de Educación Popular, Boletín Oficial del Estado, 21 de diciembre de 1944, núm. 356

${ }^{359}$ Creando los premios anuales que se mencionan para estímulo de los elementos artísticos de la cinematografía, 23 de enero de 1945, Vicesecretaría de Educación Popular, Boletín Oficial del Estado, 29 de enero de 1945, núm. 29
} 
Ello exige a esta Vicesecretaria tomar medidas encaminadas a premiar y destacar aisladamente las intervenciones que con mayor acierto hayan tenido en la realización de películas nacionales, los elementos cinematográficos más importantes, aquellos que realmente cuentan con una personalidad artística inconfundible.

En su virtud, he resuelto lo siguiente:

Artículo $1^{\circ}$ Para estímulo de los elementos artísticos de la cinematografía nacional, se crean los siguientes premios anuales:

Dirección: Premio de honor.

Interpretación femenina y masculina: Dos premios de honor y dos accésits.

Guión: Premio de honor y accésit.

Fotografía: Premio de honor y accésit.

Música: Premio de honor y accésit.

Decorados: Premio de honor y accésit.

Art. $2^{\circ}$ Serán tenidas en cuenta en el presente concurso anual las actuaciones habidas en todas las películas largas, estrenadas en España entre el $1^{\circ}$ de octubre de 1944 e igual fecha de 1945.

Art. $3^{\circ}$ Los premios consistirán en Diplomas, expedidos por esta Vicesecretaría, y en los objetos artísticos que se determinen anualmente por la Delegación Nacional de Cinematografía y Teatro.

Art. $4^{\circ} \mathrm{El}$ Jurado para la primera anualidad estará constituido de la siguiente forma:

Presidente: El Vicesecretario de Educación Popular.

Vocales: El Delegado Nacional de Cinematografía y Teatro, el Jefe del Sindicato Nacional del Espectáculo un representante del Ministerio de Industria y Comercio.

Art. $5^{\circ}$ El fallo será inapelable y se hará público antes del día 15 de octubre de cada anualidad.

Art. $6^{\circ}$ A partir del concurso correspondiente al presente año, el jurado se constituirá, formando parte de él, además, los que hayan obtenido premios de honor en el concurso del año anterior.

Madrid, 23 de enero de 1945. - El Vicesecretario, G. Arias-Salgado.

\section{Orden por el que se crean premios honoríficos al arte cinematográfico ${ }^{360}$}

\footnotetext{
${ }^{360}$ Creando premios honoríficos al arte cinematográfico, 23 de enero de 1945, Vicesecretaría de Educación Popular, Boletín Oficial del Estado, 29 de enero de 1945, núm. 29
} 
Interesa al cine nacional que todos los elementos que intervienen en la realización de una película reciban periódicamente de los Organismos cinematográficos muestras inequívocas de sus actuaciones son valoradas con independencia del resultado que la labor total haya obtenido, ya que en muchos casos, al tener en cuenta solamente la totalidad de la obra, o pasan inadvertidos esfuerzos muy estimables o aparecen galardonadas intervenciones deficientes.

Ello exige a esta Vicesecretaría tomar medidas encaminadas a premiar y destacar aisladamente las intervenciones que con mayor acierto hayan tenido en la realización de películas nacionales los elementos cinematográficos más importantes, aquellos que realmente cuentan con una personalidad artística inconfundible.

En su virtud, he resuelto lo siguiente:

Artículo $1^{\circ}$. Para estímulo de los elementos artísticos de la cinematografía nacional se crean los siguientes premios anuales:

Dirección : Premio de honor.

Interpretación femenina y masculina: Dos premios de honor y dos de accésits. Premio de honor y accésit.

Música : Premio de honor y accésit.

Decorados : Premio de honor y accésit.

Art. $2^{\circ}$. Serán tenidas en cuenta en el presente concurso anual las actuaciones habidas en todas las películas largas estrenadas en España entre el 1 de octubre de 1944 e igual fecha de 1945.

Art. $3^{\circ}$. Los premios consistirán en diplomas expedidos por esta Vicesecretaría y en los objetos artísticos que se determinen anualmente por la Dirección Nacional de Cinematografía y Teatro.

Art. $4^{\circ}$. El Jurado, para la primera anualidad, estará constituido de la siguiente forma:

Presidente, el Vicesecretario de Educación Popular.

Vocales, el Delegado Nacional de Cinematografía y Teatro, el Jefe de Sindicato Nacional del Espectáculo y un representante del Ministerio de Industria y Comercio.

Art. $5^{\circ}$. El fallo será inapelable y se hará publico antes del día 15 de octubre de cada anualidad.

Art. $6^{\circ}$. A partir del concurso correspondiente al presente año, el Jurado se constituirá, formando parte de él, además los que hayan tenido premio de honor en el concurso del año anterior. 


\section{Orden por el que se crean normas para el «visionado» por los importadores de películas cinematográficas ${ }^{361}$}

El artículo $5^{\circ}$ de la Ley de 19 de julio de 1944 autoriza el « visionado » de películas cinematográficas, operación que ha de ser intervenida por la Dirección General de Aduanas.

Procede, en consecuencia, establecer las normas preventivas a que deben someterse las operaciones expresadas, ya tal efecto.

Este Ministerio, de conformidad con lo propuesto por V.I., ha resuelto disponer:

$1^{\circ}$. Los importadores de películas positivas que, antes de la importación definitiva, deseen conocerlas, pueden solicitar de la Dirección General de Aduanas el «visionado» de las mismas, señalando la Aduana donde se encuentre la película, el documento aduanero que la ampare y e lugar y local donde haya de tener efecto la operación.

$2^{\circ}$. Una vez concedida la autorización para el "visionado», la Aduana donde se encuentre la película, después de sentar la correspondiente autorización en un registro especial, precintará la película debidamente, y acompañada de una guía duplicada la remitirá al Despacho Central de Aduanas o a la Aduana del lugar que se señale. En la guía se hará constar la fecha de presentación, nombre y señas del solicitante, título, metraje, peso de la película y número con que aparece registrada. Al día siguiente al de su recepción en la Administración o despacho de Aduanas habilitado al efecto se señalará, para dentro de las cinco fechas siguientes, la de la proyección, comunicándola al importador en el domicilio fijado en la guía, sin que los precintos correspondientes sean abiertos hasta el momento de la proyección.

$3^{\circ}$. La proyección se realizará privadamente en el local que la Dirección General de Aduanas señale con intervención del funcionario que ésta designe, y terminada que sea aquélla, el importador presentará solicitud de importación o re-exportación.

$4^{\circ}$. Caso de optar por la importación, la Aduana respectiva o el Despacho Central realizará en el acto el aforo y formalización de aquélla en la forma procedente. Si se solicitara la reexportación, la película será seguidamente reembalada, y debidamente precintada se remitirá a la Aduana de origen, acompañando uno de los ejemplares de la guía con la que se recibió, en cuyo documento se consignará, en forma visible, que la película es a «reexportar». Comprobados por aquélla los precintos, pesos, títulos y demás características de la película, dispondrá la inmediata salida de la misma para el país de origen, cancelando el asiento producido en el registro de entrada y dando cuenta a la Dirección General de haberla realizado.

$5^{\circ}$. Todos los gastos de transportes, precinto, proyección y demás que ocasionen, en todo caso, las antedichas operaciones, serán de cuenta del solicitante del «visionado»,

\footnotetext{
${ }^{361}$ Normas para el «visionado» por los importadores de películas cinematográficas, 13 de febrero de 1945, Ministerio de Hacienda, Boletín Oficial del Estado, 15 de febrero de 1945, núm. 46
} 
así como serán de su cargo los daños que pueda sufrir la mercancía con ocasión de todo ello.

$6^{\circ}$. La Dirección General de Aduanas queda facultada para denegar la autorización de «visionado», siempre que razones fundadas lo aconsejen. Asimismo, en caso especialmente justificado, podrá autorizar, con arreglo a las normas anteriores, el «visionado» de las positivas especiales tipo «Lavander» y análogos.

$7^{\circ}$. Por la Dirección General de Aduanas se adoptarán las disposiciones que mejor convenga al cumplimiento de cuanto en la presente Orden se previene.

\section{Orden sobre importación y reexportación de películas extranjeras destinadas al doblaje ${ }^{362}$}

Existe la posibilidad de que los Estudios y Laboratorios cinematográficos nacionales tengan que efectuar operaciones de doblaje en idiomas extranjeros, sobre películas también extranjeras, a cuyo efecto será preciso autorizar previamente la importación de tales películas, teniendo en cuenta que no han de quedar en el país.

El indudable beneficio que ello puede suponer para la industria cinematográfica nacional aconseja facilitar, en el aspecto fiscal, las operaciones de doblaje, estableciendo previamente el importe de la garantía que haya de presentarse en el momento de la importación de las películas objeto de doblaje.

La base de la garantía en las importaciones especiales está expresada por el importe de los derechos arancelarios de la mercancía motivo de la concesión. Pero en el caso particular de las películas cinematográficas es de advertir que la determinación de los derechos arancelarios definitivos queda subordinada la clasificación que corresponda a la película de que se trate, dentro de las tres categorías para el adeudo de las mismas se establecen en la Ley 19 de junio de 1944, por lo que procede facilitar, en cuanto sea posible, las operaciones de importación preliminares al doblaje, señalando una garantía de tipo mínimo en orden fiscal para cada película que con tales fines se importe en régimen de suspensión de pago de derechos, sin perjuicio de la reserva consiguiente a la posible rectificación por la categoría que finalmente pudiera corresponder en caso de que la película importada para el doblaje a quedar definitivamente en el país.

Este Ministerio, atendiendo a tales consideraciones y de conformidad con lo propuesto por la V.I., ha resuelto:

Autorizar, en régimen especial de aplazamiento del pago de derechos arancelarios, la importación y subsiguiente reexportación de las películas extranjeras que se

\footnotetext{
${ }^{362}$ Sobre importación y reexportación de películas extranjeras destinadas al doblaje, 13 de febrero de 1945, Ministerio de Hacienda, Boletín Oficial del Estado, 15 de febrero de 1945, núm. 46
} 
destinen al doblaje, en idiomas propios de otras naciones, debiendo quedar esta autorización subordinada al cumplimiento de los requisitos siguientes:

$1^{\circ}$. El importador solicitará de la Dirección General de Aduanas, en cada caso, el permiso correspondiente, señalando en la instancia el título de la película, el Laboratorio a que se destine y la Aduana de entrada.

$2^{\circ}$. La Aduana de entrada observará en el despacho de las formalidades prevenidas en el artículo $7^{\circ}$ de la Ley de 19 de julio de 1944, exigiendo por cada película importada en la forma que el expresado artículo señala, garantía que cubra el importe de los derechos que por tarifa convencional corresponda en la tercera categoría, según se trate de películas de largo metraje o de corto metraje y sin perjuicio de la rectificación consiguiente a una posible importación definitiva.

$3^{\circ}$. La reexportación de la película importada en régimen especial deberá realizarse con las formalidades reglamentarias y haciendo las oportunas referencias a los documentos de importación a los actos de cancelación de la garantía.

$4^{\circ}$. El plazo máximo de permanencia en España de las películas importadas en las condiciones dichas será de seis meses, contados a partir de la fecha de la ultimación del despacho o de la terminación de los trabajos de doblaje, según las circunstancias que en cada caso concurran. En este mismo supuesto será obligada la intervención de las operaciones de doblaje por parte de los Servicios de Aduanas.

$5^{\circ}$. Se autoriza a la Dirección General de Aduanas para dictar las normas precisas para el cumplimiento de lo que por la presente Orden se dispone.

\section{Orden: normas para la exportación temporal de películas cinematográficas ${ }^{363}$}

Con el fin de regular la exportación temporal de películas positivas proyectables, nacionales o nacionalizadas, mediante el pago de derechos, tanto a países extranjeros como a Canarias y a los puertos francos y Posesiones de África, operaciones autorizadas, respectivamente, por el caso 13 de la disposición $6^{a}$; el caso $7^{\circ}$, apartado e) de la disposición $7^{\mathrm{a}}$ y el caso $9^{\circ}$, apartado e) de la disposición $8^{\mathrm{a}}$ del Arancel.

Este Ministerio, de conformidad con lo propuesto por V.I., ha resuelto disponer:

$1^{\circ}$. Los productores o industriales españoles que remitan películas para su proyección en Canarias, Posesiones Españolas del Norte de Africa en el extranjero, podrán reimportarlas en la Península, dentro del plazo de un año, sin pago de derechos arancelarios. Para disfrutar de este beneficio será preciso que antes de formalizar en la Aduana la documentación correspondiente al despacho de salida de la Península se presente instancia, por duplicado, haciendo constar en ella que serán reimportadas, y

\footnotetext{
${ }^{363}$ Normas para la exportación temporal de películas cinematográficas, 13 de febrero de 1945, Ministerio de Hacienda, Boletín Oficial del Estado, 15 de febrero de 1945, núm. 46
} 
asimismo el título, marca, metraje, peso de la película y un sucinto argumento de la misma, de cuya instancia quedará un ejemplar en la Aduana, y el otro, debidamente visado por ésta, acompañará a la película para presentarlo al reimportarla, lo que se hará precisamente por la misma Aduana por la que se hubiera exportado, cuya dependencia suscribirá nota de anulación en ambas instancias, que seguidamente archivará.

$2^{\circ}$. La exportación temporal de películas sólo podrá realizarse por las Aduanas de Barcelona, Valencia, Málaga, Algeciras, Cádiz, La Línea, Sevilla, Badajoz, La Coruña, Irún y el Despacho Central de Aduanas de Madrid, en las que llevará un registro especial de las exportaciones que se efectúen al amparo de este artículo, consignando su fecha y la reimportación en la que se cancele el asiento, dando cuenta mensualmente a la Dirección General de las Exportaciones y Reimportaciones efectuadas.

$3^{\circ}$. En casos especialmente justificados la Dirección General de Aduanas podrá autorizar la exportación temporal de películas negativas nacionales o nacionalizadas, mediante el pago de derechos bajo las mismas reglas anteriormente consignadas.

$4^{\circ}$. Podrá autorizarse por este Ministerio, previo informe y propuesta formulados por la Dirección General de Aduanas para cada caso, la reimportación de las películas en negativo rodadas en el extranjero. Canarias, Marruecos y Posesiones de Africa, sobre películas vírgenes previamente exportadas de la Península y cuyos negativos se reimporten al objeto de obtener las copias positivas en los laboratorios y talleres cinematográficos nacionales.

$5^{\circ}$. Como garantía de la identificación para reimportación de tales negativos, se exigirá por las Aduanas la presentación de una declaración haciendo referencia a la factura de exportación de las correspondientes películas vírgenes, y asimismo justificación documental de que los negativos que se reimporten proceden del rodaje de las películas vírgenes exportadas.

$6^{\circ}$. Por la Dirección General de Aduanas se dictarán las disposiciones convenientes para el mejor cumplimiento de esta Orden.

\section{Orden sobre reimportación de películas exportadas en régimen temporal ${ }^{364}$}

Las películas cinematográficas nacionales exportadas temporalmente para su explotación fuera del territorio español y desnacionalizadas por haber vencido, sin ser reimportadas, los plazos señalados en los respectivos documentos de exportación temporal y asimismo las copias obtenidas en el extranjero sobre películas cinematográficas nacionales exportadas temporalmente, no pueden beneficiarse de los derechos arancelarios anteriores a la Ley de 19 de julio de 1944 en razón a la imposibilidad de dar cumplimiento en tales casos a los requisitos contenidos en los artículos $2^{\circ}$ y $3^{\circ}$ de la

\footnotetext{
${ }^{364}$ Sobre reimportación de películas exportadas en régimen temporal, 17 de febrero de 1945, Ministerio de Hacienda, Boletín Oficial del Estado, 22 de febrero de 1945, núm. 22
} 
mencionada Ley, siendo también evidente en atención a las particularidades de su orígen, la improcedencia de hacer a tales mercacías objeto del gravamen que a la importación establecen las partidas 692 bis y 692 ter, para Is mercancías similares extranjeras. Se trata en ambos casos de películas cinematográficas nacionales o producidas con elementos nacionales, que por tal circunstancia y siempre que se justifique que las copias de películas nacionales a que se hace referencia no pueden producirse en España, pueden considerarse como parte integrante o como elementos complementarios o auxiliares de la explotación de la película nacional originaria, elementos que la Ley de 19 de julio de 1944 admite y clasifica en la partida 692 cuater, que es la que procede considerar como más adecuada, por cuyas razones este Ministerio, de acuerdo con las precedentes consideraciones y con lo expuesto por V.I., ha resuelto disponer :

$1^{\circ}$. Las películas nacionales exportadas temporalmente y que en razón a haber quedado desnacionalizadas por extinción del plazo concedido para su permanencia en el extranjero necesita previa obtención de la correspondiente licencia de importación, satisfarán al reimportarse, los derechos arancelarios establecidos en la partida 692 cuater por la Ley de 19 de julio de 1944.

$2^{\circ}$. Cuando las películas nacionales se exporten temporalmente con destino exclusivo a la obtención de sus copias en país extranjero, en razón a que éstas no puedan obtenerse en España, tales copias, a su importación en la Península, adeudarán por la partida 692 cuater. Para la aplicación de este régimen será preciso solicitarlo en cada caso de la Dirección General de Aduanas, demostrando previamente que las copias de referencia no pueden obtenerse en España y por el expresado Centro, al concederse la autorización de exportación temporal, se haga constar con toda exactitud el número de copias que hayan de ser objeto de la importación de referencia, particulares que habrán de reseñarse en la documentación de salida correspondiente al despacho de exportación temporal de la película tipo de que se trate.

$3^{\circ}$. Por la Dirección General de Aduanas se dictarán las instrucciones complementarias que exija el desarrollo de la presente Orden.

\section{Orden regulando plazo de exportación de películas extranjeras ${ }^{365}$}

Existiendo algunas dudas sobre la vida legal de las películas que se importan en España, a los efectos de sus rendimientos a vendedores extranjeros, lo que da lugar a pagos en divisas al exterior, y siendo norma corriente en los contratos de explotación de películas el período máximo de cinco años, tanto para aquellas que se ceden a porcentaje, las que se venden a precio fijo, este Ministerio de Industria y Comercio a propuesta del Instituto Español de Moneda Extranjera, ha acordado lo siguiente :

\footnotetext{
${ }^{365}$ Regulando plazo de exportación de películas extranjeras, 3 de abril de 1945, Ministerio de Industria y Comercio, 6 de abril de 1945, Boletín Oficial del Estado, núm. 96
} 
Artículo $1^{\circ}$. Las películas que se hayan importado en España, o que se importen en lo sucesivo, a porcentaje, así como aquellas que lo hayan sido o lo sean en venta a precio fijo, se considerarán con una vida máxima de explotación de cinco años, a partir de la fecha de su primer estreno en España, sus posesiones y colonias.

Art. $2^{\circ}$. Por ello, transcurrido este período de tiempo podrán, en los casos de importaciones a porcentaje, seguir produciendo rendimiento alguno para el vendedor extranjero y, por lo tanto, transferencias de divisas al extranjero y situaciones de cantidades en cuentas bloqueadas.

En los casos de películas vendidas a precio fijo, tampoco podrá pretenderse transferencias al extranjero, ampliación de pago por prórroga de explotación.

Art. $3^{\circ}$. En los casos en que indebidamente se hayan situado cantidades en cuentas extranjeras, producidas con posterioridad a los cinco años de explotación de las mismas, estas cantidades deberán ser retiradas de las referidas cuentas.

Art. $4^{\circ}$. Teniendo en cuenta que puedan existir algunos casos en que durante los cinco años de explotación normal de las películas importadas, es decir, a partir de su estreno, haya tenido que ser suspendida dicha explotación por causas ajenas a la voluntad del distribuidor, podrá descontarse este período de suspensión a los efectos de la aplicación de esta Orden. Para ello, la entidad deberá justificarlo debidamente ante el Ministerio de Industria y Comercio (Subcomisión Reguladora de la Cinematografía) quien de considerarlo justo ratificará dicha prórroga y la comunicará al Instituto Español de Moneda Extranjera para su aplicación.

Art. $5^{\circ}$. Transcurridos cinco años a partir de la fecha del estreno de una película extranjera en España, si el propietario de la misma desea continuar su explotación, bien entendido que sin pago alguno ni transferencia para el vendedor extranjero, deberá solicitarlo del Ministerio de Industria y Comercio (Subcomisión Reguladora de la Cinematografía) indicando los motivos que lo justifiquen y acompañando autorización del vendedor extranjero en que renuncia a toda participación o nuevo pago, declaración de copias en explotación y su estado, declaración de la suma global aproximada de contratos pendientes y cuantos datos crea oportunos para apoyar su solicitud.

La Subcomisión Reguladora de la Cinematografía decidirá en cada caso si puede continuar o no la explotación de la película.

Art. $6^{\circ}$. El Instituto Español de Moneda Extranjera y la Subcomisión Reguladora de la Cinematografía se encargarán del exacto cumplimiento de esta disposición. 


\section{Orden aclarando e interpretando las órdenes de 13 y 17 de febrero último sobre importación y exportación de películas ${ }^{366}$}

El Boletín Oficial del Estado de 15 y 22 de febrero de 1945 publica 3 Ordenes del Ministerio de Hacienda, relativas a las normas preventivas a que debe someterse la entrada de películas extranjeras en España para su visado; la entrada de películas extranjeras en régimen especial de aplazamiento del pago de derechos arancelarios y subsiguiente reexportación de películas extranjeras, destinadas al doblaje, en idiomas propios de otros países; normas a las que deberá ajustarse la exportación temporal de películas cinematográficas a países extranjeros, a Canarias y a las plazas y posesiones de Africa cuando, respectivamente, hayan de reimportarse de aquellos países y territorios, y normas para la exportación de copias obtenidas en países extranjeros sobre películas nacionales exportadas temporalmente a este efecto.

Al objeto de evitar confusiones a los interesados en cualquiera de estas operaciones de importación y exportación, que pudiesen interpretar que los requisitos establecidos en las anteriores Ordenes del Ministerio de Hacienda son los exclusivamente necesarios para realizar estas operaciones.

Este Ministerio de Industria y Comercio aclara y confirma los trámites imprescindibles para llevar a cabo dichas operaciones, en lo que a el se refiere, en la siguiente forma:

\section{Artículo $1^{\circ}$}

a) Toda persona o entidad que desee entrar en España, para su previo visado, una película extranjera, antes de obtener la licencia de importación definitiva deberá obtener permiso de la Dirección General de Comercio y Política Arancelaria a este fin.

b) Para ello deberá solicitarlo por conducto de la Subcomisión Reguladora de la Cinematografía, organismo dependiente de este Ministerio quien a la mayor brevedad posible, y siempre que no haya inconveniente para ello, gestionará la oportuna autorización.

c) Esta autorización tendrá un plazo máximo de validez de quince días, a partir de la fecha en que la película entre en España, finalizado el cual deberá ser depositada en la Aduana por donde se introdujo, o ser devuelta definitivamente al país de origen.

\section{Artículo $2^{\circ}$}

a) Toda persona o entidad que desee importar en España una película extranjera en régimen especial de aplazamiento del pago de derechos arancelarios, al objeto de su doblaje en idiomas extranjeros y su posterior reexportación, sin ser explotado en territorio nacional, necesitará obtener la oportuna licencia de la Dirección General de Comercio y Política Arancelaria que fije específicamente que la referida película se importa a los exclusivos efectos de su doblaje en idiomas extranjeros, sin que ni el origen ni las copias obtenidas puedan ser explotadas ni en España ni en sus posesiones y colonias.

\footnotetext{
${ }^{366}$ Aclarando e interpretando las ordenes de 13 y 17 de febrero ultimo sobre importación y exportación de películas, 3 de abril de 1945, Ministerio de Industria y Comercio, Boletín Oficial del Estado, 6 de abril de 1945, núm. 96
} 
Una vez realizado el doblaje, la salida de España de la película importada a este fin, así como de las copias dobladas a que se ha dado lugar, requerirán la confesión por la Dirección General de Comercio y Política Arancelaria de la oportuna licencia de exportación.

b) A este fin, los interesados presentarán la oportuna solicitud en la Subcomisión Reguladora de la Cinematografía, organismo dependiente de este Ministerio, acompañada de cuantos datos y documentos estimen necesarios este organismo para considerar si procede o no la concesión de la licencia.

Artículo $3^{\circ}$

a) Toda persona o entidad que desee exportar temporalmente películas cinematográficas a países extranjeros necesitará obtener de la Dirección General de Comercio y Política Arancelaria el oportuno permiso de exportación temporal.

b) Toda persona o entidad que desee remitir películas, tanto nacionales como extranjeras a Canarias, plazas y posesiones de Africa y Andorra para su explotación y posterior devolución a la Península, necesitan la correspondiente autorización de la Subcomisión Reguladora de la Cinematografía, organismo dependiente de este Ministerio.

c) Toda persona o entidad que desee exportar al extranjero, Canarias, posesiones y colonias españolas de Africa, material virgen para su rodaje y posterior reimportación para revelado en la Península y destino de la producción nacional deberá obtener el oportuno permiso de la Subcomisión Reguladora de la Cinematografía, organismo dependiente de este Ministerio.

d) Todas las solicitudes a que hacen referencia los apartados anteriores, deberán plantearse ante la Subcomisión Reguladora de la Cinematografía, acompañando cuantos documentos y datos estime oportuno el mencionado organismo.

Artículo $4^{\circ}$

a) Toda persona o entidad que desee exportar temporalmente películas nacionales para obtener copias en el extranjero e importarlas posteriormente en España, una vez realizado este trabajo, deberá obtener de la Dirección General de Comercio y Política Arancelaria el oportuno permiso de exportación temporal a este fin.

b) Las copias que como consecuencia del apartado anterior hubiesen sido obtenidas en el Extranjero y hayan de ser importadas en España, necesitarán obtener la oportuna licencia de importación de la Dirección General de Comercio y Política Arancelaria.

c) Al igual que en los casos anteriores estas solicitudes deberán plantearse en la Subcomisión Reguladora de la Cinematografía, organismo dependiente del Ministerio de Industria y Comercio. 


\section{Decreto-ley aplicando a la producción cinematográfica la ley de 24 de noviembre de 1939 de ordenación de la industria nacional ${ }^{367}$}

En las circunstancias que concurren en la Industria de la producción cinematográfica, especialmente en los aspectos educativos, intrínsecamente unidos a la exhibición de las películas, y la importancia extraordinaria que este espectáculo ha llegado a adquirir en el país, aconsejan adoptar sucesivamente una serie de nuevas y especiales medidas de protección a nuestra producción que, como requisito previo, exige garantizar el carácter nacional de las empresas afectadas.

Dictada con fecha de 24 de noviembre de 1939 la Ley sobre Ordenación y defensa de la Industria nacional, a sus preceptos habrán de acogerse las actividades afectadas por esta disposición, con las modalidades que de la misma se deducen.

En su virtud, dispongo:

Artículo $1^{\circ}$ Son de aplicación a las industrias de la producción cinematográfica nacional, como incluidas en el apartado D) del art. $3^{\circ}$ de la Ley del 24 de noviembre de 1939 , todas las prescripciones contenidas en la misma, con las modalidades que se deducen de los artículos siguientes.

Artículo $2^{\circ}$ Respetando las situaciones actualmente existentes en el grado y medida permitidos por las disposiciones en vigor, el capital social de las empresas que posean o exploten estudios, laboratorios o, en general, establecimientos para la producción cinematográfica en España, así como el de las dedicadas a las producciones de esta índole, doblaje o actividad asimilable, será íntegramente español. Las acciones correspondientes serán precisamente nominativas, intransferibles a extranjeros, y quedarán registradas en libros llevados al efecto por las empresas, en los que se anotarán detalladamente las transmisiones que entre españoles puedan efectuarse.

Artículo $3^{\circ}$ Aunque las prescripciones de este Decreto Ley se aplicaran íntegramente desde la fecha de su publicación en el Boletín Oficial del Estado dentro del plazo de sesenta días naturales, contados desde la misma, todas las empresas afectadas efectuarán la transformación de sus acciones al portador en acciones nominativas, siguiendo las inscripciones de detalle que sobre el particular se dicten, y dando cuenta al Ministerio de Industria y Comercio, en los treinta días siguientes, de las acciones resultantes en poder de extranjeros, por ser de su propiedad, al publicarse este Decreto Ley.

Las empresas colectivas y comanditarias simples aceptadas por este Decreto Ley, y las individuales, que no sean propiedad de nacionales, deberán presentar también la oportuna declaración al citado Departamento.

Artículo $4^{\circ}$ Queda prohibido a las personas individuales o jurídicas, propietarias de estudios, laboratorios y, en general, centros de producción cinematográfica, el efectuar

\footnotetext{
${ }^{367}$ Aplicando a la producción cinematográfica la ley de 24 de noviembre de 1939 de ordenación de la industria nacional, 25 de enero de 1946, Jefatura del Estado, Boletín Oficial del Estado, 7 de febrero de1946, núm. 38
} 
contratos de arrendamiento, cesión o similares que, de manera directa o indirecta, pudieran contravenir las finalidades que en este Decreto Ley se concretan.

Por lo que se refiere a los contratos actualmente en vigor, que pudieran resultar afectados por lo que en este artículo se dispone, las entidades propietarias presentarán copia autorizada de los mismos al Ministerio de Industria y Comercio en plazo no superior a treinta días, contados desde la fecha de publicación de este Decreto Ley.

Artículo $5^{\circ}$ A tenor de lo dispuesto en el artículo $7^{\circ}$ de la Ley de 24 de noviembre de 1939, en casos excepcionales, por razones de reciprocidad similares y, en todo caso, de alta conveniencia nacional, el Gobierno, previa deliberación en Consejo de Ministros, podrá variar las restricciones contenidas en el art. $2^{\circ}$ y los demás concordantes de este Decreto Ley.

Artículo $6^{\circ}$ Por el Ministerio de Hacienda se dictarán las disposiciones pertinentes en orden a la exención total de los impuestos correspondientes a la transformación de acciones al portador en nominativas.

Artículo $7^{\circ}$ El Ministerio de Industria y Comercio queda facultado para dictar las disposiciones complementarias a la más exacta aplicación de este Decreto Ley.

Artículo $8^{\circ}$ Del presente Decreto Ley se dará cuenta a las Cortes en cumplimiento de lo que dispone el art. 13 de la Ley de 17 de julio de 1942.

\section{Orden creando la Junta Superior de Orientación Cinematográfica ${ }^{368}$}

La misión de orientar la Cinematografía española, que en gran parte realizan los Servicios de censura cinematográfica, dependientes de la Dirección General de Cinematografía y Teatro, pone de manifiesto la necesidad de un organismo superior consultivo que asesore a la Dirección General sobre aquellas cuestiones que la alta orientación de la cinematografía plantea, y cuya falta ha venido supliéndose hasta el presente por los citados organismos censores.

Por todo ello parece aconsejable que, a la par que se confíe a una sola entidad la realización de las funciones indicadas, para así robustecer el criterio de unidad que debe presidir sus decisiones y simplificar también el despacho de los asuntos, convenga asimismo ampliar el campo de sus atribuciones y elevar su rango e influencia.

En su virtud.

Este Ministerio se ha servido disponer lo siguiente:

\footnotetext{
${ }^{368}$ Creando la Junta Superior de Orientación Cinematográfica, 28 de junio de 1946, Ministerio de Educación Nacional, Boletín Oficial del Estado, 19 de julio de 1946, núm. 200
} 
$1^{\circ}$ La Junta Superior de Censura Cinematográfica y la Comisión Nacional de Censura Cinematográfica se refunden en un solo organismo, que se denominará Junta Superior de Orientación Cinematográfica.

$2^{\circ} \quad$ La Junta Superior de Orientación Cinematográfica estará integrada por un Presidente, un Vicepresidente y diez Vocales, libremente designados por este Ministerio, a excepción del Vocal representante de la Iglesia, que será nombrado a propuesta del Ordinario diocesano.

$3^{\circ}$ Competen a la Junta Superior de Orientación Cinematográfica:

a) Ser el órgano, supremo de carácter consultivo en materia de cinematografía y en tal concepto formular dictamen sobre los asuntos que le sean sometidos a su estudio, así como elevar a la Superioridad los informes y proyectos que estime convenientes para la mejor ordenación de la cinematografía española.

b) Proponer la condición de películas de interés nacional que establece la Orden de 15 de junio de 1944.

c) Determinar en su caso las películas que por su deficiente calidad artística no deben ser exportadas al extranjero.

d) Determinar en su caso las películas que por la misma razón citada en el apartado anterior, no puedan ser exhibidas en locales de primera y segunda categoría, como dispone la Orden de 13 de octubre de 1944 (R. 1944, 1407).

e) Autorizar o denegar el doblaje de las películas extranjeras y, en su caso, la exhibición de las mismas con rótulos en castellano.

f)Clasificar las distintas películas nacionales o extranjeras a los efectos que procedan.

g) Ejercer la censura de toda clase de películas nacionales y extranjeras que hayan de proyectarse en territorio nacional, así como la del material de propaganda que las casas distribuidoras o propietarias de películas remitan con éstas a las salas de proyección.

$4^{\circ}$ Los acuerdos de la Junta serán tomados por mayoría. No obstante, el

voto del representante de la Iglesia será especialmente digno de respeto en las cuestiones morales. Y será dirimente en los casos graves de moral en los que expresamente haga constar su veto.

$5^{\circ}$ Los recursos de revisión que se interponen serán resueltos por el ilustrísimo señor Subsecretario de Educación Popular, previo informe de la Junta de Orientación Cinematográfica, preceptivamente constituida bajo su presidencia. En caso de desacuerdo expreso entre el veto del Vocal eclesiástico y la mayoría de la Junta, la Dirección General de Cinematografía y Teatro podrá acudir en apelación del fallo ante el Ordinario diocesano para que por sí mismo o mediante un nuevo delegado dicte la resolución definitiva.

$6^{\circ}$ Hasta tanto no sea publicado el Reglamento de la Junta Superior de Orientación Cinematográfica se mantendrá en vigor las atribuciones concedidas por la Orden de 23 de Noviembre de 1942, que regularán su funcionamiento en todo aquello que no entrañe contraposición con la presente Orden. 


\section{Orden para la concesión de permisos de doblaje ${ }^{369}$}

$1^{\circ}$ A partir del día $1^{\circ}$ de enero de 1947 las autorizaciones de doblaje al castellano de las películas extranjeras, destinadas a su exhibición en España, se concederán única y exclusivamente a aquellas personas o entidades que produzcan películas nacionales que por su calidad técnico-artística obtengan la aprobación de la Junta Superior de Orientación Cinematográfica.

$2^{\circ} \quad$ Las películas de producción nacional serán clasificadas en tres diferentes categorías:

a)La primera categoría comprenderá aquellas películas que supongan un avance considerable en alguno de los distintos aspectos de la producción o que posean, al menos en su conjunto el decoro y méritos suficientes para que sean objeto de aprecio y protección. Las películas a las que se declare de primera categoría tendrán derecho a la concesión de cuatro permisos de doblaje, y a cinco si obtienen la declaración de película de interés nacional.

b)La segunda categoría comprenderá aquellas películas que sin sobresalir del nivel medio de la producción cinematográfica española sean, no obstante, acreedoras a la protección del Estado. Las películas declaradas de segunda categoría tendrán derecho a dos permisos de doblaje.

c) Se consideran películas de tercera categoría aquellas producciones que por su calidad artística o técnica supongan un descrédito para la cinematografía española y no sean en consecuencia merecedoras de protección alguna. Las películas declaradas de tercera categoría no tendrán derecho a la concesión de ningún permiso de doblaje.

$3^{\circ}$ Las casas productoras beneficiadas con la concesión de permisos de doblaje podrán aplicarlos libremente, tanto para las autorizaciones de doblaje de las películas extranjeras que importen, como para negociar dichos permisos con otra entidad cinematográfica cualquiera, previa conformidad en este caso de la Dirección General de Cinematografía y Teatro.

$4^{\circ}$ No se podrá autorizar la explotación de ninguna película extranjera doblada a nuestro idioma que no haya sido previamente presentada para su dictamen en versión original, ni se autorizará el doblaje de la misma si a su documentación no acompañase el correspondiente y necesario permiso de doblaje que ampare aquel derecho.

$5^{\circ}$ En el caso de que por cualquier clase de razones hubiera de prohibirse la explotación en España de una película importada, podrá transferirse a otro título el permiso de doblaje que hubiese sido aplicado a la primera.

\footnotetext{
${ }^{369}$ Concesión de permisos de doblaje, 31 de diciembre de 1946, Ministerio de Educación Nacional, Boletín Oficial del Estado, 25 de enero de 1947, núm. 25
} 
$6^{\circ}$ Cuando la Junta Superior de Orientación Cinematográfica considere conveniente el doblaje al castellano de una producción extranjera, podrá tomar el acuerdo de autorizar exclusivamente su rotulación, siendo aplicable a otro título el permiso de doblaje en que estuviese amparada. En este caso la entidad importadora o propietaria de la misma podrá recurrir de nuevo ante la Junta, perceptivamente constituida bajo la presidencia del ilustrísimo señor Subsecretario de Educación Popular.

$7^{\circ}$ Las películas extranjeras que no posean permiso de doblaje serán explotadas en su versión original, pudiendo ser rotuladas en castellano, excepto en aquellos casos de importación por intercambio de una película española, en los que excepcionalmente podrá concederse una autorización de doblaje, cuando la película española se haya exhibido en el idioma y país al que la película extranjera pertenezca.

$8^{\circ}$ Las entidades cinematográficas que con anterioridad a la presente disposición hubieran presentado producciones nacionales al dictamen de la Junta Superior de Orientación Cinematográfica u organismos refundidos en ella, podrán solicitar de la citada Junta la clasificación de las mismas a los efectos de concesión de permisos de doblaje, debiendo manifestar, mediante declaración jurada y de acuerdo con el detalle que les sea exigido, las películas extranjeras ya importadas como consecuencia de la producción nacional presentada, e indicando asimismo el número de las películas extranjeras que les fueron ya autorizadas para su doblaje y explotación en España.

$9^{\circ}$ Dentro del plazo de tres meses, a partir de la fecha de la publicación de la presente Orden, las producciones nacionales comprendidas en el apartado anterior podrán obtener tantos permisos de doblaje a nuestro idioma como películas tengan pendientes de importación o doblaje, pero siempre que éstas no sean superiores en número a los permisos que las correspondieran de acuerdo con la categoría en que fueron clasificadas por la Junta Superior de Orientación Cinematográfica.

$10^{\circ}$ Las películas de corto metraje, bien sean de dibujos, documentales, muñecos animados o películas de ficción, se ajustarán en un todo a las normas establecidas por la presente Orden, clasificándose en las mismas categorías que las de largo metraje a los efectos a los efectos de concesión de los correspondientes permisos de doblaje que hayan de aplicarse exclusivamente a películas cortas.

$11^{\circ}$ En aquellas películas importadas en España por cualquiera de las formas establecidas en el régimen de compensaciones e intercambios, la Dirección General de Cinematografía y Teatro podrá exigir la prueba documental que estime necesaria de los acuerdos y contratos de compensación que se establezcan con las casas productoras o distribuidoras de los países importadores con los que se efectúen las referidas operaciones de intercambio. 


\section{Orden creando el Patronato de Experiencias y Divulgaciones Cinematográficas ${ }^{370}$}

Dispone:

$1^{\circ}$ Dependiente de la Dirección General de Cinematografía y Teatro se crea el Patronato de Experiencias y Divulgaciones Cinematográficas, que tiene por objeto desarrollar y dirigir las investigaciones y enseñanzas de carácter cinematográfico que se establezcan.

$2^{\circ}$ El Patronato de Experiencias y Divulgaciones Cinematográficas quedará constituido en la forma siguiente:

Presidente, el ilustrísimo señor Director general de Cinematografía y Teatro.

Vicepresidente $1^{\circ}$, el ilustrísimo señor Director general de Enseñanza Profesional y Técnica.

Vicepresidente $2^{\circ}$, el Director de la Escuela Especial de Ingenieros Industriales.

Vocales : (Siguen los nombres en numero de diez).

Secretario general, D. .... Secretario General de Cinematografía y Teatro.

$3^{\circ}$ El Patronato de Experiencias y Divulgaciones Cinematográficas elevará a la aprobación de este Ministerio el Reglamento que regule los cursos de investigación y enseñanzas cinematográficas que establezcan.

\section{Orden modificando lo dispuesto en la orden de 31 diciembre 1946 sobre permisos de doblaje $e^{371}$}

Las películas declaradas en primera categoría tendrán derecho a la concesión de tres o de cuatro permisos de doblaje, de acuerdo con lo que en cada caso se dictamine por la Junta Superior de Orientación Cinematográfica.

Tendrán asimismo derecho a obtener, según su calidad, uno o dos permisos de doblaje las películas que sean declaradas en segunda categoría.

\footnotetext{
${ }^{370}$ Creando el Patronato de Experiencias y Divulgaciones Cinematográficas, 18 de febrero de 1947, Ministerio de Educación Nacional, Boletín Oficial del Estado, 19 de febrero de 1947, núm. 50

${ }^{371}$ Modificando lo dispuesto en la orden de 31 diciembre 1946 sobre permisos de doblaje, 12 de junio de 1947 , Ministerio de Educación Nacional, Boletín Oficial del Estado, 15 de junio de 1947, núm. 166
} 


\section{Orden sobre devolución de derechos arancelarios de películas prohibidas por la censura ${ }^{372}$}

$1^{\circ}$ El importador de las películas extranjeras que hayan adeudado en firme los correspondientes derechos arancelarios, podrá solicitar de ese Centro directivo, antes de haber tenido efecto la exhibición de las mismas, que se acuerde la procedencia de la devolución de aquellos derechos, en el caso de que la proyección haya sido prohibida por los respectivos organismos oficiales encargados de la censura.

$2^{\circ}$ La instancia irá acompañada de los siguientes justificantes:

a)Certificación expedida por el organismo oficial que haya censurado la película desfavorablemente y prohibido en su consecuencia su proyección en España, en cuya certificación se consignará el título de la película en español y en el idioma de origen.

b)Certificación de despacho de importación definitiva de las películas y del ingreso de los correspondientes derechos arancelarios, expedida por la respectiva Aduana.

c) Certificación de exportación al extranjero o introducción en un depósito franco de las películas prohibidas, expedida asimismo por la respectiva Aduana.

d) Certificación de la Subcomisión Reguladora de la Cinematografía acreditativa de que las referidas películas -consignando su título en español y en el idioma de origen- no han llegado a proyectarse; y

e) Resumen del guión de la película, que se presentará autorizado con la firma del importador y visado por la Subcomisión Reguladora de la Cinematografía o, en su defecto, por el organismo oficial que haya acordado la prohibición.

$3^{\circ}$ Ese Centro directivo acordará, a la vista de tales documentos, la procedencia o improcedencia de la petición, a efectos de la instrucción del oportuno expediente de devolución, comunicándolo en el primer caso a la Aduana en que se hubiese efectuado el despacho de importación de las películas de que se trate.

$4^{\circ}$ La Inspección General de Aduanas tomará nota de los acuerdos referidos, con el fin de que puedan perseguirse las películas con la devolución si alguna copia obtenida por procedimientos fraudulentos se proyectase ilegalmente.

\footnotetext{
372 Devolución de derechos arancelarios de películas prohibidas por la censura, 22 de junio de 1948, Ministerio de Hacienda, Boletín Oficial del Estado, 27 de junio de 1948, núm. 179
} 


\section{Orden salvando error, orden anterior ${ }^{373}$}

Salvo error deslizado al publicar esta Orden, del modo siguiente:

En el párrafo cuarto de la exposición, donde dice “... en la práctica, por la circunstancia de que la prohibición de la proyección de la película, rectificación de un anterior acuerdo...", debe decirse: "...en la práctica, por la circunstancia de que la prohibición de la proyección de la película, por rectificación de un anterior acuerdo...”.

\section{Orden sobre permisos de doblaje a películas declaradas de Interés Nacional $^{374}$}

$1^{\circ}$ Las películas declaradas de "Interés Nacional" tendrán derecho a la concesión de tres permisos de doblaje. A las clasificadas en primer categoría les corresponderán dos permisos, y uno a las de segunda.

$2^{\circ}$ A las producciones de corto metrajes se las reconocerá un permiso de doblaje únicamente cuando sean declaradas de "interés nacional".

$3^{\circ}$ Las películas cuyos permisos de rodaje estén extendidos con fecha anterior a la presente Orden se clasificarán con arreglo a lo dispuesto en la de 12 de junio de 1947.

\section{Orden sobre creación de la Cámara de Directores Cinematográficos ${ }^{375}$}

$1^{\circ}$ Dependiente de la Dirección General de Cinematografía y Teatro se constituye una Cámara de Directores Cinematográficos que tendrá por objeto:

a) Emitir informes de carácter exclusivamente técnico, artístico o literario sobre aquellos guiones cinematográficos que le sean a este efecto sometidos por la Dirección General de Cinematografía y Teatro para la oportuna concesión del permiso de rodaje correspondiente.

b)Entender en los recursos de apelación promovidos por las productoras cinematográficas, como consecuencia de las denegaciones de los permisos de rodaje que

\footnotetext{
${ }^{373}$ Salvando error, orden anterior, 22 de junio de 1948, Presidencia, Boletín Oficial del Estado, 1 de julio de 1948 , núm. 183

${ }^{374}$ Permisos de doblaje a películas declaradas de Interés Nacional, 29 de julio de 1948, Ministerio de Educación Nacional, Boletín Oficial del Estado, 10 de agosto de 1948, mún. 223
}

${ }^{375}$ Creación de la cámara de directores cinematográficos, 22 de octubre de 1948, Ministerio de Educación Nacional, Boletín Oficial del Estado, 28 de noviembre de 1948, núm. 333 
tuvieran solicitados, siempre que dicha denegación haya sido motivada por razones de carácter técnico, artístico o argumental y literario.

c) Informar las peticiones que se eleven a la Junta Superior de Orientación Cinematográfica, solicitando de ésta la concesión para alguna película de título de "interés nacional".

d) Informar las peticiones de revisión que se eleven a la Junta Superior de Orientación Cinematográfica solicitando mejora de la clasificación otorgada por ésta, cuando se refieren a los efectos de concesión de permisos de doblaje exclusivamente.

$2^{\circ}$ Para ser miembro de la Cámara de Directores Cinematográficos es requisito indispensable el de haber dirigido cuando menos una película de largo metraje que haya obtenido el primer premio en certámenes oficiales de carácter nacional o internacional.

Será Presidente de la misma el Director más antiguo, y actuará como Secretario de ella el Jefe de la Sección de Cinematografía de la Dirección General de Cinematografía y Teatro.

$3^{\circ}$ Los miembros de la Cámara de Directores emitirán por escrito sus informes, haciendo constar en los mismos, cuando éstos se refieran a la calificación de guiones, el juicio que les merece éste, así como las modificaciones o supresiones que consideren necesario aconsejar para contribuir a la mayor perfección de la futura película.

$4^{\circ}$ De acuerdo con lo establecido en el apartado segundo de la presente Orden, la Cámara de Directores Cinematográficos queda integrada por los señores siguientes: (siguen los nombres)

\section{Circular sobre recursos de clasificación de películas ${ }^{376}$}

$1^{\circ}$ Las entidades cinematográficas no podrán interponer recurso ninguno contra el fallo dictado por la Junta Superior de Orientación Cinematográfica en la clasificación de películas españolas hasta tanto que dichas películas no hayan sido a su vez calificadas por la Junta Clasificadora del Ministerio de Industria y Comercio.

$2^{\circ}$ Clasificada la película por el organismo del citado Ministerio, las entidades productoras podrán interponer recurso contra el fallo dictado en su día por la Junta Superior de Orientación Cinematográfica. El recurso en cuestión pasará al estudio y resolución de dicha Junta una vez convenientemente informado por la Cámara de Directores.

$3^{\circ}$ La declaración de "Película de Interés Nacional", cuando la misma sea solicitada a instancia de parte, será informada previamente por la Cámara de Directores y resuelta, según en cada caso proceda, por la Junta Superior de Orientación Cinematográfica.

\footnotetext{
${ }^{376}$ Recursos de clasificación de películas, 28 de diciembre de 1948, Subsecretaría de Educación Popular. Dirección General de Cinematografía y Teatro, Boletín Oficial del Estado, 8 de enero de 1949, núm. 8
} 


\section{Orden que recoge la reglamentación nacional del trabajo en la industria cinematográfica ${ }^{377}$}

\section{CAPITULO PRIMERO}

\section{Extensión}

Artículo $1^{\circ}$ Ambito funcional.- Las presentes Ordenanzas regulan las relaciones de trabajo en las Empresas de las Industrias Cinematográficas.

A efectos de la aplicación de las presentes Ordenanzas se entiende por Industria Cinematográfica la que se dedica conjunta o separadamente a la producción, rodaje, elaboración, sincronización y distribución de películas cinematográficas.

Se incluyen, por tanto, en la presente Reglamentación:

A) Los llamados Estudios Cinematográfico.

B) Las Empresas Productoras que editan películas cinematográficas.

C) Los Laboratorios que se dedican a las operaciones de revelado y positivado de las películas.

D) Las Empresas distribuidoras dedicadas a la distribución de películas mediante compra, arrendamiento, préstamo o cesión gratuita.

E)Empresas dedicadas a doblaje y sincronización de películas.

Art. $2^{\circ}$ Ambito personal.- Se regirán por las presentes Ordenanzas todos los trabajadores que actúan en la Industria Cinematográfica, tanto si realizan una función técnica, artística o administrativa como si solo prestan su esfuerzo físico o de atención.

Se excluyen, por tanto :

a) Las funciones de alta dirección económica o artística, alto gobierno o alto consejo, características de los siguientes cargos u otros semejantes: Director y Subdirector (general, técnico, de producción o películas), Gerente, Secretario y Administrador general, etc.

b) El personal estipulado por contrata a quien se encomiende algún servicio determinado (casas de modas, figurinistas, sastres, etc.), sin continuidad en el trabajo, ni sujeción a jornada, y sin que figure, por lo tanto, en la plantilla de la Empresa ni en el contrato de la producción de la película.

c) Los Agentes Comerciales que trabajen en la Industria Cinematográfica exclusivamente a comisión de una Empresa, con libertad de representar a otras dedicadas

\footnotetext{
${ }^{377}$ Reglamentación nacional del trabajo en la industria cinematográfica, 31 de diciembre de 1948. (Rectificada en fecha 28-5-1949), Ministerio de Industria y Comercio, Boletín Oficial del Estado, 24 de enero de 1949, núm. 24
} 
a igual o distinta actividad, pero no el personal encuadrado en estas Ordenanzas que tenga a su servicio.

Art. $3^{\circ}$ Ambito territorial.- Las presentes Ordenanzas de trabajo serán de aplicación en todo el territorio nacional y Plazas de Soberanía del Norte de Africa.

Art. $4^{\circ}$ Ámbito temporal.- Las normas de esta Reglamentación empezarán a regir a partir del día señalado en su Orden aprobatoria y no tendrán plazo señalado de validez.

\section{CAPITULO ॥}

\section{Organización del trabajo.}

Art. $5^{\circ}$ La organización práctica del trabajo, dentro de las normas y orientaciones de esta Reglamentación y de las disposiciones legales, es facultad exclusiva de la Empresa que responderá de su uso ante el Estado.

No obstante, los sistemas de racionalización, mecanización o división del trabajo que se adopten no podrán nunca perjudicar la formación profesional que el personal tiene el derecho y el deber de completar y perfeccionar con la práctica diaria; y tampoco ha de olvidarse que la eficacia y el rendimiento del personal y, en definitiva, la prosperidad de la Empresa depende de la satisfacción que nace no sólo de una retribución decorosa y justa, sino de que las relaciones todas de trabajo y, en especial, las que sean consecuencia del ejercicio de la libertad que se reconoce a las Empresas, estén asentadas sobre la justicia.

Art. $6^{\circ}$ Con objeto de establecer la debida jerarquía en los distintos ordenes de la producción, la Empresa procurará organizar sus servicios de forma que los Jefes de cualquier categoría vengan obligados a transmitir las instrucciones de la Dirección y las sugerencias del personal por conducto jerárquico concretamente reglamentado, a fin de que nunca se desvirtúen su contenido y finalidad.

\section{CAPITULO III}

Del personal

\section{SECCION $1^{\text {a }}$-Clasificación}

Art. $7^{\circ}$ Disposiciones genéricas.- Las clasificaciones de personal consignadas en la presente Reglamentación son meramente enunciativas y no suponen la obligación de tener provistas todas las plazas enumeradas si la necesidad y volumen de la industria no lo requiere.

Sin embargo, desde el momento mismo en que exista en una Empresa un trabajador que realice las funciones especificadas en la definición de una categoría profesional determinada, habrá de ser remunerado, por lo menos, con la retribución que a la misma asigne esta Reglamentación.

Son, asimismo, enunciativos los distintos cometidos asignados a esta categoría o especialidad, pues todo trabajador de la industria está obligado a ejecutar cuantos trabajos 
y operaciones le ordenen sus superiores, dentro de los generales cometidos propios de su competencia profesional.

Art. $8^{\circ}$ En atención al carácter de su contrato, el personal de la Industria Cinematográfica se clasificará en personal permanente o temporal.

Se entiende por personal permanente el que tiene asignado un trabajo fijo y continuado, sin limitación en cuanto al tiempo de duración.

Es personal temporal el contratado para realizar una labor determinada en una película, etcétera, acabada la cual cesa su contrato de trabajo y su relación con la Empresa.

Todas las Empresas se clasificarán dentro de uno de los siguientes Ciclos:

I. Producción.

II. Estudios Cinematográficos.

III. Laboratorios Cinematográficos.

IV. Distribución.

V. Sincronización y doblaje.

Dentro de cada Ciclo, el personal se clasificará en los Grupos siguientes:

1. Técnicos.

2. Artistas.

3. Técnicos-Administrativos.

4. Administrativos.

5. Subalternos.

6. Obreros.

Art. $9^{\circ}$ Ciclo de Producción.- El personal incluido en este Ciclo se clasificará en: Grupo $1^{\circ}$-TÉCNICOS

A) JEFES TÉCNICOS

a) Primer operador (Tomavistas).

b) Montadores.

C) Decoradores.

B) TÉCNICOS ESPECIALIZADOS

a) Segundo operador (Tomavistas).

b) Maquillador.

c) Primer Ayudante de Dirección.

d) Primer Ayudante de Producción.

e) Secretario de rodaje. 

f) Fotógrafo (Foto fija).
C) AYUDANTES TÉCNICOS
a) Ayudante de Montaje.
b) Ayudante de operadora (Tomavistas).
c) Ayudante de Maquillador.
d) Segundo Ayudante de Producción (Regidor).
e) Ayudante decorador.
D) AUXILIARES TÉCNICOS
a) Auxiliar de Montaje.
b) Auxiliar de Maquillador.
c) Auxiliar de Dirección.
d) Auxiliar de Producción.

Grupo $2^{\circ}$-ARTISTAS
A. Actores.
B. Figuración y Comparsería.

\section{Grupo $3^{\circ}$-TÉCNICOS-ADMINISTRATIVOS}
A. Jefe de Escenario.

Art. $10^{\circ}$ Ciclo de estudios cinematográficos.- El personal de este Ciclo se clasifica :

\section{Grupo $1^{\circ}$-TÉCNICOS}
A) JEFES TÉCNICOS
a) Jefe de Sonido.
B) AYUDANTES TÉCNICOS
b) Constructor realizador de decorados.
c) Jefe electricista.
d) Operador de Sonido.
e) Operador de Cabina.
C) AUXILIARES TÉCNICOS
a) Ayudante de Sonido.
b) Ayudante de Cabina. 
Art. $11^{\circ}$ Ciclo de Laboratorios.- Se incluyen dentro de este Ciclo las siguientes categorías:

\section{Grupo $1^{\circ}$-TÉCNICOS}

A) JEFES TÉCNICOS

a) Jefe de Laboratorio.

B) TÉCNICOS ESPECIALIZADOS

b) Jefe de Sección.

c) Etalonador.

d) Encargado de trucaje.

C) AYUDANTES TÉCNICOS

a) Revelador.

b) Positivador.

c) Mecánico especialista.

d) Electricista especializado.

e) Repaso y Preparación.

f) Controlador de copias.

D) AUXILIARES TÉCNICOS
a) Ayudante de Revelado.
b) Ayudante de Positivado.
c) Armarista.
d) Ayudante de Control y Copias.
e) Ayudante de Repaso y Preparación.

Art. $12^{\circ}$ Ciclo de Distribución.- En este Ciclo se distingue el personal de las Casas Centrales del de las Sucursales, incluyendo en este segundo apartado las Casas Distribuidoras que no tengan sucursales, que se consideran como Sucursales en las zonas donde radiquen. En las Casas Centrales se incluyen:

\section{Grupo $1^{\circ}$-TÉCNICOS}
A) JEFES TÉCNICOS
a) Jefe de Publicidad.
B) AYUDANTES TÉCNICOS
b) Ayudante de Publicidad. 
C) Operador de Cabina.

d) Jefe de Repaso.

Grupo $3^{\circ}$-TÉCNICOS-ADMINISTRATIVOS

a) Jefe administrativo o Contable general.

b) Jefe de Contratación.

c) Jefe de Control y Copias.

Art. $13^{\circ}$ El personal de Distribución que preste sus servicios en las Sucursales y Distribuidoras sin Sucursales se clasifica como sigue:

Grupo $1^{\circ}$-TÉCNICOS
A) JEFES TÉCNICOS
a) Jefe de Sucursal.
B) AUXILIARES TÉCNICOS
a) Repasadora.
b) Ayudante de Cabina.

Grupo $3^{\circ}$-TÉCNICOS-ADMINISTRATIVOS
a) Programista.
b) Viajante.
c) Ayudante de Programista.

Art. $14^{\circ}$ Ciclo de Doblaje y sincronización.- En este apartado se incluyen:

\section{Grupo $1^{\circ}$-TÉCNICOS}
A) JEFES TÉCNICOS
a) Jefe de Sonido.
b) Montador.
B) TÉCNICOS ESPECIALIZADOS
a) Adaptador de Diálogo.
C) AYUDANTES TÉCNICOS
a) Operador de Sonido.
b) Ayudante de Montaje.
c) Operador de Cabina. 


\section{A) AUXILIARES TÉCNICOS}
a) Ayudante de Sonido.
b) Auxiliar de Montaje.
c) Ayudante de Cabina.

\section{Grupo $2^{\circ}$-ARTISTAS}

\section{SINCRONIZADORES Y DOBLADORES}

Art. $15^{\circ}$ Personal Administrativo.- El personal administrativo, que será común a todos los Ciclos, se clasifica:

\section{Grupo $4^{\circ}$-ADMINISTRATIVOS}
a) Jefe de Sección Administrativa.
b) Jefe de Negociado.
c) Jefe de Almacén.
d) Oficiales de primera.
e) Oficiales de segunda.
f) Auxiliares.
g) Aspirantes.

Art. $16^{\circ}$ Subalternos, común a todos los Ciclos.
a) Auxiliares de Almacén.
b) Mozos de Almacén.
c) Conserje.
d) Portero y Ordenanzas.
e) Guardas y Serenos.
f) Recadistas y Botones.
g) Encargados de Camerinos.
h) Encargada de Vestuario.
i) Avisadores.
j) Mujeres de Limpieza.

Art. $17^{\circ}$ Obreros, común a todos los Ciclos 


\section{Grupo $6^{\circ}$-OBREROS}

A) OBREROS EN GENERAL

1. ${ }^{\circ}$ Capataz o Encargado de Taller.

2. ${ }^{\circ}$ Maquinista de elaboración de la madera.

3. ${ }^{\circ}$ Profesionales del oficio.

a) Oficial de primera.

b) Oficial de segunda.

$4 .^{\circ}$ Mozos.

A) OBREROS DURANTE EL RODAJE

$1 .{ }^{\circ}$ Capataz de Electricistas.

2. ${ }^{\circ}$ Electricistas.

a) Oficial primero.

b) Oficial segundo.

3..$^{\circ}$ lluminadores.

4. ${ }^{\circ}$ Asistencias de primera y segunda.

\section{SECCION $2^{\mathrm{a}}$-Definiciones}

Art. $18^{\circ}$-Producción.- TÉCNICOS.

A) JEFES TÉCNICOS.- Comprende esta categoría al personal que desempeña jefatura, con la responsabilidad consiguiente, dentro del ciclo completo de producción.

a) Primer operador (Tomavistas).-Es el responsable de la iluminación e impresión fotográfica de las escenas que componen la película a él encomendada.

b) Montador.- Es el que tiene la responsabilidad de articular las diversas escenas de una película, verificadas en el rodaje, dándoles unidad y ritmo, efectuando la preparación precisa y necesaria para dejar el negativo de la película en codiciones de sacar copias.

c) Decorador.- Es aquel que boceta los decorados y dirige la construcción de los mismos, cuidando los detalles de ambientación antes del rodaje de las escenas.

B) TÉCNICOS ESPECIALIZADOS.- Son los que, a las órdenes del Jefe técnico correspondiente, realizan las funciones propias de su especialidad dentro del rodaje de una película.

a) Segundos Operadores (Tomavistas).- Son los técnicos fotográficos que, a las órdenes del Primer Operador, le ayudan en las funciones encomendadas al mismo, teniendo la responsabilidad directa del movimiento de la cámara. 
b) Maquillador.- Es el que ejecuta y tiene la responsabilidad de la caracterización de los personajes que figuran en el reparto de la película, de acuerdo con el criterio de la Dirección.

c) Primer Ayudante de Dirección.- Es el que está a las órdenes del Jefe de Producción, interpreta y hace cumplir todo cuanto éste le ordene y tenga relación con la función encomendada a la Dirección. En caso de ausencia del Director de la película deberá suplirle en sus funciones, si así lo dispusiere la Empresa.

d) Primer Ayudante de Producción.- Es el que a las órdenes del Jefe de Producción interpreta y hace cumplir todo cuanto éste le ordene, en lo que hace referencia a la organización del rodaje de una película, tanto en su parte artística como en la técnica y administrativa.

e) Secretario de Rodaje.- Es el que a las órdenes de la Dirección anota cuantas indicaciones le hagan, estando obligado a tomar nota de las situaciones en que queden, en cada plano, los personajes (posición, caracterización, vestuario, y detalle) y de todo cuanto figura en los mismos, con el fin de que en planos sucesivos tengan la situación de continuidad necesaria.

f) Fotógrafos (Foto fija).- Se entiende por tales los técnicos fotógrafos que toman las escenas indicadas por el Director de la película o por la Empresa, para los fines que crea necesarios, estando obligados al revelado de las mismas y a sacar hasta cinco copias.

C) AYUDANTES TÉCNICOS.- Comprende este Subgrupo a los que a las órdenes del Jefe Técnico o del Técnico especializado, realizan las funciones técnicas que aquellos les encomienden dentro de su respectiva especialidad.

a) Ayudantes de Montaje.- Es aquel personal especializado que, a las órdenes del Montador de la película, ejecuta todos los trabajos manuales y mecánicos que se presentan durante el montaje de cada película.

b) Ayudante de Operador (Tomavista).- Es el personal que, a las órdenes del Primero y Segundo Operador, realiza las funciones técnicas y auxiliares que le encomienden. Deberá ser el responsable del foco de la cámara durante el rodaje.

c) Ayudante de Maquillador.- Es el que, a las órdenes del Maquillador, ejecuta los trabajos de caracterización y maquillaje sin la responsabilidad que incumbe al primero.

d) Segundo Ayudante de Producción (Regidor).- Es el que a las órdenes del Jefe de Producción y Primer Ayudante ejecuta todos los trabajos de preparación y organización que se le ordenen. Asimismo cuidará del orden en el lugar del rodaje.

e) Ayudante Decorador.- Es el que a las órdenes del Decorador Jefe ejecuta los trabajos que éste le asigna, relacionados con los específicos de su cargo. Se incluirá en esta categoría al dibujante.

\section{D) AUXILIARES TÉCNICOS}

a) Auxiliar de Montaje.- Es el que a las órdenes del Maquillador y de sus Ayudantes ejecuta los trabajos manuales que se le encomienden. 
b) Auxiliar de Maquillador.- Es el que auxilia al Maquillador y sus Ayudantes en las funciones propias cuando se trata del rodaje de escenas en las que interviene numerosa figuración.

c) Auxiliar de Dirección.- Es aquel que, siguiendo las órdenes de la Dirección, obedece sus indicaciones, sirviéndole al propio tiempo de enseñanza los trabajos que se realizan.

d) Auxiliar de Producción.- Es aquel que, siguiendo las órdenes de la Jefatura de Producción, obedece sus indicaciones, sirviendo al propio tiempo de enseñanza los trabajos que se realizan.

Artículo 19.- Producción.- ARTISTAS.

a) Actores.- Comprende todo el personal que, a las órdenes del Director de una película, interpretan los personajes que figuran en el "reparto" con papel que le haya sido previamente asignado.

b) Figuración.- Abarca al personal que forma los conjuntos de la película, siempre que éstos sean superiores a cincuenta personas en cada una de las diversas escenas.

c) Comparsería.- Comprende el personal artístico que interviene en las escenas de una película sin papel que figure en su "reparto".

Artículo 20.- Producción.- PERSONAL TÉCNICO-ADMINISTRATIVO.

\section{A) JEFE DE ESCENARIO}

Es el que asumiendo la responsabilidad de asistencia y vigilancia de todo el personal ocupado en el rodaje coordina el plan de trabajo de los Estudios con el plan de rodaje.

Artículo 21. Estudios cinematográficos.- PERSONAL TÉCNICO.

\section{Grupo $1^{\circ}$.- TÉCNICOS}

\section{A) JEFES TÉCNICOS}

a) Jefe de Sonido.- Es el técnico que, especializado en sonido, responde del registro y del funcionamiento y conservación de los aparatos a él encomendados.

\section{B) AYUDANTES TÉCNICOS}

a) Constructor realizador de decorados.- Es el que ateniéndose a los planos e indicaciones del decorador, los interpreta, ejecuta y hace ejecutar todos los trabajos de construcción y decoración que requiera la película.

b) Jefe electricista.- Es el personal especializado en electricidad que coordina los servicios del personal, asumiendo la responsabilidad de la conservación y entretenimiento de todo el material eléctrico.

c) Operador de Sonido.- Es aquel que a las órdenes del técnico de sonido cuida de la maquinaria, de la impresión y demás funciones que aquél le asigne. 
d) Operador de Cabina.- Es aquel que con el título legal correspondiente cuida de la proyección de la película, así como del entretenimiento y conservación de los aparatos que intervienen en ella.

C) AUXILIARES TÉCNICOS

a) Ayudantes de Sonido.- Comprende esta categoría al personal auxiliar en cometidos materiales y mecánicos. Tiene como misión principal el movimiento y colocación del micrófono, de acuerdo con las órdenes recibidas.

b) Ayudantes de Cabina.- Son aquellos que, sin título legal, trabajan a las órdenes de los operadores, obedeciendo sus indicaciones y sirviéndoles de enseñanza su propio trabajo.

Artículo 22. Laboratorios.-TÉCNICOS

Grupo $1^{\circ}$.-TÉCNICOS

A) JEFES TECNICOS

a) Jefe de Laboratorio.- Es aquel que conoce todas las actividades de un laboratorio, sin excepción, y que puede resolver en cualquier momento todo lo concerniente al mismo.

\section{B) TECNICOS ESPECIALIZADOS}

a) Jefes de Secciones.- Son aquellos que, conociendo todas las actividades de la Sección a que sean destinados, dirigen el trabajo de una o varias secciones.

b) Etalonadores.- Son aquellos que, bajo su responsabilidad, controlan la luz de los negativos, ejecutando los trabajos precisos para ello.

c) Encargados de trucaje.- Son aquellos que ejecutan y hacen ejecutar los trabajos de "Truco" a ellos encomendados.

\section{C) AYUDANTES TECNICOS}

a) Reveladores.- Son los que a las órdenes del Encargado de la Sección responden del revelado de la película, vigilando el tono de la misma; asimismo tendrán a su cargo el entretenimiento y conservación de las máquinas a ellos asignadas.

b) Positivadores.- Son los que a las órdenes del Jefe de Sección correspondiente manejan, bajo su responsabilidad, la máquina positivadora. En atención a la delicadeza que requieren estos trabajos, tendrán la responsabilidad durante los mismos de la conservación de la película, evitando los desperfectos y deterioros de la misma; asimismo tendrán a su cargo el entretenimiento y conservación de las máquinas a ellos asignadas.

c) Mecánico especialista.- Es aquel personal encargado de cuidar y reparar toda la maquinaria del Laboratorio.

d) Electricista especializado.- Es el que tiene a su cargo la reparación y buen funcionamiento de todo lo concerniente a la electricidad del Laboratorio. 
e) Repaso y preparación.- Este personal tiene a su cargo la preparación de todos los negativos para su positivado, colocar trucos, cortinillas, esmerilar y poner "star" descartando las escenas en las producciones y ordenando la limpieza de los negativos para que pasen al positivado en debidas condiciones.

f) Controlador de copias.- Es aquel personal encargado de comprobar si el revelado y positivado de la copia está en condiciones perfectas para su entrega.

D) AUXILIARES TECNICOS

a) Ayudantes de Reveladores.- Son los que a las órdenes de los Reveladores le ayudan en su cometido, ejecutando los trabajos que les encomienden.

b) Ayudantes de positivado.- Son los que a las órdenes de los positivadores los ayudan en su cometido, ejecutando los trabajos que les encomienden.

c) Armaristas.- Es aquel personal encargado del funcionamiento del armario de secado, vigilando la buena marcha de la película y subsanando los posibles entorpecimientos que surjan.

e) Ayudantes de Control y Copias.- Son aquellos que a las órdenes del controlador de copias le ayudan en su cometido, ejecutando los trabajos que les encomiende.

f) Ayudantes de Repaso y Preparación.- Son los que a las órdenes del Encargado de Repaso le ayudan en sus trabajos, ejecutando los trabajos que les encomiende. Tendrán a su cargo el limpiado de negativos.

Artículo 23. Distribución (Casas Centrales).- PERSONAL TECNICO

Grupo $1^{\circ}$.- TECNICOS

\section{A) TECNICOS ESPECIALIZADOS}

a) Jefe de Publicidad.- Es aquel que por su preparación crea ideas y da órdenes para el mejor lanzamiento de las películas en el territorio nacional y, al mismo tiempo, aprovecha el éxito comercial de un título para acreditar la marca, cuida de la confección de carteles, folletos, postales, gacetillas y frases publicitarias, siluetas, fachadas, etc., etc. Este cargo podrá desempeñarlo la Dirección de la Empresa, debiendo tener en este caso los Ayudantes de Publicidad necesarios.

\section{B) AYUDANTES TECNICOS}

a) Ayudantes de Publicidad.- Son aquellos que se encargan de ejecutar las órdenes que emanan directamente de la Dirección o del Jefe de Publicidad, si lo hubiere, en todos los trabajos referentes a la publicidad.

b) Operador de Cabina.- Es el que, con el título legal correspondiente, cuida de la proyección de la película, así como del entretenimiento y conservación de los aparatos que intervienen en ella, con responsabilidad restringida.

c) Jefe de Repaso.- Es la persona que responde de la buena marcha de su Sección, teniendo a su cargo la reconstrucción de copias.

Grupo $3^{\circ}$.- TECNICOS ADMINISTRATIVOS 
a) Jefe administrativo o Contable general.- Comprende esta categoría el que tiene una responsabilidad administrativa en todos los aspectos de la Empresa, fiscalizando y ordenando contablemente todas las operaciones bajo la dependencia exclusiva de la Dirección o Gerencia.

b) Jefe de Contratación.- Es aquel que por sus conocimientos, y bajo las órdenes de la Dirección de la Empresa, cuida de señalar los rendimientos posibles de una película, estando subordinados a él todos los elementos de la contratación, quienes someterán a su aprobación todos los contratos y operaciones que realicen.

c) Jefe de Control y Copias.- Es la persona que, con sus datos estadísticos auxilia a la Dirección o Gerencia y Jefes de Contratación. Controlará el trabajo que realicen los Jefes y Programistas de sucursal en todo cuanto le sea ordenado por la Dirección; asimismo cuidará del mejor acoplamiento de las copias de que disponga la Empresa.

Artículo 24. Distribución (Casas Sucursales).- PERSONAL TECNICO

Grupo $1^{\circ}$.- TECNICOS

A)

\section{JEFES TECNICOS}

a) Jefe de Sucursal.- Es la representación comercial y administrativa de la Casa Central, bajo las órdenes directas de la Dirección; tiene a su cargo toda una zona determinada de la Península.

\section{B) AUXILIARES TECNICOS}

a) Repasadoras.- Llevan la dirección del repaso de copias, teniendo que conocer al detalle el estado tanto básico como accesorio de las mismas. Deberán comunicar al programista cualquier deficiencia que encuentren en el estado de salida en relación con el de entrada. Se clasificarán en tres categorías, denominadas de $1^{\mathrm{a}}$, de $2^{\mathrm{a}}$ y aprendizas de repaso. Son Repasadoras de $1^{\text {a }}$ las que llevan siete años de servicios consecutivos, demostrados documentalmente. Son Repasadoras de $2^{a}$ las que cuenten con más de cuatro años de servicios, sin llegar a siete, y se considerarán como aprendizas de repaso las que no lleguen a cuatro años de servicios.

\section{Grupo $3^{\circ}$.- TECNICOS ADMINISTRATIVOS}

a) Programistas.- El Programista acoplará las fechas de proyección a los títulos contratados o que pudieran surgir de nuevos acuerdos, vigilando la programación de los circuitos de su zona. Vigilará el cumplimiento de los convenios firmados, no debiendo en ningún caso dejar que se cancelen los contratos sin que éstos estén totalmente cumplidos. Asimismo cuidará la correspondencia de la programación. De acuerdo con las directrices de la Dirección o Gerencia, visitará a las Empresas de la capital de su zona para la consecución de fechas de proyección o celebración de nuevos contratos o convenios. Por orden del Gerente o Jefe de Sucursal podrá desplazarse a visitar Empresas fuera de la ciudad.

b) Viajante.- Es misión de éste la celebración de contratos entre la distribuidora que representa y los empresarios de su zona; estará a las órdenes del Gerente o Jefe de Sucursal, quien le marcará las rutas, viniendo obligado a someterle todas las operaciones realizadas o en proyecto. Asimismo es misión del viajante conseguir, en ruta o en plaza, 
fechas de programación para el material pendiente de exhibición y el cobro de los saldos pendientes de las Empresas que se encuentren en ruta, controlando los locales que se le encomienden dentro de su ruta.

c) Ayudante de Programista.- Es el que, conjuntamente con el Jefe de Reclamación solicita de las Empresas fecha de proyección y llevan la programación de un determinado número de películas.

Artículo 25. Doblaje y sincronización.

Grupo $1^{\circ}$.- TECNICOS

a) Jefe de Sonido.- Es el que, dentro de los estudios de doblaje, se encuentra especializado en sonido, respondiendo del registro y del funcionamiento y conservación de los aparatos que tenga encomendados.

b) Montador.- Es el que tiene la responsabilidad de articular las diversas escenas de una película que se han doblado y sincronizado, dándoles unidad y ritmo y efectúa la preparación precisa y necesaria para dejar el negativo de la película en condiciones de casar copias.

\section{B) TECNICOS ESPECIALIZADOS}

a) Adaptador de Diálogo.- Es aquel que, sobre un texto traducido, ajusta y adapta los diálogos que han de ser sincronizados.

C)

AYUDANTES TECNICOS

a) Operador de Sonido.- Es aquel que a las órdenes del Técnico del sonido cuida de la maquinaria de la impresión y demás funciones que aquél le asigne.

b) Ayudante de Montaje.- Es el personal especializado que, a las órdenes del montador de la película, ejecuta todos los trabajos manuales y mecánicos que se presentan durante el montaje de cada película.

c) Montador de Cabina.- Es el que, con el título legal correspondiente, cuida de la proyección de las películas, así como del entretenimiento y conservación de los aparatos que intervienen en ella con responsabilidad restringida.

D)

\section{AUXILIARES TECNICOS}

a) Auxiliares de Sonido.- Comprende esta categoría al personal auxiliar dedicado a cometidos materiales y mecánicos. Tiene como misión principal el movimiento y colocación del micrófono de acuerdo con las órdenes recibidas.

b) Auxiliar de Montaje.- Es el que a las órdenes del montador y de sus ayudantes, si los hubiere, ejecuta los trabajos manuales que se le encomiendan, relacionados con el montaje.

c) Ayudantes de Cabina.- Son aquellos que sin título legal trabajan a las órdenes de los operadores en la proyección de las películas, obedeciendo sus indicaciones y sirviéndoles de enseñanza su propio trabajo.

Grupo $2^{\circ}$.- ARTISTAS 
a) Sincronizadores y Dobladores (actores de doblaje).- Son los artistas que tienen por misión reproducir en idioma nacional los diálogos en las películas nacionales o importadas del extranjero. A efectos de nomenclatura se dividen en fijos y eventuales. Son fijos los que tienen contrato escrito hecho por un estudio de doblaje por un término superior a tres meses, con obligación de sincronizar cualquier clase de papeles que le encomienden en las diversas películas que se sincronicen en la Empresa de que forma parte, dentro de la jornada ordinaria de trabajo. Son eventuales los llamados a actuar el día que la Empresa lo considere necesario, distinguiéndose a efectos de retribución tres categorías, según doblen papeles de actores de reparto de primera o segunda o de simple comparsería, con breves intervenciones orales.

Artículo 26. PERSONAL ADMINISTRATIVO.- Es aquel que desempeña funciones burocráticas, de contabilidad u otras análogas y que por sus características se considera común a todos los Ciclos.

a) Jefe de Sección administrativa.- Comprende esta categoría al personal que con los conocimientos exigidos por el Reglamento de régimen interior asume, bajo la dependencia directa de la Dirección, Gerencia o Administración, el mando y responsabilidad de un sector de actividades de tipo burocrático, teniendo a sus órdenes el personal que requieran los servicios.

b) Jefe de Negociado.- Comprende esta categoría a los que tienen a sus órdenes uno o más oficiales y dirigen el trabajo de éstos en algunos de los negociados u organismos inferiores que la Empresa tenga establecidos, o establezca, para el mejor cumplimiento de sus fines.

c) Jefe de Almacén.- Es la persona que por sí, o con personal a sus órdenes, ha de despachar los pedidos, recibir mercancias, la propaganda, distribuirla en todo el ámbito de la Empresa y ordenarlas, registrando en los libros el movimiento de las mismas que haya habido durante la jornada. En aquellas centrales que cuenten con una sola persona al frente del almacén será considerada con la categoría de Jefe.

d) Oficial de primera.- Es el que tiene a su cargo un servicio determinado, dentro del cual ejerce iniciativa y posee responsabilidad, con o sin otros empleados a sus órdenes, y que lleva a cabo en particular las siguientes funciones: Cajero de cobro y pago, sin firma ni fianza; taquimecanógrafo en idioma extranjero; transcripción en Libro de Cuentas corrientes, Diario, Mayor, Corresponsales, etc., etc.

e) Oficial de segunda.- Es el empleado que por iniciativa y responsabilidad restringida efectúa funciones auxiliares de estadística y contabilidad o coadyuvantes de las mismas, transcripción en libros y demás trabajos similares, taquimecanografía en idioma nacional con cien palabras y trescientas pulsaciones.

f) Auxiliares.- Se considera como tales a los empleados sin iniciativa ni responsabilidad que se dediquen, dentro de la oficina, a operaciones elementales administrativas y, en general, a las puramente mecánicas, inherentes al trabajo de aquéllas. Quedan incluídas las telefonistas.

g) Aspirantes.- Se entenderá por tales a los que dentro de la edad de catorce a veinte años trabajen en labores propias de oficina, dispuestos a iniciarse en las peculiares de cada especialidad. 
Artículo 27. PERSONAL SUBALTERNO.- Es el personal que realiza funciones de limpieza y vigilancia de las dependencias y recintos, cobros y pagos, así como otras de carácter elemental, con el fin de facilitar la labor de los empleados y elementos directivos. Por su especial característica se entiende común a todos los Ciclos.

a) Auxiliar de Almacén.- Es el personal que se dedica a trabajos que exigen cierta práctica en su ejecución, preparación de mercancías, embalaje de las mismas, extendiendo albaranes, de propaganda y llevando los ficheros correspondientes. Deberá transportar las mercancías en caso necesarío, pudiendo hacer cobro de recibos, los ingresos en Bancos y trabajos similares.

b) Mozos de Almacén.- Son los que efectúan transportes de mercancías fuera o dentro del Establecimiento, reparten paquetes o realizan cualquier trabajo que exige predominantemente esfuerzo.

c) Conserje.- Tendrá la mencionada categoría el que al frente de los ordenanzas, porteros, recadistas, botones y mujeres de limpieza cuida de la distribución del trabajo y del ornato y policía de las distintas dependencias.

d) Porteros y Ordenanzas.- Son los que tienen a su cargo la vigilancia de los locales de las oficinas, la copia a prensa de documentos, el franqueo, recogida y entrega de correspondencia y la ejecución de los encargos y recados que se les encomienden.

e) Guardas y Serenos.- Son los que realizan funciones de custodia y vigilancia de las distintas dependencias, cumpliendo sus deberes con sujeción a las disposiciones señaladas por las leyes que regulan el ejercicio de la misión que les está asignada.

f) Recadistas y Botones.- Son los subalternos mayores de catorce años y menores de veinte que realizan funciones similares a las de ordenanzas.

g) Encargada de Camerinos.- Comprende esta categoría al personal femenino que vigila y cuida de las asistencias y orden de los camerinos.

h) Encargada de Vestuario.- Es el personal femenino que cuida del entretenimiento y conservación del vestuario de todo el personal artístico que interviene en la película, así como de realizar todo cuanto ordene la Dirección de la película en el momento del rodaje y que haga referencia al atuendo del personal artístico que interviene.

i) Avisadores.- Son los que ejecutan los encargos y recados que se le encomienden, estando a las órdenes directas del segundo ayudante de producción.

j) Mujeres de limpieza.- Se entiende por tales las que se ocupan del aseo y limpieza de las oficinas y dependencias de la Empresa.

Artículo 28. PERSONAL OBRERO.- Es el que ejecuta el trabajo de orden mecánico y material. Por sus características se entenderán comunes a todos los ciclos.

\section{A) OBREROS EN GENERAL}

$1^{\circ}$ Capataz o Encargado de taller.- Se considera como tal aquel que al frente del grupo o brigada de operarios, y bajo la dependencia correspondiente, trabaja, vigila y cuida de la asistencia y disciplina del personal a sus ordenes, y de los detalles de la recta aplicación de las órdenes recibidas, en lo que se refiere a la ejecución de obras y trabajo. 
$2^{\circ}$ Maquinistas de elaboración de la madera.- Es aquel trabajador que posee conocimientos y experiencia necesarias para el funcionamiento de toda clase de máquinas para la elaboración de la madera, que existan en el Estudio, teniendo a su cargo la limpieza y conservación de las mismas.

$3^{\circ}$ Profesionales o de oficio.- Comprenden esta categoría los obreros que después de un aprendizaje, realizado en un taller, efectúan trabajos de un oficio determinado, tales como electricistas, escayolistas, pintores, albañiles, conductores de vehículos, etc., etc. Las definiciones específicas son las que constan en las respectivas Reglamentaciones. Los operarios de estos oficios quedarán clasificados en la siguiente forma :

a) Oficial primero.- Es el obrero que con la debida perfección conoce los trabajos de uno de los oficios detallados anteriormente, sabiendo plantear, trazar y preparar obras corrientes. Tendrán esta categoría los conductores de turismo o camiones a quienes se les exija carnet especial.

b) Oficial segundo.- Es el obrero que con la debida perfección conoce los trabajos de uno de los oficios detallados anteriormente, sabiendo preparar obra de menos cuantía. Tendrán asimismo esta categoría los conductores de turismo o camión con carnet de primera o de segunda, y los montadores de fotograbado.

c)Ayudante.- Son los obreros mayores de dieciocho años que unen al trabajo que se les encomienda una cierta responsabilidad y atención especial

$1^{\circ}$ Mozos.- Son los obreros mayores de dieciocho años que ejecutan trabajos para los cuales no se requiere preparación alguna ni conocimiento teórico-práctico de ninguna clase, pues la índole de su trabajo consiste exclusivamente en la aportación de su esfuerzo físico, y no exige otra condición que la atención debida a la voluntad de llevar a cabo aquello que se le ordene, teniendo como misión principal la carga y descarga.

\section{B) OBREROS DURANTE EL RODAJE}

$1^{\circ}$ Capataz de electricista.- Se considera como tal aquel que al frente de un grupo de electricistas, que trabaja bajo su dependencia, ejecuta y hace ejecutar las órdenes recibidas, en lo que se refiere a la parte eléctrica de la Empresa.

$2^{\circ}$ Electricistas.- Tienen por función el manejo e instalación y conservación de aparatos, luces, supletorios, instalaciones microfónicas y, en general, cuanto afecta a esta profesión, siempre que las referidas instalaciones se encuentren en los locales de la Empresa o tengan relación con la industria cinematográfica, distinguiéndose, según su capacidad y rendimiento, dos categorías : Oficiales primeros y segundos, de acuerdo con lo establecido en el apartado anterior.

$3^{\circ}$ Iluminadores.- Es el personal que tiene a su cargo el montaje y desmontaje del material eléctrico en los lugares de rodaje que se le indique, manejando este material y el de luz solar; asimismo montará los soportes necesarios cuando éstos sean por sistema de suspensión de peines.

$4^{\circ}$ Asistentes de primera y segunda.- Es el personal obrero que sin reunir una especialidad determinada atenderá la restauración de los pequeños desperfectos que se ocasionen durante el rodaje, así como el transporte de cámara, montaje, desmontaje y movimiento de travelling, traqueta y efectuar los trabajos de orden mecánico y manual que 
les encomienden en los lugares de trabajo. Este personal podrán integrarlo los trabajadores fijos de los estudios, volviendo, una vez terminado el rodaje de la película, a su destino de procedencia.

\section{SECCION $3^{\mathrm{a}}$.- Ingresos, ascensos, plantillas y escalafones.}

Artículo 29. Ingresos.- La admisión de personal por las Empresas se realizará de aucerdo con las normas legales vigentes en general, y muy especialmente con las dictadas en materia de colocación, turnos preferentes, etc.

Como norma general, los ingresos se efectuarán en cada grupo profesional, salvo en el de artistas, por la última categoría.

No obstante, las Empresas que por necesidades de su propia organización tengan que admitir personal ajeno a las mismas, en categorías superiores a las señaladas para el ingreso, podrán hacerlo dando cuenta a la Delegación Provincial de Trabajo correspondiente, a fin de salvaguardar los intereses del personal a quien hubiese podido corresponder el ascenso.

El ingreso del personal técnico, administrativo y técnico-administrativo hagrá de verificarse mediante concurso-oposición, cuyas condiciones se determinarán en el Reglamento de Régimen Interior, de acuerdo siempre con las normas contenidas en esta Reglamentación.

Las admisiones de personal se considerarán provisionales durante un período de prueba, variable según la índole de la labor que a cada trabajador sea destinado y que en ningún caso podrá exceder del que se señala en la siguiente escala :

Para el personal técnico, cuatro meses.

Para el personal administrativo y técnico-administrativo, dos meses.

Para el resto del personal, un mes.

Durante este período tanto el trabajador como el empresario podrán, respectivamente, desistir de la prueba o proceder al despido, sin previo aviso, sin que ninguna de las partes tenga por ello derecho a indemnización.

En todo caso, el trabajador tendrá derecho al percibo, durante el período de prueba, de la retribución correspondiente a la categoría profesional del trabajo encomendado.

Transcurrido el plazo referido, el trabajador pasará a figurar en la plantilla de la Empresa, y el tiempo que cada trabajador hubiere servido en calidad de prueba le será computado a efectos de los aumentos periódicos por tiempo de servicios que establece la presente Reglamentación.

El período de prueba, de que queda hecho mérito, no es de carácter obligatorio, y los empresarios podrán en consecuencia proceder a la admisión de personal, con renuncia total o parcial de su utilización.

Queda exceptuado de las normas comprendidas en este artículo todo el personal incluído en la categoría de actores. 
Artículo 30. Ascensos.- Todo el personal de la Empresa tendrá, en igualdad de condiciones, derecho preferente para cubrir las vacantes que en la misma puedan producirse en las categorías inmediatamente superiores a las desempeñadas.

La enumeracioón y preferencia de los méritos para los ascensos de toda clase de personal se determinará en el Reglamento de Régimen Interior.

El personal del grupo primero, técnicos, y tercero, técnicos-administrativos, serán de libre elección o contratación de las Empresas entre los que posean los títulos o condiciones correspondientes.

Artículo 31. Grupo $2^{\circ}$.- ARTISTAS.- Todo el personal será libremente nombrado por la Empresa entre el que figura alistado en el Censo profesional correspondiente. No obstante, las Empresas podrán contratar como actores personal no incluído en el Censo, previa autorización del organismo correspondiente.

Los contratos de este personal deberán constar necesariamente por escrito y por cuadruplicado, que serán sometidos al visado de la Delegación Provincial de Trabajo correspondiente, la que archivará uno de los ejemplares, devolviendo los tres restantes, que quedarán el poder del Sindicato Provincial, la Empresa e interesado, respectivamente.

En el plazo de un mes, el Sindicato Nacional del Espectáculo someterá a la aprobación de la Dirección General de Trabajo el modelo de contrato-tipo a que este artículo se refiere.

Artículo 32. Grupo $4^{\circ}$.- ADMINISTRATIVOS.- La Empresa proveerá las vacantes de Jefe de Sección Administrativa entre Jefes de Negociado y Oficiales primeros, mediante pruebas de aptitud, cuyas condiciones se fijarán en el Reglamento de Régimen Interior.

En las categorías de Jefe de Negociado, Oficiales y Auxiliares, el ascenso se hará mediante prueba de aptitud y entre el personal de categoría inferior y personal subalterno $u$ obrero de la propia Empresa.

A falta de personal apto de la misma Empresa podrán cubrir las vacantes de las categorías consignadas en el párrafo anterior con personal ajeno de otras Empresas o en paro que reúna las condiciones que fije el Reglamento de Régimen Interior, según lo preceptuado en el artículo 29 de esta Reglamentación.

Los aspirantes, previo examen de capacitación pasarán a la categoría de Auxiliares al cumplir la edad de veinte años, siempre que haya vacante de esta categoría; en caso contrario, optarán entre marcharse de la Empresa o percibir dentro de ella la mitad de la diferencia, siempre que no desempeñen funciones de categoría auxilien, en cuyo caso cobrarán la diferencia íntegra.

Artículo 33. Grupo $5^{\circ}$.- SUBALTERNOS.- Los Conserjes serán nombrados por la Empresa de entre los porteros y ordenanzas.

Las plazas de estas últimas categorías se proveerán, dentro de las Empresas, entre sus trabajadores que hayan sufrido examen o alguna incapacidad y no tengan derecho a subsidio o pensión, como asimismo entre quienes no puedan desempeñar otro oficio o empleo con el rendimiento normal a causa de defecto físico, enfermedad o edad 
avanzada. El restante personal de este Grupo será de libre elección de entre el personal de la Empresa.

Artículo 34. Grupo 6.- OBREROS.- El porcentaje mínimo de Oficiales de primera o segunda de oficios determinados en el artículo 17 de estas Ordenanzas se designará por libre elección de la Empresa entre integrantes de la categoría profesional de Oficiales que, en prueba de aptitud, demostraren la capacidad señalada en el contenido de las funciones fijadas en cada oficio. En caso contrario podrá la Empresa sacar las vacantes a oposición libre entre personal ajeno a la misma.

Artículo 35. El Reglamento de Régimen Interior establecerá los exámenes y pruebas de aptitud y exigirá los méritos o títulos precisos para asegurar la capacidad profesional, así como las condiciones físicas y psíquicas necesarias para todos los ascensos. Asimismo fijará la puntuación de los méritos a considerar, debiéndose computar la antigüedad en la Empresa como mérito preferente, en igualdad de circunstancias.

Estas pruebas de capacidad deberán orientarse de tal forma que no exijan grandes esfuerzos de memoria, siendo más bien de carácter práctico, y se referirán preferentemente a los trabajos o funciones que vayan a desempeñarse.

El Tribunal juzgará la prueba de aptitud. Exámenes de capacidad, concursos de ingresos y ascensos será presidido por el Jefe de la Empresa o un representante de éste, quien estará asistido por dos Vocales de igual o superior categoría de la vacante o puesto de nueva creación que haya de proveerse; uno de ellos será libremente designado por la Empresa, y el otro elegido por ésta de una terna de su personal, que a tal fin presentará el Sindicato correspondiente.

Artículo 36. Plantillas.- En el plazo de un mes, a partir de la publicación de las presentes Ordenanzas, todas las Empresas afectadas por las mismas deberán confeccionar la plantilla general de todo su personal considerado como permanente, clasificado con arreglo a la función que específicamente desarrolle, en la forma establecida en la Sección $2^{\mathrm{a}}$ del capítulo III de este Reglamento, no pudiendo, naturalmente, reducir el número de los que existan en la actualidad.

En las Empresas de pequeña importancia numérica, el personal que realice trabajos correspondientes a diversas categorías será clasificado en una categoría determinada, fijada en atención a los cometidos que en tiempo e importancia ocupen preferentemente sus actividades.

Dichas plantillas, que quedarán incorporadas al Reglamento de Régimen Interior, se aprobarán o rectificarán por las Delegaciones de Trabajo respectivas en el término de diez días, y contra este aucerdo podrán interponer recurso tanto la Empresa como su personal, ante la Dirección General de Trabajo, por conducto de la propia Delegación y en el término de los diez días siguientes.

Las Empresas mixtas que abarquen dentro de sus actividades distintas industrias de las señaladas en el artículo $1 .^{\circ}$ confeccionarán plantilla separada para el personal adscrito a cada Ciclo de producción. 
Artículo 37. Escalafones.- Dentro de los treinta días siguientes al de la aprobación de las plantillas se formará por las Empresas el Escalafón de su personal, de acuerdo con la clasificación en grupos y categorías, en la forma establecida por esta Reglamentación.

En el citado Escalafón se relacionará nominalmente al personal por categorías, y dentro de éstas, por antigüedad en el cargo o categorías, haciéndose constar además las circunstancias siguientes: Nombres y apellidos del interesado, fecha de nacimiento y de antigüedad en la Empresa, antigüedad en la categoría, sueldo o salario-base asignado a la misma, quinquenios devengados y fecha en que le corresponda el primer aumento periódico por tiempo de servicios.

Artículo 38. El Escalafón, confeccionado con arreglo a las normas del artículo anterior, deberá darse a conocer a todo el personal, permaneciendo expuesto en sitio visible del centro o centros de trabajo durante quince días, dentro de cuyo plazo los interesados que estimen que no se les ha incluído en la categoría y lugar que les corresponde podrán reclamar por escrito ante la Dirección de la Empresa, que sellará y fechará el duplicado de la reclamación, debiendo resolver la misma dentro de los quince días siguientes.

Si la petición fuera desestimada o hubiera transcurrido el plazo marcado sin que la Empresa se pronunciase sobre ella, podrá el recurrente acudir dentro de los quince días siguientes ante la Delegación de Trabajo. Contra los acuerdos de los Delegados Provinciales de Trabajo cabe interponer recurso, tanto por la Empresa como por el trabajador, ante la Dirección General de Trabajo, en el término de diez días, desde la fecha en que se hubiese notificado el acuerdo recurrido.

Contra la resolución que dicte la Dirección General no puede interponerse recurso de ninguna clase.

\section{CAPITULO IV}

\section{Formación profesional}

Artículo 39. Inspirándose en los escritos que orientan la doctrina y legislación social del nuevo Estado, las Empresas que integran las Industrias Cinematográficas pondrán el máximo interés en la formación de personal capacitado, admitiendo para las especialidades fundamentales meritorios, a quienes facilitarán las enseñanzas oportunas para su mayor rapidez de perfeccionamiento profesional.

Estos meritorios se contratarán necesariamente por escrito triplicado, que será visado por el Sindicato correspondiente, archivando una copia y devolviendo las otras dos a las partes interesadas.

El meritorio que haya desempeñado satisfactoriamente sus funciones durante un mínimo de tres películas podrá pasar a la categoría inferior de la Sección en que haya practicado su aprendizaje, y durante el desempeño de sus funciones percibirá como mínimo el 60 por 100 de la retribución correspondiente a la especialidad en la cual realice sus prácticas. 
Dada la especialidad de la Industria Cinematográfica, no se considera necesario la admisión de aprendices dentro del Grupo $6^{\circ}$. Obreros; pero en el caso de que se admitiesen se regularán sus relaciones laborales con la Empresa por las Normas generales dictadas sobre aprendizaje, percibiendo los jornales correspondientes a las actividades cuyo aprendizaje realice efectivamente el aprendiz contratado.

\section{CAPITULO V}

Retribución.

\section{SECCIÓN $1^{\mathrm{a}}$.- Principios generales.}

Artículo 40. La remuneración del personal que actúe en las Industrias Cinematográficas podrá establecerse sobre la base de salario fijo o de otro sistema de retribución que estimule al personal en la producción, aumentando su rendimiento y eficacia.

De acuerdo con lo dispuesto en la Ley de Contrato de Trabajo, se admite la contratación a trato alzado por la intervención del personal en obra cierta y determinada, siempre que se fije el tiempo de duración del contrato y sin que la cantidad fijada como remuneración sea inferior a la que correspondería de haberse contratado durante el tiempo establecido con arreglo al salario fijado en esta Reglamentación para la respectiva categoría profesional.

Artículo 41. La retribución que se fija en el presente capítulo se entenderá, por jornada completa, pudiendo hacerse su abono por semanas, decenas, quincenas o meses, de acuerdo con los usos locales, que se recogerá en los Reglamentos de Régimen Interior, teniendo el personal derecho a percibir anticipos a cuenta del trabajo ya realizado, previa justificación de su urgente necesidad y hasta el límite del 90 por 100 de las cantidades que tenga ya devengadas.

Artículo 42. Los sueldos y salarios señalados en estas Ordenanzas se entienden mínimos y con carácter de ingreso garantizado, en los casos en que la retribución sea de sólo comisión o compuesta de sueldo y comisiones.

En los oficios en los que no se consignen sueldos o salarios para las mujeres se entenderá que tienen éstas la misma retribución que los varones.

Artículo 43. Con independencia de la retribución mínima que se marca, se establecen aumentos periódicos por tiempo de servicio a favor de todo el personal permanente.

\section{SECCIÓN $2^{\mathrm{a}}$.- Salario o retribución fija por jornada.}

Artículo 44. A los efectos de fijación de sueldos y jornales del personal que presta sus servicios en la Industria Cinematográfica, se considera Zona única todo el territorio nacional.

No obstante, y en la que respecta al pesonal de Sucursales del Ciclo de distribución, se fijan las tres Zonas siguientes :

\section{Zona $1^{\circ}$.- Madrid y Barcelona.}


Zona $2^{\circ}$.- Valencia, Sevilla y Bilbao.

Zona $3^{\circ}$.- Las restantes provincias no especificadas anteriormente.

La remuneración por Zonas habrá de abonarse atendiendo al lugar donde el personal preste sus servicios.

\section{CUADRO DE SALARIOS \\ CICLO DE PRODUCCIÓN \\ Técnicos}

Jefes técnicos:

Semanales

Pesetas

Primer Operador (Tomavistas)

700.00

Montador

700.00

Docorador

700.00

Técnios especialistas:

Segundo Operador (Tomavistas).

600.00

Maquillador.

550.00

Primer Ayudante de Dirección.

500.00

Primer Ayudante de Producción.

500.00

Secretario de Rodaje.

350.00

Fotógrafo (Foto-Fija).

350.00

Ayudantes Técnicos:

Ayudante de Montaje

250.00

Ayudante de Operador (Tomavistas) ............................................................ 250.00

Ayudante de Maquillador.

250.00

Segundo Ayudante de Producción (Regidor)

350.00

Ayudante de Decorador.

250.00

Auxiliares técnicos:

Auxiliar de Maquillador.

175.00

Auxiliar de Montaje.

175.00

Auxiliar de Dirección.

175.00

Auxiliar de Producción.

175.00

Artistas:

Diarias

Pesetas

150.00

Actores

45.00

Comparsería.

55.00

Comparsería con traje de etiqueta.

70.00

Comparsería con intervención oral...

30.00 
Técnicos administrativos:

Mensuales

Pesetas

Jefe de Escenario

1.600 .00

CICLO DE ESTUDIOS

Técnicos

Jefes Técnicos:

Semanales

Pesetas

Jefe de Sonido.

700.00

Ayudantes Técnicos:

Constructor, Realizador de Decorados.............................................................. 450.00

Jefe Electricista........................................................................................... 400.00

Operador de Sonido............................................................................. 350.00

Operador de Cabina....................................................................................... 200.00

SUCURSALES

Técnicos

Jefes Técnicos:

Jefe de Sucursal.

Auxiliares Técnicos :

Repasadora de primeras.

Pepasadora segunda

Aprendiza de repaso

Ayudante de Cabina.

Técnicos administrativos:

Programista.

Viajante

Ayudante de Programista.

\begin{tabular}{|c|c|c|}
\hline Zona $1^{\mathrm{a}}$ & Zona $2^{\mathrm{a}}$ & Zona $3^{a}$ \\
\hline Pes & Pesetas & Pesetas \\
\hline
\end{tabular}

Mensuales

$\begin{array}{lll}2.000 .00 & 1.750 .00 & 1.500 .00\end{array}$

Semanales

$\begin{array}{lll}179.00 & 130.00 & 125.00\end{array}$

$\begin{array}{lll}145.00 & 110.00 & 100.00\end{array}$

$\begin{array}{lll}110.00 & 90.00 & 80.00\end{array}$

$\begin{array}{lll}175.00 & 175.00 & 150.00\end{array}$

Mensuales

$\begin{array}{lll}1.500 .00 & 1.350 .00 & 1.150 .00\end{array}$

$\begin{array}{lll}1.200 .00 & 1.200 .00 & 1.200 .00\end{array}$

$\begin{array}{lll}950.00 & 850.00 & 750.00\end{array}$

\section{CICLO DE DOBLAJE Y SINCRONIZACIÓN}

Técnicos

Jefes Técnicos:

Semanales

Pesetas

700.00

Jefe de Sonido.

700.00

Montador. 
Técnicos especializados:

Adaptador de Diálogos.

Ayudantes técnicos:

Operador de Sonido.............................................................................. 250.00

Ayudante de Montaje................................................................................ 250.00

Operador de Cabina ............................................................................. 200.00

Auxiliares técnicos:

Ayudante de Sonido...................................................................... 175.00

Auxiliar de Montaje ................................................................................. 175.00

Ayudante de Cabina........................................................................... 175.00

Artistas:

Sincronizadores (actores de doblaje)

Fijos.

Auxiliares técnios:

Ayudante de Sonido.................................................................. 175.00

Ayudante de Cabina.......................................................................... 175.00

\section{CICLO DE LABORATORIOS}

Técnicos

Jefes técnicos:

Semanales

Jefe de Laboratorio.

Pesetas
700.00

Técnicos especializados:

Jefe de Sección......................................................................... 600.00

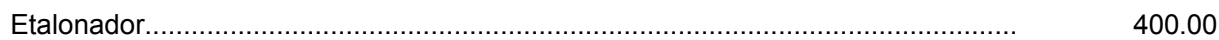

Encargado de Trucaje...................................................................... 350.00

Ayudantes de técnicos:

Revelador................................................................................... 275.00

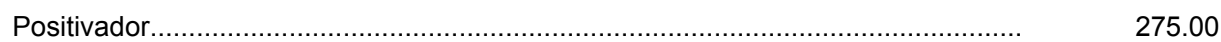

Mecánico Especialista.............................................................................. 225.00

Electricista Especializado.................................................................... 225.00

Repaso y Preparación.............................................................................. 200.00

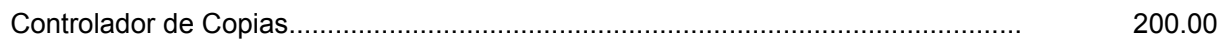

Auxiliares técnicos:

Ayudante de Revelado......................................................................... 150.00

Ayudante de Positivado.............................................................................. 150.00

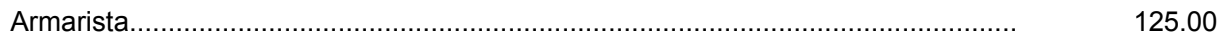

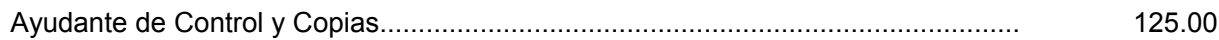




\section{CICLO DE DISTRIBUCIÓN}

\section{Casas centrales}

Técnicos especializados:

Mensuales

Jefe de Publicidad.

Pesetas

2.000 .00

\section{Ayudantes técnicos:}

Mensuales

Ayudante de Publicidad

Pesetas

1.100 .00

Semanales

Operador de Cabina

Pesetas

200.00

Jefe de Repaso

200.00

Técnicos administrativos:

Jefe Administrativo o Contable General.

2.500 .00

Jefe de Contratación

2.500 .00

Jefe de Control y Copia

2.000 .00

\section{Artistas:}

Diarias

Sincronizadores (Actores de doblaje), eventuales:

Sincronizando papeles de primera

Pesetas

Sincronizando papeles de segunda

Personal administrativo

(Común a todos los Ciclos)

Jefe de Sección Administrativa

\begin{tabular}{l} 
Mensuales \\
\hline Pesetas \\
\hline 1.700 .00 \\
1.500 .00 \\
1.250 .00 \\
1.250 .00 \\
900.00 \\
650.00
\end{tabular}

\section{Aspirantes:}

De 14 a 16 años.

De 16 a 18 años.

De 18 a 20 años. 
Subalternos:

(Común a todos los Ciclos)

Auxiliares de Almacén..

750.00

Mozos de Almacén...........................................................................................

Conserje.

600.00

Portero y Ordenazas.

500.00

Guardas y Serenos.

500.00

Recadistas y Botones

300.00

Encargada de Camerinos

375.00

Encargada de Vestuario

400.00

Avisadores

550.00

Mujeres de limpieza (por horas)

3.50

Obreros:

Diarias

Capataz o Encargado de Taller.

Pesetas

33.00

Maquinista de elavoración de la madera.

29.00

Profesionales de oficio:

Oficial de primera.

Oficial de seguna.

Ayudantes

Mozos

Obreros durante el rodaje:

Capataz de Electricista

Electricistas:

Oficial de primera.

Oficial de segunda

lluminadores.

18.00

Asistencias de primera.

16.00

Asistencias de segunda.

14.00

\section{SECCIÓN $3^{\mathrm{a}}$.- Casos especiales de retribución.}

Artículo 45. Trabajos de categoría superior.- El personal de la Industria Cinematográfica podrá realizar trabajos sencillos de la categoría inmediata superior a aquella en que está clasificado, no como ocupación habitual, sino en casos excepcionales de necesidad perentoria en la Industria.

Durante el tiempo de esta sustitución los interesados cobrarán la remuneración asignada a la categoría determinada circunstancialmente, pasando en definitiva a ella si se prolongara por un período superior a dos meses, salvo en el caso en que la situación sea por enfermedad del titular, debidamente justificada, en cuya circunstancia necesitará un año para consolidar definitivamente su superior categoría. 
Artículo 46. Acoplamiento del personal con capacidad disminuída.- Con objeto de mantener en el trabajo, sin llegar al despido, a aquel personal que por deficiencia de sus condiciones físicas y psíquicas o por otras causas no se halle en situación de dar un rendimiento normal en su categoría, se podrá acordar su pase a otro trabajo más adecuado a sus especiales condiciones.

Para ser colocados en esta situación tendrán preferencia los trabajadores que carezcan de subsidio, pensión o medios propios para su sostenimiento.

Artículo 47. Desplazamientos.- Todo el personal que por necesidades de la Industria y por orden de la Empresa tenga que efectuar viajes o desplazamientos a población distinta de la en que radique su Empresa o centro de trabajo, disfrutará sobre su salario o jornal de una dieta que, como mínimo, será :

a) Sesenta pesetas por día para los que disfruten remuneración base inferior a setecientas cincuenta pesetas mensuales. tope.

b) Setenta y cinco pesetas para aquellos cuya remuneración exceda del referido

c) Los Actores percibirán setenta y cinco pesetas diarias.

Los viajes de ida y vuelta serán siempre de cuenta del empresario, que vendrá obligado a facilitar a los trabajadores billetes de las clases siguientes, como mínimo :

a) En tercera, los que perciban hasta 500 pesetas mensuales.

b) En segunda, los que excedan de esa cifra y no lleguen a 750 pesetas.

c) En primera, los que perciban cantidad superior a 750 pesetas.

d) Los desplazamientos de los Actores serán siempre en primera clase.

Los días de salida devengarán idénticas dietas a las señaladas anteiormente, y la del día de llegada quedará reducida a la mitad cuando el interesado pernocte en su domicilio, a no ser que hubiera de realizar fuera del mismo las dos comidas principales.

Si por circunstancias especiales los gastos originados por el desplazamiento sobrepasen el importe de las dietas, el exceso deberá ser abonado por la Empresa, previo conocimiento de la misma y posterior justificación de los gastos realizados.

Los viajantes de distribución disfrutarán, cuando viajen, no sólo las dietas y gastos de locomoción que anteriormente se señalan, sino las comisiones, participaciones y otros emolumentos que libremente tengan concertados con sus respectivas Empresas.

Artículo 48. Gratificaciones especiales.- A fin de que los trabajadores de la Industria Cinematográfica puedan solemnizar las fiestas que conmemoran la Natividad del Señor, de tan honda raigambre espiritual y española, las Empresas regidas por esta Reglamentación de Trabajo abonarán a todo su personal una gratificación de Navidad equivalente a treinta días de haber.

Con ocasión de las fiestas de Exaltación al Trabajo (18 de julio), las Empresas concederán a todo su personal una gratificación equivalente a quince días de haber. 
A estos efectos se entenderá como haber el sueldo o retribución-base establecido en esta Reglamentación con los aumentos periódicos por años de servicios.

Artículo 49. Al personal que hubiere ingresado o cesado en la Empresa en el transcurso del año se le abonará la gratificación prorrateando su importe en relación con el tiempo trabajado en la Empresa, para lo cual la fracción de semana o de mes se computará como unidad completa.

La gratificación de Navidad será pagada en el día laborable inmediatamente anterior al 23 de diciembre; la del 18 de julio, en el día laborable anterior a dicha fecha.

Artículo 50. Plus de cargas familiares.- Para cooperar al sostenimiento de las cagas de familia, se establece un plus, equivalente al 10 por 100 del importe total de la nómina de la Empresa, que se distribuirá conforme a lo dispuesto en la Orden de 29 de marzo de 1946.

Dada la especial modalidad del trabajo en los Ciclos de Producción y Estudio, el cómputo en los mismos se efectuará en relación con el importe de cada nómina en lugar de por las nóminas del anterior trimestre.

Se considerarán comprendidos en la excepción establecida en el apartado $d$ ) del artículo $4^{\circ}$ de dicha Orden y, por tanto, exceptuados del percibo de este plus (no entrando sus retribuciones en el fondo a repartir) todo aquel personal cuya retribución reglamentaria exceda de 125 pesetas diarias.

Artículo 51. Como norma general, las Empresas deberán facilitar a sus trabajadores las herramientas que necesiten para el cometido de su función. No obstante, cuando por la índole de su trabajo o por costumbre tradicional, el trabajador aporte con conocimiento de la Empresa, herramientas de corte de su propiedad, percibirá en concepto de indemnización por desgaste de las mismas, las cantidades siguientes: tres pesetas por semana los Oficiales y una cincuenta los Ayudantes.

El Modelista y Pintor escenógrafo por la especialidad de su trabajo artístico cobrará sobre el jornal de Oficial primero un aumento diario de cinco pesetas.

Artículo 52. Participación en beneficios.- En cumplimiento del principio que proclama el Fuero de los españoles, con referencia a la participación del personal en los beneficios que obtengan las Empresas, se establece provisionalmente, y mientras no se legisle a este respecto con carácter general, la participación del personal de las Industrias Cinematográficas en los resultados económicos de las mismas, que se fija en el 8,33 por 100 (equivalente a la dozava parte) del importe de los salarios o sueldos base incrementados con los aumentos por tiempo de servicios percibidos durante el año correspondiente a la respectiva categoría profesional, según se fijan en el correspondiente cuadro de salarios.

El personal que cesara en el curso del ejercicio económico o no hubiera prestado servicio durante la total duración del mismo, tendrá derecho a la parte proporcional correspondiente al tiempo trabajado, computándose a este efecto como semana o mes completo la fración de los mismos.

Los que se encuentran en estas circunstancias deberán solicitar por ecrito su inclusión entre los que se consideran con tal derecho, dentro del tres de enero de cada año, 
percibiendo, si no lo hicieran, el derecho al percibo de parte que por este concepto les pudiera corresponder.

Quedan exceptuadas del cumplimiento de los dispuesto en el presente artículo las Empresas que se encuentren en situación legal de quiebra.

El abono de las cantidades que por participación en beenficios corresponda deberá efectuarse dentro de los dos meses siguientes a la terminación del ejercicio económico.

El régimen establecido en el presente artículo, por su propio carácter de circunstancial y transitorio, terminará totalmente en el momento en que se dicte una disposición de carácter general que regule participación en beneficios.

Art.53. Todo el personal del grupo $6^{\circ}$, Obreros, cuyo contrato sea temporal o eventual, percibirá la retribución asignada para su categoría incrementada en un 40 por 100 , sin perjuicio de los demás elementos que le puedan corresponder.

\section{SECCIÓN 4a_-Aumentos periódicos por tiempo de servicios.}

Art. 54. A fin de fomentar la vinculación sus respectivas Empresas del personal que trabaja en la Industria Cinematográfica, se establecen documentos periódicos por tiempo de servicios dentro de la propia entidad a favor de todo el personal.

Estos aumentos consistirán en ocho quinquenios de cuantía siguiente:

Sueldos o salarios inferiores a 1.000 pesetas mensuales, el 10 por 100.

Sueldos superiores a 1.000 pesetas, sin exceder de 2.000, 7,50 por 100 .

Sueldos y salarios superiores a 2.000 pesetas, 5 por 100 .

Estos quinquenios se computarán en cada categoría en razón de se computarán en categoría en razón del tiempo servido en la misma, devengándose a partir del primer día del mes siguiente al en que se cumpla, empezándose a contar a partir del primero de octubre 1944, fecha de la entrada en vigor del la anterior Reglamentación aunque los efectos económicos se devengarán desde la vigencia de las presentes normas.

Los que asciendan de categoría cobrarán el sueldo o salario base de la nueva, a menos que éste sea igual o inferior al sueldo que viniese percibiendo. En estos últimos casos el ascendido tendrá derecho a percibir de entre sueldos de la escala de su nueva categoría (escala que resulta de añadir al sueldo base de ésta los aumentos por tiempo) el inmediatamente superior al que cobraba antes del ascenso y devengar íntegramente, cuando corresponda, el importe de los quinquenios que cumpla en la categoría a la cual ascendió.

Estas bonificaciones formarán parte íntegramente del salario, pero podrán ser calculadas y abonadas aparte. Si ello facilita los pagos. Serán también abonadas en relación con las horas extraordinarias que puedan realizarse, calculándose siempre las bonificaciones sobre la base de los sueldos o salarios mínimos fijados en el artículo 46 de las presentes Ordenanzas. 


\section{CAPITULO VI}

Jornada, descanso y horas extraordinarias.

Art. 55. Jornada normal.-Con carácter general se establece en las Industrias Cinematográficas la jornada legal de trabajo y ocho horas semanales en jornada partida, o de siete horas diarias y cuarenta y dos semanales, si el trabajo se hace en jornada continuada.

No obstante lo dispuesto en el apartado anterior, serán mantenidas por las Empresas las jornadas de trabajo que tengan establecidas con carácter normal a la aplicación de estas normas, siempre que sean más beneficiosas para el personal.

Asimismo en las Empresas que tengan establecidos por años de trabajo, de forma que queden libres las tardes de los sábados, la mantendrán en la misma forma que en la actualidad.

Art. 56. Excepciones.-la índole especial del trabajo en la Industria Cinematográfica, quedan exceptuados de la aplicación de la jornada legal:

a) El personal técnico de producción contratado a plazo corto fijo, a base de un tanto alzado por su intervención en la actualidad o en partes semanales de una película determinada, aunque sele efectúe pagos escalonados, siempre que conste en su contrato respectivo.

b) El personal incluido dentro del Grupo $1^{\circ}$ Técnicos, considerados dentro de la categoría de Jefes técnicos.

c) Los viajantes.

d) Los porteros que disfruten casa-habitación y el de los guardas que tengan asignado el cuidado de una zona limitada con casa-habitación dentro de ella, siempre y cuando no se le exija una vigilancia constante.

e) El personal artístico que perciba un sueldo superior a 300 pesetas diarias.

Las Empresas someterán a la aprobación de la Inspección Provincial de Trabajo de su demarcación el cuadro horario correspondiente a todo su personal sujeto a jornada legal, coordinándolo en los distintos servicios para el más eficaz rendimiento, siendo facultad privativa de la Empresa organizar turnos y relevos y cambiar aquéllos cuando lo crea necesario o conveniente, sin más limitaciones que las fijadas en esta Reglamentación y la obligación de obtener permiso de la Inspección de Trabajo cuando estas medidas signifiquen cambio de horario.

El horario y régimen de trabajo del restante personal que actúa en una película lo fijará y hará público la Empresa con una anticipación mínima de doce horas, debiendo en todo caso darse al personal exceptuado de jornada legal una hora como mínimo, para el almuerzo y ocho horas continuas de descanso nocturno.

Cuando el horario fijado por la Empresa sea continuo y tenga parte del mismo comprendido íntegramente entre las doce y las quince horas, o entre las veinte y las veintitrés, deberá abonar al personal incluido en el mismo una dieta de veinte pesetas en concepto de indemnización por comida o cena. 
Art. 57. Horas extraordinarias.-Para el personal exento de la jornada legal no se computarán horas extraordinarias, debiéndose pagar proporcionalmente al contrato estipulado los días o semanas que excedan de los consignados en el contrato como plazos de su actividad en la película.

El restante personal, previa obtención de la autorización pertinente, expedida por la respectiva Delegación de Trabajo, dentro de los límites señalados por la Ley de Jornada máxima, podrá trabajar en la Industria Cinematográfica horas extraordinarias, abonadas con los recargos establecidos por aquella Ley. El número de estas, dada la particularidad de la Industria, podrá aumentarse sobre el tope máximo señalado por la Ley, previa autorización para cada película de la Delegación de Trabajo.

\section{CAPITULO VII}

Enfermedades, excedencias, servicio militar, Licencias y vacaciones.

Art. 58. Enfermedades.-Con independencia de lo regulado en la Ley y Reglamento del Seguro de Enfermedad y en el artículo 68 del Contrato de Trabajo, con respecto a indemnizaciones con ocasión de enfermedad, se reservará durante un año el puesto de trabajo al personal de plantilla que contraiga alguna de dichas enfermedades que no tengan carácter profesional. En todo caso se respetarán las condiciones que en virtud de uso o costumbre local, o merced a concesiones espontáneas, tengan establecidas las Empresas.

El trabajador que ocupe la vacante producida por enfermedad tendrá la consideración de eventual durante el plazo señalado, sin otro derecho cuando se le despida que al percibo de una indemnización correspondiente a los casos de despido normal.

Si el trabajador enfermo no se reincorporase a su puesto en el plazo señalado, el eventual adquirirá los derechos correspondientes al personal de su categoría, respetándose en todo caso las normas que se establecen sobre ingresos y ascensos, debiendo computársele, a efectos de antigüedad, el periodo en que hubiera actuado en calidad de suplente.

El personal de la plantilla excluido del Seguro de Enfermedad tendrá derecho, en caso de tal enfermedad, al disfrute del salario íntegro durante un periodo de tres meses, a la percepción de medio sueldo otros tres, y a la reserva del puesto de trabajo sin sueldo durante los seis meses restantes para completar el plazo de un año señalado en el apartado primero de este artículo.

En caso de enfermedad del personal perteneciente a la categoría de Actores, debidamente justificada, la Empresa podrá rescindir el contrato, debiendo abonar en este caso, en concepto de indemnización, el 30 por 100 de la cantidad que le falte por recibir en el momento en que se le comunique la rescisión.

Art. 59. Excedencias-Se reconoce dos clases de excedencias: voluntaria y forzosa, pero ninguna de ellas dará derecho a sueldo mientras el excedente no se incorpore al servicio activo. 
Para solicitar la excedencia voluntaria todos los trabajadores que lleven por lo menos dos años al servicio de la Empresa.

Las peticiones de excedencia se resolverán dentro del mes siguiente a su presentación y serán atendidas dentro de las necesidades del servicio.

En todo caso se procurará despacharlas favorablemente cuando se funden en terminación de estudios, exigencias familiares u otras causa suficientes y análogas a las expresadas, que señalarán en el Reglamento de Régimen Interior.

Al terminar esta situación de excedencia, el personal tendrá derecho a ocupar la primera vacante que se produzca en su categoría si no hubiere empleados en situación de excedencia forzosa.

La excedencia voluntaria se concederá por una sola vez, por plazo no inferior a un año ni superior a cinco y sin derecho a prórroga. A ningún efecto se computará el tiempo que los empleados permanezcan en esta situación.

Se perderá el derecho a reingreso en la entidad si no se solicita antes de expirar el plazo por el cual se concedió la excedencia. siguientes:

Dará lugar a la situación de excedencia forzosa cualquiera de las causas

a) Nombramiento por cargo político o del Movimiento que haya de hacerse por Decreto o por designación del Secretario general.

b) Enfermedad

c) Matrimonio del personal femenino.

En los casos expresados en el apartado a) del artículo anterior, la excedencia se prolongará por el tiempo que dure el cargo de la determinada y otorgará derecho a ocupar la misma plaza que desempeñaba anteriormente y a que se le compute el tiempo de excedencia a efectos pasivos.

Los empleados o subalternos que se encuentren en esta situación deberán solicitar el reingreso en el mes siguiente a su cese en el cargo.

Los enfermos serán considerados en situación de excedencia forzosa a partir del día siguiente al último en que hayan cobrado la indemnización como consecuencia de su enfermedad.

La duración máxima de esta excedencia será de un año, con derecho a reserva de plaza de la misma categoría que vinieron desempeñando.

El personal excedente por causa enfermedad estará sometido a la vigilancia del servicio médico de la Empresa, que podrá declararle útil para volver al servicio activo.

El personal femenino que contraiga matrimonio quedará en situación de excedente forzoso en tanto no se constituya en cabeza de familia; cuando esto ocurra, deberá solicitar el reingreso dentro de los treinta días siguientes al hecho que lo determine, y deberá adjudicarse la primera vacante en su categoría que ocurra. 
Este personal tendrá derecho, en concepto de dote, a una cantidad equivalente a tantas mensualidades de sueldo o salario base como bienios de servicios haya prestado a la Empresa, sin que pueda exceder de seis mensualidades, contando a estos efectos como años completos la fracción superior a seis meses.

Las mujeres casadas que actualmente presten servicios podrán optar entre continuar trabajando en la misma Empresa o pedir excedencia, con los mismos derechos establecidos en el párrafo anterior.

El derecho a esta opción deberá ejercitarlo en el plazo de dos meses, a partir, a partir de la vigencia de este Reglamento, y en caso de solicitar la excedencia se concederá por rigurosa antigüedad.

En aquellas Empresas en que el personal femenino efectúe trabajos de los que tradicionalmente están reservados a la mano de obra femenina y que no exija aportación notable de esfuerzo físico, será potestativo de sus Empresas acogerse o no al régimen de excedencia forzosa, sin perjuicio del abono de la dote para las mujeres que contraigan matrimonio, siempre que en la localidad o pueblo cercano en donde radique la industria no haya personal femenino en paro forzoso, justificándose este extremo ante la Delegación Provincial de Trabajo.

El personal femenino excede con percepción de dote se considerará que renuncia al derecho de colocarse como trabajadora en cualquier Empresa, sea cual fuere su actividad, mientras subsista en matrimonio.

Art. 60. Servicio militar.-Todos los trabajadores que se incorporen a filas tendrán reservado su puesto de trabajo durante el período que comprenda el servicio militar y dos meses más, computándose tal tiempo a efectos de antigüedad.

Los licenciados del servicio militar o con permiso temporal superior a tres meses podrán reintegrarse al trabajo; en los casos de permiso de inferior duración será potestativo de la Empresa acordar su admisión temporal.

Quien ocupe la vacante temporalmente producida por servicio militar cesará en el desempeño de la misma al incorporarse aquel a quien hubiese sustituido, volviendo a su antiguo puesto de trabajo si pertenecía ya a la Empresa, o cesando definitivamente si hubiere ingresado con aquella condición; pero se le avisará con ocho días de anticipación o se le abonará una indemnización equivalente a tal plazo.

Si el trabajador fijo no se incorpora a su puesto de en el plazo de dos meses señalado en el apartado anterior, el suplente adquirirá los derechos correspondientes al personal de la plantilla, sin perjuicio de lo dispuesto sobre ingresos y ascensos, computándose, a efectos de antigüedad, el tiempo de suplencia.

Art. 61. Licencias y vacaciones.-Con independencia de los casos previstos en los artículos 67 y 68 del texto refundido de la vigente Ley de Contrato de Trabajo, todo trabajador tendrá derecho, en caso de matrimonio, a que se le conceda un permiso de siete días naturales, con disfrute con toda clase de haberes.

Las Empresas concederán las licencias que se soliciten, siempre que no excedan en total de diez días al año y medie causa justificada, tal como fallecimiento de padres, cónyuge, hijo, nietos, o hermanos alumbramiento de la esposa u otra análoga naturaleza. 
Los Reglamentos del Régimen Interior concretarán las causas y la duración de las licencias como abono de haberes que se deban conceder por cada una de tales causas.

En casos extraordinarios y debidamente acreditados se otorgarán licencias por tiempo que sea preciso, según las circunstancias; pero deberán convenirse las condiciones en que se conceden, pudiendo acordarse el no percibo de haberes e incluso el descuento del tiempo extraordinario de licencias a efectos de antigüedad.

En ningún caso las licencias podrán descontarse de las vacaciones.

El régimen de vacación retribuida del personal del personal regido por estas normas será el siguiente:

a) Subalternos y obreros: diez días naturales de entrada y quince días si lleva si lleva más de cinco años al servicio de la Empresa.

b) El resto del personal disfrutará de veinticinco días naturales de entrada y treinta días si llevase más de cinco años al servicio de la Empresa.

El personal menor de veintiún años, tratándose de varones, y el menor de diecisiete años, si se tratare de personal femenino gozarán de un periodo de vacaciones de veinte días naturales, de acuerdo con la Orden de 29 de diciembre de 1945, cualquiera que sea la categoría y grupo a que pertenezcan; siempre que dicho periodo se emplee en asistir a campamentos, cursos, viajes etc., del Frente de Juventudes, con tal que las Delegaciones del mismo comuniquen a las Empresas, con la anterioridad mínima de un mes, los nombres de los menores que hubieran de hacer uso de este derecho.

Para los efectos de la escala señalada anteriormente, la antigüedad se computará desde primero de enero de cada año, considerando como año entero de servicios aquel en que ingresó el trabajador, cualquiera que fuere la fecha en que comenzase a prestar sus servicios.

Ello no obstante, el primer año natural de colocación sólo dará derecho al trabajador a disfrutar vacaciones proporcionalmente al tiempo trabajado en dicho primer año.

Los días de vacaciones serán ininterrumpidos y podrán compensarse en metálico, en todo ni en parte, debiendo disfrutarse preferentemente en verano, otorgándose de acuerdo con las necesidades del servicio, procurando complacer al personal en cuanto la época de su disfrute, resolviendo en caso de desacuerdo, la Magistratura de trabajo.

El personal que cese en el transcurso del año tendrá derecho a la parte proporcional de las vacaciones, según el tiempo trabajado computándose como mes completo la fracción del mismo.

\section{CAPITULO VIII}

Faltas, sanciones y premios.

Art. 62. Premios.-En el Reglamento particular de cada Empresa se establecerá la forma de premiar la conducta, rendimiento, laboriosidad o condiciones sobresalientes del personal. 
Los premios podrán consistir en viajes o bolsas de estudios, cantidades en metálico, sobresueldos, etcétera, y llevarán anejas la concesión de puntos o preferencias para el paso de unas a otras categorías.

Art. 63. Faltas del personal; sus sanciones._Las faltas, aparte las de puntualidad, cuya especial naturaleza exige un régimen particular, se clasificarán en leves, graves y muy graves.

Son leves: Las faltas cometidas que así sean clasificadas por cada Empresa en su Reglamento Interior.

Son graves: Las cometidas contra la disciplina en el trabajo o contra el respeto debido a los superiores, compañeros o subordinados.

La falta de aseo que produzca queja justificada de los compañeros de trabajo.

El quebrantamiento o violación de secretos o la reserva obligada, sin que se produzca gran perjuicio a la Empresa.

Simular la presencia de otro empleado, fichando o firmando por él; ausentarse sin licencia del centro de trabajo, fingir enfermedad o pedir permiso alegando causas no existentes y otros actos semejantes que puedan proporcionar a la Empresa una información falsa.

Son muy graves: El trabajo para otra actividad de Cinematografía sin autorización de la propia.

Los malos tratos de palabra u obra o la falta grave de respeto o consideración o respeto debido al público.

El fraude, hurto o robo, tanto a la Empresa como a los compañeros de trabajo.

La deslealtad, el abuso de confianza y, en general, los actos que produzcan perjuicio grave a la Empresa.

La enumeración de las faltas que anteceden no es limitativa, sino simplemente enunciativa. El Reglamento de Régimen Interior habrá de completarla, señalando, además, las circunstancias que determinan el cambio de clasificación de la falta y clasificando las de consideración o respeto debido al público.

El abuso de autoridad por parte de los jefes será considerado como falta muy grave. El que lo sufra, deberá ponerlo en conocimiento del Jefe de la Empresa, quien ordenará la inmediata instrucción del expediente.

Art. 64. Las sanciones que procederá a imponer en cada caso según las faltas cometidas, serán las siguientes:

Por faltas leves:

Amonestación verbal.

Amonestación por escrito.

Multa hasta de un día de haber.

Por faltas graves: 
Disminución o pérdida total del periodo de vacaciones.

Multa no superior a la séptima parte de una mensualidad.

Recargo hasta el doble de los años que la vigente Reglamentación establece para los aumentos por tiempo de servicios.

La Inhabilitación temporal, por plazo no superior a cuatro años, para pasar a categoría superior.

Represión pública.

Por faltas muy graves:

Pérdida temporal o definitiva de la categoría.

Suspensión de empleo y sueldo por tiempo no inferior a tres meses ni superior a seis.

Inhabilitación definitiva para pasar a categoría superior.

Despido.

Dentro de los límites fijados, y teniendo en cuenta su experiencia y características, cada Empresa determinará en su Reglamento particular la grabación de las faltas y sanciones.

Las sanciones que en el orden laboral puedan imponerse, se entienden sin perjuicio de pasar el tanto de culpa a los Tribunales cuando la falta cometida pueda constituir delito, o de dar cuenta a las autoridades gubernativas, si procediera.

Art. 65. El retraso de más de cinco minutos del personal obligado a firmar o fichar a la entrada se sancionará con multas del 10 por 100 del haber de un día; en el caso de que estas faltas se repitan en el mismo mes más de tres veces, la multa será del 20 por 100 por cada falta, a partir de la cuarta, y medio día de haber a partir de la séptima; la repetición de esta falta más de diez veces en el mismo mes será considerada como falta muy grave.

Art. 66. Tramitación.-Corresponde al jefe de la Empresa la facultad de imponer las sanciones por faltas leves, graves o muy graves, sin otra excepción que la de despido, que se reserva a la Magistratura de Trabajo, ante la cual formulará aquél la correspondiente propuesta.

No será necesaria la previa instrucción de expediente en los casos de faltas leves, pero sí lo será en los de faltas graves o muy graves; el Reglamento interior determinará a los trámites y plazos del expediente, cuya duración no podrá exceder de dos meses, sobre la base de que sea oído el inculpado y de que se admitan cuantas pruebas propongan en su descargo; así mismo concretará dicho Reglamento los casos de faltas muy graves en que la Empresa podrá acordar, como medida previa, la suspensión de empleo y sueldo por el tiempo que dure el expediente.

Las sanciones graves o muy graves que impongan la Empresas al personal serán recurribles ante la Magistratura de trabajo en el término de diez días. 
Tanto en el caso de recurso como en el de propuesta de despidos, el Magistrado resolverá por auto, dentro del plazo de diez días, a la vista de expediente de la Empresa y con audiencia del interesado, que podrá aportar las pruebas que a su derecho convengan.

La resolución que dicte la Magistratura será inapelable, y hará la oportuna declaración sobre la suspensión del empleo y sueldo que, como medida previa, hubiera acordado la Empresa en la tramitación de los expedientes en las faltas muy graves.

Art. 67. Las Empresas anotarán en los expedientes personales de sus empleados las sanciones por faltas graves o muy graves que se les impusieren, pudiendo anotar también las reincidencias en faltas leves.

El Reglamento Interior podrá determinar los cargos y condiciones en que la conducta y actuación del sancionado, posteriores a la falta, anulen estas notas desfavorables.

Las faltas leves prescribirán al mes de su conocimiento por la Empresa, y las graves y muy graves, a los tres meses.

La Empresa deberá dar cuenta al Sindicato de toda sanción impuesta por faltas graves o muy graves.

Art. 68. Sanciones a las Empresas.-Las Delegaciones de Trabajo podrán sancionar a las Empresas que infrinjan la presente Reglamentación con multas de 1.000 y 10.000 pesetas o proponer a la Dirección General que eleve su cuantía hasta 25.000 en casos de residencia, o cuando así lo aconsejen la naturaleza y circunstancias de la falta de infractores. Cuando la sanción fuera impuesta por el Delegado de Trabajo, cabrá el oportuno recurso ante la Dirección General, que deberá imponerse en el plazo de diez días hábiles, contados desde el día siguiente a la notificación de aquélla.

En estos casos la Dirección General de Trabajo, además de imponer sanción económica, podrá proponer al Ministerio el cese de los Jefes, Directores generales o miembros del Consejo de Administración responsables de la conducta de la Empresa, y el Gobierno, a propuesta del Ministro de Trabajo, acordar su inhabilitación temporal o definitiva para ocupar aquellos cargos $u$ otros semejantes o de jefatura en cualquier Empresa.

Art. 69. Cuando en un establecimiento, sucursal, etc., se falte reiteradamente a las prescripciones de este Reglamento o de las Leyes reguladoras del trabajo, el Director que esté al frente incurrirá en falta muy grave, y aparte la sanción económica que a la Empresa puede imponerse, según lo dispuesto en el apartado anterior, podrá ser también inhabilitado temporal o definitivamente para ocupar puesto de dirección o de jefatura en cualquier actividad: esta resolución deberá adoptarse por el Ministerio de Trabajo, a propuesta del Director general.

\section{CAPITULO IX}

\section{Del Reglamento de Régimen interior en las Empresas.}

Art. 70. Las Empresas sujetas a las presentes Ordenanzas y que cuente con más de diez trabajadores vendrán obligadas, en el plazo de tres mese, contados desde el día 
siguiente al de la inserción de estas normas en el Boletín Oficial del Estado, a redactar un proyecto de Reglamento de Régimen Interior, que habrá de seguir el mismo orden de materia de esta Reglamentación, adaptando las reglas de ésta a su peculiar organización de trabajo.

Los citados Reglamentos habrán de tratar especialmente, y según las características particulares de cada Empresa, de los temas siguientes:

a) Clases de actividades a que se dedica la Empresa y lugares donde se encuentren enclavados su centro de trabajo.

b) Plantillas, con el porcentaje del personal femenino empleado en la Empresa.

c) Recargos con que se abonarán las horas extraordinarias, cuando difieran de los legales, así como las remuneraciones especiales establecidas en cuanto a determinados trabajos y los beneficios de otra índole concedidos voluntariamente por la Empresa.

d) Régimen especial de trabajo a tareas, prima o destajo, con expresión de los Departamentos o Secciones en los que haya de trabajarse con dichas modalidades.

e) Cuadro de faltas, sanciones y recompensas, en cuanto difieran de las consignas en el correspondiente capítulo. establecidas.

f) Medidas especiales de prevención e higiene que las Empresas tengan

El proyecto se presentará por triplicado, ante Dirección General del Trabajo, si la Empresa desenvuelve sus actividades en más de una provincia, y ante la correspondiente Delegación del trabajo, si únicamente tuviera centros de trabajo en la misma provincia, debiendo remitir copia del mismo a la Vicesecretaría Nacional de Ordenación Social o Sindicato Provincial, respectivamente.

Tanto la Dirección Nacional como las Delegaciones Provinciales adoptarán el acuerdo que proceda en el término de un mes, a contar desde la recepción del informe sindical, o de cualquier otra dependencia oficial, cuando este último se estimara conveniente, entendiéndose que queda aprobado por la táctica si no recayera resolución en los plazos señalados.

Contra el acuerdo dictado podrá interponerse recurso dentro de los diez días hábiles, contados a partir de la notificación del mismo, el cual deberá presentarse ante la misma autoridad que lo hubiese pronunciado, y será dirigido al Ministro, si hubiese intervenido en primera instancia la Dirección General de Trabajo, o a esta Dirección si hubiera actuado una Delegación.

Para resolver el recurso formalizado dispondrá el organismo competente de otros quince días hábiles.

Las Empresas que incumplan la obligación que este artículo impone serán sancionadas por la Dirección General de trabajo con multas de 500 a 10.000 pesetas, atendida su importancia industrial y económica.

\section{CAPITULO $X$}


Previsión.

Art. 71. Para atender a los fines específicos de la Previsión Social se creará una Sección independiente en el Montepío Nacional de Actividades diversas, en la que estarán integradas obligatoriamente todas las Empresas y trabajadores afectados por las presentes Ordenanzas.

Las obligaciones que deberán ser atendidas por este Montepío o por el que en su día se constituya, serán las prestaciones o mejoras en pensiones de jubilación, viudedad y orfandad preferentemente, y cualquiera otras que se estimen convenientes o necesarias a medida que la entidad de Previsión Laboral cuente con medios económicos para ello.

Art. 72. Para atender aquellas obligaciones contribuirán los trabajadores con el tres por ciento de su sueldo o salario efectivo y las Empresas con el seis por ciento de los mismos.

La Jefatura del Servicio de Mutualidades y Montepíos Laborables redactará el capítulo de Prestaciones, que se incorporará al Estatuto del Montepío de Actividades Diversas y que servirán de base para otorgar los beneficios que habrán de percibir los trabajadores de las Industrias Cinematográficas.

\section{CAPITULO XI}

\section{Disposiciones varias.}

Art. 73. Traslados.—Los traslados del personal podrán efectuarse:

a) Por solicitud del interesado.

b) Por convenio entre la Empresa y el interesado.

c) Por necesidades del servicio.

d) Como sanción en la forma establecida en la presente Reglamentación.

Cuando el traslado se efectúe en virtud de solicitud del interesado, aceptada por la Empresa, esta podrá modificar el salario advirtiéndoselo previamente por escrito de acuerdo con el que corresponda a la nueva zona de trabajo, en el caso en que exista. Será obligatoria tal modificación si dicho salario es superior al de la zona de origen. El traslado no tendrá derecho a indemnización alguna por los gastos que se originen por cambio de residencia.

Si el traslado se efectúa por mutuo acuerdo entre la Empresa y su personal, se estará a las condicione convenidas entre ambas partes.

Cuando las necesidades del servicio lo justifique y no se llegase al acuerdo a que se refiere el apartado anterior, la Empresa podrá imponer obligatoriamente el traslado; pero conservando el trabajador todos su derechos en lo concerniente a salario y a cualquier otro aspecto de remuneración, si el cambio tuviese lugar desde zona superior a zona inferior.

En tales casos de traslado forzoso se tendrá derecho al percibo del importe de, los gastos de locomoción del interesado y miembros de su familia que dependan económicamente: gastos de traslado del mobiliario, ropa y enseres y una indemnización en 
metálico equivalente a sesenta o treinta días (dos meses o un mes) de retribución, según sean o no cabeza de familia.

No cubriéndose una vacante por mutuo acuerdo acerca del traslado y renunciando la Empresa a hacer uso de la facultad reconocida en el apartado d) de este artículo, quedará la misma en libertad para proveer la plaza con personal ajeno a la plantilla, pero siguiendo en todo caso los preceptos que se fijan en este Reglamento para los trabajadores de nuevo ingreso o proveyéndola en ascenso, con el consiguiente corrimiento de escala.

Art. 74. Permutas.-Los trabajadores con destino en localidades distintas pertenecientes a la misma Empresa, categoría y grupo, podrán concertar las permutas de sus respectivos puestos, a reserva de lo que aquella decida en cada caso, teniendo en cuenta las necesidades de servicio, la aptitud de ambos permutantes para sus nuevos destinos y demás circunstancias que sean dignas de apreciación.

De consumarse la permuta, los trabajadores aceptarán las modificaciones de salario a que pudiera dar lugar el cambio de zona, renunciando a toda indemnización por gastos de traslado.

Art. 75. Ceses.-Todo el personal puede solicitar voluntariamente su cese en el servicio de la Empresa; pero deberá anunciarlo a su Jefe correspondiente con ocho días de antelación si se tratase de obreros, y con treinta días, si perteneciese a las restantes categorías profesionales, a fin de que la Empresa pueda prever la debida sustitución, particularmente en los casos en que por naturaleza del trabajo o por circunstancias específicas puedan originarse perjuicios a la Empresa, compañeros o instalaciones, 0 interrumpir la buena marcha del servicio.

Sin perjuicio de lo dispuesto en la Ley de Contrato de trabajo, el trabajador que no avise con antelación anteriormente marcada perderá la parte proporcional de las gratificaciones especiales establecidas en estas Normas, que de otra forma podrán corresponderle.

Art. 76. Despidos.-En todos los casos en que sea necesario efectuar algún despido de personal, con excepción de aquellos que sean consecuencia de falta infracción (mediante la instrucción del oportuno expediente), habrá de tramitarse de acuerdo con las disposiciones legales que regulan esta materia, pero observándose siempre, dentro de cada categoría, un orden riguroso inverso de antigüedad en la Empresa, teniendo opción el personal interesado para pasar a la categoría inmediata inferior, si anteriormente hubiera prestado servicio en ella y en la misma existiera personal más moderno que el propio interesado.

En cuanto al personal perteneciente a las Sucursales del ciclo de Distribución incluidas en la Zona $3^{\mathrm{a}}$ se podrá reducir su sueldo en un 25 por 100 en relación con el fijado en la presente Reglamentación por razón de crisis de trabajo debida a la falta de copias, pero la Empresa deberá ponerlo en conocimiento de la Delegación de Trabajo respectiva expresando los motivos económicos que motivan tal determinación.

Art. 77. Las Empresas podrán contratar la presentación de servicios de personal técnico especializados para funciones de alto asesoramiento científico, cuyos servicios de pura investigación y consulta no se realicen de modo continuo en la Empresa. Este personal no constará en plantilla ni se regirá por estas Ordenanzas. 
Art. 78. Cesión o traspaso de una Empresa.—La Empresa que jurídicamente o de hecho continúe el negocio de otra se hará cargo de sus plantillas y de todo el personal, que se someterá al régimen de la adquiriente o conservar el suyo propio, según el cual de ellos responda mejor a las normas y orientaciones de la presente Reglamentación, no sólo en cuanto capacitación, sino a retribuciones; en caso de duda resolverá la Delegación General de Trabajo, según la extensión territorial de las Empresas fundidas.

En ningún caso y por ningún concepto de la Empresa adquirente podrá pedir personal antiguo ni nuevo, y cuantas reorganizaciones se realizarán serán sobre la base de mejorar o, al menos, mantener la situación de unos y otros. Tan solo previa solicitud justificada podrá amortizar las vacantes que ocurran.

El personal de nuevo ingreso, aunque sea destinado a establecimientos de la Empresa adquirida, se someterá en todo caso al régimen de la adquiriente.

Se evitará siempre mantener duplicidad de regímenes en establecimientos que realmente forman una Empresa.

Art. 79. Respecto a las condiciones más beneficiosas.-Por ser condiciones mínimas las establecidas en la presente Reglamentación de Trabajo, habrán de representarse las que vengan implantadas por disposición legal o costumbre reiteradas cuando, examinadas en su conjunto, resulten más beneficiosas para el personal, tanto en lo relativo a remuneración como en lo referente a otras materias.

Por tanto, si en algún caso la actual retribución, incluido el sueldo o salario, más el plus de carestía de vida, es superior al establecido en esta Reglamentación, ha de ser respetado en lo que exceda, así como se han de conservar las jornadas en vigor siempre que supongan un beneficio para el personal, aplicándose en toda su integridad lo referente a estas materias al personal de nuevo ingreso.

Art. 80. Aplicación de la legislación general.-En lo no previsto o regulado en la presente Reglamentación del Trabajo serán de aplicación las normas que sobre la materia respectiva están establecidas por la legislación de tipo general.

\section{DISPOSICIÓN TRANSITORIA}

El personal perteneciente a la Empresas regidas por este Reglamento que no estuviese clasificado con arreglo a las categorías contenidas en el mismo, así como aquel a quien corresponda ser promovido a categoría superior, se clasificará por la Empresa de acuerdo con las funciones que efectivamente realiza, en el plazo de un mes, a partir de la publicación de este Reglamento.

Las clasificaciones habrán de consignarse en los escalafones que se refiere el artículo 37 de las presentes Normas, pudiendo promoverse contra las mismas las reclamaciones a que hace referencia el artículo 38 .

El personal que al momento de la publicación de la presente Reglamentación se encuentre encuadrado en categorías profesionales declaradas a extinguir, tales como Jefes de cabina, etc., mantendrán esta categoría con carácter personal, percibiendo el sueldo de la categoría inmediata inferior (Operador de cabina, etc.), aumentado en un 25 por 100. 


\section{DISPOSICION FINAL}

Quedan derogadas cuantas bases, normas, pactos y demás disposiciones legales se opongan a lo dispuesto en ésta Reglamentación.

\section{Orden que informa sobre la subasta de películas cinematográficas abandonadas $^{378}$}

$1^{\circ}$ Declarado el abandono definitivo de las películas y su incautación a nombre de la Hacienda por los respectivos Servicios de Aduanas, Aeropuertos, Depósitos francos o de Comercio, esos Servicios comunicarán a los consignatorios o destinatarios de las películas, si son conocidos, y en caso contrario, a la respectiva Cámara Oficial de Comercio o Consulado de la nación de procedencia de las películas, según que estas procedan de territorio políticamente español o extranjero, en todo caso a la Dirección General de Cinematografía y Teatro, que transcurrido un plazo de dos meses sin que se hubiese realizado por quien corresponda el despacho de importación de las películas con los requisitos y formalidades reglamentarias, se procederá a su cuenta en pública subasta como desperdicios de celuloide, Previo el troceado de las mismas por cuenta del rematante con antelación a su entrega a éste.

$2^{\circ}$ Transcurrido el plazo fijado en el apartado anterior, se anunciará la venta en pública subasta de las películas como desperdicios de celuloide; operación que se realizará por lo demás con todas las formalidades y requisitos establecidos en la vigente legislación aduanera, consignando que el rematante en la venta queda obligado al troceado de las películas por su cuenta en local autorizado por la respectiva oficina y bajo la constante intervención de ésta, como requisito previo para hacerse cargo de aquellas, levantándose acta de la operación, que firmará el rematante con los funcionarios interventores de la misma, y de la que quedará un ejemplar unido al expediente.

\section{Orden que eleva a Orden ministerial la Circular num. 262 de clasificación de películas importadas ${ }^{379}$}

Este Ministerio, de conformidad con lo propuesto por V. I., acuerda convalidar, a todos los efectos legales propios de la Orden ministerial a cuyo rango se eleva, el contenido de la repetida Circular num. 262 de ese Centro directivo relativa a la clasificación

\footnotetext{
${ }^{378}$ Subasta de películas cinematográficas abandonadas, 6 de mayo de 1949, Ministerio de Hacienda, Boletín Oficial del Estado, 15 de mayo de 1949, núm. 135

${ }^{379}$ Eleva a orden ministerial la circular num. 262 de clasificación de películas importadas, 8 de septiembre de 1949, Ministerio de Hacienda, Boletín Oficial del Estado, 13 de septiembre de 1949, núm. 256
} 
arancelaria de las películas cinematográficas que se importen en territorio español, y, en consecuencia, que se entienda que " para el adeudo de las películas en negro-positivas intermedias o negativas - o tecnicolor se aplicarán las partidas 692 bis o 692 ter de los vigentes Aranceles de Aduanas, según metraje y en la categoría que corresponda a la copia que pudiera llamarse principal, o sea a la primera del título que se presente al despacho, y que las demás copias que de igual título se importen, estén o no comprendidas en la misma licencia, adeudarán al peso por la partida 692 cuart".

\section{Orden sobre la clasificación de películas autorizadas o toleradas para menores $^{380}$}

$1^{\circ}$ Las películas ya dictaminadas y las que en lo sucesivo se clasifiquen por la Junta Superior de Orientación Cinematográfica como "toleradas" lo serán para los menores de catorce años de edad.

$2^{\circ}$ En lo sucesivo quedan rigurosamente obligadas todas la Empresas cinematográficas a hacer constar en los anuncios, carteles, pizarras, programas, y, en general, toda clase de propaganda al público, la correspondiente clasificación acordada por la Junta Superior de Orientación Cinematográfica como "tolerada" o "autorizada" en cada caso.

\footnotetext{
${ }^{380}$ Clasificación de películas autorizadas o toleradas para menores, 29 de octubre de 1949, Ministerio de Educación Nacional, Boletín Oficial del Estado, 31 de octubre de 1949, núm. 304
} 


\section{GLOSARIO JURÍDICO 381}

Recurso de Contrafuero.- Contrafuero era todo acto legislativo o disposición general del Gobierno que vulnerase los Principios del Movimiento Nacional o las demás Leyes Fundamentales del Reino.

Se trataba de un recurso interpuesto ante el Jefe del Estado para los supuestos en que se considerase que no se habían respetado las leyes en los derechos fundamentales reconocidos en las normas fundamentales del Reino.

Podían promoverlo el Consejo Nacional y la Comisión Permanente de las Cortes.

Se entablaba ante el Consejo del Reino en un plazo de dos meses, dándose cuenta al Jefe del Estado, proponiéndole también a éste la resolución que estime procedente.

Decreto-Ley.- Norma jurídica con rango de Ley dictada por el Gobierno que debiera regularse por Ley Ordinaria. Por circunstancias de urgente necesidad se aprueba anticipadamente por el Gobierno, debiendo ser convalidada por las Cortes en el plazo legalmente fijado.

Ley Orgánica.- Norma jurídica aprobada en votación por el poder legislativo por mayoría absoluta, en materias reguladoras de los derechos fundamentales y libertades públicas, estatutos de Autonomía y régimen electoral general.

Ley Fundamental.- Textos legales aprobados durante el régimen de Franco con valor legal y político de Constitución.

\footnotetext{
${ }^{381}$ Texto extraído de la web: http://www.fuenterrebollo.com/Franco/terminologia.html [visitada el 15 de junio de 2003]
} 
ANEXOS IV

I CERTAMEN CINEMATOGRÁFICO HISPANOAMERICANO 
27 de junio al 4 de julio de 1948

Organizado por la Argentina, Méjico y España y representación cubana, se organizó y llevó a cabo al Certamen cinematográfico hispano-americano, cuya apertura tuvo lugar en Ateneo de Madrid, el día 27 de junio de 1948, clausurándose el día 4 de julio.

Fueron elegidos presidente del mismo: don Vicente Salgado, por España; don Miguel Narchiandirena, por la Argentina, y don Jesús Grovas por Méjico.

Secretario: Alberto Fernández Galar.

Uno de los primeros ausntos a tratar fue la selección de películas que habían de entrar en concurso, acordándose que éstas fueran seis de cada país, que son las siguientes:

\section{España:}

1. Las aguas bajan negras

2. Don Quijote de la Mancha

3. Locura de Amor, Mariona Rebull

4. La princesa de los Ursinos

5. Reina Santa.

Méjico:

1. Crepúsculo

2. Río escondido

3. La otra

4. Que Dios me perdone

5. La barraca

6. Campeón sin corona.

Argentina:

1. Dios se lo pague

2. Su mejor alumno

3. Pobre de mi madre querida

4. La posada del caballito blanco

5. María de los Angeles

6. A sangre fría 
Jurado español: Vicente Sempere, por los productores; Rafael Durán, por los actores; Marino Cuevas, por los exhibidores, y Antonio Barbero, por los críticos cinematográficos.

Jurado argentino: Señores Marchiandirena, Casini, Mendarti y otro a designar entre los delegados.

Jurado mejicano: Señores Grovas, Patiño, Gómez, León y Riquelme.

Viernes, 25 de junio

10,30 mañana. En el cine Capitol. Proyección de Reina Santa (española) y la posada del caballito blanco (argentina).

6 tarde: Segunda reunión previa plenaria para: 1. ${ }^{\circ}$ Fijación del temario de discusión y división del mismo por ponencia; $3 .^{\circ}$ Aprobación del Reglamento de régimen interior.

8 tarde; Visita al Instituto de Investigaciones Científicas.

Sábado, 26 de junio

10,30, mañana: Cine Gran Vía: Proyección de la otra (mejicana) y la princesa de los Ursinos (española).

6 tarde: Reunión previa, por ponencias, para: $10^{\circ}$ En cada ponencia, elección de presidente y secretario; $2 .^{\circ}$ Fijación, en líneas generales, de los puntos que se han de discutir; $3 .^{\circ}$ Establecimiento de turnos para la discusión y fijación del orden interno de cada ponencia; $4 .^{\circ}$ Entrega por el secretario de cada ponencia de los acuerdos previamente tomados, al secretario del Certamen.

8 tarde: Vino español ofrecido por "Cifesa", en el domicilio de su consejero don Vicente Casanova.

Domingo, 27 de junio

12 mañana: Inauguración oficial del Certamen en el Ateneo de Madrid (Prado, 21). 1. Salutación a los congresistas por el jefe nacional del Sindicato del Espectáculo; $2 .^{\circ}$ Palabras de la representación argentina; $3 .^{\circ}$ Palabras de la representación mejicana; $4 .^{\circ}$ Palabras de la representación cubana; $5 .^{\circ}$ Lectura de los acuerdos previos sobre presidencia, Jurados y ponencias. $6 .^{\circ}$ Discurso oficial de inauguración.

2 tarde: Almuerzo en el Hotel Felipe II, de El Escorial, ofrecido por la Dirección General de Cinematografía, Teatro.

6 tarde: Reunión de las ponencias.

Martes, 29 de junio

10,30 mañana: Cine Rialto: Pobre mi madre querida (argentina) y Don Quijote de la Mancha (española). 
2,30 tarde: Almuerzo de confraternidad sindical en la Institución "Virgen de la paloma".

6 tarde: Reunión de las ponencias.

Miércoles, 30 de junio

10,30 mañana: Cine Palacio de la Prensa: Proyección de Río escondido (mejicana) y Mariona Rebull (española).

6 tarde: Reunión de ponencias.

11 noche: Visita a los Estudios "Roptence"

Jueves, 1 de julio

10,30 mañana: Cine Callao: proyección de A sangre fría (argentina) y la barraca (mejicana).

2,30 tarde: Visita al Museo Universal de Bebidas, de Perico Chicote.

6 tarde: Reunión de las ponencias y redacción de las resoluciones para elevar al Pleno por cada una de ellas.

Viernes, 2 de julio

10,30 mañana: Cine Palacio de la Música: Proyección de María de los Angeles (argentina) y Locura de amor (española).

5,30 tarde: Reunión plenaria en el Palacio del Consejo Nacional.

8,30 tarde: Visita a los Estudios “C.E.A.”.

Sábado, 3 de julio

10,30 mañana: Cine Avenida: Proyección de Dios se lo pague (argentina) y Campeón sin corona (mejicana).

2 tarde: Visita a los Estudios de "Sevilla Films" y almuerzo ofrecido por "Suevia Films": Proyección de Las aguas bajan negras (española) y Que Dios me perdone (mejicana).

tarde: Reunión de los Jurados de largo y corto metraje y adjudicación de los premios.

Domingo, 4 de julio

12 mañana: Clausura oficial del Certamen en el Palacio del Consejo Nacional: 1. ${ }^{\circ}$ Acuerdos de las ponencias; $2 .^{\circ}$ Fallo de los Concursos: $3 .^{\circ}$ Entrega de premios: 4. ${ }^{\circ}$ Palabras de clausura.

2 tarde: Almuerzo en la Ciudad Universitaria, ofrecido por el Instituto de Cultura Hispánica.

10,30 noche: Verbena en Villa Romana, ofrecida por los actores cinematográficos españoles. 
Los asuntos a tratar en el certamen son amplios y de gran magnitud, divididos en dos partes:

"Vamos a este Certamen, dijo David Jato, con una gran ilusión. Con una ilusión enorme lo han acogido nuestros invitados. Tanto como el propio Certamen, nos interesa terminarlo, consiguiendo, a su final la fecha fija del próximo y el lugar donde haya de celebrarse. Los problemas que van a debatirse nos interesan mutuamente, sin olvidar nunca que el numero de todas las salas de proyección de la América de habla española, juntas, no iguala al de España.

Méjico no goza de protección oficial para su cinematografía; la Argentina y España, sí. Para vosotros, tengo una grata noticia en particular: se instituirán tres premios, aparte de los ya clásicos de interpretación, dirección, decorado, etc., para los periodistas mejicanos, argentinos y para los de aquí, que premiarán las tres mejores crónicas sobre el Certamen..."

La segunda parte del Certamen se concretará a temas de discusión, siendo los puntos principales a debatir los concernientes a la Unión Aduanera Cinematográfica entre los países hispanos. Reglamentación del trato entre los elementos cinematográficos hispanoamericanos y libertad de contratación.

El día 4 de julio tuvo lugar la clausura del Certamen de Cinematografía Hispanoamericana, ocupando la presidencia el delegado nacional de Sindicatos, señor Sanz Orrio con los directores generales de Cinematografía, señor Rodríguez Martínez; señor Rodriguez Martínez; marqués de la Valdavia y otras personalidades, y asistieron las comisiones argentina, americana y cubana y directores y artistas cinematográficos españoles.

El secretario de la primera sección, Fernando Viola, a quien se debe la iniciativa y realización del Primer Congreso Hispanoamericano, celebrado el año 1932, leyó los acuerdos de ésta, por los que se crea la Unión Cinematográfica Hispanoamericana, a la que pueden pertenecer todas las entidades cinematográficas de los países de habla española. Los secretarios de las demás secciones leyeron sus respectivas ponencias que por ser de capital importancia insertamos a continuación:

La Ponencia encargada de estudiar la creación de una asociación entre los Sindicatos Cinematográficos Hispanoamericanos, acuerda propones al Pleno del Certamen Cinematográfico Hispanoamericano la creación de una Unión Cinematográfica Hispanoamericana, con arreglo a las siguientes bases:

Primero. La Unión Cinematográfica Hispanoamericana se constituye con el objeto de hacer realidad las conclusiones a que se llegue por el Pleno de los Certámenes Cinematográficos Hispanoamericanos y para establecer una eficaz coordinación como organismo de enlace entre los productores, artistas y trabajadores del cinema en los países adheridos.

Segundo. Constituyen de principio la Unión Cinematográfica Hispanoamericana las siguientes entidades:

a) Sindicato Nacional del Espectáculo de España. 
b) Sindicato de Productores de Películas Argentinas (APPA).

c) Asociaciones de Productores y Distribuidores de Películas Mexicanas.

d) Sindicato de Trabajadores de la Producción Cinematográfica de la República Mexicana.

e) Asociación Nacional de Actores (México)

f) Periodistas cinematográficos mexicanos (Asociación civil).

g) Círculo de Escritores Cinematográficos (España).

h) Asociación de Cronistas Cinematográficos (Argentina) ; y, en su día, cuantos Sindicatos, Entidades o asociaciones deseen ingresar en la Unión Cinematográfica Hispanoamericana.

Todas las Asociaciones, Sindicatos o Entidades que ingresen en la Unión Cinematográfica Hispanoamericana, durante un plazo de seis meses a partir de la fecha de su creación, serán considerados como miembros fundadores de la misma.

Tercero. La Unión Cinematográfica Hispanoamericana tendrá su residencia en Madrid. A fin de mantener una comunicación constante de dicho organismo internacional hispanoamericano con las asociaciones, entidades o Sindicatos adheridos y de ponerles al corriente de sus trabajos e iniciativas, se crea asimismo, como órganos de enlace, una Secretaría General coordinador de sus trabajos.

Cuarto. En cada una de las naciones en que existan entidades, Sindicatos o Asociaciones adheridos, habrá una delegación permanente de la Unión Cinematográfica Hispanoamericana, enlazada con la misma por su Secretaría general.

Quinto. La Secretaría General formulará anualmente una Memoria de la labor realizada, con resúmenes estadísticos que sirvan de guía para establecer las posibilidades de toda clase de la Industria Cinematográfica Hispanoamericana, recabando los datos correspondientes de la Delegaciones Nacionales.

Sexto. Las Asociaciones o Sindicatos que integren esta Unión se comprometen a la más leal colaboración y al más sincero cumplimiento de lo acordado.

Séptimo. El lema de la Unión Cinematográfica Hispanoamericana será el del Sindicato de Trabajadores de la Producción Cinematográfica Similares y Conexos de la República Mexicana; Igualdad, Derecho, Justicia.

Octavo. El emblema de la Unión Cinematográfica Hispanoamericana, será el ya utilizado en el Certamen Cinematográfico Hispanoamericano: Un Pegaso de color blanco sobre fondo azul.

Noveno. La Secretaría General de la Unión Cinematográfica Hispanoamericana redactará un proyecto de Reglamento de la misma, que se someterá a la aprobación de las delegaciones Nacionales, las que a su vez confeccionarán sus correspondientes reglamentos de orden - interior.

Décimo. La Unión Cinematográfica Hispanoamericana creará un órgano periódico portavoz de las informaciones de las mismas. 
Undécimo. La Unión Cinematográfica Hispanoamericana estimulará en los países adheridos la producción de película virgén.

Duodécimo. La Unión Cinematográfica Hispanoamericana fomentará el intercambio comercial libre de aquellas publicaciones especializadas en cinematografía que se editen en los países de habla hispana y se consideren de interés.

La Ponencia encargada de estudiar el intercambio de películas, considerando, por razones obvias, la necesidad imprescindible de suprimir entre los países congresistas todas las barreras que detengan el libre intercambio de películas hispanoamericanas en los distintos países de habla española, acuerda proponer las siguientes conclusiones:

Primero. El Certamen Cinematográfico Hispanoamericano estima que deben derogarse los cánones, permisos previos de importación, gravámenes especiales y, en general, todas las trabas que de cualquier manera impidan la libre entrada y puesta en explotación de las películas rodadas originariamente en castellano en los países de habla española.

Segundo. El Certamen Cinematográfico Hispanoamericano, con preferencia a los distintos derechos aduaneros que gravan la importación de películas hispanoamericanas, expresa su deseo de que se llegue a una armonización, de tal modo que no puedan resultar ostensiblemente superiores los de un país en relación con los de otro.

Tercero. El Certamen Cinematográfico Hispanoamericano afirma el inalienable derecho del productor cinematográfico a disponer libremente de los fondos provenientes de la explotación de sus películas en los distintos países de habla española, a cuyo efecto aconseja la realización de acuerdos que permitan llegar a ese resultado, bien por disponibilidad de fondos en los países en que se originen o por cualquier otro procedimiento que se considere eficaz a los efectos que se persiguen.

Cuarto. El Certamen Cinematográfico Hispanoamericano, a los fines de convertir en realidad los propósitos expresados en las conclusiones precedentes de organismo permanente, la realización de todas las cuestiones que sean indispensables ante los Gobiernos de todos los países de habla española.

La Ponencia encargada del estudio del intercambio de películas, considerando que es conveniente que se tomen todas las previsiones que tiendan a establecer un mejor y más leal entendimiento entre los Productores y Distribuidores que negocian películas hispanoamericanas recomiendan la aprobación de las siguientes conclusiones:

Primero. El Certamen Cinematográfico Hispanoamericano considera indispensable que las películas de habla castellana que se importen en cualquiera de los países hispanoamericanos, especifiquen en su presentación la fecha en que han sido rodadas.

Segundo. Toda falsa declaración en cuanto a la fecha en que ha sido rodada en una película deberá ser puesta en conocimiento de la Unión Cinematográfica 
Hispanoamericana por el que resultare víctima de engaño, a los fines de que esta tome las medidas que considere oportuno.

La Ponencia de intercambio de películas, considerando que los criterios dispares de las Censuras de los respectivos países crean graves inconvenientes a la producción, proponen al Pleno del Certamen Cinematográfico Hispanoamericano la aprobación de la conclusión siguiente:

Que por la Secretaría Hispanoamericana se redacten con la máxima urgencia un Código de normas generales, amplias y precisas, que una vez aprobado por los organismos oficiales de los respectivos países, regulen con igualdad de criterio esta importante materia.

La Ponencia de intercambio de películas, considerando el profundo valor que tiene el poder llegar a una coproducción de películas, propone la aprobación de la conclusión siguiente:

El Certamen Cinematográfico Hispanoamericano estima que el capital utilizado en la producción o coproducción de películas habladas en español siempre que sea hispanoamericano, debe ser considerado como nacional a los efectos del país donde la película se filme.

La Ponencia encargada de estudiar el doblaje de las películas, tomando en consideración la trascendencia que encierra para las industrias nacionales de cada uno de los países que toman parte en este Congreso, la necesidad de tomar medidas proteccionista que incrementan económicamente las industrias locales, presenta las siguientes conclusiones:

Primero. El Certamen Cinematográfico Hispanoamericano; expresa la necesidad capital de que todos los países de habla española tiendan a la supresión del doblaje de las películas rodadas originariamente en otro idioma, por entender que es la mejor manera de fomentar el engrandecimiento de la industria cinematográfica de cada país.

Segundo. El Certamen Cinematográfico Hispanoamericano encomienda a la Unión Cinematográfica Hispanoamericana el que realice las gestiones las gestiones necesarias ante los Gobiernos de todos los países de habla castellana, en los que se permite el doblaje, con objeto de obtener una reducción progresiva del número de películas extranjeras que hayan de doblarse y que tienda a la supresión de doblaje con respecto de los derechos adquiridos y sin otra limitación que la de aquellos que por sus excepcionales condiciones artísticas se hagan acreedores a este beneficio, que, en todo momento, deberá compensar económicamente y en forma francamente proteccionista a la producción de los países en donde estas películas extranjeras se explotan.

Tercero. En cualquier caso, solo podrán exhibirse películas dobladas cuando este doblaje haya sido realizado en el mismo país en donde haya de tener lugar la explotación. 
La Ponencia encargada de estudiar la libertad de contratación de técnicos y artistas cinematográficos hispanoamericanos, acuerda proponer al Certamen Cinematográfico la aprobación de las siguientes conclusiones:

Primero. Que, sin prejuicio de las consideraciones que a todo trabajador se concede en los respectivos países, los actores argentinos, mexicanos, españoles y de cualquier otra nación de habla castellana en donde se pueda organizar la industria cinematográfica, con las mismas garantías y condiciones que los nacionales de cada uno de los respectivos países.

Segundo. Que los autores, compositores y músicos, quedarán sujetos a las mismas condiciones y garantías a que se refiere el acuerdo anterior.

Tercero. Que respecto a los técnicos que colaboran en la producción de películas, sea para su contratación y trabajo en los respectivos países, de acuerdo con las entidades sindicales que los representan en cada uno de ellos.

Cuarto. Régimen de divisas. Considerándose de gran importancia el que los actores, técnicos y demás colaboradores de la industria cinematográfica puedan percibir la mayor parte posible de los sueldos que les sean asignados en países distintos a los de su origen, recomienda con especial interés a la Unión Cinematográfica Hispanoamericana que estudie conjuntamente con el proyecto de intercambio de películas la posibilidad de conseguir este depósito.

Quinto. No estando representados en este Certamen todos los Sindicatos y Entidades que agrupan y representan a los distintos sectores de la industria cinematográfica hispanoamericana, los anteriores acuerdos sólo tendrán validez una vez que hayan sido ratificados por dichos Sindicatos y Entidades, por acta dirigida a la Unión Cinematográfica Hispanoamericana.

La Ponencia encargada de estudiar los varios asuntos de carácter cinematográfico que no tienen encaje en la otras ponencias de este Certamen, acuerda proponer al mismo las siguientes conclusiones:

Primero. Que se solicite de los Gobiernos de las naciones representadas en este Certamen la creación y abastecimiento de cinematecas y que, como punto de partida para la tormación de las mismas, su dotación se inicie con copias de las tres películas que obtengan los primeros premios en el presente evento. Dejando, para lo sucesivo, que sea la Unión Cinematográfico Hispanoamericana la que determine la mejor forma de hacer factible este acuerdo.

Segundo. Que el Certamen Cinematográfico Hispanoamericano cree el premio honorífico "Miguel de Cervantes Saavedra", para ser otorgado, anualmente, aquella producción cinematográfica de Hispanoamérica que a él se haga acreedora por la 
singularidad de enaltecer, en muy alto grado, los valores espirituales más tradicionales de nuestra raza.

Seguidamente, se dio cuenta del fallo del concurso de películas proyectadas durante la semana del Certamen y los premios concedidos son como sigue:

A la mejor película española, Locura de amor; a la mejor película argentina, Que Dios se lo pague; a la mejor película mejicana, Río escondido. Se han concedido tres accesits para la película española Don Quijote de la Mancha, a la argentina A sangre fría, y a la mejicana La otra.

El premio a los mejores directores recayó en el español Juan de Orduña, el argentino Luis César Amadori y el mejicano Emilio Fernández realizadores de las tres películas que han merecido los primeros premios.

En cuanto a los artistas, la interpretación femenina correspondió, por España, a Aurora Bautista, protagonista de Locura de amor; a Amelia Bence, agentina, por A sangre fría, y a la mejicana Dolores del Río, por La otra.

Los premios a la interpretación masculina se otorgaron al español Rafael Rivelles por Don Quijote de la Mancha; al argentino Enrique Muiño, por Su mejor alumno, y al mejicano Domingo Soler, por La barraca.

De la interpretación secundaria lo que respecta a artistas españoles, destacan a Sarita Montiel, por Mariona Rebull; Jesús Tordesillas, por Locura de amor; al argentino Antonio Herrero, por A sangre fría; a Héctor Calcaño, por El retrato; a la mejicana Lilia Vicent, por Crepúsculo, y a Victor Junco, por La otra.

Finalmente se concedió también premio a la fotografía de Alfredo Fraile en Don Quijote de la Mancha; de Alberto Etchebehere, por A sangre fría, y Gabriel Figueroa, por Río escondido; para las partituras musicales de Juan Quintero en Locura de amor; a Juan Ehlert, por A sangre fría, y a Raúl Lavista, por La otra; para los mejores decorados de Sigfrifo Burmann en Locura de amor; Gori Muñoz, en Dios se lo pague, y Jorge Fernández, en La otra; para los mejores argumentos originales, a Carlos Blanco, por La princesa de los Ursinos; A. Verlisky y E. Villalba Welsh, por Río escondido; y para los mejores guiones, a Antonio Abad Ojuel, por Don Quijote de la Mancha; Luis Saslavsky, por A sangre fría, y Roberto Gabaldón y José Revueltas, por La otra.

Acto seguido se efectuó la entrega de los premios a productores y artistas que tomaron parte en las películas premiadas, así como los que se han hecho acreedores a los accésits de honor.

En esta sesión de clausura pronunciaron elocuentes palabras el presidente de la Comisión cubana, don Benito Suárez; el jefe de la representación argentina, señor Machinandiarena, y el delegado de Méjico, señor Bustamante.

Cerró el acto con un discurso el señor Sanz Orrio, quien hizo un canto a las glorias y gestas de la Hispanidad, y dijo que para nosotros es motivo de orgullo la altivez de los 
Estados libres e independientes de los pueblos hispanoamericanos surgidos de la madre España. 
ANEXOS V PREMIOS DEL CÍRCULO DE ESCRITORES CINEMATOGRÁFICOS 


\begin{tabular}{|lll|}
\hline $\begin{array}{l}\text { Premios pertenecientes al año: } \\
\text { Premio }\end{array}$ & Galardonado & \\
\hline Mejor película del año: & Los últimos de Filipinas & Los últimos de Filipinas \\
\hline Mejor director: & Antonio Román & Los últimos de Filipinas \\
\hline Mejor actor: & Armando Calvo & Los últimos de Filipinas \\
\hline Mejor actriz: & Ana Mariscal & Una sombra en la ventana \\
\hline & Mary Delgado & El fantasma y doña Juanita \\
\hline Mejor actor secundario: & José María Lado & Tierra sedienta \\
\hline Mejor actriz secundaria: & Maruja Isbert & Un hombre de negocios \\
\hline Mejor argumento original: & Edgar Neville & La vida en un hilo \\
\hline Mejor guión cinematográfico: & Edgar Neville & La vida en un hilo \\
\hline Mejor labor fotográfica: & Alfredo Fraile & \\
\hline Mejor labor musical: & Ernesto Halffter & Bambú \\
\hline Mejor crítica cinematográfica: & Luis Gómez Mesa & \\
\hline $\begin{array}{l}\text { Mejor labor literaria sobre } \\
\text { cuestiones cinematográficas: }\end{array}$ & Carlos Fernández Cuenca & \\
\hline
\end{tabular}

\begin{tabular}{|c|c|c|}
\hline \multicolumn{3}{|c|}{ Premios pertenecientes al año: 1946} \\
\hline Premio & Galardonado & Título \\
\hline Mejor película del año: & Un drama nuevo & Un drama nuevo \\
\hline Mejor director: & Juan de Orduña & Un drama nuevo \\
\hline Mejor actor: & Rafael Durán & La Pródiga \\
\hline Mejor actriz: & Mary Delgado & El crimen de la calle Bordadores \\
\hline Mejor actor secundario: & Fernando Rey & La Pródiga \\
\hline Mejor actriz secundaria: & Antonia Plana & El crimen de la calle Bordadores \\
\hline Mejor argumento original: & José López Rubio & El crimen de Pepe Conde \\
\hline Mejor guión cinematográfico: & Desierto & \\
\hline Mejor labor fotográfica: & Alfredo Fraile & La Pródiga \\
\hline Mejor labor musical: & Juan Quintero & $\begin{array}{l}\text { La Pródiga } \\
\text { Un drama nuevo }\end{array}$ \\
\hline Mejor crítica cinematográfica: & José Luis Gómez Tello & \\
\hline $\begin{array}{l}\text { Premio especial de } \\
\text { interpretación: }\end{array}$ & Manuel Luna & $\begin{array}{l}\text { Misión Blanca/ El crimen de la } \\
\text { calle Bordadores/ Viento de } \\
\text { siglos/ Un drama nuevo }\end{array}$ \\
\hline $\begin{array}{l}\text { Mejor labor literaria sobre } \\
\text { cuestiones cinematográficas: }\end{array}$ & Joaquín Romero Marchent & \\
\hline
\end{tabular}




\begin{tabular}{|c|c|c|}
\hline Premio & Galardonado & Título \\
\hline Mejor película del año: & La princesa de los Ursinos & La princesa de los Ursinos \\
\hline Mejor director: & José Luis Sáenz de Heredia & Mariona Rebull \\
\hline Mejor actor: & José María Seoane & Mariona Rebull \\
\hline Mejor actriz: & Amparo Rivelles & La fe/ Fuenteovejuna \\
\hline Mejor actor secundario: & Jesús Tordesillas & $\begin{array}{l}\text { Las inquietudes de Shanti Andía } \\
\text { Serenata española } \\
\text { La nao Capitana } \\
\text { La Lola se va a los puertos }\end{array}$ \\
\hline Mejor actriz secundaria: & Camino Garrigó & $\begin{array}{l}\text { La fe } \\
\text { Cuando los ángeles duermen }\end{array}$ \\
\hline Mejor argumento original: & Desierto & \\
\hline Mejor guión cinematográfico: & Carlos Blanco & La princesa de los Ursinos \\
\hline Mejor decorado: & Luis Santamaría & Mariona Rebull \\
\hline Mejor labor fotográfica: & Manuel Berenguer & $\begin{array}{l}\text { Las inquietudes de Shanti Andía } \\
\text { Dulcinea } \\
\text { La nao Capitana } \\
\text { La dama del armiño } \\
\text { Cuatro mujeres }\end{array}$ \\
\hline Mejor labor musical: & Jesús García Leoz & $\begin{array}{l}\text { María Fernanda la Jerezana } \\
\text { Las inquietudes de Shanti Andía } \\
\text { Abel Sánchez } \\
\text { El huésped del cuarto número } 13 \\
\text { Serenata española } \\
\text { El otro Fu Manchú } \\
\text { Cuatro mujeres } \\
\text { Obsesión } \\
\text { La Lola se va a los puertos }\end{array}$ \\
\hline Mejor crítica cinematográfica: & Antonio Barbero(Cámara) & \\
\hline $\begin{array}{l}\text { Mejor labor literaria sobre } \\
\text { cuestiones cinematográficas: }\end{array}$ & $\begin{array}{l}\text { Domingo Fernández } \\
\text { Barreira(Primer Plano y } \\
\text { Triunfo) }\end{array}$ & \\
\hline Premio especial de dirección: & Rafael Gil & $\begin{array}{l}\text { La fe } \\
\text { Reina Santa }\end{array}$ \\
\hline $\begin{array}{l}\text { Premio «Jimeno», para } \\
\text { noveles: }\end{array}$ & Antonio Ruiz-Castillo & $\begin{array}{l}\text { Las inquietudes de Shanti Andía } \\
\text { Obsesión }\end{array}$ \\
\hline Mejor película extranjera: & & Los mejores años de nuestra vida \\
\hline
\end{tabular}


Premios pertenecientes al año: 1948

\begin{tabular}{|l|l|l|}
\hline Premio & Galardonado & Película \\
\hline Mejor película del año: & Locura de amor & Mare Nostrum \\
\hline Mejor director: & Rafael Gil & Mare Nostrum \\
\hline Mejor actor: & Fernando Rey & Locura de amor \\
\hline Mejor actriz: & Aurora Bautista & Las aguas bajan negras \\
\hline Mejor actor secundario: & Luis Pérez de León & La vida encadenada \\
\hline Mejor actriz secundaria: & Asunción Sancho & La calle sin sol \\
\hline Mejor argumento original: & Miguel Mihura & \\
\hline Mejor guión cinematográfico: & Desierto & Angustia \\
\hline Mejor labor fotográfica: & José Fernández Aguayo & La vida encadenada \\
\hline Mejor labor musical: & Manuel Parada & \\
\hline Mejor crítica cinematográfica: & Luis Ardila (Pueblo) & \\
\hline $\begin{array}{l}\text { Mejor labor literaria sobre } \\
\text { cuestiones cinematográficas: }\end{array}$ & $\begin{array}{l}\text { Carlos Fernández Cuenca } \\
\text { (Radio Nacional de España) }\end{array}$ & Angustia \\
\hline Mejor decorado: & Antonio Labrada & \\
\hline $\begin{array}{l}\text { Premio especial para artistas } \\
\text { extranjeros en películas } \\
\text { españolas: }\end{array}$ & Antonio Vilar & ¿Qué bello es vivir! \\
\hline $\begin{array}{l}\text { Premio «Jimeno», para } \\
\text { noveles: }\end{array}$ & «Valencia Films» & \\
\hline Premio especial: & Rafael Rivelles & Don Quijote de la Mancha \\
\hline Mejor película extranjera: & ¡Qué bello es vivir! & \\
\hline
\end{tabular}




\begin{tabular}{|l|l|l|}
\hline \multicolumn{2}{|l|}{ Premios pertenecientes al año: 1949} & Título \\
\hline Premio & La mies es mucha & La mies es mucha \\
\hline Mejor película del año: & José Luis Sáenz de Heredia & La mies es mucha \\
\hline Mejor director: & Tomás Blanco & El santuario no se rinde \\
\hline Mejor actor: & Ana Mariscal & Un hombre va por el camino \\
\hline Mejor actriz: & Rafael Romero-Marchent & La mies es mucha \\
\hline Mejor actor secundario: & Julia Caba Alba & La mies es mucha \\
\hline Mejor actriz secundaria: & Desierto & \\
\hline Mejor argumento original: & Desierto & $\begin{array}{l}\text { Un hombre va por el camino } \\
\text { neutralidad }\end{array}$ \\
\hline Mejor guión cinematográfico: & Manuel Berenguer & Un hombre va por el camino \\
\hline Mejor labor fotográfica: & Historia del cine \\
\hline Mejor labor musical: & Jesús García Leoz & \\
\hline Mejor crítica cinematográfica: & Carlos Fernández Cuenca & Neutralidad \\
\hline $\begin{array}{l}\text { Mejor labor literaria sobre } \\
\text { cuestiones cinematográficas: }\end{array}$ & Ángel Zúñiga & Un hombre va por el camino \\
\hline Mejor decorado: & Teddy Villalba & Hamlet \\
\hline Premio «Jimeno», para noveles: & Manuel Mur Oti & \\
\hline Mejor película extranjera: & Hamlet & \\
\hline
\end{tabular}


ANEXOS VI

BASES DE DATOS EN INTERNET 


\section{España:}

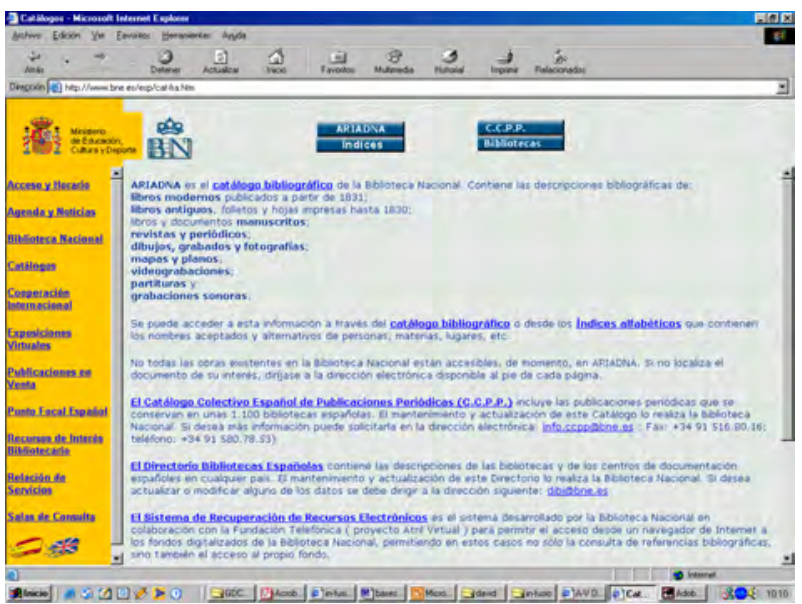

Imagen 101: http://www.bne.es/esp/cat-fra.htm

\section{Ariadna:}

\section{http://www.bne.es/esp/cat-fra.htm}

Es el catálogo bibliográfico de la Biblioteca Nacional de España. Contiene las descripciones bibliográficas de: libros modernos publicados a partir de 1831; libros antiguos, folletos y hojas impresas hasta 1830; libros y documentos manuscritos; revistas y periódicos; dibujos, grabados y fotografías; mapas y planos; videograbaciones; partituras y grabaciones sonoras.

\section{Basinfa (TVE y RNE):}

\section{http://www.rtve.es/rne/areas/ar docum.htm}

Textual. Contiene referencias de informaciones de actualidad extraídas de publicaciones periódicas, de las bibliotecas de TVE y RNE y de las carpetas de Archivos Históricos de TVE y RNE. Consta de casi 500.000 referencias (con un incremento anual de 65.000 y cobertura desde el 1 de enero de 1986). Aunque el acceso está restringido al personal de RTVE, es posible obtener documentación, previa autorización, mediante dos modalidades: Directa por parte del usuario de los fondos abiertos (Biblioteca, Hemeroteca), asistida y asesorada por los documentalistas del Departamento, previa cumplimentación del formulario de solicitud de información, y Consulta exterior al Centro (procedente de Emisoras Territoriales, TVE, etc., se realiza por teléfono y los documentos son enviados por FAX o por correo). 


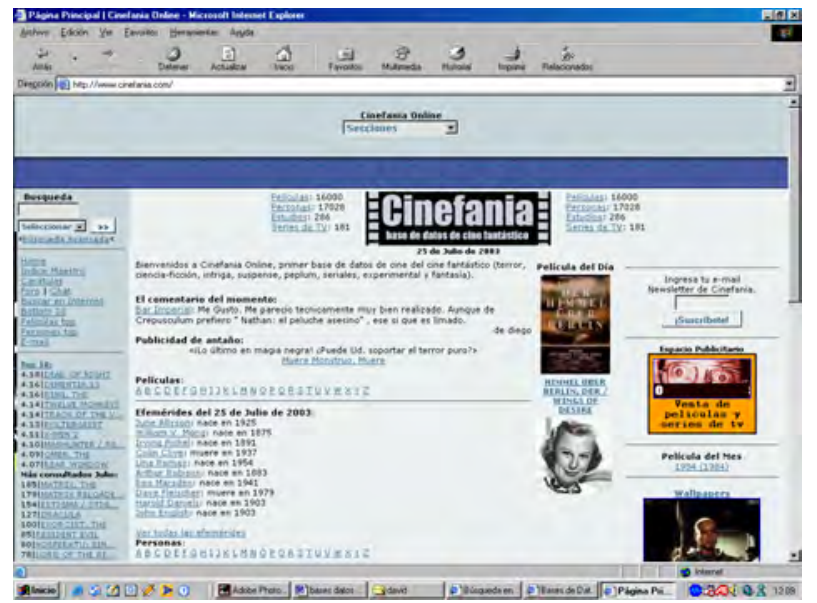

Imagen 102: http://www.cinefania.com

\section{Cinefania:}

\section{http://www.cinefania.com}

Primera base de datos española de cine fantástico (terror, ciencia-ficción, intriga, suspense, peplum, seriales, experimental y fantasía). Cuenta con información sobre 16.000 películas, 17.028 personas relacionada con el género, 286 estudios y 181 series de televisión.

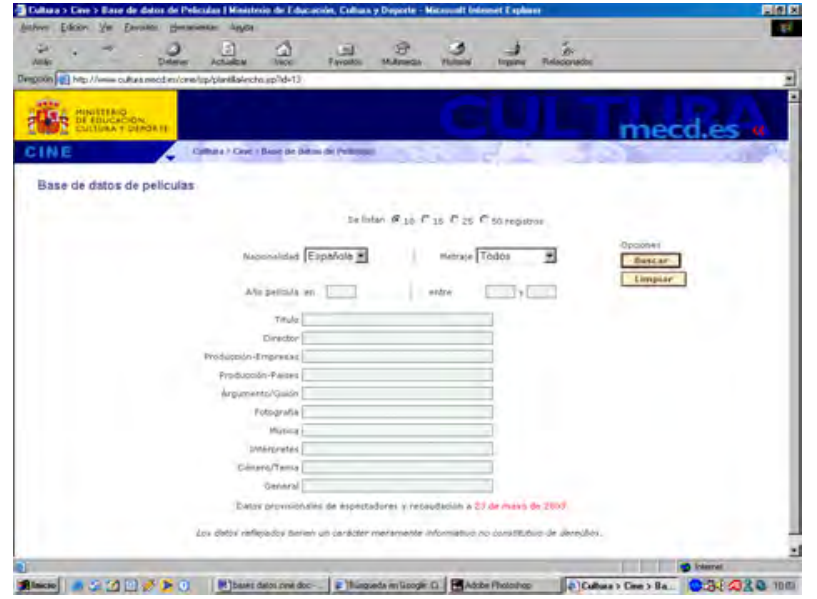

Imagen 103: http://www.cultura.mecd.es/cine/jsp/plantillaAncho.jsp?id=13

\section{Cinematografía (Ministerio de cultura):}

http://www.cultura.mecd.es/cine/jsp/plantillaAncho.jsp?id=13 
Base de datos del Instituto de la Cinematografía y de las Artes Audiovisuales (dependiente del Ministerio de Educación, Cultura y Deporte). Es, además, la base de datos de la filmoteca española.

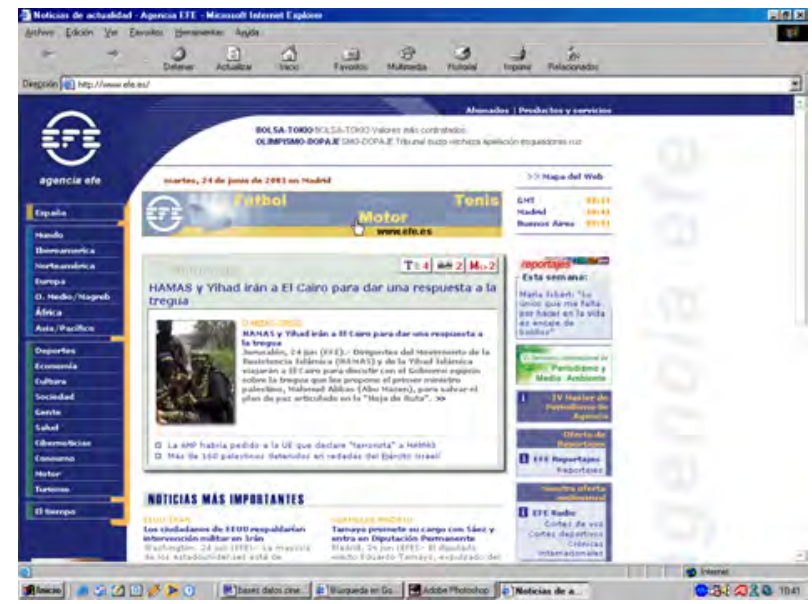

Imagen 104: http://efedata.efe.es

\section{Efedata:}

\section{http://efedata.efe.es}

Es la base de datos de noticias, biografías, organizaciones, documentos, efemérides, etc de la Agencia Efe. Es necesario estar registrado para acceder a los documentos.

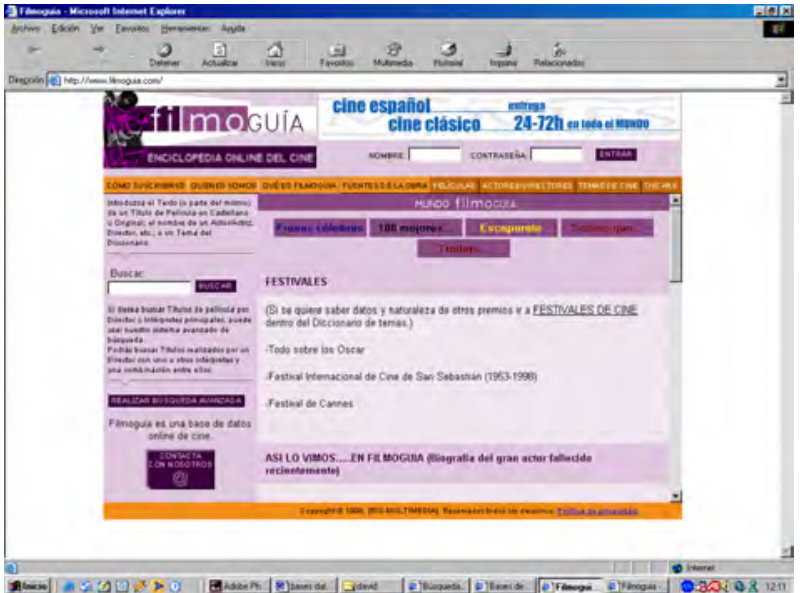

Imagen 105: http://www.filmoguia.com 


\section{Filmoguía (Enciclopedia online cinematográfica):}

\section{http://www.filmoguia.com}

La más amplia recopilación de datos sobre cine. En Español. Todo el cine desde 1895 hasta nuestros días. Contiene más de 22.000 títulos (en continua actualización), más de 6.000 biofilmografías, información sobre los Oscar, diccionario temático, más de 6.500 documentos gráficos (Fotos, Fotogramas y Carteles). Filmoguía contiene la FICHA TECNICA y COMENTARIO crítico de todos los títulos del cine Español desde sus inicios y de todas las películas estrenadas en circuitos comerciales en España. Constituye el mayor FONDO FILMOGRAFICO existente en castellano. Es una fuente inagotable de datos, donde consultar datos de títulos de películas antiguos y modernas ya que se mantiene en continua actualización. Pone a su disposición un potente sistema de búsqueda que le permite localizar los títulos deseados y acceder a ellos con gran rapidez.

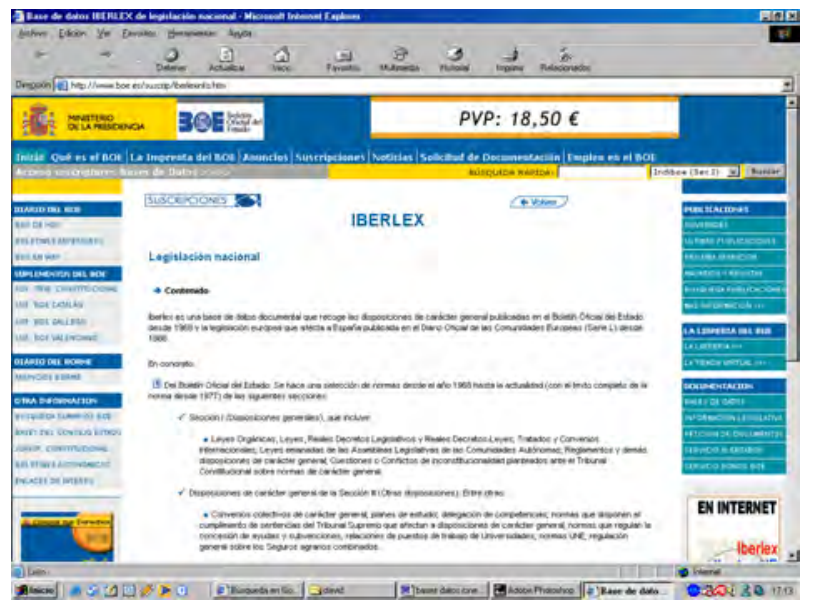

Imagen 106: http://www.boe.es/suscrip/iberlexinfo.htm

Iberlex:

\section{http://www.boe.es/suscrip/iberlexinfo.htm}

Es una base de datos documental que recoge las disposiciones de carácter general publicadas en el Boletín Oficial del Estado desde 1968 y la legislación europea que afecta a España publicada en el Diario Oficial de las Comunidades Europeas (Serie L) desde 1986. Mediante un sistema de suscripción (bien a través de la web o en formato CdRom) se posibilita el acceso a 99.000 documentos (a fecha de marzo de 2001). 


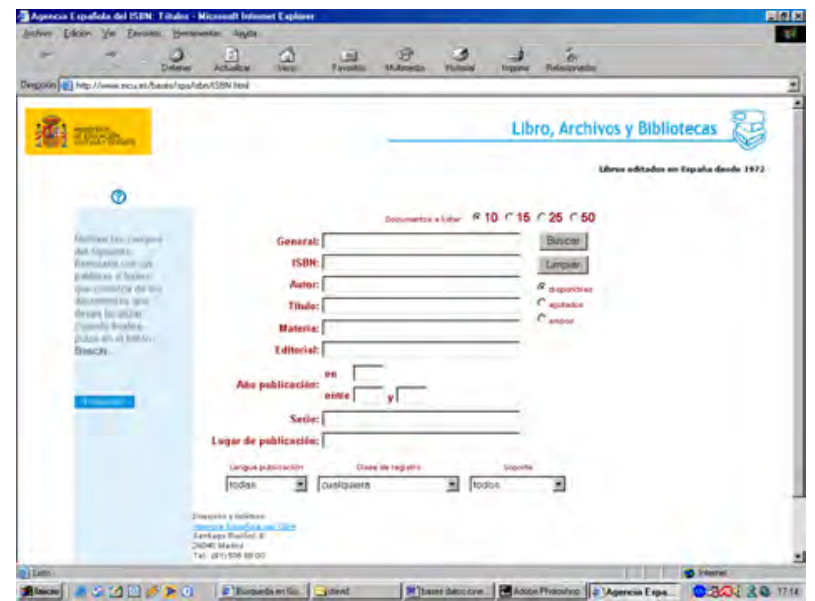

Imagen 107: http://www.mcu.es/bases/spa/isbn/ISBN.html

\section{ISBN:}

\section{http://www.mcu.es/bases/spa/isbn/ISBN.html}

Base de datos de los libros editados en España desde 1972.

\section{Mediateca Científica del CSIC (CSIC -CINE):}

\section{http://www.asecic.csic.es/media.htm}

Puesta en marcha a finales del año 2001 por el Ministerio de Ciencia y Tecnología en el Museo Nacional de Ciencias Naturales. La Mediateca de CSIC surge tras la firma de un convenio entre la Comunidad de Madrid, el Consejo Superior de Investigaciones Científicas (CSIC) y la Asociación Española de Cine Científico (ASECIC), mediante el cual las tres instituciones se comprometen a conservar y difundir, y en una segunda etapa promocionar la creación de nuevos productos multimedia de contenido Científico. Contiene más de 20.000 documentales, imágenes y sonidos etnográficos, de flora, fauna y anatomía. La sala dispone de capacidad para 20 personas para la proyección de audiovisuales para grupos, así como otra zona con 28 terminales individuales para que los interesados puedan visionar, escuchar y realizar completas búsquedas en una base de datos. Por el momento no existe ningún fondo disponible online.

\section{Músicas (Radio Nacional de España):}

\section{http://www.rtve.es/rne/areas/ar docum.htm}

Archivo sonoro. Recoge desde 1.986 la información sobre los fondos de Música del Archivo Sonoro y está dividida en cinco bases que agrupan a los documentos en grandes categorías: MCLASIC (Música Clásica, 114.941), VCLASIC (Música Clásica, volcado de la catalogación de fichas "a mano", 30.404), MLIGERA (Música Ligera, 
429.638), MTRADES (Música Tradicional Española, 9.344) y MTRADIN (Música Tradicional Internacional, 1.007). El tratamiento documental es muy pormenorizado, tanto desde el punto de vista de la catalogación como de su clasificación en géneros y formas.

\section{Palabra (Radio Nacional de España):}

\section{http://www.rtve.es/rne/areas/ar docum.htm}

Archivo sonoro. Desde 1.988 contiene referencias de documentos, divididas en cuatro bases: PALABRA (18.092 documentos de información general y programas cuyo destino es el archivo definitivo), TEMPORAL (Documentos de actualidad que se expurgan tras un año de permanencia en archivo. Ingresan en este dominio 300 documentos al año, aproximadamente), DRAMATIC (2.537 documentos de obras dramáticas y adaptaciones literarias producidas por RNE u otras entidades) y EFECTOS (Agrupa 6.951 documentos cuyo contenido son anuncios, sintonías, sonidos, ruidos, ambientes, etc).

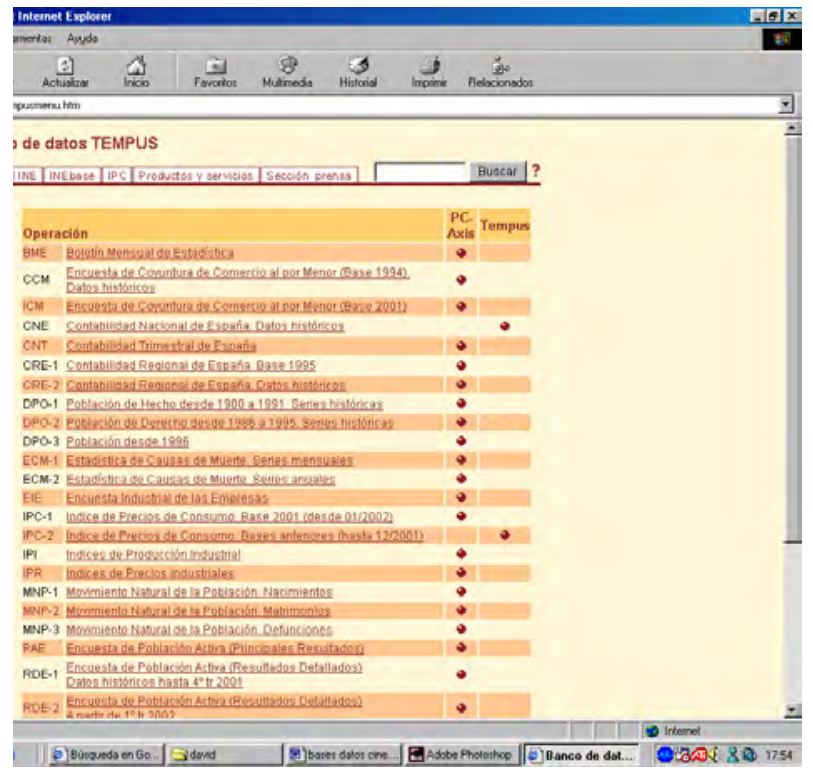

Imagen 108: http://www.ine.es/tempus2/tempusmenu.htm

\section{Tempus:}

\section{http://www.ine.es/tempus2/tempusmenu.htm}

El Banco de datos Tempus es el sistema clásico del INE (Instituto Nacional de Estadística) para la difusión de resultados detallados en forma de series temporales. Se puso en marcha en 1987 y funciona en Internet desde 1997. Desde abril de 2000 Tempus se ha integrado en el sistema de almacenamiento INEbase con la idea de difundir las series como ficheros PC-Axis, siendo de esta manera más rápido el acceso a los datos y 
permitiendo además utilizar las opciones del programa PC-Axis en cuanto a selección de variables y categorías de las variables, número de períodos a considerar, rotación de filas y columnas, etc.

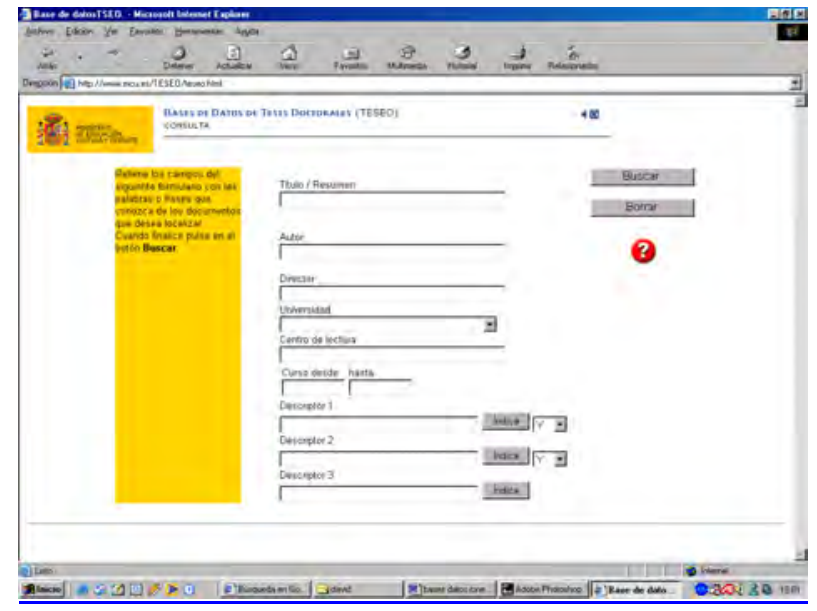

Imagen 109: http://www.mcu.es/TESEO/teseo.html

\section{Teseo:}

http://www.mcu.es/TESEO/teseo.html

Base de datos que recoge todas las tesis doctorales leídas en las Universidades españolas desde 1976. 


\section{Extranjero:}

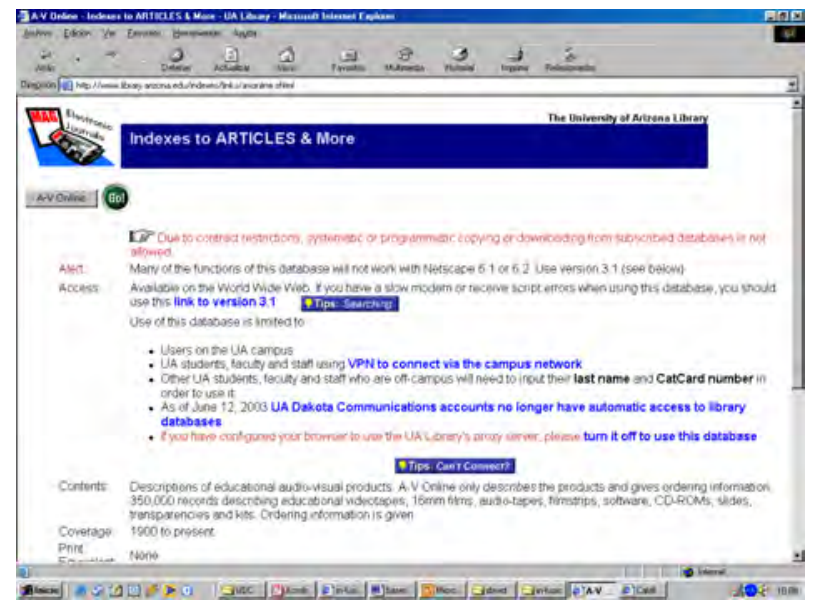

Imagen 110: http://www.library.arizona.edu/indexes/links/avonline.shtml

\section{A-V online:}

http://www.library.arizona.edu/indexes/links/avonline.shtml

Archivo online de productos audiovisuales educativos. Sólo describe los contenidos y facilita información sobre su adquisición. Posee más de 350.000 entradas de cintas, películas en $16 \mathrm{~mm}$, cassettes, filmstrips, software, CD-Roms, transparencias y diapositivas desde 1900 hasta la actualidad. Permite sólo el acceso a personal autorizado (desde ordenadores del campus de la universidad de Arizona, etc) 


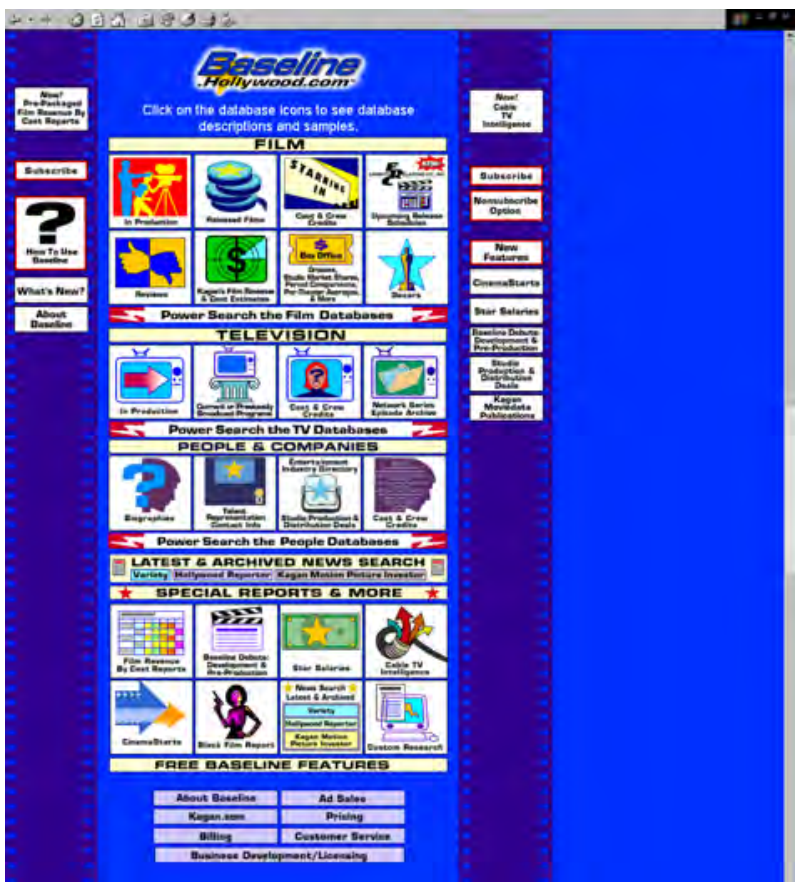

Imagen 111: http://baseline.hollywood.com

\section{Baseline (Cinemascore):}

\section{http://baseline.hollywood.com}

Lanzada hace casi dos décadas Baseline.Hollywood.com es la pionera online en la información B2B de la industria del entretenimiento. Alberga 1,5 millones de datos sobre estadísticas, contratos, noticias, etc sobre múltiples plataformas como cine y televisión: 900,000 actores, productores, equipos de rodaje además de 7.000 biografías sobre figuras clave de la industria. Detallada información de producción sobre 100.000 películas, series de $t v$, teleseries, mini-series, etc (40.000 películas estrenadas en cines o en festivales). Información sobre taquilla, etc. Bajo suscripción. 


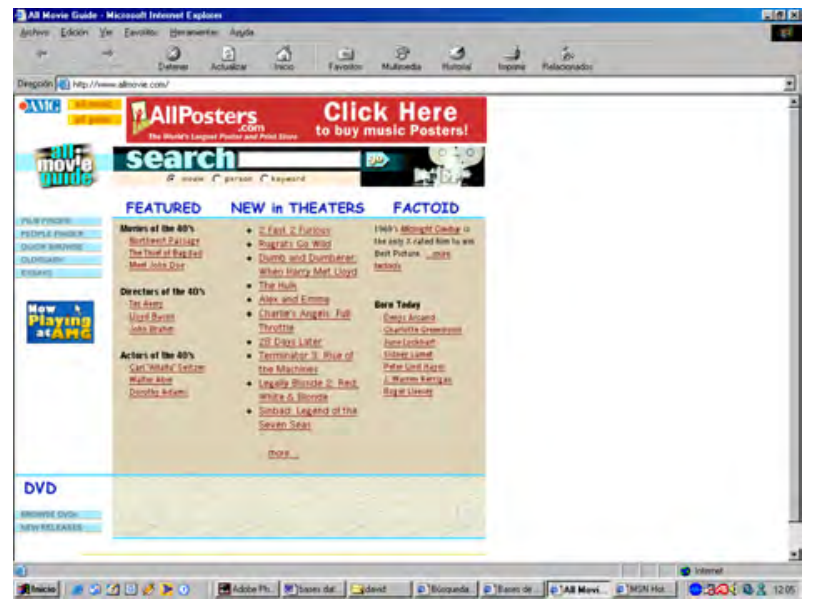

Imagen 112: http://www.allmovie.com

\section{All movie Guide (AEC One Stop Group, Inc.):}

\section{http://www.allmovie.com}

Completa base de datos de películas (desde los años 30) que incluye reseñas, detalladas fichas técnicas y artísticas y fragmentos de las mismas para ver en streaming, así como vínculos a películas de temática similar, otras películas del mismo director, etc.

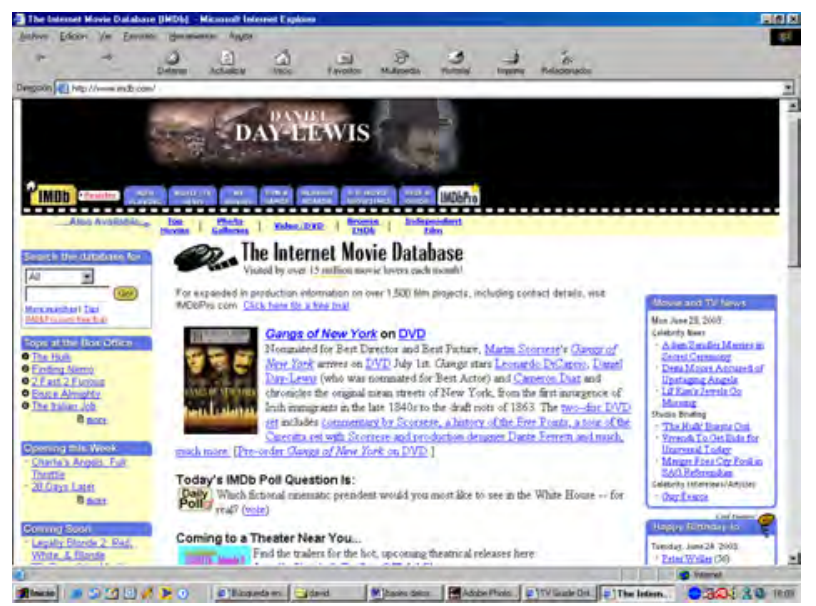

Imagen 113: http://www.imdb.com/

\section{IMDB (International Movie Database):}

http://www.imdb.com/ 
Base de datos filmográfica perteneciente a la tienda de comercio electrónico Amazon.com. Tiene una media mensual de 15 millones de visitantes. Oferta actualmente, además de la base de datos con información sobre largometrajes, su servicio de pago IMDBPro con información adicional sobre 1.500 películas y proyectos televisivos, así como información sobre 26.000 profesionales de la industria y 5.800 compañías (además de noticias, taquilla, etc).

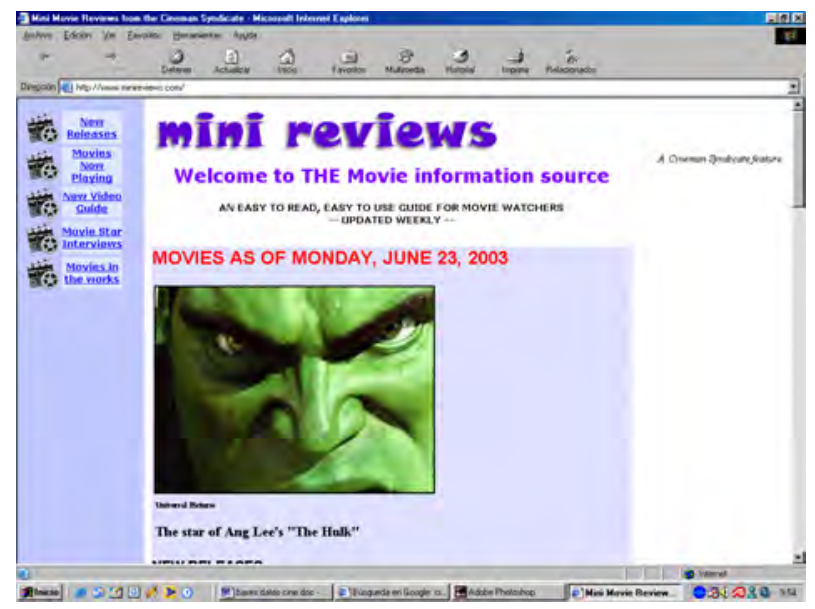

Imagen 114: http://www.minireviews.com

\section{Cineman Movie Reviews:}

http://www.minireviews.com

Contiene 8.000 críticas de películas desde los años 30. Esta base de datos fue establecida por Cineman Syndicate hace más de 26 años. Entre los críticos que firman para esta base se encuentran: Jay A. Brown, John P. McCarthy, Robert Edelstein, Prairie Miller, Lisa Mulcahy y Patrick Legare. También realizan una guía de reseñas musicales y de vídeo así como entrevistas a estrellas del celuloide. 


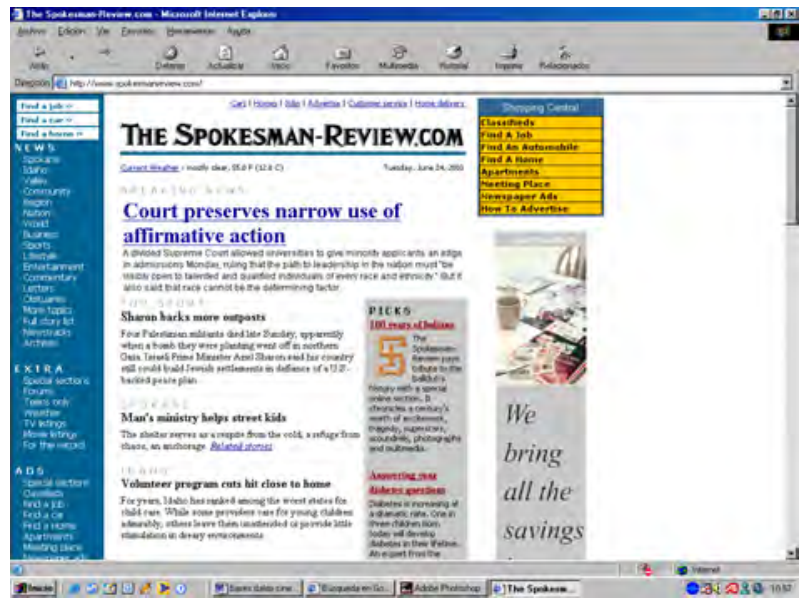

Imagen 115: http://www.spokesmanreview.com/sections/entertai/movies/movie2col.asp?ID=reviewscover

\section{Electronic Editions: the spokesman. Review and spokane chronicle.}

http://www.spokesmanreview.com/sections/entertai/movies/movie2col.asp ?ID=reviewscover

Base da datos de reseñas cinematográficas. Sólo texto.

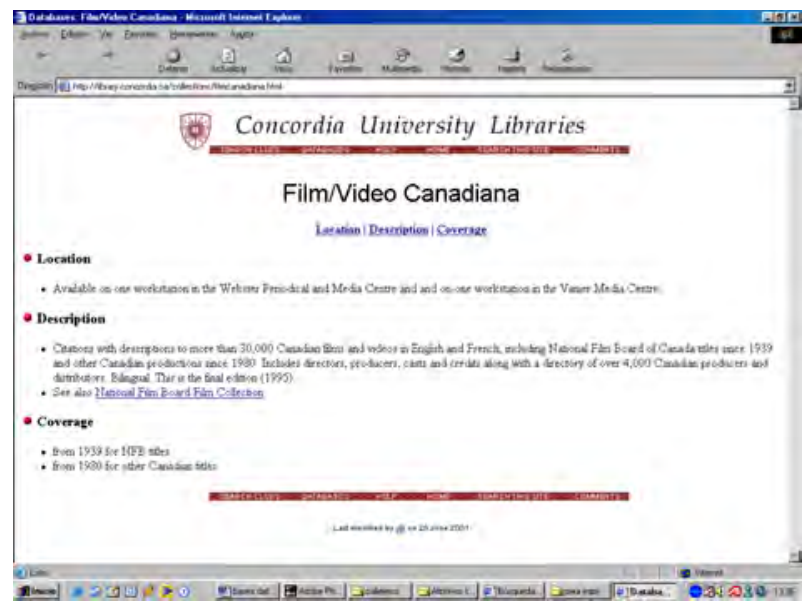

Imagen 116: http://library.concordia.ca/collections/filmcanadiana.html

\section{Film Video Canadiana}

http://library.concordia.ca/collections/filmcanadiana.html 
No está disponible online. Sólo es accesible desde el Webster Periodical and Media Centre y el Vanier Media Centre. Descriptores de más de 30.000 películas y vídeos canadienses (tanto en inglés como en francés) incluyendo los títulos de la National Film Board of Canada desde 1939. Incluye un directorio con los créditos de producción, dirección, reparto, etc, así como información sobre 4.000 productores y distribuidores canadienses.

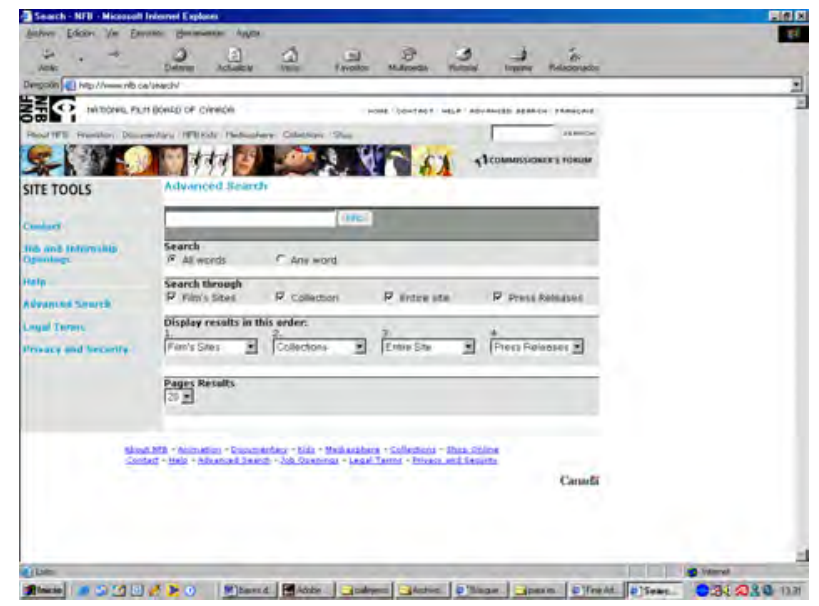

Imagen 117: http://library.concordia.ca/collections/nfbfilm.html

\section{National Film Board (NFB) Film Collection}

http://library.concordia.ca/collections/nfbfilm.html

Descriptores de más de 10.000 películas canadienses producidas, co-producidas o distribuidas por el

National Film Board desde 1939. Los fondos se encuentran divididos en dos colecciones: una de producciones en francés y la otra de producciones en inglés. 


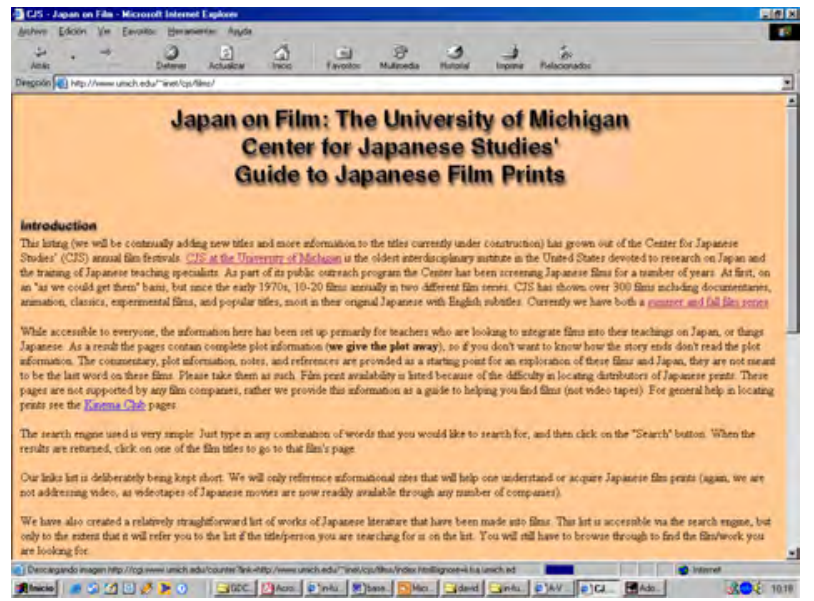

Imagen 118: http://www.umich.edu/ iinet/cjs/films

\section{Japan on Films (Universidad de Michigan):}

http://www.umich.edu/ iinet/cjs/films

Base de datos (sólo texto) sobre cine japonés del Centro de Estudios Japoneses de la Universidad de Michigan.

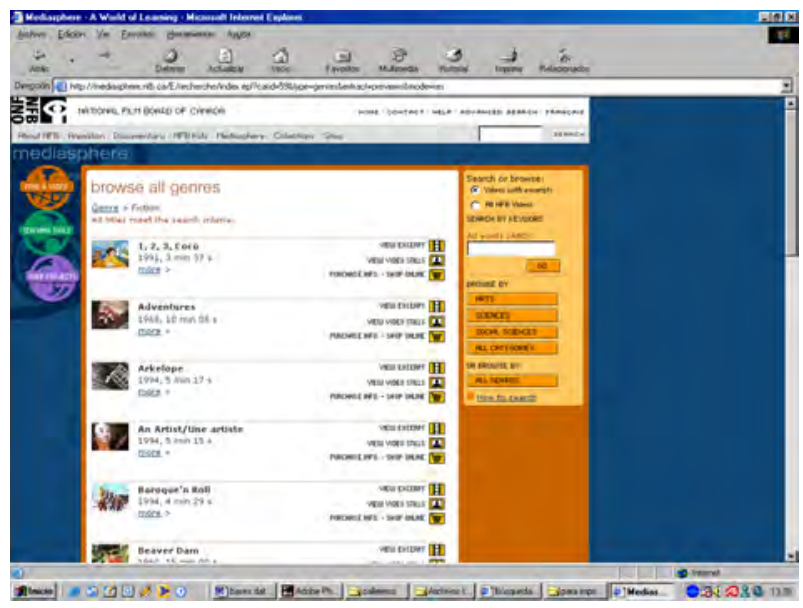

Imagen 119: http://mediasphere.nfb.ca/E/index.epl

\section{Mediasphere (NFB)}

http://mediasphere.nfb.ca/E/index.epl 
Contiene unos fondos de más de 6.200 títulos que cubren una amplia variedad de temas educativos y de entretenimiento. Junto a los descriptores (ficha técnica, temática, edad en el caso de las películas educativas, resumen, etc) se ofrecen imágenes y fragmentos que se pueden ver online en streaming. Facilita, también de forma online, la adquisición de cualquiera de estos materiales.

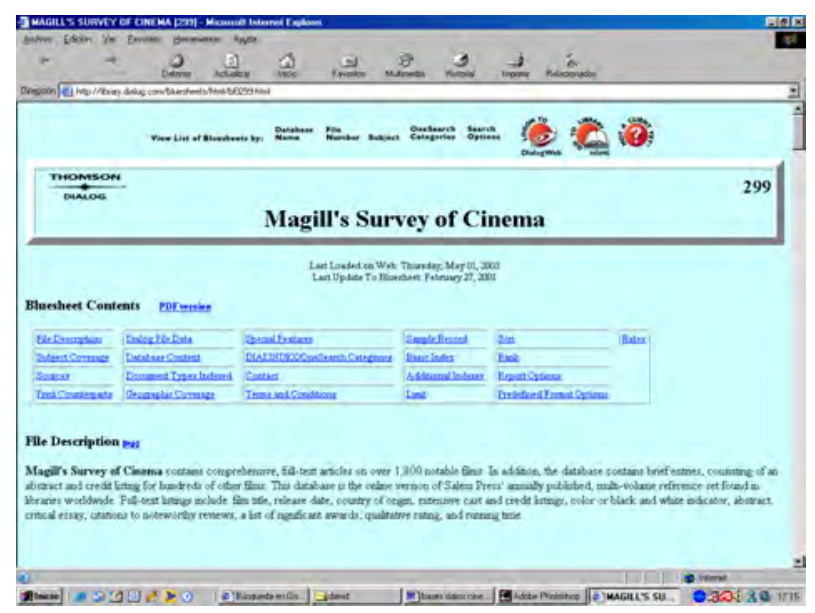

Imagen 120: http://library.dialog.com/bluesheets/html/bl0299.htmI

\section{Magill's Survey of Cinema: \\ http://library.dialog.com/bluesheets/html/bl0299.html}

Versión online de la publicación anual de Salem Press sobre películas de interés. Contiene entradas y artículos sobre 1.800 largometrajes. Entre la información que aporta se encuentran las fichas técnico-artísticas (título, director, país de producción, duración, fecha, reparto, etc) y ensayos críticos o referencias a los mismos así como galardones recibidos, etc. Recoge películas desde 1902 hasta la actualidad. 


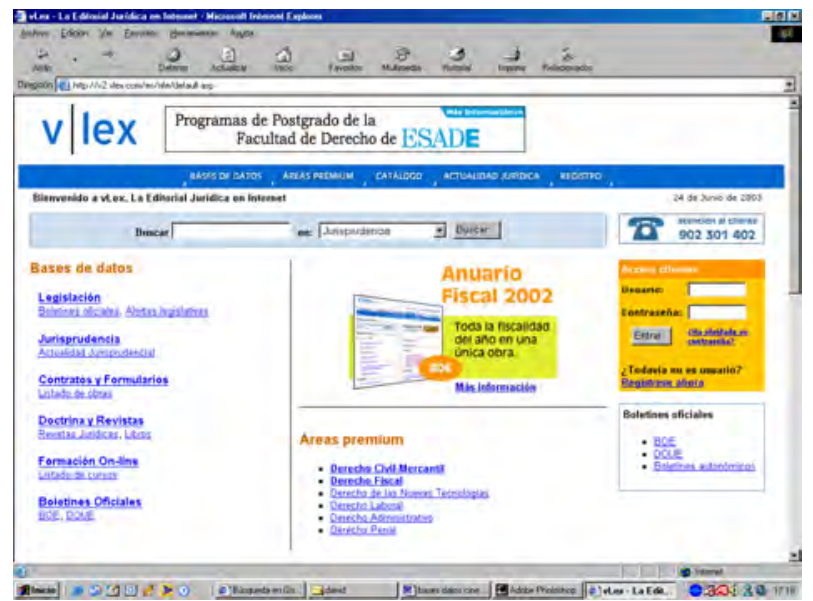

Imagen 121: http://v2.vlex.com/es/site/default.asp

\section{Lex:}

http://v2.vlex.com/es/site/default.asp

Bases de datos online sobre Legislación (más de 200.000 normas de legislación estatal, comunitaria y autonómica, BOE, etc, actualizada a diario), Jurisprudencia, Contratos y formularios (más de 4.500 modelos seleccionados y ordenados por categorías), Convenios colectivos (más de 34.000 convenidos publicados desde 1990) y Formación online.

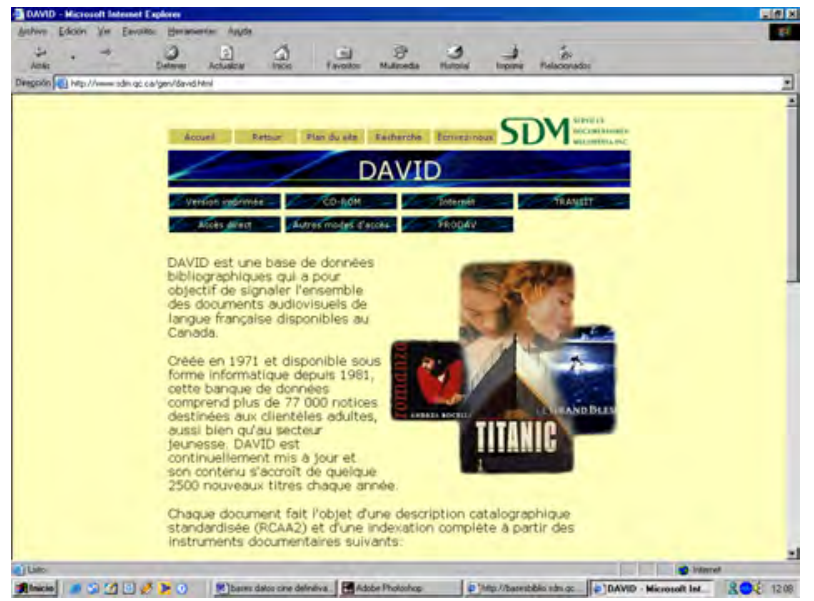

Imagen 122: http://david.sdm.qc.ca

DAVID (anteriormente Prodav): 


\section{http://david.sdm.qc.ca}

Base de datos desarrollada por Services Documentaires Multimedia (SDM) que contiene 75.000 referencias sobre documentos audiovisuales. Creada en 1971 se encuentra en formato informático desde 1981. Contiene más de 77.000 artículos y crece al ritmo de 2.500 películas por año. Títulos clasificados según el índice Dewey y la signatura de la Biblioteca del Congreso de los EE.UU. Bajo suscripción. También existe una versión en CD-ROM.

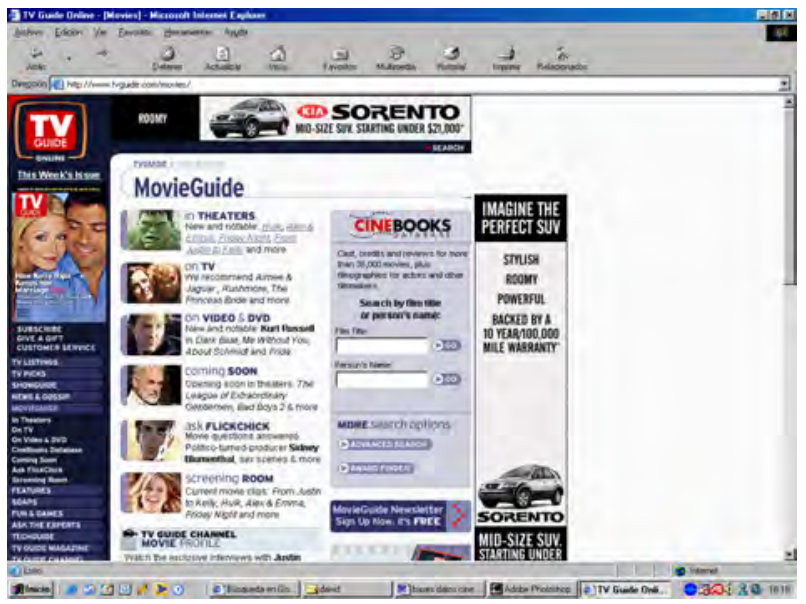

Imagen 123: http://www.tvguide.com/movies/database

\section{TV Guide Movie Database:}

http://www.tvguide.com/movies/database

Recoge información sobre actores, equipo, género, etc, de más de 35.000 películas. Incluye filmografías, reseñas, etc. 


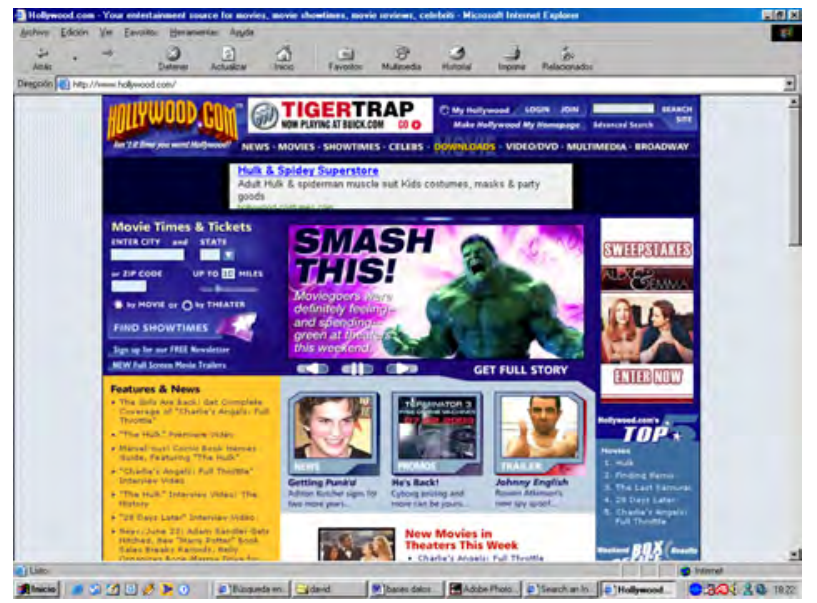

Imagen 124: http://www.hollywood.com

\section{Hollywood.com: (Hollywood Media Corp.)}

\section{http://www.hollywood.com}

Es uno de los sites líderes sobre información cinematográfica en internet, cubriendo más de un millón de páginas. Incluye reseñas, horarios de exhibición en salas cinematográficas y librería multimedia (en la que se pueden ver trailers y entrevistas, etc). Además posee una colección de cine independiente accesible únicamente mediante suscripción mensual.

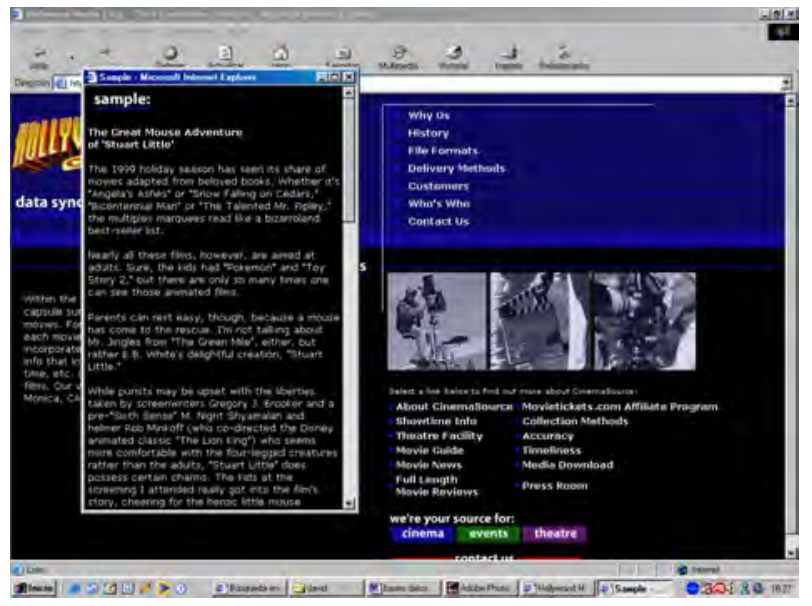

Imagen 125: http://www.cinema-source.com

cinemaSource: (Hollywood Media Corp.) 


\section{http://www.cinema-source.com}

Servicio de sindicación de información cinematográfica, de eventos y teatral que contiene una base de datos con información de más de 36.000 películas exhibidas en EE.UU y Canadá. (entre los medios a los que sindica se encuentran The New York Times, Tell Me y AOL's Digital City, entre otros). Ofrece también trailers en streaming de los últimos estrenos cinematográficos.

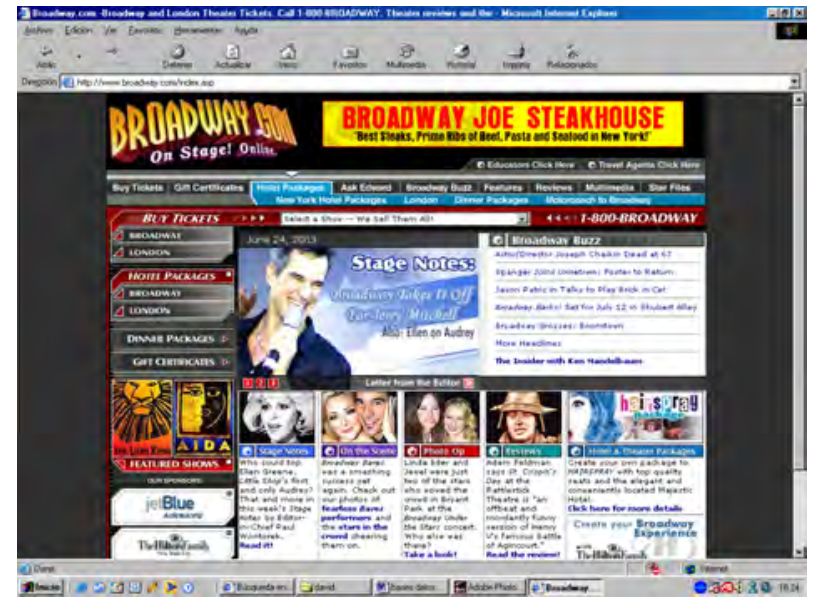

Imagen 126: http://www.broadway.com/index.asp

\section{Broadway.com (Hollywood Media Corp.)}

\section{http://www.broadway.com/index.asp}

La mayor base de datos online del mundo sobre espectáculos teatrales. Ofrece información sobre las funciones (horarios, sinopsis, etc) así como de los principales profesionales norteamericanos y londinenses. También ofrece noticias relacionadas con el mundo del teatro, entrevistas con los actores, reseñas y clips seleccionados de determinados espectáculos. Además provee de información sobre la taquilla, biografías y un apartado especial sobre los Premios Tony. 


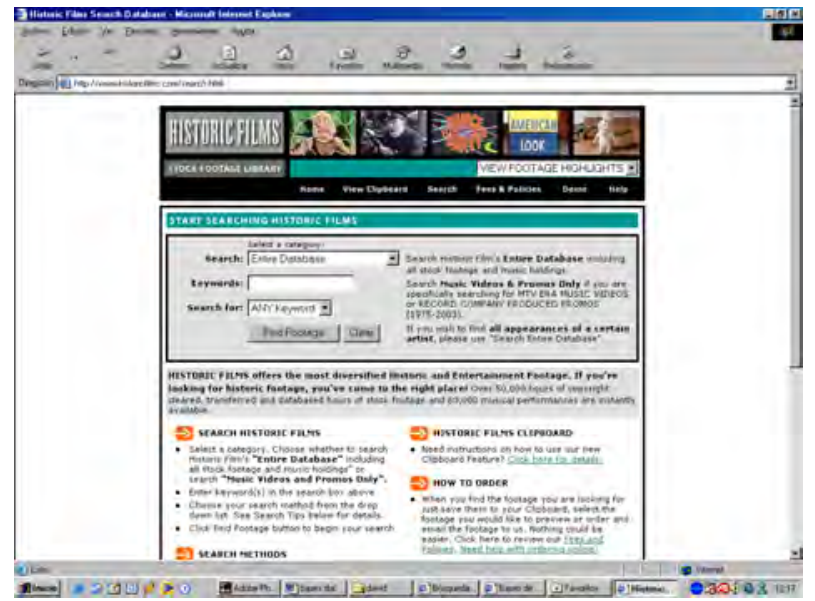

Imagen 127: http://www.historicfilms.com/index2.html

\section{Historic Films:}

http://www.historicfilms.com/index2.html

Base de datos que contiene 45.000 horas y metraje almacenado de más de 30.000 clips musicales (desde 1895 hasta 1990). Los fondos provienen de más de 70 colecciones desde The Ed Sullivan Show a The Steve Allen Show, Pathe News, Studio 54 Collection o Fox Movietone Newsreel Outtake.

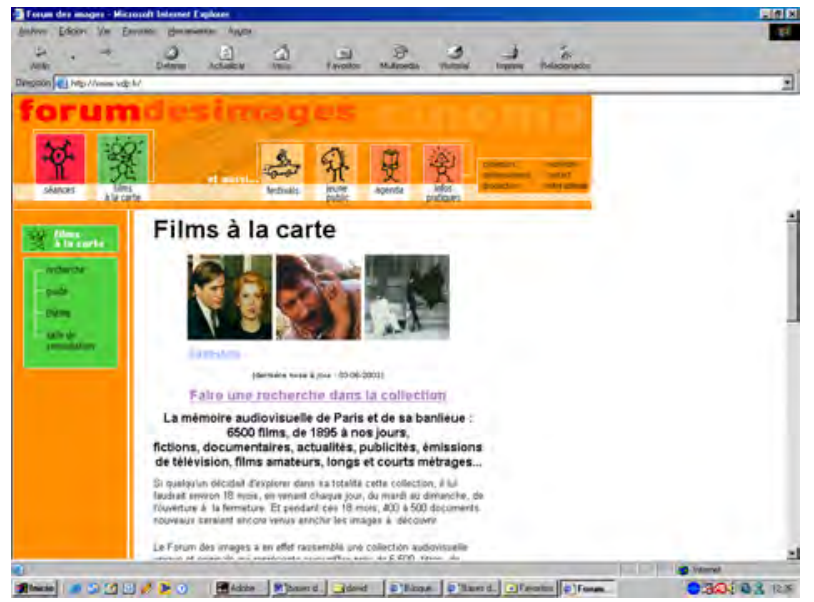

Imagen 128: http://www.vdp.fr

Forum des Images:

http://www.vdp.fr 
6.700 películas (de 1895 a nuestros días, de los hermanos Lumière a Chris Marker) en los que se recoge la "memoria audiovisual de París". Del documental a la ficción, la publicidad, los vídeos amateur, las emisiones televisivas, etc, pretenden dar una visión caleidoscópica y plural del París más romántico al más sórdido, de lo turístico a lo cotidiano, realizando unas aproximaciones temáticas que muestren las mil caras y momentos de la ciudad.

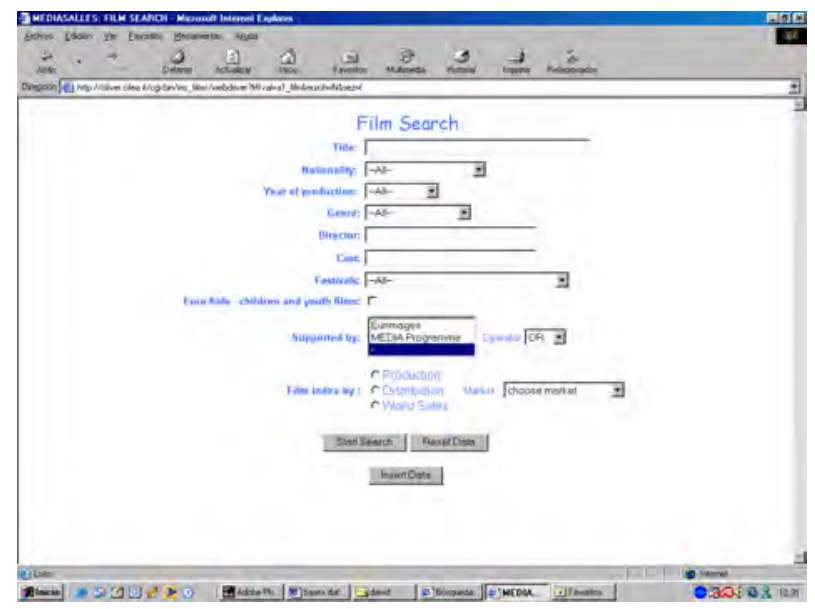

Imagen 129: http://www.mediasalles.it

\section{Cinema D'Europa:}

http://www.mediasalles.it

Iniciativa del programa MEDIA cuya base de datos contiene seis directorios principales: películas, producción, distribución, ventas, teatros y compañías de exhibición. Cada directorio está hipervinculado al resto de forma que se puedan extrapolar datos de uno a otro. Pretende dar una visión general de la industria cinematográfica europea, recogiendo las películas producidas a partir de 1995. Actualizada semanalmente, en estos momentos cuenta con información sobre 3.300 películas y 7.000 compañías. 
ANEXOS VII «MÉTODO DE ANÁLISIS DE LA MÚSICA CIINEMATOGRÁFICA» JOSEP LLUIS I FALCÓ 


\section{Método de análisis de la música cinematográfica ${ }^{382}$.}

A continuación se reproduce (en su traducción al castellano) un artículo aparecido en la revista D'Art, editada por el Departamento de Historia del Arte de la Universidad de Barcelona, en el $n^{\circ} 21$ (1995). En el mismo se propone, de manera sucinta, un método de análisis de la música cinematográfica en su percepción conjunta con la imagen. Aunque algunos de los parámetros han sido matizados con posterioridad a la publicación de dicho artículo, se ha respetado el texto original (exceptuando la corrección de algunos errores de imprenta u ortográficos).

El método completo está siendo desarrollado en un trabajo que llevará por título El análisis de la banda sonora musical cinematográfica: del proceso creador al proceso recreador $^{383}$.

\section{Parámetros para el análisis de la banda sonora musical cinematográfica}

Hablar de cine, empleando términos visuales, resulta factible aun no visionando la película, ya que existe un lenguaje preciso, una terminología abundante que nos permite una comunicación verbal positiva. Pero hablar de cine utilizando términos auditivos comporta siempre una serie de riesgos, motivados por la poca precisión terminológica y la falta de un corpus global de términos delimitados y definidos que nos permitan comunicar de manera verbal los mil y un recursos que nuestro oído percibe ante una película.

\section{Algunos matices y precisiones}

Un error común perpetuado hasta hoy, y que seguro permanecerá tras la publicación de este artículo, ha sido hablar de banda sonora como sinónimo inequívoco de música de cine. Nada más alejado de la realidad: podemos hablar de música de cine desde el primer acompañamiento musical que se realizó en una proyección de cine mudo; pero sólo podemos hablar de banda sonora a partir de la aparición del cine sonoro ${ }^{384}$. De este modo podemos afirmar que TODAS las bandas sonoras musicales (véase el siguiente

\footnotetext{
${ }^{382}$ Lluis i Falcó, J. «Método de análisis de la música cinematográfica», en Compositores cinematográficos en el estado español. [en línea]. Disponible en web: http://usuarios.lycos.es/compositores/

${ }^{383}$ En breve (hacia febrero del 2002) se publicará la versión 2.0 de este artículo, revisado y notoriamente ampliado, en el número especial de secuencias de música de cine editado por la A.C.D.M.C. posteriormente será colgado de esta web para su decarga en pdf o word.

${ }^{384}$ Habría que matizar históricamente estas fechas: aunque se da, popularmente, El Cantor de jazz (The Jazz Singer, Alan Crosland, 1927) como primera película sonora de largometraje, hay que decir que el año anterior se hizo Don Juan (Don Juan, Alan Crosland, 1926) con música de William Axt y efectos de sonido sincrónicos, aunque todavía sin la presencia de la voz humana. El Cantor de jazz fue, y eso sí que es cierto, la primera película "hablada" (aunque sus fragmentos hablados son sólo un pequeño porcentaje del metraje total). No obstante, estas películas no tenían todavía el sonido incorporado al film, sino que éste iba en un disco de baquelita aparte: era el llamado sistema Vitaphone que duró sólo los primeros años del sonoro, hasta la llegada e implantación definitiva del sistema de sonido que hoy conocemos, ya inseparable de su soporte cinematográfico.
} 
párrafo, que aclara este concepto, antes de sacar conclusiones precipitadas) son música de cine, pero que no toda la música de cine forma parte de una banda sonora, ya que la música cinematográfica anterior a la aparición del cine sonoro no fue grabada sobre el citado soporte físico y, por tanto, quedó reducida a partituras, hojas de indicaciones musicales, etc. que, en demasiadas ocasiones, se han perdido sin remedio ${ }^{385}$.

Pero no termina aquí nuestra matización, ya que creemos necesario diferenciar también entre banda sonora musical (a partir de ahora BSM) y banda sonora no musical (simplemente BS), e intentar utilizar siempre con precisión ambos términos, de manera que no se confundan. Mencionar banda sonora no es mencionar la BSM, ya que la amplitud del primer término incluye también diálogos, ruidos e incluso silencios ${ }^{386}$. Decir que Nino Rota es el autor de la banda sonora de Ensayo de orquesta (Prova d'Orchestra. Federico Fellini, 1979) es tan falso como asegurar que la Capilla Sixtina es obra de Miguel Ángel: si en el segundo caso tenemos claro que Miguel Ángel sólo pintó los frescos que la decoran, en el primer caso hemos de tener igualmente claro que Rota se limitó a componer la parte musical (BSM), pero no el resto de sonidos (estructurados o no) que configuran la totalidad de la banda sonora, pista de sonido o soundtrack.

Todavía un matiz más: por lo que respecta al tema de las ediciones discográficas ${ }^{387}$, tenemos que hacer notar que aquello que los aficionados escuchan en ellas es música de cine (MDC), pero tampoco BSM, ya que ellos disfrutan de su audición descontextualizada, desmembrada de la película que le da razón de ser y sin la cual no se habría creado. Aquí no existe el dilema sobre que fue primero, si el huevo o la gallina. La MDC es música funcional, música aplicada a una imagen, y este factor no puede ser obviado. Su audición fuera de contexto tiene total validez, tanta como la audición de una edición discográfica de Aida, La Bohème, Turandot o cualquier otra música operística extraída de su contexto escénico. Pero su análisis como BSM nunca puede hacerse sólo mediante esta edición discográfica, porque entonces se estaría analizando sólo como música, prescindiendo de su funcionalidad original y no teniendo en cuenta más características que las puramente captables por el oído, dejando a un lado toda interacción con la imagen. El análisis de la BSM debe ser siempre audiovisual y no sólo auditivo; en

\footnotetext{
${ }^{385}$ La historia de la música en el cine mudo es mucho más rica y compleja de lo que popularmente se cree y, aunque queda todavía mucho por hacer, merece la pena prestar atención a algunos trabajos que sobre el tema se han escrito. Parece que desde el principio de la exhibición cinematográfica el acompañamiento musical estuvo presente. Sabemos, por ejemplo, que en algunas sesiones de los hermanos Lumière, todavía en el Grand Cafe de París, realizadas en 1896, se hallaba Monsieur Emile Maraval tocando un piano de la Casa Gaveau, aunque no se puede asegurar que su intervención fuese sincrónica con el film. Se convervan partituras originales escritas exproceso para el cine ya desde 1908: Camille Saint-Saëns compuso la música para el film L'assassinat du duc de Guisse, de Charles-Gustave-Auguste Le Bargy y André Calmettes, y el ruso Ippolitov-Ivanov hizo la del film Sten'ka Razin de Aleksandr Drankov. La nómina sería demasiado extensa para tan poco espacio; para más información sobre este tema recomendaríamos la lectura de los primeros capítulos del libro de Gianni Rondolino (Cinema e musica, Torino, 1991).

${ }^{386}$ En este sentido Jean MITRY (Estética y psicología del cine. Madrid 1989, Vol. 2: Las formas, pág. 106) se expresa diciendo: "El peso del silencio no existe más que después del cine hablado, y como sabemos su poder expresivo no es un recurso de poca monta". El silencio cinematográfico es, sin embargo, una asignatura pendiente en muchos análisis, y sería necesario incidir más en este tema.
}

${ }^{387}$ Hemos incluído el término anglófono al final del párrafo anterior con toda la intención, ya que, por su inclusión en estas ediciones discográficas (donde aparece como reclamo comercial la expresión "original soundtrack") lo consideramos el principal responsable del mal uso del término banda sonora como sinónimo de música de cine al cual nos referíamos arriba. 
caso contrario, insistimos, nos hallaríamos ante el análisis, no de una BSM, sino de MDC. Pero es en este punto donde se inician los problemas:

La falta de unos parámetros de análisis y de una terminología adecuada y precisa que permita delimitar todos los recursos que son susceptibles de configurar una BSM, a la cual nos referíamos al iniciar este artículo, se hace aquí evidente. Si bien algunos de estos recursos se hallan ya delimitados, se conoce el efecto que producen, porqué se utilizan, se ha hecho su historia, se conoce su origen e, incluso, gozan de un término propio, la mayoría acostumbran a mencionarse explicándolos o describiéndolos en su totalidad ${ }^{388}$. Por otro lado, una buena parte de la bibliografía existente cita estos recursos ya definidos un tras otro sin un criterio coherente que justifique su agrupación. Sucede algo similar que con los géneros cinematográficos que se citan en un mismo cajón de sastre sin atender al parámetro que define unos $u$ otros, y poniéndolos además en compartimentos estancos, como si un western, por ejemplo, no pudiese ser un drama o una comedia, al mismo tiempo que ser una película de aventuras o un musical ${ }^{389}$. Así, en el caso de los recursos musicales empleados a lo largo de una BSM, encontramos en un mismo nivel términos como leitmotiv, mickeymousing, música dietética, telón sonoro... sin ningún tipo de distinción jerárquica, cuando el parámetro que define cada uno de ellos es -como veremos- diferente, y el problema de los géneros se repite también en lo que respecta a la impermeabilidad de los recursos, como si un mismo fragmento musical sólo pudiese ser identificado con uno de los recursos definidos hasta hoy ${ }^{390}$.

El profundo convencimiento que tenemos (y que ya hemos manifestado con creces arriba) de la funcionalidad de la BSM y de la imposibilidad de analizarla descontextualizadamente, nos condujo de manera inevitable a la necesidad de definir los diferentes usos que se hacen de la música en un film, clasificarlos y agruparlos de un modo coherente y razonado de acuerdo a unos parámetros que les fuesen comunes, estableciendo una terminología que permita el diálogo, casi siempre difícil, entre compositor y director, o entre analista y lector. Todos estos parámetros y los recursos que a ellos se adscriben ayudan de manera notable a definir el estilo audiovisual (si lo tiene) de cualquier compositor cinematográfico, y a delimitar el grado de libertad con el cual ha trabajado. Las líneas que siguen no pretenden tanto ser un mero glosario de términos, como una

\footnotetext{
${ }^{388}$ Imaginemos que cada vez que un director tuviera que pedir una panorámica dijese: "¿puedes hacer un movimiento de cámara de izquierda a derecha, haciéndola girar sobre su propio eje; pero sin que haya desplazamiento?" Absurdo ¿verdad? Igual de absurdo que escuchar cómo un director de cine le pide a un compositor: "Aquí colocas una música que dé miedo, como tachán tatachán chun chun, y que entre... de sopetón". Francamente, muy técnico (por desgracia, la frase es verídica).

${ }^{389}$ Notemos que el western tiene como referencias básicas de identificación parámetros físicos que afectan más a continente que al contenido (un western lo podemos identificar sólo con un fotograma); pero para identificar un drama debemos atender a parámetros psicológicos o anímicos (ahora relativos al contenido y no al continente). Una cierta mezcla de ambos parámetros nos resultaría útil para definir, por ejemplo, una película histórica, en la que entrarían en juego nuestros conocimientos culturales y no sólo nuestra sensibilidad o percepción.

${ }^{390}$ Haciendo una comparación con otra disciplina, imaginémonos que en un estudio demográfico encontrásemos una clasificación de la población de un determinado país que hiciese cuatro grupos básicos: casados, parados, rubios y católicos. Es evidente la mezcla de criterios empleados para realizar esta clasificación, ya que se toman como parámetros válidos factores tan divergentes como el estado civil, la situación laboral, el color del pelo y la religión. Cualquier investigador rechazaría una clasificación como esta, y aún más si se tomasen como impermeables cada una de estas categorías, afirmando que un casado no puede ser ni rubio, ni católico, y que un parado no puede estar casado, etc. Esto es lo que suecede al hablar de géneros cinematográficos, y música de cine, sin que esta mezcla arbitrária de criterios provoque el menor rechazo en los investigadores.
} 
exposición razonada de estos parámetros que hemos considerado operativos para analizar la BSM.

\section{Parámetros para el análisis de la MDC}

Ya hemos establecido arriba la diferencia entre MDC y BSM y no la repetiremos. Pero sí que querríamos enumerar los parámetros que pueden emplearse en el análisis de la MDC, ya que — dos de ellos— son los más utilizados por algunos de los críticos y presuntos estudiosos para el comentario y análisis (también presunto) de bandas sonoras. Además, hay que reconocer que estos dos más utilizados nos resultarán útiles como parámetros auxiliares para el posterior análisis de la BSM.

Tres son estos parámetros, que hay que tener en cuenta a la hora de analizar una música cinematográfica fuera de su contexto fílmico: el método de selección del bloque, su estructuración temática, y su carácter dominante. Explicarlos queda para otro trabajo más extenso, en fase de redacción, que lleva por título La banda sonora musical cinematográfica. Del proceso creador al proceso recreador ${ }^{391}$. Que sirva como avance que los tres tienen sólo en cuenta la música, prescindiendo de la interacción audiovisual, lo cual permite el tradicional comentario basado en la simple audición discográfica, válido sólo como crítica musical, pero nunca, insistimos, como crítica o análisis audiovisual, es decir, de la BSM y destinado a explicar en muchos casos como es la música, y no de qué manera se utiliza.

\section{Parámetros para el análisis de la BSM}

En primer lugar es necesario que tengamos claro que la BSM se divide, desde el punto de vista estrictamente cinematográfico, en "bloques" ${ }^{392}$, que a su vez se pueden dividir en temas, las posibles subdivisiones o la posible configuración de los cuales entran ya de pleno en el terreno musical, por lo cual no corresponde analizarlas aquí.

Los parámetros que usaremos se relacionan con el proceso creador de la BSM y, de hecho, de la misma película. Poco a poco iremos avanzando, aunque no de manera necesariamente lineal, por el citado proceso, enfrentándonos a una serie de dilemas creativos que, al necesitar una respuesta, generan los citados parámetros.

En la fase de preproducción, una fase en la cual no interviene necesariamente el compositor $^{393}$, se planifica la película, presencia musical incluida. Lo que es habitual es que

\footnotetext{
${ }^{391}$ Un esquema completo de las jerarquías establecidas en este trabajo tanto para el análisis de la MDC como para el de la BSM puede verse en las Tablas.

392 "Bloque" es el término que se utiliza en música cinematográfica para designar cada uno de los fragmentos musicales. Éstos van normalmente numerados y con la indicación de tiempo (en minutos y segundos) anotada de manera visibe en la partitura.

${ }^{393}$ Aunque sería del todo deseable que interviniese, esto sólo acostumbra a suceder en contadas ocasiones, y este primer parámetro, junto con los dos que analizaremos a continuación, viene definido normalmente por la actuación del
} 
la película contenga música a posteriori, como "acompañamiento" o "fondo musical", y que por tanto, lo que prevalezca sea la imagen. Pero en casos especiales (ópera y ballet filmados, películas musicales...) ocurre todo lo contrario, y es la música la que prima e, incluso, preexiste a la imagen ${ }^{394}$. La funcionalidad en este caso se invierte y deberíamos hablar más de imagen funcional que de música funcional. Lo que cambia en ambos casos es la función articuladora de la música que, en el primer caso, estableceremos que es secundaria, mientras que en el segundo, el que pertenece al cine musical en cualquiera de sus formas, será protagónica, ya que las imágenes se estructuran, construyen y articulan en torno a la música y a partir de ella.

También en esta fase de preproducción (en el guión, el storyboard, etc.) se plantea la justificación de la presencia musical en la película a dos niveles distintos: su justificación óptica y su justificación (o coherencia) argumental.

En lo que respecta a la justificación óptica, o presencia en pantalla, hace su aparición la tan citada música diegética (opuesta a lo que se acostumbra a denominar música incidental) ${ }^{395}$. Entendemos que hay que tener en cuenta la presencia en pantalla no de la música en sí, sino de la fuente sonora que la produce, que podrá ser real o irreal (y que correspondería a la música diegética e incidental, respectivamente). La real es aquella cuya fuente sonora aparece en pantalla, y es, por tanto, una fuente sonora óptimamente real (un aparato de radio, un cantante, etc.) el sonido de la cual es sincrónico a la fuente (no a la imagen en movimiento). La irreal (la más común) es todo lo contrario, es música que proviene de la nada, música cuya presencia no tiene ninguna justificación física, ya que no hay ninguna fuente sonora que la produzca (no obstante, su presencia sonora es un convencionalismo que aceptamos).

El parámetro de coherencia argumental nos permite ver si la presencia del bloque musical está justificada o no por el argumento; si lo está, diremos que su presencia está integrada, y si no, diremos que es ajena. Se hace necesario recordar aquí que estamos indicando parámetros que tienen por objeto el análisis sólo de la música y no de la letra, y que, por tanto, si en una secuencia existe un bloque musical cantado, el que el texto de la canción tenga o no que ver con el argumento no implica que la presencia de música sea coherente, ya que el mismo texto podría haber sido declamado. A diferencia del parámetro anterior, lo que el guionista y el director pretenden justificar ahora es la presencia de música per se, integrando (o no) esta presencia en el argumento. El hecho de que exista música diegética no implica una justificación argumental de la misma: que un personaje cante en pantalla es un caso claro de diégesis pero, si nos preguntamos qué es lo que justifica

guionista y/o director. Sobre la conveniencia del trabajo en equipo, nos permitiremos adoptar como propias las palabras de Jean MITRY (Estética y ..., pág. 141) cuando decía que "si el guión técnico debe ser obra del director, no por ello debe de dejar de pedir ayuda al autor de los diálogos, al compositor, al operador y al decorador, puesto que cada uno de ellos tiene algo que decir y un papel que jugar en la ejecución del proyecto. Sólo así la obra puede alcanzar cierta perfección..." (el subrayado es nuestro).

${ }^{394}$ De hecho, el método de trabajo también cambia cuando se filma una película musical: la música (tanto la parte instrumental como la vocal) se graba previamente al rodaje y se utiliza como playback durante el mismo para obtener una perfecta sincronía, tanto en el movimiento de los labios, como en la coreografía.

${ }^{395}$ Los temas que se han empleado para definir ambos recursos se han multiplicado a lo largo de los años. Karel REISZ (Técnica del montaje, Madrid 1960) hablaba de música sincrónica en oposición a música asincrónica, siendo la primera la equivalente a la diegética; y más recientemente Michel CHION (La audiovisión. Introducción a un análisis conjunto de la imagen y el sonido, Barcelona/Buenos Aires/México 1990) habla de "música de pantalla" en oposición a "música de foso". 
argumentalmente que cante, nos enfrentamos a un problema de coherencia argumental. Por poner un par de ejemplos muy claros y, al mismo tiempo, conocidos: que Gene Kelly en Cantando bajo la lluvia (Singin'in the Rain, Gene Kelly, Stanley Donen, 1952) cante y baile en la calle, chapoteando y subiéndose a una farola, tendría como única explicación "coherente" una locura transitoria del personaje que interpreta (o bien un exceso de alcohol, por supuesto). Por otro lado, y bromas aparte, que Liza Minelli en Cabaret (Cabaret, Bob Fosse, 1972) cante y baile tiene coherencia, ya que la profesión del personaje que interpreta lo justifica, y nunca canta ni baila con profesionalidad fuera del escenario del cabaret donde su personaje actúa. En el ejemplo de Gene Kelly nos hallaríamos ante un bloque musical ajeno al argumento, mientras que en el de Liza Minelli, ante un bloque musical integrado en él ${ }^{396}$.

La interacción semántica acostumbra a ser el parámetro de análisis cuyo control corresponde más al compositor que al director. Tanto si nos encontramos ante una BSM compuesta a propósito, como si hemos optado por un poutpourri de éxitos, piezas clásicas tópicas o similares ${ }^{397}$, topamos con una cuestión capital: ¿cuál es el mensaje que debe llegar al espectador gracias a la conjunción de música e imagen? Aquí el compositor (o quien sea), ya en plena fase de producción, se encuentra limitado por el mensaje, que es algo que no le pertenece a él sino al director (o al guionista) de la película. El significado le viene dado por el guión y, como profesional al servicio de un proyecto colectivo, se debe supeditar a este. De todos modos, y en esta misma fase del proceso de creación, se proporciona al compositor una pequeña dosis de libertad, ya que es él (y sólo él) quien puede decidir cómo transmite musicalmente ese mensaje, qué tipo de música utiliza. Este es quizás el único punto en el cual el compositor es libre de utilizar su propio lenguaje: conceptos, materiales y técnicas que le son propios y habitualmente ajenos a los cineastas (armonía, contrapunto, fuga, instrumentación...). Esta es la fase en la que lo más importante es la interacción entre dos mensajes, el musical y el visual, que pueden reforzarse u oponerse entre sí según la intención creadora. Es decir, música e imagen pueden llevar mensajes convergentes o divergentes, aunque la pretensión final sea siempre una semántica $^{398}$. En la bibliografía tradicional sobre el tema se habla del uso de clichés

\footnotetext{
${ }^{396}$ De hecho, hay opiniones enfrentadas sobre si se puede o no considerar Cabaret como una película musical o bien si es sólo un drama con presencia de algunos números musicales, precisamente por esta integración de los números en el argumento. Por otro lado, Rick ALTMAN (cfr. Genre, The Musical, Londres 1981, pág. 10) define el musical como el film en el cual las secuencias bailadas y cantadas no corten el curso de la acción y resulten imprescindibles para la narración. Sea como sea, no son estas líneas las óptimas para discutir sobre una definición del musical como género, aunque consideramos que la clasificación hecha teniendo en cuenta la coherencia argumental de los números (integrada o ajena) puede ser de utilidad.

${ }^{397}$ Aquí intervendría, como auxiliar, el parámetro de análisis de la MDC "Método de selección del bloque", por el cual delimitamos la responsabilidad del bloque musical, que puede ser de un compositor contratado expresamente para llevar a cabo el encargo, o bien puede ser obra del director, el montador o un director musical que se encarga de seleccionar piezas preexistentes y decidir su uso en el film. Por este motivo no hablamos de método de composición, si no de método de selección.

398 Michel CHION (La audiovisión..., pág. 19) habla de "música empática" y "música anempática", pero esta terminología no nos convence. Para Chion la "música empática" (lo que nosotros llamamos convergencia) es aquella que participa de la emoción de la escena, mientras que considera música anempática (para nosotros divergencia) aquella que "muestra por el contrario una indiferencia ostensible ante la situación, progresando de manera regular, impávida e ineluctable, como un texto escrito. Y sobre el fondo mismo de esta "indiferencia" se desarrolla la escena, lo que tiene por efecto, no la congelación de la emoción sino, por el contrario, su intensificación, su inscripción en un fondo cósmico"; y añade que no participa de la citada emoción. Consideramos que el uso de una música de fondo que lleve una carga emotiva divergente de la que lleva la imagen no puede ser calificada de indiferente, ni se puede decir que no sea partícipe de la emoción que transmite visualmente. De hecho, el mismo Chion reconoce que intensifica la emoción. La música anempática, y por tanto incapaz de reflejar la emoción de las imágenes, existiría por una falta de
} 
musicales (ADORNO, 1976, págs. 31 a 34), aunque reduciendo esta utilización a ilustrar estados anímicos. Nosotros consideramos que existen también "clichés" musicales aplicables a acciones físicas o a determinados lugares, épocas o conceptos. Debe quedar claro que el cliché o estereotipo no lo constituye aquí la interacción audiovisual, sino el hecho de dotar a música e imagen de una significación determinada. Es decir, que no consideramos como cliché el uso de una música triste para una secuencia triste, sino el que esta música y esta secuencia sean catalogadas como tristes, lo cual puede ser razonable en lo relativo a la imagen (aunque muchas veces es gracias al argumento y no a necesariamente a sus valores visuales); pero poco menos que convencional en lo que respecta a la música. Tres son las tipologías que nosotros establecemos tanto de convergencia como de divergencia: anímica, física y cultural. Aunque las tres tienen un fuerte componente cultural, sólo una recibe este nombre. El motivo es simple, pero históricamente complejo: debemos tener en cuenta, de entrada, que el ámbito de este artículo y de las ideas que en él se exponen queda circunscrito al cine y la música occidentales. Lo que para nosotros puede ser una música o una imagen triste, para un guerrero batusi, un santón hindú o un nativo de la isla de Bali puede ser alegre, y viceversa. Pero tomándola como premisa básica, convendremos que todos nosotros identificamos determinados tipos de música (clichés) con determinados sentimientos (convergencia anímica), o con determinados movimientos y acciones (convergencia física). Por lo tanto, no es necesario tener una cultura musical específica para detectar los dos recursos citados, aunque sí será necesario tener una cierta sensibilidad "occidental". Pero la convergencia cultural sí que reclama una cierta educación que permita identificarlo y convertirlo en un recurso efectivo.

Como convergencia cultural entenderemos aquella que usa música característica de una determinada región o ambiente físico para acompañar imágenes del mismo (convergencia cultural local), de una determinada época (convergencia cultural cronológica), o bien piezas musicales características que por sí mismas no tienen un significado, pero a las que la tradición ha dotado de sentido, y que se utilizan para ilustrar determinadas situaciones. Es aquello a lo que Adorno (1976, Pág. 30-31) llama "stock music", citando como ejemplos todavía hoy perfectamente válidos la "Marcha Nupcial" de El sueño de una noche de verano de Mendelssohn para ilustrar una boda, la "Sonata Claro de Luna" de Beethoven para una secuencia romántica, nocturna, etc., que tanto Adorno como Kracauer consideran un defecto de la $\mathrm{BSM}^{399}$. Nosotros damos un nuevo término a este

oficio del compositor, el director o el montador que la usarían para llenar un vacío, sin ninguna intención creativa, y con una interacción semántica carente de contenido o con un contenido accidental y no fruto de ninguna voluntad creativa. Quien habla de paralelismo y contrapunto (quizás la terminología más extendida), no sólo refiriéndose a la música cinematográfica, sino a todo lo que es sonido en el cine, es Siegfried KRACAUER (cfr. Teoría del cine. La redención de la realidad física, Barcelona/Buenos Aires/México, 1989 [1960], págs. 139-203), pero sin Ilegar a establecer ninguna jerarquía derivada de ambas utilizaciones. Por su parte, el compositor Hanns EISLER (Composing for the films, Londres 1947, pág. 69) decía que "picture and music, however indirectly or even antithetically, must correspond to each other" (el subrayado es nuestro). Jean MITRY, por otro lado, es radicalmente contrario al uso del término contrapunto en este sentido (cfr. Estética y..., págs. 138-139), y propone emplear el término contraste.

${ }^{399}$ Concretamente KRACAUER (Teoría del cine..., pág. 185) dice que "este defecto cegador suelen producirlo sobre todo las partituras arregladas sobre la base de melodías con significados fijos; como las músicas populares que asociamos tradicionalmente con las actuaciones circenses, los funerales y otros hechos típicos de la vida real. Cada vez que estas melodías, convertidas en clichés desde hace mucho tiempo, se sincronizan con las imágenes que les corresponde, automáticamente provocan reacciones estereotipadas". Y añade en nota, en la página 186: "esas melodías archiconocidas o estereotipos visuales pueden justificarse como breves insertos en casos en que, de no ser por ellos, serían precisas fastidiosas disertaciones para hace avanzar la acción." 
recurso hablando de convergencia cultural conceptual, e incluimos la utilización de música en una secuencia por afinidad intelectual e ideológica con el argumento, como sucede en La naranja mecánica (A Clockwork Orange, Stanley Kubrick, 1971; música de W. Carlos), donde se utiliza música de Beethoven porque su protagonista siente por ella verdadera pasión.

Si veíamos ahora cómo la música podía interactuar con el mensaje visual, veamos a continuación como lo hace con los dos vehículos portadores de este mensaje: por un lado, con la narración en sí misma y, por otro, con lo que podemos entender que es el soporte estructural de esta narración, el montaje cinematográfico.

Teniendo en cuenta la relación del bloque con la línea argumental de la película es decir, su ubicación en la narración- encontramos distintas formas narrativas como pueden ser el tema circunstancial, el leitmotiv, la elipse, la irrupción y la interrupción musicales, el número musical, y el mickeymousing. De todos ellos nos detendremos sólo ahora en el leitmotiv, ya que consideramos que se utiliza a veces de manera errónea.

Es bien sabido que el leitmotiv wagneriano, del cual procede el cinematográfico, es un motivo o tema breve que se identifica con un personaje o con una situación concretos de la obra en la que aparece, de manera que cada vez que aparece o se alude a este personaje o situación, suena "su" leitmotiv ${ }^{400}$. Éste puede presentarse con distintas variaciones de timbre, ritmo, intensidad, etc. pero queda claro que una misma línea melódica no sirve para distintos personajes o situaciones. No obstante, muchos críticos y analistas de música cinematográfica hablan de leitmotiv cuando un mismo motivo o tema se utiliza a lo largo de una película como fondo para distintos personajes o diferentes situaciones, cambiando timbre, ritmo, intensidad... cada vez. Esto es lo que sucede, por ejemplo, en Desayuno con diamantes (Breakfast at Tiffany's, Blake Edwards, 1961, música de Henry Mancini) en la que el ahora popular tema "Moon River" aparece continuadamente a lo largo de toda la película, pero con distintos ritmos e instrumentación según acompañe una secuencias triste, alegre, dinámica, etc. Se ha dicho y se ha repetido hasta el cansancio que "Moon River" es el leitmotiv del film: nosotros afirmamos que "Moon River" no es sino un tema (en este caso el principal) que se podría convertir en leitmotiv si de la película se hiciese una segunda parte ${ }^{401}$, pero que no actúa como leitmotiv dentro de "su" film. Creemos, sin embargo, que actúa como una especie de leitmotiv de la película, aunque fuera de su contexto fílmico, en la vida cotidiana, y por el poder evocador de la MDC, caracterizando así la película fuera del ambiente cinematográfico ${ }^{402}$. Esta

\footnotetext{
${ }^{400}$ La definición de leitmotiv que da el prestigioso The New Grove Dictionary of Music and Musicians es muy clara: "A theme, or other ocherent musical idea, clearly defined so as to retain identity if modified on subsequent appearances, whose purpose is to represent or symbolize a person, object, place, idea, state of mind, supernatural force or any other ingredient in a dramatic work, usually operatic but also vocal, choral or instrumental. The leitmotif may be musically unaltered on its return, o altered in its rhythm, intervallic structure, harmony, orchestations or accompaniment and also may be combined with other leitmotifs in order to suggest a new dramatic condition..." (WARACK, John. "Leitmotif" en SADIE, Stanley (ed.). The New Dictionary of Music and Musicians, Londres 1980. Vol. X, pág. 644).

${ }^{401}$ De hecho, sí que podemos halbar de leitmotiv de un film completo en series de largometrajes como las dedicadas a Superman, Indiana Jones, James Bond 007, etc., que ya asocian un tema a un personaje o a un grupo concreto de personajes que son los protagonistas de toda la serie. En TV hablaríamos de sintonía.
}

402 Sucede lo mismo con piezas como "Raindrops Keep Falling On My Head" de Dos hombres y un destino (Butch Cassidy and the Sundance Kid, George Roy Hill, 1969, música de Burt Bacharach), "In the Windmills of Your Mind" de El caso Thomas Crown (The Thomas Crown Affair, Norman Jewison, 1968, música de Michel Legrand): clasificadas 
circunstancia, de todos modos, pertenece ya al proceso recreador y no al proceso creador, por lo que no nos detendremos más en ella.

Hasta aquí el compositor podía haber trabajado sólo con el guión, con notas, con indicaciones del director..., podía incluso haber visto un premontaje sobre el cual tomar unas notas sobre papel pautado, aunque no fuesen definitivas. Pero es ahora cuando la música debe acotarse físicamente y debe ser ubicada dentro del montaje. Estamos, de hecho, en la fase de postproducción (en la cual las prisas para componer la música son habituales). Manuel Valls decía que el cine "ha dictado la ley en lo que concierne a la creación musical, en cuya norma el cálculo substituye al concepto romántico de la inspiración y, por ello, no es ningún secreto que la música cinematográfica, pensada y creada para servir de fondo sonoro a unas secuencias, se compone y recompone con un centímetro en la mano y un cronómetro en la otra, pues el compositor, en su trabajo, ha de ceñirse con total precisión a la duración asignada a casa pasaje" ${ }^{403}$.

Definidos por este parámetro de ubicación en el montaje, convendremos en señalar las tipologías siguientes: bloques genéricos (de entrada, salida o enlace), que corresponden a los títulos de crédito $^{404}$; bloque-secuencia (total o parcial), que coincidiría con el desarrollo de una secuencia (o parte de esta); bloque de transición, utilizado como paso de una secuencia a otra; bloque-plano, generalmente atemático y breve; y el bloque continuo, que podemos encontrar de manera singular en películas de los años treinta (como lastre todavía del acompañamiento musical ininterrumpido de la época silente) o en el cine de animación ${ }^{405}$.

erróneamente como leitmotiv porque su audición evoca el film de origen, pero que aparecen sólo en una secuencia y, por tanto, no pueden actuar como leitmotiv, ya que para ello deberían repetirse en circunstancias idénticas a las cuales acompañan. Creemos que el quid de la cuestión, para justificar la presencia de estas piezas, está en el hecho que son piezas de fácil asimilación que se han hecho populares rápidamente, con el consiguiente éxito comercial y económico (amén de conseguir, en ambos casos, el Oscar a la mejor canción), lo cual posibilita que se conviertan en un leitmotiv fuera de contexto. Similar es el caso del "Tema de Lara" perteneciente a la BSM de Dr. Zhivago (Dr. Zhivago, David Lean, 1965, música de Maurice Jarre), que aparece en múltiples ocasiones a lo largo de la película en situaciones diferentes, sin una adscripción regular, pero cuya audición nos evoca inevitablemente el film de origen.

${ }^{403}$ VALLS, Manel; PADROL, Joan, Música y cine, 1986, pág. 16-17.

${ }^{404}$ Los bloques genéricos de enlace se encuentran en contadas ocasiones y sólo en determinadas películas de largometraje que disfrutaban (?!) de un descanso durante el cual se paraba la proyección y aparecía un rótulo anunciando el intermedio, mientras una música, compuesta exprofeso para acompañar aquel rótulo, sonaba en la sala. Recordemos ejemplos como Lo que el viento se llevó (Gone With the Wind, Victor Fleming, 1939, música de Max Steiner), Los diez mandamientos (The Ten Commandments, Cecil B. De Mile, 1956, música de Elmer Bernstein), Espartaco (Spartacvs, Stanley Kubrick, 1960, música de Alex North), Lawrence de Arabia (Lawrence of Arabia, David Lean, 1962, música de Maurice Jarre), o La conquista del Oeste (How the West was won, Henry Hathaway, John Ford y George Marshall, 1962, música de Alfred Newman). Todavía hoy en Italia se mantiene la costumbre de interrumpir la película para realizar un descanso independientemente del metraje del film, que, además, si es de producción italiana contiene ya el rótulo indicativo del descanso. También encontramos bloques genéricos de enlace en películas de episodios, entre un episodio y otro. A veces, mucho más esporádicamente, encontramos un bloque musical anterior a la aparición de los títulos de crédito de entrada, que puede o no ir acompañado de imagen en la pantalla. Citamos sólo como ejemplos Camelot (Camelot, Joshua Logan, 1967) o Creemos en el amor (Three Coins in the Fountain, 1954, Jean Negulesco, música de Víctor Young), con sendas oberturas: en el primer caso un bloque instrumental, y en el segundo un bloque cantado. Estas oberturas las podríamos también calificar como bloque genérico de enlace, ya que actúan como una especie de enlace entre la realidad de la sala y la ficción de la pantalla.

${ }^{405}$ Siegfried KRACAUER (Teoría del cine..., pág. 184) habla de continuum, del cual dice que su "único polo viene señalado por una música que apunta o transmite el carácter particular de todo un relato; más que a subrayar cualquier secuencia concreta". Si tenemos en cuenta que este continuum (para nosotros bloque continuo) puede ser politemático, y que cada tema puede tener un carácter dominante distinto, esta afirmación pierde validez, ya que mezcla criterios que nosotros separamos. 
El último parámetro que tendremos en cuenta a la hora de analizar un determinado bloque de la BSM es el plano auditivo. Éste, por desgracia, se puede decidir (y se acostumbra a hacer así) en la fase de postproducción y a veces suscita la ira del compositor, que ve como su música queda oculta tras una cortina de ruidos y efectos que director, montador y/o ingeniero de sonido consideran más necesarios para la comprensión de la película. Debemos tener en cuenta los distintos elementos sonoros que configuran la totalidad de una BS (diálogos, ruidos y música) para determinar el plano auditivo. Cualquiera de estos se puede situar en primer plano, en plano secundario o en un plano que nosotros llamaremos plano de figuración, y que corresponde, por lo que respecta a la BSM, a lo que tradicionalmente se ha llamado "telón sonoro" o "música de fondo"406.

Para finalizar, conviene citar algunos de los defectos comunes de la BSM que hay que tener en cuanta a la hora de enfrentarse a ella mediante un análisis serio. Si bien algunos aparecen ya en el momento de la producción — bloque de recurso ${ }^{407}$, falso leitmotiv $^{408}$, corte brusco, disminución del volumen-, otros son fruto de manipulaciones ajenas al proceso creativo hechas normalmente en el proceso de exhibición (alteraciones en el doblaje y uso de la música como censura). Debemos estar especialmente alerta ante estos dos últimos, ya que no sería la primera vez que un análisis de una BSM se basa en MDC que no tiene nada que ver con la que se compuso para el film original, hecho que vicia sin remedio las posibles conclusiones que, del citado análisis, pudieran derivarse. Aun entendiendo los problemas técnicos que se derivaban del doblaje, cabe pensar que se podría haber tenido más cuidado en seleccionar las piezas "suplentes" ${ }^{409}$.

\section{Análisis de una secuencia.}

Para ejemplificar este nuevo método de análisis se ha escogido una película fácilmente localizable, al tiempo que suficientemente conocida: En busca del arca perdida (Raiders of the Lost Ark, 1981, Steven Spielberg). No se ha querido analizar, sin embargo, el film entero, ya que habría sido poco operativo en tan poco espacio. Se ha preferido centrar el análisis en una secuencia, la secuencia prólogo, que en cierto modo presenta el personaje de Indiana y Belloch, su antagonista, y nos introduce de lleno en el género del film. De este modo se podrá entrar más en detalles que se podrían perder analizando todo el film (a no ser que ocupásemos una treintena de páginas sólo para el análisis).

\footnotetext{
${ }^{406}$ Lo cierto es que, a veces, resulta muy difícil diferenciar entre el plano secundario y el plano de figuración cuando sólo aparecen dos elementos auditivos; pero la experiencia nos ha hecho ver la necesidad de mantener ambos.

${ }^{407}$ Son los "agujeros" a los cuales aludía el compositor Maurice Jaubert cuando decía: "¿Qué le piden a la música la mayoría de nuestros directores? En primer lugar tapar los "agujeros" sonoros, bien porque consideren demasiado silencioso tal pasaje, bien porque el director no haya sabido encontrar en su realización un sonido verdaderamente plausible, sobre todo, si no se lo ha sugerido la imagen" ("La musique de film", en Esprit, 1 de abril de 1936, citado por MITRY, Estética y..., vol. 2, pág. 139).

${ }^{408}$ Sería el caso ya citado en la nota 19, de Dr. Zhivago, donde el "Tema de Lara" se convierte en una especia de comodín musical empleado para todo.

${ }^{409} \mathrm{El}$ poco respeto que se ha tenido hacia la música cinematográfica no se ha limitado, no obstante, a justificables problemas técnicos de doblaje: ya en la época del cine mudo, Josep Palau se lamentaba de que Entr'acte de Rene Clair se había visto en Barcelona con el acompañamiento de la "Rapsody in blue" de George Gershwin, y que nunca se había podido escuchar la música original de Erik Satie (cfr. PALAU, J. "Després de la sessió Mirador", en Mirador, $\mathrm{n}^{\circ} 222,4$ de mayo de 1933).
} 
Argumentalmente, la secuencia prólogo es simple: un grupo reducido de personas caminan por la jungla. Distinguimos diversos porteadores, dos guías y un personaje, del cual se nos oculta el rostro, que es el que abre siempre la marcha. Al llegar a una especia de tótem los porteadores huyen despavoridos. La marcha continúa, conscientes todos, al encontrar un dardo envenenado en un árbol, que miembros de la tribu de los obitos están cerca. Llegan a una cascada y entonces el misterioso personaje del rostro oculto coge un viejo papel que parece un mapa. Uno de los guías intenta una oscura maniobra con el revolver, pero es abortada a golpe de látigo por el misterioso personaje que, evidentemente, es Indiana Jones. Quedan juntos sólo uno de los guías y Indiana, que entran en una cueva llena de trampas mortales. Tras sortearlas todas llegan a una sala donde hay un ídolo de oro: el objetivo final del trayecto. Indiana lo coge y justo en ese momento la cueva empieza a desmoronarse, de manera que ambos deben huir precipitadamente. En un punto en el que hay un abismo, Indiana y el guía quedan separados: el guía, que queda más cerca de la salida, tiene el látigo, y Indiana el ídolo. El guía propone un intercambio, pero huye con el ídolo dejando a Indiana abandonado. No obstante, Indiana consigue saltar al otro lado del abismo, donde el guía ha perdido la vida en una de las trampas, y recupera el ídolo. En ese momento, una gran piedra esférica se abalanza imparable contra Indiana que corre hasta salir de la cueva y volver al lado de la cascada. Allí, para sorpresa suya, le esperan los obitos, que han matado al otro guía, y Belloch, el competidor que le quita el ídolo. Indiana huye corriendo perseguido por los obitos, y recorriendo el camino del principio en sentido inverso llega a un hidroavión con el que consigue salvarse. Desde aquí se enlaza con la secuencia siguiente, en la universidad.

Musicalmente, la secuencia presenta tres bloques, de los cuales podemos decir (prescindiendo del contexto fílmico: MDC) que han sido compuestos por un compositor profesional de la música cinematográfica, en esta caso John Williams ${ }^{410}$. Presentan una estructura politemática y un caracter predominantemente físico, aunque el primer bloque podría también ser considerado como anímico. Los tres bloques son:

a) Bloque $1\left(4^{\prime} 02 "\right)^{411}$. Acompañando el trayecto de Indiana, los guías y los porteadores primero, hasta la entrada de la cueva donde está el ídolo.

b) Bloque 2 (5'17") Sigue el bloque anterior sin una clara solución de continuidad dentro de la cueva y hasta la salida de Indiana cuando ve que le esperan Belloch y los obitos.

\footnotetext{
${ }^{410}$ John Williams (New York, 1932) compositor formado en la Julliard School of Music y en la UCLA. Sus inicios en el terreno musical lo sitúan como intérprete de piano clásico y de jazz, al tiempo que ejercía como arreglista. Desde 1958 toma contacto con el audiovisual, componiendo música para TV y, desde 1960, también para el cine donde ha logrado su fama. Simplificando mucho, podemos decir que su música cinematográfica ha evolucionado desde un estilo próximo al de Henry Mancini —con comedias como Como robar un millón y... (How to steal a million, William Wyler, 1966) o Cuidado con el mayordomo (Fitzwilly, Delbert Mann, 1967) — hasta un retorno al sinfonismo que tiene como primera gran obra Tiburón (Jaws, Steven Spielberg, 1977) o La Guerra de las Galaxias (Star Wars, Georges Lucas, 1977), momento en el cual ya se empezará a hablar del "sonido Williams", imitado por muchos otros compositores: retorno al sinfonismo de las grandes orquestas, utilización del leitmotiv, casi omnipresencia de la música creando largos temas (sobre todo en los genéricos de salida, que se alargan considerablemente), etc.

${ }^{411}$ Estos minutos corresponde a la duración de la música en la copia en video y no corresponden a los minutos del CD editado por Silva Screen (RAIDERS 001) en 1995, donde las equivalencias serían las siguientes:

Bloque 1: "Main Title: South America, 1936" (4'10")

Bloque 2: "In the Idol's Temple" (5'26")

Bloque 3: "Flight from Peru" (2'20")
} 
c) Bloque 3 (2'03"). Tras haberle sido quitado el ídolo, Indiana huye perseguido por los obitos, hasta que llega y sube al hidroavión que despega con el aventurero sano y salvo. Este bloque acaba en transición hacia la secuencia siguiente, en la universidad.

Analicemos a continuación los tres bloques atendiendo a los distintos parámetros que tenemos en cuenta.

En lo relativo a la función articuladora, podemos decir que en todos los casos encontramos que ésta es secundaria y no protagónica, porque la música es sólo un acompañamiento de la imagen, adquiere una forma adjetiva y no sustantiva, como sucedería en el caso contrario. Es evidente que no estamos ante un número musical, y que aquí la música sirve a la imagen articulándose en torno a esta.

Si atendemos al parámetro de justificación óptica convendremos en señalar que es irreal en todos los casos, ya que la fuente sonora de la cual procede la música ni aparece ni se intuye en ningún momento en la pantalla; es una música que proviene de la nada y, por tanto, tiene también una coherencia argumental ajena: ¿qué sentido tiene que suene música de orquesta en mitad de la jungla?

La interacción semántica que se establece es ligeramente más compleja: se establece en los tres casos una convergencia física, aunque en el primero podríamos intuir también una cierta convergencia anímica, ya que existe un cierto aire de misterio. Pero aquí nos podríamos preguntar si las imágenes son realmente misteriosas o enigmáticas por sí mismas. Viendo el film desprovisto de su banda sonora, nos damos cuenta de que el único elemento enigmático es la identidad del personaje que abre la marcha por la jungla, y que incluso éste es un enigma relativo, ya que todos sabemos a priori que se trata de Indiana Jones (Harrison Ford). Deberíamos aceptar que el misterio le viene dado, a la imagen, por la música que lo acompaña. La convergencia (ahora anímica y física: tensión) la vemos claramente cuando Indiana Jones se dispone a coger el ídolo de la cueva: un crescendo acompaña la creciente tensión emocional y física del momento (fotogramas 1 y 2 ).

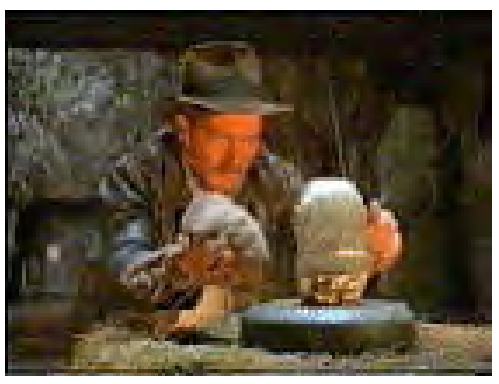

Fotograma 1

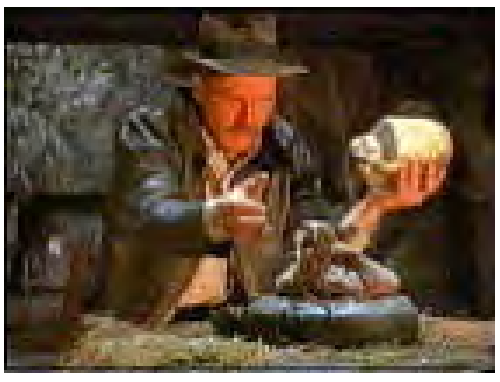

Fotograma 2

También utiliza una convergencia física al ilustrar la fragilidad, al tiempo que la agilidad, de las tarántulas que Indiana jones y su guía tienen en la espalda, con un pizzicato de la cuerda (fotogramas 3 y 4 ). 


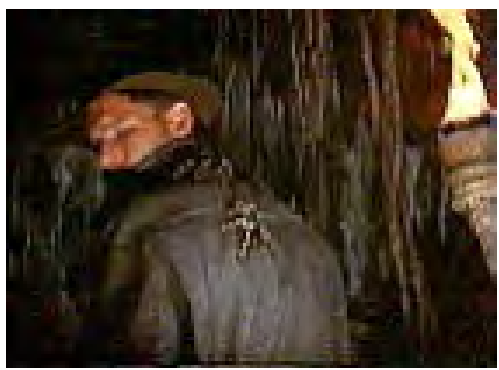

Fotograma 3

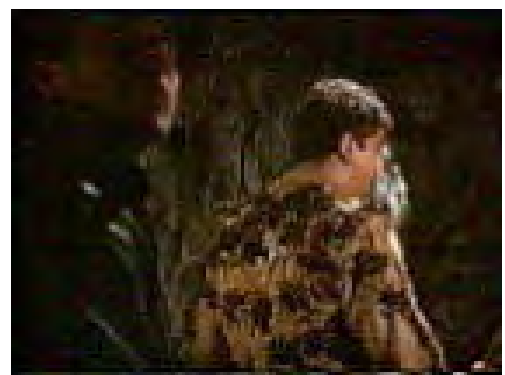

Fotograma 4

Tengamos en cuenta ahora la ubicación en el montaje: el bloque 1 es sin duda un bloque genérico de entrada, ya que acompaña los créditos iniciales del film (ver fotogramas 5 y 6$)$

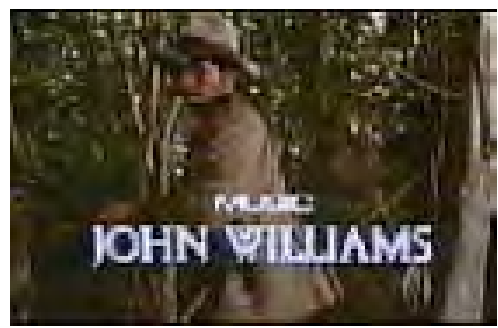

Fotograma 5

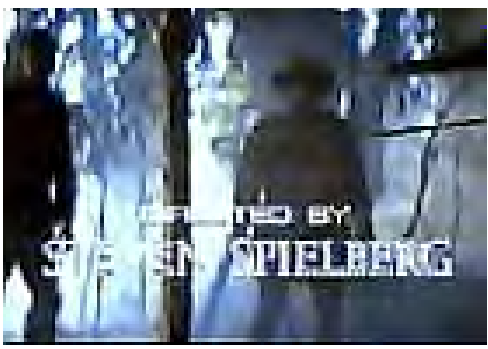

Fotograma 6

Aunque veremos más adelante cómo esta no es su única función. Los bloques 2 y 3 pierden esta función a pesar de estar todavía inmersos dentro de esta secuencia prólogo, que de hecho aún no forma parte del hilo argumental de la película. En una sola secuencia encontramos tres bloques largos: alguien podría incluso argumentar (y no sería descabellado) que son dos las secuencias (la primera agruparía los bloques 1 y 2, y la segunda, el 3); por tanto, son bloques secuencia parciales.

Si tenemos en cuenta que la forma narrativa puede afectar a un bloque de manera unitaria, pero que también diversas formas narrativas pueden ser presentadas en un solo bloque, podremos ver con claridad como estos tres bloques presentan diversas formas narrativas cada uno. Lo que hay que ver es cuál es la forma narrativa más común, y por tanto (y siempre según esta pequeña muestra) la más utilizada y característica del estilo de John Williams. Por un lado, vemos cómo los dos temas básicos que estructuran los bloques son temas circunstanciales, que no aparecen más a lo largo del film, y que se han utilizado sólo para estas situaciones o circunstancias concretas, y no para otras. No obstante, el 
tercer bloque contiene en dos ocasiones la presencia del conocido leitmotiv del personaje de Indiana:

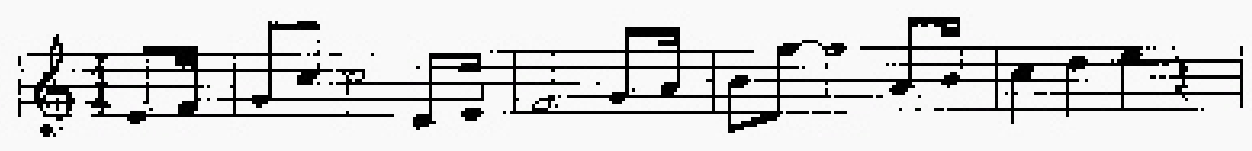

Este leitmotiv aparece a lo largo de la película en distintas ocasiones y no siempre de manera regular: no siempre que aparece, Inidiana Jones realiza alguna gesta heroica, ni siempre que realiza una gesta heroica aparece el tema; pero queda claro que el leitmotiv no acompaña la aparición de ningún personaje que no sea él. Es un leitmotiv atípico (incluso podría no ser un leitmotiv en esta primera película de la serie), que aparece por primera vez cuando Indiana Jones, ayudado de una liana, se escapa de los obitos para arrojarse al río, donde le espera un hidroavión (fotograma 7).

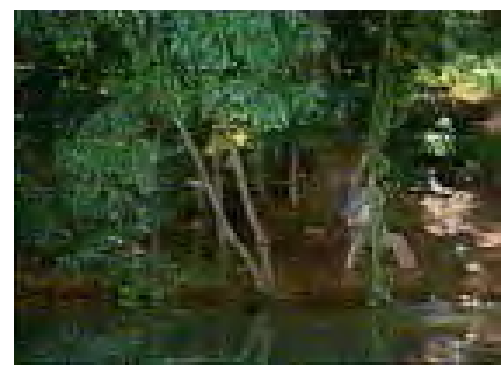

Fotograma 7

Los recursos más habituales son, sin embargo, la irrupción y la interrupción musical. Por ejemplo, al aparecer de entre las plantas el tótem que asusta al porteador (fotogramas 8 y 9 )

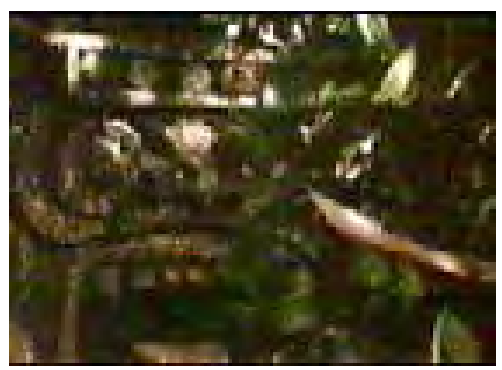

Fotograma 8

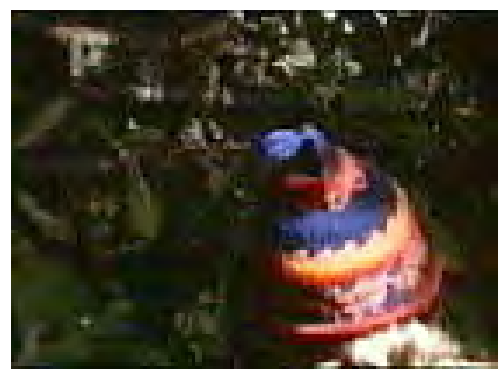

Fotograma 9 
... o cuando Indiana usa su látigo contra uno de los guías (fotograma 10).

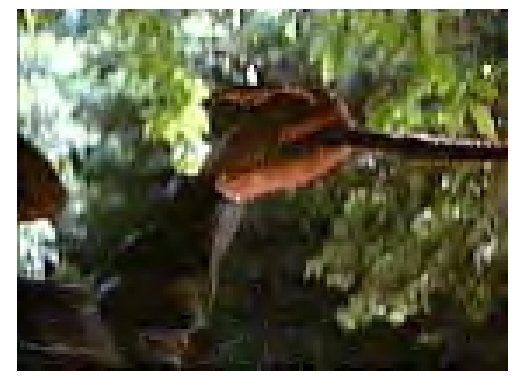

Fotograma 10

.., esto si nos referimos a la irrupción. Incluso cuando Indiana consigue salir de la cueva y se encuentra de repente rodeado de obitos (fotogramas 11 y 12),

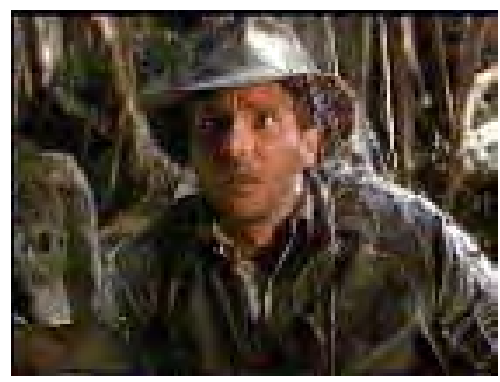

Fotograma 11

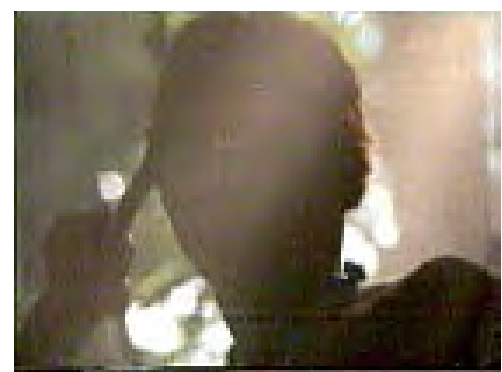

Fotograma 12

...todo ello para conseguir manipular la percepción del audio visor.

Aquí se hace difícil decir cuál es el plano auditivo en el cual se sitúa la música aunque nosotros pensamos que se sitúa en primer plano, ya que casi toda la información ambiental nos viene dada por la BSM. No se observan defectos de ningún tipo: el respeto a la obra de Williams ha sido total a priori y a posteriori, y por informaciones complementarias sabemos que Steven Spielberg y John Williams trabajan juntos desde el inicio del proyecto.

Como se puede ver, esta pequeña muestra nos permite definir una serie de recursos empleados por Williams en una secuencia y definir su estilo a pequeña escala:

a) Uso de bloques politemáticos.

b) Predominio del carácter físico de la música por encima del anímico. 
c) Interacción semántica convergente: establece básicamente convergencias físicas.

d) Bloques largos, que abarcan preferentemente una secuencia entera o buena parte de ésta.

e) Utilización de las irrupciones musicales como un recurso predominante.

f) Uso del leitmotiv para caracterizar un personaje, aunque sea en circunstancias distintas.

Si extendiésemos el análisis a todo el film, e incluso a la trilogía de Indiana Jones (o, por qué no, a toda la obra de Williams), podríamos llegar a definir el estilo y el método de trabajo, los cuales, al tomar sólo esta pequeña muestra como ejemplo, pueden haber quedado desvirtuados.

Como decíamos arriba, hablar de cine empleando términos auditivos o relativos al sonido resulta todavía difícil. Perder de vista las imágenes que aparecen ante nosotros intentando descontextualizar el sonido que las acompaña es una tarea ardua que pide horas y horas de visionado para llegar, precisamente, a prescindir de las imágenes para poder analizar sólo la BSM y definir el estilo de un creador (el compositor) supeditado a otro (el director).

Tabla

\begin{tabular}{|c|c|c|c|}
\hline \multirow{13}{*}{ MDC } & \multirow{5}{*}{ Método de selección } & \multirow{2}{*}{ Composición expresa } & Compositor profesional \\
\hline & & & Compositor ajeno \\
\hline & & \multirow{2}{*}{ Composición preexistente } & Inclusión sin variaciones \\
\hline & & & Inclusión con variaciones \\
\hline & & \multicolumn{2}{|c|}{ Combinación de ambas opciones } \\
\hline & \multirow{3}{*}{ Estructura temática } & \multirow{2}{*}{ Bloque temático } & Bloque monotemático \\
\hline & & & Bloque politemático \\
\hline & & \multicolumn{2}{|l|}{ Bloque atemático } \\
\hline & \multirow{5}{*}{ Carácter } & \multicolumn{2}{|l|}{ Anímico } \\
\hline & & \multicolumn{2}{|l|}{ Físico } \\
\hline & & \multirow{3}{*}{ Cultural } & Local \\
\hline & & & Cronológico \\
\hline & & & Conceptual \\
\hline \multirow[t]{9}{*}{ BSM } & \multirow{2}{*}{ Función articuladora } & \multicolumn{2}{|l|}{ Protagónica } \\
\hline & & \multicolumn{2}{|l|}{ Secundaria } \\
\hline & \multirow{6}{*}{$\begin{array}{l}\text { Justificación óptica o } \\
\text { Presencia en pantalla de la } \\
\text { fuente sonora }\end{array}$} & \multirow{2}{*}{ Real } & Dentro de campo (ON) \\
\hline & & & Fuera de campo (OFF) \\
\hline & & \multicolumn{2}{|l|}{ Irreal } \\
\hline & & \multirow{3}{*}{ Formas de paso } & Real a irreal \\
\hline & & & Irreal a real \\
\hline & & & $\begin{array}{l}\text { Identificación (forma } \\
\text { ambigua) }\end{array}$ \\
\hline & Coherencia argumental & \multicolumn{2}{|l|}{ Integrada } \\
\hline
\end{tabular}


ANEXO VII: "MÉTODO DE ANÁLISIS DE LA MÚSICA CINEMATOGRÁFICA" JOSEP LLUIS I FALCÓ

\begin{tabular}{|c|c|c|c|c|}
\hline & \multicolumn{4}{|l|}{ Ajena } \\
\hline \multirow{10}{*}{ Interacción semántica } & \multirow{5}{*}{ Convergencia } & \multicolumn{3}{|c|}{ Anímica } \\
\hline & & \multicolumn{3}{|l|}{ Física } \\
\hline & & \multirow{3}{*}{\multicolumn{2}{|c|}{ Cultural }} & Local \\
\hline & & & & Cronológica \\
\hline & & & & Conceptual \\
\hline & \multirow{5}{*}{ Divergencia } & \multicolumn{3}{|c|}{ Anímica } \\
\hline & & \multicolumn{3}{|l|}{ Física } \\
\hline & & \multirow{3}{*}{\multicolumn{2}{|c|}{ Cultural }} & Local \\
\hline & & & & Cronológica \\
\hline & & & & Conceptual \\
\hline \multirow{8}{*}{ Ubicación en el montaje } & \multirow{3}{*}{\multicolumn{2}{|c|}{ Bloque genérico }} & De entre & \\
\hline & & & De salid & \\
\hline & & & De enla & \\
\hline & \multirow{2}{*}{\multicolumn{2}{|c|}{ Bloque-secuencia }} & Total & \\
\hline & & & Parcial & \\
\hline & \multicolumn{4}{|l|}{\begin{tabular}{|l|} 
Bloque de transición \\
\end{tabular}} \\
\hline & \multicolumn{4}{|l|}{ Bloque-plano } \\
\hline & \multicolumn{4}{|l|}{ Bloque continuo } \\
\hline \multirow{10}{*}{$\begin{array}{l}\text { Ubicación en la narración } \\
\text { (forma narrativa) }\end{array}$} & \multicolumn{4}{|l|}{ Tema circunstancial } \\
\hline & \multicolumn{4}{|l|}{ Leitmotiv } \\
\hline & \multicolumn{4}{|l|}{\begin{tabular}{|l|} 
Elipse \\
\end{tabular}} \\
\hline & \multirow{2}{*}{\multicolumn{2}{|c|}{ Irrupción musical }} & \multicolumn{2}{|c|}{ Prolongada } \\
\hline & & & \multicolumn{2}{|l|}{ Acotada } \\
\hline & \multirow{2}{*}{\multicolumn{2}{|c|}{ Interrupción musical }} & Conclus & \\
\hline & & & Suspens & \\
\hline & \multicolumn{4}{|c|}{ "Secuencia de montaje" } \\
\hline & \multicolumn{4}{|l|}{ Número musical } \\
\hline & \multicolumn{4}{|l|}{ Mickeymousing } \\
\hline & \multicolumn{4}{|l|}{ Primer plano } \\
\hline Plano auditivo & Plano secundario & & & \\
\hline & Plano de figuración & & & \\
\hline & & & Bloque c & recurso \\
\hline & Producción & & Falso lei & otiv \\
\hline Refortore & rionuction & & Corte br & \\
\hline Derecios & & & Disminu & on del volumen \\
\hline & Eybibición & & Alteracic & es del doblaje \\
\hline & & & Censura & \\
\hline
\end{tabular}


ANEXOS VIII

FIGURAS 


\section{Imágenes}

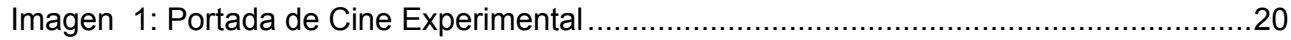

Imagen 2: Letra de la canción "Pu-pu-pi-du”. Primer Plano, 1 de enero de 1942 ................25

Imagen 3: RadioCinema, año VIII, núm 130, 1 diciembre 1946 .......................................27

Imagen 4: «El Amor Brujo» Gran película española .......................................................30

Imagen 5: Imagen extraída de la noticia: Fiesta en casa de los Perojo..............................32

Imagen 6: Caricatura de Durán Alemany publicada en ABC ............................................34

Imagen 7: « Ernesto Halffter ha escrito un poema sinfónico para "Bambú"», en Primer

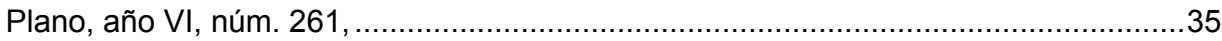

Imagen 8: Portada y hoja interior del cuadernillo en homenaje al maestro Quiroga............37

Imagen 9: Hoja del curriculum vitae de Juan Quintero Muñoz ............................................39

Imagen 10: Programa de mano de "La rueda de la vida" .................................................43

Imagen 11: Texto escrito a mano por Juan Quintero en el reverso de una de las hojas del

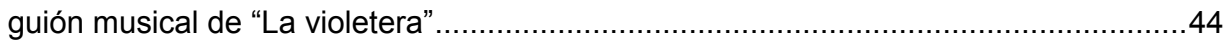

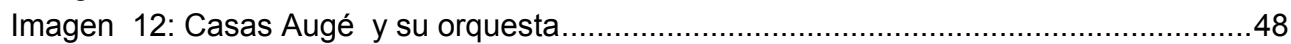

Imagen 13: Durán Alemany al piano junto al grupo "Orfeo" ............................................48

Imagen 14: Juan Quintero tocando el piano durante el rodaje de Pequeñeces ..................48

Imagen 15: El maestro Rebollo aleccionando a Ismael Merlo (entre ellos Ardavín)............48

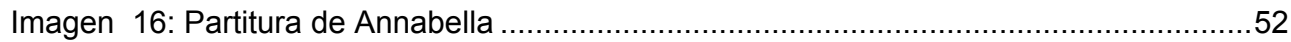

Imagen 17: «Reglamentación del doblaje» en Primer Plano, año X, núm. 431.................86

Imagen 18: «En el tercer año de NO-DO, los operadores, los del equipo sonoro y sus

anécdotas»), en Primer Plano, año IV, número 222 ...................................................95

Imagen 19: «EI CEC hace entrega de los premios correspondientes a 1947», en

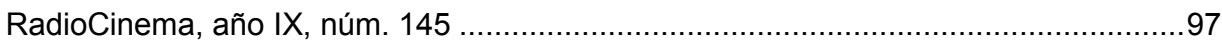

Imagen 20: «¿Qué le ha parecido su premio?», en RadioCinema, año IX, núm. 143 ........98

Imagen 21: «Garbancito de la Mancha» en Primer Plano, año IV, número 133..............115 Imagen 22: "La salvación del cine español está en la música española», en Primer Plano,

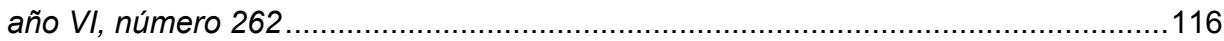

Imagen 23: «Horas antes del estreno con el director y los autores de "Garbancito de la

Mancha"»), en Primer Plano, año VII, número 291 .............................................117

Imagen 24: «Este el camino del cine hablado en español» en Cámara, año VIII, núm. 140,

Imagen 25: Cámara de registro de sonido del Sistema Sonoro de Laffón-Selgas ............197

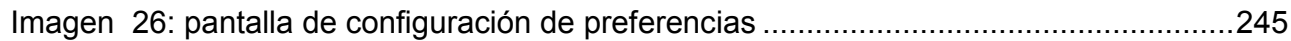

Imagen 27: Pantalla general de Fichas Catalográficas .................................................248

Imagen 28: barra de navegación de ficha ...................................................................249

Imagen 29: barra de navegación de ficha (con botón de acceso a documentos gráficos) 249

Imagen 30: barra de navegación de ficha (con botón de acceso a documentos sonoros) 249

Imagen 31: Adobe Acrobat reproduciendo un cartel ................................................250

Imagen 32: Windows Media Player reproduciendo el tema principal de Locura de amor. 251

Imagen 33: Producción cinematográfica: menú de búsqueda .......................................253

Imagen 34: Producción Cinematográfica: Ficha general (Administrador) ............................253

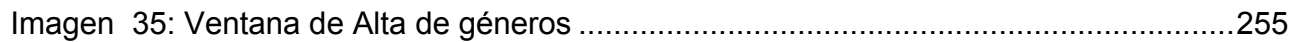

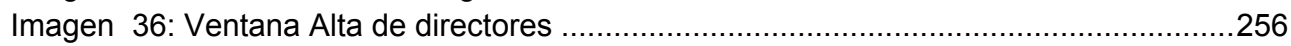

Imagen 37: Producción cinematográfica: Música (administrador) ….............................257 


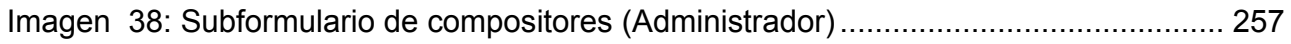

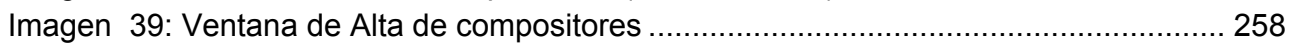

Imagen 40: subinforme Canciones (Administrador) ................................................... 260

Imagen 41: Producción cinematográfica: Ficha artística (Administrador) .......................... 261

Imagen 42: subinforme Intérpretes (Administrador) ................................................. 262

Imagen 43: Ventana Alta Actores ............................................................................ 262

Imagen 44: Producción cinematográfica: Ficha técnica (Administrador) .......................... 263

Imagen 45: Producción cinematográfica: Argumento y observaciones (Administrador) ... 264

Imagen 46: Producción cinematográfica: Distribución y calificacioenes (Administrador).. 265

Imagen 47: Ficha de Prensa (Administrador) ............................................................. 266

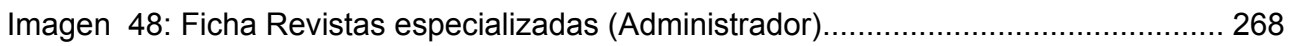

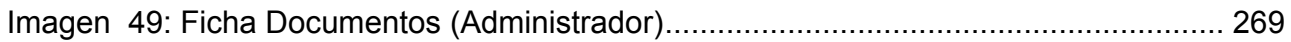

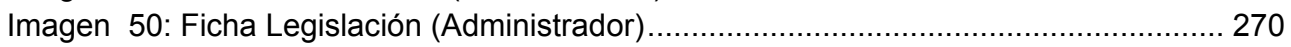

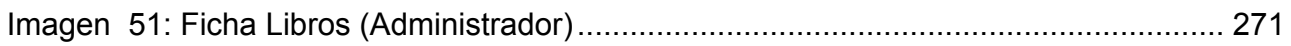

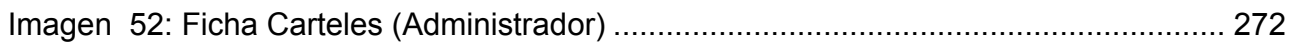

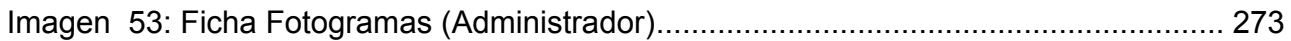

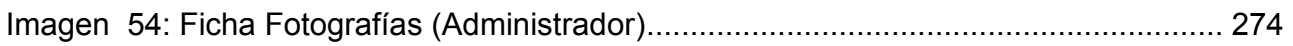

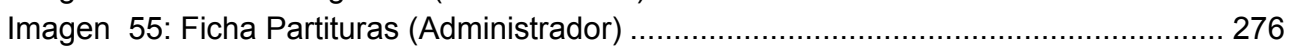

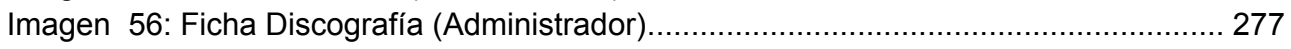

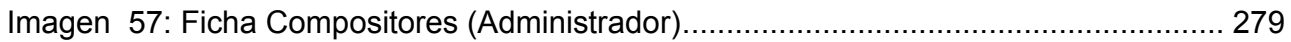

Imagen 58: Ficha Compositores con búsqueda desplegaba (Administrador).................. 279

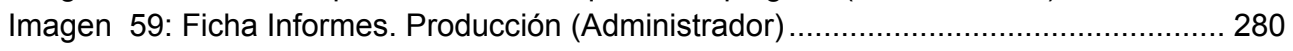

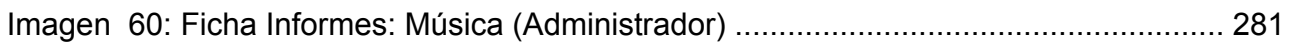

Imagen 61: Ficha Informes: Documentación (Administrador) ....................................... 282

Imagen 62: Ventana Selección de Informe de una película ............................................... 283

Imagen 63: Ventana de visualización de Informe ............................................................ 283

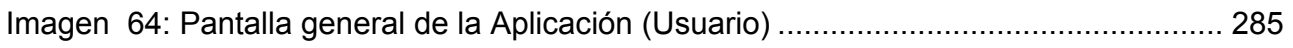

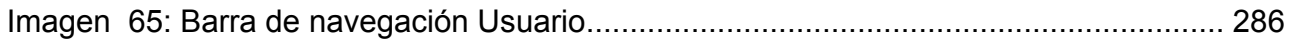

Imagen 66: Barra de navegación Usuario (con botón de acceso a documento gráfico) ... 287

Imagen 67: Barra de navegación Usuario (con botón de acceso a documentos sonoros) 287

Imagen 68: Adobe Acrobat reproduciendo un cartel (Usuario) ..................................... 288

Imagen 69: Windows Media Player reproduciendo el tema principal de Locura de amor

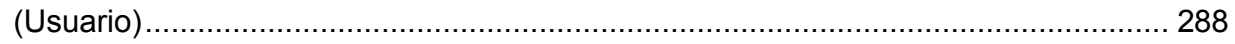

Imagen 70: Producción cinematográfica. Búsqueda de registro (Usuario) ........................ 290

Imagen 71: Ficha Producción cinematográfica: Ficha general (Usuario) .......................... 290

Imagen 72: Ficha Producción cinematográfica: Música (Usuario) .................................. 292

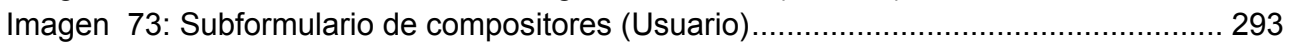

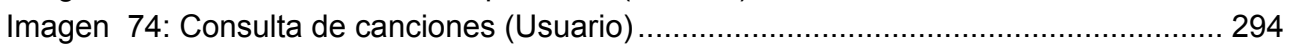

Imagen 75: Ficha Producción cinematográfica: Ficha artística (Usuario) ......................... 295

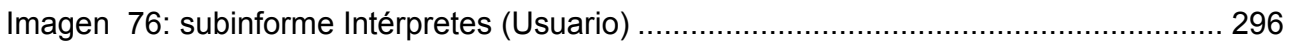

Imagen 77: Ficha Producción cinematográfica: Ficha técnica (Usuario) ......................... 296

Imagen 78: Ficha Producción cinematográfica: Argumento y observaciones (Usuario) ... 298

Imagen 79: Ficha Producción cinematográfica: Distribución y calificaciones (Usuario).... 298

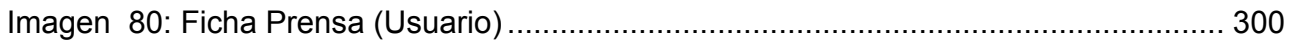

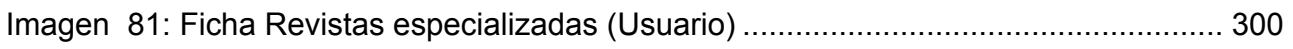

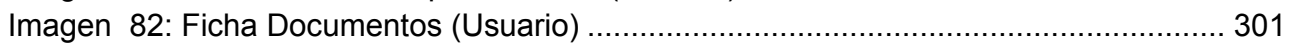

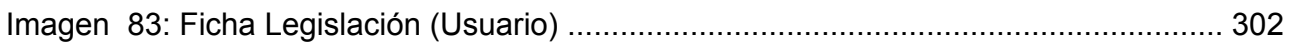




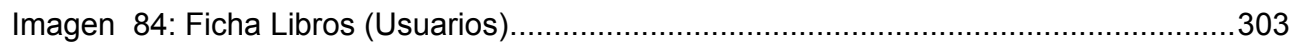

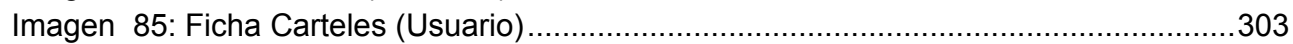

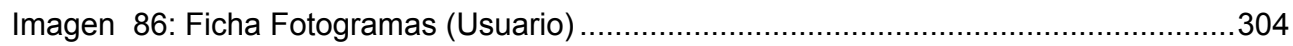

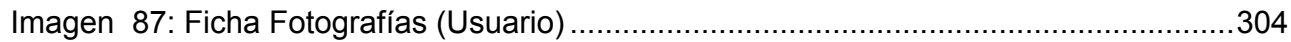

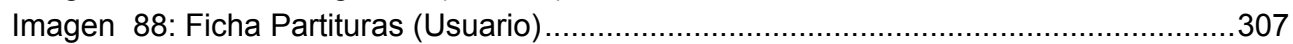

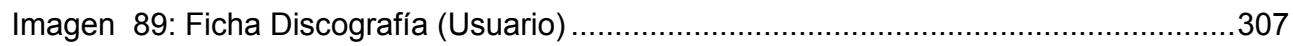

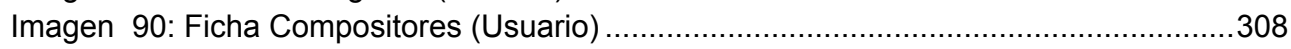

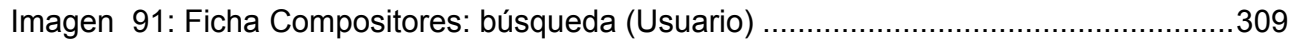

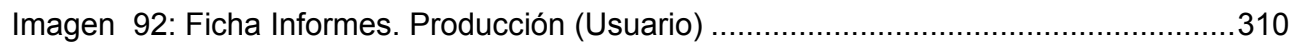

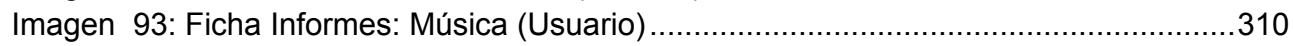

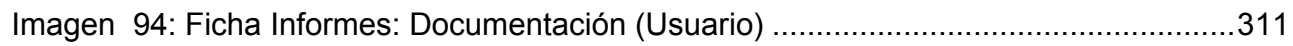

Imagen 95: Ventana Selección de Informe de una película .............................................312

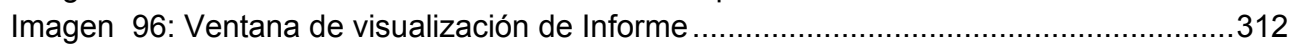

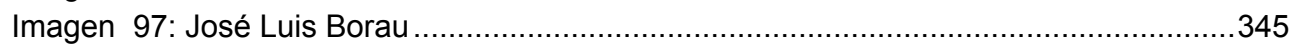

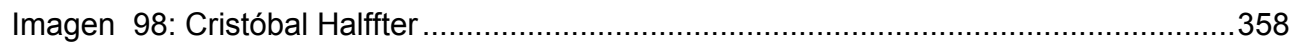

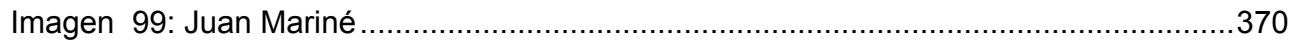

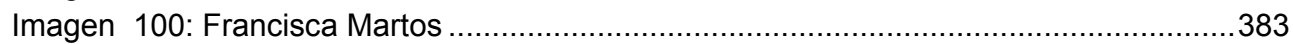

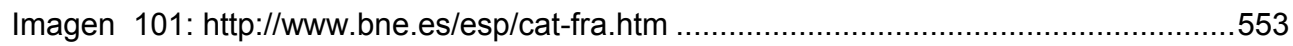

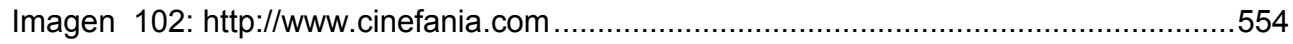

Imagen 103: http://www.cultura.mecd.es/cine/jsp/plantillaAncho.jsp?id=13 ...................554

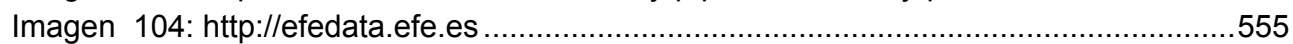

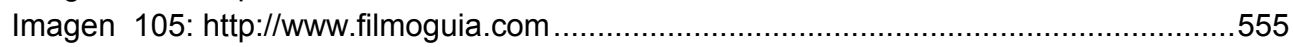

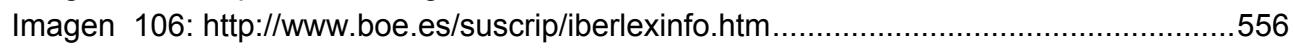

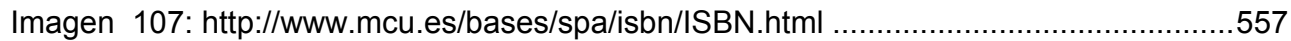

Imagen 108: http://www.ine.es/tempus2/tempusmenu.htm ............................................558

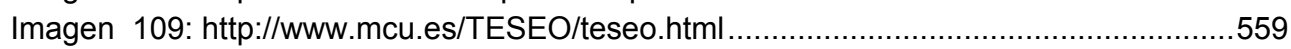

Imagen 110: http://www.library.arizona.edu/indexes/links/avonline.shtml .......................560

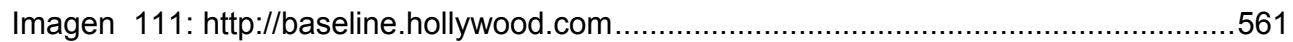

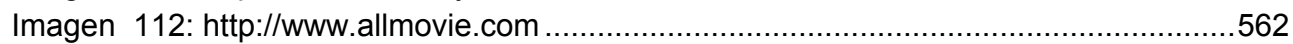

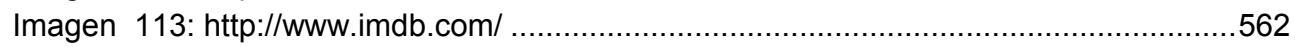

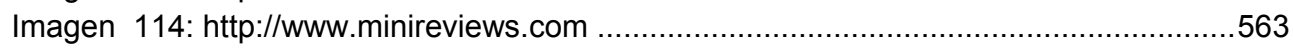

Imagen 115:

http://www.spokesmanreview.com/sections/entertai/movies/movie2col.asp?ID=reviewscover ...564

Imagen 116: http://library.concordia.ca/collections/filmcanadiana.html ...........................564

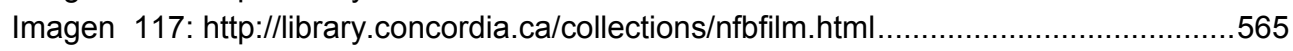

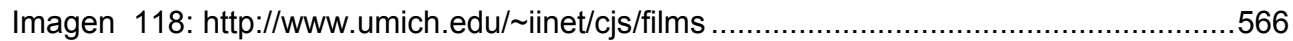

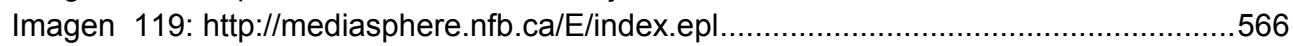

Imagen 120: http://library.dialog.com/bluesheets/html/bl0299.html .............................567

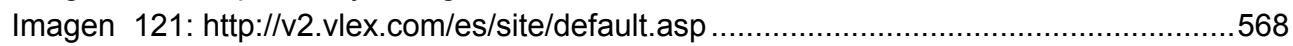

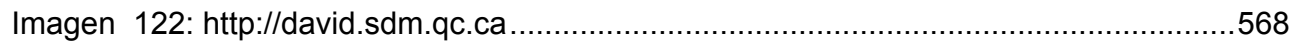

Imagen 123: http://www.tvguide.com/movies/database ..............................................569

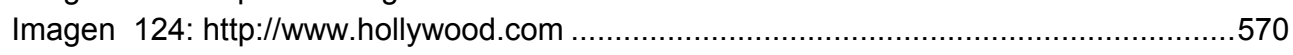

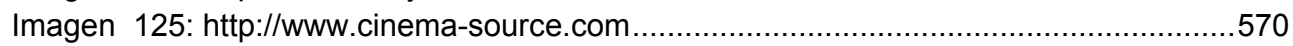

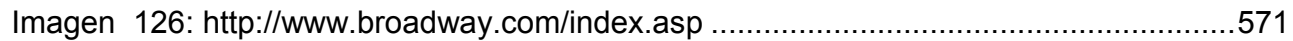

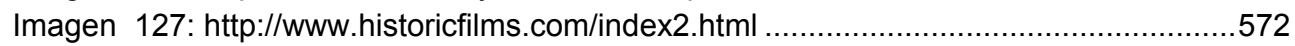

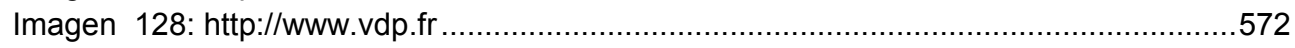

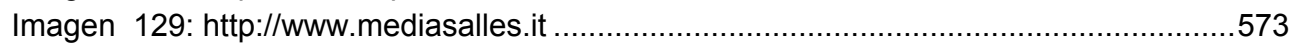




\section{Tablas}

Tabla 1: Nombre de publicaciones diarias con artículos con referencia a compositores..... 29

Tabla 2: Referencias a promociones de películas ............................................................ 36

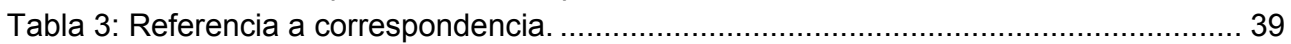

Tabla 4: Ejemplo de referencias a las entrevistas. ..................................................... 42

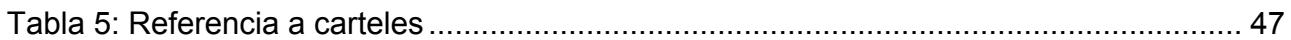

Tabla 6: Referencias al material fotográfico.................................................................... 50

Tabla 7: Referencias a fotogramas y foto fija............................................................. 51

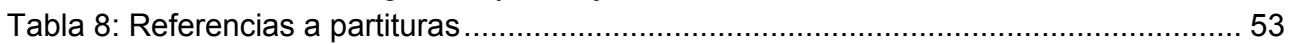

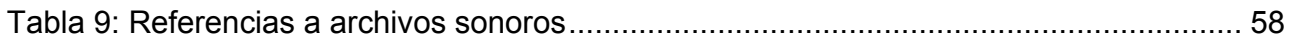

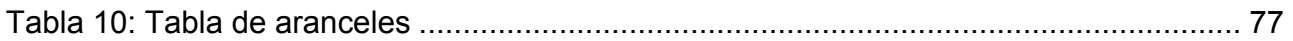

Tabla 11: Ejemplo de coexistencia de los permisos de doblaje e importación .................... 86

Tabla 12: Listado de géneros. Fuente: Catálogo de Cine Español de Películas de Ficción

Tabla 13: Listado de géneros en la Base de Datos MCE40 .............................................. 112

Tabla 14: Datos de la producción de cortos de animación ............................................... 114

Tabla 15: Datos de la evolución de la comedia (1941 a 1950) .......................................... 119

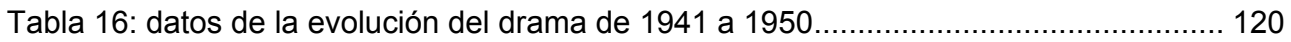

Tabla 17: Asignación de calificaciones en función del género............................................ 124

Tabla 18: Listado de productoras con número de películas realizadas entre 1939-1950.

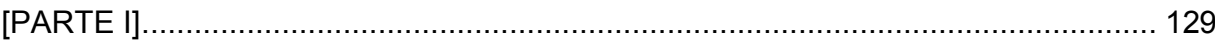

Tabla 19: Listado de productoras con número de películas realizadas entre 1939-1950.

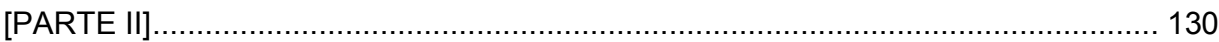

Tabla 20: Listado de productoras con número de películas realizadas entre 1939-1950.

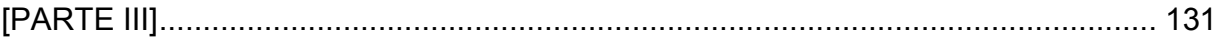

Tabla 21: Películas estrenadas en Madrid según su nacionalidad. ................................. 134

Tabla 22: Presupuesto medio por película en pesetas .................................................... 137

Tabla 23: Producción Nacional e importación (1939 a 1950) ............................................ 138

Tabla 24: Películas estrenadas en Madrid por países de origen (1939 a 1950) ................ 140

Tabla 25: Películas españolas estrenadas en Hispanoamérica...................................... 145

Tabla 26: listado de películas en las que participó López-Quiroga durante la década de los

cuarenta. Datos proporcionados por la Filmoteca Nacional .................................... 171

Tabla 27 listado corregido de películas en las que participó López-Quiroga durante la década de los cuarenta [corregida]. ............................................................. 175

Tabla 28: Listado de autores con el número de producción realizadas y labor desempeñada

Tabla 29: Sistemas de sonido y su repercusión en la producción nacional (1941 - 1950) 195

Tabla 30: Tabla de análisis músico-fílmico ................................................................. 203

Tabla 31: Norma de nombramiento de los documentos digitales ..................................... 251

Tabla 32: Nomenclatura de archivos digitales ............................................................. 289

Tabla 33: Recuadro de la Ficha Fotografía ( fuente: libro) ............................................. 305

Tabla 34: Recuadro de la Ficha Fotografía ( fuente: prensa) ........................................... 305

Tabla 35: Recuadro de la Ficha Fotografía ( fuente: revistas especializadas)................... 305

Tabla 36: Recuadro de la Ficha Fotografía ( fuente: particular) ..................................... 306

Tabla 37: Recuadro de la Ficha Fotografía ( fuente: discografía) ................................. 306 


\section{Gráficas}

Gráfica 1: Incidencia de artículos musicales en revistas ...............................................18

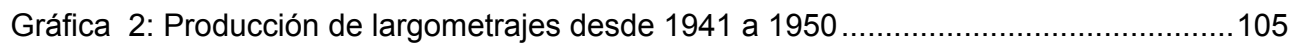

Gráfica 3: Productoras y coproducciones entre 1939 a 1950 ............................................ 132

Gráfica 4: producción española por géneros (1939 a 1945)..........................................133

Gráfica 5: Películas estrenadas en Madrid por países de origen (1939 a 1945) ..............133

Gráfica 6: Producción de largometrajes (1941 a 1950) .................................................137

Gráfica 7: Producción nacional e internacional (1945 a 1950) .........................................138

Gráfica 8: Películas estrenadas en Madrid por países de origen (1946 a 1950) ...............140

Gráfica 9: Películas españolas estrenadas en Hispanoamérica.......................................144

Gráfica 10: Actividad desempeñada por los compositores sobre la producción total (1939 a

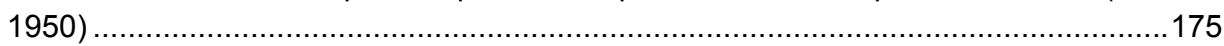

Gráfica 11: Compositores cuya producción es de ocho largometrajes o superior .............183

Gráfica 12: Compositores cuya producción es inferior a ocho largometrajes ...................183

Gráfica 13: Sistemas de sonido y su repercusión en la producción nacional (1941 - 1950)

Gráfica 14: Repercusión de los 6 sistemas de sonido más extendidos por años (1941 -

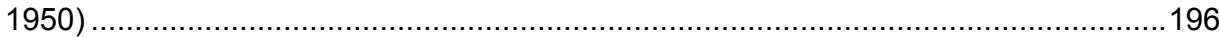

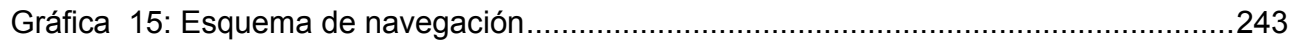

\section{Ilustraciones}

Ilustración 1: Deliciosamente tontos (1943) - cartel ......................................................232

Ilustración 2: diagrama de flujo del recorrido del Administrador ........................................247

Ilustración 3: diagrama de flujo del recorrido del Usuario..................................................284

\section{Fotogramas}

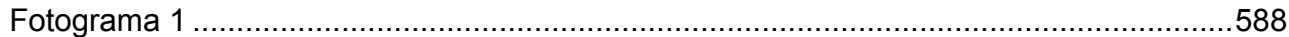

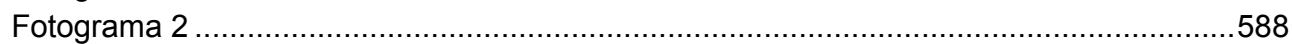

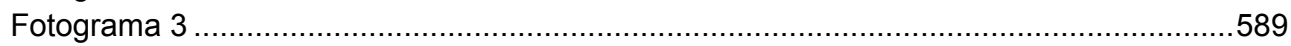

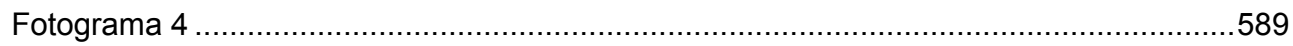

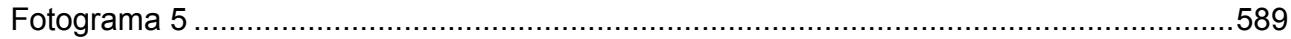

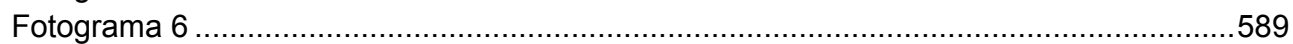

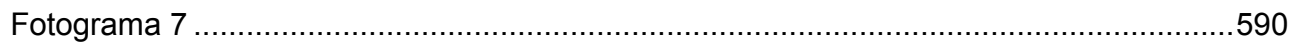

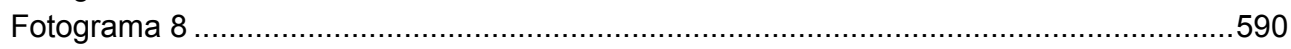

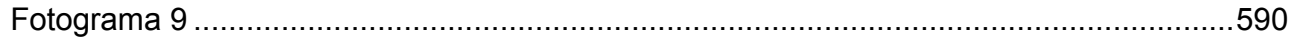

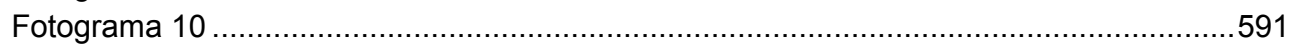

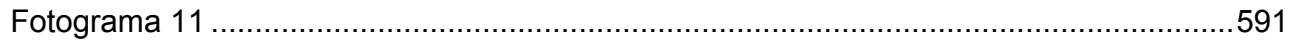

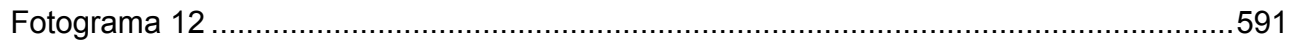

